\title{
Excusable evil : an analysis of complete defenses in International Criminal Law
}

Citation for published version (APA):

Krabbe, M. J. M. (2014). Excusable evil : an analysis of complete defenses in International Criminal Law. [Doctoral Thesis, Maastricht University]. Intersentia. https://doi.org/10.26481/dis.20140410mk

Document status and date:

Published: 01/01/2014

DOI:

10.26481/dis.20140410mk

Document Version:

Publisher's PDF, also known as Version of record

\section{Please check the document version of this publication:}

- A submitted manuscript is the version of the article upon submission and before peer-review. There can be important differences between the submitted version and the official published version of record.

People interested in the research are advised to contact the author for the final version of the publication, or visit the DOI to the publisher's website.

- The final author version and the galley proof are versions of the publication after peer review.

- The final published version features the final layout of the paper including the volume, issue and page numbers.

Link to publication

\footnotetext{
General rights rights.

- You may freely distribute the URL identifying the publication in the public portal. please follow below link for the End User Agreement:

www.umlib.nl/taverne-license

Take down policy

If you believe that this document breaches copyright please contact us at:

repository@maastrichtuniversity.nl

providing details and we will investigate your claim.
}

Copyright and moral rights for the publications made accessible in the public portal are retained by the authors and/or other copyright owners and it is a condition of accessing publications that users recognise and abide by the legal requirements associated with these

- Users may download and print one copy of any publication from the public portal for the purpose of private study or research.

- You may not further distribute the material or use it for any profit-making activity or commercial gain

If the publication is distributed under the terms of Article $25 \mathrm{fa}$ of the Dutch Copyright Act, indicated by the "Taverne" license above, 
Excusable Evil

An Analysis of Complete Defenses in International Criminal Law 
Excusable Evil

An Analysis of Complete Defenses in International Criminal Law 
Cover photograph: (C) Nadine Maas

School of Human Rights Research Series, Volume 50

A commercial edition of this dissertation will be published by Intersentia under ISBN 978-1-78068-204-4.

The titles published in this series are listed at the end of this volume.

No part of this publication may be reproduced, stored in an automated data system or transmitted in any form or by any means, electronic, mechanical or photocopying, recording, or otherwise, without the prior written permission from the author/publisher. 


\section{Excusable Evil}

An Analysis of Complete Defenses in International Criminal Law

\section{PROEFSCHRIFT}

ter verkrijging van de graad van doctor aan de Universiteit Maastricht, op gezag van de Rector Magnificus, Prof. L.L.G. Soete, volgens het besluit van het College van Decanen, in het openbaar te verdedigen op donderdag 10 april 2014 om 12.00 uur

door

Maartje Jacqueline Mathilde Krabbe geboren op 27 januari 1977 te Amsterdam 


\section{Promotor:}

Prof. mr. A.H. Klip

\section{Co-promotor:}

Prof. mr. G. de Jonge

\section{Beoordelingscommissie:}

Prof. mr. T.N.M.B. Spronken (voorzitter)

Prof. mr. E. Lijnzaad

Dr. F.O. Raimondo

Prof. mr. E. van Sliedregt (Vrije Universiteit Amsterdam)

Prof. mr. H.G. van der Wilt (Universiteit van Amsterdam) 
School of Human Rights Research Series, Volume 50

The titles published in this series are listed at the end of this volume. 
Excusable Evil

An Analysis of Complete Defenses in International Criminal Law

MaArtje KrabBe

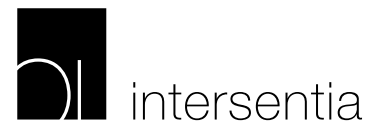

Cambridge - Antwerp - Portland 
Intersentia Publishing Ltd.

Sheraton House | Castle Park

Cambridge | CB3 0AX | United Kingdom

Tel.: +44 1223370170 | Email: mail@intersentia.co.uk

Maartje Krabbe

Excusable Evil. An Analysis of Complete Defenses in International Criminal Law

ISBN 978-1-78068-204-4

D/2014/7849/36

NUR 828

Cover image: Nadine Maas

(C) 2014 Intersentia

www.intersentia.com | www.intersentia.co.uk

British Library Cataloguing in Publication Data. A catalogue record for this book is available from the British Library.

No part of this book may be reproduced in any form, by print, photoprint, microfilm or any other means, without written permission from the publisher. 
To Krabbie and Tineke 



\section{ACKNOWLEDGEMENTS}

The extent of support I received in completing this dissertation humbles me. I am immensely grateful to André Klip, for offering me this project and to Gerard de Jonge, for stepping on board. Thank you for your confidence and innovative suggestions. Working with two creative and independent minds like yours has been truly inspirational.

I owe much gratitude to Liesbeth Lijnzaad, Fabián Raimondo, Elies van Sliedregt, Taru Spronken and Harmen van der Wilt for reading and commenting on the text published in this book. It is an honour to have you among my examiners.

Several others proved to be meticulous critics of this book as it was in the making. I am indebted to Jeroen Blomsma, for his comments on sizeable amounts of text in different stages of the writing process. Many thanks as well to Wilma Dreissen for her work on the procedural part of this book. I am grateful to Corine de Ruiter who advised me on the insanity defense. Annemieke van Verseveld, I thank for her help with a number of drafts on the topic of mistake.

During the course of this research, I had fantastic colleagues, both at Maastricht University and at Radboud University. We had many interesting discussions and animated informal lunches. Thank you all for your friendship and support!

Without an army of babysitters, this book would not have been finished. I especially like to thank my in-laws Paul and Jet, and Catleen and Paul. Not only for the babysitting, but also for making me feel at home in Nijmegen.

Regular distraction is an important aspect of thesis writing. It meant the world to me that I had a Monday night escape. Thank you Ricky, for taking me into your circle of Monday night models. Models: thank you for being there!

Many thanks I also owe to my paranimfen. Karin, we started our Ph.D. projects together and I'm glad we became friends in the process. Your support has been invaluable. Daphne, although we are well beyond the giggly age, I still consider you my best friend. There is this unconditional touch to our friendship that I deeply appreciate.

Nadine, I'm so happy that it is you who designed the cover image of this book! 
Tineke and Krabbie, you have contributed to this book in every possible way. Thank you for your unrelenting support at so many levels. What is more: thank you for a magnificent childhood, for which I am grateful beyond words. I dedicate this book to you.

Maarten and Ellis, I feel intensely privileged that your little spirits have come to live with us. If this book is not what it could have been, because of all those days and nights I spend with you, it has been definitely worth it!

Bright, witty and solid as a rock, Robbert, you've been an incredible tower of strength in work and life. Thanks for your help and patience. You truly are a wonderful man.

Lent, October 2013 


\section{Contents}

Acknowledgements ............................. vii

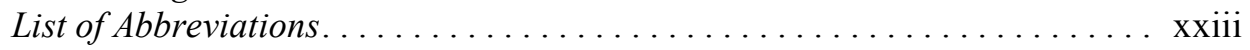

\section{Part I}

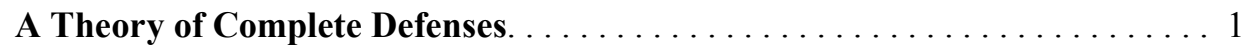

Chapter I

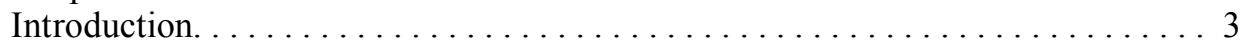

1. Excusable evil? ........................... 3

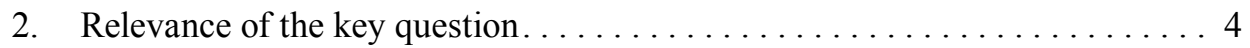

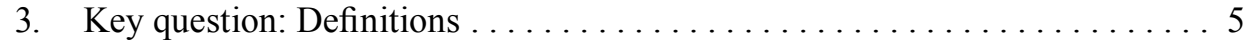

3.1. Complete defenses. ....................... 5

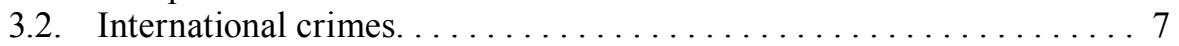

3.2.1. International crimes in general $\ldots \ldots \ldots \ldots \ldots \ldots \ldots$

3.2.2. Genocide...................... 8

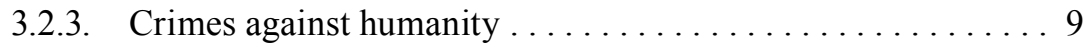

3.2.4. War crimes ........................ 10

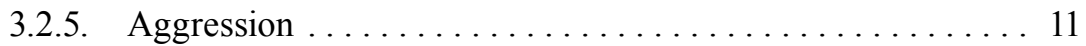

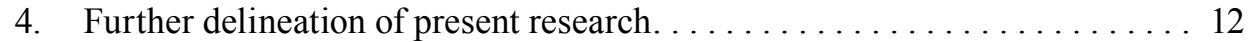

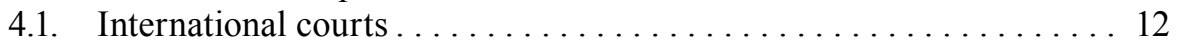

4.2. Sources of international criminal law . . . . . . . . . . . . . . . . 12

4.2.1. Sources of the active $a d$ hoc tribunals . . . . . . . . . . 13

4.2.2. Article 21 of the ICC Statute . . . . . . . . . . . . 16

4.2.3. Sources of international criminal law included in this research....................... 17

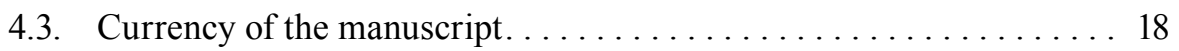

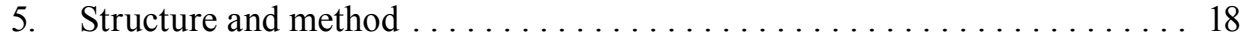

Chapter II

A theoretical background on complete defenses $\ldots \ldots \ldots \ldots \ldots \ldots \ldots$

1. Introduction. . . . . . . . . . . . . . . . . . . . . . . . . . .

2. "I did it": The general requirements for criminal liability . . . . . . . . . 24

2.1. General requirements for criminal liability . . . . . . . . . . . 24

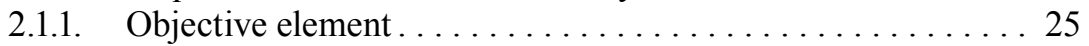

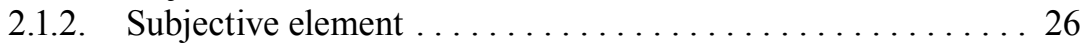

3. "But I should not be punished": Complete defenses and criminal liability . . 31

3.1. Confession and avoidance .................. 32 
Contents

3.2. Negation of the subjective element $\ldots \ldots \ldots \ldots \ldots \ldots \ldots \ldots \ldots$

3.3. Conclusion.............................. 33

4. Categorization of defenses: Justifications and excuses. . . . . . . . . 35

4.1. Justifications, excuses and the relationship between complete defenses and the general requirements for criminal liability . . . . . 38

5. Procedural issues related to complete defenses . . . . . . . . . . . 39

5.1. Grounds stated in judgments. . . . . . . . . . . . . . . . 40

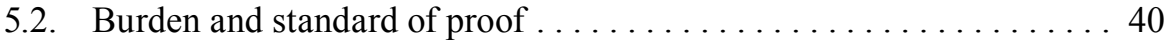

5.3. Prosecutor v. Aleksovski ......................... 45

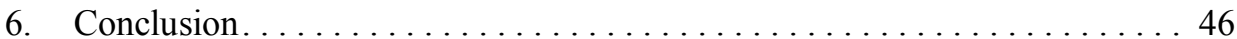

\section{Part II}

Complete Defenses in Practice. . . . . . . . . . . . . . . . . . . . . . . 49

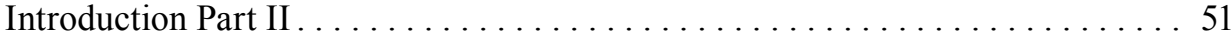

Chapter III

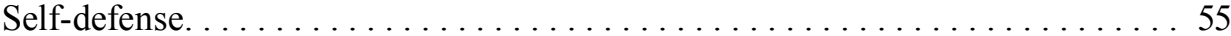

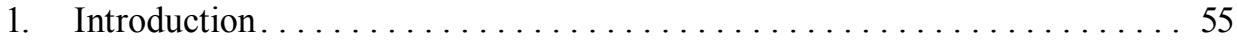

2. Self-defense in the Nuremberg Judgment. . . . . . . . . . . . . . . 55

2.1. The verdict on Erich Raeder . . . . . . . . . . . . . . 55

2.1.1. Relevant passages.................... 55

2.1.2. Applicability...................... 57

2.1.3. Scope ......................... 57

2.1.4. Nature of self-defense. . . . . . . . . . . . . . . . . . . . 58

3. Self-defense in the Tokyo Judgment . . . . . . . . . . . . . . . . . . . . 59

3.1. Relevant passages . . . . . . . . . . . . . . . . . . . . 59

3.1.1. The general part of the Judgment. . . . . . . . . . . . . . . . . 59

3.1.2. The Verdict on Shigetaro Shimada, Hideki Tojo, Shigenori

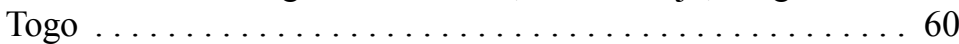

3.2. Analysis of self-defense in the Tokyo Judgment. . . . . . . . . . . . . 62

3.2.1. Applicability....................... 62

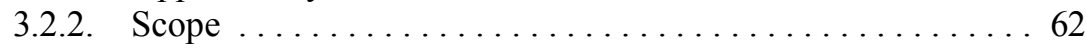

3.2.3 Nature of self-defense. . . . . . . . . . . . . . 63

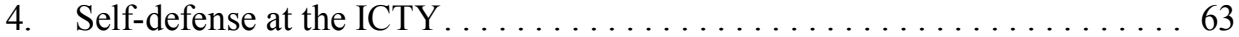

4.1. Prosecutor v. Kordić and Čerkez .................... 63

4.1.1. Relevant passages..................... 63

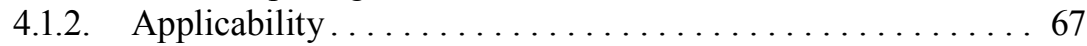

4.1.3. Scope ........................ 68

4.1.4. Nature of self-defense. . . . . . . . . . . . . . . . . . 69

4.2. Prosecutor v. Stakić. . . . . . . . . . . . . . . . . . . . . . 71

4.2.1. Relevant passages..................... 71

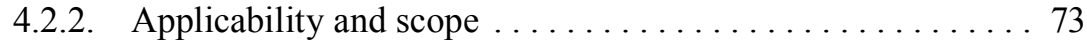


4.2.3. Nature of self-defense. . . . . . . . . . . . . . . . . . . . 73

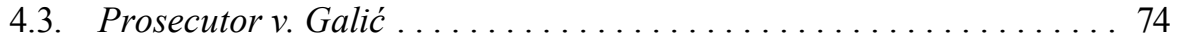

4.3.1. Relevant passages...................... 74

4.3.2. Applicability. ....................... 74

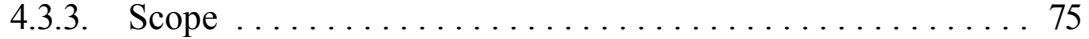

4.3.4. Nature of self-defense. . . . . . . . . . . . . . . . . . 75

4.4. Prosecutor v. Hadžihasanović and Kubura . . . . . . . . . . . . . 75

4.4.1. Relevant passages...................... 75

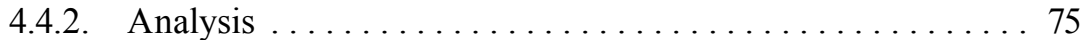

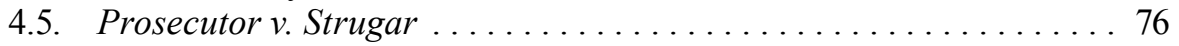

4.5.1. Relevant passages.................... 76

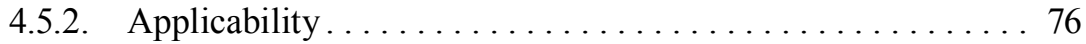

4.5.3. Scope ......................... 76

4.5.4. Nature of self-defense. . . . . . . . . . . . . . . . . . 76

4.6. Prosecutor v. Delić . . . . . . . . . . . . . . . . . . . . . . 77

4.6.1. Relevant passages....................... 77

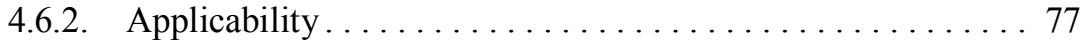

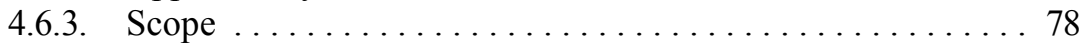

4.6.4. Nature of self-defense. . . . . . . . . . . . . . . . 78

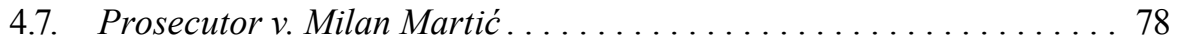

4.7.1. Relevant passages........................ 78

4.7.2. Applicability........................ 79

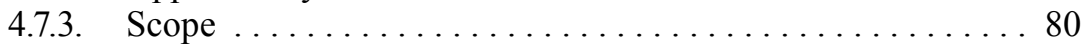

4.7.4. Nature of self-defense. . . . . . . . . . . . . . . . . . 80

4.8. Prosecutor v. Boškoski and Tarčulovski ................. 80

4.8.1. Relevant passages...................... 80

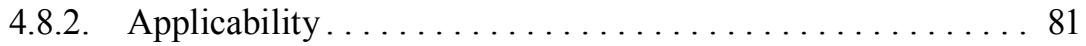

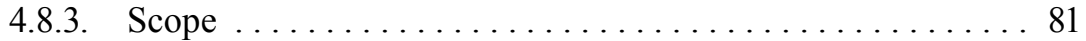

4.8.4. Nature of self-defense. . . . . . . . . . . . . . . . . . . 82

4.9. Prosecutor v. Đorđević . . . . . . . . . . . . . . . . . 82

4.9.1. Relevant passages...................... 82

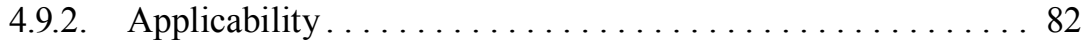

4.9.3. Nature of self-defense. . . . . . . . . . . . . . . . . . 83

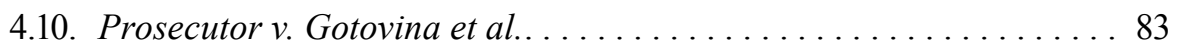

4.10.1. Relevant passages.................... 83

4.10.2. Applicability ... . . . . . . . . . . . . . . . . 84

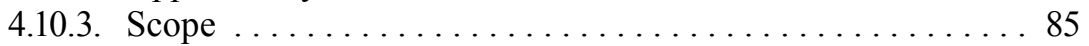

4.10.4. Nature of self-defense. . . . . . . . . . . . . . . . . 85

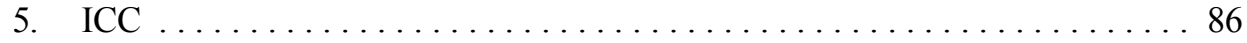

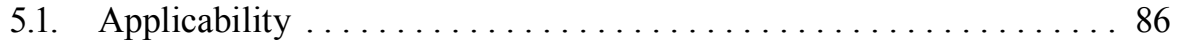

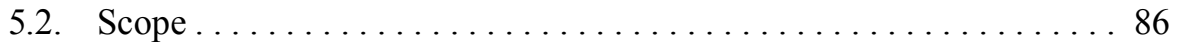

5.3. Nature of self-defense . . . . . . . . . . . . . . . . . . . 89

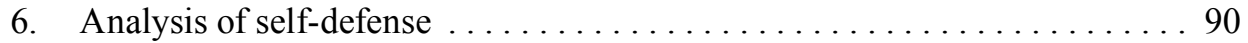


Contents

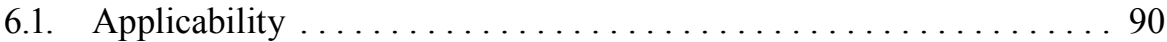

6.2. Scope ............................... 91

6.3. Nature of self-defense . . . . . . . . . . . . . . . . . . . . . . . 93

6.3.1. Self-defense in the sphere of ius ad bellum . . . . . . . . . 93

6.3.2. Private self-defense. . . . . . . . . . . . . . . . . . . . . . . . 94

6.4. Categorization ............................. 94

6.5. Conclusion on self-defense . . . . . . . . . . . . . . . . 96

6.6. Preview Part III . . . . . . . . . . . . . . . . . . . . . . . . . . . 97

\section{Chapter IV}

Consent ... . . . . . . . . . . . . . . . . . . . . . . . . . . . . . . 99

1. Introduction. . . . . . . . . . . . . . . . . . . . . . . . . 99

2. Consent in the Nuremberg Judgment . . . . . . . . . . . . . . . . . . 99

2.1. The general part of the Nuremberg Judgment in conjunction with the verdict on Konstantin von Neurath . . . . . . . . . . . . . . . . . . 99

2.1.1. Relevant passages....................... . . 99

2.1.2. Applicability ........................ 101

2.1.3. Scope ......................... 101

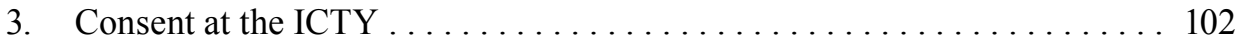

3.1. Prosecutor v. Kunarac et al. . . . . . . . . . . . . . . . . . . . . . 102

3.1.1. Relevant passages......................... 102

3.1.2. Analysis .......................... 103

4. Consent at the ICTR . . . . . . . . . . . . . . . . . . . . . . . . . . . . . . . . 104

4.1. Prosecutor v. Gacumbitsi . . . . . . . . . . . . . . . . . . . 104

4.1.1. Relevant passages....................... 104

4.1.2. Analysis ......................... 106

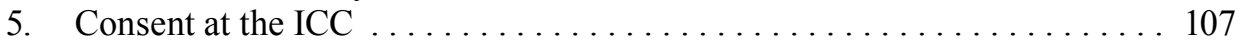

6. Analysis of consent ... . . . . . . . . . . . . . . . . . 108

6.1. Applicability . . . . . . . . . . . . . . . . . . . . . . 108

6.2. Scope ............................... 109

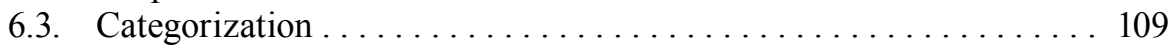

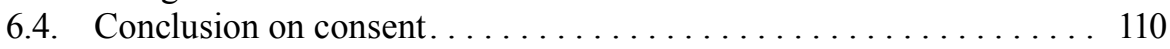

6.5. Preview Part III . . . . . . . . . . . . . . . . . . . . . . . . . . 110

Chapter V

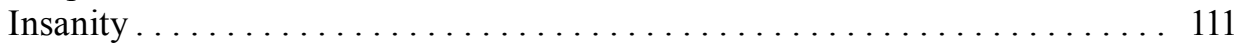

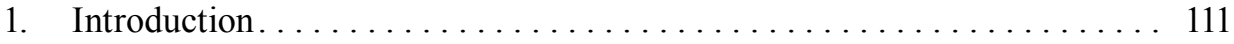

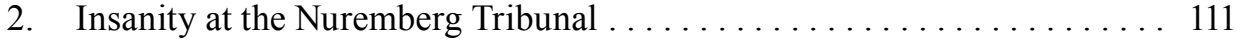

2.1. The verdict on Rudolf Hess . . . . . . . . . . . . . . . . . . . . . . . 111

2.1.1. Relevant passages....................... 111

2.1.2. Analysis ......................... 112

2.1.3. Expert examination and legal consequences . . . . . . . . 113 
3. Insanity at the ICTY . . . . . . . . . . . . . . . . . . . . . 113

3.1. Prosecutor v. Erdemović .......................... 113

3.1.1. Relevant passages........................ 113

3.1.2. Analysis ............................... 114

3.2. Prosecutor v. Mucić et al. .......................... 114

3.2.1. Relevant passages............................ 114

3.2.2. Applicability .......................... 121

3.2.3. Scope .............................. 121

3.2.4. Expert examination and legal consequences .......... 123

4. Insanity at the ICTR . . . . . . . . . . . . . . . . . . . . . 124

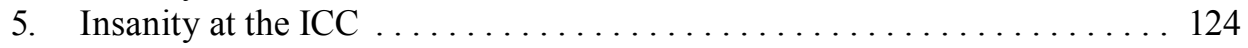

5.1. Applicability .............................. 124

5.2. Scope ................................ 124

5.3. Expert examination and legal consequences.............. 126

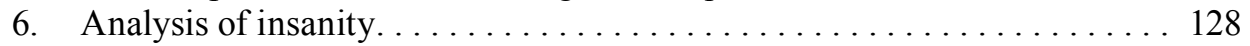

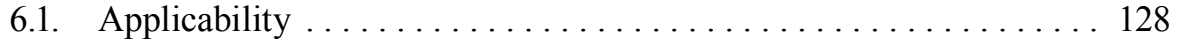

6.2. Scope ................................. 128

6.3. Categorization ............................. 129

6.4. Expert examination and legal consequences.............. 130

6.4.1. Expert examination . . . . . . . . . . . . . . . . . . 130

6.4.2. Legal consequences ........................ 131

6.5. Conclusion on insanity $\ldots \ldots \ldots \ldots \ldots \ldots \ldots \ldots \ldots \ldots \ldots \ldots \ldots$

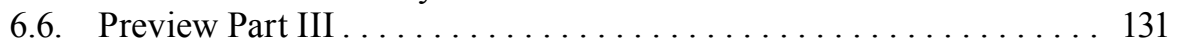

Chapter VI

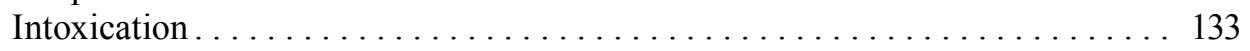

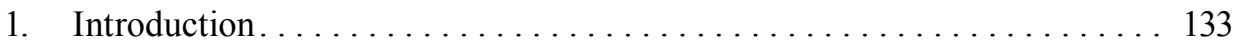

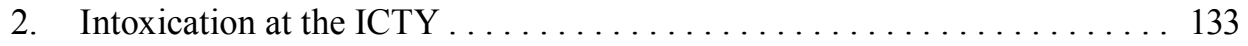

2.1. Relevant passages ........................... 133

2.2. Analysis of ICTY case law on intoxication. . . . . . . . . . . 134

3. Intoxication at the ICTR . . . . . . . . . . . . . . . . . . . 135

3.1. Prosecutor v. Kamuhanda........................ 135

3.1.1. Relevant passages......................... 135

3.1.2. Analysis . . . . . . . . . . . . . . . . . . . . 135

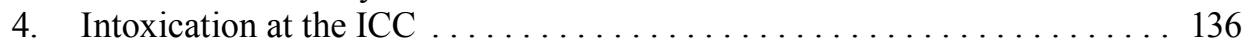

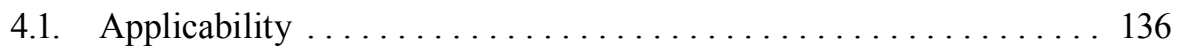

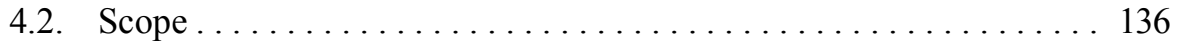

5. Analysis of intoxication . . . . . . . . . . . . . . . . . . . . . 139

5.1. Applicability ................................. 139

5.2. Scope ................................ 139

5.3. Voluntary and involuntary intoxication $\ldots \ldots \ldots \ldots \ldots \ldots \ldots . \ldots \ldots$

5.4. Categorization ............................ 141

5.5. Conclusion on intoxication $\ldots \ldots \ldots \ldots \ldots \ldots \ldots \ldots \ldots \ldots \ldots$ 
Contents

5.6. Preview Part III .

Chapter VII

Mistake.

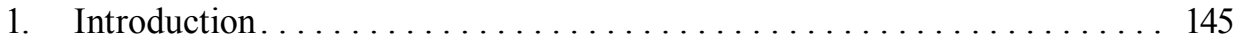

2. Mistake at Nuremberg. . . . . . . . . . . . . . . . . . . . . 145

2.1. Hermann Göring and Erich Raeder: Crimes Against Peace

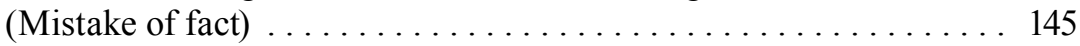

2.1.1. Relevant passages . . . . . . . . . . . . . . . . . . . 145

2.1.2. Applicability...... . . . . . . . . . . . . . . . . . . . 147

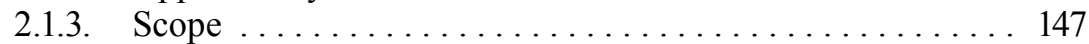

2.2. The occupation of Bohemia and Moravia . . . . . . . . . . . . . . 148

2.2.1. Relevant passages . . . . . . . . . . . . . . . . . . . . 148

2.2.2. Applicability . . . . . . . . . . . . . . . . . . . . . . . 149

2.2.3. Scope ............................ 149

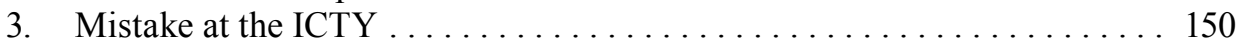

3.1. Prosecutor v. Mucić et al. ...................... 150

3.1.1. Relevant passages........................ 150

3.1.2. Applicability....................... 150

3.1.3. Scope ........................ 151

3.2. Prosecutor v. Dragomir Milošević . . . . . . . . . . . . . . 151

3.2.1. Relevant passages........................ 151

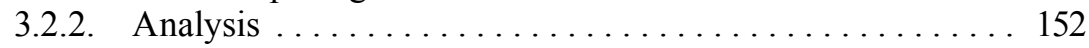

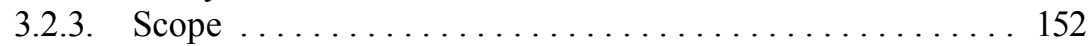

3.3. Mistake of fact mentioned in other cases . . . . . . . . . . . . 152

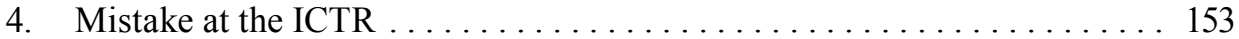

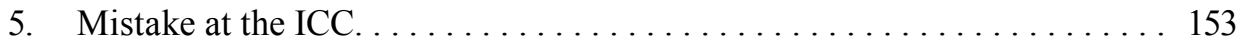

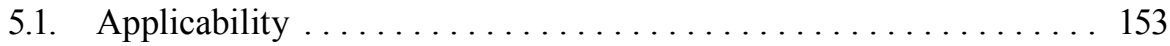

5.2. Scope ............................ 153

5.2.1. The distinction between mistake of fact and mistake of law. 154

5.2.2. Mistake of fact (article 32(1)) . . . . . . . . . . . . . 156

5.2.3. Mistake of law ................... 158

5.2.4. General comments on article $32 \ldots \ldots \ldots \ldots \ldots$. . . . . . . 159

5.2.5. Prosecutor v. Lubanga Dyilo . . . . . . . . . . . . . . 162

6. Analysis of mistake. . . . . . . . . . . . . . . . . . . 166

6.1. Applicability: Mistake of fact . . . . . . . . . . . . . . 166

6.2. Applicability: Mistake of law . . . . . . . . . . . . . . . . . . 167

6.3. Scope: Mistake of fact . . . . . . . . . . . . . . . . . . . . . . . . 167

6.4. Scope: Mistake of law . . . . . . . . . . . . . . . . . . . . . . 168

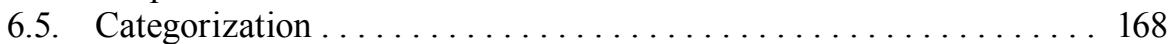

6.6. Conclusion on mistake. . . . . . . . . . . . . . . . . . . . 169

6.7. Preview Part III . . . . . . . . . . . . . . . . . . . . . . . . . . . . 170 


\section{Chapter VIII}

Superior orders and prescription of law $\ldots \ldots \ldots \ldots \ldots \ldots \ldots \ldots \ldots \ldots$

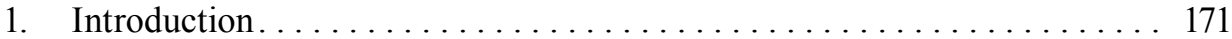

2. Superior orders and prescription of law in the Nuremberg Judgment . . . . 172

3. Superior orders and prescription of law in the Tokyo Judgment . . . . . . . 174

4. Superior orders and prescription of law at the ICTY . . . . . . . . . 175

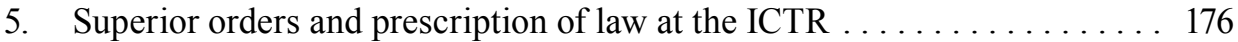

6. Superior orders and prescription of law at the ICC $\ldots \ldots \ldots \ldots \ldots \ldots$

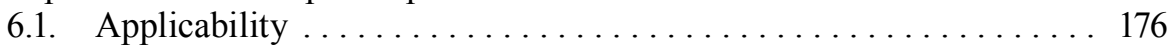

6.2. Scope . . . . . . . . . . . . . . . . . . . . . 177

6.3. Relationship with article $32 \ldots \ldots \ldots \ldots \ldots \ldots \ldots \ldots \ldots 18 \ldots \ldots$

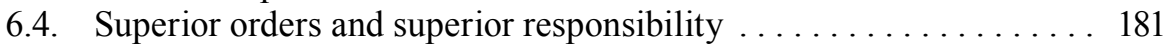

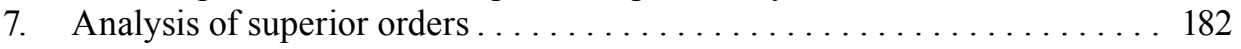

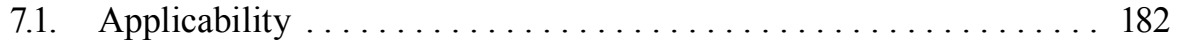

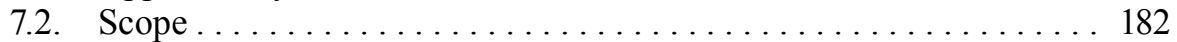

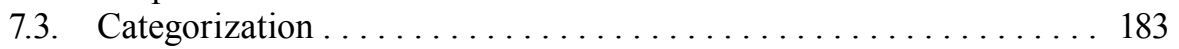

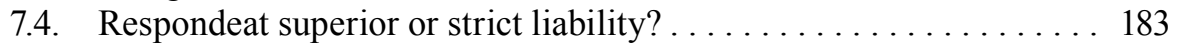

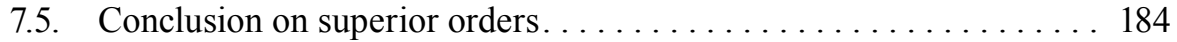

7.6. Preview Part III . . . . . . . . . . . . . . . . . . . . . . . . . . . . . . . . 184

\section{Chapter IX}

Necessity and duress. . . . . . . . . . . . . . . . . . . 185

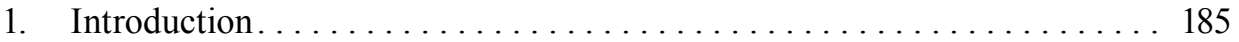

2. Nuremberg. . . . . . . . . . . . . . . . . . . . . . . 186

2.1. The general part of the Judgment: Plunder . . . . . . . . . . . . . 186

2.1.1. Relevant passages....................... 186

2.1.2. Applicability ....................... 186

2.1.3. Scope ........................ 187

2.1.4. Necessity/duress . . . . . . . . . . . . . . . . . . . . 187

2.2. The verdict on Karl Dönitz . . . . . . . . . . . . . . . . . . . . . . 187

2.2.1. Relevant passages........................ 187

2.2.2. Applicability....................... 188

2.2.3. Scope ........................ 188

2.2.4. Necessity/duress . . . . . . . . . . . . . . . . . . . . 188

3. Tokyo. . . . . . . . . . . . . . . . . . . . . . . . . . 189

3.1. The verdict on Shigenori Togo . . . . . . . . . . . . . . . . . . . 189

3.1.1. Relevant passages......................... 189

3.1.2. Applicability. . . . . . . . . . . . . . . . . . . 189

3.1.3. Scope ........................... 189

3.1.4. Necessity/duress . . . . . . . . . . . . . . . . . . . . . . . 190

3.2. The verdict on Kenji Dohihara . . . . . . . . . . . . . . . . . . 190

3.2.1. Relevant passages....................... 190 
Contents

3.2.2. Applicability.............................. 190

3.2.3. Scope .............................. 191

3.2.4. Necessity/duress . . . . . . . . . . . . . . . . . . . . . . . 191

3.3. The verdict on Seishiro Itagaki . . . . . . . . . . . . . . . . . 191

3.3.1. Relevant passages........................... 191

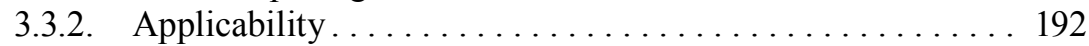

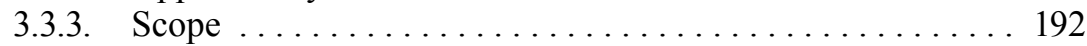

3.3.4. Necessity/duress . . . . . . . . . . . . . . . . . . . . . . . . . . . 192

3.4. The Verdict on Iwane Matsui . . . . . . . . . . . . . . . . . . . . 192

3.4.1. Relevant passages........................... 192

3.4.2. Applicability ............................ 193

3.4.3. Scope . . . . . . . . . . . . . . . . . . . . . . . . . . . . 193

3.4.4. Necessity/duress . . . . . . . . . . . . . . . . . . . . . . . . . . . . . 193

4. Necessity and duress at the ICTY ...................... 193

4.1. Prosecutor v. Erdemović ........................... 193

4.1.1. The facts of the case . . . . . . . . . . . . . . . . . . . . . . 194

4.1.2. Trial Chamber I . . . . . . . . . . . . . . . . . . . . . . . . 194

4.1.3. Appeals Chamber, Joint Separate Opinion of Judge McDonald and Judge Vohrah and Separate and Dissenting Opinion of Judge Li . . . . . . . . . . . . . . . . . . . . . 197

4.1.4. Separate and dissenting opinion of Judge Cassese . . . . . . 202

4.1.5. Separate and Dissenting Opinion of Judge Stephen ...... 205

4.1.6. Trial Chamber II. . . . . . . . . . . . . . . . . . . . . . 207

4.1.7. Conclusion on Prosecutor v. Erdemović . . . . . . . . . . . . 208

4.2. Prosecutor v. Aleksovski .......................... 212

4.2.1. Relevant passages......................... 212

4.2.2. Applicability............................. 214

4.2.3. Scope ................................ 214

4.2.4. Necessity/duress . . . . . . . . . . . . . . . . . . . . . . . . . . . . . 214

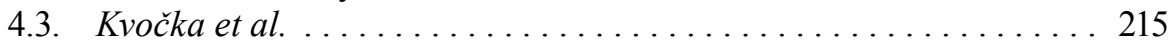

4.3.1. Relevant passages.......................... 215

4.3.2. Applicability.......................... 216

4.3.3. Scope ............................... 217

4.3.4. Necessity/duress . . . . . . . . . . . . . . . . . . . . . . . . 217

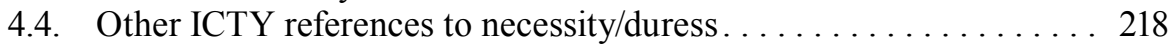

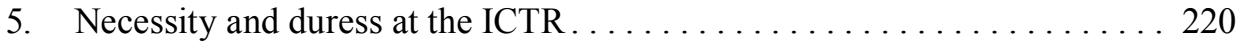

5.1. Prosecutor v. Kajelijeli . . . . . . . . . . . . . . . . . . . . . . . 220

5.1.1. Relevant passages.......................... 220

5.1.2. Applicability .......................... 221

5.1.3. Scope .............................. 221

5.1.4. Necessity/duress . . . . . . . . . . . . . . . . . . . . . . . . . 221

5.2. Prosecutor v. Kamuhanda...................... 221

5.2.1. Relevant passages....................... 221 
5.2.2. Applicability.......................... 222

5.2.3. Scope ............................. 223

5.2.4. Necessity/duress . . . . . . . . . . . . . . . . . . . . 223

5.3. Other ICTR references to necessity/duress . . . . . . . . . . . 223

6. Necessity and duress at the ICC . . . . . . . . . . . . . . . . . 224

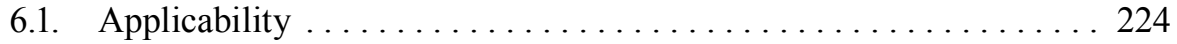

6.2. Scope .................................. 224

6.3. Necessity/duress ............................ 228

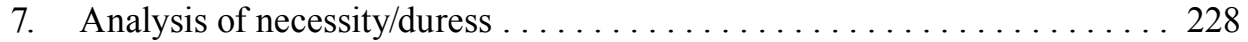

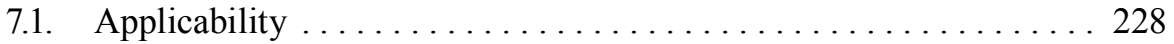

7.1.1. In principle ............................ 228

7.1.2. In casu .................................. 229

7.1.3. Mitigation............................... 229

7.1.4. Other legal consequences..................... 230

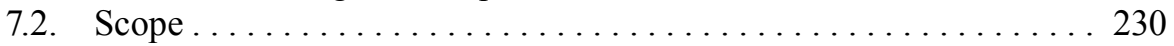

7.3. Necessity/duress ........................... 231

7.4. Categorization ........................... 232

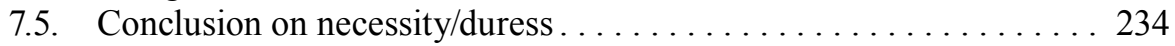

7.6. Preview Part III . . . . . . . . . . . . . . . . . . . . 234

Chapter X

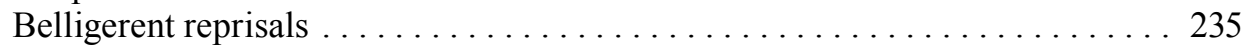

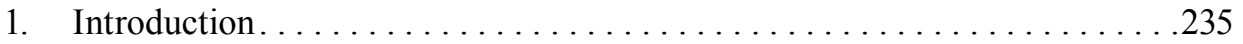

2. Reprisals at the ICTY ............................. 235

2.1. Prosecutor v. Kupreškić ......................... 235

2.1.1. Facts of the case ........................ 235

2.1.2. Applicability ......................... 235

2.1.3. Scope ............................ 237

2.2. Prosecutor v. Milan Martić........................ 238

2.2.1. Facts of the case . . . . . . . . . . . . . . . . . . 238

2.2.2. Applicability......................... 238

2.2.3. Scope ............................... 239

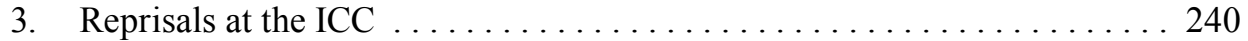

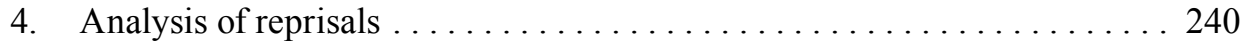

4.1. Applicability ............................ 240

4.2. Scope ................................. 241

4.3. Categorization .............................. 241

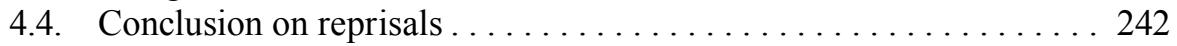

4.5. Preview Part III .............................. 242 
Contents

\section{Chapter XI}

Tu quoque

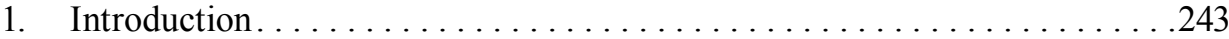

2. Tu quoque at Nuremberg. ............................ 243

2.1. The verdict on Karl Dönitz . . . . . . . . . . . . . . . . . . . . . . . . . 243

2.1.1. Relevant passages.......................... 243

2.1.2. Applicability............................. 244

2.1.3. Scope ................................. 244

2.2. The verdict on Erich Raeder ....................... 245

2.3. Other sources on tu quoque at Nuremberg . . . . . . . . . . . . . 245

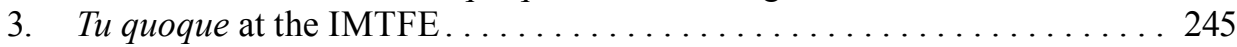

4. Tu quoque at the ICTY ........................... 246

4.1. Prosecutor vs. Kupreškić. .......................... 246

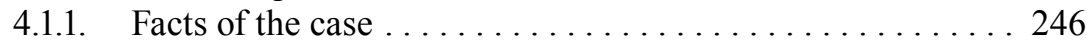

4.1.2. Applicability .......................... 246

4.1.3. Scope .............................. 247

4.2. Prosecutor v. Kordić and Čerkez . . . . . . . . . . . . . . . . . . . . 247

4.2.1. Relevant passages............................ 247

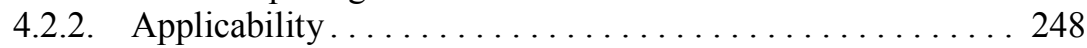

4.2.3. Scope . . . . . . . . . . . . . . . . . . . . . . . 248

4.3. Prosecutor v. Milan Martić. . . . . . . . . . . . . . . . . . . . . . . 248

4.3.1. Relevant passages......................... 248

4.3.2. Applicability............................. 248

4.3.3. Scope ............................. 249

4.4. Other sources on $t u$ quoque at the ICTY.................. . 249

5. Tu quoque at the ICTR ............................ 249

5.1. Prosecutor vs. Bagosora et al. . ........................ 249

5.1.1. Relevant passages............................... 249

5.1.2. Applicability......................... 250

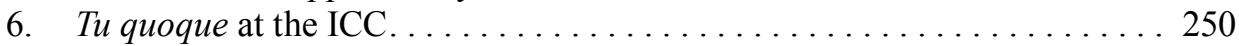

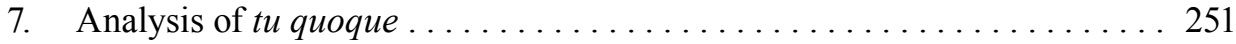

7.1. Applicability and scope......................... 251

7.2. Categorization .............................. 252

7.3. Conclusion on $t u$ quoque ....................... 253

7.4. Preview Part III . . . . . . . . . . . . . . . . . . . . . . . . 253

Chapter XII

Other possible complete defenses in international criminal law ......... 255

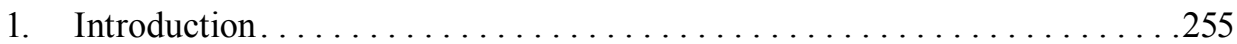

2. Other possible complete defenses at the ICTY and ICTR . . . . . . . 255

3. Other possible complete defenses at the ICC $\ldots \ldots \ldots \ldots \ldots \ldots \ldots 256$

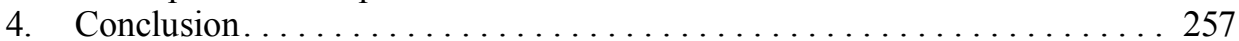

5. Preview Part III .................................. 258 
Analysis Part II

Analysis of complete defenses in international criminal law in general . . . . . 259

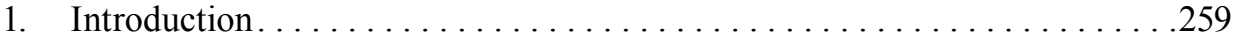

2. General recognition of complete defenses . . . . . . . . . . . . 260

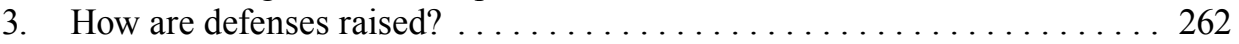

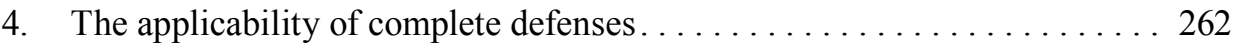

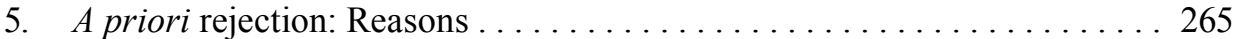

5.1. Self-defense ad bellum . . . . . . . . . . . . . . . . . . 265

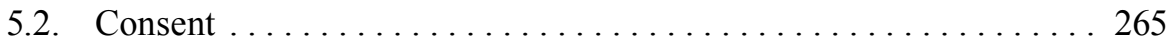

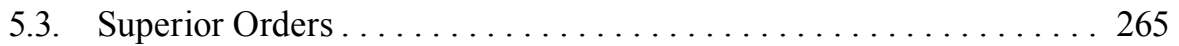

5.4. Necessity/duress . . . . . . . . . . . . . . . . . . . . 266

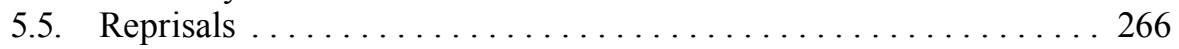

5.6. Tu quoque .......................... 266

5.7. Conclusion on reasons for a priori rejection. . . . . . . . . . . 267

6. Recognition in principle (explicit recognition) . . . . . . . . . . . . . 267

7. Grounds for rejection on merits (implicit recognition) . . . . . . . . . . 267

7.1. Self-defense............................ 267

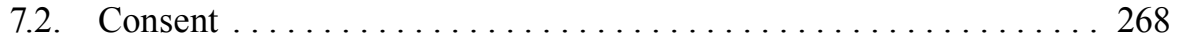

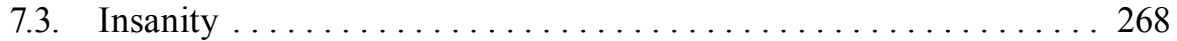

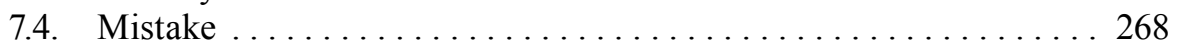

7.5. Necessity/duress . . . . . . . . . . . . . . . . . . . . 268

7.6. Reprisals . . . . . . . . . . . . . . . . . . . . . . . . . 269

7.7. Conclusion................................ 269

8. Complete defenses and mitigating circumstances . . . . . . . . . . . . . . 269

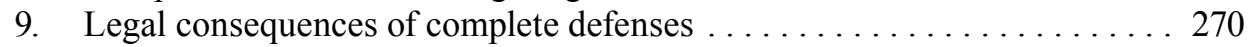

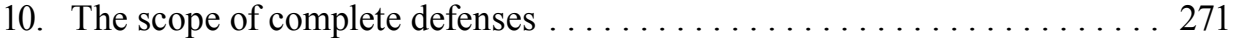

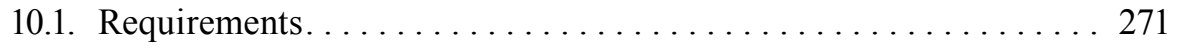

10.2. Analysis of the scope of complete defenses . . . . . . . . . 273

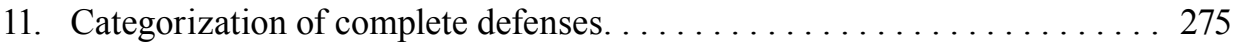

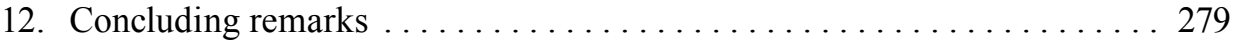

\section{Part III}

Recommendations........................... 281

Introduction Part III $\ldots \ldots \ldots \ldots \ldots \ldots \ldots \ldots \ldots \ldots \ldots \ldots \ldots \ldots \ldots \ldots \ldots$

Chapter XIII

Should complete defenses apply to international crimes? . . . . . . . . . . 285

1. Introduction . . . . . . . . . . . . . . . . . . . . . . .

2. Arguments pro the availability of complete defenses in international criminal law . . . . . . . . . . . . . . . . . . . . . . 285

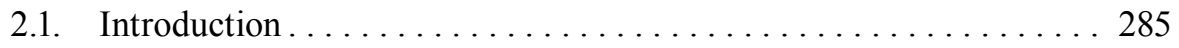


Contents

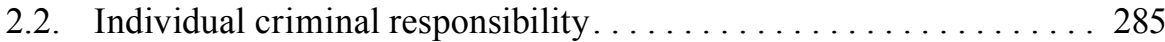

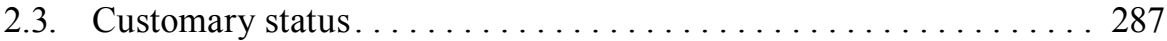

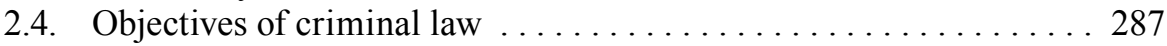

2.5. Availability under national law . . . . . . . . . . . . . . . . . . 290

2.6. Credibility of international criminal courts . . . . . . . . . . . . . 291

3. Arguments contra complete defenses in international criminal law . . . . 292

3.1. Introduction . . . . . . . . . . . . . . . . . . . . . . . . . . . . . . . 292

3.2. Ethical reasons. . . . . . . . . . . . . . . . . . . . . . . 292

3.2.1. Introduction . . . . . . . . . . . . . . . . . . . . 292

3.2.2. The abhorrent nature of international crimes. . . . . . . . . 293

3.2.3. Absolute character of international crimes . . . . . . . . . . . . 294

3.2.4. Meeting the requirements of complete defenses in case of international crimes . . . . . . . . . . . . . . . . . . . 295

3.3. Technical arguments . . . . . . . . . . . . . . . . . . . . 296

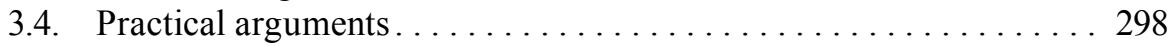

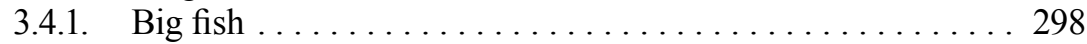

3.4.2. System criminality . . . . . . . . . . . . . . . . . . . . . 299

3.4.3. Acquittal is not a popular option . . . . . . . . . 300

3.4.4. Guilty pleas. ........................ 301

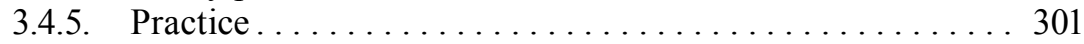

3.4.6. Discussion. . . . . . . . . . . . . . . . . . . . . . . 301

3.5. Conclusion .......................... 302

Chapter XIV

How should complete defenses be applied under international criminal law

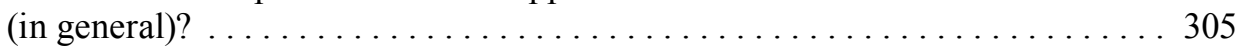

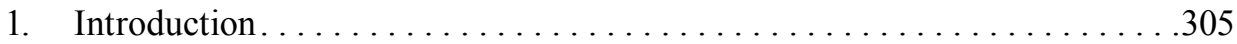

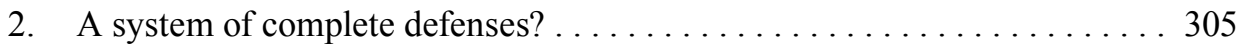

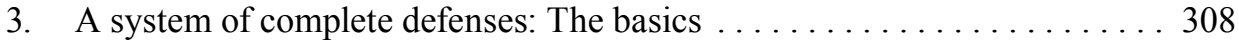

3.1. A distinction between justifications and excuses . . . . . . . . . . . 308

3.2. The definition of justification and excuse . . . . . . . . . . . 310

3.2.1. Justifications: The definition from case law . . . . . . . . . . 310

3.2.2. Excuses: The definition from case law. . . . . . . . . . . . . . 313

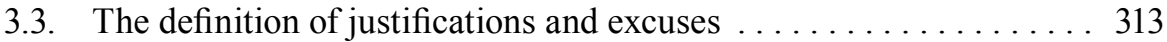

3.3.1. Justifications . . . . . . . . . . . . . . . 313

3.3.2. Excuses ......................... 316

3.3.3. A model of justifications and excuses . . . . . . . . . 326

4. The effect of justifications and excuses on the crime charged . . . . . . . . 327

5. Failed complete defenses in mitigation. . . . . . . . . . . . . . 331

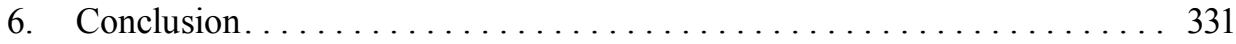




\section{Chapter XV}

How should complete defenses be applied under international criminal law (for each defense)?.

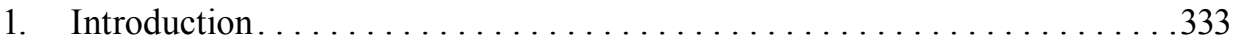

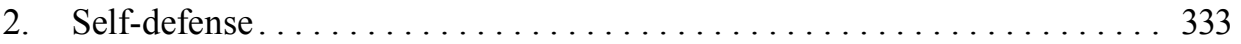

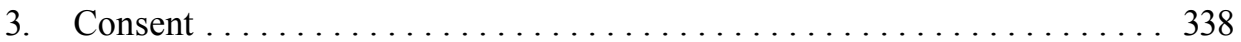

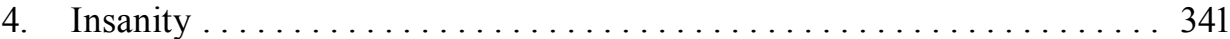

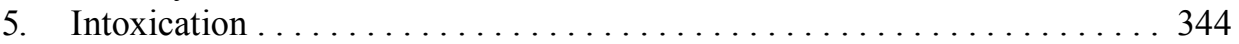

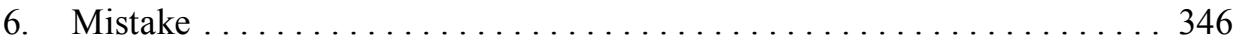

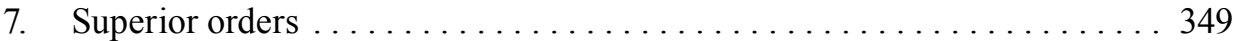

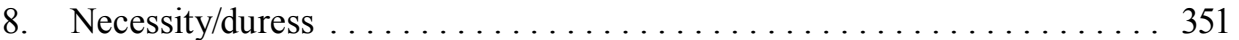

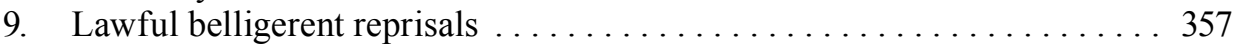

10. ти quoque ............................... 359

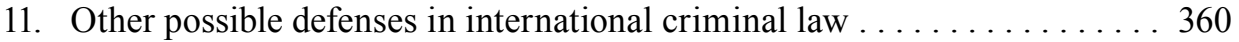

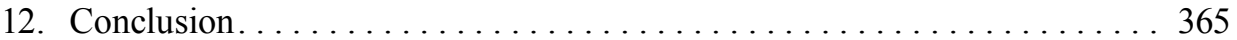

\section{Chapter XVI}

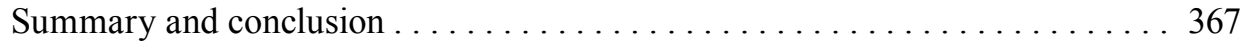

Part I Theory. . . . . . . . . . . . . . . . . . . . . . . . 367

Part II Practice . . . . . . . . . . . . . . . . . . . . . . . . . . . . . 368

Part III Recommendations . . . . . . . . . . . . . . . . . . . . . . . . . . . . 369

Final Words. . . . . . . . . . . . . . . . . . . . . . . . . . . . . . 372

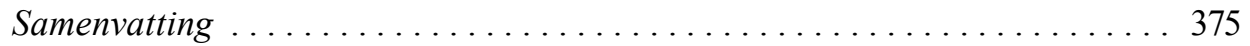

Bibliography.......................... 383 



\section{List of Abbreviations}

$\begin{array}{ll}\text { ABiH } & \text { Army of Bosnia and Herzegovina } \\ \text { CAH } & \text { crimes against humanity } \\ \text { DRC } & \text { Democratic Republic of Congo } \\ \text { ECCC } & \text { Extraordinary Chambers in the Courts of Cambodia } \\ \text { ECHR } & \text { European Convention on Human Rights } \\ \text { HVO } & \text { Croatian Defense Council } \\ \text { ICC } & \text { International Criminal Court } \\ \text { ICCPR } & \text { International Covenant on Civil and Political Rights } \\ \text { ICJ } & \text { International Court of Justice } \\ \text { ICL } & \text { international criminal law } \\ \text { ICRC } & \text { International Committee of the Red Cross } \\ \text { ICTR } & \text { International Criminal Tribunal for Rwanda } \\ \text { ICTY } & \text { International Criminal Tribunal for the former Yugoslavia } \\ \text { ILC } & \text { International Law Commission } \\ \text { IMT } & \text { International Military Tribunal of Nuremberg } \\ \text { IMTFE } & \text { International Military Tribunal for the Far East } \\ \text { JCE } & \text { joint criminal enterprise } \\ \text { JNA } & \text { Yugoslav People's Army } \\ \text { POW } & \text { prisoner of war } \\ \text { ROE } & \text { Rules of Engagement } \\ \text { RPE } & \text { Rules of Procedure and Evidence } \\ \text { RPF } & \text { Rwandan Patriotic Front } \\ \text { SCSL } & \text { Special Court for Sierra Leone } \\ \text { SPSC } & \text { Special Panels for Serious Crimes within the District Court of Dili } \\ \text { SRK } & \text { Sarajevo Romanija Corps } \\ \text { STL } & \text { Special Tribunal for Lebanon } \\ \text { UNWCC } & \text { United Nations War Crimes Commission } \\ \text { VRS } & \text { Bosnian Serb Army }\end{array}$





\section{Part I}

\section{A Theory of Complete Defenses}





\section{Chapter I \\ INTRODUCTION}

\section{EXCUSABLE EVIL?}

Students usually walk out of a classroom chitchatting or checking their smart phones. Not when we have been discussing Prosecutor v. Erdemović. Packing books and pens, slowly moving towards the door, they continue the discussion:

"He should have been acquitted."

"No, convicted."

"But he did not have a choice."

"Yeah, but he killed about 70 people. With an automatic rifle."

This case gets to the students. Always. I'm not surprised. Prosecutor $v$. Erdemovic has haunted me for years. The case has triggered me to write this thesis.

Prosecutor v. Erdemović revolves around a young Croatian soldier named Dražen Erdemović. In the early nineties he decides to join the Bosnian Serb Army (VRS) to support himself and his family and to gain some status as a Croat in Serbian territory. He deliberately joins a multi-ethnic VRS unit and carries out ordinary military tasks, such as reconnaissance in force. Up to this point, the story of Dražen Erdemović is little staggering.

Everything changes in the early morning of 16 July 1995. Erdemović is ordered to prepare for a secret mission. When he arrives at a farm in Pilica, Erdemović is told he is to massacre hundreds of Muslims that day. Erdemović immediately refuses to carry out the order. However, his refusal is countered with an instant death threat. "If you don't carry out the order," his superiors tell him, "you can hand in your rifle and stand between the Muslims, so we can shoot you".

Erdemović has the choice to kill or be killed. He chooses to kill. That day he is one of the many participants in the mass killings of 7,000-8,000 Bosnian Muslims following the fall of Srebrenica. Approximately 1,200 of them were murdered at Pilica. Erdemović estimates he killed about 70 men himself.

A year later, Erdemović is charged for crimes against humanity by the International Criminal Tribunal for the Former Yugoslavia (ICTY). When pleading guilty to these charges, he adds:

Your honour, I had to do this. If I had refused, I would have been killed together with the victims. When I refused, they told me: "If you're sorry for them, stand up, line up with them and we will kill you too." I am not sorry for myself but for my family, my wife, my son who then had nine months, and I could not refuse because then they would have killed me".

1 ICTY, Prosecutor v. Erdemović, Trial Chamber I, 27 November 1996, par. 10. 
Erdemović acknowledges that he did something evil, but pleads to be excused. In legal technical terms Erdemović brings up the complete defense of necessity or duress ${ }^{2}$ which amounts to saying: "I did commit a crime, but I was forced to do so. Therefore I should not be punished". The Chambers dealing with this case have a hard time coming to a decision. On the one hand Erdemović killed about 70 people, on the other hand he did not really have a choice - apart from sacrificing his own life. In the end Erdemović is convicted, but the extremity of the situation is brought in mitigation.

Had Erdemović - under the same amount of pressure - committed one single murder, he would have been able to successfully plead duress under most national jurisdictions. ${ }^{3}$ The rejection of duress in the Erdemović case therefore raises the question whether not only duress, but also other complete defenses (i.e. reasons why a defendant should not be punished) such as self-defense and insanity, can be available to a defendant charged with international crimes. Are these crimes so large scale and horrendous, that they can never be excused? Or should a defendant charged with an international crime have access to the same legal arguments as a defendant charged under domestic law? These are the questions underlying the key research question of this thesis:

\section{How, if at all, should complete defenses be available in case of international crimes?}

\section{Relevance OF THE KeY QUESTION}

Why is it important to know whether and how complete defenses should be available in case of international crimes? To understand the relevance of this study, one has to look at the larger picture of international criminal law in general and individual criminal responsibility for international crimes specifically. With the establishment of the International Military Tribunal of Nuremberg (IMT) after World War II, individual criminal responsibility for international crimes was a fact. ${ }^{4}$ After Nuremberg international criminal law has developed as a separate field of law. However, like any relatively new field of law, international criminal law is experiencing teething troubles. One of these troubles is the role of complete defenses. Despite a catalogue of complete defenses in the Statute of the International Criminal Court (ICC), their status is not unchallenged, as this book will

2 The nature of the defense brought up by Erdemović and the difference between the defenses of necessity and duress in the case law of international criminal courts are, respectively, discussed in Chapter IX, Section 4.1 and 7.3.

3 Blomsma, J., Mens rea and defences in European Criminal Law, Intersentia, Antwerp, 2012, pp. $457-460$.

$4 \quad$ Usually illustrated with the famous quote: "Crimes against international law are committed by men, not by abstract entities". See: IMT, Judgment and sentences, 1 October 1946, In: American Journal of International Law, 41 (1947), p. 221. 
demonstrate. However, if fair trials are to be conducted at international criminal courts, defendants, judges and prosecutors must know how criminal liability is defined. Criminal liability is not only dependent on the definitions of specific crimes such as 'genocide' or 'crimes against humanity', but also on other tenets represented by the so-called general part of criminal law containing for example matters like participation, inchoate offenses (e.g. preparation, attempt) and complete defenses. Since complete defenses co-determine the criminal liability of the defendant, their status should be undisputed and their contents foreseeable.

\section{Key QUESTION: Definitions}

In order to gain some deeper understanding of the key research question of this thesis How, if at all, should complete defenses be applied in case of international crimes? The concepts contained in this question need further clarification. This paragraph first discusses the concept of complete defenses (3.1), followed by an explanation of the scope of international crimes (3.2).

\subsection{Complete defenses}

A defense, in its most simple sense, is a claim submitted by the defendant seeking acquittal. 5 This could be any kind of argument from "I could not have done it, because I was out of the country" to "I did it, but I was forced to do so". This thesis however does not cover just any kind of defense, but is restricted to general complete substantive defenses invoked by individuals.

The notion general refers to the fact that these defenses may be raised against any criminal offense. The counterparts of general defenses are so-called specific defenses that can only be invoked against particular crimes. ${ }^{6}$ For example, under Dutch law 'acting in good faith in the interest of the general public' is a specific defense to libel, ${ }^{7}$ so that not every newspaper is in trouble for revealing dirt on prominent figures.

The word complete denotes that a successful appeal to such a defense will completely absolve the defendant from criminal liability. A complete defense thus leads to acquittal, instead of mere mitigation. ${ }^{8}$

5 Bantekas, I., 'Defences in International Criminal Law', In: McColdrick, D. (ed.), The Permanent International Criminal Court, Hart Publishing, Oxford, 2004, pp. 263-284, p. 263 and Zahar, A. and Sluiter, G., International Criminal Law, Oxford University Press, 2008, p. 396.

6 Bantekas, I. and Nash, S., International Criminal Law, Third Edition, Routledge-Cavendish, London and New York, 2007, p. 52 and Schabas, W.A., Genocide in International Law, Second Edition, Cambridge University Press, 2009, p. 368.

7 See article 261(2) of the Dutch Penal Code.

8 Scaliotti, M., 'Defences before the International Criminal Court: Substantive Grounds for Excluding Criminal Responsibility - Part 1', In: International Criminal Law Review, Vol. 1, 2001, pp. 111-172, p. 111 and Werle, G., Principles of International Criminal Law, T.M.C. Asser 
The expression substantive defense refers to the situation where the defendant argues: "I did it, but I don't think I should be punished". In other words, the defendant admits that he committed the actual crime, ${ }^{9}$ but for a reason which is acceptable under the relevant criminal justice system. ${ }^{10}$ For example, the defendant has ignored a "no trespassing" sign (crime), but he did so in order to save a child from drowning in a pond (acceptable reason). Substantive defenses are to be distinguished from defenses that deny a crime (the "I did it" part) has taken place, such as alibi ("I could not have committed the crime because I was not there") and abandonment ("I did not attempt to commit a crime because I voluntarily gave up going through with it").

Sometimes the acceptable reason is incorporated into the definition of a crime. With reference to the "no trespassing" example above, this would be the case when the same crime was defined as "trespassing is prohibited when no person is drowning". In this case, arguing that trespassing took place for the acceptable reason that a person was drowning, would not amount to a substantive defense, for the defendant does not acknowledge that "he did it" (i.e. that he trespassed without anyone drowning). On the contrary, he denies committing the crime by denying part of the definition (the part that no person is drowning). Defenses that negate part of the definition of a crime ${ }^{11}$ are called definitional defenses. ${ }^{12}$ They are normally not general substantive defenses and therefore not subject to the research reflected in this thesis. ${ }^{13}$

Substantive defenses must also be distinguished from procedural defenses. These defenses precede substantive defenses. They do not discuss the merits, but argue that no prosecution should take place due to the fact that procedural rules have been violated. ${ }^{14}$ Referring again to the example above, this means that the defendant does not argue whether he violated the prohibition on trespassing or not,

Press, The Hague, 2005, p. 96. See also: ICTY, Prosecutor v. Delalić et al., Appeals Chamber, 20 February 2001, par. 582.

9 In technical legal terms the defendant agrees that he - at least - committed the objective element of the crime, see Chapter II, Section 2.1.1.

10 See for this distinction: e.g. Bantekas, I. and Nash, S., 2007, p. 53 and Eser, A., “'Defences" in War Crime Trials', In: Dinstein, Y. and Tabory, M. (ed.), War Crimes in International Law, Martinus Nijhoff Publishers, The Hague, 1996, pp. 251-273, p. 251.

11 In a technical legal sense: defenses that negate the objective element of a crime. See Chapter II.

12 Bantekas, I. and Nash, S., 2007, p. 69.

13 For more information on these kinds of defenses, see: Bogert, P.C., Voor rechtvaardiging en schulduitsluiting, Kluwer, Deventer, 2005, especially p. 310. For examples of these kinds of defenses in international criminal law, see the Elements of Crime of the ICC Statute, e.g. article 8 (2) (b) (xiii) (War crime of destroying or seizing the enemy's property), which can be justified by military necessity. For an ICTY example, see the definition of deportation, which must be preformed "without grounds permitted under international law" (ICTY, Prosecutor v. Martić, Trial Chamber, 12 June 2007, par. 107).

14 Cryer, R., et al., An Introduction to International Criminal Law and Procedure, Cambridge University Press, 2007, p. 33; Scaliotti, M., 2001, p. 111; Schabas, W.A., 2009, p. 368 and Werle, G., 2005, p. 96. 
but argues that he should not be prosecuted for this crime because, for instance, he has been prosecuted for the same crime before (ne bis in idem). Other examples of procedural defenses are nullum crimen and nulla poena sine lege, statute of limitations, amnesties, truth and reconciliation committees, immunities and age. ${ }^{15}$ Procedural defenses are not subject to the research reflected in this thesis.

General complete substantive defenses (hereinafter 'complete defenses') can be either criminal law defenses or international law defenses. The difference between these two types is that criminal law defenses have their roots in domestic criminal law, while international law defenses originate from public international law. ${ }^{16}$ Consequently, criminal law defenses tend to avert responsibility for a personal act, while international law defenses traditionally negate the responsibility of the State. For instance, when a State is attacked, it has the right to strike back in self-defense. On the other hand, if an individual is personally attacked, he can invoke selfdefense as a criminal law defense. However, in international criminal law the distinction between international law defenses and criminal law defenses has blurred, because the individual charged with an international crime can invoke both types of defenses. ${ }^{17}$ In the context of this thesis, the following defenses with an international law origin have arisen: international self-defense, lawful belligerent reprisals and $t u$ quoque. ${ }^{18}$ Criminal law defenses that have surfaced are necessity/duress, private self-defense, consent, insanity, intoxication, mistake of fact, mistake of law and superior orders. Both types of defenses are subject to the research reflected in this thesis. However, international law defenses will only be considered in as far as individuals have invoked them. The concept of complete defenses is further elaborated on in Chapter II of this thesis.

\subsection{International crimes}

\subsubsection{International crimes in general}

In order to answer the core question of this thesis How, if at all, should complete defenses be applied in case of international crimes? the concept of international crimes must also be defined. Formally, international crimes are breaches of international rules entailing the personal criminal liability of individuals. ${ }^{19}$ This definition, however, provokes a subsequent question: which international rules

15 Khan, K. and Dixon, R. (eds.), Archbold International Criminal Courts: Practice, Procedure and Evidence, Sweet and Maxwell, Second Edition, London, 2005, p. 759-774 and Werle, G., 2005, p. 96.

16 Sliedregt, E. van, Individual Criminal Responsibility in International Law, Oxford University Press, 2012, p. 215.

17 Sliedregt, E. van, 2012, p. 215.

18 Schabas, W.A., 2009, p. 367.

19 Cassese, A., International Criminal Law, Second Edition, Oxford University Press, 2008, p. 11 and Werle, G., 2005, p. 37. 
establish international crimes? Opinions differ on this issue. ${ }^{20}$ Generally, there are broad definitions and narrow definitions of international crimes. ${ }^{21}$ The first category encompasses any kind of crime as long as the relevant behavior is covered by international convention or custom. Examples of crimes included by this broad category are: terrorism, human trafficking, and drug trafficking. ${ }^{22}$ The latter category - the narrow definition - only refers to: genocide, crimes against humanity, war crimes and aggression. ${ }^{23}$ These are the so-called international core crimes (hereinafter 'core crimes'). They are frequently mentioned in the statutes of international courts. Core crimes differ from the crimes falling under the broad definition in that they take place in a context of organized violence, usually with a political or ideological dimension. Consequently, core crimes tend to be committed on a large scale. ${ }^{24}$ The violent context of core crimes is reflected in their doublelayered structure: apart from the intent to commit the actual crime (murder, rape), the violent context is an element of the crime (e.g. the intent to destroy a group as a whole, knowledge of widespread attacks on the civilian population or the presence of an armed conflict). Due to their violent context and mass-scale, these core crimes are often said to be the concern of the international community as a whole. ${ }^{25}$ The definition of 'international crimes' employed in this thesis is restricted to the crimes mentioned in the statutes of international courts subject to this research, all of which are core crimes. Below, each of these crimes is further defined.

\subsubsection{Genocide}

Genocide concerns the intentional destruction or extermination in whole or in part of a national, ethnic, racial or religious group. This destruction can be accomplished by killing, but also by, for example, causing bodily harm or preventing births. Genocide thus requires the intentional commission of an underlying offense (e.g. intent to kill) plus the intent to destroy a group (genocidal intent). ${ }^{26}$ This latter intent has been characterized as special intent or dolus specialis, which "demands that the perpetrator clearly seeks to produce the act charged". 27

20 Scaliotti, M., 2001, p. 113.

21 Bassiouni, M.C., Introduction to International Criminal Law, Transnational Publishers, Inc., Ardsley, 2003, pp. 114-121; Cassese, A., 2008, p. 12; Kok, R., Statutory Limitations in International Criminal Law, T.M.C. Asser Press, The Hague, 2007, p. 4; Scaliotti, M., 2001, pp. 113/114 and Werle, G., 2005, p. 37.

22 For example: Werle, G., 2005, p. 37.

23 Some authors argue that torture, extreme forms of terrorism and corruption could also be core crimes. See, for example: Cassese, A., 2008, p. 12 and Boersma, M., Corruption: A Violation of Human Rights and A Crime Under International Law?, Intersentia, Antwerp, 2012.

24 Cassese, A., 2008, p. 54 and Werle, G., 2005.

25 Cryer, R., Prosecuting International Crimes: Selectivity in the International Criminal Law Regime, Cambridge University Press, 2005, p. 4.

26 Article 2 of the Convention on the Prevention and Punishment of the Crime of Genocide (1948).

27 Cassese, A., 2008, p. 137. 
There was no genocide provision in the charters of the IMT and the International Military Tribunal for the Far East (IMTFE) ${ }^{28}$ However, the crime against humanity of persecution on discriminatory grounds (article 6(c) of the IMT Charter and 5(c) of the IMTFE Charter) can be seen as a prequel to later genocide provisions. ${ }^{29}$ The Statutes of the ICTY and the International Criminal Tribunal for Rwanda (ICTR) bear the verbatim text of article 2 and 3 of the 1948 Genocide convention. The Statute of the ICC only bears the verbatim text of article 2 . The different modes of criminal responsibility, summed up in article 3 of the Genocide convention are covered by article 25 of the ICC Statute. ${ }^{30}$ All crimes in the ICC Statute are more elaborately defined in the Elements of Crimes, which is secondary ICC law, based upon article 9 of the ICC Statute.

\subsubsection{Crimes against humanity}

Crimes against humanity are particularly odious crimes ("inhumane acts") that are part of a widespread or systematic attack against the civilian population. ${ }^{31}$ The perpetrator of a crime against humanity (e.g. murder, enslavement) has to be aware of its context (the widespread or systematic attack). This means that the perpetrator needs at least to be aware of the risk that his act is part of the attack. He does not need to know the details of the attack. ${ }^{32}$ A desire to attack - as required in case of genocide - is not a condition either. In all statutes subject to this research, there is a crimes against humanity provision. The earlier ad hoc tribunals required a connection between the crime against humanity and another crime within the jurisdiction of the court (crimes against peace or war crimes). Also the ICTY Statute requires a connection to an armed conflict. However, in the statutes of the ICTR and ICC, this connection is no longer a requirement. Another difference between the crimes against humanity provisions in the statutes of international courts (from Nuremberg to the ICC) is constituted by the gradually expanding list of the various inhumane acts mentioned. All provisions bear a non-exhaustive list of inhumane acts. The ICTR provision is the only one bearing the requirement that the act must be committed on national, political, ethnic, racial or religious grounds. This is a controversial condition, for lack of basis in international criminal law. ${ }^{33}$

28 Also known as the Tokyo Tribunal.

29 Morris, V. and Scharf, M., The International Criminal Tribunal for Rwanda, Transnational Publishers Inc., Irvington-on-Hudson, 1998, p. 165.

30 See for an elaborate account of genocide in international criminal law: Schabas, W., Genocide in International Law, Cambridge University Press, 2009.

31 Cassese, A., 2008, pp. 98/99.

32 Cassese, A., 2008, p. 115.

33 This is probably the reason why the ICTR refers to this requirement as a jurisdictional element. See: Herik, L. van, The Contribution of the Rwanda Tribunal to the Development of International Law, Koninklijke Brill, Leiden, 2005, p. 178. See also: Cryer, R., 2005, p. 252 on the possible political reasons for the introduction of this "jurisdictional element". 


\subsubsection{War crimes}

War crimes constitute serious violations of customary law or, if applicable, treaty rules belonging to the corpus of the international humanitarian law of armed conflict. ${ }^{34}$ International humanitarian law comprises both 'the law of The Hague' (Hague Conventions of 1899 and 1907) and 'the law of Geneva' (the four Geneva Conventions of 1949 and the two Additional Protocols of 1977). These conventions regulate the various categories of lawful combatants, means and methods of warfare and the treatment of civilians, prisoners of war, the wounded, sick, and shipwrecked. ${ }^{35}$ War crimes may be perpetrated both in internal and international armed conflicts. ${ }^{36}$ The difference between war crimes on the one hand and genocide and crimes against humanity on the other, is that the perpetrator of a war crime does not have to be aware of the contextual element (i.e. the armed conflict). However, a link between crime and armed conflict must be established. ${ }^{37}$

All statutes subject to this research contain war crimes provisions. The IMT war crimes provision consists of a non-exhaustive list of war crimes and is based on the 1907 Hague Convention and Regulations and the 1929 Geneva Convention Relative to the Treatment of Prisoners of War. The IMTFE Statute contains a similar provision, however, without an explicit enumeration of crimes. The ICTY Statute contains two war crimes provisions. Article 2 reproduces and recombines grave breaches ${ }^{38}$ from the four Geneva Conventions and Additional Protocol I and is only applicable to international armed conflicts. ${ }^{39}$ Article 3 of the ICTY Statute is based on article 6(b) of the IMT Charter and produces a similar, but slightly different, non-exhaustive account of war crimes. This article is also applicable in case of internal armed conflicts. ${ }^{40}$ The ICTR Statute contains one war crimes provision: article 4. This article is based on common article 3 of the 1949 Geneva Conventions and article 4 of Additional Protocol II and thus applicable to internal

\footnotetext{
Cassese, A., 2008, p. 81.

Cassese, A., 2008, p. 82.

Cassese, A., 2008, p. 81.

Cassese, A., 2008, p. 82.
}

Grave breaches - such as "willful killing", "torture" or "compelling a prisoner of war or civilian to serve in the forces of a hostile power" - are the more serious violations of the law of Geneva. Contracting States must penalize these breaches in their own legislation. They are also obliged to bring the perpetrators of grave breaches before their own courts or to extradite them. By lack of jurisdictional rules on grave breaches, the relevant provisions of the Geneva law are often interpreted as allowing for universal jurisdiction (that is jurisdiction irrespective of the place of the act or the nationality of the perpetrator). See: Kalshoven, F. and Zegveld, L., Constraints on the Waging of War: An introduction to International Humanitarian Law, Third Edition, International Committee of the Red Cross, Geneva, 2001, p. 80. former Yugoslavia, Transnational Publishers Inc., Irvington-on Hudson, 1995, p. 54.

40 ICTY, Prosecutor v. Duško Tadić, Decision on the Defence Motion for Interlocutory Appeal on Jurisdiction, Appeals Chamber, 2 October 1995, par. 134. 
armed conflicts. The provision contains a non-exhaustive account of war crimes. The ICC Statute has the most extensive list of war crimes. Article 8 covers: the grave breaches of the 1949 Geneva Conventions, other serious violations of the laws and customs of both international and internal armed conflict and violations of common article 3 of the 1949 Geneva Conventions. In contrast to the ad hoc tribunals, the provision displays exhaustive lists of crimes.

\subsubsection{Aggression}

Aggression is different from other international crimes for it focuses on inter-state conflict. ${ }^{41}$ Essentially, the crime comes down to the use of armed force by a State against the sovereignty, territorial integrity or political independence of another State. ${ }^{42}$ In case of aggression there is no contextual element the defendant has to be aware of. Aggression can be found in article 6(a) of the IMT Charter and article 5(a) of the IMTFE Charter (crimes against peace) and in article 8bis of the ICC Statute. ${ }^{43}$ The ICC, however, will not be able to exercise jurisdiction over this crime until after 1 January 2017, when a decision is to be made by State Parties to activate jurisdiction. ${ }^{44}$ Aggression is not a crime under the statutes of the ICTY and ICTR.

Schematically, the crimes in the statutes subject to this research provide the following picture (" $\mathrm{X}$ " indicates that a particular type of crime is included by the statute of a specific court):

\begin{tabular}{|l|c|c|c|c|}
\hline & Genocide & $\begin{array}{l}\text { Crimes against } \\
\text { humanity }\end{array}$ & War Crimes & Aggression \\
\hline IMT & & $\mathrm{X}$ & $\mathrm{X}$ & $\mathrm{X}$ \\
\hline IMTFE & & $\mathrm{X}$ & $\mathrm{X}$ & $\mathrm{X}$ \\
\hline ICTY & $\mathrm{X}$ & $\mathrm{X}$ & $\mathrm{X}$ & \\
\hline ICTR & $\mathrm{X}$ & $\mathrm{X}$ & $\mathrm{X}$ & \\
\hline ICC & $\mathrm{X}$ & $\mathrm{X}$ & $\mathrm{X}$ & $\mathrm{X}^{*}$ \\
\hline
\end{tabular}

* After 1 January 2017.

$41 \quad$ Cryer, R., 2010, p. 320.

42 See possible future ICC provision, article 8 bis(2).

43 For a systematic study on the definition of the crime of aggression see: Kemp, G., Individual Criminal Liability for the International Crime of Aggression, Intersentia, Antwerp, 2010. 
Chapter I

\section{FuRTHER DELINEATION OF PRESENT RESEARCH}

Apart from defining the concepts of 'complete defenses' and 'international crimes' the previous Section has also indicated which complete defenses and international crimes fall within the scope of this study. The present Section further delineates the scope of this thesis by discussing the international courts subject to this study (4.1), the sources of law consulted (4.2), and the currency of the manuscript (4.3).

\subsection{International courts}

As can be gathered from the previous Sections, the research reflected in this thesis focuses on international criminal courts: the IMT, IMTFE, ICTY, ICTR and ICC. All these courts have been established by some sort of international agreement and apply predominantly ${ }^{45}$ international law. Their law mirrors the status of complete defenses in international criminal law in its purest form. National courts adjudicating international crimes and mixed courts - the Special Court for Sierra Leone (SCSL), the Extraordinary Chambers in the Courts of Cambodia (ECCC), the Special Panels for Serious Crimes within the District Court of Dili (SPSC) and the Special Tribunal for Lebanon (STL) - are left out of consideration. These courts adjudicate international crimes by mixing both domestic and international law through different structures. ${ }^{46}$ Therefore their statutes and judgments do not provide information on complete defenses from an exclusive international criminal law angle.

\subsection{Sources of international criminal law}

In order to answer the key question of this thesis, different sources of international criminal law were studied. The operative ad hoc tribunals (i.e., the ICTY and ICTR) and the ICC draw from slightly different sources of law. International criminal law literature generally accepts that tribunals draw from the general sources of international law ex article 38 of the Statute of the International Court of Justice (ICJ Statute), for international criminal law is a branch of international law. ${ }^{47}$ The ICC, however, has its own sources (article 21 ICC Statue).

This sub-Section first discusses the current sources of international criminal law. Section 4.2.1 is devoted to the sources available to the active ad hoc tribunals.

45 There are exceptions, see for example: article 24 of the ICTY Statute, which provides "In determining the terms of imprisonment, the Trial Chambers shall have recourse to the general practice regarding prison sentences in the courts of the former Yugoslavia" or article 21(1)(c) of the ICC Statute, which allows for consultation of "the national laws of States that would normally exercise jurisdiction over the crime".

46

47

Akande, D., 'Sources of International Criminal Law', In: Cassese, A. (ed.), The Oxford Companion to International Criminal Justice, Oxford University Press, 2009, pp. 41-53, p. 43; Bassiouni, M.C., 2003, pp. 2-4 and Herik, L. van, 2005, p. 274. 
Section 4.2.2. discusses the sources available to the ICC. Next, this Section reveals which sources have been employed to answer the key question of this thesis (4.2.3).

\subsubsection{Sources of the active ad hoc tribunals}

According to article 38 of the ICJ Statute, the sources of international (criminal) law are: treaties, custom, general principles of law and, as a subsidiary source, judicial decisions and the teachings of publicists. A brief explanation of each source is provided below.

\section{TREATIES}

Although the statutes of the ICTY and ICTR are technically not a treaty (they are UN Security Council Resolutions adopted under Chapter VII of the UN Charter, and thus decisions based upon treaties) they have been described as 'proximate in nature to a treaty'. ${ }^{48}$ Apart from statutes as a primary source of law, ${ }^{49}$ the tribunals take recourse to rules based upon statutes, such as Rules of Procedure and Evidence. In addition to their own statute and Rules, the tribunals may rely on other treaties. Some statute provisions directly refer to these treaties. For example, article 2 of the ICTY Statute refers to the 'grave breaches' of the 1949 Geneva Conventions and article 4 of the ICTR Statute refers to serious violations of Common Article 3 of these Conventions. Other treaties may also be applied by the tribunals, for example, human rights treaties for the interpretation of fair trial guarantees ${ }^{50}$ or the Geneva Conventions where they directly impose criminal responsibility on individuals. ${ }^{51}$ The relevance of a statute of a specific international court to another (e.g. the ICTR or ICC Statute 52 to the ICTY) is limited, since such a statute would not be applicable to the conflict at issue. It can however be a source of custom or principles or law. ${ }^{53}$

\section{Custom}

Customary law is defined by practice and opinio iuris of States. ${ }^{54}$ In the field of international criminal law, custom is usually deduced from both international and

\footnotetext{
48 ICTR, Prosecutor v. Kanyabashi, Appeals Chamber (Dissenting Opinion of Judge Shahabuddeen), 3 June 1999, par. 21. See also, Cassese, A., 2008, p. 16.

49 Akande, D., 2009, p. 44 and Cassese, A., 2008, p. 15.

50 Akande, D., 2009, p. 49.

51 Cryer, R., 2010, p. 10.

52 The ICC Statute is a treaty.

53 Cassese, A., 2008, p. 17.

54 ICJ, Columbia v. Peru (Asylum Case), Judgment, 20 November 1950, p. 266; ICJ, Fed. Rep. Of Germany v. Denmark and v. The Netherlands (North Sea Continental Shelf), Judgment, 20 February 1969, par. 70-78 and ICJ, Nicaragua v. U.S. (Military and Paramilitary activities in and against Nicaragua), Judgment, 27 June 1986, par. 183-186.
} 
domestic case law. ${ }^{55}$ However, other sources can be employed to determine custom as well, such as official behavior of states (e.g. legislative measures, declarations by representatives), treaties that are not binding on the parties to the conflict, decisions and practices of international organizations, comments of the International Law Commission or international scholarly associations, ${ }^{56}$ and ius cogens. ${ }^{57}$ Custom can be either relevant when referred to by the statute (e.g. the "laws or customs of war" ex article 3 of the ICTY Statute) or when the statute is silent on a certain matter, to fill a specific gap (as has happened, for example, in case of the doctrine of joint criminal enterprise). ${ }^{58}$

\section{General PRINCIPLES}

Another gap-filler are the general principles of law recognized by civilized nations. The clause refers to two types of principles:

- Principles which underlie the international system;

- Principles which are found in national legal systems and which can be transposed to the international realm. ${ }^{59}$

In a criminal law context, the first category presumably refers to the principles that govern the criminal law process (legality, equality of arms), while the second category refers to more specific rules (e.g. the exact definition of a specific crime or complete defense). ${ }^{60}$ In practice, the ICTY and ICTR have mainly resorted to the latter type of principles by studying national (case) law. ${ }^{61}$ For a domestic principle to be regarded as generally accepted it must be recognized by most legal systems, but not all. ${ }^{62}$ Generally, international tribunals have referred to principles, which they were familiar with (Western European and Anglo-Saxon systems), and omitted reference to systems that would represent a worldwide consensus (e.g. Arabic and African systems). ${ }^{63}$ Some principles may underlie both the international and the

Cassese, A., 2008, pp. 17/18.

Werle, G., 2005, pp. 46/47 and pp. 52/53.

Brownlie, I., Principles of Public International Law, Fifth Edition, Oxford University Press, 1998, p. 515.

Akande, D., 2009, p. 49/50 and Cassese, A., 2008, p. 19.

Bantekas, I. and Nash, S., 2007, p. 4.

Akande, D., 2009, p. 51; Raimondo, F.O., General Principles of Law in the Decisions of International Criminal Courts and Tribunals, Martinus Nijhoff Publishers, Leiden, 2008, p. 194. Cassese, A., 2008, p. 18.

Bantekas, I. And Nash, S., 2007, p. 4.

Raimondo, F.O., 2008, p. 194. What is more, the ICTY and ICTR generally do not clarify whether legal concepts are the same only in name or also in essence. See: Bantekas, I. And Nash, S., 2007, p. 5. 
national legal order. Also, the distinction between principles and custom is not always clear-cut, ${ }^{64}$ for they can be derived from similar sources. ${ }^{65}$

\section{JUDICIAL DECISIONS}

According to article 59 of the ICJ Statute judicial decisions have no binding force "except between the parties and in respect of that particular case". They are, however, mentioned by article 38 of the ICJ Statute as a secondary source of law. However, at the ICTY and ICTR - to an extent - the principle of stare decisis (i.e. to follow precedents established by prior decisions) is applied. The ICTY Appeals Chamber decided in Prosecutor v. Aleksovski that Trial Chambers are bound by Appeals Chamber's decisions and that the Appeals Chamber may only depart from its own previous decisions for cogent reasons. In addition, the Appeals Chamber in the same case held that Trial Chambers are free to follow the decision of another Trial Chamber, but are not bound by it. ${ }^{66}$ Practice at the ICTR demonstrates that ICTR Trial Chambers usually follow the Appeals Chamber. ${ }^{67}$ Finally, international tribunals can also refer to case law other than their own as a source of law. ${ }^{68}$ These would then qualify as judicial decisions in the sense of article 38 of the ICJ Statute (a secondary source of law) or as sources of custom or principles of law. ${ }^{69}$

\section{PuBlicists}

As a final secondary source of law, article 38 of the ICJ Statute mentions teachings of the most highly qualified publicists of the various nations. These can be, for example, analyses of the existing law or de lege ferenda proposals. ${ }^{70}$

\section{HIERARCHY}

According to international law literature there is no strict hierarchy of sources ex article 38 (except for that between primary and secondary sources). ${ }^{71}$ However, in international criminal law a certain hierarchy has been established both by doctrine and in case law. According to this hierarchy, tribunals should first look at their own

\footnotetext{
64 Werle, G., 2005, p. 48. See also Raimondo, F.O., 2008, pp. 99/100 providing an example of the ICTY Trial Chamber failing to distinguish between general principles of law and customary law.

65 Cassese, A., 2008, pp. 17/18.

66 ICTY, Prosecutor v. Aleksovski, Appeals Chamber, 24 March 2000, par. 92-115.

67 Herik, L. van, 2005, p. 61.

68 Cryer, R., 2010, p. 12.

69 Akande, D., 2009, p. 53.

70 Bassiouni, M.C., 2003, p. 6 and Knoops, G.A., Defences in Contemporary International Criminal Law, Transnational Publishers Inc., Ardsley, 2001, p. 116.

71 Malanczuk, P., Akehurst's Modern Introduction to International Law, Seventh Edition, Routledge, London, 1997, p. 56/57.
} 
statutes, ${ }^{72}$ then at treaties and custom, next at general principles, and finally at the secondary sources of international law (judicial decisions and doctrine). ${ }^{73}$

\subsubsection{Article 21 of the ICC Statute}

The ICC Statute has its own provision (article 21) considering the law to be applied. Contrary to the ICJ provision, article 21 of the ICC Statute does contain an explicit order of preference. In the first place, the ICC shall not only apply its Statute and its Rules of Procedure and Evidence (RPE), but - and this is a difference with the operative ad hoc tribunals - also its Elements of Crimes. These Elements of Crimes contain elaborate definitions of the crimes over which the ICC has jurisdiction and are intended to "assist the Court in the interpretation and application of the provisions of Article 6, 7 and 8"74 (i.e. the crimes contained in the Statute). Article 9(3) and article 51(5) of the ICC Statute establish that in case of inconsistency between the Statute and the two other instruments the Statute prevails.

Paragraph 1(b) of article 21 refers to secondary sources of law: applicable treaties; principles of international law including the established principles of international armed conflict; and rules of international law. "Applicable treaties" probably refers to the international agreements that are binding on the states that could have jurisdiction over the offense. ${ }^{75}$ More confusing is the clause "principles and rules of international law". As opposed to paragraph (c) (discussed below), the principles ex paragraph (b) are not defined. This probably means that paragraph (b) refers to the principles not referred to in (c): principles of international law that are not derived from national laws, i.e. the principles of law, which underlie the international legal system (discussed above). The word, "rules" is probably an awkward reference to customary law. ${ }^{76}$ Note that statutes ${ }^{77}$ and judgments ${ }^{78}$ of ad hoc tribunals (e.g. the IMT) can be sources of custom or of principles of law to the ICC. Finally, in relation to the principles of armed conflict it is not clear to which principles article 21(1)(b)

72 Akande, D., 2009, p. 44 and Cassese, A., 2008, p. 15.

73 ICTY, Prosecutor v. Kupreškić et al., Trial Chamber, 14 January 2000, par. 540; ICTY, Prosecutor v. Mucić et al., Appeals Chamber, 20 February 2001, par. 583; Cassese, A., 2008, p. 15 (According to Cassese a court should first look at general principles of international (criminal) law, and next at general principles of national law) and Knoops, G.J., 2001, p. 13.

74 Article 9 ICC Statute.

75 McAuliffe deGuzman, M., 'Applicable Law', In: Triffterer, O. (ed.), Commentary on the Rome Statute of the International Criminal Court: Observers' Notes, Article by Article, Hart Publishing, Oxford, 2008, pp. 701-712, p. 706.

76 McAuliffe deGuzman, M., 2008, p. 706.

77 Cassese, A., 2008, p. 17.

78 Akande, D., 2009, p. 53 and Nerlich, V., 'The Status of the ICTY and ICTR Precedent in Proceedings Before the ICC', In: Stahn, C. and Sluiter, G. (Eds.), The Emerging Practice of the International Criminal Court, Martinus Nijhoff Publishers, Leiden, 2009, pp. 305-325, pp. $324 / 325$. 
refers. If it refers to other principles than the ones laid out in article 8 of the ICC Statute, there may be a problem with nullum crimen sine lege. ${ }^{79}$

Paragraph (c) functions as a safety net, in case the sources ex (a) and (b) are of no avail. In this case the Court can derive general principles of law from national laws of legal systems of the world, including the national laws of States that would normally exercise jurisdiction over the crime. As to the methods of comparative legal analysis, article 21 (1)(c) does not set a standard. However, an applicable legal principle probably need not be accepted unanimously by all the legal systems in the world. ${ }^{80}$

Paragraph 21 (2) allows for a discretionary use of precedent, which means there is no stare decisis obligation as applied by the ad hoc tribunals. ${ }^{81}$ Essentially, paragraph 2 reflects a compromise between common law (stare decisis) and civil law (where judicial decisions are only binding between parties in a specific case) ${ }^{82}$

Finally, paragraph (3) demands the Court to apply and interpret the law consistent with internationally recognized human rights. This means that ICC judges can refuse to apply a rule, even a statutory rule, in case of inconsistency with human rights norms. ${ }^{83}$

Although article 38 of the ICJ Statute and article 21 of the ICC Statute are quite similar, there are some remarkable differences between these articles and thus between the ad hoc tribunals on the one hand and the ICC on the other:

- Contrary to the ad hoc tribunals, the ICC Statute and its Elements of Crimes contain very detailed descriptions. Considering these detailed descriptions recourse to principles and custom will probably be less of an issue at the ICC. ${ }^{84}$

- The ICC does not employ a doctrine of stare decisis as opposed to the operative ad hoc tribunals.

- The ICC Statute does not mention doctrine as a source of law.

\subsubsection{Sources of international criminal law included in this research}

For the purpose of this thesis sources have been studied that are directly linked to the international criminal courts subject to this research - i.e. statutes, secondary sources based upon statutes and judgments. Due to this latter restriction (judgments only) it is very well possible that more complete defenses have been brought up/ discussed, than the ones analyzed in this thesis. For example, complete defenses in

\footnotetext{
79 McAuliffe deGuzman, M., 2008, p. 707.

80 Bantekas, I. and Nash, S., 2007, p. 4 and McAuliffe deGuzman, M., 2008, p. 708.

81 Cryer, R., 2010, p. 12.

82 McAuliffe deGuzman, M., 2008, p. 711.

83 Bitti, G., 'Article 21 of the ICC and the Treatment of Sources of Law in the Jurisprudence of the ICC', In: The Emerging Practice of the International Criminal Court, Stahn, C. and Sluiter, G. (Eds.), Martinus Nijhoff Publishers, Leiden, 2009, pp. 285-304, p. 304.

Akande, D., 2009, p. 50.
} 
Defense pleas, which the relevant court did not discuss and debates on complete defenses in pre-trial decisions. Although these sources of international criminal law are not officially included in the systematic set up of this research, they are occasionally referred to when relevant.

The choice to limit the research to the above-mentioned sources of international criminal law is motivated by the fact that several extensive previous studies have approached the topic of complete defenses from a mainly comparative law angle. ${ }^{85}$ This study does not aim to portray all possible complete defenses in international criminal law that can be induced from domestic law. Almost 20 years have gone by since international criminal law moved into the new era of contemporary ad hoc tribunals and the ICC. Therefore I believe the time has come to generate an overview of the rules on complete defenses produced by international criminal justice as an autonomous field of law. As a result, the core (Part II) of this research consists of an analysis of the (fragments of) judgments of international courts discussing complete defenses. This overview hopes to reveal patterns upon which recommendations can be made, relevant to the future of international criminal justice and the law of complete defenses in particular.

\subsection{Currency of the manuscript}

This research covers judgments produced by international courts and relevant (legal) documents existing before 1 January 2013. Later developments have been included only in part.

\section{STRUCTURe AND METHOD}

The key research question of this thesis How, if at all, should complete defenses be available in case of international crimes? consists of two separate questions:

a. Should complete defenses be available in case of international crimes? And, if this question is answered in the positive:

b. How should complete defenses be available in case of international crimes?

In order to answer the first question (a), the current status of complete defenses must be explored. First the concept of complete defenses is defined more precisely. This is done in the following chapters of Part I of this thesis. The central research question of this Part is What are complete defenses, both in a substantive and in a procedural sense? Next the practice of complete defenses is studied. The central question of Part II is therefore Which complete defenses have featured in the

85 Blomsma, J., 2012; Sliedregt, E. van, 2012; Knoops, G.J., 2001 and Nill-Theobald, C., "Defences" bei Kriegsverbrechen am Beispiel Deutschlands und der USA, Iuscrim, Freiburg im Breisgau, 1998. 
statutes and case law of international criminal courts? The central question of Part III of this book is Is the current practice of complete defenses desirable or is a different approach recommended? The first Chapter of Part III provides an overview of arguments pro and contra complete defenses in international criminal law. This overview results in a positive answer to question (a). In order to answer question (b) the current status of complete defenses must be evaluated. This evaluation is the starting point for several recommendations in the concluding part of this book.

The structure and research method of the three Parts of this thesis are elaborately discussed below.

\section{Part I A theory of Complete defenses}

Central question: What are complete defenses, both in a substantive and in a procedural sense?

The remains of Part I elaborate on the different definitions of complete defenses. The focus is on the relationship between the basic requirements for criminal liability and complete defenses: how does the presence of a complete defense influence the general requirements for criminal liability? Also procedural aspects of complete defenses are examined. Up for discussion are the rules related to grounds stated in judgments and the rules considering the relevant burden and standard of proof for complete defenses.

\section{METHOD}

The findings on substantive law in this Part are based on information available in international criminal law handbooks. The choice to focus on international criminal law (and not comparative criminal law) has been discussed in Section 4.2.2. The procedural part of this Chapter is mostly based on legal texts (mainly Rules of Procedure and Evidence of international courts) and case law, because little information on the procedural aspects of complete defenses is available in international criminal law literature. The purpose of this part is to quickly canvas the law relevant to complete defenses in international criminal law. A more thorough evaluation of several topical discussions in the field of complete defenses is provided for in Part III (Recommendations).

\section{Part II Complete defenses in PRACTICE}

Central question: Which complete defenses have featured in the statutes and case law of international criminal courts? 
Part II addresses the complete defenses that have featured in the statutes (and secondary sources) and case law of international criminal courts. It discusses (a) which complete defenses came up at the institutions subject to this research, (b) how international courts have reacted to these complete defenses and (c) what can be said about their reaction.

\section{METHOD}

In order to assess point (a)-(c) I have designed a list of questions that is applied to every complete defense mentioned at the courts subject to this research. This list contains questions such as "Was the defense recognized?" and "What are the requirements of the defense?". The analysis at the end of Part II is based upon the answers to these questions. The core (Part II) of this research thus consists of an analysis of primary sources (international criminal (case) law) through inductive method. Secondary sources (literature, comments) are mainly discussed in Part I and Part III.

The questionnaire ex Part II is applied to the following defenses: self-defense, consent, insanity, intoxication, mistake, superior orders, necessity/duress, lawful belligerent reprisals and tu quoque. Information on complete defenses at the IMT is gathered from the IMT Charter, ${ }^{86}$ its Rules of Procedure ${ }^{87}$ and its Judgment, ${ }^{88}$ a single document containing the different verdicts on all defendants. Information on complete defenses at the IMTFE is gathered from the IMTFE Charter, ${ }^{89}$ its Rules of Procedure ${ }^{90}$ and its Judgment, ${ }^{91}$ again a single document, containing the different verdicts on all defendants. Information on complete defenses at the ICTY is gathered from the ICTY Statute, its Rules of Procedure and Evidence and the ICTY judgments. ${ }^{92}$ Information on complete defenses at the ICTR is gathered from equivalent sources: the ICTR Statute, its Rules of Procedure and Evidence and the ICTR judgments. ${ }^{93}$ Contrary to the ad hoc tribunals, the ICC Statute contains a catalogue of complete defenses. Other legal sources containing information on complete defenses at the ICC are the Rules of Procedure and Evidence and the

86 Http://avalon.law.yale.edu/imt/imtconst.asp (January 2012).

87 Http://avalon.law.yale.edu/imt/imtrules.asp (January 2012).

88 International Military Tribunal (Nuremberg), Judgment and Sentences, 1 October 1946. In: American Journal of International Law, vol. 41, 1947.

89 Https://www.wcl.american.edu/warcrimes/wcro_docs/collections/imt/IMT(FE)_-

Nuremberg_\&_Far_East_Tribunals/IMTFE_Charter_\&_Rules/(January 2012).

90 Www.wcl.american.edu/warcrimes/wcro_docs/collections/imt/IMT(FE)_-_Nuremberg_\&_Far_ East_Tribunals/IMTFE_Charter_\&_Rules/(January 2012).

91 Röling and Rüter (Eds.), The Tokyo Judgment: The International Military Tribunal of the Far East (I.M.T.F.E.), 29 April 1946 - 12 November 1948, vol. I and II, University Press Amsterdam BV, Amsterdam, 1977.

92 All of which can be found at the website of the ICTY: www.icty.org (January 2012).

93 All of which can be found at the website of the ICTR: www.ictr.org (January 2012). 
Elements of Crimes. ${ }^{94}$ Since the ICC had produced few judgments by January 2013 featuring complete defenses, Comments on the ICC Statute by several authors are studied to elucidate the ICC provisions.

\section{Part III Recommendations}

Central question: Is the current practice on complete defenses desirable or is a different approach recommended?

Whether and how complete defenses should be applied in case of international crimes is discussed in the final part of this book. First an overview is provided of all arguments in favor of and against the availability of complete defenses in international criminal law. Upon finding that complete defenses must be available in international criminal law, the question is discussed whether the current practice concerning complete defenses is a desirable one. This question is answered in the negative. Subsequently an alternative system of complete defenses is presented in outline. Finally, recommendations are formulated for each specific defense featuring in Part II of this thesis. These recommendations result in a proposal for a revised complete defenses provision in the ICC Statute.

\section{METHOD}

The recommendations in Part III are based on the research results of the previous Chapters and (international) criminal law literature. My recommendations heavily lean on the principle of individual criminal responsibility. The definition and rationale of the principle of individual criminal responsibility is addressed in Chapter II, Section 2.1. The relevance of this principle to international criminal law is argued in Chapter XIII, Section 2.2. Part III does not provide a general overview of (international) criminal law doctrine on complete defenses, as this has been excellently done elsewhere, ${ }^{95}$ but only refers to the discussions relevant to support the recommendations contained in the final part of this book. In order to illustrate the positions argued, numerous examples are employed throughout this book. I have taken examples from international criminal law when possible and functional. However, in cases where international criminal law examples are unnecessarily complicating, I employ quick and simple domestic law examples. 



\section{Chapter II \\ A THEORETICAL BACKGROUND \\ ON COMPLETE DEFENSES}

\section{INTRODUCTION}

"I did it, but don't think I should be punished". That is what a complete substantive defense (hereinafter 'complete defense') comes down to. ${ }^{96}$ However, what does this statement mean in a technical legal sense: what exactly must a defendant have done and how does he substantiate that he should not be punished? The first part of this Chapter addresses these questions by providing a theoretical foundation of complete defenses. Procedural aspects of complete defenses are addressed in the second part of this Chapter. The central question of this Chapter can therefore be put as What is a complete defense, both in a substantive and procedural sense? This question must be addressed in order to make a conclusive statement on the key question of this thesis How, if at all, should complete defenses be available in case of international crimes?

In addition to defining the concept of complete defenses, the purpose of this Chapter is to outline legal concepts related to complete defenses, such as 'objective element' and 'blameworthiness'. Defining such concepts is necessary in order to have a frame of reference for the analysis of case law in the following Chapters.

General requirements for criminal liability - the objective and the subjective element - are described in Section 2. In relation to the subjective element, the definitional subjective element (intent, negligence etc.) and the concept of blameworthiness are addressed. The nexus between the requirements for criminal liability and complete defenses is put down in Section 3. Generally there are two theories that describe this relationship: 'confession and avoidance' (3.1) and 'negation of the subjective element' (3.2). Section 4 discusses the categorization of complete defenses in justifications and excuses, a distinction more common to international criminal theory than practice. Section 5 addresses procedural aspects related to complete defenses: rules considering grounds stated in judgments (5.1) and considering the relevant burden and standard of proof (5.2). Finally, Section 6 answers the key question of this Chapter What is a complete defense, both in a substantive and in a procedural sense? by concluding that it is impossible to provide for a uniform definition of complete defenses. The reason for this is the existence of different theories in international criminal literature related to the subject matter. This variety of theories, again, is probably caused by the fact that different species of complete defenses do exist. Through combining different theories, three different types of complete defenses can be distinguished. 
Chapter II

\section{2. “I DID IT": THE GENERAL REQUIREMENTS FOR CRIMINAL LIABILITY}

When elucidating the statement "I did it, but I don't think I should be punished", the "I did it" part is up for analysis first. What does the defendant acknowledge by this statement? That he fulfilled all requirements for criminal liability or only some of them? In order to answer these questions, the general requirements for criminal liability in international criminal law must be explained first.

\subsection{General requirements for criminal liability}

When is a State entitled to punish its subjects? In case its subjects break the law, seems to be the obvious answer. Legal theory on this matter, however, is slightly subtler. National legal systems tend to distinguish between two cumulative conditions as general requirements for criminal responsibility. ${ }^{97}$ An objective element, being the criminal conduct and a subjective element, which refers to the culpable state of mind of the defendant. For example, the crime of stealing has been perpetrated when a) a book is stolen (criminal conduct) and b) the defendant meant to steal the book (culpable state of mind). If a defendant is convicted without these two elements being present, this generally amounts to a violation of the principle of individual criminal responsibility.

The principle of individual criminal responsibility is founded on some of the purposes of criminal law (i.e. deterrence, retribution, and rehabilitation). ${ }^{98}$ The idea behind the principle is that when either the objective or the subjective element is absent (or both), the defendant could not have controlled the criminal behavior. Therefore it would be both morally wrong ${ }^{99}$ and ineffective ${ }^{100}$ to punish him. For, if a defendant had no control over a situation one could not have guided his conduct by imposing punishment. Under such circumstances the deterrent effect of punishment is absent. In addition, it would not be fair to punish a person who had no control over the criminal act that occurred. Retribution would thus be out of place. Finally, what is there to rehabilitate if the defendant behaved, as any person with no control would have done?

The conditions of an objective and a subjective element thus prevent a defendant from being convicted when he had no control over the situation. It is therefore not

97 Cassese, A., 2008, p. 53. That is, the two elements have to be present. Some legal cultures employ a different categorization, see: Sliedregt, E. van, The Criminal Responsibility of Individuals for Violations of International Humanitarian Law, T.M.C. Asser Press, 2003, p. 5/6. For a slightly different view see: Fletcher, G.P., The Grammar of Criminal Law: American, Comparative and International. Volume One: Foundations, Oxford University Press, 2007, p. 295.

98 Cryer, R. et al., 2010, pp. 22-30.

99 According to categorical moral reasoning. See: Kant, I., Grundlegung zur Metaphysik der Sitten (1785), Heimann, Berlin, 1870.

100 According to consequentialist moral reasoning. See, for example: Bentham, J., An Introduction to the Principles of Morals and Legislation (1789), Hafner Publishing, New York, 1948. 
surprising that this classical dichotomy appears to have been sustained in international criminal legal theory. ${ }^{101,102}$ However, even though doctrine seems to agree on the fact that a crime consists of an objective and a subjective element, authors hold different opinions as to the exact definition of these elements.

\subsubsection{Objective element}

The objective element - often referred to as actus reus (culpable act) or material element - is usually defined as 'conduct contrary to international criminal law'. 103 Some definitions are more specific and hold that the objective element does not only cover conduct, but also its consequences and the circumstances under which the conduct takes place ${ }^{104}$ or stress that the actus reus refers to the external elements of the offense (while the subjective element, in contrast, refers to the internal elements). ${ }^{105}$ The exact scope of this conduct, its consequences and the relevant circumstances, can be derived from the definitions of international crimes. ${ }^{106}$ Often, however, not the entire definition qualifies as objective element: the objective element needs to be filtered out. For example, it is a war crime to intentionally direct attacks against the civilian population. ${ }^{107}$ The conduct contrary to international criminal law (objective element) in this definition would be to "direct attacks against the civilian population". The word "intentionally" refers to the subjective element (see Section 2.1.2).

Bantekas and Nash define the objective element as "a physical act."108 This characterization, however, undermines the reality of international criminal liability, which can also be incurred for omissions. ${ }^{109}$

101 See for example: Bantekas, I. and Nash, S., 2007, p. 51; Cassese, A., 2008, p. 53; Cryer, R., et al., 2007, p. 301 et seq.; Dinstein, Y., 'Defences', In: Kirk McDonald, G. (ed.), Substantive and Procedural Aspects of International Criminal Law, Kluwer International, The Hague, 2000, pp. 371-388, p. 371; Francisco Francisco, M.I., Aspects of Implementing the Culpability Principle both under National and International Criminal Law, Wolf Legal Publishers, Nijmegen, 2003, p. 35; Knoops, G.J., 2001, p. 29; Than, C. de and Shorts, E., International Criminal Law and Human Rights, Sweet \& Maxwell, London, 2003, p. 3 and Werle, G., 2005, p. 101.

102 There are no crimes of strict liability in international criminal law, i.e. crimes for which no subjective element needs to be proved, see: Than, C. de and Shorts, E., 2003, p. 3 and Francisco Francisco, M.I., 2003, p. 44.

103 Cassese, A., 2008, p. 53 and Than C. de, and Shorts E., 2003, p. 3.

104 Werle. G., 2005, p. 95.

105 Vallini, A., 'Mens Rea', In: Cassese, A. (ed.), The Oxford Companion to International Criminal Justice, Oxford University Press, 2009, pp. 412-415, p. 412.

106 See Introduction, Section 3.2.

107 Art. 8 par. 2(b)(i) ICC Statute.

108 Bantekas, I. and Nash, S., 2007, p. 51.

109 Daqun, L., 'Actus Reus', In: Cassese, A. (ed.), The Oxford Companion to International Criminal Justice, Oxford University Press, 2009, pp. 229/230. See, for example, art. 28 ICC Statute, under which a commander can be held responsible for crimes committed by his subordinates. 
An issue frequently addressed in handbooks on national criminal law is whether the objective element has to be voluntary or merely a physical movement. ${ }^{110}$ The relevance of this issue is best shown through an example:

$X$ throws $Y$ from the roof of a five-story building. Y lands on Z. Z dies.

How should the role of $\mathrm{Y}$ be appreciated? If the objective element was fulfilled by the presence of physical movement, the objective element can be established, for $\mathrm{Y}$ is moved from the roof to $\mathrm{Z}$. However if the objective element required voluntary conduct, no objective element could be established, for $\mathrm{Y}$ was merely a tool in the hands of $\mathrm{X}$ and did not behave voluntarily. The distinction is one of categorization and does not have any practical implications. In neither situation would $\mathrm{Y}$ be criminally responsible: in the second case the objective element is lacking and in the first case the subjective element (culpable state of mind) cannot be proved. ${ }^{111}$ The discussion whether conduct needs to be voluntary in order to fulfill the objective element has so far not been an issue in international criminal law literature.

In short, the objective element in international criminal law refers to the criminal conduct of the defendant. It encompasses both acts and omissions and it is not clear whether this objective element requires voluntary behavior.

\subsubsection{Subjective element}

In order to incur responsibility for an international crime, the presence of prohibited conduct is not sufficient. A subjective element - frequently referred to as mens rea (guilty mind) or mental element - is also required. This subjective element sets a standard for the personal guilt of the defendant. Looking at the example of a war crime in the previous paragraph (to intentionally direct attacks against the civilian population), the required standard for personal guilt (subjective element) in this definition would be to perform this act intentionally.

This example is rather simplified. Not every international criminal law provision explicitly mentions the subjective element ${ }^{112}$ and even if it does, different ideas exist on whether the element mentioned - such as "intentionally" - covers the whole subjective element. Some authors hold that the definitional subjective element (e.g. intent, negligence) ${ }^{113}$ does not suffice in order to fulfill the subjective element, and

110 Ashworth, A., Principles of Criminal Law, Sixth Edition, Oxford University Press, 2009, p. 87 and Fletcher, G.P., 2007, pp. 273-285. Fletcher himself holds that the requirement of action blurs into the requirement of voluntary action and in turn into the element of mens rea and culpability (p. 287).

111 See Section 2.1.2.

112 Cassese, A., 2008, p. 56. In which case the court defines the required mens rea, see: Sliedregt, E. van, 2012, p. 50.

113 The term "definitional element" is rather confusing since, in international criminal law, this element is not always part of the statutory definition. However, lacking a better alternative, the term will be used throughout this dissertation. 
that an additional condition is required. This view can be brought back to the existence of two different theories on the subjective element that are represented in literature on criminal law: the psychological and the normative theory. ${ }^{114}$ According to the psychological theory, the subjective element is restricted to the definitional subjective element. ${ }^{115}$ From the perspective of this theory, the subjective element of the war crime "to intentionally direct attacks against the civilian population", would be 'intent'. The normative theory puts the definitional subjective elements in a larger context by requiring an extra - normative - condition for the fulfillment of the mental element in the form of culpability or blameworthiness. ${ }^{116}$ Regarding the war crime example, this means that the subjective element of this crime could be described as 'intent plus blameworthiness'.

At this point the distinction between the psychological and the normative theory, and the difference between 'definitional subjective element' and 'blameworthiness' seems rather abstract. The following pages are devoted to explicating both the definitional subjective element and the concept of blameworthiness.

\section{Definitional SUbJeCtive ELEMENT}

The definitional subjective element is the part of the definition of a crime that contains information on the state of mind of the defendant. More precisely, the definitional subjective element reflects the state of mind necessary to incur criminal responsibility for performing the conduct described in the objective element. Returning to the example above, committing the objective element of "directing attacks against the civilian population" incurs criminal responsibility when this is done with "intent" (definitional subjective element).

Since crimes are not always committed with the same state of mind, the definitional subjective element can be reflected in various forms, each representing a different level of culpability. ${ }^{117}$ The definitional subjective elements common to international criminal law are: intent - which is defined in a broad sense, including dolus eventualis or recklessness -, special intent, knowledge and negligence. Due to the different sources of international criminal law ${ }^{118}$ different terms (e.g. willfully, wantonly) can refer to the same definitional subjective elements, some of which still need to be defined in case law. ${ }^{119}$

\footnotetext{
114 Fletcher, G.P., 2007, pp. 307-329 and Bassiouni, M.C., 2003, p. 281.

115 Than, C. de and Shorts, E., 2003, p. 3 and Werle, G., 2005, p. 95.

116 See for example: Badar, M.E., 'Rethinking Mens Rea in the Jurisprudence of the International Criminal Tribunals for the Former Yugoslavia and Rwanda'. In: Olusanya, O. (ed.), Rethinking International Criminal Law: The Substantive Part, Europa Law Publishing, Groningen, 2007, pp. 13-33, p. 32 and Knoops, G.J., 2001, pp. 10 and 63/64.

117 This is contested by G.P. Fletcher in, for example, Fletcher, G.P., Basic Concepts of Criminal Law, Oxford University Press, 1998, p. 116.

118 See Introduction.

119 Werle, G., 2005, pp. 106/107.
} 
The definitional subjective elements common to international criminal law with the exception of knowledge - are determined by both cognitive (Did the defendant have knowledge of the objective element?) and volitional (Did the defendant desire to materialize the objective element?) components, which vary for each definitional subjective element. ${ }^{120}$ The definitional subjective elements common to international criminal law are discussed below.

\section{INTENT}

When the definitional subjective element is intent, the perpetrator wishes (volitional aspect) to cause the prohibited result and he is aware (cognitive aspect) that by engaging in certain conduct he will bring about this result. ${ }^{121}$ In reference to the previously cited war crimes example, this means, that a perpetrator intended his action when, for instance, he wants to direct attacks against the civilian population and knows that throwing a bomb on a village will have the desired result.

International courts have stretched the meaning of intent to what is known - in the civil law world - as dolus eventualis: the perpetrator is aware (cognitive aspect) that his conduct will most likely lead to the prohibited result, but he willingly (volitional aspect) takes that risk. ${ }^{122}$ This would be the case, for example, when a perpetrator wants to destroy a military target, but knows that this will most likely kill several civilians. However, despite this knowledge, he willingly takes the risk. International courts frequently apply the dolus eventualis standard. ${ }^{123}$ According to case law, the concept of dolus eventualis and the common law concept of recklessness meet the same criteria. ${ }^{124,125}$ Most international crimes require some form of intent as definitional subjective element. ${ }^{126}$

\section{SPECIAL INTENT}

As pointed out in the Introduction to this thesis, many international core crimes require not only a subjective element for the underlying offense but also a subjective element in relation to the violent context of the crime. For example in case of

\footnotetext{
120 Badar, M.E., 2007, p. 32 and Eser, A., 'Mental Elements - Mistake of Fact and Mistake of Law', In: Cassese, A. et al. (eds.), The Rome Statute of the ICC: A Commentary, Oxford University Press, Vol. 1, 2002, pp. 889-948, p. 905.

121 Cassese, A., 2008, p. 60.

122 Cassese, A., 2008, p. 66 and Sliedregt, E. van, 2012, p. 51.

123 Werle, G., p. 2005, p. 116.

124 Werle, G., p. 2005, p. 115.

125 This view may be contrary to comparative legal theory. See, for example, Fletcher, who holds that the concept of dolus eventualis, where the actor is aware of a certain risk, but is indifferent/ reconciled to this risk differs from the concept of recklessness, which requires an affirmative aversion to the harmful side effect. Fletcher, G.P., Rethinking Criminal Law, Little, Brown and Co., Boston, 1978, pp. 445/446.

Cassese, A., 2008, p. 60.
} 
genocide, not only the intent to commit an underlying offense is required (e.g. killing), but also the intent to destroy - in whole or in part - a national, ethnical, racial or religious group. Intent is thus required in addition to the intent for the underlying offense. This is called special intent, double intent or dolus specialis. Special intent does probably not extend to dolus eventualis. ${ }^{127}$

\section{KNOWLEDGE}

The status of 'knowledge' in international criminal law is somewhat confusing. The reason for this is that the function of 'knowledge' is ambiguous in domestic criminal law. In civil law traditions knowledge is absorbed - as the cognitive aspect - by the concept of 'intent'. In common law systems the status of 'knowledge' - and its relation to 'intent' - is not entirely clear. Sometimes 'knowledge' is presented in conjunction with intent as a separate requirement, ${ }^{128}$ on other occasions it is - as in civil law - covered by 'intent'. ${ }^{129}$ The problem seems to be one of categorization, since the knowledge requirement is covered either way. ${ }^{130}$ Both versions of knowledge (i.e. as part of intent and in conjunction with intent) are upheld in international criminal law. ${ }^{131}$ An example of 'knowledge' in conjunction with intent can be found in article 30 paragraph 1 of the ICC Statute, which requires the material elements of a crime to be committed with "intent and knowledge". An example of 'knowledge' as part of 'intent' can be found in this ICTR definition: "The result is intended when it is the actor's purpose, or the actor is aware that it will occur in the ordinary course of events." 132

Apart from knowledge in conjunction with - or absorbed by - intent, a third notion of knowledge is common to international criminal law. This notion of knowledge stands on its own. It is disconnected from intent and related to the specific character of international crimes. ${ }^{133}$ An example of this type of knowledge can be found in the definition of crimes against humanity. ${ }^{134}$ In addition to the intent required for the underlying offense (e.g. murder), the perpetrator needs to have knowledge of the factual circumstances (i.e., that this murder is part of a widespread or systematic attack directed against a civilian population). The perpetrator, thus, does not have to intend this attack, or to be aware that his conduct will most likely lead to an attack, but willingly taking that risk. He merely has to know about the attack. ${ }^{135}$

\footnotetext{
127 ICTY, Prosecutor v. Krstić, Trial Chamber, 2 August 2001, par. 571. See also Cassese, who argues that dolus specialis and dolus eventualis are incompatible: Cassese, A., 2008, p. 137. This is, however, not clearly established in case law. See: Zahar, A. and Sluiter, G., 2008, p. 163.

128 Cassese, A., 2008, p. 62.

129 Eser, A., 2002, pp. 906/907.

130 Cassese, A., 2008, p. 62.

131 Cassese, A., 2008, p. 63.

132 ICTR, Prosecutor v. Kayishema and Ruzindana, Judgment, 21 May 1999, par. 139.

133 See Introduction.

134 See, for example, article 7(1) of the ICC Statute.

135 Cassese, A., 2008, pp. 62/63 and 64/65.
} 


\section{NEGLigENCE}

When the definitional subjective element amounts to negligence, the perpetrator is aware that his conduct incorporates a risk of harm, but believes that this risk will not materialize (cognitive aspect) and acts anyway (volitional aspect). ${ }^{136}$ When this behavior of the perpetrator falls short of a reasonable person standard (could and should ${ }^{137}$ an average reasonable person have acted in the same way?), his conduct is negligent. Negligence is the least degree of culpability. Usually a higher degree of culpability is required in case of international crimes. ${ }^{138}$ Negligence is, however, required in case of superior responsibility (i.e. responsibility by superiors), where, for example, a superior can incur criminal responsibility when he should have known that his forces were committing crimes and he failed to take the necessary measures. ${ }^{139,} 140$ The mental state of simple negligence (the defendant is not aware of risk but should have been) does not seem to operate as a standard of liability in international criminal law. ${ }^{141}$

\section{BLAMEWORTHINESS}

As mentioned above, some authors put the definitional subjective element in a larger context by requiring an extra condition for the presence of a subjective element or for criminal liability in general: a normative condition in the form of culpability ${ }^{142}$ or blameworthiness. An example may clarify why more than a definitional subjective element may be necessary in order to establish the presence of a subjective element:

A commander forces a soldier at gunpoint to kill a civilian. This commander has just shot a fellow combatant, who refused to kill the very same civilian. What is more, the superior threatens that if the soldier does not obey he will not only kill him, but also his friend standing next to him. If the soldier kills the civilian, his act would qualify as "willful killing" under the 1949 Geneva Conventions. He killed a person (objective element), and he willfully did so (definitional subjective element), because he wanted to save himself and his friend. However, although the soldier fulfilled

136

The volitional aspect is embedded in the fact that the perpetrator also has the choice not to take the risk.

'Could' referring to the blameworthiness of the actor and 'should' to the wrongfulness of the act.

Cassese, A., 2008, p. 70.

See article 28 of the ICC Statute.

Cassese, A., 2008, pp. 70-73; Vallini, A., 2009, p. 413. For the different levels of the definitional subjective element in international criminal law, see also: Sliedregt, E. van, 2012, p. 52.

Cassese, A., 2008, p. 70.

This terminology is, however, confusing, since the definitional subjective element is often referred to in terms of culpa (i.e. degrees of culpability). Therefore, in this thesis, culpability in the blameworthiness-sense, will be referred to as blameworthiness. 
both the objective and the definitional subjective element of the crime, common sense says that he cannot really be blamed for what he did.

This is where the concept of blameworthiness enters the arena. However, although authors hint at this requirement, little has been theorized on the subject of blameworthiness in the field of international criminal law. There is no standard definition of the concept. It has so far been defined as the ability to choose, ${ }^{143}$ not doing what any reasonable person would have done ${ }^{144}$ and as the freedom of will, mental capacity or knowledge of law. ${ }^{145}$ In reference to the example above, one could say that according to these definitions the soldier is not blameworthy because he did not have the ability to choose, did exactly what any reasonable person would have done or lacked freedom of will, because of the threat by his superior.

The relationship between the definitional subjective element and blameworthiness remains undiscussed in international criminal law literature. Remarkable is that the two show an interesting overlap. Both the definitional subjective element of negligence and the concept of blameworthiness can require a reasonable person test. This suggests that the definitional subjective element and blameworthiness overlap in case the required mental element constitutes negligence. ${ }^{146}$

\section{CONCLUSION ON THE SUBJECTIVE ELEMENT}

The subjective element sets a standard for the personal guilt of the perpetrator. According to literature on international criminal law this subjective element is either restricted to the definitional subjective element ((special) intent, knowledge and negligence) or combined with a normative condition (blameworthiness). Blameworthiness is defined as the ability to choose, not doing what any reasonable person would have done and as freedom of will, mental capacity or knowledge of law.

\section{3. "But I SHOULD NOT BE PUNISHED": COMPLETE DEFENSES AND CRIMINAL LIABILITY}

The previous Sections discussed the general requirements for criminal liability in international criminal law: the objective and the subjective element. Next, the question arises whether these requirements for criminal liability are fulfilled when a perpetrator confesses to committing a crime, but legitimately claims that he

\footnotetext{
143 Knoops, G.J., 2001, p. 62.

144 Knoops, G.J., 2001, p. 97.

145 Bassiouni, M.C., 2003, p. 281.

146 That negligence includes both blameworthiness and wrongfulness is a view confirmed by criminal law theory in general. See for example: Fletcher, G.P., 1998, p. 126.
} 
should not be punished. In other words: are any requirements for criminal liability negated by the presence of a complete defense?

In literature on international criminal law, different views exist as to the relationship between complete defenses and the general requirements for criminal liability. The following paragraphs address two different perceptions of this relationship: 'confession and avoidance' (3.1) and 'negation of subjective element' (3.2).

\subsection{Confession and avoidance}

When a defendant argues by means of confession and avoidance, complete defenses do not negate the presence of the objective and the subjective element. On the contrary, the objective and subjective element are confessed, but avoided by stating reasons (complete defenses) why the presence of these confessed elements will not lead to criminal liability. ${ }^{147}$ The perspective of confession and avoidance is rooted in common law ${ }^{148}$ and is only endorsed by Werle in the field of international criminal law. According to him, the confession part consists of the objective element and the definitional subjective element. ${ }^{149}$

Schematically, the theory of confession and avoidance provides for the following possible relationships between the general requirements for criminal liability and complete defenses:

a) When the general requirements for criminal liability consist of the objective element and the definitional subjective element:

\begin{tabular}{|l|c|}
\hline Confession & Defense \\
\hline $\begin{array}{l}\text { Objective element }+ \text { definitional subjective } \\
\text { element }\end{array}$ & $X$ \\
\hline
\end{tabular}

$X=$ 'reasons why presence of the confessed elements will not lead to criminal liability'

b) When the general requirement for criminal liability consist of the objective element, definitional subjective element and blameworthiness:

\begin{tabular}{|l|l|}
\hline Confession & Defense \\
\hline $\begin{array}{l}\text { Objective element }+ \text { definitional subjective } \\
\text { element }\end{array}$ & No blameworthiness \\
\hline $\begin{array}{l}\text { Objective element }+ \text { definitional subjective } \\
\text { element }\end{array}$ & $X$ \\
\hline
\end{tabular}

$X=$ '(other) reasons (besides lack of blameworthiness) why presence of the confessed elements will not lead to criminal liability'

147 Fletcher, G.P., 1998, p. 96.

148 Fletcher, G.P., 1998, p. 93; Francisco Francisco, M.I., 2003, p. 171.

149 Werle, G., 2005, p. 95. 


\subsection{Negation of the subjective element}

The majority of writers in international criminal law hold that complete defenses negate the subjective element. Some leave it at that, without defining the subjective element or explaining how a complete defense negates it. ${ }^{150}$ Cassese holds that complete defenses negate the 'culpable mens rea' required for liability. ${ }^{151}$ Still, he does not elaborate on the definition of this culpability and its relationship with mens rea. He does, however, distinguish between defenses that negate the culpability aspect and defenses that negate both the culpability aspect and the definitional subjective element. ${ }^{152}$ Other writers make a similar distinction. ${ }^{153}$

The theory of negation of subjective element provides for the following possible relationships between the general requirements for criminal liability and complete defenses:

a) When the general requirements for criminal liability consist of the objective element and the definitional subjective element:

\begin{tabular}{|l|}
\hline Defense \\
\hline No definitional subjective element \\
\hline
\end{tabular}

b) When the general requirement for criminal liability consist of the objective element, subjective element and blameworthiness:

\begin{tabular}{|l|}
\hline Defense \\
\hline No definitional subjective element \\
\hline No blameworthiness \\
\hline No definitional subjective element + no blameworthiness \\
\hline
\end{tabular}

\subsection{Conclusion}

There seems to be no univocal theory on the relationship between complete defenses and the general requirements for criminal liability in international criminal law. This is no surprise, since there is no uniform theory on the general requirements for criminal liability either. Whereas the definition of the objective element does not show dramatic differences between authors, the definition of the

150 Bantekas, I., 2004, p. 266; Than, C. de and Shorts, E., 2003, p. 3. Considering excuses, see: Dinstein, Y., 2000, pp. 372 and 382.

151 Cassese, A., 2008, p. 256.

152 Cassese, A., 2008, pp. 262/263 and Cassese, A., 'Justifications and Excuses in International Criminal Law', In: Cassese, A. et al. (eds.), The Rome Statute of the ICC: A Commentary, Oxford University Press, Vol. 1, 2002, pp. 951-956, p. 952.

Cryer, R., et al., 2007, p. 332 and Scaliotti, M., 2001, p. 112. 
subjective element is susceptible to variation. Two visions on the subjective element predominate: the psychological and the normative theory.

Not many writers in the field of international criminal law have expressed their views on the relationship between complete defenses and criminal liability, but the few who did can be grouped along two lines of thought: (a) 'confession and avoidance' and (b) 'negation of the subjective element'. The first argues that complete defenses do not negate the general requirements for criminal liability, the second that complete defenses negate the subjective element. Therefore, when a defendant, in a context of international criminal law, argues "I did it, but I don't think I should be punished", in a technical legal sense he either says "I committed both the objective and the subjective element but I don't think I should be punished" or "I committed the objective element, but the subjective element cannot be established".

'Confession and avoidance' and 'negation of subjective element' sound like two opposing theories, but they do not have to bite each other. On one occasion the theories even overlap. Namely, when the general requirements for criminal liability are defined as objective element + definitional subjective element + blameworthiness. In that case the perpetrator may confess the objective element and the definitional subjective element of intent (confession $=$ objective element + definitional subjective element), while the complete defense at issue negates the blameworthiness of the perpetrator (defense $=$ no blameworthiness), so that both theories apply (see the bold italic expressions in the columns on the previous pages).

On other occasions, the theories, although technically not compatible, seem to complement each other in outlining the diversity of relationships between general requirements for criminal liability and complete defenses, depending on (a) the definition of the general requirements for criminal liability (objective element + definitional subjective element or objective element + definitional subjective element + blameworthiness) and on (b) the contents of the complete defense at issue.

When the general requirements for criminal liability are objective element + definitional subjective element, we can see the following relationships between complete defenses and the general requirements for criminal liability when merging the theories of confession and avoidance and negation of subjective element:

\begin{tabular}{|l|l|}
\hline Defense & Effect \\
\hline$X$ & $\begin{array}{l}\text { General requirements for criminal liability are } \text { not } \\
\text { negated }\end{array}$ \\
\hline No definitional subjective element & Defense negates definitional subjective element \\
\hline
\end{tabular}

When the general requirements for criminal liability are objective element + definitional subjective element + blameworthiness, we can see more possibilities: 
A theoretical background on complete defenses

\begin{tabular}{|l|l|}
\hline Defense & Effect \\
\hline No blameworthiness & Defense negates blameworthiness \\
\hline$X$ & $\begin{array}{l}\text { General requirements for criminal liability are not } \\
\text { negated }\end{array}$ \\
\hline No definitional subjective element & Defense negates definitional subjective element \\
\hline $\begin{array}{l}\text { No definitional subjective element and no } \\
\text { blameworthiness }\end{array}$ & $\begin{array}{l}\text { Defense negates definitional subjective element } \\
\text { and blameworthiness }\end{array}$ \\
\hline
\end{tabular}

Apart from the particular definition of the general requirements for criminal liability employed, this leaves the following options as to the contents and effects of complete defenses: ${ }^{154}$

\begin{tabular}{|l|l|}
\hline Defense & Effect \\
\hline$X$ & $\begin{array}{l}\text { General requirements for criminal liability are } \text { not } \\
\text { negated }\end{array}$ \\
\hline No definitional subjective element & $\begin{array}{l}\text { Defense negates a general requirement: } \text { the } \\
\text { definitional subjective element }\end{array}$ \\
\hline No blameworthiness & $\begin{array}{l}\text { Defense negates a possible general requirement: } \\
\text { blameworthiness }\end{array}$ \\
\hline $\begin{array}{l}\text { No definitional subjective element and no } \\
\text { blameworthiness }\end{array}$ & $\begin{array}{l}\text { Defense negates general requirement: definitional } \\
\text { subjective element; } \text { and a possible general } \\
\text { requirement: blameworthiness }\end{array}$ \\
\hline
\end{tabular}

$X=$ '(other) reasons (than absence of blameworthiness or absence of a definitional subjective element) why presence of the confessed elements will not lead to criminal liability'

\section{CATEgorization OF DEFENSES: JuSTIFICATIONS AND EXCUSES}

Some legal theorists, mainly in the common law world, speak of complete defenses in the omnibus sense as 'grounds for excluding responsibility'. Others divide complete defenses in two subcategories: justifications and excuses. ${ }^{155}$ In international criminal law, legal practice generally follows the first approach (defenses in the omnibus sense), ${ }^{156}$ while legal theory inclines towards the second (justifications and excuses). ${ }^{157}$

\footnotetext{
154 Note this table only differs from the previous one considering the status of the general requirements for criminal responsibility, represented in the right column.

155 Cryer, R., et al., 2007, p. 331.

156 Bantekas, I. and Nash, S., 2007, p. 53; Cassese, A., 2008, p. 259; Cryer, R., et al., 2007, p. 332; Werle, G., 2005, p. 96 and Schabas, W.A., 2009, p. 376.

157 Cassese, A., 2002, p. 955 and Knoops, G.J., 2001, p. 29.
} 
Justifications refer to the situation where the defendant has fulfilled the definitional elements of a crime, ${ }^{158}$ but his conduct is not considered wrongful, ${ }^{159}$ because the legal community approves of his act. ${ }^{160}$ For example, a civilian woman in the hands of the enemy occupant, wounds an enemy serviceman in order to prevent rape. ${ }^{161}$ The civilian woman has fulfilled the definitional elements of a crime (the intentional wounding of enemy serviceman), but her conduct is not considered wrongful because the legal community would approve of her act.

The approval of the entire legal community seems to be a rather abstract indicator for the presence of a justification. Not every person in a random legal community has the same values, for instance. However, in international criminal law, little has been theorized on these grounds, for approval by the legal community. Cassese holds that the legal community would approve of an otherwise illegal act when it is the lesser of two evils. ${ }^{162}$ In reference to the example above, this means that the woman has to choose between two evils. Either she wounds another person in self-defense or she will be raped. Because society would rather see the innocent person unharmed (and not the attacker), wounding the enemy serviceman is the lesser of the two evils and therefore justified.

Excuses are related to the concept of blameworthiness as discussed in Section 2.1.2. They refer to the situation where the perpetrator has fulfilled the objective element, this conduct is wrongful, but the perpetrator has a claim to remain unpunished because he is not blameworthy. ${ }^{163}$ For example, when a soldier shoots a POW because his superior puts a gun to the soldier's head and forces him to do so, his act cannot be justified, for he is killing an innocent person. However, his behavior may not be blameworthy because he has no ability to choose, or any reasonable person would have acted the way he did, or he was not in a position to determine his will freely. ${ }^{164}$ Consequently, the acknowledgement of excuses within the theory of justification and excuse - equals the recognition of blameworthiness as a general requirement for criminal liability.

In order to clarify the difference between justifications and excuses one should remember that justifications are act-oriented. They justify the act of the perpetrator because the act is not wrongful. Excuses, on the contrary, are applicable when the act is wrongful, but the conduct of the actor is not blameworthy. This distinction has several consequences.

158 I.e. in as far as these definitional elements do not touch upon the wrongfulness of the act or the blameworthiness of the actor.

159 Bantekas, I. and Nash, S., 2007, p. 53.

160 Cassese, A., 2008, p. 255; Cryer, R., et al., 2007, p. 331 and Knoops, G.J., 2001, p. 29.

161 Cassese, A, 2008, p. 259.

162 Cassese, A., 2008, p. 225.

163 Bantekas, I. and Nash, S., 2007, p. 53; Cassese, A., 2008, p. 256; Cryer, R., et al., 2007, p. 331; Eser, A., 'Justification and Excuse', In: American Journal of Comparative Law, Vol. 24, 1976, pp. 621-637, p. 628 and Knoops, G.J., 2001, p. 170. 
Firstly, since excuses only apply to wrongful acts, justifications and excuses are mutually exclusive. If a justification is applicable, the blameworthiness of the actor is not an issue, for the act committed is not a crime. If an excuse is applicable, the act must be wrongful and can therefore not be justified. Because an unjustifiable act is a prerequisite for an excuse to be applicable, justifications precede excuses. That is, in order to know whether an excuse is applicable it must first be established whether a justification applies.

Secondly, excuses have an individual effect. In case of participation an accessory can be held responsible for a certain crime, while the principal perpetrator is excused. This would be the case when a soldier, who suffers from mental delusions, kills a POW, because he thinks that the POW is possessed by the devil and that killing him is the only way to save his battalion. An accessory that does not suffer from mental delusions helps him. Killing the POW, the act cannot be justified. The insanity of the principal perpetrator does not make the act less wrongful. However, due to his insanity the principal perpetrator can be excused. Because the accessory does not suffer from such insanity, he can still incur criminal liability for his participation in the crime. In contrast, when a justification is accepted in the context of participation (for example, when a civilian woman in the hands of the enemy occupant wounds an enemy serviceman, for the purpose of preventing rape), ${ }^{165}$ there can technically be no accessory, since the act at issue is not wrongful, i.e. there is no crime. ${ }^{166,167}$

A third consequence of the distinction justification-excuse is relevant when resisting an aggressor. It is lawful to resist an excused aggressor, e.g. to invoke self-defense against an insane attacker. Although the attacker's insanity provides him with an excuse (he had no choice), his act remains wrongful (he did not act in accordance with the lesser evil), which gives the victim the right to defend himself. Conversely, whenever a seemingly illegal attack is justified, the right to self-defense ceases to exist, for the act is not wrongful. ${ }^{168}$

The distinction justification-excuse may also have financial consequences. A defendant that raises a successful excuse may still be liable to pay compensation, for his excuse does not erase the wrongfulness of his act. However, if an act is justified, no such obligation arises. ${ }^{169}$

165 Self-defense includes the defense of the other, see Chapter III.

166 Cassese, A., 2008, pp. 256/257; Cryer, R., et al., 2007, p. 332; Eser, A., 1976, p. 622 and Knoops, G.J., 2001, p. 30.

167 This view is reflected in international criminal law literature. Whether this is the correct view, remains to be seen. The Dutch author De Hullu, for example, remarks that the act of an accessory can still be wrongful, although the act of the principal is justified. For example, if the accessory exceeds the limits of proportionality. See: Hullu, J. de, Matrieel Strafrecht. Over algemene leerstukken van strafrechtelijke aansprakelijkheid naar Nederlands recht, Fifth Edition, Kluwer, Deventer, 2012, p. 368.

169 Cassese, A., 2008, p. 257 and Cryer, R., et al., 2007, p. 332. 
Chapter II

\subsection{Justifications, excuses and the relationship between complete defenses and the general requirements for criminal liability}

Section 3.3 has demonstrated the following types of defenses and their effect on the general requirements for criminal liability:

\begin{tabular}{|l|l|}
\hline Defense & Effect \\
\hline$X$ & $\begin{array}{l}\text { General requirements for criminal liability are not } \\
\text { negated }\end{array}$ \\
\hline No definitional subjective element & Defense negates definitional subjective element \\
\hline No blameworthiness & Defense negates blameworthiness \\
\hline $\begin{array}{l}\text { No definitional subjective element and no } \\
\text { blameworthiness }\end{array}$ & $\begin{array}{l}\text { Defense negates definitional subjective element } \\
\text { and blameworthiness }\end{array}$ \\
\hline
\end{tabular}

$X=$ 'other reasons why presence of the confessed elements will not lead to criminal liability'

The question now arises whether these different species of defenses can be classified as either a justification or an excuse. At this point, this seem to be problematic, since qualifying these types of defenses as either justifications or excuses leads to the following results.

Defense $=X$

Argument $\mathrm{X}$ does not deny the presence of the general requirements for criminal liability. Neither does it argue the absence of blameworthiness, for this is already a separate category. Since a claim negating blameworthiness equals an excuse, X cannot be an excuse. Consequently $\mathrm{X}$ could be a claim, negating the wrongfulness of the act, and therefore a justification.

\section{Defense $=$ No definitional subjective element}

When a defense contains the argument that the definitional subjective element is lacking, there are several possibilities considering the classification as either a justification or an excuse. Only if the definitional subjective element bears an element of blameworthiness and wrongfulness - as is the case with negligence -170 a justification or excuse can challenge the definitional subjective element. When the definitional subjective element does not bear an element of blameworthiness or wrongfulness, as is the case with intent, neither a justification, nor an excuse can negate the definitional subjective element. 


\section{Defense $=$ No blameworthiness}

When a defense negates the blameworthiness of the defendant it must be an excuse, for only an excuse negates the blameworthiness of the actor.

\section{Defense $=$ No definitional subjective element and no blameworthiness}

To qualify as a justification or excuse, both elements must be negated. Above is argued that neither a justification, nor an excuse can negate the definitional subjective element when void of blameworthiness and wrongfulness. Since blameworthiness is singled out, the definitional subjective element in this category theoretically either incorporates wrongfulness or stands on its own. Either way, an excuse in this case will only claim blameworthiness is absent, whereas a justification could only argue the definitional subjective element is lacking. Consequently a justification or an excuse never directly challenges both elements. This category is therefore inadequate and must be dropped from the classification.

The above analysis leaves us with following types of defenses in terms of justifications and excuses:

\begin{tabular}{|l|l|l|}
\hline Defense & Effect & Justification or excuse? \\
\hline$X$ & $\begin{array}{l}\text { General requirements for } \\
\text { criminal liability are not negated }\end{array}$ & Justification \\
\hline $\begin{array}{l}\text { No definitional subjective } \\
\text { element }\end{array}$ & $\begin{array}{l}\text { Defense negates definitional } \\
\text { subjective element }\end{array}$ & Justification or excuse \\
\hline No blameworthiness & $\begin{array}{l}\text { Defense negates } \\
\text { blameworthiness }\end{array}$ & Excuse \\
\hline
\end{tabular}

The characterization of complete defenses as justifications or excuses will be continued in Part II, where the complete defenses that can be identified in international criminal law are analyzed.

\section{Procedural issues Related to complete defenses}

Having discussed the major substantive issues considering complete defenses in international criminal law, this Section moves on to procedural matters. Section 5.1 discusses requirements directed at judges: are they obliged to mention the ground(s) in their judgments for accepting or declining a complete defense? Section 5.2 elaborates on the burden of proof. When a complete defense might be applicable, should the prosecution prove its absence or must the defense prove its presence? Moreover, in either case, what is the applicable standard of proof (e.g. 
beyond reasonable doubt, by preponderance of evidence)? Finally, Section 5.3 discusses Prosecutor v. Aleksovski in which it was determined that complete defenses can only be raised during the trial-phase.

\subsection{Grounds stated in judgments}

When the defendant brings up a complete defense, are judges obliged to mention the ground(s) in their judgment for accepting or rejecting a complete defense? The charters, statutes and Rules of the international courts subject to this research show no specific rules related to grounds in the context of complete defenses. However, the Nuremberg Charter and the statutes of the ICTY, ICTR, and ICC do require a "reasoned" judgment. ${ }^{171}$ The Tokyo Charter does not contain a similar requirement.

From the case law of the Nuremberg Tribunal, the ICTY, the ICTR, the ICC and even the Tokyo Tribunal, it can be deduced that these courts included rejected complete defenses in their reasoned judgments. It is, however, not certain whether they discussed every single complete defense brought up by the defense. This can only be affirmed with certainty after looking at the defense pleas, an investigation well beyond the scope of this research. ${ }^{172}$

In conclusion, judges at international tribunals are not specifically required by law to mention the ground(s) for their decisions on complete defenses. Still, they seem to have the habit of discussing them.

\subsection{Burden and standard of proof}

A fundamental principle in almost any legal system is the presumption of innocence, meaning that the defendant is innocent until proven guilty. Although the earlier ad hoc tribunals have not explicitly recognized this principle in their charters, it can nowadays been found in the statutes of the ICTY, ICTR and ICC. ${ }^{173}$ The presumption of innocence implies that the prosecution has the burden of proving the guilt of the accused. ${ }^{174}$ In a technical legal sense: the prosecution has to

171 Article 26 IMT Charter, Article 23 ICTY Statute, Article 22 ICTR Statute and Article 74 ICC Statute.

172 However, according to my own sample survey of the Nuremberg defense pleas, not every single complete defense that was brought up by the Defense has been discussed by the Tribunal. Source: The Trial of the major war criminals: Proceedings of the international military tribunal sitting at Nuremberg, part 1-23, Taken from the official transcript, under the authority of H.M AttorneyGeneral by his majesty's stationery office, London 1947. According to van Poelgeest the Tokyo Judgment did not discuss every defense that has been brought up by the counselors (Poelgeest, L. van, Nederland en het Tokyo Tribunaal, Gouda Quint, Arnhem, 1989, p. 94). Similar statements on the other courts cannot be derived from secondary literature. 
establish guilt beyond reasonable doubt, by proving all elements contained by the definition of the crime charged, i.e. the objective and the definitional subjective element. ${ }^{175}$ In the context of complete defenses the crucial question therefore is: which party has the burden of proof when it comes to complete defenses? Must the prosecution, apart from establishing that the accused committed a crime, also prove that the accused cannot resort to any complete defense or is it up to the defense to prove that a complete defense is applicable?

The IMT and IMTFE Charters do not contain any rules on the burden of proof in case of defenses. However, the RPE of the ICTY, ICTR and ICC contain regulations ${ }^{176}$ that prescribe the way the defense has to inform the prosecution (and in case of the ICC also the Trial Chamber) if they want to bring up a complete defense. ${ }^{177}$ By demanding the defense to abide to certain criteria when bringing up a complete defense, the rules of these courts suggest that it is up to the defense to raise complete defenses. However, if the defense has to raise complete defenses, does it also have to prove their validity, and if so, by which standard (e.g. beyond reasonable doubt, by preponderance of evidence)?

The statutes of international courts do not directly answer this question. The only interesting provisions in this respect can be found in the ICC Statute. Article 66(2) places the onus of proof on the prosecutor. He must show beyond reasonable doubt that the accused is guilty of the crimes charged. According to article 67(1)(i) (Rights of the Accused), the accused has the right "Not to have imposed on him or her any reversal of the burden of proof or any onus of rebuttal". This article limits the evidential obligations of the accused in general, thus also when it comes to complete defenses. Rule 69 allows the defense and prosecution to "agree that an alleged fact, which is contained in the charges, the contents of a document, the expected testimony of a witness or other evidence is not contested and, accordingly, a Chamber may consider such alleged fact as being proven, unless the Chamber is of the opinion that a more complete presentation of the alleged facts is required in the interests of justice, in particular the interests of the victims". This Rule demonstrates that in some cases an evidential standard may not be necessary at all.

Case law of international tribunals bears more information specifically related to defenses. It demonstrates that the defendant who raises a complete defense also bears the evidential burden. ${ }^{178}$ The evidential burden is defined by the ICTY as the obligation to establish the facts of a particular case. ${ }^{179}$ This burden is also referred

\footnotetext{
175 ICTY and ICTR Rule 87 (A), Article 66 (3) ICC Statute.

176 Rule 67 of the ICTY and ICTR RPE, Rule 79 (1)(b) and 80 of the ICC RPE.

177 Verbatim text of the ICTY and ICTR Rules: "any special defences, including that of diminished or lack of mental responsibility". Verbatim text of the ICC Rules: "ground for excluding criminal responsibility under article 31, paragraph 3".

178 ICTY, Prosecutor v. Hadžihasanović and Kubura, Trial Chamber, 15 March 2006, par. 230.

179 ICTY, Prosecutor v. Hadžihasanović and Kubura, Trial Chamber, 15 March 2006, par. 234.
} 
to as the obligation to "demonstrate" 180 or the "onus of establishing"181 or the "burden of production"182 or "burden of proof". 183, 184

As to the standard of this burden (i.e. by which these facts must be established), the case law of international tribunals is not entirely clear. In Prosecutor v. Delalic et al. the Appeals Chamber holds that this standard is complied with when the applicability of a "defense in a true sense" (in casu insanity) is "more probable than not". ${ }^{185}$ In Prosecutor v. Hadžihasanović and Kubura the Trial Chamber holds that for an insanity defense, the defendant "is required to adduce sufficient evidence to establish the cogency of such defence on the balance of probabilities" (italics added). In case of other defenses "such as self-defence, duress, alibi, automatism (involuntary uncontrollable reflexes) and provocation" this "higher standard" (i.e. balance of probabilities) is not applicable. In these cases the Trial Chamber refers to the "the evidential burden" of the defendant without elaborating on its standard. ${ }^{186}$ The Appeals Chamber in Prosecutor v. Kvočka remarks that intoxication also is a defense that must be proved on the balance of probabilities. ${ }^{187}$

What can be deducted from these judgments? The Chambers in Prosecutor $v$. Delalić, and Prosecutor v. Hadžihasanović and Kubura refer to the standard of balance of probabilities (when a certain fact is more probable than not) ${ }^{188}$ in case of an insanity defense. The same standard is applicable for intoxication, according to the Appeals Chamber in Prosecutor v. Kvočka. The Appeals Chamber in Prosecutor v. Delalic suggests that other (than insanity) defenses "in a true sense" should be proved by the same standard (balance of probabilities), but refrains from defining or specifying these defenses. Neither does it reveal the standard applicable to other defenses (i.e. defenses that are not "defenses in a true sense"). The later judgment of the Trial Chamber in Prosecutor v. Hadžihasanović and Kubura contradicts this judgment by isolating insanity as the only defense requiring the

180 ICTY, Prosecutor v. Kordić and Čerkez, Appeals Chamber, 17 December 2004, par. 835-838.

181 ICTY, Prosecutor v. Delalić et al., Appeals Chamber, 20 February 2001, par. 582. In the same Judgment the Appeals Chamber held that the Trial Chamber is not obliged to define a "special defence" in advance of evidence being given (par. 577).

Which is defined as "the burden to introduce evidence providing prima facie support for the defence", clearly a reference to the evidential burden (see footnote below) in ICTR, Prosecutor v. Gacumbitsi, Appeals Chamber, 7 July 2006, par. 153. ICTY, Prosecutor v. Kunarac et al., Trial Chamber, 22 February 2001, p. 463. In case of complete defenses the Courts do not always seem to make a sharp distinction between the concepts of evidential burden (the obligation to adduce sufficient evidence to raise an issue for the court to consider) and the burden of proof (the obligation to satisfy the judge, to a special standard of proof, that certain facts are true). Nevertheless, the Defense seems to carry both species of burdens (see, for the definitions of these concepts: Dennis, I.H., The law of evidence, Sweet \& Maxwell, London, 2007, pp. 438-440). issue of complete defenses was not discussed on Appeal. 
balance of probabilities standard. In case of other defenses such as self-defense, duress and automatism, a lesser evidential burden is required. Does this mean these are not defenses in a true sense? The Trial Chamber does not provide clarity on this issue, and again refrains from defining this lesser evidential burden. Both judgments also raise questions as to the status of defenses such as necessity, mistake of fact, mistake of law and superior orders? Are they - in line with Prosecutor v. Delalić - possibly defenses "in a true sense" that should be proved on the balance of probabilities or are they - in line with Prosecutor v. Hadžihasanović and Kubura - defenses that should be proved according to some lesser evidential standard?

It seems difficult to determine which judgment is authoritative, since the lower authority (Trial Chamber) has passed the 2006 judgment (Prosecutor $v$. Hadžihasanović and Kubura), while the higher authority has passed the 2001 judgment (Prosecutor v. Delalić). However, the Appeals Chamber Judgment in Prosecutor v. Kvočka (2005) - which holds that the balance of probabilities standard is applicable in case of intoxication - seems to support Prosecutor v. Delalic in that insanity is not the only defense that must be proved on the balance of probabilities. Also in Prosecutor v. Kamuhanda, defenses in a proper sense are broadly defined as "grounds excluding criminal responsibility although the accused has fulfilled the legal elements of a criminal offense", 189 suggesting the existence of several defenses in a true sense. Apart from that, the relevant quotation from Prosecutor v. Delalić that defenses in a true sense require a balance of probabilities standard - has been reiterated by the ICTR in Prosecutor v. Kajelijeli. ${ }^{190}$ What is more, the Appeals Chamber Prosecutor v. Aleksovski has indicated that its decisions (i.e. the ratio decidendi) are binding precedents on Trial Chambers. ${ }^{191}$ In this light, the fact that Prosecutor v. Hadžihasanović and Kubura contradicts the ratio decidendi ${ }^{192}$ in Prosecutor v. Delalić must be seen as an error of the Trial Chamber in Prosecutor v. Hadžihasanović and Kubura.

Conclusively, the information on burden and standard of proof that can be derived from ICTY and ICTR (case) law is that defenses must be raised by the defendant. The insanity and intoxication defense should be proved by the defendant on the balance of probabilities. In case of other complete defenses, the standard depends on whether the defense at issue is a "defense in a true sense". Defenses in a true sense should also be proved on the balance of probabilities, whereas other defenses require a lesser standard. As to the nature of this standard the courts are not clear. A high evidentiary standard - beyond reasonable doubt - has not been mentioned by international tribunals in the context of complete defenses.

189 ICTR, Prosecutor v. Kamuhanda, Appeals Chamber, 19 September 2005, par. 167.

190 ICTR, Prosecutor v. Kajelijeli, Trial Chamber, 1 December 2003, par. 165.

191 ICTY, Prosecutor v. Aleksovski, Appeals Chamber, 24 March 2000, par. 113.

192 The issue that had to be decided here was whether diminished responsibility constitutes a complete defense. In substantiating that this legal figure does not constitute a complete defense, the Appeals Chamber had to explain what does. 
Commentators of the ICC Statute have argued that a defendant at the ICC only bears the burden of production, when it comes to complete defenses. Reason is that the ICC Prosecutor is under the legal obligation to investigate exonerating circumstances (article 54(1)(a) ICC Statute) and that article 67(1)(i) may also apply to defenses. 193

Although international courts do not clarify which defenses are a "defense in a true sense", Prosecutor v. Kamuhanda (as stated above) defines these defenses as "grounds excluding criminal responsibility although the accused has fulfilled the legal elements of a criminal offense". In literature these defenses are referred to as "affirmative defenses". Affirmative defenses do not negate any specific element of the prosecution's case. The defense has to prove these defenses. Affirmative defenses must be satisfied by the accused on a balance of probabilities. ${ }^{194}$ However, if we assume that "defenses in a true sense" equal affirmative defenses, it is still not clear which defenses are affirmative.

Despite of the fact that it is difficult to determine which defenses are affirmative, the idea that there are two types of complete defenses - affirmative defenses, that should be proved on the balance of probabilities and defenses that negate an element of the prosecution's case and must be proved by a lesser standard - seems to be emerging in the case law of international criminal courts. Combined with the different types of defenses put down in Section 3.3, this provides the following picture:

\begin{tabular}{|l|l|l|}
\hline Defense & Effect & Affirmative or not? \\
\hline$X$ & $\begin{array}{l}\text { General requirements for } \\
\text { criminal liability are not negated }\end{array}$ & Affirmative \\
\hline $\begin{array}{l}\text { No definitional subjective } \\
\text { element }\end{array}$ & $\begin{array}{l}\text { Defense negates definitional } \\
\text { subjective element }\end{array}$ & Not affirmative \\
\hline No blameworthiness & $\begin{array}{l}\text { Defense negates } \\
\text { blameworthiness }\end{array}$ & Affirmative \\
\hline
\end{tabular}

$X=$ 'other reasons why presence of the confessed elements will not lead to criminal liability'

Defenses are thus affirmative when they do not negate the definition of the crime, because they a) do not negate general requirements for criminal liability $(X)$ or b) they negate the blameworthiness of the crime, which is not part of the definition

193 Ambos, K., Treatise on International Criminal Law. Volume I: Foundations and General Part, Oxford University Press, 2013, p. 313.

194 Bantekas, I., 2004, p. 283 and Fletcher, G.P., Rethinking Criminal Law, Oxford University Press, Second Edition, 2000, p. 518. See also Black's Law Dictionary (2004) which defines affirmative defense as follows: "A defendant's assertion of facts and arguments that, if true, will defeat the plaintiff's or Prosecution's claim, even if all the allegations in the complaint are true. The defendant bears the burden of proving an affirmative defense. Examples of affirmative defenses are duress (in a civil case) and insanity and self-defence (in a criminal case)." 
(No blameworthiness). Defenses are not affirmative when they negate the definition of the crime (No definitional subjective element).

The possible categorization of complete defenses in affirmative or not will be continued in Chapter II, where the complete defenses that can be identified in international criminal law are analyzed.

\subsection{Prosecutor v. Aleksovski}

The last Section of this Chapter is devoted to Prosecutor v. Aleksovski in which it was determined that complete defenses cannot be raised on Appeal. In casu the Appeals Chamber rejects a necessity/duress argument because it:

[...] considers that, in general, accused before this Tribunal have to raise all possible defences, where necessary in the alternative, during the trial, and where so required under the Rules of Procedure and Evidence of the International Tribunal ("Rules"), before trial. It follows that accused, generally, cannot raise a defence for the first time on appeal. ${ }^{195}$

Next, the Appeals Chamber substantiates why defenses must be raised during the trial-phase. It holds that this rule originates from:

a. The Rules (Rules 65ter and Rule 67);

b. The obligation of the accused to plead to the charges against him;

c. The equality of arms principle (the prosecution should have the opportunity to cross-examine witnesses and call rebuttal witnesses in relation to the defense); and

d. The problems caused for the Appeals Chamber, when it has to assess a Trial judgment where the Defense failed to raise a defense expressly. ${ }^{196}$

However, it is doubtful whether this rule (i.e. no complete defenses for the first time on appeal) is absolute. The Appeals Chamber namely later stresses that because the necessity-argument should be rejected anyway, ${ }^{197}$ it will not dwell on whether the Civil Law "principle of iuri novit curia"198, 199 should be applied in this case. Thereby the Appeals Chamber suggests that this principle - according to which the court can apply concepts such as necessity based upon the facts brought up by parties - could be applicable in other Appeal cases.

199 Translation to English: the court knows the laws. 


\section{Conclusion}

The central question of this Chapter is "What is a complete defense, both in a substantive and procedural sense?".

In a substantive sense, saying "I did it, but I don't think I should be punished", means, according to the different theories in international criminal law, that the defendant acknowledges he committed the objective element of the crime, but argues either that although the subjective element can also be established, there are still reasons why the presence of these confessed elements will not lead to criminal liability (confession and avoidance), or that the subjective element can not be established (negation subjective element). The fact that there is no univocal theory on the relationship between the requirements for criminal liability and complete defenses can be explained by the fact that there is no uniform theory on the general requirements for criminal liability either. The definition of the objective element does not show dramatic differences between authors, but the definition of the subjective element is susceptible to variation. Two visions on the subjective element predominate: the psychological and the normative theory.

Legal theory tends to divide complete defenses into justifications and excuses. Justifications refer to the situation where the defendant has fulfilled the definitional elements of a crime, but his conduct is not considered wrongful because the legal community positively approves of his act. Excuses are related to the concept of blameworthiness. They refer to the situation where the defendant has fulfilled the objective element, this conduct is wrongful, but the defendant remains unpunished because he is not blameworthy. Recognition of the theory of justification and excuse implies that blameworthiness is a general requirement for criminal responsibility.

In a procedural sense a complete defense is not a legal figure that requires judges at international tribunals to mention grounds. Still, judges seem to have the habit of discussing complete defenses.

The evidential burden (the obligation to establish the facts of a particular case) of complete defenses is on the defendant. The defenses of insanity and intoxication should be established on the balance of probabilities. The standard required for other defenses depends on whether the defense at issue is a "defense in a true sense". Which defenses can be qualified as such is not entirely clear. However, the idea that there are at least two types of complete defenses - affirmative defenses or "defenses in a true sense", that should be proved on the balance of probabilities and defenses that negate an element of the prosecution's case that must be proved by a lesser standard - seems to be emerging in the case law of international criminal courts.

When combining the theories of confession and avoidance and negation of subjective element, three theoretically possible types of defenses can be identified. Some of these types can be categorized as justification or excuse and/or as affirmative/not affirmative: 
A theoretical background on complete defenses

\begin{tabular}{|l|l|l|l|}
\hline Defense & Effect & $\begin{array}{l}\text { Justification or } \\
\text { excuse? }\end{array}$ & Affirmative or not? \\
\hline$X$ & $\begin{array}{l}\text { General requirements } \\
\text { for criminal liability are } \\
\text { not negated }\end{array}$ & Justification & Affirmative \\
\hline $\begin{array}{l}\text { No definitional } \\
\text { subjective element }\end{array}$ & $\begin{array}{l}\text { Defense negates } \\
\text { definitional subjective } \\
\text { element }\end{array}$ & Justification or excuse & Not affirmative \\
\hline No blameworthiness & $\begin{array}{l}\text { Defense negates } \\
\text { blameworthiness }\end{array}$ & Excuse & Affirmative \\
\hline
\end{tabular}

$X=$ 'other reasons why presence of the confessed elements will not lead to criminal liability'

The following Parts discuss whether these theoretical types are (Part II) and should be (Part III) represented in international criminal law. 



\section{Part II}

\section{Complete Defenses in Practice}





\section{Introduction Part II}

Complete defenses and international crimes: at first sight not only an unhappy marriage, but also an immoral one. For how can the most severe crimes in the world be justified, or even be excused? It seems unimaginable that a government official claiming, "I planned this genocide because I was drunk" would get off the hook. Reality is, however, that complete defenses have appeared at the international courts subject to this research, be it not in the exaggerated form of the previous example.

In order to answer the key question of this thesis How, if at all, should complete defenses be available in case of international crimes?, the current status of complete defenses in international criminal law must be mapped out. Which defenses have come up, and what has been said about them?

This Part addresses (a) which complete defenses did come up at the institutions subject to this research, (b) how international courts have reacted to these complete defenses and (c) what can be said about their reaction.

Plan

The following complete defenses did come up at the international courts, object of this research: self-defense (Chapter III), consent (Chapter IV), insanity (Chapter V), intoxication (Chapter VI), mistake (Chapter VII), superior orders (Chapter VIII), necessity/duress (Chapter IX), lawful belligerent reprisals (Chapter X) and tu quoque (Chapter XI). Chapter XII briefly discusses the discretionary power of operative international criminal courts to construct new defenses.

Each specific defense is addressed per court (e.g. self-defense at the IMT, selfdefense at the IMTFE, self-defense at the ICTY, etc.). For each defense, first the relevant passages are cited. Next, a comment is provided. Note that this comment is restricted to de lege lata. De lege ferenda is addressed in Part III (Recommendations). For each defense, the comment will discuss the following questions:

1) Considering the applicability of the defense:

- How is the defense raised? (Did the defense bring it up, or did the court discuss the defense proprio motu?)

- Is the defense recognized in principle, or a priori rejected (either by statute or through case law)?

A priori rejection refers to the situation where a defense is rejected beforehand, and thus not on its merits. An example of an a priori rejection would be: "Duress is never a complete defense in case of genocide". An example of a rejection on merits 
would be: "The necessity-requirement for duress has not been met in this specific case, for the defendant had other options to act." However, and this is slightly confusing, a rejection on the merits can also be an a priori rejection, namely when the court holds that in case of a certain crime or crimes, a specific requirement of the defense is never met. For example: "In case of genocide the necessity requirement of duress can never be met".

Considering the recognition in principle of defenses: for the purpose of this thesis a complete defense is not only accepted in principle when a court explicitly says it does, but also when a defense is rejected on its merits. A rejection on merits namely implies that if the relevant requirements had been met, the defense would have been applicable. In addition, the fact that the Defense explicitly refers to a defense and the court does not deny its existence is also an indication that a defense is recognized in principle.

- Why is the defense a priori rejected/recognized in principle?

- If the defense is recognized in principle, is it accepted or rejected in the present case?

- What are the grounds for its acceptance/rejection?

- Did the acceptance or rejection of the defense in casu have any remarkable legal consequences (i.e. consequences other than acquittal and conviction)?

2) Considering the scope of the defense:

- How is the defense defined?

- What are the requirements for this specific defense?

- How are the criteria for the defense tested: objectively or subjectively?

For the purpose of this thesis an objective test refers to an assessment of the situation from an outsider perspective. The (subjective) thoughts of the defendant are not part of the equation. The crucial question is always whether the objective circumstances exonerate the defendant from criminal liability. For example, in case of self-defense, the decisive issue is whether there was an objective self-defense situation and not whether the (subjective) defendant believed he had to defend himself. Hence, self-defense requires an objective test.

A subjective test, on the other hand, is an assessment of the situation from an insider perspective, i.e. the perspective of the defendant. Contrary to an objective test, this test does focus on the actor's state of mind. The crucial question is whether the subjective state of mind of the actor exonerates him from criminal liability. For example, in case of (the ICC definition of) mistake the decisive issue is whether the defendant knew about certain facts, and not whether his mistake is objectively reasonable. ${ }^{200}$

200 See, Fletcher, G.P., 1978, p. 504 et seq. for the different notions of objectivity and subjectivity in criminal law. 
In addition to the questions sub 1) and 2), additional questions are discussed that are specific to a particular defense. These questions - if there are any - are mentioned in the introduction to each Chapter on an individual defense.

Sometimes defenses are technically not brought up, but discussed in a different manner, as an obiter dictum, for example, or in a dissenting opinion. In these cases not all of the above questions are answered, but only those that are relevant to the specific context.

Each Chapter on a specific defense concludes with a general statement on the defense as a whole. These sub-conclusions discuss the following questions:

1) Considering the applicability of the defense:

- How did the defense come up?

- Is the defense recognized in principle or a priori rejected?

- Why is the defense a priori rejected/recognized in principle?

- If the defense is recognized in principle, is it accepted or rejected in case law?

- What are the grounds for its acceptance/rejection?

- Was the defense ever applied in mitigation?

- Did the acceptance or rejection of the defense have any remarkable legal consequences?

2) Considering the scope of the defense:

- How is the defense defined?

- What are the requirements for this specific defense? The overview of these requirements is an accumulation of all requirements mentioned by the sources studied. Note that this may result in the narrowest scope possible of a specific defense (and not necessarily in the most desirable scope, which is discussed in Part III of this thesis).

- How are the criteria tested: objectively or subjectively?

3) Considering the categorization of the defense, Chapter I demonstrated that three different types of complete defenses exist:

\begin{tabular}{|l|l|l|l|}
\hline Defense & Effect & $\begin{array}{l}\text { Justification or } \\
\text { excuse? }\end{array}$ & Affirmative or not? \\
\hline$X$ & $\begin{array}{l}\text { General requirements } \\
\text { for criminal liability } \\
\text { are not negated }\end{array}$ & Justification & Affirmative \\
\hline $\begin{array}{l}\text { No definitional } \\
\text { subjective element }\end{array}$ & $\begin{array}{l}\text { Defense negates } \\
\text { definitional subjective } \\
\text { element }\end{array}$ & Justification or excuse & Not affirmative \\
\hline No blameworthiness & $\begin{array}{l}\text { Defense negates } \\
\text { blameworthiness }\end{array}$ & Excuse & Affirmative \\
\hline
\end{tabular}


The question discussed in relation to this categorization is: can the requirements for a specific defense be translated to one or more of the three types of complete defenses as presented in Chapter I?

Each section on a defense as a whole ends with several questions on the grey areas (e.g. contradictory case law, several interpretations possible) of that defense, which need to be resolved. These questions are, if possible, answered in Part III of this thesis. A preview of these answers is provided in the final section of each Chapter on a specific defense.

Finally, the Conclusion to Part II discusses the following questions:

1) Considering the applicability of complete defenses:

- Is the legal figure of complete defenses generally recognized?

- How do defenses come up?

- Which defenses are recognized in principle?

- Which defenses are rejected a priori?

- Why are defenses a priori rejected?

- Why are defenses recognized in principle?

- Which defenses are only rejected in case law?

- Which defenses are accepted in case law?

- What can be said, in general, about the grounds for acceptation or rejection?

- What is the relationship between complete defenses and mitigating circumstances?

- Which are the possible legal consequences of complete defenses?

2) Considering the scope of complete defenses:

- Do the requirements for complete defenses demonstrate common denominators (e.g. proportionality, necessity, reasonable person test, Garantenstellung, prior fault, mental element)?

- Are these common denominators always tested in the same manner (i.e. objectively or subjectively)?

- Do defenses overlap?

3) Considering the categorization of complete defenses:

- Which types of the three categories of defenses from Chapter I can be found in international criminal law?

- What do the findings on the categorization of complete defenses contribute to theory on the relationship between complete defenses and general requirements for criminal liability? 


\section{Chapter III \\ SELF-DEFENSE}

\section{INTRODUCTION}

In general, self-defense amounts to the defense of oneself or another against the unlawful use of force. For example, A hits B and B strikes back. Consequently, B's action cannot be qualified as a crime (e.g. assault), for he acted in self-defense. Selfdefense has been discussed by the IMT, the IMTFE and the ICTY. It can also be found in article 31 of the ICC Statute.

Traditionally two types of self-defense exist: self-defense under domestic criminal law and self-defense under international law. The first type of selfdefense tends to avert responsibility for a personal act, while the latter negates the responsibility of the State. International self-defense is nowadays embedded in article 51 of the UN Charter. ${ }^{201}$ Note that this is a codification of ius ad bellum (the right to go to war), as opposed to ius in bello (the law applicable during war). The rationale of this distinction is to avoid that a righteous cause to engage in armed conflict (an ad bellum situation) becomes an alibi for violations of international humanitarian law (an in bello situation). Or, conversely, that an unlawful attack by an aggressor state provides a license to the victim state to commit war crimes in defense. ${ }^{202}$ Apart from addressing the research questions submitted in the introduction to this Part, this Chapter investigates whether and how both international and domestic self-defense have merged into international criminal law. The conclusion to this Chapter demonstrates that two types of self-defense can be distinguished in international criminal law, each bearing traits of either domestic self-defense or both international and domestic selfdefense.

\section{Self-defense in the Nuremberg Judgment}

\subsection{The verdict on Erich Raeder}

\subsubsection{Relevant passages}

The part of the Nuremberg Judgment that discusses the individual criminal responsibility of the defendants, addresses an appeal to self-defense by top executive in the Third Reich navy Erich Raeder, concerning his share in the

201 Ambos, K., 2013, p. 334.

202 Wilt, H.G. van der, 2009, p. 532. 
invasion of Norway (crimes against peace, article 6(a) of the IMT Charter). The Tribunal rejects this plea by stating:

It is not necessary again to discuss this defence, which has heretofore been treated in some detail, concluding that Germany's invasion of Norway and Denmark was aggressive war. ${ }^{203}$

The Judgment does not mention where this plea is dealt with, but probably refers to the pages 205-207 of the general part, that treat the invasion of Denmark and Norway. In this section the Tribunal indicates that:

The defence that has been made here is that Germany was compelled to attack Norway to forestall an Allied invasion, and her action was therefore preventive. ${ }^{204}$

In order to establish the relevant requirements for an appeal to self-defense in case of preventive action, the Tribunal cites some criteria from the Caroline Case: ${ }^{205}$

[...] preventive action in foreign territory is justified only in case of "an instant and overwhelming necessity for self-defence, leaving no choice of means and no moment of deliberation" 206

The Tribunal does not discuss these criteria. Instead, it cites evidence both supporting and negating the view that Germany believed the Allies intended to occupy Norway ${ }^{207}$ and concludes:

From all this it is clear that when the plans for an attack on Norway were being made, they were not made for the purpose of forestalling an imminent Allied landing, but, at the most, that they might prevent an Allied occupation at some future date. ${ }^{208}$

The Tribunal thus holds that Germany did not attack Norway with the intention to prevent an imminent Allied attack. According to the Tribunal, Germany had other - less honorable - motives:

International Military Tribunal (Nuremberg), Judgment and Sentences, 1 October 1946, p. 307. International Military Tribunal (Nuremberg), Judgment and Sentences, 1 October 1946, p. 205. The Caroline Case is a 1837 incident whereby British subjects caused the death of two American citizens. During the aftermath, diplomatic correspondence took place between Great Britain and the United States. In this correspondence the often quoted criteria for self-defense, as a justification for invading foreign territory, were established: there must be a "necessity of selfdefence, instant, overwhelming, leaving no choice of means, and no moment of deliberation", the action taken must not be "unreasonable or excessive", and it must be "limited by that necessity and kept clearly with it." See: Malanczuk, P., 1997, p. 314.

International Military Tribunal (Nuremberg), Judgment and Sentences, 1 October 1946, p. 205.

International Military Tribunal (Nuremberg), Judgment and Sentences, 1 October 1946, pp. $205 / 206$.

International Military Tribunal (Nuremberg), Judgment and Sentences, 1 October 1946, p. 206. 
Norway was occupied by Germany to afford her bases from which a more effective attack on England and France might be made [...]. ${ }^{209}$

The Tribunal adds that although documents - captured by the Germans after the invasion of Norway - show that Allied plans existed to occupy parts of Norway, these plans are "in all points considerably behind the German plan" and "were not the cause of the German invasion in Norway". The Tribunal continues by discussing another argument brought up by the defense:

It was further argued that Germany alone could decide, in accordance with the reservations made by many of the Signatory Powers to the Kellogg-Briand Pact, whether preventive action was a necessity, and that in making her decision her judgment was conclusive. ${ }^{210}$

The Tribunal quickly rejects this argument, because:

[...] whether action taken under the claim of self-defence was in fact aggressive or defensive must ultimately be subject to investigation and adjudication if international law is ever to be enforced. ${ }^{211}$

\subsubsection{Applicability}

By discussing the requirements of (preventive) self-defense in its Judgment, the IMT implicitly recognizes this legal figure. Nevertheless, self-defense is rejected in casu. The Tribunal substantiates this rejection by arguing that evidence shows that Germany did not attack Norway with the intention to prevent an imminent Allied attack. Instead, Germany occupied Norway with another motive: to afford her bases for attacks on England and France. Apart from that, the Allied plans to invade Norway were not imminent, for they were not as advanced as the German plans. Remarkable is that the Tribunal cites criteria for self-defense from the Caroline Case, and then brings up a third criterion, i.e. the defendant's intention in relation to his alleged action in self-defense.

\subsubsection{Scope}

The Tribunal refers to several of the Caroline criteria when defining self-defense. It holds that self-defense in the context of preventive action is only justified when this is immediately (there is no moment for deliberation) necessary (there is no choice of means to avert the attack). Legitimate self-defense in this case requires thus at least (a) immediacy and (b) necessity. However, the decisive requirement seems to be a

209 International Military Tribunal (Nuremberg), Judgment and Sentences, 1 October 1946, p. 206.

210 International Military Tribunal (Nuremberg), Judgment and Sentences, 1 October 1946, p. 207.

211 International Military Tribunal (Nuremberg), Judgment and Sentences, 1 October 1946, p. 207. 
third, subjective, criterion: the defendant must act with the intent of legitimate selfdefense (c).

Since criterion (c) seems to be decisive, requirements (a) and (b) are barely elaborated on. The Tribunal, however, does observe that the Allied plan for their occupation of Norway was 'behind the German plans'. Through this remark the Tribunal suggests that, even if Germany had acted with the intent of legitimate selfdefense, the immediacy requirement (a) would not have been met. For at the point of the German invasion of Norway, the Allied plans for the occupation of Norway were not imminent. Consequently, preventative self-defense was not immediately necessary.

Note that the IMT denies Germany the right to make a conclusive judgment on its action in self-defense, but instead leaves this power to "investigation and adjudication", thereby subjecting the autonomy of the State to a higher authority. The Tribunal substantiates this position by the fact that international law on this point would be useless if only States could ultimately decide whether they had a right to self-defense.

Requirement (c) is a subjective criterion, for it requires an investigation of the defendant's state of mind. Whether criteria (a) and (b) must be tested objectively (did the defendant objectively meet these requirements?) or subjectively (did the defendant reasonably believe that he acted in accordance with these requirements?) cannot be derived from the Judgment. However, the remark that the Allied plan was behind the German plans - implying that the Germans invasion was not a reaction to the Allied plans - suggests an objective approach in relation to the immediacy requirement (a).

\subsubsection{Nature of self-defense}

Raeder is charged with individual criminal responsibility for State aggression (crimes against peace). To negate this charge, the defense must either establish that (a) there is no State aggression or if there is, that (b) the defendant is not individually responsible for this aggression. The reasoning employed by Raeder is the first type of argument (sub (a)): an individual appeal to self-defense ad bellum. The difference between the classic notion of international self-defense and the self-defense brought up in Raeder is that the first aims at negating the responsibility of the State, while the latter attempts to negate individual criminal responsibility through negating the responsibility of the State. Consequently, the plea entered is a mixture of domestic (negating individual criminal responsibility) and international (negating State responsibility) self-defense.

A note to the observations on the Erich Raeder case is that the case revolved around an individual appeal to preventive international self-defense. Criteria for international self-defense in general may be different. 


\section{Self-defense in the Tokyo Judgment}

\subsection{Relevant passages}

\subsubsection{The general part of the Judgment}

The right to self-defense is recognized by the Tokyo Tribunal in Chapter III of the Judgment. This Chapter discusses "Obligations Assumed and Rights Acquired by Japan" by enumerating several international treaties relevant to the case at issue. When discussing the Kellogg-Briand Pact (27 August 1929), the Tribunal recalls that this pact, to which Japan was party, condemns aggressive war and promotes peaceful settlement of international conflicts. ${ }^{212}$ However, the Tribunal acknowledges that the tenor of the pact is not absolute, for:

[...] some of the Signatory Powers made declarations reserving the right to wage war in self-defence. ${ }^{213}$

The Tribunal continues by explicitly acknowledging this right to self-defense - not particularly in relation to the Kellogg-Briand Pact, but in a universal way - by stating that:

Any law, international or municipal, which prohibits recourse to force, is necessarily limited by the right of self-defence. ${ }^{214}$

Next, the Tribunal discusses some of the conditions of this right:

The right to self-defence involves the right of the State threatened with an impending attack to judge for itself in the first instance whether it is justified in resorting to force. ${ }^{215}$

Emphasis is put on the first instance since, according to the Tribunal, a State can never have the last word when determining whether its action in self-defense was justified:

Under the most liberal interpretation of the Kellogg-Briand Pact, the right to selfdefence does not confer upon the State resorting to war the authority to make a final

212 Röling and Rüter (Eds.), The Tokyo Judgment: The International Military Tribunal of the Far East (I.M.T.F.E.), 29 April 1946 - 12 November 1948, Vol. I, pp. 46/47.

213 Röling and Rüter (Eds.), The Tokyo Judgment: The International Military Tribunal of the Far East (I.M.T.F.E.), 29 April 1946 - 12 November 1948, Vol. I, p. 47.

214 Röling and Rüter (Eds.), The Tokyo Judgment: The International Military Tribunal of the Far East (I.M.T.F.E.), 29 April 1946 - 12 November 1948, Vol. I, p. 47.

215 Röling and Rüter (Eds.), The Tokyo Judgment: The International Military Tribunal of the Far East (I.M.T.F.E.), 29 April 1946 - 12 November 1948, Vol. I, p. 47. 
Chapter III

determination upon the justification for its action. Any other interpretation would nullify the Pact; and this Tribunal does not believe that the Powers in concluding the Pact intended to make an empty gesture. ${ }^{216}$

\subsubsection{The Verdict on Shigetaro Shimada, Hideki Tojo, Shigenori Togo}

On several occasions (Shigetaro Shimada, Hideki Tojo, Shigenori Togo), the part of the Tokyo Judgment that evaluates the individual criminal responsibility of the defendants (Chapter X) mentions an appeal to self-defense against several counts of Crimes against peace (article 5(a) of the IMTFE Charter). The Tribunal always rejects this plea by stating that it has been dealt with elsewhere. ${ }^{217}$

Although the Judgment does not mention the pages where this plea is dealt with, the Tribunal probably refers to Chapter VII of the Judgment that discusses Crimes against peace in the context of the Pacific war. In this Chapter the Tribunal mentions that multiple defendants advanced the contention that:

Japan's acts of aggression against France, her attack against the Netherlands, and her attacks on Great Britain and the United States of America were justifiable measures of self-defence. ${ }^{218}$

Next, the Tribunal summarizes the arguments of the defendants:

It is argued that these Powers [i.e. France, the Netherlands, Great Britain and the USA] took such measures to restrict the economy of Japan that she had no way of preserving the welfare and prosperity of her nationals but to go to war. ${ }^{219}$

The Tribunal rejects the appeal to self-defense through three arguments. First it explains that the measures taken by Japan's adversaries were justified:

The measures which were taken by these Powers to restrict Japanese trade were taken in an entirely justifiable attempt to induce Japan to depart from a course of aggression on which she had long been embarked and upon which she had determined to continue. ${ }^{220}$

216 Röling and Rüter (Eds.), The Tokyo Judgment: The International Military Tribunal of the Far East (I.M.T.F.E.), 29 April 1946 - 12 November 1948, Vol. I, p. 47.

217 Röling and Rüter (Eds.), The Tokyo Judgment: The International Military Tribunal of the Far East (I.M.T.F.E.), 29 April 1946 - 12 November 1948, Vol. I, pp. 458, 461 and 462.

218 Röling and Rüter (Eds.), The Tokyo Judgment: The International Military Tribunal of the Far East (I.M.T.F.E.), 29 April 1946 - 12 November 1948, Vol. I, p. 380.

219 Röling and Rüter (Eds.), The Tokyo Judgment: The International Military Tribunal of the Far East (I.M.T.F.E.), 29 April 1946 - 12 November 1948, Vol. I, pp. 380/381.

220 Röling and Rüter (Eds.), The Tokyo Judgment: The International Military Tribunal of the Far East (I.M.T.F.E.), 29 April 1946 - 12 November 1948, Vol. I, p. 381. 
The Tribunal progresses by mentioning examples of these measures and their justification: the USA terminated a commerce and navigation treaty, after Japan seized Manchuria and a large part of China and when Japan ceased to respect the rights and interest of the nationals of the USA in China. Embargoes were imposed when it became clear that Japan had determined to attack the territories and interests of France, the Netherlands, Great Britain and the USA. These embargoes were imposed in an attempt to induce Japan to depart from its aggressive policy and in order that the Powers might no longer supply Japan with the materials to wage war against them. Sometimes embargoes were also taken in order to build up the supplies, which were needed by the nations resisting aggressors. ${ }^{221}$ In all these cases the Tribunal holds that the measures taken were justified.

The second argument of the Tribunal in rejecting the appeal to self-defense is that Japan's expansion plans existed before the economic measures were taken. In irritation the Tribunal continues:

The argument [i.e. self-defence] is indeed merely a repetition of Japanese propaganda issued at the time she was preparing for her wars of aggression. It is not easy to have patience with its lengthy repetition at this date when documents are at length available which demonstrate that Japan's decision to expand to the North, to the West and to the South at the expense of her neighbours was taken long before any economic measures were directed against her and was never departed from. ${ }^{222}$

The third argument of the Tribunal stresses that the documents mentioned above, do not reveal self-defense as a motive for Japan's attacks:

The evidence clearly establishes contrary to the contention of the defense that the acts of aggression against France, and the attack on Britain, the United-States and the Netherlands were prompted by the desire to deprive China of any aid in the struggle she was waging against Japan's aggression and to secure for Japan the possessions of her neighbours in the South. ${ }^{223}$

In the part of the Judgment that discusses the individual criminal responsibility of the defendant, the self-defense argument of Shimada is also rejected by the words that:

This defence leaves out of account the fact that the gains to retain which he was determined to fight were, to his knowledge, gains Japan had acquired in years of aggressive war. ${ }^{224}$

221 Röling and Rüter (Eds.), The Tokyo Judgment: The International Military Tribunal of the Far East (I.M.T.F.E.), 29 April 1946 - 12 November 1948, Vol. I, p. 381.

222 Röling and Rüter (Eds.), The Tokyo Judgment: The International Military Tribunal of the Far East (I.M.T.F.E.), 29 April 1946 - 12 November 1948, Vol. I, p. 381.

223 Röling and Rüter (Eds.), The Tokyo Judgment: The International Military Tribunal of the Far East (I.M.T.F.E.), 29 April 1946 - 12 November 1948, Vol. I, p. 381.

224 Röling and Rüter (Eds.), The Tokyo Judgment: The International Military Tribunal of the Far East (I.M.T.F.E.), 29 April 1946 - 12 November 1948, Vol. I, p. 459. 
Chapter III

\subsection{Analysis of self-defense in the Tokyo Judgment}

\subsubsection{Applicability}

In the passages cited from the general part of the Judgment, the Tokyo Tribunal explicitly recognizes the right to self-defense. However, the individual appeal to self-defense by Hideki Tojo and others is rejected in casu. The rejection of the Tribunal is founded on four arguments: (1) the 'attack' by the adversary was lawful,

(2) the plans for attacks by Japan existed before the actual 'attack' by the adversary,

(3) these plans were not motivated by self-defense and (4) that the objects of defense were unlawfully acquired in the first place.

\subsubsection{Scope}

As a general condition for self-defense the Tribunal only explicitly mentions the threat of an impending attack. However, the four arguments employed by the Tribunal in its rejection of self-defense, reveal several other requirements. By stating that the appeal to self-defense is not valid because the Allied 'attack' (in the form of economic restrictions) was justified, the Tribunal suggests that an appeal to self-defense can only be successful in case of an unjustified (or unlawful) attack. What is more, by holding that the appeal to self-defense is not valid because the plans for attacks by Japan existed before the actual 'attack' by the adversary, the Tribunal suggests that Japan's actions were not motivated by selfdefense and not objectively necessary. This implies two requirements: (i) the defendant must have the intention to act in self-defense and (ii) the act in selfdefense must be objectively necessary. The third argument of the Tribunal, again, substantiates that Japans actions were not motivated by self-defense by demonstrating alternative motives for the relevant attack. The fourth argument of the Tribunal refers to the fact that the defensible interests were unlawfully acquired, which implies that the right to self-defense only exist in case of lawful possession. The five conditions for self-defense that can be derived from the Tokyo Judgment are thus that:
a. There must be a threat of an impending attack;
b. This attack must be unlawful;
c. Self-defense must be necessary;
d. The perpetrator must have the intention to act in legitimate self-defense, and;
e. The defensible interest must have been lawfully acquired.

Like the IMT, the IMTFE denies that a State has the final authority in determining whether an action in self-defense is legitimate, and substantiates this position with more or less the same argument. 
Requirement (a) is not tested in the Judgment. Requirements (b), (c) and (d) are tested objectively (Japan's attacks were unjustified because they were directed at lawful action, Japan's plans existed before the Allies launched their lawful attack and the object of defense was not lawfully acquired). Requirement (d) is a subjective criterion, for it relates to the defendant's state of mind. However, to make things more confusing, this subjective criterion is determined by an objective test.

\subsubsection{Nature of self-defense}

In the passages cited from the general part of the Judgment, the Tokyo Tribunal explicitly recognizes self-defense in relation to "Any law [...], which prohibits recourse, to force" and stresses that this law can be either "international or municipal". The Tribunal thus seems to recognize any kind of self-defense, including international self-defense (self-defense ad bellum) and domestic selfdefense. However, the conditions for self-defense, cited in this passage, only refer to self-defense ad bellum ("the right of a State"). The appeal to self-defense by Hideki Tojo and others is similar to the plea entered by Erich Raeder: an individual appeal to self-defense ad bellum. Tojo et al. aim at negating their individual criminal responsibility for crimes against peace by negating the responsibility of the State.

\section{Self-defense at The ICTY}

\subsection{Prosecutor v. Kordić and Čerkez}

\subsubsection{Relevant passages}

Between 1991 and 1995 Dario Kordić was one of the leading political figures in the Bosnian Croat community. As he stands trial - for Grave breaches of the Geneva Conventions of 1949 (Article 2 ICTY Statute), Violations of the laws and customs of war (Article 3 ICTY Statute) and Crimes against humanity (article 5 ICTY Statute) - his Defense argues self-defense in relation to these charges. ${ }^{225}$ According to the Trial Chamber, the Kordić Defense has argued "the Bosnian Croats were acting in self-defence". They have presented evidence to substantiate this. This evidence consisted of proof of "ABiH attacks and offensives in Central Bosnia"226 and the attempt to demonstrate "that the Bosnian Croats were victims of Muslim aggression in Central Bosnia". 227 The Trial Chamber then continues, not by discussing this selfdefense argument, but by raising a preliminary question, namely:

\footnotetext{
225 ICTY, Prosecutor v. Kordić and Čerkez, Trial Chamber, 26 February 2001, par. 448. In relation to exactly which charges self-defense is argued, cannot be derived from the Judgment.

$226 \mathrm{ABiH}$ stands for 'Army of Bosnia and Herzegovina'.

227 ICTY, Prosecutor v. Kordić and Čerkez, Trial Chamber, 26 February 2001, par. 448.
} 
Chapter III

[...] whether defensive action or self-defence may amount to a ground for excluding criminal responsibility for the commission of serious violations of international humanitarian law. ${ }^{228}$

Before answering this question the Trial Chamber stresses that:

[...] the Statute of the International Tribunal does not provide for self-defence as a ground for excluding criminal responsibility. "Defences" however form part of the general principles of criminal law, which the International Tribunal must take into account in deciding the cases before it. ${ }^{229}$

It also provides for a brief definition of self-defense, being:

[...] a defence to a person who acts to defend or protect himself or his property (or another person's property) against an attack, provided that the acts constitute a reasonable, necessary and proportionate reaction to the attack. ${ }^{230}$

Next, the Trial Chamber specifies this definition by citing the ICC self-defense provision, article 31(1)(c):

1. In addition to other grounds for excluding criminal responsibility provided for in this Statute, a person shall not be criminally responsible if, at the time of that persons conduct:

$[\ldots]$

(c) The person acts reasonably to defend himself or herself or another person or, in the case of war crimes, property which is essential for the survival of the person or another person or property which is essential for a military mission against an imminent and unlawful use of force in a manner proportionate to the degree of danger to the person or the other person or property protected. The fact that the person was involved in a defensive operation conducted by forces shall not in itself constitute a ground for excluding criminal responsibility under this subparagraph. ${ }^{231}$

The exact requirements of this ICC provision are discussed below (Section 5). For now it suffices to say that the ICTY Trial Chamber confirms the ICC definition of self-defense and even declares that this definition "may be regarded as constituting a rule of customary international law". ${ }^{232}$ The fact that the ICTY endorses the article 31(1)(c) definition of self-defense, seems to answer the question put by the Court at the beginning of its contemplation "whether defensive action or self-

ICTY, Prosecutor v. Kordić and Čerkez, Trial Chamber, 26 February 2001, par. 448.

ICTY, Prosecutor v. Kordić and Čerkez, Trial Chamber, 26 February 2001, par. 449.

ICTY, Prosecutor v. Kordić and Čerkez, Trial Chamber, 26 February 2001, par. 449.

ICTY, Prosecutor v. Kordić and Čerkez, Trial Chamber, 26 February 2001, par. 450.

ICTY, Prosecutor v. Kordić and Čerkez, Trial Chamber, 26 February 2001, par. 451. 
defence may amount to a ground for excluding criminal responsibility for the commission of serious violations of international humanitarian law." Namely, the quoted ICC provision holds that that self-defense may amount to a ground for excluding criminal responsibility for the commission of any international crime over which the ICC (or, in this case, the ICTY) has jurisdiction, thus also if this crime amounts to a serious violation of international humanitarian law. However, in relation to defensive operations, the Trial Chamber states:

Of particular relevance to this case is the last sentence in the above provision to the effect that the involvement of a person in a "defensive operation" does not "in itself" constitute a ground for excluding criminal responsibility. It is therefore clear that any argument raising self-defence must be assessed on its own facts in the specific circumstances relating to each charge. The Trial Chamber, however, would emphasize that military operations in self-defence do not provide a justification for serious violations of international humanitarian law. ${ }^{233}$

Throughout the rest of the Judgment the Trial Chamber briefly addresses the selfdefense argument in different situations. In every case the argument is rejected.

When addressing the violations of article 2, 3 and 5 of the ICTY Statute in the context of the conflict in Busovača, the Trial Chamber "rejects the Defence case that the $\mathrm{HVO}^{234}$ were on the defensive in Busovača". Reason for this rejection is that the attacks of the HVO were "the beginning of a pattern of attacks in the locality, the purpose of which was to remove or subdue the Muslim population". 235 Self-defense is thus rejected, because the relevant attack was motivated by reasons other than self-defense.

When addressing again the violations of articles 2, 3 and 5 of the ICTY Statute in the context of the HVO attack on the village of Ahmići, the Trial Chamber finds:

[...] that the overwhelming evidence points to a well-organized and planned HVO attack upon Ahmići with the aim of killing or driving out the Muslim population, resulting in a massacre. The assertion that this attack was justified strategically, defensively, or in any other way, is wholly without foundation: Such defenders as were available were taken completely by surprise and any defence put up thereafter was rudimentary, as the results of the day show. Furthermore, the Trial Chamber draws the inference from this evidence (and the evidence of other HVO attacks in April 1993) that there was by this time a common design or plan conceived and executed by the Bosnian Croat leadership to ethnically cleanse the Lašva Valley of Muslims. ${ }^{236}$ 
Here, the Trial Chamber rejects the appeal to self-defense because: (a) evidence points to the attack being motivated by reasons other than self-defense (i.e. ethnic cleansing), (b) these other reasons were part of a plan and (c) defenders were surprised by the attack and the defense was rudimentary. The latter point demonstrates that, objectively, there was hardly a defensive action going on.

When addressing the violations of articles 2, 3 and 5 of the ICTY Statute in the context of the Stupni Do attack, the Trial Chamber holds:

[...] that the attack on Stupni Do was a concerted attack by the HVO upon the village, with a view to removing the Muslim population. Whatever the immediate motive, it was part of the HVO offensive against the Muslim population of Central Bosnia and the result was a massacre. Some defense was offered but there was no justification for the attack. ${ }^{237}$

Again, the Trial Chamber's rejection of self-defense is substantiated by the presence of a motive other than self-defense.

When discussing the crime of persecution (article 5(h) of the ICTY Statute), the Trial Chamber reiterates:

The Defence case that these events amounted to a civil war in which the Bosnian Croats were on the defensive, and themselves subject to persecution, is rejected.

Then the Trial Chamber adds:

For these purposes, as has been pointed out, the fact that individual atrocities were committed against Bosnian Croats is for these purposes irrelevant although they may be the subject of other criminal proceedings. (It is inherent in the above finding that there existed a common plan or design in the Bosnian Croat leadership to conduct this persecution. $)^{238}$

In sum, self-defense in Prosecutor v. Kordić and Čerkez is rejected because the military actions at issue were not motivated by self-defense. On the contrary, according to the Trial Chamber these actions had the aim of killing or driving out the Muslim population. The fact that "individual atrocities" were committed against the Bosnian Croats does not change that.

The Appeals Chamber in Prosecutor v. Kordić and Čerkez mainly discusses procedural issues, which are reviewed elsewhere (Chapter II, Section 5.2). However, the Appeals Chamber reiterates the contention of the Trial Chamber that: 
“"Defences' [...] form part of the general principles of criminal law which the International Tribunal must take into account in deciding the cases before it." 239

Another interesting remark, relevant to the issue of self-defense, is made in the context of a claim made by Čerkez, that "the Trial Chamber failed to assess the evidence that supported a possible conclusion that the HVO's action followed a militarily justifiable plan". ${ }^{240}$ The Appeals Chamber, however, holds that it was not necessary for the Trial Chamber to assess this issue, because:

[...] whether an attack was ordered as pre-emptive, defensive or offensive is from a legal point of view irrelevant, as is the issue of whether the "other side" was taken by surprise. The issue at hand is whether the way the military action was carried out was criminal or not. ${ }^{241}$

\subsubsection{Applicability}

The Kordić and Čerkez Trial Chamber Judgment not only acknowledges complete defenses as a legal figure in general, it also recognizes self-defense as put down in article 31 (1)(c) of the ICC Statute as customary law. However, another species of self-defense - referred to as defensive operations - seems to be rejected a priori. The Trial Chamber holds that these operations "do not provide a justification for serious violations of international humanitarian law". Nevertheless, the formulation of this a priori rejection is not absolute. If these operations can not be a justification for serious violations of international humanitarian law, they can theoretically still be a) an excuse for serious violations of international humanitarian law or b) a justification or an excuse in case of violations of international humanitarian law that are not serious or c) a justification or an excuse for violations of international criminal law that are not covered by international humanitarian law. However, although the Trial Chamber in Kordić and Čerkez implicitly acknowledges that there are situations in which defensive operations can be a complete defense ("any argument" must be assessed on its own facts and circumstances), it does not specify these situations, let alone refer to the applicable criteria (are these the criteria ex paragraph 1 (c) or other?).

All appeals to self-defense in Prosecutor v. Kordić and Čerkez are rejected in casu. In each case, rejection is essentially motivated by the same argument: the intent to act in self-defense is absent (or on one occasion: this intent is not predominant). ${ }^{242}$ The lack of intent to act in self-defense is demonstrated by revealing alternative intentions behind certain operations, i.e. to secede from Bosnia and

\footnotetext{
239 ICTY, Prosecutor v. Kordić and Čerkez, Appeals Chamber, 17 December 2004, par. 837.

240 ICTY, Prosecutor v. Kordić and Čerkez, Appeals Chamber, 17 December 2004, par. 809.

241 ICTY, Prosecutor v. Kordić and Čerkez, Appeals Chamber, 17 December 2004, par. 812.

242 ICTY, Prosecutor v. Kordić and Čerkez, Trial Chamber, 26 February 2001, par. 750.
} 
Herzegovina and unify with Croatia or to remove, subdue or kill the Muslim population.

The criterion 'intent to act in self-defense' in Prosecutor v. Kordić and Čerkez is somewhat opaque. This lack of clarity is caused by the fact the Trial Chamber does not reveal whether the appeals to self-defense in this case must be qualified as an appeal to self-defense in the sense of the first sentence of article 31(1)(c) of the ICC Statute or as a defensive operation. In the first situation the criteria ex article 31(1) (c) are applicable. In the second situation - according to the Trial Chamber - an appeal to self-defense cannot be "a justification for serious violations of international humanitarian law". In Prosecutor v. Kordić and Čerkez some aspects indicate that the Trial Chamber is discussing the first type of self-defense while other facets point out that it is discussing the latter.

On the one hand, the type of self-defense discussed in Prosecutor v. Kordic and Čerkez seems to be operational self-defense. All cases mentioned revolve around military operations. What is more, the Trial Chamber, that has stressed that "the last sentence" of article 31(1)(c) - which refers to defensive operations - is of "particular relevance" to this case.

However, if the type of self-defense at issue were defensive operations, the Trial Chamber, following its own rules, should have either rejected self-defense a priori by stating that self-defense can not be a justification in case of serious violations of international humanitarian law or it should have demonstrated that this is an exceptional situation (one of the circumstances (a)-(c), mentioned above), and test the appeal on its merits. The Trial Chamber, however, refrains from doing so. This, together with the fact that the crimes at issue involve serious violations of international humanitarian law, indicates that the Trial Chamber is not discussing operational self-defense.

Conclusion is that the Trial Chamber in Kordić and Čerkez is sending mixed messages in relation to the nature of the appeals to self-defense in this case. The confusion seems to be caused by the fact that the Trial Chamber intends to discuss operational self-defense, but does not reason in accordance with its self proclaimed rules. It is therefore difficult to map out both the structure of the rejection of selfdefense in this case and to infer rules from it. Consequently, it is impossible to figure out in which context (ICC self-defense or operational self-defense) the repeatedly discussed intent requirement must be placed. The mix-up is not rectified on appeal.

\subsubsection{Scope}

Considering the scope of self-defense, the Trial Chamber in Kordić and Čerkez falls back on the ICC criteria for this defense. These criteria are discussed below (Section 5). For now, I would only like to draw attention to the fact the present case is the first in international criminal law to refer to the proportionality requirement in the context of self-defense. 
As to self-defense in the sense of defensive operations, Prosecutor v. Kordic and Čerkez, seems to leave this defense available in a limited amount of situations. However, the Judgment is neither clear on the situations in which this defense could be available nor on its requirements. Still, despite of the lack of clarity in the Judgment, it seems that "the intent to act in self-defence" could be a requirement for self-defense in the sense of defensive operations as well.

\subsubsection{Nature of self-defense}

The Trial Chamber in Kordić and Čerkez distinguishes between self-defense in the sense of the first sentence of article 31(1)(c) of the ICC Statute and self-defense in the sense of operational self-defense (as referred to in the second sentence of article 31(1)(c) of the ICC Statute). The first type of self-defense is defined by the criteria mentioned in the first sentence of article 31(1)(c). The second type of selfdefense is not "in itself" a ground for excluding criminal responsibility "under this subparagraph". What is more, according to the Trial Chamber in Kordic and Cerkez this defense does not provide "a justification for serious violations of international humanitarian law". In Section 4.1.2 is explained that it is not clear which type of self-defense the Trial Chamber in Kordić and Čerkez intends to discuss. Consequently it is difficult to classify the type of self-defense discussed in this case.

In order to classify the defense touched upon in Kordić and Čerkez, a better understanding of the relationship between criminal law self-defense and defensive operations is paramount. The key to this relationship can be found in the last sentence of article 31(1)(c) ("The fact that the person was involved in a defensive operation conducted by forces shall not in itself constitute a ground for excluding criminal responsibility under this subparagraph"). This sentence was originally inserted to elucidate the difference between operational and individual self-defense. The sentence was meant to make clear that participation in a defensive operation by a collective entity does not automatically legitimize international crimes committed by individuals during the course of such an operation. ${ }^{243}$ The Kordic and Čerkez Appeals Chamber confirms this idea.

This restriction does not mean that crimes committed during a defensive operation can never provide a ground for excluding criminal responsibility under the ICC Statute. However, different opinions exist on how operational self-defense can provide a complete defense. Bantekas holds that although a defensive operation cannot "in itself" be a ground for excluding criminal responsibility, it can be a

243 Ambos, K., 'Other Grounds for Excluding Criminal Responsibility', In: Cassese, A. et al. (eds.), The Rome Statute of the ICC: A Commentary, Oxford University Press, Vol. 1, 2002, pp. 10031048, p. 1033; Eser, A., 2008, 'Article 31: Grounds for Excluding Criminal Responsibility', In: Triffterer, O. (ed.), Commentary on the Rome Statute of the International Criminal Court: Observers' Notes, Article by Article, Hart Publishing, Oxford, 2008, pp. 863-893, p. 879 and Scaliotti, M., 2001, p. 166. 
complete defense if the individual involvement in the operation is in accordance with the requirements of paragraph (1)(c). ${ }^{244}$ Eser, however, holds that the scope of the first sentence of paragraph (1)(c) is restricted to private self-defense (which he defines as "self-defence by an individual in his non-official capacity"). According to Eser, individual participation in a defensive operation can provide a complete defense through article 31(3), which allows the Court to make up new defenses. ${ }^{245}$ Other writers seem to be in line with Bantekas, holding that an individual appeal to self-defense must always (whether he is involved in a defensive operation or not) behave within the limits of self-defense as defined in article 31, and do not hold, like Eser, that article $31(1)(\mathrm{c})$ is restricted to private self-defense in a non-official capacity only. ${ }^{246}$

In short, all authors agree that at least private self-defense in a non-official capacity is covered by the criteria ex article 31(1)(c) and that crimes committed in the context of a defensive operation do not bar a complete defense under the Rome Statute. The difference of opinion is restricted to the question how individual involvement in defensive operations can be a complete defense (i.e. whether this form of self-defense is covered by article 31(1)(c) or by 31(3)). In practice an individual can thus appeal to self-defense under the ICC Statute when a crime has been committed both during a defensive operation (self-defense in bello) and outside the realms of a defensive operation (private self-defense). However, the decision to engage in a defensive operation - a decision in the sphere of $i u s$ ad bellum - is not covered by article 31(1)(c). ${ }^{247}$ The Trial Chamber decision in Kordić and $\check{C}$ erkez differs from the ICC perspective in that it a priori restricts the number of situations in which defensive operations can be a complete defense (however, confusingly, does not apply this distinction in its own Judgment), but not in line with the ICC distinction between ius ad bellum and ius in bello.

Canvassing the outlines of the relationship between criminal law self-defense and defensive operations sheds another light on the defense brought up in Kordic and Čerkez. The arguments made by the defense and the reaction of the Appeals Chamber indicate that the case revolves around an individual appeal to self-defense in the sphere of ius ad bellum against crimes committed in the sphere of ius in bello (during an armed conflict). The fact that an ineffective defense was raised international self-defense can only be raised against the crime of aggression, formerly known as crimes against peace - against the crimes charged may explain the unfathomable reasoning in this case.

244 Bantekas, I., 2004, p. 278.

245 Eser, A., 2008, p. 879. Article 31(3) is elaborately discussed in Chapter XII, Section 3 (Other possible complete defenses at the ICC).

246 Ambos, K., 2002, p. 1033 and Scaliotti, M., 2001, p. 171.

247 Ambos, K, 2013, p. 335. 


\subsection{Prosecutor v. Stakić}

\subsubsection{Relevant passages}

Around 1992 a pattern of atrocities against the non-Serb population took place in Prijedor municipality (north-western Bosnia and Herzegovina). At the time, Milomir Stakić was the leading political figure in this municipality (President of the Serb controlled Prijedor Municipality Crisis Staff and head of the Municipal Council for National Defense in Prijedor). ${ }^{248} \mathrm{He}$ was charged by the ICTY for genocide (article 4 of the ICTY Statute), crimes against humanity (article 5 of the ICTY Statute) and violations of the laws and customs of war (article 3 of the ICTY Statute). ${ }^{249}$ Self-defense comes up in the context of two armed attacks by Serbian soldiers against the non-Serb civilian population. The first attack took place after a shooting incident in the vicinity of the village of Hambarine, initiated by the adversary (Muslims). As a reaction to this incident the Serbs issued an ultimatum according to which weapons and perpetrators must be handed in. When this ultimatum was not complied with, the Serbs attacked the civilian population of Hambarine. ${ }^{250}$ The second attack is related to the first. After the attack on Hambarine, the Muslim town of Kozarac received a Serb ultimatum to surrender weapons. When this ultimatum was not met, a Serbian military convoy approached Kozarac and commenced an attack on the civilian population. However, one day before this attack, "Muslim extremists" allegedly attacked a Serb convoy. ${ }^{251}$

In its analysis of the two events described above, the Trial Chamber discusses the right to self-defense. It recognizes that:

[...] as a matter of principle, the soldiers at the checkpoint in Hambarine and the Serb columns in Kozarac [...] had a right to self-defence. ${ }^{252}$

However, from the reasoning that follows can be derived that the Trial Chamber holds that several of the requirements for legitimate self-defense have not been met. The Trial Chamber first discusses the requirements of proportionality and necessity. It holds that:

[...] any armed response must be proportionate to the initial attack. As the Defence military expert General Wilmot testified, other courses of action were at the Serb force's disposal in both situations ... 253

\footnotetext{
248 ICTY, Prosecutor v. Stakić, Trial Chamber, 31 July 2003, par. 184.

249 ICTY, Prosecutor v. Stakić, Trial Chamber, 31 July 2003, par. 11.

250 ICTY, Prosecutor v. Stakić, Trial Chamber, 31 July 2003, par. 129-138.

251 ICTY, Prosecutor v. Stakić, Trial Chamber, 31 July 2003, par. 139-149.

252 ICTY, Prosecutor v. Stakić, Trial Chamber, 31 July 2003, par. 153.

253 ICTY, Prosecutor v. Stakić, Trial Chamber, 31 July 2003, par. 153.
} 
The Trial Chamber continues by providing examples of alternative courses of action that the Serbs could have taken:

$[\ldots]$ to dispatch units to search for the alleged perpetrators [...] to secure the area before performing such search. ${ }^{254}$

It concludes its contemplation by holding that launching:

[...] what can only be described as planned, co-ordinated, and sustained armed attacks on civilian settlements does not meet the requirements imposed by the fundamental principle of proportionality, particularly when considering the eyewitness testimony that fire was also opened with heavy weapons on the fleeing civilian population. The disproportionality and the use of armed force against the civilian population rendered both attacks illegal. 255

Next, the Trial Chamber discusses the immediacy requirement, by holding that:

[...] any act of self-defence must be temporally connected with the initial attack. Thus, the launching of full-fledged military maneuvers one day after the initial attacks does not fulfill this prerequisite for legal military acts of "self-defence". ${ }^{256}$

The Trial Chamber thus denies the presence of legitimate self-defense because the requirements of proportionality, necessity and immediacy have not been met. However, the Trial Chamber does not stop there, but continues by stating that the absence of proportionality and immediacy indicates that the initial incidents (at the checkpoint in Hambarine and the with the Serb columns in Kozarac) only served as a pretext for the Serbs to proceed with their actual agenda. It holds that:

The delay in attacking the settlements taken together with the planned and co-ordinated character of the disproportionate attacks launched by the Serb authorities on these predominantly Muslim areas indicate that the initial incidents, because that is all that they were, only served as the long expected pretext for the Serb authorities to finally cleanse the Hambarine and Kozarac areas of their nonSerb population. ${ }^{257}$

According to the Trial Chamber the Serbs had a plan to attack Hambarine and Kozarac. This plan was not motivated by self-defense but by ethnic cleansing and existed before the defensible incidents took place. 


\subsubsection{Applicability and scope}

Although the Trial Chamber in Prosecutor v. Stakić explicitly recognizes the legal figure of self-defense, the defense is rejected in casu. The reasons for this rejection equal the four requirements for self-defense that can be derived from this case:

a. The action in self-defense must be proportionate;

b. The action in self-defense must be necessary;

c. The action in self-defense must be "temporarily connected with the initial attack";

d. The defendant must have had the intent to act in self-defense.

The first requirement (a) was not met because the alleged action in self-defense as a reaction to two shooting incidents directed at soldiers consisted of "planned, co-ordinated and sustained armed attacks on civilian settlements" and because "fire was also opened with heavy weapons on the fleeing civilian population". These grounds for rejecting the proportionality requirement bear several indications as to cases in which the proportionality requirement would not be fulfilled. When an operation is well thought through (planned, coordinated), continuous (sustained) and/or aimed at the civilian population (as opposed to combatants), it is highly unlikely that the proportionality requirement has been met. The same goes for the use of heavy weapons on the fleeing civilian population.

The necessity requirement (b) was not met, because the Serbs could have opted for other courses of action.

The immediacy requirement (c) was not complied with, because the alleged military maneuvers in self-defense were launched one day after the initial attack. One day between initial attack and action in self-defense, it seems, is too long a stretch of time to meet this requirement.

The intent requirement (d) is not met because the attacks were not motivated by self-defense, but by the desire to "cleanse" the Hambarine and Kozarac areas of their non-Serb population. The intent requirement is thus negated by demonstrating alternative motives for the alleged action in self-defense. This alternative intent is demonstrated by the disproportionality of the action, the lack of temporal connection between attack and defense and the fact that the 'defense' was prepared.

Criteria (a), (b) and (c) are tested from an outsider perspective and thus objectively. Requirement (d) is a subjective test for it investigates the subjective state of mind of the perpetrator. However, this subjective test is determined by objective factors (e.g. planning, disproportionality) and not by subjective (what did the perpetrator think?).

\subsubsection{Nature of self-defense}

The nature of the self-defense argument discussed in Prosecutor v. Stakić must be qualified as an individual appeal to self-defense ad bellum, for it contains that the 
purpose of the military action was legitimate. As in Kordić and Čerkez, an individual appeal to self-defense ad bellum is advanced to counter charges of crimes against humanity and war crimes committed in bello. If Stakić had wanted to successfully deny the crimes charged by means of a complete defense he should thus not have argued that the operation was lawful, but that the crimes during the operation were committed because of a legitimate reason (e.g. self-defense).

\subsection{Prosecutor v. Galić}

\subsubsection{Relevant passages}

In the early 1990s the VRS conducted a campaign of sniping and shelling attacks on the city of Sarajevo. At that time, Stanislav Galić held several top positions within the Sarajevo Romanija Corps (SRK) of the VRS. ${ }^{258}$ Galić was tried by the ICTY for crimes against humanity (article 5 of the ICTY Statute) and violations of the laws and customs of war (article 3 of the ICTY Statute). ${ }^{259}$ In relation to the sniping and shelling attacks on Sarajevo, the Defense argues:

[...] the pattern of fire into the city of Sarajevo shows that the Serbian forces wanted peace, harboured no territorial ambition and merely wished to "defend" territory regarded as belonging to the Bosnian Serbs, and which was already within the purview of the SRK. To this end, SRK's operations were defensive in nature, not aggressive. ${ }^{260}$

The Trial Chamber rejects this contention, based on evidence holding that:

[...] the purpose behind the campaign of targeting civilians [...] was a crude application of pressure on the BH government. It explains that the purposes of the campaign was to undermine the government's popular support from within the city to maintain the conflict, and to undermine the morale of the $\mathrm{ABiH}$ combatants, by reminding them that so long as they fought, their families behind them were in more danger than themselves. ${ }^{261}$

Through this statement the Trial Chamber demonstrates that it does not think that the attacks at issue were motivated by self-defense.

\subsubsection{Applicability}

The Trial Chamber in Prosecutor v. Galić does not explicitly acknowledge or decline the legal figure of self-defense. The defense is, however, rejected in casu.

ICTY, Prosecutor v. Galić, Trial Chamber, 5 December 2003, par. 604.

ICTY, Prosecutor v. Galić, Trial Chamber, 5 December 2003, par. 4.

ICTY, Prosecutor v. Galić, Trial Chamber, 5 December 2003, par. 565.

ICTY, Prosecutor v. Galić, Trial Chamber, 5 December 2003, par. 576. 
Rejection is based on the fact that the sniping and shelling in Sarajevo was not motivated by self-defense, but by the desire to put pressure on the army of Bosnia and Herzegovina. The intent to act in self-defense is thus absent.

\subsubsection{Scope}

Little information can be gathered from Prosecutor v. Galić on the requirements for self-defense. The Judgment only confirms that the intent to act in self-defense is an important factor and that this intent can be negated by the presence of an alternative motive for the alleged action in self-defense.

\subsubsection{Nature of self-defense}

The nature of the appeal to self-defense discussed in Prosecutor v. Galic must be qualified as an individual appeal to self-defense ad bellum, for the defendant claims the attacks had a defensive nature. However, as in Kordić and Čerkez, and Stakić an individual appeal to international self-defense (ad bellum) is advanced to counter charges of crimes against humanity and war crimes committed in bello. Again, the Defense seems to be barking up the wrong tree.

\subsection{Prosecutor v. Hadžihasanović and Kubura}

\subsubsection{Relevant passages}

During the conflict in the former Yugoslavia, Enver Hadžihasanović held several top positions in the Army of Bosnia and Herzegovina (ABiH). He was charged by the ICTY for violations of laws or customs of war (article 3 of the ICTY Statute). The Defense argues acquittal on all counts. Among other arguments, this request is substantiated by the position that "Hadžihasanović's actions were purely defensive in nature". ${ }^{262}$ The Trial Chamber, however, does not discuss this argument.

\subsubsection{Analysis}

Since the Trial Chamber does not discuss the validity of the self-defense argument, it is difficult to draw conclusions from this case. The argument was not an issue on appeal either. The nature of the self-defense brought up in this case must again be qualified as an individual appeal to self-defense ad bellum (to counter charges of war crimes committed in bello), for the defendant argues that the purpose of the operation was defensive.

262 ICTY, Prosecutor v. Hadžihasanović and Kubura, Trial Chamber, 15 March 2006, par. 2065. 
Chapter III

\subsection{Prosecutor v. Strugar}

\subsubsection{Relevant passages}

On 6 December 1991 the Yugoslav People's Army (JNA) attacked the Croatian town of Dubrovnik. During this attack not only many civilians were killed, also numerous historic monuments in the Old Town were destroyed. Pavle Strugar, at the time the commander of the JNA division that conducted this operation, was charged by the ICTY for violations of the laws or customs of war (article 3 of the ICTY Statute). ${ }^{263}$ When discussing Strugar's responsibility for the attacks on the Old Town of Dubrovnik, the Defense submits that "the attack on the Old Town by the JNA was merely a response to Croatian fire from its positions", ${ }^{264}$ suggesting that the attack was an action in self-defense. Although the Trial Chamber acknowledges that in some cases "the JNA forces did target Croatian and other military positions", it holds that "none of them were in the Old Town" and that "the cause of the established and large-scale damage to the Old Town was deliberate shelling". 265

\subsubsection{Applicability}

The Trial Chamber in Prosecutor v. Strugar does not explicitly acknowledge or decline the legal figure of self-defense. The defense is, however, rejected in casu. Rejection is based on the fact that possible actions in self-defense were not directed at the Old Town and that the attack on the Old Town was not motivated by selfdefense.

\subsubsection{Scope}

Little information can be gathered from Prosecutor v. Strugar on the requirements for self-defense. The Judgment only confirms that the intent to act in self-defense is an important factor and that this intent can be negated by the presence of an alternative motive for the alleged action in self-defense.

\subsubsection{Nature of self-defense}

The nature of the self-defense brought up in this case must again be qualified as an individual appeal to self-defense ad bellum (to counter charges of war crimes committed in bello), for the defendant argues that the purpose of the operation was defensive.

\footnotetext{
263 ICTY, Prosecutor v. Strugar, Trial Chamber, 31 January 2005, par. 2.

264 ICTY, Prosecutor v. Strugar, Trial Chamber, 31 January 2005, par. 182.

265 ICTY, Prosecutor v. Strugar, Trial Chamber, 31 January 2005, par. 214.
} 


\subsection{Prosecutor v. Delić}

\subsubsection{Relevant passages}

Rasim Delić, a commander of the $\mathrm{ABiH},{ }^{266}$ was charged by the ICTY for crimes committed by his subordinates under article 3 of the ICTY Statute (violations of laws or customs of war). ${ }^{267}$ When discussing a single murder, committed by one of his alleged subordinates (a Mujahedin), the Defense argues that this killing was the result of an action in self-defense. ${ }^{268}$ The Trial Chamber describes the situation in which the killing took place:

One of the captives, a mentally retarded person named Milenko Stanić, protested against one of the women being beaten. When Stanic grabbed the throat of one Mujahedin, this Mujahedin fired several shots from an automatic rifle at him. After he had fallen to the ground, the same Mujahedin stabbed the chest of Stanic a number of times with a knife and fired more bullets from the automatic rifle into his head. Stanić's corpse was then thrown into a ditch on the side of the road. ${ }^{269}$

The Trial Chamber concludes that it is not persuaded that "the Mujahedin who killed him acted in self-defense". 270

\subsubsection{Applicability}

The Trial Chamber in Prosecutor v. Delic indirectly acknowledges the legal figure of self-defense by stating it is not persuaded that the Mujahedin acted in selfdefense, thereby suggesting that it could have been persuaded if the requirements had been met. The defense is, however, rejected in casu. The reasons for this rejection are not explicitly summed up. Instead, the Trial Chamber suffices with a description of the relevant situation. The Trial Chamber does not link this description to requirements for self-defense. However, when assessing the facts as described by the Trial Chamber, it is obvious that the proportionality requirement has not been met. For, although the Mujahedin was attacked, he clearly used excessive force to avert the attack. Technically, if an armed reaction was at all proportionate, the attack by Stanic had been averted from the moment "he had fallen to the ground". Everything that happens after that moment (the stabbing and the shooting) must be qualified as not necessary. Another possibility that can be drawn from the facts as presented by the Trial Chamber, is that the victim, Stanić, was exercising his right to legitimate self-defense (of another), which 
negates the right to self-defense of the adversary (i.e. the Mujahedin), because he would not be acting against an unlawful attack. ${ }^{271}$ Either way, these are only speculations, since the Trial Chamber does not reveal its exact reasons for its rejection of self-defense.

The rejection of self-defense in this case has no consequences for the accused, since his command responsibility in relation to the murder of Milenko Stanic could not be established. ${ }^{272}$

\subsubsection{Scope}

Because the Trial Chamber in Prosecutor v. Delić does not reveal its grounds for rejecting the defense, little can be inferred from this case as to the requirements for self-defense. One can however establish that the Trial Chamber assesses the situation objectively (and thus not how the attack was perceived by the Mujahedin).

\subsubsection{Nature of self-defense}

The nature of the appeal to self-defense discussed in Prosecutor v. Delic must be qualified as private self-defense, because the Mudjahedin was not acting as agent of a collective entity operating in self-defense, but rather defending himself in his private capacity from an allegedly unlawful attack.

\subsection{Prosecutor v. Milan Martić}

\subsubsection{Relevant passages}

On 2 and 3 May 1995 Zagreb was shelled by Serbian units, resulting in injury and death among civilians. Milan Martić, who held several top positions in the Serb dominated Krajina region, ordered this operation. He was charged and convicted by the ICTY for violations of laws and customs of war (article 3 of the ICTY Statute) and crimes against humanity (article 5 of the ICTY Statute) committed during this operation. ${ }^{273}$ On appeal he argues that:

$[\ldots]$ the shelling of Zagreb was a lawful military action conducted in self-defence. ${ }^{274}$

See Chapter XV, Section 2.

ICTY, Prosecutor v. Delić, Trial Chamber, 15 September 2008, par. 557.

ICTY, Prosecutor v. Martić, Appeals Chamber, 8 October 2008, par. 216.

ICTY, Prosecutor v. Martić, Appeals Chamber, 8 October 2008, par. 268. 
The Appeals Chamber rejects this contention by stating that:

[...] whether an attack was ordered as pre-emptive, defensive or offensive is from a legal point of view irrelevant $[\ldots]$. The issue at hand is whether the way the military action was carried out was criminal or not. 275

It continues:

As Martic has failed to show any error in the Trial Chamber's conclusion that he deliberately targeted the civilian population of Zagreb, his argument that the shelling of Zagreb was conducted in self-defence must fail. ${ }^{276}$

The Appeals Chamber concludes by stating that it:

[... ] takes note of Martić's arguments in his concluding statement at the appeal hearing that "the Serbs were not aggressors but rather defended themselves in a situation when the United Nations made no attempt to protect them [...] However, in particular in light of the fact that the prohibition against attacking civilians is absolute, the Appeals Chamber fails to see how this claim could justify Martić's actions in relation to the shelling of Zagreb. ${ }^{277}$

\subsubsection{Applicability}

In Martić, the Appeals Chamber rejects the self-defense argument on its merits for three reasons:

a. The self-defense argument is irrelevant: the purpose of an order does not ensure that the order is carried out in conformity with law.

If Martic had wanted to successfully deny the crimes charged by means of a complete defense he should thus not have argued that the purpose of operation was lawful, but that the crimes perpetrated during the operation were committed because of a legitimate reason (e.g. self-defense). However, self-defense as a defense to the carrying out of the order is also rejected, because:

b. The Appeals Chamber demonstrates that the Trial Chamber rightly concluded that the order was carried out in a criminal way, for it was not motivated by selfdefense but by the intent to target civilians.

c. The relevant attack involved civilians, which is absolutely prohibited.

The statement that the prohibition on attacks against civilians is absolute and cannot be justified is remarkable. However, whether this means that complete defenses (or

275 ICTY, Prosecutor v. Martić, Appeals Chamber, 8 October 2008, par. 268.
276 ICTY, Prosecutor v. Martic, Appeals Chamber, 8 October 2008, par. 268.
277 ICTY, Prosecutor v. Martic, Appeals Chamber, 8 October 2008, par. 268. 
maybe only justifications) are never applicable in these cases, cannot be derived from the Judgment.

\subsubsection{Scope}

Little information can be gathered from Prosecutor v. Martic on the requirements for self-defense. The Judgment confirms that the intent to act in self-defense is an important factor and that this intent can be negated by the presence of an alternative motive for the alleged action in self-defense. In addition, the Judgment suggests that complete defenses could be a priori excluded in case of attacks on civilians.

\subsubsection{Nature of self-defense}

The appeal to self-defense in casu equals an appeal to self-defense ad bellum for the argument claims that the action was legitimately ordered (as opposed to carried $o u t$ ). However, again the defense is ineffective by nature, since it is advanced to counter charges of crimes against humanity and war crimes committed in bello.

\subsection{Prosecutor v. Boškoski and Tarčulovski}

\subsubsection{Relevant passages}

On 12 August 2001 a Macedonian police unit attacked the Albanian population of the village of Ljuboten, resulting in death and destruction. Johan Tarčulovski was the commander of this unit. He was charged by the ICTY for violations of laws and customs of war under article 3 of the ICTY Statute. In his second ground of appeal Tarčulovski argues that the events in Ljuboten did not violate laws and customs of war. Firstly, because article 3 of the ICTY Statute does not apply in case of a sovereign State acting in self-defense against "terrorists who live or hide amongst the civilian population". ${ }^{278}$ Tarčulovski adds that:

$[\ldots]$ the operation in Ljuboten [...] had the "legitimate goal(s)" of countering internal terrorist activity and of not harming civilians.

And continues by submitting that:

[...] the Trial Chamber failed to consider what would constitute proportionate behaviour in an armed conflict when a sovereign State responds to a domestic terrorist attack in which terrorists hide among civilians. ${ }^{279}$

278 ICTY, Prosecutor v. Boškoski and Tarčulovski, Appeals Chamber, 19 May 2010, par. 39.

279 ICTY, Prosecutor v. Boškoski and Tarčulovski, Appeals Chamber, 19 May 2010, par. 39. 
The Appeals Chamber rejects Tarčulovski's arguments by stating that:

[...] the Appeals Chamber recalls the fundamental distinction in international law between the rules governing a State's right to resort to armed force (ius ad bellum) and the rules applicable in armed conflict (ius in bello). The Appeals Chamber had previously held that the application of the latter rules is not affected by the legitimacy of the use of force by a party to the armed conflict. [...] The Appeals Chamber further notes that an operation whose objective was a legitimate and defensive action against "terrorists" would not render Common Article 3 inapplicable. The issue is whether the conduct of the individual was in violation of international humanitarian law. ${ }^{280}$

In addition, the Appeals Chamber denies that the relevant attack was proportionate:

[...] the Appeals Chamber recalls that the targeting of civilians is absolutely prohibited in customary international law, and that civilian casualties are only legitimate if their deaths are incidental to military operations. The Trial Chamber's finding that the predominant objective of the operation was to indiscriminately attack ethnic Albanians establishes that the Trial Chamber was satisfied that the casualties were not incidental to the conduct of the operation in Ljuboten. ${ }^{281}$

\subsubsection{Applicability}

In this case, the Appeals Chamber implicitly recognizes self-defense by rejecting it on grounds. Tarčulovski argues that article 3 of the ICTY Statute does not apply in case of legitimate domestic self-defense. He also suggests that the relevant action in self-defense was proportionate (and thus legitimate). The Appeals Chamber rejects this contention because a State's right to resort to self-defense (ius ad bellum) does not affect the application of the rules of armed conflict (ius in bello). Consequently, legitimate action against terrorists, does not render article 3 inapplicable. The Appeals Chamber adds that the action in casu was not legitimate anyway, because civilians were targeted and this is absolutely prohibited.

\subsubsection{Scope}

The only requirement for self-defense mentioned is proportionality. In casu the proportionality requirement was not met because, in case of civilian casualties, only incidental deaths are considered proportionate. Since, according to the Trial Chamber, the purpose of the relevant attack was to "indiscriminately attack ethnic Albanians", these killings were not incidental and thus not proportionate. The proportionality requirement is tested objectively, for it is evaluated from an outsider perspective. Whether the State thought it was acting proportionately, is not relevant.

280 ICTY, Prosecutor v. Boškoski and Tarčulovski, Appeals Chamber, 19 May 2010, par. 44 and 45.

281 ICTY, Prosecutor v. Boškoski and Tarčulovski, Appeals Chamber, 19 May 2010, par. 46. 


\subsubsection{Nature of self-defense}

Tarčulovski's appeal to self-defense must be characterized as an individual appeal to self-defense ad bellum (to counter charges of war crimes committed in bello), for he claims the purpose of his defensive action was legitimate (ius ad bellum), not the way it was carried out (ius in bello).

\subsection{Prosecutor v. Đorđević}

\subsubsection{Relevant passages}

In the late nineties Serbia and Kosovo (then a province of Serbia) were fighting over the independence of Kosovo. During this conflict - which ended after the NATO bombing campaign in 1999 - Serbs committed large-scale crimes (deportation, murder, rape) against the Albanian civilians of Kosovo. Former senior Serbian police official Vlastimir Đorđević was charged by the ICTY for crimes against humanity and violations of the laws and customs of war committed during this period (respectively article 5 and article 3 of the ICTY Statute). As a defense to these charges the Defense relied on:

[...] article 51 of the Charter of the United Nations which recognizes a State's "inherent right of individual or collective self-defence if an armed attack occurs against a Member of the United Nations" to argue that States have a right to respond to terrorist acts in exercise of their right to self-defence. ${ }^{282}$

The Trial Chamber however rejects this defense, because it:

[...] takes the view that the question of the legitimacy of the decision to resort to force is irrelevant to the determination of individual criminal responsibility for violations of international humanitarian law; it recalls that "whether an attack was ordered as preemptive, defensive or offensive is from a legal point irrelevant [...] The issue at hand is whether the way the military action was carried out [during an armed conflict] was criminal or not". Therefore the circumstance that the FRY and Serbia were conducting anti-terrorist activities is irrelevant to, and not determinative of, the question whether violations of international humanitarian law were carried out. ${ }^{283}$

\subsubsection{Applicability}

Again, the ICTY Trial Chamber a priori rejects legitimate use of force in the ad bellum sense as a complete defense to violation of the rules of armed conflict (ius in bello), because the legitimacy of the decision to attack (ius ad bellum) is irrelevant 
to the determination of the legality of the crimes committed during this attack (ius in bello).

\subsubsection{Nature of self-defense}

The appeal to self-defense in this case comes down to an appeal to international self-defense (ius ad bellum): the defendant argues his actions were legitimate for they were in conformity with article 51 of the UN Charter. However, the defense is advanced to counter charges of crimes against humanity and war crimes committed in bello. Consequently, it is ineffective.

\subsection{Prosecutor v. Gotovina et al.}

\subsubsection{Relevant passages}

In August 1995 Croatia launched a military offensive known as Operation Storm. The objective of this operation was the re-taking of the Krajina region from the Serbs. Ante Gotovina (Colonel General of the Croatian army), Mladen Markač (Assistant Minister of Interior in charge of Special Police matters) and Ivan Čermak (Commander of the Knin Garrison) were charged with crimes against humanity and violations of the laws and customs of war committed during this operation. ${ }^{284}$ In relation to three murder charges, the Trial Chamber refers to appeals to selfdefense:

In relation to three incidents (Manda Tišma, Sava Šolaja, and Jovanka Mizdrak), the issue of self-defence was raised by the parties or in local courts trying the perpetrators. $^{285}$

The self-defense argument is, however, rejected in all three cases. First the Trial Chamber establishes the status of the victims:

The Trial Chamber considered it necessary to establish the status of the victims under international humanitarian law before turning to the question of self-defence. All three victims were civilians and Tišma and Mizdrak had not taken up arms. In relation to the killing of Sava Šolaja, the Trial Chamber is satisfied that the victim was not involved in the exploding of the grenade, which injured the perpetrator. As a result, in all three incidents, the victims were civilians not having taken part in hostilities. ${ }^{286}$

284 Čermak was acquitted, Markač en Gotovina were acquitted on appeal (ICTY, Prosecutor v. Gotovina and Markač, Appeals Chamber, 16 November 2012), however not for reasons pertaining to complete defenses.

286 ICTY, Prosecutor v. Gotovina et al., Trial Chamber, 15 April 2011, par. 1730. 
Chapter III

Next the Trial Chamber rejects the self-defense argument:

In relation to the question of self-defence, the Trial Chamber considered that neither incident presented an immediate illegitimate attack on the perpetrator. The Trial Chamber further considered the perpetrators' conduct, even if an immediate illegitimate attack could be assumed, to be disproportionate, where other ways of thwarting any possible danger instead of firing lethal shots were available. ${ }^{287}$

Remarkable in this case is that self-defense was not only brought up by the parties. It seems as if the Trial Chamber felt obliged to address the issue of self-defense, because an appeal to self-defense had been successful at a local court trying direct perpetrators of one of the killings (the killing of Sava Šlaja):

On 27 May 1997 the County Court in Zadar acquitted Nikola Rašić, Zvonimir Lasan-Zorobabel, and Ivan Jakovljević of charges relating to the alleged murder of Sava Šlaja. The Croatian Court determined that on 20 August 1995, the accused, travelling in a personal car stopped on a road passing near Očestovo, at which point Jakovljević stayed with the car while Rašić and Lasan-Zorobabel went towards a nearby house. As determined by the statements of the accused at the main hearing and during the investigation, the Court found that as Lasan-Zorobabel and Rašić entered the home a hand grenade detonated inflicting multiple wounds on LasanZorobabel and a light wound on Rašić. After Rašić helped Lasan exit the house he returned to ensure their safety and threw a hand grenade into the house. The window shutters then opened and a male appeared who Rašić shot at, killing him. The man killed was identified as Sava Šolaja, a 70 year-old handicapped Serb. The Croatian Court acquitted Lasan and Jakovljević based on their lack of involvement in the killing, and acquitted Rašić because his actions were committed in self-defence. In its judgment the Court noted that the accused were engaged as Croatian soldiers of the $15^{\text {th }}$ Home Guard Regiment during the relevant time of the incident. ${ }^{288}$

\subsubsection{Applicability}

The ICTY Trial Chamber, implicitly recognizing self-defense, rejects the defense in all three cases because:

- Neither incident consisted of immediate illegitimate attacks on the perpetrators;

- The reactions to the alleged immediate, illegitimate attacks were disproportionate anyway (there were less violent ways to avert the danger).

It is remarkable that the ICTY in this case rejects an appeal to self-defense, while in one of the cases the direct perpetrator has successfully pleaded self-defense at a local court. Essentially, the ICTY sends the message here that one can be guilty as a 
superior for an act committed by a subordinate that is not wrongful in the first place. What makes the decision even more opaque is that the ICTY does not substantiate its decision. The court does not explain why the attack on Rasic and his colleagues was not, immediate and/or illegitimate and how they could have avoided the danger in a more proportionate way. It only reveals that Solaja was not involved in the explosion of the grenade. In sum, the ICTY thus deviates from the decision of a domestic court involving the same factual circumstances, without substantiating its judgment.

As to the legal consequences of the rejection of self-defense in this case: to Ivan Čermak this rejection was of no consequence. He was acquitted for other reasons (no command responsibility, not part of the relevant joint criminal enterprise). ${ }^{289}$

The civilian status of the victims is a point of importance in this case. The Trial Chamber notes that the victims were civilians not taking part in hostilities, thereby suggesting that the outcome of the case would have been different if the victims had a different status (e.g. combatants). ${ }^{290}$

\subsubsection{Scope}

The Gotovina-case mentions three criteria of self-defense that have not been met:

- The immediacy requirement;

- The illegitimate attack requirement;

- The proportionality requirement.

Why the first two requirements have not been met is not substantiated. As to the third requirement the Trial Chamber holds that there where "other ways of thwarting any possible danger instead of firing lethal shots where available", thereby suggesting that the danger could have been averted by less invading means. This latter requirement is tested objectively.

\subsubsection{Nature of self-defense}

The appeal to self-defense in these cases seems to be of a private nature, because soldiers were not acting in self-defense as agents of a collective, but rather defending themselves in their private capacity against an allegedly unlawful attack by civilians. killing them would not qualify as a war crime and the discussion on the applicability of selfdefense would be useless. See Chapter XV Section 2. 
Chapter III

\section{ICC}

\subsection{Applicability}

Self-defense is recognized by the ICC in article 31 paragraph (1) (c) and heading (Grounds for excluding criminal responsibility) of the ICC Statute:

1. In addition to other grounds for excluding criminal responsibility provided for in this Statute, a person shall not be criminally responsible if, at the time of that [...] persons conduct:

(c) The person acts reasonably to defend himself or herself or another person or, in the case of war crimes, property which is essential for the survival of the person or another person or property which is essential for a military mission against an imminent and unlawful use of force in a manner proportionate to the degree of danger to the person or the other person or property protected. The fact that the person was involved in a defensive operation conducted by forces shall not in itself constitute a ground for excluding criminal responsibility under this subparagraph.

Technically an unsuccessful appeal to self-defense could still be considered in mitigation under Rule 145(2)(a)(i), which provides that "circumstances falling short of constituting grounds of exclusion of criminal responsibility, such as substantially diminished mental capacity" may be taken in mitigation.

\subsection{Scope}

The heading of article 31 suggests that the grounds mentioned in this article are not the only complete defenses ("in addition to") contained in the ICC Statute. Indeed, the ICC Statute explicitly provides for the complete defenses in article 32 and article 33 . What is more, the Rome Statute refers to supplementary complete defenses, to be made up by the Court through paragraph 2 and 3 of article 31 (discussed in Chapter XII of this Part). In addition, the heading of article 31 displays that the defendant is only absolved from liability when the required conditions are present "at the time of that persons conduct". A similar requirement is not provided for in article 32 and 33. Paragraph (1)

(c) of article 31 bears several conditions for a successful appeal to self-defense:

a. There must be an imminent and unlawful use of force;

b. The self-defense must be employed to protect:

- the defendant $o r$

- another person or

- in case of war crimes: property which is essential for the survival of the person or another person or

- in case of war crimes: property which is essential for accomplishing a military mission; 
c. The action in self-defense must be reasonable;

d. The action in self-defense must be proportionate to the degree of danger;

e. The defendant must possess a subjective element in relation to the action in selfdefense.

The following Section provides an analysis - per condition - of the self-defense provision in the ICC Statute.

(a) Imminent and unlawful use of force

In order to act in legitimate self-defense, the defendant must have operated against "an imminent and unlawful use of force". The concept of force ex article 31 (c) must be understood in a broad way, including both physical and psychological threats. ${ }^{291}$ The force must be imminent, i.e. immediately antecedent, presently exercised or still enduring. ${ }^{292}$ In this way a defender does not have to wait until a danger has become present, but is not allowed to use self-defense pre-emptively or as a means of retaliation. ${ }^{293}$ Self-defense can only be used against unlawful force. Werle suggests that this means that the force used against the defendant may not be covered by a ground excluding criminal responsibility. ${ }^{294}$ Cryer has a broader definition of the word "unlawfulness". He holds that the force used against the defendant may not be covered by a justification (which negates the unlawfulness of the act), but can be covered by an excuse (which leaves the illegality of the act untouched). ${ }^{295}$ In addition, the word "unlawful" must be defined in the light of the applicable rules (e.g. treaties, Rules of Engagement and other legal principles). For example, in war, attacking an enemy combatant is not a crime, and thus comes down to a lawful attack. ${ }^{296}$ Averting such an attack is also lawful under the laws of war, and therefore not legitimized through the ICC definition of self-defense.

(b) Defensible interests

Article 31(1)(c) mentions several defensible interests. The self-defense must be related to:

- the defendant or

- another person or

- in case of war crimes: property, which is essential for the survival of the person or another person or

- in case of war crimes: property, which is essential for accomplishing a military mission. 
The first two defensible interests are general and related to persons; the latter two are only applicable in case of war crimes. They are specified and related to property. The nature of the defensible property is narrowed down to property essential for the survival of the defendant or another person and to property essential for accomplishing a military mission. The first property defense seems to be an extension of the general defense of persons. If property is "essential for the survival" of persons, a person's very existence must be dependent on this property. Saving the property must indirectly save a person's life. ${ }^{297}$ The second property defense is difficult to define, because the concept of 'essential military property' is hard to pin down. ${ }^{298}$ However, the wording of this property clause indicates that not only the defended property has to ensure that the mission's objectives can be realized ("accomplish"), but also that achieving the mission's goals is dependent on that property ("essential"). If the attacked property is replaceable and its substitution does not hinder the accomplishment of the mission, it is not protected under article 31(1)(c). ${ }^{299}$ The 'essential military property'- clause must not be confused with 'military necessity', which is not bound by the requirement of an unlawful attack. 300

\section{(c) Reasonability}

The defendant must have acted reasonably. Generally, this means that the defense must have been necessary and adequate to prevent the danger. Thus, a reasonable reaction must (a) only create as much harm as is necessary to repel the attack and (b) the means applied must be efficient. ${ }^{301}$ Whether the defendant has acted reasonably in case of self-exposure (culpa in causa or prior fault) $)^{302}$ was left for the Court to decide under paragraph 2 of article 31,303 which allows the Court to adapt the defenses reflected in the ICC catalogue.

\section{(d) Proportionality}

Apart from being reasonable, the defendant must have acted proportionally, i.e. the defensive reaction must have been proportionate to the degree of danger sought to be avoided. ${ }^{304}$ If the response is superior to the degree of danger, such a response is no longer justified and regains its illegal character. Note that the deadly defensive reaction is not a priori excluded. However, the requirement of proportionality probably demands that such a reaction is only permissible in cases where either death or serious bodily harm must be prevented. ${ }^{305}$ Whether a disproportional, but

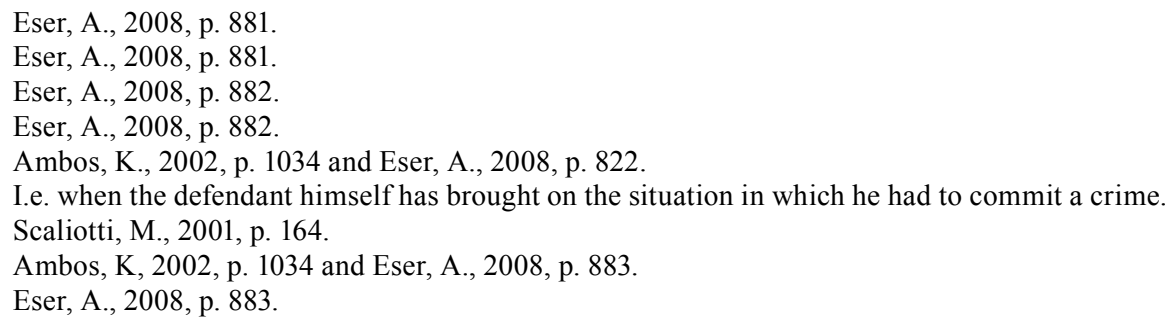


excusable reaction falls within the scope of article 31(1)(c) was left for the Court to decide under paragraph 2 of article 31.306

\section{(e) Subjective element}

The defendant must have acted "to defend" the protected interests. This requirement embodies the subjective element for self-defense. ${ }^{307}$ A defendant who objectively acted in self-defense, but did not know he was doing so, cannot successfully appeal to article 31 (1)(c). As to the nature of this subjective element, the provision is not entirely clear. ${ }^{308}$ "To defend" seems to demand more than mere knowledge of the unlawful attack. However, it is controversial whether the action in self-defense must also be motivated by this knowledge. ${ }^{309}$ Eser suggests a middle of the road solution: since "to defend" incorporates a volitional element, countering an unlawful attack must not exclusively, but at least partially, be motivated by defensive ends. ${ }^{310}$

\section{Objective/subjective}

Requirements (a)-(d) must be objectively present and not only exist in the subjective belief of the defendant. ${ }^{311}$ However, this objectivity can be subjectivated through paragraph 2 of article 31 or article 32 (mistake of fact) of the ICC Statute. ${ }^{312}$ Requirement (e) is a subjective criterion for it focuses on the state of mind of the perpetrator. Whether this requirement must be tested by objective or subjective factors (or both) cannot be derived from the comments.

\subsection{Nature of self-defense}

The last sentence of paragraph (1)(c) is not as much a condition, but was inserted to clarify the difference between operational and individual self-defense. The interpretation of this sentence has been discussed in Section 4.1.4, concluding that it is not clear whether the requirements of paragraph (1)(c) are only applicable to private self-defense or whether this defense is also open to individuals participating in a defensive operation. Nevertheless, the ICC leaves room for both defenses. The decision to engage in a defensive operation - a decision in the sphere of ius ad bellum - is not covered by article 31(1)(c).

306 Eser, A., 2008, p. 889. According to Van Sliedregt this disproportionate but excusable action in self-defense could also fall within the scope of article 31(1)(a) (mental incapacity).

307 Ambos, K., 2002, p. 1035.

308 This is in line with some controversy in domestic criminal law doctrine. See: Fletcher, G.P., 1998, p. 137, which briefly describes the difference of opinion between Fletcher and Robinson on this point.

309 Ambos, K., 2002, 1035.

310 Eser, A., 2008, p. 883.

311 Ambos, K., 2002, p. 1032; Eser, A., 2008, p. 882 and Scaliotti, M., 2001, p. 171.

312 Eser, A., 2008, p. 882. Although the latter solution is controversial, see Chapter VII, Section 5 (Mistake at the ICC). 
Chapter III

\section{Analysis of SELF-Defense}

\subsection{Applicability}

All international courts discussed in this Chapter have recognized the legal figure of self-defense. The IMT, IMTFE and ICTY through their case law, and the ICC in its Statute. ${ }^{313}$ The reaction to self-defense can be grouped along three categories: (a) rejection without grounds, (b) a priori rejection and (c) rejection on grounds.

\section{(a) Rejection without grounds}

Prosecutor v. Hadžihasanović and Kubura is the only case in which self-defense was brought up, but not discussed. In Prosecutor v. Delić the defense was discussed and rejected. However, grounds were not explicitly mentioned (only implicitly by describing the situation).

\section{(b) A priori rejection}

In Prosecutor v. Kordić and Čerkez a specific type of self-defense, i.e. self-defense ad bellum, was a priori rejected. This rejection is, however, not absolute, but limited to justifications for serious violations of international humanitarian law. Theoretically, this leaves room for defensive operations to be a) an excuse for serious violations of international humanitarian law or b) a justification or an excuse in case of violations of international humanitarian law that are not serious or c) a justification or an excuse for violations of international criminal law that are not covered by international humanitarian law. Prosecutor v. Martić and Prosecutor $v$. Boškoski and Tarčulovski suggest that self-defense, and possibly other defenses, may be a priori excluded in case of attacks on civilians. Finally, in several cases (Prosecutor v. Kordić and Čerkez, Prosecutor v. Martić, Prosecutor v. Boškoski and Tarčulovski and Prosecutor v. Đorđević) the defense brought up was considered irrelevant because it was aimed at the legitimacy of the attack itself (ad bellum) and not at the legitimacy of the crimes committed during the attack (in bello). Remarkable is, that despite of this finding, in most cases, the defense was still tested on its merits.

\section{(c) Rejection on grounds}

In the majority of cases self-defense was rejected on grounds. Remarkable is that in almost all of these cases (except for Boškoski and Tarčulovski and Gotovina) the intent to act in self-defense is lacking and that the relevant court substantiates this lack of intent by finding alternative motives for the alleged action in self-defense. In some cases other lacking requirements are discussed as well, i.e.: the necessity

313 Remarkable is that self-defense in the sense of this research has not surfaced at the ICTR. Research data do not reveal whether self-defense was not discussed because it was not brought up by the Defense or because it was not addressed by the court (or both). 
requirement (Verdict on Hideiki Tojo, Prosecutor v. Stakić), the unlawful attack requirement (Tojo, Prosecutor v. Gotovina and possibly Prosecutor v. Delić), the immediacy requirement (Raeder, the general part of the Tokyo Judgment, Prosecutor v. Stakić and Prosecutor v. Gotovina) and the proportionality requirement (Prosecutor v. Stakić, possibly also in Prosecutor v. Delić, Prosecutor v. Boškoski and Tarčulovski and in Prosecutor v. Gotovina).

In most cases, rejection of self-defense contributed to the conviction of the defendant. Exceptions are Prosecutor v. Delić, where the rejection of self-defense did not influence the criminal responsibility of the accused because his command responsibility in relation to relevant crime could not be established and Prosecutor v. Gotovina where one of the defendants (Čermak) was also acquitted for other reasons.

Self-defense was never explicitly applied as a mitigating factor, but could be taken in mitigation by the ICC under rule 145(2)(a)(i).

\subsection{Scope}

The requirements for self-defense that can be extracted both from case law and from the ICC Statute are:

\section{(a) The attack must be immediate}

This requirement was mentioned in Raeder, the general part of the Tokyo Judgment, Stakic, Gotovina and in the ICC Statute. According to Raeder, citing the Caroline criteria, the immediacy requirement is met when there is "no moment for deliberation". Rejection of self-defense in this case was partly based on the fact that there was no imminent attack planned by the Allied forces, for their plans were lagging behind the German plans. The general part of the Tokyo Judgment, similarly, demands that the attack is "impending". In Gotovina the rejection based on lack of immediacy is not substantiated. In Stakic the requirement was not met because the alleged maneuvers in self-defense were launched one day after the initial attack. According to the commentators on the Rome Statute the immediacy requirement is met when the attack is immediately antecedent, presently exercised or still enduring.

\section{(b) The attack must be unlawful}

This requirement was mentioned in Tojo, Gotovina and in the ICC Statute. According to the commentators on the Rome Statute, this means that the attack cannot be justified and/or is not in accordance with the rules applicable to the case at issue. 
(c) The defense must be necessary

This requirement is mentioned in Raeder, Tojo, Stakic and in the ICC Statute. According to Raeder, citing the Caroline criteria, this requirement is met when there are no alternative means to avert the attack. This definition is confirmed in Stakic. In Tojo the necessity requirement was absent because the plans for the alleged defensive action existed before the plans for the attack, meaning that the alleged action in self-defense could not qualify as a reaction to an attack. In the ICC Statute, the necessity requirement is covered by the word "reasonably". However, the reasonable act requirement in the Rome Statute does not only demand that the reaction of the defendant is necessary, but also that the means applied by the defendant are efficient.

\section{(d) The defense must be proportionate}

This requirement is mentioned in Stakić, Boškoski and Tarčulovski, Gotovina and in the ICC Statute. According to the commentators of the Rome Statute the defensive reaction must have been proportionate to the danger sought to be avoided. The attack in Stakic consisted of two shootings at soldiers. Proportionality was absent because the alleged action in self-defense consisted of "planned, co-ordinated and sustained armed attacks on civilian settlements" and because "fire was also opened at with heavy weapons on the fleeing civilian population". In Gotovina the defense was not proportionate because there were more proportionate ways of averting the attack, than the means employed.

\section{(e) The defense must be related to a defensible interest}

This requirement can only be found in the Rome Statute and in the IMTFE Judgment. The defensible interests mentioned in the Rome Statute are:

- the defendant $o r$

- another person or

- in case of war crimes: property which is essential for the survival of the person or another person or

- in case of war crimes: property, which is essential for accomplishing a military mission.

The IMTFE mentions that:

- the object of defense must have been lawfully acquired.

\section{(f) The defendant must act with the intent to act in legitimate self-defense}

This requirement is mentioned in Raeder, Tojo, Kordić and Čerkez, Stakić, Galić, Strugar, Martic and in the Rome Statute. That this relevant intent is lacking is demonstrated by revealing alternative motives for the alleged action in self-defense. Stakic demonstrates that preparation, disproportionality and lack of temporal 
connection are indicators for absence of the required mental element for selfdefense. The commentators on the Rome Statute are not sure whether the mental element for self-defense is only covered by knowledge or whether it also includes a volitional element.

\section{Objective/subjective}

Generally, all requirements are tested objectively. Exception is the occasional subjective testing of the subjective element (see above, sub (f)). The ICC Statute allows for subjectivation through article 31(2) and possibly article 32 of the ICC Statute (Mistake of fact). In general, thus, self-defense requires an objective test.

\subsection{Nature of self-defense}

In the introduction to this Chapter on self-defense the question was put whether and how both international and domestic self-defense have merged into international criminal law. Generally two types of self-defense can be distinguished in international criminal law practice: (a) an individual appeal to self-defense in the sphere of ius ad bellum and (b) private self-defense. The first species of self-defense contains traits of both domestic self-defense and self-defense ad bellum, the second is similar to domestic self-defense.

\subsubsection{Self-defense in the sphere of ius ad bellum}

Most appeals to self-defense in international criminal law are appeals by individuals to self-defense in the sphere of ius ad bellum. This species of selfdefense has been brought up at the IMT, the IMTFE and in Kordić and Čerkez, Stakić, Galić, Hadžihasanović and Kubura, Strugar, Martić, Boškoski and Tarčulovski and Đorđević. A successful appeal to self-defense in the sphere of ius ad bellum by an individual aims at negating the individual criminal responsibility of the defendant through negating the illegality of the defensive operation. Therefore this legal figure contains traits of both domestic and international selfdefense.

Self-defense ad bellum was only accepted in principle at the IMT and IMTFE against charges of crimes against peace, the prequel of the crime of aggression. It is therefore remarkable that the ICC self-defense provision is not a defense against aggression.

In case of other charges than aggression (e.g. war crimes, crimes against humanity) it is not entirely clear whether self-defense ad bellum may provide a complete defense. Fact is that a legitimate action in self-defense ad bellum does not automatically legitimize the crimes committed during this lawful action (ICC Statute, Kordić and Čerkez, Martić, Boškoski and Tarčulovski, Đorđević). For example, if a State is attacked it has a right to defend itself. However, this right 
does not automatically justify any violation of international criminal law committed during this action in self-defense. In principle, this right to self-defense must not be exercised beyond the boundaries of the laws of war. Nevertheless, if the action in self-defense does exceed these limits, it cannot be derived from ICTY judgments whether self-defense ad bellum can still offer a complete defense. Case law is contradictory. In Kordić and Čerkez it was established that selfdefense ad bellum is not a justification in case of serious violations of international humanitarian law. In Martić and Boškoski and Tarčulovski the ICTY mentions that the prohibition of (disproportionate) attacks on civilians is absolute, thereby possibly a priori excluding any kind of defense in these cases. Following these cases, there is not much room for a complete defense: self-defense is a justification and most crimes charged under international criminal law involve serious violations of international humanitarian law, namely, large scale killings of civilians. On the other hand however, the ICTY occasionally tests appeals to selfdefense ad bellum - as a defense to crimes involving the killings of civilians - on its merits (Stakić, Galić, Strugar, Martić and Boškoski and Tarčulovski), thereby implying that an appeal to self-defense ad bellum is theoretically possible in these cases. Some confusion seems to be caused by the fact that the nature of the selfdefense brought up must be qualified as an individual appeal to self-defense $a d$ bellum, while the crimes charged involve crimes committed in bello. Whether another type of self-defense (than self-defense ad bellum) against crimes committed in bello could be available cannot be derived from the ICTY judgments. However, the commentators on the ICC Statute agree that a successful appeal to self-defense is possible in these cases. Consequently, self-defense in bello could be a third species of self-defense, available under international criminal law (apart from self-defense ad bellum and private self-defense, which is discussed below).

\subsubsection{Private self-defense}

Private self-defense is different from the previous type of self-defense in that criminal liability is not dependent on the legality of a collective action. It is the direct right of an individual to react to an unlawful attack by committing an international crime. This type of self-defense was brought up and recognized in Delic and probably also in Gotovina, and is covered by the first sentence of article 31(1)(c) of the ICC Statute. Private self-defense is similar to the classic notion of domestic self-defense.

\subsection{Categorization}

Chapter II has demonstrated that international criminal theory distinguishes between three different types of complete defenses: 


\begin{tabular}{|l|l|l|l|}
\hline Defense & Effect & $\begin{array}{l}\text { Justification or } \\
\text { excuse? }\end{array}$ & Affirmative or not? \\
\hline$X$ & $\begin{array}{l}\text { General requirements } \\
\text { for criminal liability are } \\
\text { not negated }\end{array}$ & Justification & Affirmative \\
\hline $\begin{array}{l}\text { No definitional } \\
\text { subjective element }\end{array}$ & $\begin{array}{l}\text { Defense negates } \\
\text { definitional subjective } \\
\text { element }\end{array}$ & A justification or excuse & Not affirmative \\
\hline No blameworthiness & $\begin{array}{l}\text { Defense negates } \\
\text { blameworthiness }\end{array}$ & Excuse & Affirmative \\
\hline
\end{tabular}

The question answered in the subsection is whether self-defense in international criminal law matches any of these three types. More precisely, what is the effect of the fulfillment of requirements (a)-(f) on the offense charged? ${ }^{314}$ Two scenarios are possible.

When conditions (a)-(f) are - as required - objectively met, this would justify the crime charged. The defendant had a choice between two evils: hurting the aggressor or letting an innocent person or object be hurt. When the criteria for selfdefense are complied with, the defendant has objectively chosen the best course of action, which negates the wrongfulness of his act. ${ }^{315}$ If the fulfillment of conditions (a)-(f) equals a justification, self-defense could be qualified as either defense $=x$ or defense $=$ no definitional subjective element:

\begin{tabular}{|l|l|l|l|}
\hline Self-defense & Effect & $\begin{array}{l}\text { Justification or } \\
\text { excuse? }\end{array}$ & Affirmative or not? \\
\hline$X$ & $\begin{array}{l}\text { General requirements } \\
\text { for criminal liability are } \\
\text { not negated }\end{array}$ & Justification & Affirmative \\
\hline $\begin{array}{l}\text { No definitional } \\
\text { subjective element }\end{array}$ & $\begin{array}{l}\text { Defense negates } \\
\text { definitional subjective } \\
\text { element }\end{array}$ & A justification or excuse & Not affirmative \\
\hline
\end{tabular}

If self-defense qualifies as defense $=x$, it does not negate the general requirements for criminal liability, for a justification merely negates the wrongfulness of an act. What is more, in this case the defendant has fulfilled the definitional elements of a crime, ${ }^{316}$ which would make the defense affirmative (i.e. not touching upon the prosecution's case).

314 Although the different types of self-defense mentioned above may have different requirements, it is not unambiguous which these conditions exactly are. This is due to the lack of clarity in case law and the ICC Statute (see comment at the end of this Chapter). Therefore the categorization of self-defense is not linked to the various types of this defense.

316 See Chapter II, Section 2. 
The other classification of self-defense as a justification (defense $=$ no definitional subjective element) refers to the situation where the blameworthiness of the actor is embedded in the definitional subjective element, as is the case with negligence. ${ }^{317}$ In this case, the presence of self-defense would negate the wrongfulness of the act, which makes it impossible to establish the definitional subjective element. Because this type of self-defense touches upon the prosecution's case, it must be qualified as not affirmative. That self-defense could be qualified as a justification is confirmed on several occasions by the language employed in the case law discussed in this Chapter. ${ }^{318}$

The classification of self-defense as a justification automatically discharges the qualification defense $=$ no blameworthiness, for a defense aimed at exemption from blame (i.e. an excuse) implies the presence of a wrongful (i.e. unjustifiable) act. ${ }^{319}$ However, when criteria (a)-(e) are tested subjectively (does the subjective state of mind of the actor exonerate him from criminal liability?) self-defense could be qualified as defense negates blameworthiness. For, if the defendant has acted in accordance with the subjective criteria, the wrongfulness of the act is not negated (the defendant did not objectively choose the lesser evil), but a court can still conclude that the defendant is not blameworthy, if the perpetrator did have no ability to choose, did what any reasonable person would have done or did not have the required freedom of will or mental capacity. This type of self-defense, however, would either fall within the scope of mistake of fact (which has been recognized in international criminal law) ${ }^{320}$ or disproportionate self-defense (which has not been recognized in international criminal law, but could be a defense under article 31(2) of the ICC Statute).

\subsection{Conclusion on self-defense}

The analyses of self-defense case law in this Section demonstrate that three types of self-defense may exist in international criminal law: self-defense ad bellum, self defense in bello and private self-defense. Although the contours of these defenses are clear, and they seem to have similar requirements, their exact applicability and scope remains unsettled. This is caused by several factors.

317 See Chapter II, Section 2.

318 Raeder (IMT, Judgment and sentences, 1 October 1946, In: American Journal of International Law, 41, 1947, p. 205); General part of the Tokyo Judgment (Röling, B.V.A. and Rüter, C.F. (eds.), The Tokyo Judgment: The international military tribunal of the far east (I.M.T.F.E.), 29 April 1946 - 12 November 1948, Vol. 1, APA-University Press Amsterdam BV, Amsterdam, 1977, p. 47); Tojo (Röling, B.V.A. and Rüter, C.F. (eds.), The Tokyo Judgment: The international military tribunal of the far east (I.M.T.F.E.), 29 April 1946 - 12 November 1948, Vol. I, APAUniversity Press Amsterdam BV, Amsterdam, 1977, p. 380); ICTY, Prosecutor v. Kordić and Čerkez, Trial Chamber, 26 February 2001, par. 750 and ICTY, Prosecutor v. Martić, Appeals Chamber, 8 October 2008, par. 268. 
Firstly, the status of self-defense ad bellum as a complete defense is controversial. Some sources exclude this defense a priori, while others seem to accept this defense in principle. Secondly, the status of the ICC criteria is uncertain. Are they reflective of customary law? The Trial Chamber in Kordić and Čerkez seems to think so. However, both in Kordić and $\breve{C} e r k e z$ and in the cases that follow, the ICTY refrains from referring to these criteria. Thirdly, even if the ICC criteria were reflective of customary law, it is not exactly clear which species of self-defense it defines. Although authors seem to agree that article 31(1)(c) of the Statute covers private self-defense and that self-defense in bello is covered by the Statute as well, they hold different opinions as to the grounds of the latter type of self-defense. Consequently, it is not clear whether self-defense in bello abides to the same criteria as private self-defense.

The following three questions are paramount in the further development of selfdefense in international criminal law:

1. What is the availability of the different types of self-defense in international criminal law?

2. What is the scope of these different types of self-defense in international criminal law (do they abide to the same criteria?)?

3. How do these types of self-defense translate to the ICC Statute? (Which types of self-defense are covered by the criteria mentioned in the first sentence of article 31(1)(c) and which are not?)

\subsection{Preview Part III}

Part III of this thesis demonstrates that all species of self-defense can be a justification, however, within the limits of international humanitarian law. What is more, in Part III it is argued that all three types of self-defense should abide to the same basic criteria, such as necessity and proportionality. Since all three types of self-defense should abide to the same basic criteria, they can also be covered by the same article in the ICC Statute. 



\section{Chapter IV \\ Consent}

\section{INTRODUCTION}

The defense of consent amounts to the argument that no crime has been committed because the victim consented to the commission of the crime. For example, A hits B. However, B wanted A to hit him. Because B consented to A hitting him, A is not liable for assault.

In international criminal law, consent has been discussed at the IMT, the ICTY, and the ICTR. Moreover, rules applicable at the ICC bear the possibility of consent as a complete defense. The conclusion to this Chapter demonstrates that consent is a possible complete defense in international criminal law, but its status is far from established.

\section{Consent in the Nuremberg Judgment}

\subsection{The general part of the Nuremberg Judgment in conjunction with the verdict on Konstantin von Neurath}

\subsubsection{Relevant passages}

When discussing the occupation of Bohemia and Moravia in the general part of the Nuremberg Judgment, the Tribunal casually touches upon the defense of consent, which has been brought up by several defendants. ${ }^{321}$ The Tribunal does neither specify these defendants, nor mention to which charge consent was argued. However, since the defense was brought up in relation to the occupation of Bohemia and Moravia, the relevant offense would probably be crimes against peace (article 6 (a) of the IMT Charter). First the Tribunal reiterates the consentargument:

[...] one of the arguments frequently presented by the Defence in the present case is that the Defendants were induced to think that their conduct [the occupation of Bohemia and Moravia], was not in breach of international law by the acquiescence of other powers. ${ }^{322}$

321 International Military Tribunal (Nuremberg), Judgment and Sentences, 1 October 1946, p. 198.

322 International Military Tribunal (Nuremberg), Judgment and Sentences, 1 October 1946, p. 198. 
The Tribunal quickly waves this argument aside, and holds that:

The declarations of Great Britain and France showed, at least, that this view could be held no longer. ${ }^{323}$

The relevant declarations are described at the beginning of the paragraph:

Following on the occupation of Bohemia and Moravia by Germany on 15 March 1939, which was a flagrant breach of the Munich Agreement, Great Britain gave an assurance to Poland on 31 March 1939 that in the event of any action which clearly threatened Polish independence, and which the Polish Government accordingly considered vital to resist with the National Forces, Great Britain would feel itself bound at once to lend Poland all the support in its power. The French government took the same stand. ${ }^{324}$

The Tribunal thus holds that the reaction of France and Great Britain to the invasion of Bohemia and Moravia - consisting of future support to Poland, if necessary does not demonstrate consent. On the contrary, their reaction reveals that in case Germany would invade another country, they would not sit back - as they did during the invasion of Bohemia and Moravia - but take action.

In relation to the invasion of Bohemia and Moravia the Defense apparently not only argued that other Powers consented to this invasion, but - at least in case of the individual criminal responsibility of Konstantin Von Neurath -325 also that this invasion received the consent of Emil Hácha, the president of Czechoslovakia. This argument is rejected as well:

Bohemia and Moravia were occupied by military force. Hácha's consent obtained as it was by duress, cannot be considered as justifying the occupation. ${ }^{326}$

The way Hácha's consent was obtained, is described in the general part of the Judgment:

On 14 March 1939 the Czech President Hácha and his Foreign Minister Chvalkovsky came to Berlin at the suggestion of Hitler, and attended a meeting at which the Defendants Von Ribbentrop, Göring, and Keitel were present, with others. The proposal was made to Hácha that if he would sign an agreement consenting to the incorporation of the Czech people in the German Reich at once, Bohemia and Moravia would be saved from destruction. He was informed that German troops had

\footnotetext{
323 International Military Tribunal (Nuremberg), Judgment and Sentences, 1 October 1946, p. 198.

324 International Military Tribunal (Nuremberg), Judgment and Sentences, 1 October 1946, p. 198.

325 Konstantin Von Neurath was Minister of Foreign Affairs until Joachim Von Ribbentrop took over in 1938. From then onwards he was Minister without office and Reichsprotektor of Bohemia and Moravia. He resigned in 1943. 
already received orders to march and that any resistance would be broken with physical force. The Defendant Göring added the threat that he would destroy Prague completely from air. Faced by this dreadful alternative, Hácha and his foreign Minister put their signatures to the necessary agreement at 4:30 in the morning, and Hitler and Ribbentrop signed on behalf of Germany. ${ }^{327}$

\subsubsection{Applicability}

Consent is implicitly recognized in the Nuremberg Judgment by rejecting the defense on its merits. In casu consent is thus rejected. Reason for this rejection is that neither the international community nor the president of Czechoslovakia genuinely - consented to the invasion of Bohemia and Moravia. Although the President of Czechoslovakia formally consented to the invasion, his consent was obtained under duress and is therefore invalid. The lack of consent of the international community is, according to the Tribunal, demonstrated by the fact that Great Britain and France declared to resist against a future invasion of Poland. The latter argument is not convincing, since the declarations made by Great Britain could be motivated by their disapproval of the German invasion, but do not necessarily have to be. Likewise, Great Britain and France could also have declared their support to Poland because - as opposed to the invasion of Bohemia and Moravia - they will not consent to an invasion of Poland.

\subsubsection{Scope}

Considering the scope of consent, the Nuremberg Judgment provides one key requirement: consent may not be obtained under duress. It is remarkable is that not only the consent of the victim is discussed but also the consent of a third party (the international community). However, which consent is crucial, cannot be derived from the Judgment. What is more, the Judgment demonstrates that the absence of consent does not have to be derived from a direct statement ("I do not consent") but can be traced back to either coercive circumstances (as in the cited passage on Hácha's consent under duress), or to a statement that could imply the absence of consent ("The next time he does that, I will resist"). It is, however, doubtful whether the latter line of reasoning sufficiently demonstrates the absence of consent, for it is rather an indication than proof (see previous Section).

Another interesting aspect of the type of consent brought up in this case, is that it has both traits of a domestic and an international law defense: it aims at negating the individual criminal responsibility of the defendants through negating the responsibility of the State. The presence of consent is assessed from an outsider perspective (the state of mind of the defendant is not relevant) and thus objectively. 
Chapter IV

\section{Consent at THE ICTY}

\subsection{Prosecutor v. Kunarac et al.}

\subsubsection{Relevant passages}

Prosecutor v. Kunarac et al. revolves around the crimes committed in the early nineties by Bosnian Serb forces during a campaign set up to remove Muslims from the Fǒca area. In this case the prosecution argues that:

[L]ack of consent is not an element of the offense of rape (or any other sexual assault) as defined by the law and rules of the Tribunal, and the existence of force, threat of force, or coercion vitiates consent as a defence. ${ }^{328}$

The prosecution refers to Rule 96, to substantiate both that consent is a defense, and that this defense is available in limited circumstances. Rule 96 provides:

In cases of sexual assault:

i. No corroboration of the victim's testimony shall be required;

ii. Consent shall not be allowed as a defence if the victim

a. Has been subjected to or threatened with or has reason to fear violence, duress, detention or psychological oppression, or

b. reasonably believed that if the victim did not submit, another might be so subjected, threatened or put into fear;

iii. Before evidence of the victim's consent is admitted, the accused shall satisfy the Trial Chamber in camera that the evidence is relevant and credible;

iv. Prior sexual conduct of the victim shall not be admitted into evidence. ${ }^{329}$

The Trial Chamber rejects the prosecution's contention by stating:

The reference in the Rule to consent as a "defence" is not entirely consistent with traditional legal understanding of the concept of consent in rape. Where consent is an aspect of the definition of rape in national jurisdictions, it is generally understood (as demonstrated by many of the provisions referred to above) to be absence of consent, which is an element of the crime. The use of the word "defence", which in its technical sense carries an implication of shifting of the burden of proof to the accused, is inconsistent with this understanding. The Trial Chamber does not understand the reference to consent as a "defence" in Rule 96 to have been used in this technical way. 330

328 ICTY, Prosecutor v. Kunarac et al., Trial Chamber, 22 February 2001, p. 461.

329 ICTY, Prosecutor v. Kunarac et al., Trial Chamber, 22 February 2001, p. 462.

330 ICTY, Prosecutor v. Kunarac et al., Trial Chamber, 22 February 2001, p. 463. 
The Trial Chamber thus holds that traditionally absence of consent is an element of rape, as is demonstrated by several provisions from national jurisdictions (cited in paragraph 453 to 456), and that the word "defense" in Rule 96 does not refer to a defense in a technical sense. Next, the Trial Chamber explains that Rule 96 was only created to underline that the consent of the victim has to be genuine - and thus not be brought about through means described under Rule 96 (a) and (b) - in order to be exonerating:

The factors referred to in Rule 96 are also obviously not the only factors, which may negate consent. However, the reference to them in the Rule serves to reinforce the requirement that consent will be considered to be absent in those circumstances unless freely given. ${ }^{331}$

On appeal, when explaining the relation between "force" and "non consent" (i.e., force provides evidence of non-consent, but is not an element of rape), ${ }^{332}$ the Appeals Chamber remarks that, although absence of consent is an element of rape:

[...] it is worth observing that the circumstances giving rise to the instant appeal and that prevail in most cases charged as either war crimes or crimes against humanity will be almost universally coercive. That is to say, true consent will not be possible. ${ }^{333}$

\subsubsection{Analysis}

Prosecutor v. Kunarac et al. is different from most of the cases discussed in this Part in that the defense at issue was not appealed to by the Defense, but brought up by the prosecution in order to shift the burden of proof. The Trial Chamber however rejects the prosecution's argument and holds that absence of consent is an element of the crime of rape, as it is in most countries. Consequently, claiming that the victim consented negates the objective element of the crime charged, and is thus not a complete defense.

The ruling in Prosecutor v. Kunarac et al. seems to be consistent with ICTY case law, in which absence of consent occasionally pops up as an element of a crime $^{334}$ but never as a complete defense. Still, the fact that lack of consent can in some instances be an element of a crime does not preclude consent from being a complete defense in general. Nevertheless, (lack of) consent seems to be precluded as a complete defense (or as an element that needs proof) by the Appeals Chamber

331 ICTY, Prosecutor v. Kunarac et al., Trial Chamber, 22 February 2001, par. 464.

332 ICTY, Prosecutor v. Kunarac et al., Appeals Chamber, 12 June 2002, par. 129.

333 ICTY, Prosecutor v. Kunarac et al., Appeals Chamber, 12 June 2002, par. 129.

334 See for example ICTY, Prosecutor v. Krnojelac, Appeals Chamber, 17 September 2003, par. 191-196 (on the absence of consent as an element of involuntary labor as a form of persecution). Or: ICTY, Prosecutor v. Martić, Trial Chamber, 12 June 2007, par. 108 (on the absence of consent in case of forced transfer). 
Chapter IV

that holds that true consent is not possible in case of war crimes and crimes against humanity.

\section{Consent at THE ICTR}

\subsection{Prosecutor v. Gacumbitsi}

\subsubsection{Relevant passages}

Like at the ICTY, the ICTR has only discussed consent as a complete defense in the context of rape. Similar to Prosecutor v. Kunarac et al., the prosecution in Prosecutor v. Gacumbitsi argues, that:

[...] non-consent of the victim and the perpetrators knowledge thereof should not be considered elements of the offence that must be proved by the Prosecution; rather $[. .$.$] consent should be considered as an affirmative defence. { }^{335}$

The prosecution, thus, implies that the defense bears the evidential burden in case of consent. It substantiates this vision by three arguments, the first being that:

[...] the crime of rape only comes within the Tribunal's jurisdiction when it occurs in the context of genocide, armed conflicts, or a widespread or systematic attack against a civilian population - circumstances in which genuine consent is impossible. ${ }^{336}$

This argument, in turn, is substantiated by a quote from a report by a Special Rapporteur to the UN Commission on Human Rights:

"The manifestly coercive circumstances that exist in all armed conflict situations establish a presumption of non-consent and negate the need for the Prosecution to establish lack of consent as an element of the crime." 337

The second argument puts the crime of rape in a wider context:

[...] rape should be viewed in the same way as other violations of international criminal law, such as torture or enslavement, for which the Prosecution is not required to establish absence of consent. 338 
The third argument refers to Rule 96 (which is similar to Rule 96 of the ICTY Rules of Procedure and Evidence, discussed in the sub-Section on Prosecutor v. Kunarac et al.):

[...] Rule 96(ii) of the Rules presumes that consent is a defence that must be supported by credible evidence introduced by the accused. ${ }^{339}$

The Appeals Chamber does not agree with the prosecution and holds that:

[...] Kunarac establishes that non-consent and knowledge thereof are elements of rape as a crime against humanity. ${ }^{340}$

However, the Appeals Chamber also cites a quote from the Prosecutor v. Kunarac et al. Appeals Judgment:

[...] the circumstances giving rise to the instant appeal and that prevail in most cases charged as either war crimes or crimes against humanity will be almost universally coercive. ${ }^{341}$

Note that the Gacumbitsi Appeals Chamber refrains from citing the subsequent sentence from the Kunarac Appeals Judgment, which puts that "true consent will not be possible" in these cases. By referring to these two fragments from Kunarac, the Appeals Chamber suggests that on the one hand the absence of consent is an element of rape that the prosecution must prove, while on the other hand the crime to be proved is inherently coercive, which, does not - like Kunarac suggests extinguish the prosecution's burden of proof, but minimizes it.

Next, the Appeals Chamber indicates that it intends to elucidate the statements derived from Prosecutor v. Kunarac et al. First, it rejects the third argument of the prosecution - i.e. that Rule 96 presumes that consent is a defense - by referring to Prosecutor v. Kunarac et al., reiterating that reference to consent as a defense in Rule 96 is not correct and adds that:

Rather than changing the definition of the crime by turning an element into a defence, Rule 96 of the Rules must be read simply to define the circumstances under which evidence of consent will be admissible. ${ }^{342}$

In relation to the first argument of the prosecution (which is endorsed by the Kunarac Appeals Chamber), the Appeals Chamber holds that, according to the case

339 ICTR, Prosecutor v. Gacumbitsi, Appeals Chamber, 7 July 2006, par. 149.

340 ICTR, Prosecutor v. Gacumbitsi, Appeals Chamber, 7 July 2006, par. 153.

341 ICTR, Prosecutor v. Gacumbitsi, Appeals Chamber, 7 July 2006, par. 151. Similar reasoning in: ICTR, Prosecutor v. Muhimana, Trial Chamber, 28 April 2005, par. 546.

342 ICTR, Prosecutor v. Gacumbitsi, Appeals Chamber, 7 July 2006, par. 154. 
law of both the ICTY and the ICTR, the prosecution in rape cases merely has to prove the presence of coercive circumstances under which consent is not possible:

[...] it is not necessary, as a legal matter, for the Prosecution to induce evidence concerning the words or conduct of the victim or the victim's relationship to the perpetrator. Nor need it introduce evidence of force. Rather, the Trial Chamber is free to infer non-consent from the background circumstances, such as an ongoing genocide campaign or the detention of the victim. ${ }^{343}$

The Appeals Chamber does not discuss the prosecution's second argument, i.e. that rape is not different from other international crimes when it comes to consent.

\subsubsection{Analysis}

Both Prosecutor v. Kunarac et al. and Prosecutor v. Gacumbitsi are different from most of the cases discussed in this Part in that the defense at issue was not appealed to by the defense, but brought up by the prosecution in order to shift the burden of proof. The Appeals Chamber in Prosecutor v. Gacumbitsi, however, holds that absence of consent is an element of the crime of rape and explicitly rejects two of the prosecution's arguments (that consent is a defense and that Rule 96 refers to consent as a complete defense). As a consequence, claiming that the victim consented negates the objective element of the crime charged, and is thus not a complete defense.

The ruling in Prosecutor v. Gacumbitsi refines the remark by the Appeals Chamber in Prosecutor v. Kunarac et al. that genuine consent is not possible in case of (rape as an) international crime(s), by demanding a rather light evidential burden in rape cases: the prosecution merely has to prove the presence of coercive circumstances.

The fact that lack of consent is an element of rape, with a light evidential burden, does not preclude consent from being a complete defense in general. However, assuming absence of consent in rape cases if there are coercive circumstances will probably make it difficult to establish the presence of consent in case of international crimes in general. For if the Defense would bring up consent as a complete defense, it would be in line with the rape-case law if the prosecution merely has to demonstrate coercive circumstances in order to negate the consent-defense. This is not an enormous hurdle to take, since Kunarac and Gacumbitsi have stressed that international crimes are "almost universally coercive".

343 ICTR, Prosecutor v. Gacumbitsi, Appeals Chamber, 7 July 2006, par. 155. 


\section{Consent at THE ICC}

Consent is not literally mentioned in the ICC Statute as a ground for excluding criminal responsibility. Still, this does not preclude consent from being a complete defense under article 31(3) (discussed in Chapter XII) that allows the Court to make up new complete defenses. However, consent under article 31(3) would at least be restricted in three ways: by (a) the fact that absence of consent can be an element of the crime at issue and (b) footnote 46 and 68 of the Elements of Crimes and (c) Prosecutor v. Lubanga Dyilo, Decision on the confirmation of charges. ${ }^{344}$

\section{(a) Absence of consent as an element}

In case of several crimes (rape, enforced prostitution, sexual violence, enforced sterilization and pillaging), absence of consent is an element that must be proved by the prosecution. When, in such a case, the Defense would raise the defense of consent, this would not amount to a complete defense in the sense of this research, but to a negation of the objective element of the crime. In case of sexual violence, ${ }^{345}$ the possibility of negating absence of consent is narrowed down by Rule 70, which is similar to Rule 96 at the ICTY and ICTR and maps out situations in which consent is a priori not genuine.

\section{(b) Footnote 46 and 68 of the Elements of Crimes}

Footnote 46 and 68 of the Elements of Crimes refer to the war crimes of mutilation and of medical and scientific experiments ${ }^{346}$ and establish that consent is not a defense to these crimes. The further text of these footnotes explains the reason for this a priori exclusion:

The crime prohibits any medical procedure which is not indicated by the state of health of the person concerned and which is not consistent with generally accepted medical standards which would be applied under similar medical circumstances to persons who are nationals of the party conducting the procedure and who are in no way deprived of liberty.

344 ICC, Prosecutor v. Lubanga Dyilo, Decision on the confirmation of charges, Pre-Trial Chamber, 29 January 2007.

345 Whether this Rule is applicable in case of the crime of sexual violence (articles 7(1)(g)-6, 8(2)(b) (xxii)-6 and 8(2)(e)(vi)-6 of the Elements of Crimes) or in the case of sexual violence in general (i.e. also in case of rape, enforced prostitution etc.), cannot be derived from the RPE. However, since the Rule was created to underline that consent must be genuine, it must probably be interpreted in a broad sense.

346 Respectively, article 8(2)(b)(x)-1 and 8(2)(e)(xi)-1 (mutilation) and 8(2)(b)(x)-2 and 8(2)(e)(xi)-2 (medical and scientific experiments) of the Elements of Crimes. It is remarkable is that the war crime of mutilation ex article $8(2)(c)(i)-2$ of the Elements of Crimes is not accompanied by a footnote a priori excluding consent. 
The drafters of the Elements of Crimes clearly intended to distinguish between regular medical procedure on the one hand, and mutilation (for the purpose of experiments or otherwise) on the other. Apparently they held that the subjective consent of the victim is not enough to establish the presence of a regular medical procedure, but instead the procedure must be objectively necessary and objectively consistent with the medical standard that would be applied to the (free) nationals of the party conducting the procedure. Consequently, consent alone does not legitimize the procedure. Rather, the defendant must establish that the victim underwent a regular medical procedure, in order to be absolved from punishment. This, however, would not amount to a complete defense argument, but to a negation of the objective element. $^{347}$

Concerning the a priori exclusion of consent in footnote 46 and 68, it is interesting that this explicit exclusion can be conceived as an implicit acknowledgement of consent as a complete defense to the other crimes over which the ICC has jurisdiction. For, if consent would not be a possible complete defense to the crimes contained by the Statute, a priori exclusion would be superfluous.

\section{(c) Prosecutor v. Lubanga Dyilo}

In Prosecutor v. Lubanga Dyilo, the ICC Pre-Trial Chamber has rejected the defense of consent with respect to the charge of use of child soldiers. ${ }^{348}$ This means that when a child voluntarily becomes a soldier, the responsible adult is still liable.

In sum, consent seems to be a possible defense under article 31(3) the ICC Statute, however not in case (a) consent is an explicit element of a crime (b) when consent is precluded as a defense by footnote 46 and 68 or (c) in case of a child soldier's charge.

\section{Analysis of CONSENT}

\subsection{Applicability}

The Nuremberg Tribunal implicitly recognizes the defense of consent, be it as an individual appeal to an international law defense. Case law of the ICTY and ICTR establishes that consent is an element for rape, with a light evidential burden, but does not discuss the applicability of consent as a general defense. Within the ICC regime, consent could technically be a complete defense under article 31(3) of the

\footnotetext{
347 See paragraph (3) of the relevant crimes, which demands that the conduct was not preformed for medical reasons or in the interest of the victim.

348 ICC, Prosecutor v. Lubanga Dyilo, Decision on the confirmation of charges, Pre-Trial Chamber, 29 January 2007, par. 247. This point of view was later confirmed by the Trial Chamber in the Lubanga verdict: ICC, Prosecutor v. Lubanga Dyilo, Judgment pursuant to Article 74 of the Statute, Trial Chamber I, 14 March 2012, par. 572-618.
} 
ICC Statute, when (a) absence of consent is not an element of the crime charged and (b) consent is not a priori excluded.

The appeal to consent in the Nuremberg Judgment is rejected for two reasons: (i) although consent of the victim was present, it was not genuine and (ii) the consent of the international community was absent. Consent was never explicitly discussed as a mitigating factor.

\subsection{Scope}

Consent - as an individual appeal to an international law defense - probably has the following requirements: (a) The victim must have consented, (b) third parties must have consented and (c) consent must not have been obtained under duress. It is significant that - both at the IMT and according to the footnotes to the previously mentioned ICC provisions - an appeal to consent of the victim alone does not seem to be enough to establish the legality of an act. In both cases some sort of objective test is required (either in the form of the opinion of the international community or in the form of general medical standards). When assessing the latter criterion (c) it should be kept in mind that the ICTY and ICTR have stressed that international crimes are almost universally coercive. All criteria are objectively tested. Consent as a private defense has so far not featured in international criminal law cases, hence no criteria exist.

\subsection{Categorization}

If all requirements for - the international law version of - consent have been met, can this legal figure be classified as any of the three types of complete defenses ex Chapter II? In order to classify the requirements for consent, the first question to be answered is: when both the victim and/or third parties genuinely consent to the commission of the crime, can the act still be considered wrongful? An act is generally not wrongful when the legal community as a whole approves of the act, because the perpetrator has chosen to behave in accordance with the lesser evil. The presence of genuine consent of the victim and third parties however, does not automatically establish that the perpetrator objectively chose the lesser evil in the eyes of the entire legal community. The legal community may have other values. Consent, although referred to as such in the IMT Judgment, is therefore not an obvious justification, because choosing the lesser evil is not an explicit requirement of the defense.

If despite the consent of the victim and third parties, the act is wrongful, could the perpetrator still be excused? Classification of consent as an excuse runs into similar problems as the categorization of consent as a justification. An excuse is applicable if the defendant acted the way any reasonable person would have done (or had no ability to choose, no freedom of will, mental capacity or knowledge of 
law). Since the reasonable person test is not one of the criteria mentioned in the Nuremberg Judgment and because it is hard to determine whether consent of the victim (and others) always coincides with a positive outcome of the reasonable person test, consent cannot be qualified as an obvious excuse either.

In conclusion, consent, as it is defined in the Nuremberg Judgment, cannot be categorized as either a justification or an excuse and can therefore not be qualified as any of the three types of complete defenses ex Chapter II.

Although the case law of the ICTY and ICTR is silent on consent as a complete defense, the legal texts discussed in the ICC Section seem to suggest that consent is a possible defense. However, because the ICC criteria for consent are at this point unknown, it is not possible to classify consent as any of the three types of complete defenses ex Chapter II.

\subsection{Conclusion on consent}

Conclusion on consent in international criminal law is that although (case) law leaves room for this defense, consent does not have the technical features of a complete defense. What is more: its conditions are uncertain. The conditions that can be derived from the Nuremberg Judgment do not establish consent as a complete defense in a technical sense. Other legal sources have not mentioned the conditions for an appeal to consent. In addition, the defense is limited (a) by the fact that absence of consent is sometimes an element of a crime and (b) by the fact it is $a$ priori excluded in relation to some crimes at the ICC.

Crucial questions for the further development of consent (either as an international or as a private defense) in international criminal law are:

1. Should consent be a defense under international criminal law?

2. If it should: what are its conditions?

\subsection{Preview Part III}

Part III of this thesis argues that consent should not be a complete defense under its current definition. The most convincing argument is that consent is not a complete defense in a technical sense, for it neither justifies nor excuses an alleged criminal act. Part III suggests additional research in order to investigate whether consent could be a complete defense under (international) criminal law. 


\section{Chapter V INSANITY}

\section{INTRODUCTION}

The insanity defense is brought up when a defendant is deemed mentally disturbed at the moment he commits a crime. For example, A hits B. However, at the moment of the attack $\mathrm{A}$ is suffering from a psychosis. Because of this psychosis A thinks that $\mathrm{B}$ is a monster that he must eliminate. Consequently, A cannot be convicted for assault.

Insanity has been discussed at the IMT and the ICTY. The defense is also mentioned in the Rules of the ICTR and in article 31(1)(a) of the ICC Statute.

In national legal systems insanity is different from other complete defenses in at least two aspects: (a) the mental capacity of the defendant is usually assessed by psychological and/or psychiatric experts ${ }^{349}$ and (b) the legal consequence of a successful appeal to insanity is not restricted to an acquittal (but usually coupled with a judicial order to be committed to some sort of mental hospital or outpatient mental health treatment). ${ }^{350}$ Apart from addressing the research questions submitted in the introduction to this Part, this Chapter investigates whether and how the issues mentioned sub (a) and (b) are dealt with in international criminal law. The conclusion to this Chapter demonstrates that psychiatric and psychological expert opinions have gradually been formalized in international criminal law. However, the legal consequence of a successful insanity plea remains an unresolved issue.

\section{Insanity at the Nuremberg Tribunal}

\subsection{The verdict on Rudolf Hess}

\subsubsection{Relevant passages}

The insanity defense is briefly touched upon in the verdict on Rudolf Hess (Hitler's closest confidant until 1941) 351 $^{35}$ relation to charges of war crimes (article 6(b) of the IMT Charter) and crimes against humanity (article 6(c) of the IMT Charter). The relevant passage mainly discusses Hess's fitness to stand trial. Fitness to stand

\footnotetext{
349 Blomsma, J., 2012, pp. 483/484.

350 See for the Netherlands: www.rijksoverheid.nl/onderwerpen/tbs (04/05/2011). See for other countries: http://rechtennieuws.nl/8186/buitenland-biedt-voorbeelden-voor-nederlandse-tbs.html (04/05/2011).

351 In 1941 Hess fled to Great Britain, where he was detained. See: International Military Tribunal (Nuremberg), Judgment and Sentences, 1 October 1946, p. 275.
} 
trial is different from an insanity defense in that the first refers to the mental state of the defendant at the moment of the trial, while the latter refers to the mental state of the defendant during the commission of the crime charged. In relation to Hess's fitness to stand trial, the Tribunal holds:

That Hess acts in an abnormal manner, suffers from loss of memory and has mentally deteriorated during this Trial, may be true. But there is nothing to show that he did not realize the nature of the charges against him, or is incapable of defending himself. He was ably represented at the Trial by counsel, appointed for that purpose by the Tribunal. ${ }^{352}$

Then, out of the blue, the Tribunal says something about Hess's state of mind during the commission of the crimes charged:

There is no suggestion that Hess was not completely sane when the acts charged against him were committed. ${ }^{353}$

This is the last sentence of the verdict on Rudolf Hess.

\subsubsection{Analysis}

It cannot be derived from the text of the Judgment whether the remark on Hess's sanity at the moment of the commission of the crimes charged is a reference to the fact that none of the parties produced evidence in relation to this issue or whether it is the rejection of an insanity plea. Either way, the remark on Hess's sanity is ultimately an implicit recognition of the insanity defense. For, with its statement on insanity the Tribunal suggests that, if Hess was not completely sane at the moment he committed the crimes charged, this would have had consequences for his criminal responsibility. ${ }^{354}$

The rejection of the insanity plea is not substantiated by any arguments. This is probably due to the fact that the Tribunal neither ordered to perform research on this issue, nor took notice of existing psychiatric reports that confirmed that Hess's mental incapacity existed before his 1941 flight to Great Britain. ${ }^{355}$ Knowing that the Tribunal ignored this information, provides the remark that "there is no suggestion that Hess was not completely sane" in a different daylight. Namely, the reason that Hess was considered sane is not that the information available could not establish his insanity, but that the Tribunal ignored the information on his mental state.

\footnotetext{
352 International Military Tribunal (Nuremberg), Judgment and Sentences, 1 October 1946, p. 277.

353 International Military Tribunal (Nuremberg), Judgment and Sentences, 1 October 1946, p. 277.

354 A similar conclusion is drawn by E. van Sliedregt in: Sliedregt, E. van, 2012, p. 226.

355 Davidson, E., Trial of the Germans: An Account of the Twenty-Two Defendants before the International Military Tribunal at Nuremberg, University of Missouri Press, Columbia, 1997, p. 124.
} 
Although Hess was acquitted in relation to war crimes and crimes against humanity (but convicted for crimes against peace), this acquittal does not seem to be related to mental issues but rather to the fact that the Tribunal "does not find that the evidence sufficiently connects Hess with those crimes". 356 The absence of this connection is a logical consequence of Hess leaving the Nazi-government in 1941. Hence, he could be connected to planning and starting the war, but not as much to crimes committed during the war.

\subsubsection{Expert examination and legal consequences}

Neither the IMT Statute and Rules nor the Nuremberg Judgment provide for rules on either psychological or psychiatric expert examination or the legal consequences of an insanity plea successfully raised. Several experts of different nationalities were, however, heard to assess Hess's fitness to stand trial. ${ }^{357}$

\section{INSANITY AT THE ICTY}

\subsection{Prosecutor v. Erdemović}

\subsubsection{Relevant passages}

The case of Prosecutor v. Erdemovic is famous for its contemplations on duress. The exact details of this case are therefore discussed in Chapter IX (Necessity and duress). Apart from duress, the Erdemović Defense also pleaded insanity. While throughout the judgments in the Erdemović-case (the case went through three different Chambers) there are references to psychological reports in relation to the alleged duress applied on Erdemović, ${ }^{358}$ reference to an insanity defense is only made by the second Trial Chamber, when discussing factors in mitigation:

Whilst the Commission of Medical Experts made a finding of emotional immaturity, which is noted, there is nothing to substantiate Defence Counsel's submission to Trial Chamber I (which was not raised again before this Trial Chamber), that when the accused committed the killings he "lacked mental responsibility because he suffered a temporary mental disorder or, at best, his mental responsibility was significantly diminished also" 359

359 ICTY, Prosecutor v. Erdemović, Trial Chamber II, 5 March 1998, par. 16. 


\subsubsection{Analysis}

Trial Chamber II in Prosecutor v. Erdemović implicitly recognizes the insanity ("mental disorder") argument by discussing it, however, not as a complete defense, for it is brought into line with diminished responsibility and treated as a mitigating factor. Anyway, the appeal to insanity is rejected because it is not substantiated by the relevant medical report. Reference to a medical report is a development in respect to the Nuremberg Judgment, where the insanity plea was rejected without supplying any reasons.

\subsection{Prosecutor v. Mucić et al.}

\subsubsection{Relevant passages}

In 1992 Bosnian Muslims and Croats established the Čelebići prison camp in which they detained Bosnian Serbs. In Prosecutor v. Mucić et al. multiple defendants stand trial for their involvement in this prison camp. Esad Landžo - a former guard at the camp - is one of them. He is charged with war crimes under article 2 and 3 of the ICTY Statute. ${ }^{360}$ The Trial Chamber remarks that Landžo has advanced the plea of "diminished responsibility", 361 and continues by explaining that:

A plea of diminished responsibility is to be distinguished from a plea of insanity [...]. It should be noted, however, that both pleas are founded on an abnormality of mind. In the case of the plea of insanity, the accused is, at the time of commission of the criminal act, unaware of what he is doing or incapable of forming a rational judgment as to whether such an act is right or wrong. By contrast, the plea of diminished responsibility is based on the premise that, despite recognizing the wrongful nature of his actions, the accused, on account of his abnormality of mind, is unable to control his actions. ${ }^{362}$

As to the foundation of these defenses, the Trial Chamber refers to the Rules:

Sub Rule 67(A)(ii)(b) refers to special defences available to the accused, including that of diminished or lack of mental responsibility. ${ }^{363}$

With respect to the nature of these defenses, the Trial Chamber remarks that:

Sub Rule 67(A)(ii)(b) would indeed appear to suggest a complete defence since the words are without qualification or limitation. ${ }^{364}$

ICTY, Prosecutor v. Mucić et al., Trial Chamber, 16 November 1998, par. 4. ICTY, Prosecutor v. Mucić et al., Trial Chamber, 16 November 1998, par. 1156. ICTY, Prosecutor v. Mucić et al., Trial Chamber, 16 November 1998, par. 1156. ICTY, Prosecutor v. Mucić et al., Trial Chamber, 16 November 1998, par. 1157. ICTY, Prosecutor v. Mucić et al., Trial Chamber, 16 November 1998, par. 1164. 
Next, the Trial Chamber continues on some procedural issues. When discussing these issues, the Trial Chamber refers to the English Homicide Act of 1957 and continues to refine its definition of diminished responsibility based upon this act:

Thus, the accused must be suffering from an abnormality of mind, which has substantially impaired his mental responsibility for his acts or omissions. The abnormality of mind must have arisen from a condition of arrested or retarded development of the mind, or inherent causes induced by disease or injury. These categories clearly demonstrate that the evidence is restricted to those, which can be supported by medical evidence. Consequently, killing motivated by emotions, such as those of jealousy, rage or hate appear to be excluded. ${ }^{365}$

Next, the Trial Chamber discusses Landžo's plea of diminished responsibility. The Trial Chamber reports that five psychiatrists have been called as expert witnesses: three by the defense, one by the Trial Chamber and one by the prosecution. ${ }^{366}$ The first four witnesses held that Landžo's free will was to some degree affected by a personality disorder. ${ }^{367}$ In contrast, it may be no surprise that the prosecution's expert witness found that "the abnormality of personality which Esad Landžo exhibited had no pathological component, but merely reflected his personality traits". ${ }^{368}$ Before assessing Landžo's diminished responsibility plea, the Trial Chamber stresses that the diminished responsibility must have been present at the time that the crimes charged were committed:

It need hardly be pointed out at this stage that, for the purpose of assessing Esad Landžo's diminished responsibility defence, the Trial Chamber must be concerned with the period during which he served as a guard in the Čelebići prison camp. It is only for this period that it is relevant to determine whether Mr. Landžo suffered from an abnormality of mind that rendered him incapable of controlling his actions. ${ }^{369}$

Next, the Trial Chamber acknowledges that this is a difficult task:

Although the experts appearing for the Defence testified that the features of Mr. Landžo's personality developed long before his tenure at the prison camp, they were obviously suffering from the natural handicap of having to render their assessment approximately six years after the relevant period. Furthermore, by their own admission, the experts based their findings upon what Mr. Landžo himself told them, without having an opportunity to verify his story from any other sources. ${ }^{370}$ 
Despite these difficulties the Trial Chamber holds it has enough information to reject the plea of diminished responsibility. This rejection is based on three reasons. The first being that:

[...] the information provided by Esad Landžo relating to his own background cannot be relied upon. ${ }^{371}$

The Trial Chamber substantiates this argument as follows:

In this regard the Trial Chamber notes that Mr. Landžo told the experts several stories about himself, which he later changed and disowned. Indeed, there are so many instances that it would be tedious to reproduce them all. For example, in his discussions with various experts he took up the position that, while serving in the prison camp he would drink heavily and take pills to enhance the effect of alcohol. However, in his testimony before the Trial Chamber he denied this. Similarly, before the experts he recounted an incident where he allegedly threw a hand grenade into a room where girls were present. Again, in his testimony he changed this story, stating that he had merely fired a gun into the ceiling when he found some soldiers present in a room he had chosen for his use..$^{372}$

The second reason for rejecting the diminished responsibility defense is that the Trial Chamber does not believe that Landžo was suffering from a posttraumatic stress disorder at the time he committed the offenses charged:

Dr. Van Leeuwen's expert opinion was that Mr. Landžo's personality disorder was compounded in the Čelebići prison camp by the experience he allegedly underwent in a Croatian training camp. This opinion was based upon Esad Landžo's unsupported account of running away in the summer of 1991 with a friend, to avoid a call-up from the $\mathrm{JNA}^{373}$ for compulsory military service. According to $\mathrm{Mr}$. Landžo's account, he and his friend spent the night in a village near the Croatian border. In the morning their host took them to a Croatian training camp, where they spent the following 20 to 25 days. As part of the training, live demonstrations were held to show how to kill human beings.

The Trial Chamber finds this account to be unreliable for the following reasons. Firstly, it appears somewhat unlikely that a person who had fled from his home in order to avoid being conscripted into mandatory military service would promptly join another military training facility. Further, Mr. Landžo was unable to recall either the name of the village where the training camp was located, or the true names of those who instructed him, even though, according to him, he spent 20 to 25 days there. These considerations seriously compromise the reliability of this account and, in the

ICTY, Prosecutor v. Mucić et al., Trial Chamber, 16 November 1998, par. 1182.

ICTY, Prosecutor v. Mucić et al., Trial Chamber, 16 November 1998, par. 1182.

373

JNA stands for Yugoslav National Army. The JNA was the official army of the former Yugoslavia. After Yugoslavia's disintegration in the earlier nineties, the JNA developed into a Serbian Army. 
absence of independent support, the Trial Chamber is not convinced of its authenticity. Consequently, the opinion expressed by some of the experts that, while serving in the prison camp Mr. Landžo's personality disorder was compounded by posttraumatic stress disorder arising out of his experience in the Croatian training camp, loses much of its validity. Indeed, Dr. Van Leeuwen stated that, in his opinion, Mr. Landžo did not suffer from posttraumatic stress disorder during the relevant period. ${ }^{374}$

The third argument by which the diminished responsibility plea is rejected, is that the Trial Chamber does not believe that Landžo had a personality disorder in the form of "dependency traits", a condition explained in the fragment below:

[...] Dr Laggazi referred to the aspect of Mr. Landžo's personality disorder, which meant that he displayed dependency traits. In this context, he explained that an individual possessing a dependency trait will often conjure up in his mind a false self upon which to model his behavior. Thus, Esad Landžo considered that, to be regarded as a good soldier, he had to obey the orders of his superiors. This diminished his ability to exercise his free will in relation to orders he received from his superiors. As to the facts of the instant case, the Trial Chamber is not convinced that the criminal acts attributed to Esad Landžo were not the product of his own free will, or that they were influenced by his desire to seek the approbation of others. ${ }^{375}$

Next, the Trial Chamber substantiates this third argument:

Further, in the absence of independent supporting evidence, the Trial Chamber cannot accept Esad Landžo's statement that he committed some of the criminal acts with which he is charged on the direction of his co-accused Hazim Delić. In fact, Mr. Landžo admitted to Dr. Grippon that he would inflict pain for two reasons, first, because he was ordered to do so, and, secondly, because he was bored and frustrated. He further stated that he never experienced any difficulty in doing such things, that he actually enjoyed it and that he cannot explain why he found it to be not at all unpleasant. In this context, the Trial Chamber finds it relevant to note that, according to the expert opinion of Dr. Sparr, individuals who possess the personality traits exhibited by Esad Landžo have a tendency to blame others for their own faults. ${ }^{376}$

Finally, the Trial Chamber concludes that:

For the reasons stated, the Trial Chamber is not persuaded by the defence of diminished responsibility as canvassed on behalf of Esad Landžo. The Defence does not contend that, at the relevant time, Esad Landžo was unable to distinguish between right and wrong. Although it does appear from the testimony of experts that Mr. Landžo suffered from a personality disorder, the evidence relating to his inability to control his physical acts on account of an abnormality of mind, is not at

374 ICTY, Prosecutor v. Mucić et al., Trial Chamber, 16 November 1998, par. 1183-1184.

375 ICTY, Prosecutor v. Mucić et al., Trial Chamber, 16 November 1998, par. 1185.

376 ICTY, Prosecutor v. Mucić et al., Trial Chamber, 16 November 1998, par. 1185. 
all satisfactory. Indeed the Trial Chamber is of the view that, despite his personality disorder, Esad Landžo was quite capable of controlling his actions. ${ }^{377}$

On Appeal, the Appeals Chamber discusses whether diminished responsibility constitutes a complete defense and recapitulates that:

As stated earlier, both Landžo and the Trial Chamber appear to have assumed the existence of such a defence in international law by reason of Rule 67(A)(ii). That sub-Rule is in the following terms:

As early as reasonably practicable and in any event prior to the commencement of trial: [...] the defence shall offer:

(a) the defence of alibi; [...];

(b) any special defence including that of diminished or lack of mental responsibility;

in which case the notification shall specify the names and addresses of witnesses and any other evidence upon which the accused intends to rely to establish a special defence. ${ }^{378}$ (italics added)

Next, the Appeals Chamber explains that "lack of mental responsibility" is indeed a complete defense:

The rule is not happily phrased. [...] if the Defendant raises the issue of lack of mental capacity, he is challenging the presumption of sanity by a plea of insanity. That is a defence in a true sense, in that the Defendant bears the onus of establishing it - that, more probable than not, at the time of the offense he was laboring under such a defect of reason, from disease of the mind, as not to know the nature and quality of his act or, if he did know, that he did not know that what he was doing was wrong. Such a plea, if successful, is a complete defence to a charge and leads to an acquittal. ${ }^{379}$

In contrast, diminished responsibility is not a complete defense. The Appeals Chamber substantiates this assertion by first explaining that Rule 67 is not a legal basis for diminished responsibility as a defense:

[...] there is no reference to any defence of diminished responsibility in the Tribunal's Statute. The description of diminished mental responsibility as a "special defence" in Rule 67(A)(ii) is insufficient to constitute it as such. The rule-making powers of the judges are defined by article 15 of the Tribunal's Statute, which gives power to the judges to adopt only $-[\ldots]$ rules of procedure and evidence for the conduct of the pre-trial phase of the proceedings, trials and appeals, the admission of evidence, the protection of victims and witnesses and other appropriate matters. The

377 ICTY, Prosecutor v. Mucić et al., Trial Chamber, 16 November 1998, par. 1186.

378 ICTY, Prosecutor v. Mucić et al., Appeals Chamber, 20 February 2001, par. 580.

379 ICTY, Prosecutor v. Mucić et al., Appeals Chamber, 20 February 2001, par. 580 and 582. 
Appeals Chamber has held that this power does not permit rules to be adopted, which constitute new offences, but only rules of procedure and evidence for the conduct of matters falling within the jurisdiction of the Tribunal. It follows that there is, therefore, no power to adopt rules with constitute new defences. ${ }^{380}$

Next, the Appeals Chamber refers to other possible foundations of diminished responsibility as a defense:

If there is a "special defence" of diminished responsibility known to international law, it must be found in the usual sources of international law - in this case, in the absence of reference to such a defence in established customary or conventional law, in the general principles of law recognized by all nations. ${ }^{381}$

\section{And reports that:}

Landžo has submitted that such a "special defence" based upon the English model, with modifications, should be available in international law because it is "generally accepted as providing a fair and balanced defence", it has been recognized in the domestic laws of many countries and by the Statute of the International Criminal Court adopted in 1998 (ICC Statute). ${ }^{382}$

The Appeals Chamber, however, does not agree that the defense of diminished responsibility has been recognized by the ICC Statute:

The ICC Statute provides that a Defendant shall not be criminally responsible if, at the relevant time, he or she - [...] suffers from a mental disease or defect that destroys that person's capacity to appreciate the unlawfulness or nature of his or her conduct, or capacity to control his or her conduct to conform to the requirements of law. This is not the same as any partial defence of diminished mental responsibility, as it requires the destruction of (and not merely the impairment to) the Defendant's capacity, and leads to an acquittal. It is akin to the defence of insanity. There is no express provision in the ICC Statute, which is concerned with the consequences of impairment to such a capacity. ${ }^{383}$

As to diminished responsibility in the domestic law, the Trial Chamber holds that this legal figure is never a complete defense, but either a partial defense or a factor in mitigation:

The English Homicide Act 1957 provides that a person who kills or who is party to the killing of another shall not be convicted of murder if he establishes that he was 
suffering from an abnormality of mind (as defined) as substantially impaired his mental responsibility for his acts or omissions in doing so or being a party to the killing. The section provides that, instead, he is liable to be convicted of manslaughter. It is thus a partial defence, not a complete defence to murder. [...] in many countries where the Defendant's total mental incapacity to control his actions or to understand that they were wrong constitutes a complete defence, his diminished mental responsibility does not constitute either a partial or complete defence, but a factor in mitigation. ${ }^{384}$

Although diminished responsibility can be a partial defense under domestic law, the Trial Chamber holds that this construction is not desirable at the ICTY:

The Appeals Chamber recognizes the rationale for the partial defence provided for the offense of murder by the English Homicide Act 1957 is inapplicable to the proceedings before the Tribunal. There are no mandatory sentences. Nor is there any appropriate lesser offense available under the Tribunal's Statute for which the sentence would be lower and which could be substituted for any of the offenses it has to $\operatorname{try} .385$

The Appeals Chamber concludes its contemplation by stating that diminished responsibility must be viewed as a mitigating factor:

The Appeals Chamber accepts that the relevant general principle of law upon which, in effect, both the common law and the civil law systems have acted is that the Defendant's diminished mental responsibility is relevant to the sentence to be imposed and is not a defence leading to an acquittal in the true sense. This is the appropriate general legal principle representing the international law to be applied in the Tribunal. Rule 67(A)(ii)(b) must therefore be interpreted as referring to diminished mental responsibility where it is to be raised by the Defendant as a matter in mitigation of sentence. ${ }^{386}$

Finally, the Appeals Chamber discusses the ground of appeal by the defense, which asserts that the appeal to diminished responsibility was erroneously rejected. However, since this is an assessment of a mitigating factor, these contemplations are not subject to the research reflected in this thesis. Anyway, the Appeals Chamber backs up the Trial Chamber and concludes that:

It has not been demonstrated that the rejection of the "special defence" of diminished mental responsibility was a conclusion, which no reasonable tribunal of fact could have been reached. ${ }^{387}$ 
Insanity

\subsubsection{Applicability}

The Trial Chamber in Prosecutor v. Mucić et al. recognizes both the complete defenses of insanity and of diminished responsibility based upon Rule 67(A)(ii)(b). The acknowledgement of the insanity defense is confirmed on appeal, be it not based on Rule 67(A)(ii)(b), but on British domestic case law. The Appeals Chamber, however, denies that diminished responsibility is a complete defense, but holds it is a factor in mitigation. The Appeals Chamber substantiates this finding by demonstrating that there is no legal basis for diminished responsibility as a complete defense, not in Rule 67 (A)(ii)(b), neither in international law, nor in domestic (UK) law. Although diminished responsibility is occasionally a partial defense in domestic law, this solution does not fit the ICTY for technical reasons. Because domestic law also demonstrates that diminished responsibility can be a factor in mitigation, the Appeals Chamber finds it must be treated as such at the ICTY. In short, Prosecutor v. Mucić et al. concludes with the finding that insanity is a complete defense, while diminished responsibility is a factor in mitigation.

In the first instance the appeal to diminished responsibility (which was treated as a complete defense by the Trial Chamber) is rejected in casu. This rejection is substantiated by three reasons: (a) the information provided by Landžo on his background is found to be unreliable, (b) the Trial Chamber does not think that Landžo was suffering from a posttraumatic stress disorder at the moment of the crimes and (c) the Trial Chamber does not think that Landžo was suffering from "dependency traits". Remarkable is that the Trial Chamber does not discuss other mental diseases which were mentioned by the experts ${ }^{388}$ (and their effect on Landžo's ability to control his actions). What is more, in the end the Trial Chamber concludes that Landžo did suffer from a personality disorder, but that "the evidence relating to his inability to control his physical acts on account of an abnormality of mind" is lacking. This line of reasoning is somewhat convoluted, for the Trial Chamber basically says that (i) Landžo's statements are unreliable and (ii) they don't believe he suffered from mental disorder $\mathrm{X}$ and $\mathrm{Y}$ (while not discussing whether he suffered from disorder $\mathrm{Z}$ and Q) but (iii) he does have a personality disorder, only (iv) the relationship between his personality disorder and his lack of control has not been established. The Trial Chamber, however, refrains to substantiate the latter point. On appeal, diminished responsibility was not treated as a complete defense but as a factor in mitigation and was rejected as such.

\subsubsection{Scope}

The Trial Chamber defines both insanity and diminished responsibility as a complete defense. Insanity is defined as the situation where there is an "abnormality

388 ICTY, Prosecutor v. Mucić et al., Trial Chamber, 16 November 1998, par. 1173-1180. For example, "schizoid personality disorder" and "borderline". 
of mind" and "the accused is, at the time of commission of the act, unaware of what he is doing or incapable of forming a rational judgment as to whether such an act is right or wrong". The insanity definition of the Appeals Chamber is slightly different: "At the time of the offense he [the defendant] was laboring under such a defect of reason, from a disease of the mind, as not to know the quality of his act or, if he did know, that he did not know that what he was doing was wrong". Both versions have (three) similar requirements:

a. The defendant must have a mental defect (an abnormality of mind/defect of reason, from a disease of the mind);

b. This defect must be present at the time of commission of the act/at the time of the offense; and

c. (Because of this defect) the defendant is (i) unaware of what he is doing/does not know the quality of his act or (if he did know) (ii) is incapable of forming a rational judgment as to whether such an act is right or wrong/did not know that what he was doing was wrong.

The most significant difference between the two definitions is that the definition of the Appeals Chamber explicitly demands causality between the mental defect and the effect of this defect on the defendant. The requirements (a)-(c) refer to a subjective test, for they demand an investigation of the state of mind of the perpetrator.

The Trial Chamber defines diminished responsibility as a situation in which the defendant recognizes "the wrongful nature of his actions" but "on account of his abnormality of mind, is unable to control his actions". Later it adds that the "abnormality of mind" does not have to completely negate his mental responsibility. The plea can also be successful if the defendant's mental responsibility is "substantially impaired". What is more, the "abnormality of mind" must have arisen from (i) a condition of arrested or retarded development of the mind or from (ii) inherent causes induced by disease or injury. The Trial Chamber also adds that, like in case of insanity, the diminished responsibility must have been present at the time that the crimes charged were committed.

The Appeals Chamber stresses that diminished responsibility requires the impairment of the defendant's mental capacities (as opposed to the destruction) and holds that this legal figure is a mitigating factor (and not a complete defense). The definitions of both chambers provides us with the following requirements for diminished responsibility:

a. The defendant recognizes the wrongful nature of his actions;

b. The defendant suffers from an abnormality of mind;

c. This abnormality is present at the time that the crimes charged were committed; 
d. This abnormality must have arisen from (i) a condition of arrested or retarded development of the mind or from (ii) inherent causes induced by disease or injury;

e. The defendant is impaired to control his acts;

f. The abnormality of mind causes this inability (or substantial impairment).

Like insanity, the requirements for diminished responsibility seem to demand a subjective test. As to their requirements, the difference between insanity and diminished responsibility is that:

- In case of diminished responsibility the defendant recognizes the wrongful nature of his actions, but is impaired to control them, while in case of insanity the defendant does not know what he is doing or does not know he is doing something wrong;

- The definition of diminished responsibility specifies the sources of the abnormality of mind required;

- Diminished responsibility is a mitigating factor applicable to a defendant with impaired mental capacities, insanity a complete defense applicable to a defendant with destroyed mental capacities.

\subsubsection{Expert examination and legal consequences}

\section{EXPERT EXAMINATION}

The ICTY is the first international Tribunal to create a Rule applicable to psychiatric or psychological examination of the accused, Rule 74 bis (Medical Examination of the Accused):

The Trial Chamber may, proprio motu, or at the request of a party, order a medical, psychiatric or psychological examination of the accused. In such a case, unless the Trial Chamber otherwise orders, the Registrar shall entrust this task to one or several experts whose names appear on a list previously drawn up by the Registry and approved by the Bureau.

This Rule is probably not only applicable in case of an insanity plea, but also when diminished responsibility is brought up in mitigation or when a defendant pleads he is unfit to stand trial. The only other ICTY Rule, applicable to psychiatric or psychological expert witnesses, is Rule 94 bis, which regulates the testimony of expert witnesses in general.

\section{LEGAL CONSEQUENCES}

The legal consequences of a successful insanity plea at the ICTY are not clear. Neither the Statute nor the Rules of Procedure and Evidence address the situation of 
the accused who is found to be insane. Consequently, a mentally disturbed perpetrator seems to be free to go and is not committed to some sort of mental institution or treatment facility.

\section{INSANITY AT THE ICTR}

The plea of insanity has never been discussed at the ICTR. However, one should note that the ICTR shares its Appeals Chamber with the ICTY and that both tribunals are governed by the same RPE with respect to an insanity plea and expert witnesses in general (Rule 67, Rule 74bis and Rule 94bis of the RPE of the ICTY and ICTR).

\section{INSANITY AT THE ICC}

\subsection{Applicability}

Insanity is recognized by the ICC in article 31 paragraph (1)(a) and heading (Grounds for excluding criminal responsibility) of the ICC Statute:

1. In addition to other grounds for excluding criminal responsibility provided for in this Statute, a person shall not be criminally responsible if, at the time of that persons conduct:

(a) The person suffers from a mental disease or defect that destroys that person's capacity to appreciate the unlawfulness or nature of his or her conduct, or capacity to control his or her conduct to conform to the requirements of law;

\subsection{Scope}

The heading of article 31 is analyzed in Chapter III (self-defense). Paragraph (1)(a) of article 31 bears several conditions for a successful appeal to insanity:

a. The defendant must have suffered from a mental disease or defect;

b. This disease or defect destroys:

- the defendant's capacity to appreciate the unlawfulness or nature of his or her conduct; or

- the defendant's capacity to control his or her conduct to conform to the requirements of law.

The following Section provides an analysis - per condition - of the insanity provision in the ICC Statute. 
(a) The defendant must have suffered from a mental disease or defect

The disease or defect that the defendant is suffering from must be mental. This raises questions as to the definition of the adjective mental, the definition of and the difference between disease and defect and the nature of the diseases and defects which are covered by article 31(1)(a). However, the provision was deliberately kept broad and vague, because the label given to the mental condition is not crucial, but rather the effects of this condition on the defendant (see sub (b)). ${ }^{389}$

The broad definition of mental incapacity is, according to several authors, restricted by the word suffers, which suggests a more permanent mental condition. Momentary mental disturbances could thus be excluded by article 31(1)(a). ${ }^{390}$ However, more temporary defects could still be covered by other complete defenses, such as duress (article 31(1)(d) of the ICC Statute) and disproportionate self-defense (article 31(1)(c) in conjunction with article 31(2) of the ICC Statute).

(b) The disease or defect destroys:

- The defendant's capacity to appreciate the unlawfulness or nature of his or her conduct; or

- The defendant's capacity to control his or her conduct to conform to the requirements of law.

The disease or defect must have a destructive effect on the defendant's cognitive or volitional abilities. As to the definition of this destruction, different opinions exist. Some authors have interpreted this notion as requiring the absolute absence of cognitive or volitional abilities. From this angle, mere impairment does not suffice. ${ }^{391}$ However, Eser holds that when the cognitive abilities of the defendant are destroyed, his criminal responsibility could equally be destroyed through article 32 (1) (Mistake). ${ }^{392}$ What is more, according to Eser, the requirement of destruction ex article 31 (1)(a) sets an "unrealistic hurdle", for mental disorders usually do not leave mentally ill defendants absolutely incapacitated. For these reasons, Eser (among others) holds that "'destroyed' mental capacities may reside between substantial and absolute impairment of cognitive and/or volitional abilities". 393

Whatever the correct interpretation of article 31(1)(a) may be, when a defendant's mental capacities are substantially destroyed, this does not suffice as a ground for

389 Scaliotti, M., 'Defences before the International Criminal Court: Substantive Grounds for Excluding Criminal Responsibility - Part 2', In: International Criminal Law Review, Vol. 2, 2002, pp. 1-46, p. 27.

390 Eser, A., 2008, p. 874; Knoops, G.J., 2001, p. 114; Sliedregt, E. van, 2012, p. 226 and Werle, G., 2005, p. 159.

391 Cryer, R. et al., 2007, p. 334; Janssen, S., 'Mental Condition Defences in Supranational Criminal Law', In: International Criminal Law Review, Vol. 4, 2004, pp. 83-98, p. 85 and Scaliotti, M., 2002, p. 24.

392 See also: Knoops, G.J., 2001, p. 115.

393 Eser, A., 2008, p. 875. Also referred to in: Ambos, K., 2002, p. 1029. 
excluding criminal responsibility. Rule 145(2)(a)(i) namely provides that "circumstances falling short of constituting grounds of exclusion of criminal responsibility, such as substantially diminished mental capacity" may be taken into account as a mitigating factor. Insanity, within the regimen of the ICC, is thus a complete defense, while diminished responsibility is only a factor in mitigation.

As pointed out before, the ICC insanity provision bears both a cognitive and a volitional test. ${ }^{394}$ Criminal responsibility will only be excluded if the defendant's disease or defect has destroyed:

- his capacity to appreciate the unlawfulness of his conduct (cognitive), or

- his capacity to appreciate the nature of his conduct (cognitive), or

- his capacity to control his conduct to conform to the requirements of law (volitional).

Criminal responsibility, thus, will only be negated under article 31(1)(a) if - due to his mental condition - the defendant does not know what he is doing, does not know that his act is unlawful, or is unable to control his act.

Objective/subjective

Like the ICTY requirements for insanity, ICC requirements demand a subjective test, for the defendant's state of mind is the object of investigation.

\subsection{Expert examination and legal consequences}

\section{EXPERT EXAMINATION}

The legal foundation for a psychiatric or psychological examination can be found in Rule 135 (Medical examination of the accused):

1. The Trial Chamber may, for the purpose of discharging its obligations under article 64, paragraph 8 (a), or for any other reasons, or at the request of a party, order a medical, psychiatric or psychological examination of the accused, under the conditions set forth in rule 113.

2. The Trial Chamber shall place its reasons for any such order on the record.

3. The Trial Chamber shall appoint one or more experts from the list of experts approved by the Registrar, or an expert approved by the Trial Chamber at the $[\cdots]$ request of a party.

Rule 113 (Collection of information regarding the state of health of the person concerned) provides:

394 Cryer, R. et al., 2007, p. 334 and Sliedregt, E. van, 2012, p. 225. 
1. The Pre-Trial Chamber may, on its own initiative or at the request of the Prosecutor, the person concerned or his or her counsel, order that a person having the rights in article 55, paragraph 2, be given a medical, psychological or psychiatric examination. In making its determination, the Pre-Trial Chamber shall consider the nature and purpose of the examination and whether the person consents to the examination.

2. The Pre-Trial Chamber shall appoint one or more experts from the list of experts approved by the Registrar, or an expert approved by the Pre-Trial Chamber at the request of a party.

The (Pre-)Trial Chamber can thus, at the request of a party or proprio motu (for example to discharge its obligations under article 64(8)(a)), ${ }^{395}$ order a psychological or psychiatric examination of the accused. This examination may be done either by an expert from the lists of experts approved by the Registrar or by an expert approved by the (Pre-)Trial Chamber at the request of a party. The Trial Chamber's reasons for such an order must be placed on the record. The examination can only be performed on persons "having the rights in article 55, paragraph 2", which means that this person must have the legal status of an accused. When making the decision on the examination, the Pre-Trial Chamber must consider (a) the nature and purpose of the examination and (b) whether the defendant consents to the examination.

The ICC Statute and Rules also bear rules on experts in general, which are probably also applicable to psychological and psychiatric experts. ${ }^{396}$

\section{LEGAL CONSEQUENCES}

As to the legal consequences of a successful appeal to insanity in the ICC Statute, the title of article 31 says it all: "Grounds for excluding criminal responsibility". In other words, the defendant must be acquitted (article 81 ICC Statute). Neither the ICC Statute, nor its Rules of Procedure and Evidence address the situation of the accused who is found to be insane under article 31(1)(a). Consequently a mentally disturbed perpetrator seems to be free to go and is not committed to some sort of mental institution or treatment facility. ${ }^{397}$

\footnotetext{
395 Article 64(8)(a) of the ICC Statute demands the Trial Chamber to satisfy itself that the accused understands the nature of the charges against him.

396 See for example: article 48(4) (on the privileges and immunities of expert witnesses), article 100(1)(a) and (d) (on the costs of expert witnesses), article 56(2)(c) (rules in the Pre-Trial phase), article 93(1)(b) (on cooperation with the court) and Rule 191 (assurance to expert witness).

397 Cryer, R. et al., 2007, pp. 334/335; Gilbert, J., 'Justice not Revenge: The International Criminal Court and the 'Grounds to Exclude Criminal Responsibility' - Defences or Negation of Criminality?', In: The International Journal of Human Rights, Vol. 10, Issue 2, 2006, pp. 143160, p. 146; Janssen, S., 2004, p. 85 and Ohlin, J., 'Mental Disease', In: The Oxford Companion to International Criminal Justice, Cassese, A. (ed.), Oxford University Press, 2009, pp. 415/416, p. 415.
} 
Chapter V

\section{Analysis of InSANity}

\subsection{Applicability}

The IMT, the ICTY and the ICC have recognized the insanity defense. The first two tribunals have rejected the insanity defense. The IMT in casu without grounds. The ICTY first a priori, for the appeal to insanity was treated as a possible mitigating factor (in Erdemović). However, later, in Mucić et al. insanity was recognized as a complete defense in principle. The ICTR refers to the insanity defense in its rules, but the defense has not come up in its case law. The ICC Statute explicitly recognizes the insanity defense.

Both Mucic et al. and the ICC Rules have recognized diminished responsibility as a mitigating factor. However, the ICTY and ICC employ slightly different definitions of this legal figure. The ICTY holds that in case of diminished responsibility the volitional abilities (control) of the perpetrator are impaired. The ICC does not define the affected capacities of the defendant in case of diminished responsibility but, as opposed to the ICTY, incorporates the volitional abilities in its insanity definition. After Mucić et al. diminished responsibility has been frequently brought up as a mitigating factor at the ICTY. With no success, however. ${ }^{398}$

\subsection{Scope}

Both ICTY case law and the ICC Statute have provided a definition of the insanity defense. These definitions have the following common denominators:

\section{(a) The defendant must have had an abnormal mental condition}

The nature of this mental condition is probably not crucial, but rather its effect on the perpetrator (see sub (c)). ICC commentators have noticed that the wording of the ICC provision suggests that the mental condition must be rather permanent than temporary. The wording of the ICTY definition does not imply such an explanation. Also, in Erdemović, reference was made to a "temporary mental disorder".

\section{(b) This abnormal condition must have been present when the crime is committed}

(c) The abnormal condition causes the defendant to either:

- not know what he is doing;

- not know that he is doing something wrong/unlawful. 
The ICC definition demands that the cognitive abilities of the perpetrator are destroyed. The ICTY criteria are formulated less strongly, but probably amount to the same standard.

The most remarkable difference between the ICTY and the ICC definition of insanity is that the ICC definition mentions a third effect of the abnormal condition on the defendant, namely that this condition affects the defendants "capacity to control his or her conduct to conform to the requirements of law". Note that the ICTY Appeals Chamber in Mucić et al. refers to the ICC definition of insanity as a defense "akin to" insanity. This could imply that the ICTY Appeals Chamber does not think that the ICC definition is reflective of international law at this point. As a consequence, it is debatable whether the control element is or should be part of the insanity definition in international criminal law. Also remarkable is that this control element is part of the ICTY definition of diminished responsibility.

\section{Objective/subjective}

The requirements for insanity seem to demand a subjective test, for the crucial question is whether the subjective state of mind of the defendant exonerates him from criminal liability.

\subsection{Categorization}

Chapter II has demonstrated that international criminal theory distinguishes between three different types of complete defenses. The question answered in this subsection is whether insanity in international criminal law matches any of these three types. More precisely: what is the effect of the fulfillment of requirements (a)(c) on the offense charged?

When conditions (a)-(c) are met, this would excuse the crime charged. The insanity of the perpetrator does not make him choose objectively the best course of action. Rather, the act of the insane perpetrator is still wrongful. The blameworthiness of the defendant is, however, negated, because he had no ability to choose (or no freedom of will or knowledge of law) due to his lack of mental capacity. Being an excuse, insanity can be qualified as:

\begin{tabular}{|l|l|l|l|}
\hline Defense & Effect & $\begin{array}{l}\text { Justification or } \\
\text { excuse? }\end{array}$ & Affirmative or not? \\
\hline No blameworthiness & $\begin{array}{l}\text { Defense negates } \\
\text { blameworthiness }\end{array}$ & Excuse & Affirmative \\
\hline $\begin{array}{l}\text { No definitional } \\
\text { subjective element }\end{array}$ & $\begin{array}{l}\text { Defense negates } \\
\text { definitional subjective } \\
\text { element }\end{array}$ & Justification or excuse & Not affirmative \\
\hline
\end{tabular}


If insanity qualifies as defense = no blameworthiness, this defense negates the blameworthiness of the act. Consequently, the defense is affirmative.

The other classification of insanity as an excuse refers to the situation where blameworthiness is embedded in the definitional subjective element, as is the case with negligence. Consequently, when the perpetrator lacks blameworthiness, the definitional subjective element cannot be established.

Interestingly, in case of insanity, another scenario under the qualification defense = no definitional subjective element, may also be envisaged. For one can imagine that in some cases, depending on the mental disease at issue, the intent for the crime charged cannot be established. This would almost always be the case when the defect affects the volitional abilities of the defendant (for the defendant did not intend to hurt the victim, but he could not control his impulses), and in some cases when the defect affects his cognitive abilities (for example when the defendant has hallucinations, causing him to intend to kill a giant snake, while in fact he is killing a human being). Note that in the first case some may even argue that the actus reus cannot be established by lack of a voluntary act. ${ }^{399}$ The difference between the two distinctive scenarios under the qualification defense $=n o$ definitional subjective element is that in the first case the definitional subjective element cannot be established, because the blameworthiness of the actor cannot be established, while in the second case the blameworthiness of the defendant is irrelevant to the negation of intent. In other words, in the first case the presence of insanity has a normative effect, while in the second case this presence has a psychological effect. ${ }^{400}$ In both cases the defense affects the prosecution's case and is thus not affirmative. It is, however, debatable whether a psychological claim that negates the mental element is truly a complete defense, when this claim does not coincide with the absence of blameworthiness.

\subsection{Expert examination and legal consequences}

\subsubsection{Expert examination}

At the earlier ad hoc tribunals psychological or psychiatric expert examination was not provided for in the statute or Rules. During the proceedings in Nuremberg, Hess's fitness to stand trial was investigated, but information related to his mental health at the moment of the crime was ignored. The first reference to an examination of mental capacities at the moment of the crime can be found in Erdemovic. A few months later, psychological (and psychiatric) expert examination was formalized in Rule 74bis of the ICTY Rules. A similar regulation can be found in the Rules of the ICTR. Rule 74bis allows the Trial Chamber, proprio motu or at the request of a party, to order a psychiatric or psychological examination of the accused. Next, the

399 See Chapter II, Section 2.1.1.

400 See Chapter II, Section 2.1.2 for the distinction between psychological and normative guilt. 
Registrar entrusts this task to one or several experts whose names appear on a list previously drawn up by the Registry. The Trial Chamber may also order an examination by an expert that does not appear on this list. A similar regulation can be found in Rule 113 and 135 of the ICC Rules. However, these rules add three more details: (a) that (in the Trial phase) "the Trial Chamber shall place its reasons for any such order on the record", (b) that the psychological or psychiatric examination can only be performed on a person who has the status of an accused and (c) that the (Pre-)Trial Chamber must consider (i) the nature and purpose of the examination and (ii) whether the defendant consents to the examination.

Although the rules in relation to the psychological or psychiatric expert exam are nowadays formalized, it is remarkable that the ICTR in Mucić et al. stresses that these exams are tricky business, because of the distance in time between crime and assessment and the lack of objective sources for such an assessment (in this case the defendant was the only source).

\subsubsection{Legal consequences}

None of the institutions subject to this research has a clear legal framework, applicable to the defendant whose acquittal is based upon a successful insanity plea. Consequently, the acquitted but insane perpetrator appears to go free.

\subsection{Conclusion on insanity}

Although the legal figure of insanity has been recognized - either implicitly or explicitly - by most of the institutions subject to this research, insanity was never accepted as a complete defense. The requirements of the insanity defense produced by the ICTY and ICC are fairly clear. However, three important matters remain unresolved:

1. What is the difference between insanity and diminished responsibility? (Particularly with respect to the volitional (control) element and the destruction or impairment of mental capacities.)

2. Should temporal mental incapacities also fall within the scope of the insanity definition?

3. What is the policy in relation to the acquitted insane?

\subsection{Preview Part III}

Part III of this thesis demonstrates that the difference between insanity and diminished responsibility is that while they could both cover the cognitive and the volitional prong of the insanity defense, insanity is a complete defense only applicable in case of destruction of mental capacities, while diminished 
responsibility is a mitigating factor applicable in case of impaired mental capacities. What is more, temporal mental incapacities could also fall within the scope of the insanity definition. Finally, I recommend that the ICC prioritizes the development of a clear and reasonable policy to cope with not only the acquitted insane, but also perpetrators suffering from diminished responsibility. 


\section{Chapter VI \\ INTOXICATION}

\section{INTRODUCTION}

The defense of intoxication is brought up when a defendant is intoxicated - e.g. by alcohol or drugs - at the moment he commits a crime. For example, A hits B. However, at the moment of the attack $\mathrm{A}$ is under the influence of a hallucinatory drug. Because of this drug $\mathrm{A}$ thinks that $\mathrm{B}$ is a danger that he must eliminate. Consequently, A cannot be convicted for assault.

Intoxication has been discussed at the ICTY (as a mitigating factor) and ICTR. The defense can also be found in article 31(1)(b) of the ICC Statute.

Many national legal systems tend to distinguish between voluntary and involuntary intoxication. In several systems, involuntary intoxication is a complete defense, while voluntary intoxication is not. ${ }^{401}$ Apart from answering the questions addressed in the introduction to this Part, this Chapter also investigates whether international criminal law distinguishes between voluntary and involuntary intoxication, and if it does, how this distinction is defined and whether this distinction has consequences for the criminal responsibility of the defendant. The conclusion to this Chapter demonstrates that international criminal law neither displays clear concepts of voluntary and involuntary intoxication nor contains general rules on which types of intoxication are exempt from criminal liability.

\section{InTOXICATION AT THE ICTY}

\subsection{Relevant passages}

At the ICTY, intoxication has never been pleaded as a complete defense. Below I discuss two cases in which intoxication was brought up as a mitigating factor, because these cases contain information on the possibility of intoxication as a complete defense.

In Prosecutor v. Milan Simic the defense argues that at the time the crimes charged were committed Simić "was intoxicated and in an emotional state due to the death of his best friend" 402 The Tribunal rejects this argument and states, "voluntary intoxication is not a mitigating factor to the crimes committed 403 by Milan Simić". 404

\footnotetext{
401 Sliedregt, E. van, 2012, pp. 228-231.

402 ICTY, Prosecutor v. Milan Simić, Trial Chamber, 17 October 2002, par. 73.

403 I.e. torture (crimes against humanity, article 5 of the ICTY Statute).

404 ICTY, Prosecutor v. Milan Simić, Trial Chamber, 17 October 2002, par. 74.
} 
In Prosecutor v. Kvočka et al. defendant Zoran Žigić also brings up voluntary intoxication as a mitigating factor. ${ }^{405}$ In relation to this argument, the Trial Chamber holds that "while a state of intoxication could constitute a mitigating circumstance if it is forced or coerced, the Trial Chamber cannot accept Žigićs contention that an intentionally procured diminished mental state could result in a mitigated sentence". ${ }^{406}$ It adds: "particularly in contexts where violence is the norm and weapons are carried, intentionally consuming drugs or alcohol constitutes an aggravating rather than a mitigating factor". ${ }^{407}$ Finally, the Trial Chamber holds that it "rejects Žigić's claim that intoxication should be a mitigating factor and instead finds it an aggravating factor" (but declines to treat it as such because Žigić's voluntary intoxication was not raised by the prosecution). ${ }^{408}$

On Appeal Žigić argues that his intoxication was in fact involuntary. The pain from an injury and his previous addiction to alcohol "caused" his extreme consumption of liquor. ${ }^{409}$ The Appeals Chamber rejects this argument by stating that Žigić has not proved, on the balance of probabilities, that his intoxication was in fact involuntary. The Appeals Chamber substantiates its finding by holding that:

Žigić did not specify the particular incidents at which he had been under the influence of alcohol either at trial or in his Appeal Brief. He argues neither that he was permanently under the influence of alcohol, nor that his mental powers were impaired by its chronic abuse. Further, the Appeals Chamber notes that he has not presented any evidence to show that his intoxication was in fact involuntary. Žigić's has not, therefore, succeeded in discharging his burden. ${ }^{410}$

\subsection{Analysis of ICTY case law on intoxication}

The ICTY has rejected intoxication twice as a mitigating factor. In Prosecutor $v$. Simic the factor is a priori rejected, for the Trial Chamber holds that voluntary intoxication is not a mitigating factor in case of torture. In Prosecutor v. Kvočka et al., the Trial Chamber also a priori rejects intoxication when it is "intentionally procured" (and holds it is an aggravating circumstance instead). However, it acknowledges that intoxication can be a mitigating factor when it is "forced or coerced". The Appeals Chamber in Prosecutor v. Kvočka et al. rejects involuntary intoxication in casu, for the defendant has not proved his claim, and thus implicitly recognizes involuntary intoxication as a mitigating factor.

\footnotetext{
405 ICTY, Prosecutor v. Kvočka et al., Trial Chamber, 2 November 2001, par. 616.

406 ICTY, Prosecutor v. Kvočka et al., Trial Chamber, 2 November 2001, par. 706.

407 ICTY, Prosecutor v. Kvočka et al., Trial Chamber, 2 November 2001, par. 706.

408 ICTY, Prosecutor v. Kvočka et al., Trial Chamber, 2 November 2001, par. 748.

409 ICTY, Prosecutor v. Kvočka et al., Appeals Chamber, 28 February 2005, par. 708.

410 ICTY, Prosecutor v. Kvočka et al., Appeals Chamber, 28 February 2005, par. 707/708.
} 
Based on these judgments, the ICTY seems to a priori reject "intentionally procured" intoxication and, at least in case of torture, "voluntary intoxication". Furthermore it holds that intentionally procured intoxication is an aggravating circumstance. However, "intoxication which is forced or coerced" as well as "involuntary intoxication" could be mitigating factors.

Since intentionally procured or (in relation to torture) voluntary intoxication can never be a mitigating circumstance, one can reason that these arguments will $a$ fortiori never be accepted as a complete defense and are thus a priori excluded. Whether forced, coerced or otherwise involuntary, intoxication can - next to a mitigating circumstance - also be a complete defense, remains uncertain since the ICTY never expressed its view on this issue. However, ICTY case law leaves room for this possibility.

\section{INTOXICATION AT THE ICTR}

\subsection{Prosecutor v. Kamuhanda}

\subsubsection{Relevant passages}

The ICTR has never discussed intoxication as a result of an appeal, but mentions this legal figure as a possible defense in Prosecutor $v$. Kamuhanda when discussing defenses in general:

In general, a defence comprises grounds excluding criminal responsibility although the accused has fulfilled the legal elements of a criminal offense. [...] In the case of a defence, the criminal conduct has already been established and is not necessarily disputed by the accused who argues that due to specific circumstances he or she is not criminally responsible, e.g. due to a situation of duress or intoxication. ${ }^{411}$

\subsubsection{Analysis}

By mentioning intoxication as an example of a complete defense, the Appeals Chamber in Prosecutor v. Kamuhanda implicitly recognizes intoxication as a complete defense in general. However, the Appeals Chamber refrains from mentioning criteria or specifying voluntary and involuntary intoxication.

Apart from the reference to intoxication, this fragment is remarkable because the Appeals Chamber defines a complete defense as a "ground excluding criminal responsibility although the accused has fulfilled the legal elements of a criminal offense" and as the situation where "the criminal conduct has already been established and is not necessarily disputed by the accused who argues that due to

411 ICTR, Prosecutor v. Kamuhanda, Appeals Chamber, 19 September 2005, par. 167. 
specific circumstances he or she is not criminally responsible", thereby suggesting that complete defenses are always affirmative.

\section{INTOXICATION AT THE ICC}

\subsection{Applicability}

Intoxication is recognized by the ICC in article 31 paragraph (1)(b) and heading (Grounds for excluding criminal responsibility) of the ICC Statute:

1. In addition to other grounds for excluding criminal responsibility provided for in this Statute, a person shall not be criminally responsible if, at the time of that [...] person's conduct:

(b) The person is in a state of intoxication that destroys that person's capacity to appreciate the unlawfulness or nature of his or her conduct, or capacity to control his or her conduct to conform to the requirements of law, unless the person has become voluntarily intoxicated under such circumstances that the person knew, or disregarded the risk, that, as a result of the intoxication, he or she was likely to engage in conduct constituting a crime within the jurisdiction of the Court;

\subsection{Scope}

Paragraph (1)(b) of article 31 bears several conditions for a successful appeal to intoxication:

a. The defendant is in a state of intoxication;

b. This intoxication destroys:

- the defendant's capacity to appreciate the unlawfulness or nature of his or her conduct; or

- the defendant's capacity to control his or her conduct to conform to the requirements of law;

c. The defendant did not become voluntarily intoxicated under such circumstances that he knew, or disregarded the risk, that, as a result of the intoxication, he was likely to engage in conduct constituting a crime within the jurisdiction of the Court.

During the drafting of the ICC Statute, intoxication was one of the most controversial complete defenses. This controversy was caused by the different cultural attitudes in relation to alcohol and drug (ab)use. While some countries saw 
intoxication as a complete defense or a mitigating factor other (mostly Arab) countries considered intoxication an aggravating factor. ${ }^{412}$ In the end a definition was agreed upon, accompanied by a footnote stating "voluntary intoxication as a ground for excluding criminal responsibility would generally not apply in cases of genocide or crimes against humanity, but might apply to isolated acts constituting war crimes". 413 The present Section provides an analysis - per condition - of the defense of intoxication in the ICC Statute.

\section{(a) The defendant is in a state of intoxication}

The first two conditions ((a) and (b)) of the defense are similar to the insanity defense: a defective mental state (a) destroys either the cognitive or the volitional capacity of the defendant (b). Difference is, however, that in case of intoxication, the destruction of the defendant's capacities is not caused by a "mental disease or defect" but by a "state of intoxication".

As to the specific substances that can produce such a state of intoxication, the Statute is not specific. ${ }^{414}$ Commentators hold that the intoxication must at least be caused by consumption of an exogenous substance with the effect of intoxication, ${ }^{415}$ such as alcohol or (prescription) drugs.

\section{(b) This intoxication destroys:}

- the defendant's capacity to appreciate the unlawfulness or nature of his or her conduct; or

- the defendant's capacity to control his or her conduct to conform to the requirements of law.

The state of intoxication must have a destructive effect on the defendant's cognitive or volitional abilities. A merely diminished capacity is not sufficient for this complete defense. ${ }^{416}$ However, this requirement could be nuanced in the same way that ICC commentators have done in case of insanity. ${ }^{417}$

As pointed out above, the ICC intoxication provision bears both a cognitive and a volitional test. Criminal responsibility will only be excluded if the defendant's state of intoxication has destroyed:

\footnotetext{
412 About the controversy around (voluntary) intoxication defense in relation to the drafting of the ICC Statute, see: Ambos, K., 2002, p. 1030; Cryer, R. et al., 2007, p. 335; Eser, A., 2008, p. 876/877; Scaliotti, M., 2002, p. 33-36 and Werle, G., 2005, pp. 161/162.

413 Ambos, K., 2002, p. 1030.

414 The first drafts of the provision required the intoxication to be caused by alcohol and drugs, however, the Statute eventually opened the defense to other means. See: Sliedregt, E. van, 2012, p. 229.

415 Eser, A., 2008, p. 877.

416 Khan, K. and Dixon, R. (eds.), Archbold International Criminal Courts: Practice, Procedure and Evidence, Sweet and Maxwell, Third Edition, London, 2009, p. 1280; Cryer, R. et al., 2007, p. 336 and Werle, G., 2005, p. 161.

417 See Chapter V, Section 5 (Insanity at the ICC).
} 
- his capacity to appreciate the unlawfulness of his conduct (cognitive), or

- his capacity to appreciate the nature of his conduct (cognitive), or

- his capacity to control his conduct to conform to the requirements of law (volitional).

Criminal responsibility, thus, will only be negated under article 31(1)(b) if the defendant does not know what he is doing, does not know that his act is unlawful, or is unable to control his act.

(c) The defendant did not become voluntarily intoxicated under such circumstances that he knew, or disregarded the risk, that, as a result of the intoxication, he was likely to engage in conduct constituting a crime within the jurisdiction of the Court.

The purpose of this third requirement is to limit the scope of voluntary intoxication in case the perpetrator gets drunk on purpose, with the objective to commit a crime in a state of non-responsibility, and then later to invoke this state of non-responsibility as a defense. In literature this situation is referred to as actio libera in causa, culpa in causa or Dutch courage. ${ }^{418}$ On the other hand, this third requirement leaves an appeal to voluntary intoxication open in cases where the defendant voluntarily got intoxicated but could not have anticipated the negative side effects (i.e. criminal behavior) ${ }^{419}$ In literature some controversy exists on whether the ICC voluntary intoxication clause is reflective of general legal principles. Some authors hold it is, ${ }^{420}$ while others hold it is not. ${ }^{421}$

The appeal to voluntary intoxication is not only inaccessible to the defendant who knew that he was likely to engage in a crime, but also to the defendant who disregarded that risk. The provision thus extends the concept of Dutch courage beyond intent to engage in criminal behavior. Ambos holds that the latter requirement conflicts with the rest of the Rome Statute that "unless otherwise provided" only allows intent and knowledge as required mental elements (article 30). ${ }^{422}$ Through article 31(1)(b), a perpetrator who does not possess the required mental element at the moment of the crime, can still be held responsible if he committed a crime negligently. This way, negligence enters through the back door. Eser, however, does not think that the test ex article 31(1)(b) is one of negligence. According to Eser, the test resides between negligence and dolus eventualis, for the crucial issue is whether the defendant was aware of the risk that he would engage in the prohibited conduct (it is irrelevant how he felt about this risk, which is the distinguishing factor between negligence and dolus eventualis). ${ }^{423}$

\footnotetext{
418 Ambos, K., 2002, p. 1030; Cryer, R. et al., 2007, p. 336; Eser, A., 2008, p. 877; Scaliotti, M., 2002, p. 36 and Werle, G., 2005, p. 162.

Eser, A., 2008, p. 878.

Bantekas, I. and Nash, S., 2007, p. 67.

Cryer, R., 2005, p. 305 and Werle, G., 2005, p. 161.

Ambos, K., 2002, p. 1031.

Eser, A., 2008, p. 877. See also: Sliedregt, E. van, 2012, p. 230. For the difference between dolus eventualis and negligence see Chapter II, Section 2.
} 
Either way, the test ex article 31(1)(b) extends the required mental element beyond the scope of article 30.

A complicating factor is that the prohibited "conduct" ex article 31(1)(b) is not phrased as a regular crime but as "a crime within the jurisdiction of the court". This means that when a soldier gets drunk while being aware that he - once he is intoxicated - might commit a murder, he could invoke intoxication as a defense as long as he is not aware of the genocidal or anti-humanitarian character. ${ }^{424}$ On the other hand, it is not entirely clear whether the word "conduct" includes the relevant circumstantial elements (such as "armed conflict" "widespread or systematic" etc.). ${ }^{425}$ What is more, the footnote adhered to article 31(1)(b) will make a successful appeal to intoxication in case of genocide and crimes against humanity very unlikely.

In sum, intoxication can thus be a defense if the defendant was involuntarily intoxicated in such a way that he loses either his cognitive or his volitional abilities or when he was voluntarily intoxicated - to the same degree - but not aware of the risk that he would engage in prohibited conduct. The criteria for involuntary intoxication demand a subjective test, for the perpetrator's state of mind is the object of investigation. However, in case of voluntary intoxication this test is - apart from demanding a subjective test - objectivised by also excluding the defense in case of risk-taking.

\section{Analysis of Intoxication}

\subsection{Applicability}

The defense of intoxication is gradually gaining ground. At the first ad hoc tribunals the defense has not come up. However, the ICTY discussed intoxication as a mitigating factor. Although this Tribunal seems to a priori reject several forms of intoxication (when intentionally procured or voluntary intoxication in case of torture) in mitigation (thus also as a complete defense), ICTY case law leaves an opening in case intoxication is forced or coerced or otherwise involuntary. The ICTR implicitly recognizes intoxication as a complete defense, while the ICC does so explicitly, adding some reservations however, in the form of a footnote. Intoxication could be a mitigating factor under Rule 145(2)(a)(i) of the ICC RPE.

\subsection{Scope}

Since intoxication was never discussed as a complete defense, the only information on its conditions can be derived from the ICC Statute. These conditions have been discussed in the previous Section.

\footnotetext{
424 Eser, A., 2008, p. 878.

425 Cryer, R. et al., 2007, p. 336.
} 


\subsection{Voluntary and involuntary intoxication}

The introduction to this Section brings up the questions (a) whether international criminal law distinguishes between voluntary and involuntary intoxication, and if it does, (b) whether this distinction has consequences for the criminal responsibility of the defendant and (c) how this distinction is defined. When looking at the different sources from international courts that provide information on intoxication, one must conclude that there is no clear-cut dividing line between voluntary and involuntary intoxication. Various sources introduce different species of intoxication. The ICTY speaks, on the one hand, of voluntary intoxication (in case of torture) and intentionally procured intoxication (in general), which are not mitigating factors (and a fortiori no complete defense either), and on the other hand of forced or coerced intoxication and involuntary intoxication which can be mitigating factors (and possibly complete defenses). In neither case does the ICTY define the concept of (in)voluntary intoxication. The ICTR only refers to intoxication in general, without definition or specification. The ICC, however, does distinguish between voluntary and involuntary intoxication and provides a more detailed definition. The different sources of international criminal law, thus, establish the following picture:

\begin{tabular}{|c|c|c|}
\hline Court & (Possible)* complete defense & Not a complete defense \\
\hline ICTY & - Involuntary intoxication & $\begin{array}{l}\text { - Intentionally procured intoxication } \\
\text { - Voluntary intoxication in case of } \\
\text { torture }\end{array}$ \\
\hline ICTR & Intoxication & No information \\
\hline ICC & $\begin{array}{l}\text { - Involuntary intoxication, when } \\
\text { cognitive or volitional abilities are } \\
\text { destroyed } \\
\text { - Voluntary intoxication when cognitive } \\
\text { or volitional abilities are destroyed } \\
\text { and the defendant did not know or did } \\
\text { not disregard risk of criminal conduct }\end{array}$ & $\begin{array}{l}\text { - Voluntary and involuntary } \\
\text { intoxication, when cognitive or } \\
\text { volitional abilities are not destroyed } \\
\text { - Voluntary intoxication when cognitive } \\
\text { and volitional abilities are destroyed } \\
\text { but the defendant knew, or disregarded } \\
\text { risk, of possible criminal behavior }\end{array}$ \\
\hline
\end{tabular}

* The word "possible" is put in brackets, because the ICTY has only expressed its opinion on intoxication as a mitigating factor and not as a complete defense. Nevertheless, for reasons mentioned in Section 2.1, its case law could equally apply to complete defenses.

The picture shows that international criminal law occasionally distinguishes between voluntary and involuntary intoxication (question (a)). According to ICTY case law involuntary intoxication can be a mitigating factor, whereas voluntary intoxication in case of torture is not. However, the relevant ICC provision demonstrates that involuntary intoxication can be a complete defense when the cognitive or volitional abilities of the defendant are destroyed, while voluntary intoxication can only be a complete defense under the same circumstances, in case the defendant did not know or did not disregard the risk of criminal conduct. Since voluntary and involuntary intoxication can both be a 
ground for excluding criminal responsibility, the distinction does not seem to have direct consequences on the criminal responsibility of a defendant (question (b)). However, voluntary intoxication does demand an extra test as to the prior fault of the defendant.

In relation to the definitions of voluntary and involuntary intoxication (question (c)) a few issues are important. Firstly, do these concepts refer to the distinction coerced/not coerced or the distinction intentionally/not intentionally? This is a crucial difference, for a coerced intoxication can still be intentional (e.g. the coerced defendant intended to drink/get drunk because he did not want to be beaten) but an intentional intoxication is generally not coerced.

Another problem with the distinction voluntary/involuntary is that it is not clear whether this qualification refers to the taking of the substance or the state of intoxication itself. For example, a person voluntarily takes prescription drugs while ignorant of its intoxicating side effects. Consequently he gets intoxicated. Would this qualify as a voluntary or as an involuntary intoxication? If voluntary intoxication refers to the taking of the substance, this could qualify as voluntary intoxication. However, if voluntary intoxication refers to the state of intoxication this could qualify as involuntary intoxication, when the defendant did not intend to get intoxicated.

Even more problematic is the categorization of intoxication in case of a spiked drink. Is it voluntary because the defendant intended to take the drink? Is it involuntary, because the defendant did not intend to take a spiked drink? Or is it involuntary, because the defendant did not intend to get intoxicated? The ICTY does not define voluntariness in the above-mentioned terms. The ICC provision is not clear on the definitional distinction between voluntary and involuntary intoxication either. Finally, it is not clear how the ICTY case law should be interpreted in the light of the ICC provision. For example: does voluntary intoxication in case of torture always inculpate, or only when the ICC criteria for voluntary intoxication have not been met?

\subsection{Categorization}

Chapter II has demonstrated that international criminal theory distinguishes between three different types of complete defenses. The question answered in this subsection is whether intoxication in international criminal law matches any of these three types. More precisely: what is the effect of the fulfillment of the requirements (a)-(c) mentioned in Section 4.2 on the offense charged?

When conditions (a)-(c) are met, this would excuse the crime charged. The intoxication of the perpetrator does not make him choose objectively the best course of action. Rather, the act of the intoxicated perpetrator is still wrongful. The blameworthiness of the defendant is, however, negated, because he did not have the ability to choose, did what any reasonable person would have done, lacked freedom 
of will, mental capacity or knowledge of law. Being an excuse, intoxication can be qualified as:

\begin{tabular}{|l|l|l|l|}
\hline Defense & Effect & $\begin{array}{l}\text { Justification or } \\
\text { excuse? }\end{array}$ & Affirmative or not? \\
\hline No blameworthiness & $\begin{array}{l}\text { Defense negates } \\
\text { blameworthiness }\end{array}$ & Excuse & Affirmative \\
\hline $\begin{array}{l}\text { No definitional } \\
\text { subjective element }\end{array}$ & $\begin{array}{l}\text { Defense negates } \\
\text { definitional subjective } \\
\text { element }\end{array}$ & Justification or excuse & Not affirmative \\
\hline
\end{tabular}

If intoxication qualifies as defense = no blameworthiness, this defense negates the blameworthiness of the act. Consequently, the defense is affirmative.

The other classification of intoxication as an excuse refers to the situation where blameworthiness is embedded in the definitional subjective element, as is the case with negligence. Consequently, when the perpetrator lacks blameworthiness, the definitional subjective element cannot be established, which would make the defense not affirmative.

As with insanity, in case of intoxication another scenario is possible under the qualification defense $=$ no definitional subjective element. For in some cases, one can imagine that, depending on the mental state of the defendant, the intent for the crime charged cannot be established. This would always be the case when the intoxication affects the volitional abilities of the defendant (for the defendant did not intend to hurt the victim, but he could not control his impulses), and in some cases when the intoxication affects his cognitive abilities (for example when the defendant has taken hallucinatory drugs, causing him to intend to kill a giant snake, while in fact he is killing a human being). Note that in the first case some may even argue that the actus reus cannot be established by lack of a voluntary act. $^{426}$ The difference between the two distinctive scenario's under the qualification defense $=$ no definitional subjective element is that in the first case the definitional subjective element cannot be established, because the blameworthiness of the actor is absent, while in the second case the blameworthiness of the defendant is irrelevant to the negation of intent. In other words, in the first case the presence of intoxication has a normative effect, whereas in the second case this presence has a psychological effect. ${ }^{427}$ In both cases the defense affects the prosecution's case and is thus not affirmative. It is, however, debatable whether a psychological claim that negates the mental element is truly a complete defense, when this claim does not coincide with the absence of blameworthiness. 


\subsection{Conclusion on intoxication}

Although the defense of intoxication has gradually gained more ground, it has rarely been discussed in international criminal case law. The only existing criteria for the defense of intoxication can be found in the ICC Statute. However, these criteria (mainly the part that allows voluntary intoxication as a complete defense) are controversial for their lack of foundation on general legal principles. All in all, the defense of intoxication in international criminal law needs some work. Main points of focus are:

1. The distinction between voluntary and involuntary intoxication: is it an adequate tool to determine the criminal responsibility of the defendant?

2. If it is, how should these concepts be defined?

3. And, if it is, can voluntary intoxication be a complete defense?

4. If it is not: what should the defense of intoxication look like?

\subsection{Preview Part III}

Part III of this thesis demonstrates that the distinction voluntary/involuntary intoxication must be deleted from the Rome Statute. As a consequence the questions (2) and (3) - distinguishing between voluntary and involuntary intoxication - are no longer relevant. A new intoxication provision is proposed, combining insanity and intoxication. The essence of this provision is that it exonerates the defendant, who, at the moment of the crime a) had no other reasonable option and b) did not make a prior fault. 



\section{Chapter VII \\ MistaKe}

\section{INTRODUCTION}

Mistake is a defense where the defendant is exonerated from criminal liability because, at the moment he committed the crime, his perception of the world did not correspond with reality. For example: X shoots Z, because he mistakes him for a deer. Therefore he cannot be convicted for murder. Mistake has been discussed at the IMT, ICTY and ICC. The defense is also put down in article 32 of the ICC Statute.

Traditionally, a distinction exists between mistake of fact and mistake of law. The first refers to a wrong perception of facts, while the second refers to a wrong perception of the law. The previous example refers to a mistake of fact. However, in case $\mathrm{X}$ shoots a deer, because he intends to do so, but is ignorant of a law prohibiting the killing of wildlife, this would amount to a mistake of law. Mistake of law is generally not a ground for excluding criminal responsibility (ignorantia legis non excusat). This is not surprising. Criminal law would have no purpose if a defendant could always escape punishment by claiming that he "did not know he was not allowed to do that".

Apart from addressing the research questions submitted in the introduction to this Part, this Chapter also investigates whether the distinction mistake of fact/ mistake of law exists in international criminal law. The conclusion of this Chapter demonstrates that although both types of mistake have been acknowledged since the IMT, the ICC was the first court to formalize this distinction.

\section{Mistake at Nuremberg}

\subsection{Hermann Göring and Erich Raeder: Crimes Against Peace (Mistake of fact)}

\subsubsection{Relevant passages}

In the context of the planning of aggression (article 6(a) IMT Charter), the general part of the IMT Judgment refers to an important meeting in 1937, where Hitler according to Lieutenant Colonel Hossbach, who took notes - revealed his plans to seize Austria and Czechoslovakia, by stating:

"For the improvement of our military-political position, it must be our first aim in every case of entanglement by war to conquer Czechoslovakia and Austria 
simultaneously in order to remove any threat from the flanks in case of a possible advance westwards." 428

However, two of the defendants (Hermann Göring and Erich Raeder) who were present at this meeting deny that they were aware of the fact that an aggressive war was being planned. Göring testifies that:

[...] he did not believe at that time that Hitler actually meant to attack Austria and Czechoslovakia, and that the purpose of the conference was only to put pressure on Von Fritsch to speed up the re-armament of the Army. ${ }^{429}$

Erich Raeder testifies that he did not believe that:

[...] Hitler actually meant war, a conviction, which the Defendant Raeder claims, he held up to 22 August 1939. The basis for this conviction was his hope that Hitler would obtain a "political solution" of Germany's problems. ${ }^{430}$

In the Judgment on Erich Raeder, the Tribunal mentions in relation to this issue that Raeder:

[...] claims Hitler merely wished by this conference to spur the Army to faster rearmament, insists he believed that questions of Austria and Czechoslovakia would settle peacefully, as they were, and points to the new naval treaty with England which had just been signed. He received no orders to speed construction of U-boats, indicating that Hitler was not planning war. ${ }^{431}$

The Tribunal rejects the claims by Raeder and Göring by stating that:

But all of what this means, when examined, is the belief that Germany's position would be so good, and Germany's armed might so overwhelming that the territory desired could be obtained without fighting for it. It must be remembered too that Hitler's declared intention with regard to Austria was actually carried out within a little over four months from the date of the meeting, and within less than a year the first portion of Czechoslovakia was absorbed, and Bohemia and Moravia a few months later. If any doubts existed in the minds of any of his hearers in November 1937, after March 1939 there could no longer be any question that Hitler was in deadly earnest in his decision to resort to war. The Tribunal is satisfied that Lieutenant Colonel Hossbach's account of the meeting is substantially correct, and that those present knew that Austria and Czechoslovakia would be annexed by Germany at the first possible opportunity. ${ }^{432}$

International Military Tribunal (Nuremberg), Judgment and Sentences, 1 October 1946, p. 191. International Military Tribunal (Nuremberg), Judgment and Sentences, 1 October 1946, p. 191. International Military Tribunal (Nuremberg), Judgment and Sentences, 1 October 1946, p. 191. International Military Tribunal (Nuremberg), Judgment and Sentences, 1 October 1946, p. 307. International Military Tribunal (Nuremberg), Judgment and Sentences, 1 October 1946, p. 191. 


\subsubsection{Applicability}

The defense of mistake of fact is not explicitly recognized in this part of the Nuremberg Judgment. However, the defense is implicitly acknowledged: it is rejected because the Tribunal does not believe the defendants were mistaken, thereby implying the legal consequences would be different if they believed them.

The defense is rejected in casu, on its merits. The defendants mention several reasons why they were not aware of the fact that an aggressive war was being planned:

- The belief that the conference was held to speed up the re-armament;

- The belief in a peaceful solution;

- Not believing Hitler really wanted to wage war;

- The fact that a naval treaty with England had just been signed;

- The fact that there was no order to speed up the construction of U-boats.

The Tribunal rejects these arguments and mentions four reasons:

- The points mentioned above do not deny the fact that Germany was planning aggressive war. They merely demonstrate that Germany did not expect to fight (much) when invading certain countries.

- Two aggressive invasions took place within a year after the meeting.

- Although the defendants may have had doubt about Hitler's aggressive intentions in 1937, these intentions must have been obvious to them by March 1939 (when Germany invaded Bohemia and Moravia).

- The Tribunal believes the account by Hossbach on the relevant meeting is correct and consequently that "those present knew that Austria and Czechoslovakia would be annexed by Germany at the first possible opportunity".

The third argument is somewhat odd, for one would think that in assessing whether the defendants planned a crime against peace, it would be relevant whether the defendants were aware of Hitler's aggressive intentions at the moment of the planning and not during the invasion itself (which would be covered by waging a war of aggression, also a crime under article 6(a) of the IMT Charter). In general, the other three arguments of the Tribunal come down to the same conclusion: the Tribunal does not believe that the defendants were mistaken.

\subsubsection{Scope}

Since the defense is rejected because the Tribunal does not believe that the defendants were mistaken, the requirement that can be derived from this Judgment is that the mistake has to be sincere. Consequently, one could argue that the mistake of fact defense is tested subjectively, since the subjective state of mind of the 
defendant is crucial, i.e. whether he sincerely believed that the facts were as he perceived them to be. However, and this might be slightly confusing, this subjective test is determined both by objective and by subjective factors. On the one hand the Tribunal refers to the existence of plans for an aggressive war and the later execution of these plans (objective test) on the other hand the Tribunal asserts that the defendants knew about the plans (subjective test).

\subsection{The occupation of Bohemia and Moravia}

\subsubsection{Relevant passages}

When discussing the occupation of Bohemia and Moravia in the general part of the Judgment, the Tribunal not only touches upon the defense of consent which investigates the state of mind of the victim (discussed in Chapter IV), but also the defense of mistake of law which focuses on the state of mind of the defendant. Several defendants have brought up this defense. ${ }^{433}$ The Tribunal does neither specify these defendants, nor mention the relevant charges. However, since the defense was brought up in relation to the occupation of Bohemia and Moravia, the relevant offense would probably be crimes against peace (article 6 (a) of the IMT Charter). First the Tribunal reiterates the mistake-argument:

[...] one of the arguments frequently presented by the Defense in the present case is that the Defendants were induced to think that their conduct [i.e. the occupation of Bohemia and Moravia, mk], was not in breach of international law by the acquiescence of other powers. ${ }^{434}$

The Tribunal quickly waves this argument aside, and holds that:

The declarations of Great Britain and France showed, at least, that this view could be held no longer. ${ }^{435}$

The relevant declarations are described at the beginning of the paragraph:

Following on the occupation of Bohemia and Moravia by Germany on 15 March 1939, which was a flagrant breach of the Munich Agreement, Great Britain gave an assurance to Poland on 31 March 1939 that in the event of any action which clearly threatened Polish independence, and which the Polish Government accordingly considered it vital to resist with the National Forces, Great Britain would feel itself

\footnotetext{
433 International Military Tribunal (Nuremberg), Judgment and Sentences, 1 October 1946, p. 198. 434 International Military Tribunal (Nuremberg), Judgment and Sentences, 1 October 1946, p. 198. 435 International Military Tribunal (Nuremberg), Judgment and Sentences, 1 October 1946, p. 198.
} 
bound at once to lend Poland all the support in its power. The French government took the same stand. ${ }^{436}$

In relation to the invasion of Bohemia and Moravia the Defense apparently not only argued that other Powers consented to this invasion, but - at least in case of the individual criminal responsibility of Konstantin Von Neurath ${ }^{437}$ - also that this invasion was consented by Emil Hácha, the president of Czechoslovakia. This argument is rejected as well:

Bohemia and Moravia were occupied by military force. Hácha's consent obtained as it was by duress, cannot be considered as justifying the occupation. ${ }^{438}$

\subsubsection{Applicability}

As in the previous case, mistake of law is implicitly recognized in this part of the Nuremberg Judgment by discussing the defense on its merits. In casu the defense is, however, rejected. Reason for this rejection is that the defendants had no ground to think that their conduct was not in violation of international law. Firstly, because the international community did not approve of their actions. This lack of approval is, according to the Tribunal, demonstrated by the fact that Great Britain and France declared to resist against a future invasion of Poland. This argument (as was also pointed out in Chapter IV on consent) is, however, not convincing, since the declarations made by Great Britain could be motivated by their disapproval of the German invasion, but do not necessarily have to be. Likewise, Great Britain and France could also have declared their support to Poland because - as opposed to the invasion of Bohemia and Moravia - they would not consent to an invasion of Poland.

The second reason for rejection is the fact that the victim's (Hácha's) consent was obtained under duress.

\subsubsection{Scope}

The information on the scope of mistake of law that can be derived from this part of the Judgment is that an appeal to this defense can be rejected when the defendants, should have known the law. This criterion is different from the requirement derived from the previous case, where the Tribunal was more interested in the sincerity of the mistake. The Tribunal seems to communicate that the defendants should have known the law when a) the international community does not approve of the act and b) the consent of the victim is obtained under duress. It is remarkable that the

\footnotetext{
436 International Military Tribunal (Nuremberg), Judgment and Sentences, 1 October 1946, p. 198.

437 Konstantin Von Neurath was Minister of Foreign Affairs until Joachim Von Ribbentrop took over in 1938. From then onwards he was Minister without office and Reichsprotektor of Bohemia and Moravia. He resigned in 1943.

International Military Tribunal (Nuremberg), Judgment and Sentences, 1 October 1946, p. 325.
} 
reaction of the international community does not have to be an unequivocal statement on the legality of the action, but can also be a statement after the fact that implies the absence of legality ("The next time he does that, I will resist"). It is, however, doubtful whether the latter line of reasoning sufficiently demonstrates the illegality of the act, for it is rather an indication than proof (see previous subSection). The presence of this mistake of law is assessed objectively (Was there objective information available on the legality of the act?).

\section{Mistake at The ICTY}

\subsection{Prosecutor v. Mucić et al.}

\subsubsection{Relevant passages}

In 1992 Bosnian Muslims and Croats established the Čelebići prison camp in which they detained Bosnian Serbs. In Prosecutor v. Mucić et al. multiple defendants stand trial for their involvement in this prison camp. On appeal, mistake of law is briefly discussed. Zdravko Mucić, the former commander of Čelebići prison camp, argues that it was not proved that he had the requisite mens rea for the crime of illegal detention or unlawful confinement (article 2(g) of the ICTY Statute). The defense substantiates this argument by stating that:

Given that it is not remotely suggested that the Appellant has, or had, any expert or other knowledge of International Law, it would be a counsel of impossible perfection to conclude that in 1992 he could have known, or did know, that there was a possibility that the confinement of persons at Čelebići could, or would be, construed as illegal under an interpretation of an admixture of the Geneva Conventions and Article 2(g) of the Statute of the Tribunal, a Statute not then in existence. ${ }^{439}$

The Trial Chamber rejects this argument by stating that:

Mucić's submission has no merit because it is clear from the provisions cited above from Geneva Convention IV that the detention of those persons was illegal at the very time of their detention. ${ }^{440}$

\subsubsection{Applicability}

In Prosecutor v. Mucić et al. mistake of law is implicitly recognized by rejection. The defense is rejected in casu because the detention was illegal at the time the crime charged was committed.

439 ICTY, Prosecutor v. Mucić, Appeals Chamber, 20 February 2001, par. 373.
440 ICTY, Prosecutor v. Mucić, Appeals Chamber, 20 February 2001, par. 374. 


\subsubsection{Scope}

The contention of the Appeals Chamber provides an interesting hint as to the scope of the defense of mistake of law: when behavior is criminalized in an accessible manner at the time of the commission of the crime (in casu Geneva Convention IV), liability is a fact. Whether the defendant subjectively knew about the rule is irrelevant. The Appeals Chamber thus employs a should have known criterion, requiring an objective test.

\subsection{Prosecutor v. Dragomir Milošević}

\subsubsection{Relevant passages}

In the early nineties the VRS conducted a campaign of sniping and shelling attacks on the city of Sarajevo. At the time Dragomir Milošević held several top positions within this organization. He is charged by the ICTY for violations of laws and customs of war and crimes against humanity. ${ }^{441}$ In relation to the murder of a young boy named Adnan Kasapović by VRS soldiers (murder as a crime against humanity, article 5(a) of the ICTY Statute) Milošević argues on appeal that the soldiers could have been mistaken about the legal status of the victim:

[...] because it was known that young boys bore arms at the time, one of the reasonably possible conclusions "would be that the three boys were on guard as members of the $\mathrm{ABiH}$ and when they were passing by the passage in the vicinity of Vemex they were spotted by SRK members and legally targeted as military objectives". ${ }^{42}$

The Appeals Chamber rejects this claim by referring to several assertions made by the Trial Chamber:

With regard to the possibility that the victims could have been mistaken for members of the $\mathrm{ABiH}$, an argument raised by Milošević at trial and reiterated on appeal, the Trial Chamber noted that (i) the victims were young boys dressed in civilian clothes; (ii) there was no military activity in the area that day; (iii) the passageway was not used by ABiH soldiers; (iv) the weather conditions were good; and (v) the distance from which Kasapović was shot would have allowed for the sniper to determine whether he was carrying arms or was a combatant. Milošević does not present any clear challenge to any of these conclusions or the underlying evidence. $^{443}$

441 ICTY, Prosecutor v. Milošević, Trial Chamber, 12 December 2007, par. 5.

442 ICTY, Prosecutor v. Milošević, Appeals Chamber, 12 November 2009, par. 202.

443 ICTY, Prosecutor v. Milošević, Appeals Chamber, 12 November 2009, par. 206. 
The Appeals Chamber adds that:

The Appeals Chamber recognizes the errors and the confusion about the victim's exact age, but finds that they are without impact on [...] the Trial Chamber's conclusion that Kasapović was a young unarmed civilian who could not be mistaken for a combatant by the sniper. ${ }^{444}$

\subsubsection{Analysis}

The rejection of the defense of mistake of fact in this case, is an implicit recognition of the argument, for if the soldiers were indeed mistaken, this would have had legal consequences. The Appeals Chamber brings up several points made by the Trial Chamber to substantiate its rejection of mistake in casu. All of these arguments point in the same direction: the VRS soldiers should have been aware of the victim's identity.

\subsubsection{Scope}

The only requirement for the defense of mistake of fact that can be derived from the Milošević case is that the presence of a mistake of fact is determined by a should have known test. The Appeals Chamber assesses the objective circumstances of the case and judges whether a mistake is a reasonable possibility. Hence, the test is an objective one. The Tribunal is not interested in whether the VRS soldiers were sincerely mistaken.

It is noteworthy that the defendant in this case did not argue that the VRS soldier made a mistake, but that there is a possibility that he made a mistake. In that sense, the appeal is not truly an appeal to mistake. However, the Appeals Chamber examines the matter as if a complete defense was brought up. Bringing up the possibility of a complete defense (instead of a complete defense) seems to be a logical consequence of the fact that the physical perpetrator is not on trial (but his superior), a situation common to international criminal law.

\subsection{Mistake of fact mentioned in other cases}

Apart from Prosecutor v. Dragomir Milošević - where a plea of mistake of fact is made, but is not labeled as such - there are hints in ICTY case law at the existence of mistake of fact as a complete defense. In their Joint Separate Opinion in Prosecutor v. Erdemović, Judges Vohrah and McDonald (majority) hold that: "superior orders does not amount to a defence per se but is a factual element which may be taken into consideration in conjunction with [...] the defences of 
duress or mistake of fact ...".445 On the possibly equivocal guilty plea in Erdemović, Cassese (dissenting opinion) states: "The accused cannot be allowed on the one hand to admit his guilt and by the same token nullify this plea by claiming that he acted in self-defence, or under a mistake of fact, ..." ${ }^{446}$ These quotes from Prosecutor v. Erdemovic demonstrate that the mistake of fact plea has been explicitly recognized by several ICTY judges, by means of an obiter dictum/dissenting opinion.

\section{Mistake at The ICTR}

Mistake is not mentioned in ICTR case law as a possible defense. However, the final report of the Commission of Experts on the establishment of the ICTR refers to mistake of fact as a possible ground for excluding criminal responsibility. ${ }^{447}$

\section{Mistake at the ICC}

\subsection{Applicability}

Mistake is recognized by article 32 of the ICC Statute (mistake of fact or mistake of law):

1. A mistake of fact shall be a ground for excluding criminal responsibility only if it negates the mental element required by the crime.

2. A mistake of law as to whether a particular type of conduct is a crime within the jurisdiction of the Court shall not be a ground for excluding criminal responsibility. A mistake of law may, however, be a ground for excluding criminal responsibility if it negates the mental element required by such a crime, or as provided for in article 33.

A failed appeal to mistake can be taken as a mitigating factor (Rule 145(2)(a)(i)).

\subsection{Scope}

Article 32 of the ICC Statute distinguishes between "mistake of fact" and "mistake of law". In order to gather a deeper understanding of this provision, the difference

445 ICTY, Prosecutor v. Erdemović, Separate Opinion of Judge McDonald and Judge Vohrah, 7 October 1997, par. 34.

446 ICTY, Prosecutor v. Erdemović, Separate and Dissenting Opinion of Judge Cassese, 7 October 1997, par. 10.

$447 \mathrm{~S} / 1994 / 1405$, par. 176. 
between these two types of mistakes must be first defined; next, the requirements of each species of mistake are analyzed.

\subsubsection{The distinction between mistake of fact and mistake of law}

Article 32 of the ICC Statute refrains from defining what a mistake of fact or law is. Commentators on the Statute have defined a mistake of fact as non-recognition of a material element ${ }^{448}$ of the crime, which negatives the definitional subjective element. ${ }^{449}$ For example: a soldier mistakes a civilian for a combatant and kills him. Since he did not realize he was killing a civilian, he did not recognize a material element of the crime. Consequently the intent to kill a civilian (the definitional subjective element) cannot be proved. 450

On the other hand, when the same soldier does recognize the person in front of him as a civilian, but - because he does not know that it is prohibited to kill civilians - shoots him, this would qualify as a mistake of law. In case of a mistake of law, the defendant is aware of the material elements of the crime, but erroneously evaluates the law, because of the unawareness or misinterpretation of an existing norm. Generally this type of mistake does not touch the material elements of the crime, for a mental element related to the breaking of the law is normally not included in the definition of a crime. ${ }^{451}$ Also, according to the first sentence of article 32(2) of the ICC Statute, this type of mistake does not exempt from criminal responsibility. ${ }^{452}$

In contrast, the second sentence of article 32(2) leaves an appeal to mistake of law open in case of (a) superior orders (discussed below) and (b) in case "it negates the mental element required by such a crime". Mistake of fact and mistake of law can thus both be a complete defense if the mistake negates the mental element. The first paragraph of this Section provides an example of a mistake of fact negating the mental element. However, what would an erroneous evaluation of the law negating the mental element look like? Van Sliedregt has come up with an excellent example to demonstrate the difference between the missing mental element in case of a mistake of fact (related to the nonrecognition of a material element) and the missing mental element in case of a mistake of law (related to an erroneous evaluation of the law). The example involves intentional attacks on personnel using distinctive emblems (article 8(2) (e)(ii) ICC Statute):

448 These material elements, in turn, are subdivided in 'descriptive' and 'normative' elements. See: Sliedregt, E. van, 2012, pp. 269-271 for a treatise on this distinction.

449 Eser, A., 2002, p. 936; Khan, K. and Dixon, R. (eds.), 2009, p. 1291; Triffterer, O., 'Article 32: Mistake of Fact or Mistake of Law', Triffterer, O. (ed.), Commentary on the Rome Statute of the International Criminal Court: Observers' Notes, Article by Article, Hart Publishing, Oxford, 2008, pp. 895-929, p. 902; Werle, G., 2005, pp. 150/151. Compare article 8(2)(b)(i) of the ICC Statute.

451 Eser, A., 2002, p. 936; Scaliotti, M., 2002, p. 12; Triffterer, O., 2008, p. 902 and Werle, G., 2005, p. 151.

452 Eser, A., 2002, pp. 940/941 and Triffterer, O., 2008, p. 906. 
Combatant A sees walking towards him B who is a doctor with the Red Cross but is held by $A$ to be an enemy soldier as the distinctive emblem is not clearly visible. If $A$ shoots at $B$, it would be a clear mistake of fact. If the emblem is clearly visible to $A$ but $A$ is not aware of the rules on distinctive emblems and shoots $B$, his ignorance of protective criteria may qualify as mistake of law. 453

In both situation's A's mental element is negated by his mistake. However, in the first situation A's mental element is negated because he did not intend to attack a person wearing an emblem, while in the second situation his mental element is negated because he did not intent to attack a person wearing a distinctive emblem with all its legal implications. ${ }^{454}$

To put up a higher threshold, commentators have suggested that a defendant should not be able to claim mistake of law in case he is not aware of the exact legal provisions or jurisprudential interpretations (as almost nobody is). Only, if the perpetrator erroneously evaluated the social everyday meaning of a material element of the crime, the mental element should be negated. ${ }^{455}$ Van Sliedregt, however, suggests that this standard may vary according to the hierarchical position of the defendant (e.g. a commander should have more knowledge of the law than a soldier). ${ }^{456}$

Although the interpretation of article 32 by several commentators clarifies the significance of this article, several issues remain unresolved and will have to be settled in case law. Mainly, when and how the mental element of the crime charged is negated by a mistake. ${ }^{457}$ As Eser points out, this major lack of clarity is due to the fact that the mistake provision does not provide the conditions by which the mental element is negated. In this aspect article 32 differs from the other grounds excluding criminal responsibility in the ICC Statute. ${ }^{458}$

To determine the type of mistake one is dealing with in terms of article 32 of the ICC Statute, one could use the following scheme:

453 Sliedregt, E. van, 2012, p. 271.

454 Technically, the latter type of mistake is what Heller calls a mistake of legal element (MLE), a mistake of law regarding a norm captured in a source outside the Statute, such as 'military necessity' or hors de combat. Since these mistakes usually negate the mental element, the scope of article 32 should be narrowed to apply a negligence standard. For, according to Heller, there is no reason why soldiers should not be expected to have at least a reasonable understanding of international criminal law. See: Heller, K.J., 'Mistake of Legal Element, the Common Law, and Article 32 of the Rome Statute', In: Journal of International Criminal Justice, Volume 6, 2008, pp. 419-445.

Eser. A., 2002, p. 943 and Triffterer, O., 2008, p. 902.

456 Sliedregt, E. van, 2012, p. 273.

457 Triffterer, O., 2008, p. 900 and Weigend, T., 'The Harmonization of General Principles of Criminal Law: The Statutes and Jurisprudence of the ICTY, ICTR and the ICC', In: Nouvelles Etudes Penales, Vol. 19, 2004, pp. 319-335, p. 333.

Eser, A., 2002, p. 935/936. 


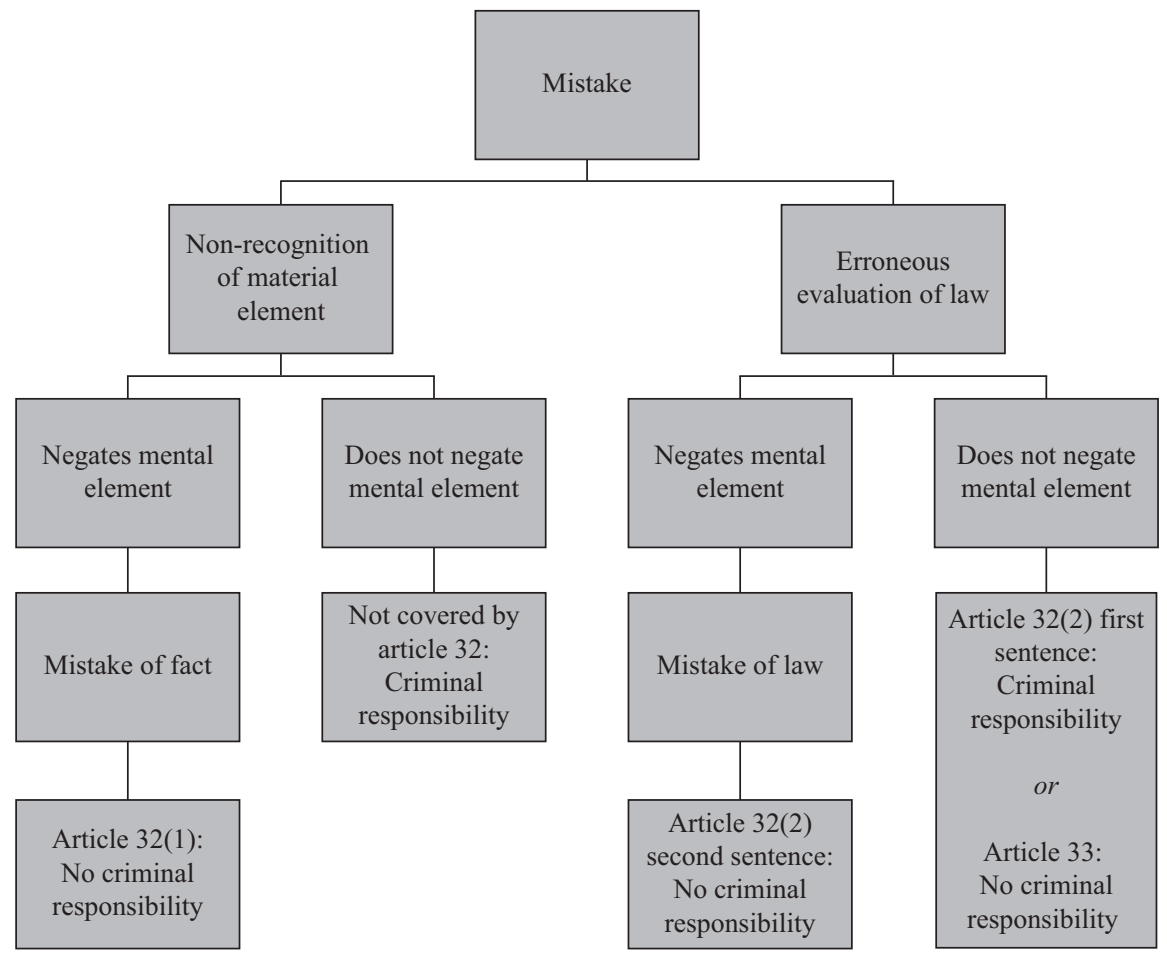

\subsubsection{Mistake of fact (article 32(1))}

\section{MistaKe OF FACT}

As explained in the previous Section, mistake of fact is a non-recognition of a material element of the crime. This focus on the crime caused ICC commentators to debate the question whether a non-recognition of a material element of a defense falls within the scope of article 32(1) (e.g. the situation where the defendant erroneously thinks he is being attacked and strikes back in self-defense, while in fact he is not being attacked at all). Opinions are divided on whether article 32(1) covers putative defenses. However, most authors agree that these defenses should (or could) be covered by the Rome Statute one way or another.

Several commentators hold that a mistake in relation to a defense, does not fall within the scope of article 32(1) because, these mistakes do not affect the mental element of the crime charged, a condition that article 32 requires. ${ }^{459}$ If, for example, a defendant kills another person, because he mistakenly believed he was attacked by 
this person, this situation does not negate the mental element for the crime of killing. Other writers hold that the question whether a mistake in relation to a defense falls within the scope of article 32(1) depends on the interpretation of this article. According to these authors, the choice between a narrow interpretation - limited to the mental element required for the definitional elements of the crime - or a broad interpretation - including the mental element required for the grounds for excluding criminal responsibility - is crucial. These authors conclude that a narrow interpretation of article 32 is in order, based upon the word "only". 460 Mistaken defenses could, nevertheless, be covered by article 31(3), ${ }^{461}$ or article 21(1)(c) of the ICC Statute. ${ }^{462}$

Eser holds that putative mistakes can be a complete defense through article 32(1). His argumentation is based on the fact that it is "a matter of accident whether a material element is formulated in a positive or a negative way". 463 By this he means that it should not depend on the phrasing of crime and defense whether a defendant has a defense. For example, if rape were defined as "sex without consent", and a defendant was mistaken about the consent of the victim, he can resort to mistake of fact, for he did not recognize a material element of the crime. However, when, in the same situation, the crime of rape were defined as "sex" and "consent" was a defense to this charge the defendant has no defense, if putative mistakes are not included in the catalogue of defenses.

Triffterer agrees to an extended interpretation of article 32(1), however for different reasons. His argumentation is based on the fact that both a narrow and a broad interpretation of article 32 (1) lead to the same result, because (a) in both situations the defendant perceives the reality incorrectly, (b) the defendant would not have committed the crime if he had perceived the reality as it was. According to Triffterer, in case of a mistake in relation to the crime, the perpetrator cannot be punished, because he did not have the mental element. In case of a mistake in relation to a defense, the perpetrator "does not deserve to be punished", since without the mistake of (the justifying) fact he would not have had the mental element to commit the crime. ${ }^{464}$

Triffterer also suggests another way to extend article 32: the word "mistake" must be interpreted to cover also "ignorance". He again substantiates this view by arguing that both situations lead to the same result: both mistaking and not perceiving a fact negate mens rea. ${ }^{465}$

460 Sliedregt, E. van, 2012, p. 283 and Weigend, T., 2004, p. 334. According to Triffterer - who holds that mistaken defenses do fall within the scope of article 32 (see next paragraph) - the word "only" is superfluous.

461 Weigend, T., 2004, p. 334.

462 Scaliotti, M., 2002, p. 15.

463 Eser, A., 2002, p. 945.

464 Triffterer, O., 2008, pp. 901 and 906.

465 Triffterer, O., 2008, p. 903. 


\section{Negates MENTAL ELEMENT}

In whichever definition of the concept of mistake of fact, the consequence of the mistake is paramount, for it must lead to the negation of the mental element. This requirement touches upon two theoretical issues that are discussed below under 5.2.4 (for they are relevant to both paragraph (1) and (2) of article 32): (a) the definition of the mental element and (b) the relationship between article 32 and article 30 (on the mental element). Both issues are related to the question whether the mental element should be interpreted in a psychological or in a normative way.

\subsubsection{Mistake of law}

\section{NOT A GROUND FOR EXCLUDING CRIMINAL RESPONSIBILITY}

As explained above (Section 5.2.1), in case of a mistake of law, the defendant is aware of the material elements of the crime, but erroneously evaluates the law, because of the unawareness or misinterpretation of an existing norm. Generally this type of mistake does not touch the material elements of the crime and according to the first sentence of article 32(2) of the ICC Statute, does therefore not exempt from criminal responsibility.

The first sentence of paragraph 2 covers two situations: (a) the case where the defendant does not know that his act constitutes a crime and (b) the case where the defendant is aware that he committed a crime, but wrongly assumes that the ICC has no jurisdiction. ${ }^{466}$ In both situations, mistake of law is not a ground for excluding criminal responsibility. Triffterer notes that the phrasing "shall not" underlines that the Court has no discretion to come to another judgment. ${ }^{467}$ Like a mistake of fact, a mistake of law negating the mental element could extend to mistaken defenses (for similar reasons as a mistake of fact, see Section 5.2.2). ${ }^{468}$

As an exception to the first sentence, the second sentence of article 32(2) leaves an appeal to mistake of law open in two cases: (a) "if it negates the mental element required by such a crime" and (b) "as provided for in article 33 ".

\section{Negates Mental element}

The first exception to the a priori rejection of mistake of law, put down in the first sentence of article 32(2), is the situation where a mistake of law negates the mental element. An example of such a situation has been provided for above (See the Van Sliedregt example in Section 5.2.1). The requirement touches upon two theoretical issues that are discussed below under 5.2.4 (for they are relevant to both paragraph

\footnotetext{
466 This distinction is also made in: Triffterer, O., 2008, p. 906 and in Eser, A., 2002, pp. 943/944.

467 Triffterer, O., 2008, p. 906.

468 Eser, A., 2002, p. 944.
} 


\section{Mistake}

(1) and (2) of article 32): (a) the definition of the mental element and (b) the relationship between article 32 and article 30 (on the mental element).

Because a successful appeal to article 32(2), second sentence, requires (a) a mental element that is open to misjudgments of a legal norm and (b) a defendant that does not even grasp the social every day meaning of this element, authors have noted that the chance of a successful appeal to this type of mistake is highly unlikely. ${ }^{469}$

\section{Article 33}

The second exception to the first sentence of article 32(2) is the situation described in article 33 of the ICC Statute. This article refers to the situation where the defendant committed a crime pursuant to an order of a Government or of a superior ("superior orders"). Under this provision an otherwise irrelevant (for the defendant does possess the requisite intent for the crime) mistake of law can negate criminal responsibility if the person did not know - and could not have known - that the order (or prescription) was unlawful. Criminal responsibility is only negated if the other conditions of article 33 have been met as well. Note that this article is only applicable in case of war crimes and possibly aggression (article 33(2) ICC Statute). The article is more elaborately discussed in Chapter VIII on superior orders.

\section{MAY BE}

It is significant that the phrasing of the second sentence of paragraph (2) contains the word "may" as opposed to "shall" in paragraph (1). According to several writers this word "may" implies that the Court has some discretionary power in acknowledging a mistake of law plea. This power could either imply that (a) only unavoidable mistakes should be exempted from punishment or that (b) the Court has a choice between exemption and mitigation or both (a) and (b). ${ }^{470}$ Cryer denies that article 32(2) second sentence contains any discretionary powers, for this would imply a violation of the culpability principle in that a defendant could be convicted without the subjective element being established. ${ }^{471}$

\subsubsection{General comments on article 32}

\section{THE DEFINITION OF THE MENTAL ELEMENT}

A mistake (of fact or law) can be a ground for excluding criminal responsibility if it negates the mental element. What is important therefore is how this mental element is defined. The ICC definition of the mental element is contained in article 30 of the ICC

\footnotetext{
469 Eser, A., 2002, p. 94 and Triffterer, O., 2008, p. 900.

470 Eser, A., 2002, p. 942 and Triffterer. O., 2008, pp. 907/908.

471 Cryer, R., et al., 2010, p. 415.
} 
Statute. This provision bears a psychological approach to the mental element. It defines the mental element as the definitional subjective element of the crime, while disregarding the existence of some sort of blameworthiness. In the context of article 32 an element of blameworthiness - that was part of earlier drafts - was dropped during negotiations. ${ }^{472}$ Still, commentators on article 32 seem to have problems with a psychological approach to this provision. Therefore, the majority of authors agree that article 32 should be interpreted as to cover an element of blameworthiness in the form of (un)reasonability or (un)avoidability. According to these authors, blameworthiness functions as a correction mechanism in two situations:

(a) When the definitional mental element cannot be established, but the perpetrator should be punished because he is still blameworthy. This would be the case when the defendant did not recognize a certain fact, or erroneously evaluated some legal matter, but this mistake was unreasonable (or could have been avoided). Going back to the example brought up by Van Sliedregt:

Combatant A sees walking towards him B who is a doctor with the Red Cross but is held by $A$ to be an enemy soldier as the distinctive emblem is not clearly visible. If $A$ shoots at $B$, it would be a clear mistake of fact.

However, if A could have easily avoided this mistake by, for example, taking one step to the left to improve his vision, his mistake is unreasonable and avoidable. Despite not possessing the required definitional mental element, he should still be punished.

(b) When the definitional mental element can be established, but the perpetrator should be acquitted, because he is not blameworthy. For example, when a defendant violates a law that he could not have been aware of, or when he makes a reasonable mistake as to the existence of a complete defense.

Authors argue that the interpretation of article 32 should be extended to contain blameworthiness in the first situation (a) ${ }^{473}$, in the second situation (b) ${ }^{474}$ or in both. ${ }^{475}$

In case of the first situation (a), an interpretation of article 32 extended to blameworthiness would be a disadvantage to the perpetrator (for he does not

472 Scaliotti, M., 2002, p. 14.

473 This interpretation of article 32 is adhered to by: Eser, A., 2002, p. 942; Dinstein, Y., 2000, p. 378; Khan, K. and Dixon R. (eds.), 2009, p. 1293; Ohlin, J., 2009, p. 423; Triffterer. O., 2008, p. 907/908 (when explaining the word "may" in the second sentence in paragraph 2 (mistake of law)) and Sliedregt, E. van, 2003, pp. 305 and 316 (either through article 32 or article 21 of the ICC Statute) and Sliedregt, E. van, 2012, p. 285.

474 This interpretation of article 32 is adhered to by: Eser, A., 2002, p. 945; Ohlin, J., 2009, p. 423; Triffterer, O., 2008, p. 902 (although he acknowledges that the provision leaves the court no discretion in case of mistake of law, see p. 906); Werle, G., 2005, p. 152.

475 Or they suggest a rephrasing of the article, such as Heller, J.K, 2008, pp. 444/445 and Verseveld, A. van, Mistake of Law: Excusing Perpetrators of International Crimes, T.M.C. Asser Press, The Hague, 2012, p. 97, to be discussed in Part III of the present thesis. 
possess the required mental element, but can still be convicted), while in the second situation (b) an extension provides an advantage (despite the fact that the mental element can be established, the defendant is not convicted). Consequently, not only the first interpretation has been called a violation of the culpability principle (guilt despite the absence of a mental element), ${ }^{476}$ but also not recognizing the second interpretation (leading to guilt without blameworthiness). ${ }^{477}$

Reading an element of blameworthiness into article 32 puts the chart at the end of Section 5.2.1 upside down in the following manner:

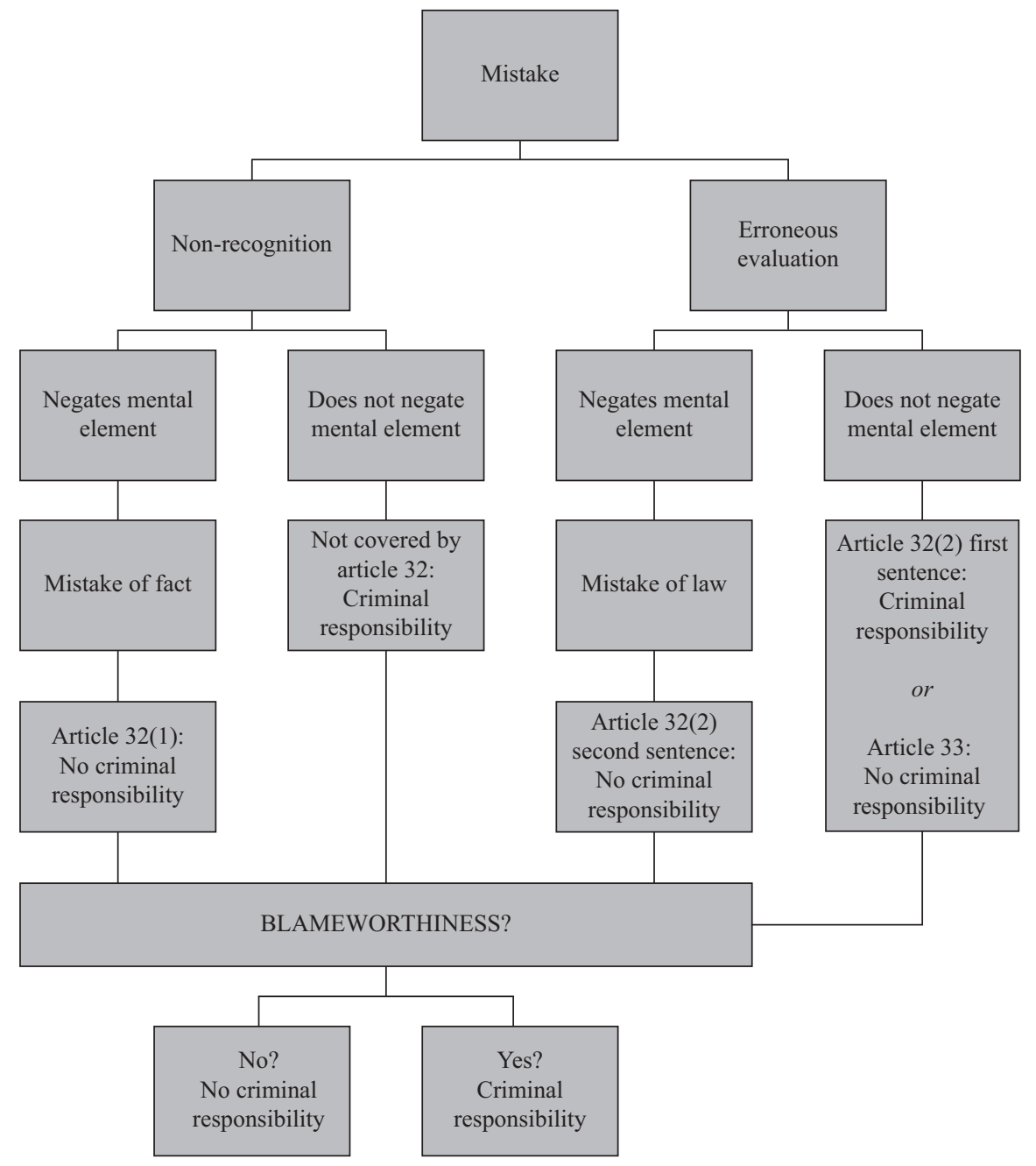

476 Cryer, R. et al., 2007, p. 342. This interpretation has also been considered inconsistent with article 30. See: Eser, A., 2002, p. 892.

477 Eser, A., 2002, p. 945 and Werle, G., 2005, p. 152. 
In other words: when blameworthiness is taken into the equation, the presence of a mental element is no longer crucial. On the contrary, the question as to the presence of a mental element becomes superfluous.

\section{RELATION TO ARTICLE 30}

Since a mistake can only exonerate when it negates the mental element, commentators have written that article 32 is merely a repetition of article 30 (mental element) and therefore superfluous. ${ }^{478}$ Other authors have marked article 32 more as a "clarification", limiting the scope of article 32 to mistakes that negate the mental element. ${ }^{479}$ However, the fact that many authors extend the provision to include an element of blameworthiness (see previous paragraphs), seems to suggest that article 32 is not merely a repetition or article 30 . Therefore this is the reason probably that Eser writes:

By now admitting mistake of law, though still under narrow conditions, as a ground for excluding criminal responsibility, Article 32(2) of the ICC Statute heralds a breakthrough to a more comprehensive understanding of culpability which doesn't fully equate to the psychological-mental elements of intent or knowledge but also requires some sort of normative blameworthiness. ${ }^{480}$

\section{OBJECTIVE/SUBJECTIVE}

The verbatim text of the ICC provision reflects a subjective test, for the crucial requirement is whether the subjective state of mind of the defendant exonerates him from criminal liability. As long as the mistake made by the defendant is sincere, he is not to blame. However, ICC commentators have suggested taking an element of blameworthiness into the equation, transforming the provision to an objective test (i.e.: was the mistake objectively reasonable?).

\subsubsection{Prosecutor v. Lubanga Dyilo}

\section{RELEVANT PASSAGES}

The research reflected in this thesis focuses on judgments of international courts. However, in the present paragraph an ICC pre-trial decision is analyzed. The reason for this is that the ICC had not yet produced any judgments on mistake when this research was concluded and the pre-trial decision contains information on the interpretation of the ICC provision on mistake of law.

478 Khan, K. and Dixon R. (eds.), 2009, p. 1291 (as to paragraph 1 of article 32) and Werle, G., 2005, p. 149. This matter was also discussed during the drafting of the ICC Statute. See: Scaliotti, M., 2002, p. 9.

479 Eser, A., 2002, p. 937 (in relation to mistake of fact) and Triffterer, O., 2008, p. 900.

480 Eser, A., 2002, p. 891. 
In the Decision on the confirmation of charges against Thomas Lubanga (former rebel leader from the Democratic Republic of Congo), the defense argues that Lubanga was unaware "of the existence of the crime of enlisting and conscripting children under the age of fifteen years and using them to participate in hostilities" which is a crime under article 8(2) of the Rome Statute. ${ }^{481}$ According to the defense, Lubanga was not aware that his conduct amounted to a crime because (a) the government had failed to inform the inhabitants about the ratification of the Rome Statute, while being obligated to do so according to article 65 of the Fourth Geneva Convention and (b) the illegality of the crime charged was not foreseeable, because it is not included in the Additional Protocols I and II to the Geneva Conventions and in the Optional Protocol to the Convention on the Rights of the Child. ${ }^{482}$

The Pre-Trial Chamber first observes that: "the scope of mistake of law within the meaning of article $32(2)$ is relatively limited". ${ }^{483}$ Next, it holds that: "there is sufficient evidence [...] to establish substantial grounds to believe that, at the time, Thomas Lubanga Dyilo was aware that voluntarily and forcibly recruiting children under the age of fifteen years and using them to participate actively in hostilities entailed his criminal responsibility under the Statute". ${ }^{484}$ The Chamber thoroughly substantiates this view by bringing up seven arguments:

1. A few months before the commission of the crimes the Democratic Republic of Congo (DRC) had ratified the ICC Statute (which subjects the crime charged to ICC jurisdiction); 485

2. Even before this ratification, the communities living in the area where the crimes were committed were familiar with the ICC Statute and its prohibitions; ${ }^{486}$

3. Both the DRC and Uganda (which had militarily occupied part of the conflictregion) ${ }^{487}$ ratified the Geneva Conventions and Protocols, which prohibit the relevant use of children under the age of $15 ; 488$

481 ICC, Prosecutor v. Lubanga Dyilo, Decision on the confirmation of charges, Pre-Trial Chamber, 29 January 2007, par. 294 and 304.

482 ICC, Prosecutor v. Lubanga Dyilo, Decision on the confirmation of charges, Pre-Trial Chamber, 29 January 2007, par. 296.

483 ICC, Prosecutor v. Lubanga Dyilo, Decision on the confirmation of charges, Pre-Trial Chamber, 29 January 2007, par. 305.

484 ICC, Prosecutor v. Lubanga Dyilo, Decision on the confirmation of charges, Pre-Trial Chamber, 29 January 2007, par. 306.

485 ICC, Prosecutor v. Lubanga Dyilo, Decision on the confirmation of charges, Pre-Trial Chamber, 29 January 2007, par. 307.

486 ICC, Prosecutor v. Lubanga Dyilo, Decision on the confirmation of charges, Pre-Trial Chamber, 29 January 2007, par. 312.

487 Weigend, T., 'Intent, Mistake of Law and Co-perpetration in the Lubanga Decision on Confirmation of Charges', In: Journal of International Criminal Justice, Vol. 6, 2008, pp. 471487, p. 474.

488 ICC, Prosecutor v. Lubanga Dyilo, Decision on the confirmation of charges, Pre-Trial Chamber, 29 January 2007, par. 308 and 309. 
4. The protection of children under international humanitarian law is recognized under the 1989 Convention of the Rights of the Child; ${ }^{489}$

5. The Appeals Chamber of the Special Court of Sierra Leone has held that, prior to November 1996, the prohibition against child recruitment had already crystallized as a customary law norm; 490

6. A witness testified that she and Lubanga discussed child protection issues in relation to the ratification of the Rome Statute, ${ }^{491}$

7. Representatives of victims observed that: "The Statute's entry into force could not have escaped the attention of Thomas Lubanga, who claims to be a politician and head of state, and who, because of his involvement in armed conflict, was directly connected". 492

Next, the Pre-Trial Chamber stresses that a mistake of law can only be a ground for excluding criminal responsibility if (a) it negates the mental element of the crime or (b) it falls within the scope of article 33 of the ICC Statute. ${ }^{493}$ It reasons that "absent a plea under article 33 of the Statute, the defense of mistake of law can succeed under article 32 of the Statute only if Thomas Lubanga Dyilo was unaware of a normative objective element of the crime as a result of not realizing its social significance (its everyday meaning). ${ }^{494}$ The court concludes by stating that "there is nothing in the evidence admitted for the purpose of the confirmation hearing to show that Thomas Lubanga Dyilo might have made any such mistake in the context in which the crimes were committed".495

\section{Analysis of Prosecutor V. Thomas Lubanga Dyilo}

In Prosecutor v. Thomas Lubanga Dyilo the defense of mistake of law is rejected on grounds. The defense argues that the defendant (a) did not know about the prohibition (because the government refrained from informing him) and (b) that he could not have known about the prohibition because it lacked foreseeability since the prohibition is not contained in a number of conventions. The Court rejects these

489 ICC, Prosecutor v. Lubanga Dyilo, Decision on the confirmation of charges, Pre-Trial Chamber, 29 January 2007, par. 310.

490 ICC, Prosecutor v. Lubanga Dyilo, Decision on the confirmation of charges, Pre-Trial Chamber, 29 January 2007, par. 311.

491 ICC, Prosecutor v. Lubanga Dyilo, Decision on the confirmation of charges, Pre-Trial Chamber, 29 January 2007, par. 313.

492 ICC, Prosecutor v. Lubanga Dyilo, Decision on the confirmation of charges, Pre-Trial Chamber, 29 January 2007, par. 314.

493 ICC, Prosecutor v. Lubanga Dyilo, Decision on the confirmation of charges, Pre-Trial Chamber, 29 January 2007, par. 315.

494 ICC, Prosecutor v. Lubanga Dyilo, Decision on the confirmation of charges, Pre-Trial Chamber, 29 January 2007, par. 316.

495 ICC, Prosecutor v. Lubanga Dyilo, Decision on the confirmation of charges, Pre-Trial Chamber, 29 January 2007, par. 316. 
arguments by stating that (a) even before the ratification of the Rome Statute, the contents of the Statute were known to the inhabitants of the relevant area and (b) the conventions mentioned by the defense $d o$ contain the relevant prohibition, which makes it foreseeable. Besides that, the Court mentions that the prohibition is customary law and that Lubanga knew (according to a witness) about the prohibition and also should have known about it (because of his hierarchical position). In short, the Court thus holds the opinion that Lubanga was aware of the relevant prohibition.

The Court continues by stating that an appeal to mistake of law - that is not an appeal to superior orders - can only be successful if the mistake negates the mental element because the perpetrator "was unaware of a normative objective element of the crime as a result of not realizing its social significance (its everyday meaning)". Apparently, the Lubanga defense made an argument in this respect. They argued that Lubanga was aware of the general prohibition of conscripting and enlisting soldiers under the age of 15 years. However, in his mind, Lubanga equated 'conscripting and enlisting' with forcible recruitment of soldiers. He therefore did not know he committed an offense when young soldiers voluntarily joined the army. ${ }^{496}$ The Pre-Trial Chamber rejects this argument by stating that it "relies on the Commentary on the Additional Protocols, according to which the principle of nonrecruitment also prohibits accepting voluntary enlistment" ${ }^{\text {" } 97}$ and thus suggesting that he should have been aware of this interpretation. At the end of its contemplation the Court also stresses that the defense has not demonstrated that Lubanga was unaware of a normative objective element of the crime.

The rejection of mistake of law in this case is interesting for several reasons. In respect of the arguments brought up by the defense in relation to the unawareness of the provision as a whole, it is remarkable that the Court explicitly rejects these arguments. The Court could also have sufficed by explaining that the argument brought up was not an argument in the sense of article 32(2) second sentence, and thus not an admissible defense according to the first sentence of this paragraph. However, by rejecting the argument on grounds the Court displays a more open attitude to this type of mistake of law defense than the Statute does.

In respect of the argument related to the second sentence of article 32(2), it is remarkable that the Pre-Trial Chamber refers to Eser, when stating that an appeal to mistake of law can only be successful if the perpetrator was unaware of a normative objective element of the crime as a result of not realizing its everyday meaning. This is notable because the Court confirms the explanation of this provision, provided for by several of the commentators on the ICC Statute (see above). Also interesting is that the Court interprets this everyday meaning to include knowledge of the commentary on the relevant Protocol. The Court also seems to be in line with the interpretation of Van Sliedregt in that it takes the hierarchical position of the defendant into account when determining his awareness of the relevant rule.

\footnotetext{
496 Weigend, T., 2008, p. 475.

497 ICC, Prosecutor v. Lubanga Dyilo, Decision on the confirmation of charges, Pre-Trial Chamber, 29 January 2007, par. 308.
} 
Furthermore what is noteworthy about this decision is that the Court does explain the meaning of article 32(2), first and second sentence, but refrains from including avoidability/reasonability/blameworthiness into its definition. In this respect the interpretation of the Court seems to differ from the explanation of the commentators. On the other hand, both most of the arguments ((1)-(5) and (7)) brought up by the Court to substantiate Lubanga's awareness of the prohibited conduct and the rejection of the argument referring to the interpretation of the provision (conscripting and enlisting), rather focus on the point that he should or must have known $n^{498}$ that his conduct was illegal, rather than on the point that he knew. It seems that when the mental element is equalized with an objective should have known criterion, blameworthiness enters through the backdoor.

\section{Analysis of mistake}

The introduction to this Chapter raises the question whether a distinction between mistake of fact and mistake of law exists in international criminal law. The previous paragraphs demonstrate that the ad hoc tribunals have discussed both types of mistakes, however without labeling them. The ICTY, however, explicitly acknowledged the mistake of fact defense and so did a document relevant to the establishment of the ICTR. Only the ICC has explicitly recognized both types of defenses and provided for some sort of definition. Below, the applicability and scope of both defenses are discussed in separate sections.

\subsection{Applicability: Mistake of fact}

Mistake of fact has never been accepted as a complete defense. It has been recognized by the IMT, ICTY and ICC, either through rejection on its merits in case law (IMT, ICTY), as an obiter dictum (ICTY) or in a provision (ICC). Moreover, the Commission of Experts on the establishment of the ICTR mentions the defense in its final report.

498 Theoretically there is a distinction between a should have known and a must have known criterion. A should have known criterion is a normative test: the court investigates whether the defendant should have been aware of a certain condition. For example, if the defendant has a very responsible position he should have informed himself better on the behavior of his subordinates. Therefore he should have been aware of their misbehavior. The must have known criterion is an objectivation of the definitional subjective element. When the testimony of the defendant does not establish his intent, the court can deduce this intent from objective information. A court can, for example, reason: "Since you have a superior position in the army, you must have been aware of the mistreatment of prisoners of war. Their mistreatment could not have been going on without you knowing about it". The distinction between a should have known and a must have known test is subtle and therefore not always evident in practice. See also Blomsma, J., 2012, pp. 57/58 on this distinction. 
Rejection is done on its merits. At the IMT, the defense is rejected in the case of Göring and Raeder because the Tribunal does not believe the defendant. In Milošević the ICTY employs an objective test, concluding that it is very unlikely that the perpetrators were mistaken. According to article 145(2)(a)(i) of the ICC Rules a failed appeal to mistake of fact can be taken in mitigation.

\subsection{Applicability: Mistake of law}

Mistake of law has never been accepted as a complete defense. It has been recognized by the IMT, ICTY and ICC, either through rejection on its merits in case law (all three courts) or in a provision (ICC). At the IMT, the defense is rejected in the case of Bohemia and Moravia because the defendants should have known that their action was illegal. In Mucić, the same test is applied. Lubanga refers to the subjective test in the ICC Statute (did the defendant possess a mental element?), but applies this test in a largely objective manner (the defendant was aware of the relevant law, because he should have been aware of this law). As with mistake of fact, a failed mistake of law can be taken in mitigation at the ICC (article 145(2)(a)(i) of the ICC Rules).

\subsection{Scope: Mistake of fact}

As to the scope of mistake of fact, the IMT employs a partly subjective, partly objective test to find out whether the defendants were honest, while the ICTY uses an objective test to determine the credibility of the mistake. The difference between these two approaches is subtle. Where the IMT says, "I don't believe you were mistaken, because we don't believe your mistake is sincere", the ICTY reasons "I don't believe you were mistaken, because it is objectively impossible to make this mistake". In the first case the Court seems to rely on witness-testimonies, objective criteria and common sense. In case of an objective test the focus is on what the defendant could have known, employing more or less similar means. In essence, the ICTY thus uses an indirect way to come to a similar conclusion as the IMT. The test employed by the ICC again, is a subjective one: a mistake of fact can only lead to acquittal when the defendant does not posses the required mental element, i.e. when he is sincerely mistaken. However, commentators on the ICC Statute have tried to objectivate this requirement by entering an element of blameworthiness.

Other information, than the above, on the contours of a mistake of fact that can be derived from the commentators on the ICC Statute, is that a mistake of fact is a non-recognition of a material element of the crime, but that this defense could be equally applicable in case of mistakes in relation to defenses. 


\subsection{Scope: Mistake of law}

As opposed to mistake of fact, the IMT employs an objective standard in case of mistake of law. As does the ICTY. The ICC provision rejects mistake of law as a complete defense unless (a) the defendant has no mental element due to an erroneous evaluation of the law caused by the unawareness or misinterpretation of an existing norm or (b) when article 33 of the ICC Statute is applicable. However, in Lubanga the ICC discusses an article 32(2) first sentence argument on its merits by largely employing a should have known test. The fact that similar arguments have been rejected on their merits by the IMT and ICTY, suggests that there may be some room for this type of argument, despite of the fact that it is a priori excluded by article 32 .

In Lubanga the ICC also tests an article 32(2) second sentence argument on its merits by employing a should have known test. The Court thus objectivises the subjective test demanded by the Statute, letting blameworthiness in through the back door. Both at the ICTY and the ICC the should-have-know-criterion seems to be met when the relevant behavior is criminalized at the moment of the crime. At the IMT the legality of the act is measured by the reaction of the international community, i.e. ex post facto.

Other information on the contours of mistake of law provided for by the commentators on the ICC Statute is that a mistake of law should be defined as an erroneous evaluation of the law, due to the unawareness or misinterpretation of an existing norm and that mistake of law should be interpreted very rigidly. Only if the perpetrator did not even realize the social everyday meaning of a provision, the defense can be successful. This point of view is shared by the Court in the Lubanga Decision. In addition, mistake of law could also be applicable in relation to mistaken defenses. Finally, the ICC possibly has some discretionary power when it comes to mistake of law in the sense of article 32(2), second sentence.

\subsection{Categorization}

Chapter II has demonstrated that international criminal theory distinguishes between three different types of complete defenses. The question answered in this subsection is whether mistake in international criminal law matches any of these three types. More precisely: what is the effect of the presence of a mistake on the offense charged?

When categorizing mistake, the definition of this defense is crucial. When the defense is only applicable in case it negates the mental element, it must be categorized as no definitional subjective element. In this case it is debatable whether mistake is an excuse, for this depends on whether this lack of intent coincides with absence of blameworthiness. 
However, if blameworthiness is part of the definition, the defense must be categorized either as no definitional subjective element (in case of negligence) or as no blameworthiness:

\begin{tabular}{|l|l|l|l|}
\hline Defense & Effect & $\begin{array}{l}\text { Justification or } \\
\text { excuse? }\end{array}$ & Affirmative or not? \\
\hline $\begin{array}{l}\text { No definitional } \\
\text { subjective element }\end{array}$ & $\begin{array}{l}\text { Defense negates } \\
\text { definitional subjective } \\
\text { element }\end{array}$ & $\begin{array}{l}\text { Justification, excuse or } \\
\text { possibly neither }\end{array}$ & Not affirmative \\
\hline No blameworthiness & $\begin{array}{l}\text { Defense negates } \\
\text { blameworthiness }\end{array}$ & Excuse & Affirmative \\
\hline
\end{tabular}

More problematic is the classification of the situation where the definitional subjective element is defined by a should have known test as is done in Lubanga. In this case the two above classifications merge because the definitional subjective element is determined by the presence of blameworthiness (i.e. the knowledge requirement is extended to a should have known requirement). What is important, however, is not so much the classification of this argumentation structure, but the awareness that in practice, there is no clear-cut dividing line between these classifications and that they can overlap.

Whatever classification is used, mistake is never a justification, for a mistaken perception does not make the perpetrator consciously choose the lesser of two evils. On the contrary, in case of a mistake, the conduct of the defendant is still wrongful, but his behavior may not be blameworthy, because, due to his mistaken perception of reality, he had no ability to choose, any reasonable person would have acted the way he did, or he was not in a position to determine his will freely.

\subsection{Conclusion on mistake}

The analysis of mistake in international criminal law demonstrates that both mistake of fact and mistake of law have been recognized. As to their requirements, the crucial issue seems to be whether the defense demands a subjective or an objective test. Case law on mistake of fact is sending mixed messages in this respect. Mistake of law judgments seem to incline more towards an objective test. Remarkable is that the ICC commentators have interpreted the subjective test, as laid down in its Statute, in a largely objective manner when it concerns mistake of law. This interpretation is confirmed in Lubanga, where the ICC employs a should have known test, thereby merging blameworthiness with the otherwise neutral mental element.

The subjective test in the ICC provision and the objective test in both doctrine and case law, reflect the tension between common law (honest mistake) and civil 
law (reasonable mistake) at this point. ${ }^{499}$ Lubanga demonstrates an interesting middle ground in this respect: the decision leaves the common law text of the provision unaltered, but its interpretation has a civil law result.

Questions that are paramount to the development of mistake in international criminal law are:

1. Should mistake require an objective or subjective test (or both)?

2. Do mistake of fact and mistake of law require different tests (i.e. is the distinction between these legal figures relevant?)?

3. How, if at all, should putative defenses be included in the mistake defense?

4. How, if at all, should the mistake defense be extended to ignorance?

\subsection{Preview Part III}

Part III of this thesis demonstrates that the defense of mistake should consist of both an objective and a subjective test, that mistake of law and mistake of fact do not require different tests, that putative defenses should be included in the mistake defense and that this defense must be extended to ignorance. Finally, Part III suggests a rephrasing of the ICC mistake provision. 


\section{Chapter VIII SUPERIOR ORDERS AND PRESCRIPTION OF LAW}

\section{INTRODUCTION}

The defense of superior orders and prescription of law (hereinafter 'superior orders') has been called the most 'frequently discussed', 'controversial'500 and 'frequently raised' 501 defense in international criminal law. The essence of this defense is the claim that the defendant is not criminally responsible for the execution of illegal orders or prescriptions of law issued by a superior or government. For example, a commander orders a soldier to execute a death sentence by shooting a civilian. The commander, however, is providing false information. The civilian has not been tried and convicted but is executed without legitimate grounds. Because the soldier could not have been aware of the legal status of the civilian, he does not know that the order is illegal. Therefore he cannot be punished. Reference to superior orders can be found in the statutes of the IMT, IMTFE, ICTY, ICTR and ICC.

Legal literature and practice has always been divided on the question whether superior orders should be a complete defense of not. ${ }^{502}$ Generally there are three theories - two opposing and one middle ground - on the availability of superior orders as a complete defense: (a) respondeat superior, (b) absolute liability and (c) conditional liability.

\section{(a) Respondeat superior}

The first theory is known as respondeat superior and portrays the idea that obedience to superior orders is automatically a complete defense to a subordinate perpetrator of international crimes. The thought behind this theory is that a subordinate should always obey his superior. The theory is rooted in national military law. ${ }^{503}$

\section{(b) Absolute liability}

Contrary to this view is the theory of absolute liability. According to this theory, superior orders is not a complete defense to the commission of international crimes. The person who executes an illegal order is automatically responsible for the crime he committed as a result. The idea behind this theory is that a subordinate only has

\footnotetext{
500 Eser, A., 1996, p. 254.

501 Sliedregt, E. van, 2012, p. 287.

502 Zimmermann, A., 'Superior Orders', In: Cassese, A. et al. (eds.), The Rome Statute of the ICC: A Commentary, Oxford University Press, Vol. 1, 2002, pp. 957-974, p. 965.

Scaliotti, M., 2001, pp. 128 and 138.
} 
to obey lawful orders issued by his superior. The theory of absolute liability is rooted in international humanitarian law. ${ }^{504}$

\section{(c) Conditional liability}

The theory of conditional liability, which exists in different versions, ${ }^{505}$ provides middle of the road solutions. It combines the previous two theories (respondeat superior and absolute liability) with the concepts of manifest illegality, knowledge and mens rea as exceptions to the general rule. For example, in case of respondeat superior the subordinate must obey his superior, unless the order is manifestly illegal. Or, in case of absolute liability, the subordinate is criminally responsible, unless the order was not manifestly illegal and/or the subordinate did not know about the illegality. Lacking mens rea also refines the concept of absolute liability: the subordinate is not liable if the mens rea for the crime charged is absent. ${ }^{506}$

Apart from addressing the research questions submitted in the introduction to this Part, this Chapter also investigates whether one of the above theories on superior orders is predominant in international criminal law. The conclusion to this Chapter demonstrates that international criminal law has recently moved from a model of (not completely airtight) absolute liability to a split model of on the one hand (airtight) absolute liability, and on the other hand conditional liability.

\section{SUPERIOR ORDERS AND PRESCRIPTION OF LAW IN THE NUREMbERG JUDGMENT}

Superior orders is a priori excluded as a complete defense by article 8 of the IMT Charter. The defense, however, may be considered as a mitigating factor. The verbatim text of article 8 is:

The fact that the Defendant acted pursuant to order of his Government or of a superior shall not free him from responsibility, but may be considered in mitigation of punishment if the Tribunal determines that justice so requires.

Apart from this general provision, the defense of prescription of law is expressly excluded in the IMT's crimes against humanity provision (article 6(c)):

[...] The following acts, or any of them, are crimes coming within the jurisdiction of the Tribunal for which there shall be individual responsibility:

\section{$[\cdots]$}

504 Bantekas I., 2004, 269; Scaliotti, M., 2001, pp. 128 and 138 and Triffterer, O. 2008, p. 920.

505 Sliedregt, E. van, 2012, p. 288.

506 Eser, A., 1996, pp. 255/256 and Zimmermann A., 2002, p. 262. 
(c) Crimes against humanity: namely, murder, extermination, enslavement, deportation, and other inhumane acts committed against any civilian population, before or during the war, or persecutions on political, racial or religious grounds in execution of or in connection with any crime within the jurisdiction of the Tribunal, whether or not in violation of the domestic law of the country where perpetrated. $[\ldots]^{507}$

Some appeals were made to superior orders as a mitigating factor. However, all of them were rejected. ${ }^{508}$

Despite the fact that an appeal to superior orders as a complete defense was $a$ priori excluded, most of the defendants submitted this plea at some point. ${ }^{509}$ In the general part of the Judgment the plea is therefore universally rejected. The Tribunal refers to article 8 of the IMT Charter and states that:

The provisions in this article are in conformity with the law of all nations. That a soldier was ordered to kill or torture in violation of the international law of war has never been recognized as a defense to such acts of brutality, though, as the Charter provides, the order may be urged in mitigation of punishment. The true test, which is found in varying degrees in the criminal law of most nations, is not the existence of the order, but whether moral choice was in fact possible. ${ }^{510}$

The arguments and statements in this excerpt refine the a priori exclusion of article 8 . However, by doing this, they leave the door open to superior orders as a complete defense for several reasons:

\section{1) Article 8 is not "in conformity with the law of all nations"}

The statement that article 8 is in line with national law is not substantiated by examples of national and case law on this issue. This is not surprising, because the assertion of the Tribunal is false: in most military codes at the time, superior orders could be a defense under certain circumstances. ${ }^{511}$

\section{2) A priori exclusion is limited to torture and killing}

The Tribunal stresses " $[\mathrm{t}]$ hat a soldier was ordered to kill or torture in violation of the international law of war has never been recognized as a defense to such acts of brutality". Linking the ban on superior orders to serious violations of international criminal law, such a torture and killing can be an indication that this ban is not

\footnotetext{
507 Emphasis added by author.

508 See for examples: International Military Tribunal (Nuremberg), Judgment and Sentences, 1 October 1946, p. 283 and 316.

509 International Military Tribunal (Nuremberg), Judgment and Sentences, 1 October 1946, p. 221.

510 International Military Tribunal (Nuremberg), Judgment and Sentences, 1 October 1946, p. 221.

511 Knoops, G.J., 2001, p. 146; Davidson, E., 1997, p. 200; Cryer, R., 2005, p. 293/294; Maogoto, J.N., 'The Defense of Superior Orders', In: Olusanya, O. (ed.), Rethinking International Criminal Law: The Substantive Part, Europa Law Publishing, Groningen, 2007, pp. 91-128, p. 109.
} 
absolute. With this statement the IMT leaves the door open for superior orders as a complete defense to crimes of lesser gravity, such as destruction of property.

3) When the defendant has "no moral choice", superior orders can be a complete defense

The Tribunal concludes its contemplation by mentioning that "the true test (...) is not the existence of the order, but whether moral choice was in fact possible". This frequently cited statement could imply that whether a superior order can be a complete defense is dependent on the "moral choice" of the defendant. 512 However, the word "test" could also refer to complete defenses in general (instead of to superior orders specifically) and thus imply that although the defense of superior orders is not available, the defendant can still resort to another defense (such as duress or mistake) when a moral choice is absent. ${ }^{513}$ Either way, the defendant has a way out. Still, what this "way out" looks like is not exactly clear, because the Tribunal does not define the concept of moral choice.

Apart from the arguments and statements derived from the quote above, there is another reason why the Nuremberg restriction on superior orders is not as absolute as it may seem:

Article 8 is only applicable to major war criminals

Since the aim of the IMT Charter is to prosecute "major war criminals" (article 6 IMT Statute), the a priori exclusion of superior orders could only be applicable to this category of defendants. Consequently, the defense may still be available to defendants from lower echelons.

In sum, the IMT Charter a priori excludes the defense of superior orders, but leaves it open as (a) a mitigating factor and possibly (b) as a complete defense in case of low ranking perpetrators, low profile crimes and when the defendant had no moral choice.

\section{SUPERIOR ORDERS AND PRESCRIPTION OF LAW IN THE TOKYO JUDGMENT}

Superior orders is a priori excluded as a complete defense by article 6 of the IMTFE Charter. The defense may, however, be considered in mitigation of punishment. The phrasing of the IMTFE provision is different from the Nuremberg article:

Gilbert, J., 2006, p. 151.

Dinstein, Y., The Defence of 'Obedience to Superior Orders', Martinus Nijhoff Publishers, Dordrecht, 1965, p. 152 and Schabas, W.A., Genocide in International Law, Cambridge University Press, 2000, p. 331. 
Neither the official position, at any time, of an accused, nor the fact that an accused acted pursuant to order of his government or of a superior shall, of itself, be sufficient to free such accused from responsibility for any crime with which he is charged, but such circumstances may be considered in mitigation of punishment if the Tribunal determines that justice so requires.

As in the IMT Charter, the defense of prescription of law is expressly excluded in the IMTFE's crimes against humanity provision (article 5(c)). This provision is an exact copy of the Nuremberg article (cited above).

As to the interpretation of the Tokyo provisions, there is hardly any information. Contrary to Nuremberg, superior orders was never raised in Tokyo, neither as a complete defense, nor as a mitigating factor. This remarkable difference can be explained by the fact that while the Germans tended to blame everything on Hitler, the Japanese refused to do the same regarding their emperor. ${ }^{514}$

There are a few - mainly textual - differences between the general superior orders provisions of Nuremberg and Tokyo. Remarkable is that the Tokyo provision includes the - procedural - official position defense. The provision also stresses that superior orders does not "of itself" relieve a person from criminal responsibility. These words suggest that the superior orders defense can be admissible in conjunction with other defenses, an idea which can also be read in the IMT's "moral choice" statement. ${ }^{515}$

In conclusion, Tokyo seems to follow Nuremberg in that superior orders is excluded as a complete defense but can be brought up (a) in mitigation and (b) possibly in conjunction with other defenses.

\section{SUPERIOR ORDERS AND PRESCRIPTION OF LAW AT THE ICTY}

The ICTY follows the line of Nuremberg and Tokyo. The defense of superior orders is a priori excluded by article 7(4) of the ICTY Statute and can merely be considered in mitigation of punishment. The verbatim text of the ICTY provision is only slightly different from the Nuremberg article:

The fact that an accused person acted pursuant to an order of a Government or of a superior shall not relieve him of criminal responsibility, but may be considered in mitigation of punishment if the International Tribunal determines that justice so requires.

Despite of the fact that superior orders is a priori excluded as a complete defense, it was discussed on several occasions. All discussions confirm the rule set out in

\footnotetext{
514 Cassese, A. and, Röling, B.V.A., The Tokyo Trial and Beyond, Polity Press, Cambridge, 1993, p. 107 and Poelgeest, L. van, 1989, p. 23.

515 Originally the words "of itself" appeared in the IMT draft article. These words were deleted at the London conference. See: Sliedregt, E. van, 2012, pp. 289/290.
} 
article 7(4). The Appeals Chamber in Prosecutor v. Boškoski and Tarčulovski, for example, confirms the preclusion on superior orders as a complete defense. ${ }^{516}$ The ban on prescription of law as a complete defense is confirmed in Prosecutor $v$. Krnojelac. ${ }^{517}$ In Prosecutor v. Erdemovic the defendant raises the plea of superior orders in combination with duress. The Erdemović Trial Chamber asserts that superior orders could be a valid mitigating factor. ${ }^{518}$ The Appeals Chamber states that the presence of superior orders can be taken into consideration in conjunction with other circumstances of the case in assessing whether the defenses of duress or mistake of fact are made out. ${ }^{519}$ The appeal to duress was rejected in Erdemović (see below), but the existence of a superior order was considered a factor in accepting duress as a mitigating circumstance. ${ }^{520}$ After Erdemović, superior orders has been brought up in mitigation, but was never accepted at the ICTY. ${ }^{521}$

\section{SUPERIOR ORDERS AND PRESCRIPTION OF LAW AT THE ICTR}

As in the ICTY Statute, the defense of superior orders is a priori excluded by article 6(4) of the ICTR Statute and can only be considered in mitigation. The provision has the same verbatim text as the ICTY provision (cited above). The complete defense was only once discussed in mitigation and rejected. ${ }^{522}$

\section{SUPERIOR ORDERS AND PRESCRIPTION OF LAW AT THE ICC}

\subsection{Applicability}

Contrary to the previous tribunals, the ICC Statute recognizes the defense of "Superior orders and prescription of law" in article 33 of its Statute:

1. The fact that a crime within the jurisdiction of the Court has been committed by a person pursuant to an order of a Government or of a superior, whether military or civilian, shall not relieve that person of criminal responsibility unless:

\footnotetext{
516 ICTY, Prosecutor v. Boškoski and Tarčulovski, Appeals Chamber, 19 May 2010, par. 167.

517 ICTY, Prosecutor v. Krnojelac, Trial Chamber, 15 March 2002, par. 114.

518 ICTY, Prosecutor v. Erdemović, Trial Chamber, 27 November 1996, par. 53.

519 ICTY, Prosecutor v. Erdemović, Appeals Chamber, 7 October 1997, par. 34.

520 ICTY, Prosecutor v. Erdemović, Trial Chamber, 5 March 1998, par. 17. This is in line with the Report of the Secretary-General Pursuant to Paragraph 2 of Security Council Resolution 808 (1993), UNSC Doc. S/25704 (1993).

521 ICTY, Prosecutor v. Mrđa, Trial Chamber, 31 March 2004, par. 67; ICTY Prosecutor v. Bralo, Trial Chamber, 7 December 2005, par. 56 and ICTY, Prosecutor v. Češić, Trial Chamber, 11 March 2004, par. 95-97.

522 ICTR, Prosecutor v. Bagosora et al., Trial Chamber, 18 December 2008, par. 2274.
} 
(a) The person was under a legal obligation to obey orders of the Government or the superior in question;

(b) The person did not know that the order was unlawful; and

(c) The order was not manifestly unlawful.

2. For the purposes of this article, orders to commit genocide or crimes against humanity are manifestly unlawful.

Unlike the earlier tribunals, the provision does not mention superior orders as a ground for mitigation. However, an unsuccessful appeal to superior orders could still be a mitigating factor under Rule 145(2)(a)(i), which provides that "circumstances falling short of constituting grounds of exclusion of criminal responsibility, such as substantially diminished mental capacity" may be taken in mitigation.

\subsection{Scope}

Article 33 is different from most provisions featuring complete defenses in that it is phrased in a negative way. ${ }^{523}$ In principle, the appeal to superior orders is excluded (heading paragraph 1). However, if certain conditions have been met, the defense may still be available (conditions (a)-(c) in paragraph 1). Unless - and this is an $a$ priori exclusion - the crime ordered constituted either of genocide or a crime against humanity. According to Zimmerman, the negative phrasing of article 33 implies a narrow interpretation. ${ }^{524}$ In short, these are the requirements for a successful appeal to superior orders under the ICC Statute:

a. The order must involve a crime within the jurisdiction of the Court;

b. The crime was committed pursuant to an order;

c. The order came from the government or from a superior;

d. The government or superior is either military or civilian;

e. The defendant was under a legal obligation to obey the order (condition (a));

f. The defendant did not know that the order was unlawful (condition (b));

g. The order was not manifestly unlawful (condition (c));

h. The order did not amount to the commission of genocide or crimes against humanity.

Below the different requirements of the article are set out in detail.

523 Triffterer, O., 2008, p. 922. The other ICC provision that is phrased in a negative way is article 32(2) on mistake of law, of which article 33 is an extension.

524 Zimmermann, A., 2002, p. 967. 
(a) The order has to involve a crime within the jurisdiction of the Court

Since the order has to involve "a crime within the jurisdiction of the court", the order must be a violation of the ICC Statute. ${ }^{525}$ What is more, all ICC requirements for jurisdiction (personal, temporal, geographical and subject matter) must have been fulfilled (articles 5, 11 and 12 of the ICC Statute).

\section{(b) The crime was committed pursuant to an order}

There must be a causal relation between order and crime. ${ }^{526}$ If a commander orders a soldier to commit a war crime (e.g. killing a civilian) and the soldier decides to commit another war crime (e.g. destroying protected property) article 33 is not applicable, despite the fact that there was both an order and a crime.

(c) The order came from the government or from a superior

An 'order by a government' is an order that comes from a legally established - or de facto accepted - government of a State, that has issued an order which is - at least formally - in accordance with the rules of that specific government. ${ }^{527}$ An 'order by a superior' is an order issued by an individual, not necessarily on behalf of the government. ${ }^{528}$ The expression 'government or superior' does not refer to alternatives: ${ }^{529}$ an order in the sense of article 33 can, for example, be issued by a superior government official.

\section{(d) The government or superior is either military or civilian}

Both the government and the superior can be either military or civilian. ${ }^{530} \mathrm{An}$ order can thus emanate from a military branch of the government, a civil servant, a military superior or a civilian superior outside the government. An example of the latter would be a corporate superior. ${ }^{531}$ Also superiors from international organizations such as the Security Council or the NATO can issue orders in the sense of article 33.532

(e) The defendant was under a legal obligation to obey the order

According to paragraph 1(a) of article 33, the defendant must have been under a legal obligation to obey the orders. The obligation can either arise from national or

\footnotetext{
525 Triffterer, O., 2008, p. 927.

526 Triffterer, O., 2008, p. 925.

527 Triffterer, O., 2008, p. 924.

528 Triffterer, O., 2008, p. 924.

529 Triffterer, O., 2008, p. 924.

530 Triffterer, O., 2008, p. 924.

531 Triffterer, O., 2008, p. 925. According to Triffterer, however, in case of civil enterprises it will be hard to fulfill the requirements of article 33. Zimmermann, has a contrary position. He holds that civilian orders fall outside the scope of article 33, but does not substantiate this conclusion. See: Zimmermann, A., 2002, p. 969.

Triffterer, O., 2008, p. 922.
} 
from international law.533 The requirement of a legal obligation excludes legal figures as incitement from the scope of article $33^{534}$ as well as orders issued by a criminal organization, for they are not legal obligations. ${ }^{535}$ However, the distinction between government/military/civil corporation on the one hand, and criminal organization on the other, is not always clear-cut. How about criminal governments or rebel commanders? It is not apparent whether these entities are covered by article 33.536

The requirement of a legal obligation is an objective requirement, which must exist at the time of the crime. ${ }^{537}$ On the hypothetical case of the defendant who thought he was under a legal obligation to obey orders (but in fact was not) doctrine is divided. According to Triffterer and Zimmermann this situation can trigger the application of article 32 (mistake). ${ }^{538}$ They, however, refrain from explaining this vision. Van Sliedregt and Cryer disagree with these authors. Their argument is that article 32 only covers mistakes that negate mens rea, while article 33 , on the contrary, is written for cases where the mental element is not negated. ${ }^{539}$ Consequently, a mistake related to the legal obligation ex article 33(1)(a) falls outside the scope of both article 32 and article 33. This can be illustrated by the following example:

A commander orders a soldier to kill a civilian who has allegedly been sentenced to death. The soldier - due to an error of law or fact - does not know that this civilian has not been tried and convicted and thinks he is under the legal obligation to obey. Still, the soldier intentionally kills a civilian, i.e. the mental element for the crime can be established. Since the mental element can be established, article 32 (mistake) is not applicable. However, because the soldier only thought he had to obey (while in fact he did not have to), article 33 (superior orders) is not applicable either.

A mistake related to the legal obligation ex article 33(1)(a) thus falls outside the scope of both article 32 and article 33. On the other hand, if - based upon article 31(2), which allows the court to adapt existing defenses - article 32 is interpreted to include an element of blameworthiness, and thus mistakes related to defenses, it could cover errors related to the legal obligation ex article 33. A similar result can be attained when article 33(1)(a) is altered to include mistaken obligations based upon article 31(2). In both cases the soldier's criminal responsibility would be negated if he could not have known that the order was not legally binding.

\footnotetext{
533 Sliedregt, E. van, 2012, p. 395. Cryer only mentions domestic law. See: Cryer, R. et al., 2010, pp. $417 / 418$.

534 Zimmermann, A., 2002, p. 969.

535 Triffterer, O., 2008, p. 924.

536 Cryer, R. et al., 2010, p. 317.

537 Triffterer, O., 2008, p. 926.

538 Triffterer, O., 2008, p. 927 (when the error is based on a false awareness of the factual situation) and Zimmermann, A., 2002, p. 969.

539 Sliedregt, E. van, 2012, p. 295 and Cryer, R., et al, 2010, around p. 317.
} 


\section{(f) The person did not know that the order was unlawful}

According to paragraph 1(b) of article 33, the defendant must not have been aware of the unlawfulness of the relevant order. The absence of the knowledge of the unlawfulness probably extends to having doubts about the legality of the order, for doubts do not equal knowledge. ${ }^{540}$ The word "unlawful" in this requirement refers to a crime within the jurisdiction of the Court. ${ }^{541}$ The test of this requirement is subjective: if the defendant lacks knowledge, this requirement has been met. The reason why he lacks knowledge is irrelevant. ${ }^{542}$

\section{(g) The order was not manifestly unlawful}

Paragraph 1 sub (c) requires that the order is not manifestly unlawful. This is a correction on the low threshold of paragraph 1(b): the defense of superior orders is available to the defendant who does not know the order was unlawful unless ... the order is manifestly unlawful. The requirement of absence of manifest unlawfulness investigates whether the defendant was culpably ignorant of the illegality of the order. If the order was obviously illegal, the defendant is to blame. An appeal to superior orders can thus only be successful if the blameworthiness of the defendant was absent. ${ }^{543}$ Criteria for manifest illegality can hardly be derived from secondary literature ${ }^{544}$ other than that the illegality has to be obvious to a person of ordinary understanding. ${ }^{55}$ Van Sliedregt, however, suggests that the standards for manifest illegality must be particularized according to rank and experience of the defendant. Some crimes may be manifestly illegal to a commander, she argues, but not to a soldier. ${ }^{546}$ Either way, the requirement is objective. ${ }^{547}$ Paragraph 2 of article 33 establishes that genocide and crimes against humanity are always manifestly illegal (see below).

(h) Orders to commit genocide or crimes against humanity are manifestly unlawful (section 2)

Since following orders to commit genocide or crimes against humanity are a priori excluded from the protection of article 33 , this provision can only be applicable in

$540 \quad$ Triffterer, O., 2008, p. 927.

541 Triffterer, O., 2008, p. 927; Zimmermann, A., 2002, p. 969. The defendant probably does not have to know that the ICC has jurisdiction (for this is a rather complex matter), but only that his behavior is criminal under international criminal law.

542 Triffterer, O., 2008, p. 927 and Zimmermann, A., 2002, p. 970.

543 Zimmermann, A., 2002, 970.

544 On superior orders (i.e. not in the context of the ICC), Mark Osiel argues that an order is manifestly unlawful when 1) the prohibition of the commanded act is exceptionally clear, 2) the act is likely to produce the very gravest human rights consequences and 3) the act transgresses established procedures. See: Osiel, M.J., Obeying Orders. Atrocity, Military Discipline and the Law of War, Transaction Publishers, New Brunswick/London, 1999, p. 83.

547 Zimmermann, A., 2002, p. 970. 
case of war crimes (and (after 2017) possibly aggression). It is worth noting that crimes against humanity and genocide can be committed by everybody, while war crimes can only be perpetrated by military and paramilitary persons. Currently article 33 thus only protects this latter category of persons. ${ }^{548}$

\section{Objective/subjective}

Most requirements are assessed from an outsider perspective. Superior orders thus requires a largely objective test. Only requirement (g) (requirement (1)(b) in article 33) is a subjective requirement, investigating the state of mind of the perpetrator (his knowledge of unlawfulness) at the time the crime was committed.

\subsection{Relationship with article 32}

As to the relationship between article 33 (Superior orders) and article 32 (Mistake) of the ICC Statute, Chapter VII explains that article 33 is a specific form of mistake of law. Article 32(2) namely states that mistake of law is not a complete defense, unless the mistake (a) negates mens rea or (b) comes down to a superior order ex article 33. The main difference between these two options is that in the first case mens rea is negated by the mistake, while in the second case the defendant does possess the requisite mens rea, but is not blameworthy, because he did not know and could not have known that he was committing a crime. Article 33 is thus an extension of article 32(2). ${ }^{549}$ However, if blameworthiness should be read into article 32 , as some authors have suggested, the article 33 situation would also fall within the scope of article 32 . In this case article 33 would technically become superfluous, although one may argue that, due to its explicit criteria for the absence of blameworthiness, it is not.

\subsection{Superior orders and superior responsibility}

The legal figure of superior orders should not be confused with the legal figure of superior responsibility. In case of a superior order, the superior is always criminally responsible, whether or not the subordinate can successfully plead the defense ex article $33 .{ }^{550}$ The responsibility of the superior is then based on article 25(3)(b) of the ICC Statute (individual criminal responsibility) and not on article 28 (responsibility of commanders and other superiors). Article 28 is written for the situation where there is no superior order, but the superior should have paid more attention to what his subordinates were doing. ${ }^{551}$

\footnotetext{
548 Triffterer, O., 2008, p. 928.

549 Cryer, R. et al., 2010, p. 420.

550 Knoops, G.J., 2001, p. 162.

551 Triffterer, O., 2008, p. 929.
} 
Chapter VIII

\section{ANALYSIS OF SUPERIOR ORDERS}

\subsection{Applicability}

Until the establishment of the ICC, all tribunals a priori rejected the defense of superior orders in their statutes. The ICC is the first international court that makes this defense available, be it under limited circumstances: the defense is still $a$ priori excluded in case of crimes against humanity and genocide. Superior orders has never been accepted in case law. The only case in which the a priori rejection of superior orders is substantiated is the Nuremberg Judgment. The IMT refers to the a priori rejection in its Statute and stresses that this provision is in conformity with the law of all nations. As has been demonstrated above, this is not true.

Interesting is that in its rejection of superior orders the Nuremberg Tribunal leaves the door to this defense slightly open in case of low ranking perpetrators, low profile crimes and in situations where the defendant lacks a moral choice. Later tribunals (IMTFE and ICTY) seem to confirm the idea that superior orders may be available in a limited amount of cases, by suggesting that it could be a complete defense in combination with other defenses. The ICC puts the ideas of the previous tribunals into practice by admitting superior orders as an extended version of mistake of law, that is only applicable in case moral choice is lacking. In this context 'moral' refers to the requirement that the defendant could not have known that the order was unlawful (manifest illegality) and 'choice' to the condition that the defendant did not know that the order was unlawful (knowledge). 552 The requirements of the ICC provision show traces of the other openings left in the Nuremberg Judgment, for an appeal to article 33 is more likely to succeed in case of a low ranking perpetrator (who does not have an extensive knowledge of international criminal law and has a legal obligation to obey his superior), committing a low profile crime (that is not manifestly unlawful as, for example, large-scale killings). ${ }^{553}$ All courts recognize superior orders as a mitigating factor, but they never accepted the defense as such.

\subsection{Scope}

Since superior orders has been persistently a priori rejected, the only available criteria for this defense come from the ICC Statute and have been discussed in the previous Section. 


\subsection{Categorization}

Chapter II has demonstrated that international criminal theory distinguishes between three different types of complete defenses. The question answered in this subsection is whether superior orders in international criminal law matches any of these three types. More precisely: what is the effect of the presence of a superior order on the offense charged?

When the - only available ICC - criteria for superior orders have been met, the blameworthiness of the perpetrator is absent, ${ }^{554}$ because he was under a legal obligation to obey, as he did not know about the unlawfulness of the order and as he could not have been aware of it. Consequently, he had no ability to choose, did what any reasonable person would have done or had no freedom of will, mental capacity or knowledge of law. However, his act is still wrongful (the ordering superior is still criminally responsible). Superior orders is thus an excuse ${ }^{555}$ and must be classified as follows:

\begin{tabular}{|l|l|l|l|}
\hline Defense & Effect & $\begin{array}{l}\text { Justification or } \\
\text { excuse? }\end{array}$ & Affirmative or not? \\
\hline $\begin{array}{l}\text { No definitional } \\
\text { subjective element }\end{array}$ & $\begin{array}{l}\text { Defense negates } \\
\text { definitional subjective } \\
\text { element }\end{array}$ & Excuse & Not affirmative \\
\hline No blameworthiness & $\begin{array}{l}\text { Defense negates } \\
\text { blameworthiness }\end{array}$ & Excuse & Affirmative \\
\hline
\end{tabular}

\subsection{Respondeat superior or strict liability?}

In the introduction to this Chapter, the question was put which of the theories on superior orders (respondeat superior, strict liability and conditional liability) are predominant in international criminal law. The separate Sections on the different international courts in this Chapter have demonstrated that international criminal law has recently moved from a model of (not completely airtight) absolute liability to a split model of on the one hand (airtight) absolute liability and on the other hand conditional liability. The statutes of the IMT, IMFTE, ICTY and ICTR all demonstrate a strict liability approach: superior orders is not a complete defense in international criminal law. However, the case law of some of these tribunals - and the wording of the IMTFE provision - leave room for a conditional liability approach: Nuremberg with its moral choice test (which can be interpreted in various ways) and the IMTFE and ICTY by suggesting the possibility of superior orders as

554 Compare Sliedregt, E. van, 2012, p. 295, who makes the same observation but refers to the requirements (a)-(c) as demonstrating 'good faith' instead of blameworthiness.

555 See also: Knoops, G.J., 2001, p. 171; Nill-Theobald, C., 1998, p. 166; Sliedregt, E. van, 2012, p. 298 and Triffterer, O., 2008, p. 920. 
a defense in combination with other defenses. Remarkable is that the ICC provision takes a different direction than the previous tribunals: it explicitly makes the defense available in specific circumstances. Although article 33 reflects a strict liability approach in case of genocide and crimes against humanity, it exposes a clear conditional liability approach (based on the obligation to obey, knowledge and manifest illegality, i.e. blameworthiness) in case of war crimes. ${ }^{556}$ None of the tribunals have adopted the national law theory of respondeat superior.

\subsection{Conclusion on superior orders}

Only recently superior orders has been explicitly added to the catalogue of available complete defenses in international criminal law. Since the only criteria for this defense are those mentioned in the ICC Statute, the final questions to this Section are related to the relatively new ICC criteria for superior orders:

1. Should superior orders in general be a complete defense in international criminal law?

2. And if so, are the ICC criteria adequate?

\subsection{Preview Part III}

Part III of this thesis demonstrates that superior orders should be a complete defense in international criminal law. However, this defense is already covered by the suggested mistake provision. Consequently, superior orders as a separate defense is superfluous. 


\section{Chapter IX NeCESSITY AND DURESS}

\section{INTRODUCTION}

The notions of 'necessity' and 'duress' in international criminal law are employed to describe a similar defense. Namely, the defense where the defendant claims he committed a crime because he found himself in an extreme situation. For example, A assaults B. However, A was forced at gunpoint to do so by C. Because A acted under extreme pressure, he is not criminally responsible. Necessity/duress has been discussed at the IMT, the IMTFE, the ICTY and the ICTR. The defense can also be found in article 31(1)(d) of the ICC Statute.

Since the definitions of - and the relation between - the concepts of necessity and duress are not exactly clear, this Chapter investigates - apart from the research questions submitted in the introduction to this Part - three additional questions:

a. Can the defenses brought up in the necessity/duress cases studied be classified as either a justification or an excuse?

b. Is this distinction similar to the distinction between necessity and duress?

c. Can necessity and duress be distinguished by any other feature(s)?

The conclusion to this Chapter demonstrates that most necessity/duress defenses can be defined in terms of a justification or an excuse, but that this categorization does not equal the linguistic distinction between necessity and duress. The word "duress", though, generally refers only to threats by other human beings.

The concept of military necessity is not addressed in this Chapter. This defense is always an element of a criminal law provision. ${ }^{557}$ Consequently, arguing military necessity does not amount to claiming a general substantive defense, but a specific definitional defense. As has been explained in the introduction to this thesis, specific and definitional defenses are not included in this research.

557 Cryer, R. et al., 2010, p. 423; Kalshoven, F. and Zegveld L., 2001, p. 84 and Sliedregt, E. van, 2012, p. 265. 
Chapter IX

\section{NurEMberG}

\subsection{The general part of the Judgment: Plunder}

\subsubsection{Relevant passages}

The general part of the Nuremberg Judgment discusses a necessity/duress defense to the charge of plunder of art in occupied territory (article 6(b) of the IMT Charter). It is not clear who brought up the defense, for the Tribunal only states:

With regard to the suggestion that the purpose of the seizure of art treasures was protective and meant for their preservation, it is necessary to say a few words. ${ }^{558}$

The Tribunal continues by referring to a decree issued by Himmler to, among others, the secret police in the annexed territories:

This decree contained administrative directions for carrying out the art seizure program, and in Clause 1 it stated: "To strengthen Germanism in the defense of the Reich, all articles mentioned in Section 2 of this decree are hereby confiscated ... They are confiscated for the benefit of the German Reich, and are at the disposal of the Reich Commissioner for the Strengthening of Germanism." 559

Finally, the Tribunal adds that:

The intention to enrich Germany by the seizures, rather then protect the seized objects, is indicated in an undated report by Dr. Hans Posse, director of the Dresden State Picture Gallery: "I was able to gain some knowledge on the public and private collections, as well as clerical property, in Cracow and Warsaw. It is true that we cannot hope too much to enrich ourselves from the acquisition of great art works of paintings and sculptures, with the exception of the Veit-Stoß altar, and the plates of Hans von Kulnback in the Church of Maria in Cracow... and several other works from the National Museum in Warsaw." 560

\subsubsection{Applicability}

This fragment displays an indirect recognition of the necessity/duress defense by rejecting the defense on its merits. The defense claims the plunder of art was motivated by honorable intentions such as protection and preservation, but the 
Tribunal demonstrates that evidence shows that the plunder was motivated by enrichment. Consequently, the defendant's intent to do the right thing was lacking.

\subsubsection{Scope}

The fragment demonstrates that in order for a necessity/duress defense to be made out, some sort of honorable intent must be present. This intent is subjectively tested, for written sources displaying motives were available.

\subsubsection{Necessity/duress}

Although technically a necessity/duress-defense was brought up, it is not referred to in any of these terms. Either way, the defense brought up must be categorized as a justification, for the defendant claims he did nothing wrong, by picking the lesser of two evils (protecting art instead of letting it be destroyed).

\subsection{The verdict on Karl Dönitz}

\subsubsection{Relevant passages}

The part of the Nuremberg Judgment that discusses the individual criminal responsibility of the defendants addresses an appeal to necessity/duress by Karl Dönitz, who was, at the time, commander of the submarine fleet. Dönitz is, among other things, charged with violation of the London Naval Agreement of 1930 and its Protocol of 1936, containing rescue provisions for naval warfare, which Dönitz refused to carry out in order to protect his fleet. Or, as the defense argued:

$[\ldots]$ the security of the submarine is, as the first rule of the sea, paramount to rescue, and that the development of aircraft made rescue impossible. ${ }^{561}$

The Tribunal rejects this argument by stating that:

This may be so, but the Protocol is explicit. If the commander cannot rescue, then under its terms he cannot sink a merchant vessel and should allow it to pass harmless before his periscope. ${ }^{562}$

561 International Military Tribunal (Nuremberg), Judgment and Sentences, 1 October 1946, p. 305.

562 International Military Tribunal (Nuremberg), Judgment and Sentences, 1 October 1946, p. 305. 


\subsubsection{Applicability}

The defense of necessity/duress is implicitly recognized for it is rejected on its merits. Dönitz argues that it was impossible to carry out rescue provisions, ${ }^{563}$ because this could only be done at the expense of his own fleet. To him it was either complying with the law by rescuing victims and not securing his submarine, or violating the law by not rescuing and securing his submarine. Although, the Tribunal seems to believe that rescue without harm to the submarine was impossible at the moment of the crime, it rejects the defense because a commander who cannot rescue, should not sink boats in the first place. Dönitz, in other words, made a wrong choice at an earlier moment. He did not have to sink the merchant vessel. Another course of action was open to him. The legal consequence of the rejection of this appeal to necessity/duress is of no connotation because, in the end Dönitz's sentence is not assessed on "his breaches of the international law of submarine warfare" based on a tu quoque reasoning (see Chapter XI). ${ }^{564}$

\subsubsection{Scope}

The rejection of the defense of necessity/duress is based on the fact that Dönitz should have made a different decision at an earlier moment (prior fault). He was not forced to commit a crime. The rejection is based on an objective test.

\subsubsection{Necessity/duress}

Although technically a necessity/duress-defense was brought up, it is not referred to in any of these terms. Either way, technically the defendant brings up two defenses: a justification and an excuse. A justification, for the defendant claims he picked the lesser of two evils. An an excuse, because the defendant claims that complying with the rules was impossible.

563 The verbatim text of the provision referred to in the Judgment (article 22 of the London Naval Agreement of 1930), to which the 1936 protocol refers, is: The following are accepted as established rules of International Law: (1) In their action with regard to merchant ships, submarines must conform to the rules of International Law to which surface vessels are subject.

(2) In particular, except in the case of persistent refusal to stop on being duly summoned, or of active resistance to visit or search, a warship, whether surface vessel or submarine, may not sink or render incapable of navigation a merchant vessel without having first placed passengers, crew and ship's papers in a place of safety. For this purpose the ship's boats are not regarded as a place of safety unless the safety of the passengers and crew is assured, in the existing sea and weather conditions, by the proximity of land, or the presence of another vessel, which is in a position to take them on board. The High Contracting Parties invite all other Powers to express their assent to the above rules.

564 International Military Tribunal (Nuremberg), Judgment and Sentences, 1 October 1946, p. 305. 


\section{ToKyo}

\subsection{The verdict on Shigenori Togo}

\subsubsection{Relevant passages}

In relation to the charge of crimes against peace (article 5(a) of the IMTFE Charter) committed by the Tojo cabinet, former Foreign minister Shigenori Togo argues that:

[...] he joined the TOJO Cabinet on the assurance that every effort would be made to bring the negotiations with the United States to a successful conclusion. ${ }^{565}$

The Tribunal however does not consider Togo's motives for joining the war cabinet legitimate:

[...] when the negotiations failed and war became inevitable, rather than resign in protest he continued in office and supported the war. To do anything else he said would have been cowardly. However his latter action completely nullifies his plea. ${ }^{566}$

\subsubsection{Applicability}

The fragment above demonstrates that an implicit recognition of the necessity/ duress argument for the defense is rejected on its merits. Togo claims he picked the lesser of two evils: he joined the cabinet in order to avoid war. The Tribunal, however, is not convinced by the sincerity of his motives. If he really joined the cabinet in order to retain peace, the Tribunal argues, he should have resigned the minute the war started. The defense is thus rejected because the Tribunal is not convinced that Tojo intended to choose the lesser of two evils.

\subsubsection{Scope}

The fragment demonstrates that in order for a necessity/duress defense to be made out the defendant must have intended to choose the lesser of two evils. This intent is objectively tested.

\footnotetext{
565 Röling and Rüter (eds.), The Tokyo Judgment: The International Military Tribunal of the Far East (I.M.T.F.E.), 29 April 1946 - 12 November 1948, Vol. I, p. 461.

566 Röling and Rüter (eds.), The Tokyo Judgment: The International Military Tribunal of the Far East (I.M.T.F.E.), 29 April 1946 - 12 November 1948, Vol. I, p. 461.
} 
Chapter IX

\subsubsection{Necessity/duress}

Although technically a necessity/duress-defense was brought up, it is not referred to in any of these terms. Either way, the defense brought up must be categorized as a justification, for the defendant claims he picked the lesser of two evils.

\subsection{The verdict on Kenji Dohihara}

\subsubsection{Relevant passages}

To a war crimes charge relating to the ill-treatment of prisoners of war (article 5(b) of the IMTFE Charter) former general Kenji Dohihara brought up the argument that:

[...]the deterioration of Japan's war position in these areas and the severance of communications made it impossible to maintain better supplies for prisoners. ${ }^{567}$

The Tribunal rejects this argument, because:

The evidence shows that food and medicine was available which could have been used to relieve the terrible conditions of the prisoners. These supplies were withheld upon a policy for which DOHIHARA was responsible. ${ }^{568}$

In relation to the food deficiency and malnutrition of the POW's, the Tribunal also notes that:

These conditions applied only to prisoners of war and did not occur among their captors. ${ }^{569}$

\subsubsection{Applicability}

Again the necessity/duress defense is implicitly recognized by rejection on its merits. The Tribunal does not believe that it was impossible for Dohihara to take better care of the prisoners because food and medicine were available and the captors were well fed. Consequently, there was no necessity for ill treatment.

567 Röling and Rüter (eds.), The Tokyo Judgment: The International Military Tribunal of the Far East (I.M.T.F.E.), 29 April 1946 - 12 November 1948, Vol. I, p. 444.

568 Röling and Rüter (eds.), The Tokyo Judgment: The International Military Tribunal of the Far East (I.M.T.F.E.), 29 April 1946 - 12 November 1948, Vol. I, p. 444.

569 Röling and Rüter (eds.), The Tokyo Judgment: The International Military Tribunal of the Far East (I.M.T.F.E.), 29 April 1946 - 12 November 1948, Vol. I, p. 444. 


\subsubsection{Scope}

The fragment demonstrates that in order for a necessity/duress argument to be made out the defendant must have had no other options available to him. If there are other, non-criminal options available to solve a difficult situation, the defense is not available. The rejection of the defense is based on an objective test.

\subsubsection{Necessity/duress}

Although technically a necessity/duress-defense was brought up, it is not referred to in any of these terms. Either way, the defense brought up must be categorized as an excuse, for the defendant does not deny the wrongfulness of his act but instead argues that he had no ability to choose, any reasonable person would have acted the way he did, or that he was not in a position to determine his will freely.

\subsection{The verdict on Seishiro Itagaki}

\subsubsection{Relevant passages}

Also Seishiro Itagaki, who held several top positions within the Japanese army, was charged with war crimes relating to the maltreatment of prisoners of war. According to the Tribunal, he argued that:

[...] the attacks of the Allies on Japanese shipping had made the transportation of supplies to these areas very difficult and that he did the best he could with the supplies he had. After the surrender, however, supplies of food and medicine were made available by Itagaki's Army to the camps in Singapore, Borneo, Java and Sumatra. The explanation tendered in evidence and argument for Itagaki is that the Japanese were expecting a long war and were conserving supplies. This amounts to the contention that Itagaki was justified under the prevailing circumstances in treating the prisoners and internees with gross inhumanity. .570

The Tribunal rejects Itagaki's arguments by stating that:

The Tribunal has no hesitation in rejecting this defense. If Itagaki, being responsible for supplies to many thousands of prisoners and internees, found himself unable to maintain them for the future, his duty under the Laws of War was to distribute such supplies as he had and in the meantime to inform his superiors that arrangements must be made, if necessary with the Allies, for the support of the prisoners and internees in the future. By the policy, which he adopted, he is responsible for the

570 Röling and Rüter (eds.), The Tokyo Judgment: The International Military Tribunal of the Far East (I.M.T.F.E.), 29 April 1946 - 12 November 1948, Vol. I, p. 450. 
Chapter IX

deaths and sufferings of thousands of people whose adequate maintenance was his duty. ${ }^{571}$

\subsubsection{Applicability}

This fragment shows an implicit recognition of the necessity/duress argument, for the defense is rejected on its merits. As in the previous case (Dohihara), the defendant has other options available to him. Although supplies were scarce, Itagaki should have distributed the supplies he had and should have made arrangements for future supplies.

\subsubsection{Scope}

The rejection of the defense of necessity/duress is based on the fact that Itagaki had other options. It was not absolutely necessary to commit a crime. The rejection of the defense is based on an objective test.

\subsubsection{Necessity/duress}

Although technically a necessity/duress-defense was brought up, it is not referred to in any of these terms. Either way, the defense brought up must be categorized as a justification, for the defendant claims he picked the lesser of two evils (the saving of supplies instead of distribution).

\subsection{The Verdict on Iwane Matsui}

\subsubsection{Relevant passages}

General Iwane Matsui was charged with disregarding the duty to take adequate steps to prevent the atrocities committed in Nanking. ${ }^{572}$ Matsui pleaded that "at the time he was ill". 573 The Tribunal rejects this argument by stating that:

His illness was not sufficient to prevent his conducting the military operations of his command nor to prevent his visiting the City for days while these atrocities were occurring. He was in command of the army responsible for these happenings. $\mathrm{He}$

\footnotetext{
571 Röling and Rüter (eds.), The Tokyo Judgment: The International Military Tribunal of the Far East (I.M.T.F.E.), 29 April 1946 - 12 November 1948, Vol. I, p. 450.

572 Under which provision(s) exactly, cannot be derived from the text of the Judgment.

573 Röling and Rüter (eds.), The Tokyo Judgment: The International Military Tribunal of the Far East (I.M.T.F.E.), 29 April 1946 - 12 November 1948, Vol. I, p. 454.
} 
knew of them. He had the power, as he had the duty, to control his troops and to protect the unfortunate citizens of Nanking. ${ }^{574}$

\subsubsection{Applicability}

Again, this fragment shows an implicit recognition of the necessity/duress argument, for the defense is rejected on its merits. The defense is rejected because the defendant has other options available to him. Although the defendant was ill, he still could have - and should have - exercised his power to stop the atrocities.

\subsubsection{Scope}

This fragment demonstrates that it must have been absolutely necessary to commit a crime (no other options available). The rejection of the defense is based on an objective test.

\subsubsection{Necessity/duress}

Although technically a necessity/duress-defense was brought up, it is not referred to in any of these terms. Either way, the defense brought up must be categorized as an excuse, for the defendant does not deny the wrongfulness of his act but claims he had no ability to choose, any reasonable person would have acted the way he did, or that he was not in a position to determine his will freely.

\section{NeCESSITY AND DURESS AT THE ICTY}

\subsection{Prosecutor v. Erdemović}

Prosecutor v. Erdemović is the complete defenses case in international criminal law. The case contains by far the most information on both complete defenses in general and on necessity/duress specifically. Due to both the length of the relevant passages and the multitude of chambers (two Trial Chambers and one Appeals Chamber) and judges (four different opinions) that discussed the case, the necessity/ duress-defense is analyzed in stages and the relevant passages are largely paraphrased. First the judgment of Trial Chamber I is analyzed, then the Appeals Chamber judgment plus the two majority opinions on duress (i.e. the joint opinion of Judge McDonald and Judge Vohrah and the opinion of Judge Li), next the dissenting opinions of Judge Cassese and Judge Stephen are discussed and finally the judgment issued by Trial Chamber II. The dissenting opinion to the second Trial

574 Röling and Rüter (eds.), The Tokyo Judgment: The International Military Tribunal of the Far East (I.M.T.F.E.), 29 April 1946 - 12 November 1948, Vol. I, p. 454. 
Chamber judgment, by Judge Shahabuddeen, is left out of consideration for it contains no information on complete defenses. The last Section on the Erdemovic Judgment displays an analysis of the case as a whole.

\subsubsection{The facts of the case}

The facts of the Erdemovic case were briefly mentioned in the introduction to this thesis. The case revolves around a young Croatian soldier named Dražen Erdemović. In the early nineties he decides to join the VRS to support himself and his family and to gain some status as a Croat in Serbian territory. He deliberately joins a multi-ethnic VRS unit and carries out ordinary military tasks, such as reconnaissance in force. However, after October 1994 the atmosphere in the unit changes, as some Serbian nationalists join. Erdemović loses his rank of lieutenant when he refuses to carry out an order implicating the civilian population. In the early morning of 16 July 1995, Erdemović is ordered to prepare for a secret mission. When he arrives at a farm in Pilica, Erdemović is told he is to massacre hundreds of Muslims that day. He immediately refuses to carry out the order. However, his refusal is countered with an instant death threat. "If you don't carry out the order," his superiors tell him, "you can hand in your rifle and stand between the Muslims, so we can shoot you". Erdemović claims that this threat was real because his superior ordered another refusing soldier to be killed. Despite this he (unsuccessfully) tried to save the life of a man who said he saved Serbs from Srebrenica.

In the end Erdemović chooses to kill. That day he is one of the many participants in the mass killings of 7,000-8,000 Bosnian Muslims following the fall of Srebrenica. Approximately 1,200 of them were murdered at Pilica. Erdemović estimates he killed about 70 men himself, at a Pilica farm.

After these killings at a Pilica farm, Erdemović refuses to participate in another mass killing of approximately 500 Muslims detained in a public building. This refusal is successful and supported by three of his comrades. However, after this refusal one of Erdemović's colleagues attempts to kill him and his comrades by means of payback. Erdemović is seriously wounded and taken to a hospital. ${ }^{575} \mathrm{He}$ decides to tell his story to the press. A few days later he is arrested and brought to the ICTY. Erdemović is charged with crimes against humanity. When pleading guilty to these charges, he adds:

Your honour, I had to do this. If I had refused, I would have been killed together with the victims. When I refused, they told me: "If you're sorry for them, stand up, line up with them and we will kill you too." I am not sorry for myself but for my family, my wife, my son who then had nine months, and I could not refuse because then they would have killed me". 576

576 ICTY, Prosecutor v. Erdemović, Trial Chamber I, 27 November 1996, par. 10. 


\subsubsection{Trial Chamber I}

\section{APPLiCABILITY}

In principle, the first Trial Chamber in Erdemović recognizes the complete defense of necessity/duress, because it "might eliminate the mens rea of the offense". 577 The Trial Chamber notes that although the Statute of the ICTY provides no guidance on duress, the Secretary-General refers to this legal figure in his report. ${ }^{578}$ What is more, a review of the United Nations War Crimes Commission (UNWCC) shows that post-World War Two military tribunals of nine nations considered duress a complete defense. ${ }^{579}$ However, the Trial Chamber stresses that "while the complete defense based on moral duress and/or a state of necessity stemming from superior orders is not ruled out absolutely, its conditions of application are particularly strict". 580 The Trial Chamber holds that the defense of necessity/duress is only applicable in case a superior order can be established first. ${ }^{581}$ Apart from that, the Trial Chamber suggests that in case of crimes against humanity the proportionality requirement can never be met, for "the life of the accused and that of the victim are not fully equivalent". As opposed to ordinary law, a crime against humanity is not directed at the physical welfare of the victim alone but at "humanity as a whole". ${ }^{582}$ A marginal note to this recognition of necessity/duress in principle is that the defense is discussed when assessing the validity of the guilty plea, and not during a full trial, which would probably demand a more thorough assessment.

In casu the complete defense of duress is rejected, because "proof of the specific circumstances which would fully exonerate the accused of his responsibility has not been provided". ${ }^{583}$ This is a rather brief rejection. The Trial Chamber does not specify which kind of proof is necessary to establish necessity/duress and which proof is missing. On the other hand, necessity/duress is rejected in mitigation because the Trial Chamber holds that "the Defense has produced no testimony, evaluation or any other elements to corroborate what the accused has said", 584 thereby indicating examples of the additional evidence missing. The Trial Chamber thus desired some sort of independent evidence supporting Erdemović's testimony (cited above).

\footnotetext{
577 ICTY, Prosecutor v. Erdemović, Trial Chamber I, 27 November 1996, par. 14.

578 ICTY, Prosecutor v. Erdemović, Trial Chamber I, 27 November 1996, par. 16.

579 ICTY, Prosecutor v. Erdemović, Trial Chamber I, 27 November 1996, par. 17.

580 ICTY, Prosecutor v. Erdemović, Trial Chamber I, 27 November 1996, par. 19.

581 ICTY, Prosecutor v. Erdemović, Trial Chamber I, 27 November 1996, par. 19.

582 ICTY, Prosecutor v. Erdemović, Trial Chamber I, 27 November 1996, par. 20.

583 ICTY, Prosecutor v. Erdemović, Trial Chamber I, 27 November 1996, par. 20.

584 ICTY, Prosecutor v. Erdemović, Trial Chamber I, 27 November 1996, par. 91.
} 
Chapter IX

SCOPE

As to the scope of necessity/duress, the Trial Chamber refers to the conditions mentioned in the approximately 2000 duress-cases investigated by the UNWCC:

a. The act charged was done to avoid an immediate danger both serious and irreparable;

b. There was no adequate means of escape;

c. The remedy was not disproportionate to the evil;

d. The act was preceded by a superior order.

Other conditions, derived from these post World War II cases that "further narrow the scope of duress", are:

- The absence of moral choice ("A soldier may be considered as being deprived of his moral choice in the face of imminent physical danger");

- The danger must be the "danger of death or serious bodily harm";

- The danger must be "clear and present" or "imminent, real and inevitable";

- Voluntary participation in an enterprise that leaves no doubt as to its end results must be taken into account when determining the individual responsibility of the accused;

- The rank of the soldier giving an order and the rank of the soldier receiving it, are indicators for the amount of duress exercised. ${ }^{585}$

The requirements for necessity/duress, as described by the Trial Chamber, are all objective. The subjective thoughts of the defendant are irrelevant.

\section{NECESSITY/DURESS}

The Trial Chamber uses the terms 'duress' and 'necessity' as synonyms. It speaks for example of "extreme necessity", 586 "moral duress and/or a state of necessity" 587 and "moral duress accompanied by the order from a military superior (sometimes referred to as "extreme necessity")". 588 What is more, the Trial Chamber also links the defense of necessity/duress to superior orders in that the defense is only applicable if a superior order is established first. 


\subsubsection{Appeals Chamber, Joint Separate Opinion of Judge McDonald and Judge Vohrah and Separate and Dissenting Opinion of Judge Li}

ApPLiCABILITY

When the issue of duress is discussed on appeal, ${ }^{589}$ the majority of the Appeals Chamber in Prosecutor v. Erdemovic rejects duress a priori as a complete defense for soldiers charged with crimes against humanity or war crimes involving the taking of innocent lives. ${ }^{590}$ This means that duress can still be available in other situations, for example, to a civilian taking an innocent life, or to a soldier committing a war crime that does not involve killing. ${ }^{591}$ Significantly the Appeals Chamber speaks of 'soldiers' instead of 'combatants', a more common term in the context of international humanitarian law. This choice of words may extend the group of persons to whom the ruling may apply. ${ }^{592}$ Judge Li adheres to a slightly different definition of the a priori exclusion of duress. According to him, duress is not available, in case of "a heinous crime, the killing of innocent civilians or prisoners of war". ${ }^{593} \mathrm{He}$ does not link the a priori exclusion to soldiers.

That duress is not a complete defense in case of killing, is substantiated by a lengthy argumentation, mainly reflected in the Joint Separate Opinion of Judge McDonald and Judge Vohrah and supported by the Separate and Dissenting opinion of Judge Li. Judge McDonald and Judge Vohrah start by criticizing the Trial Chamber judgment. First, they mention that the ruling of the Trial Chamber is inconsistent by, on the one hand, implying that in case of duress in the context of a crime against humanity, the proportionality requirement will never be fulfilled, while on the other hand, accepting that duress can, theoretically, be a complete defense in such cases. ${ }^{594}$ This, however, does not necessarily have to be inconsistent. The allegations of the Trial Chamber can also be interpreted as an a priori exclusion of duress in case of crimes against humanity, but acceptance in principle of the defense in other cases. ${ }^{595}$ Still, this interpretation is not completely satisfactory, for the Trial Chamber does not reject duress as a complete defense because the crime charged is a crime against humanity, but due to lack of evidence.

589 ICTY, Prosecutor v. Erdemović, Appeals Chamber, 7 October 1997, par. 11.

590 ICTY, Prosecutor v. Erdemović, Appeals Chamber, 7 October 1997, par. 19.

591 Compare: Linton, S., 'Reviewing the Case of Dražen Erdemović: Unchartered Waters at the International Criminal Tribunal for the Former Yugoslavia', In: Leiden Journal of International Law, Vol. 12, 1999, pp. 251-270, p. 264 and Zahar, A. and Sluiter, G., 2008, pp. 426 and 428.

592 Linton, S., 1999, p. 263.

593 ICTY, Prosecutor v. Erdemović, Separate and Dissenting Opinion of Judge Li, Appeals Chamber, 7 October 1997, par. 5.

594 ICTY, Prosecutor v. Erdemović, Joint Separate Opinion of Judge McDonald and Judge Vohrah, Appeals Chamber, 7 October 1997, par. 37.

595 Noted by Judge Stephen: ICTY, Prosecutor v. Erdemović, Separate and Dissenting Opinion of Judge Stephen, Appeals Chamber, 7 October 1997, par. 17. 
Second, Judges Vohrah and McDonald hold that the Post World War II case law, cited by the Trial Chamber, does not demonstrate a rule of customary law making duress available in case of killing. First, because the UNWCC did not specifically address the question whether duress afforded a defense to crimes involving the killing of innocent persons. Second, because the case law investigated by the UNWCC does not support the position that duress may be pleaded as a defense to a war crime involving the killing of innocents. Third, because the only case that seems to affirm the availability of duress in case of killing innocents, Einsatzgruppen, is (a) of doubtful authority for it does not refer to precedents and (b) even if this judgment would have been supportable in its time, its view cannot presently constitute authority in the light of the development of law. In order to support this last assertion Judge McDonald and Judge Vohrah show examples from national law, doctrine, and from a commentary by the International Law Commission (ILC) that demonstrate the incompatibility of duress and killing. In his separate opinion Judge Li adds that (c) the relevant passage from the Einsatzgruppen Judgment is merely a "dictum" and that (d) the appeal to duress was rejected in casu. The fourth reason why no customary rule on duress in case of killing can be deduced from post-World War II case law is, according to all three Judges, that the frequently cited moral choice-passage from the Nuremberg Tribunal does not establish a clear rule on the issue. ${ }^{596}$

Third, Judges McDonald and Vohrah hold that other cases that were brought up as "supporting the position that duress is a complete defense to the killing of innocents" do not demonstrate the existence of a rule of customary law either because of questionable relevance and authority, lack of uniform state practice or the questionable international character of the relevant courts. ${ }^{597}$

Based on the second and the third argument, all three Judges concluded that there is no rule of customary law on duress in case of killing innocents. However, although Judge Li acknowledges that there is no rule of customary law on duress in case of killing innocents, ${ }^{598}$ a few paragraphs ahead he holds that post-World War II case law establishes that duress can be a complete defense unless "the act was a heinous crime, for instance, the killing of innocent civilians or prisoners of war". 599 Li thus first denies that there is a customary rule, but later acknowledges that there is one. Since the Appeals Judgment holds that it rejects duress in the relevant situation "for reasons set out in the Joint Separate Opinion of Judge McDonald and Judge Vohrah and the Dissenting opinion of Judge Li", the contradictory statements

\footnotetext{
596 ICTY, Prosecutor v. Erdemović, Joint Separate Opinion of Judge McDonald and Judge Vohrah, Appeals Chamber, 7 October 1997, par. 42-45.

597 ICTY, Prosecutor v. Erdemović, Joint Separate Opinion of Judge McDonald and Judge Vohrah, Appeals Chamber, 7 October 1997, par. 48.

598 ICTY, Prosecutor v. Erdemović, Separate and Dissenting Opinion of Judge Li, Appeals Chamber, 7 October 1997, par. 2.

599 ICTY, Prosecutor v. Erdemović, Separate and Dissenting Opinion of Judge Li, Appeals Chamber, 7 October 1997, par. 5.
} 
of Judge Li confuses the contents of the majority opinion regarding the existence of a customary rule on duress in case of killing innocents.

Next, Judges Vohrah and McDonald investigate whether "a general principle of law recognized by civilized nations" might provide guidance on the relevant issue. ${ }^{600}$ After investigating dozens of domestic legal systems they conclude that, in general, a person acting under duress is considered less blameworthy. However and this is the fourth argument supporting the majority duress-rule - due to the different solutions in common and civil law systems, there is no specific general principle, on duress in case of killing innocents. ${ }^{601}$

Because there is both no customary law and no general principle on duress in case of killing innocents, the Judges decide to approach the problem from a different angle. They introduce a (fifth) policy argument for rejecting duress in the relevant situation. As to the contents of this policy argument, Judge Vohrah and Judge McDonald reason that the ICTY is operating in the realm of international humanitarian law, which has the objective of protecting the weak. According to the Judges, denying duress in case of killing innocents contributes to realizing this objective, for it has a normative effect. ${ }^{602}$ Judge Li specifies this normative effect. He holds that admission of duress in situations like Erdemović's encourages the subordinate under duress to kill and helps the superior in his attempt to kill. ${ }^{603}$ Referring to British Law, Judge McDonald and Judge Vohrah note that similar contemplations underlie national legislation on denying duress in case of killing. Therefore, in the context of international criminal law, duress should a fortiori be excluded in lethal cases (these cases deal with "murders often of a greater magnitude"). McDonald and Vohrah defend their policy argument by holding that separating law from social policy is inapposite because, both domestic and international law are always directed towards aims. Law and policy are therefore intertwined. 604

The sixth argument brought up by the majority is the rejection of the 'Masetti approach', referred to by Judge Casesse in his dissenting opinion (discussed below). The approach is named after the Italian Masetti case where duress was held to be admissible in cases where the victim would have died anyway. 605 Judges McDonald and Vohrah start to reject this approach because it is based on

600 ICTY, Prosecutor v. Erdemović, Joint Separate Opinion of Judge McDonald and Judge Vohrah, Appeals Chamber, 7 October 1997, par. 56.

601 ICTY, Prosecutor v. Erdemović, Joint Separate Opinion of Judge McDonald and Judge Vohrah, Appeals Chamber, 7 October 1997, par. 66.

602 ICTY, Prosecutor v. Erdemović, Joint Separate Opinion of Judge McDonald and Judge Vohrah, Appeals Chamber, 7 October 1997, par. 75-77.

603 ICTY, Prosecutor v. Erdemović, Separate and Dissenting Opinion of Judge Li, Appeals Chamber, 7 October 1997, par. 8.

604 ICTY, Prosecutor v. Erdemović, Joint Separate Opinion of Judge McDonald and Judge Vohrah, Appeals Chamber, 7 October 1997, par. 79.

605 ICTY, Prosecutor v. Erdemović, Joint Separate Opinion of Judge McDonald and Judge Vohrah, Appeals Chamber, 7 October 1997, par. 78. 
the "strict utilitarian logic" that "if the victim will die anyway, the accused is not at all morally blameworthy for taking part in a execution". Judges McDonald and Vohrah argue there are more ways to look at duress in case of killing than reducing it to a "balancing of harms". They repeat their policy argument. They also point out that recourse to the "utilitarian" proportionality criterion runs into practical problems, for it is impossible to "weigh" human lives. Because of this impossibility, Judges McDonald and Vohrah opt for mitigation as the appropriate tool in these cases. Another point of criticism on the Masetti reasoning by Judges McDonald and Vohrah is that this approach is a "half-way house". It is not an answer to the criticism on the majority approach, which, according to the minority, "expects from its subjects what no reasonable man can live up to". According to Judges McDonald and Vohrah "[t]his is because it is equally unrealistic to expect a reasonable person to sacrifice his own life or the lives of loved ones [...] even if by this sacrifice, the lives of the victims would be saved." They add that "Either duress should be admitted as a defense to killing innocent persons generally based upon an objective test of how the ordinary person would have acted in the same circumstance or not admitted as a defense to murder at all". ${ }^{606}$ Judge Li generally holds that the Masetti argument is absurd because "it would justify every one of the criminal group who participated in the joint massacre of innocent persons". 607

Although Judge McDonald and Judge Vohrah seem to favor the reasonable person test over the Masetti approach, they reject this test as well (seventh argument), Firstly, because whether duress is a defense in case of killing should not be dependent on a reasonable person test but must be determined by "an absolute moral postulate". Secondly, because soldiers should exercise a greater degree of resistance to a threat than civilians. A reasonable soldier test is, however, no option, because it is simply unacceptable that a trained fighter would have recourse to duress. Thirdly, because an a priori rejection of duress in case of killing does not expect a person to be a hero and "throw his life away", for, the threat under which the defendant acted can mitigate his punishment, in some cases even to "no punishment at all". 608

The legal consequence of the a priori rejection of duress as a complete defense in case of killing by the majority of the Appeals Chamber is that duress is not available to Erdemović as a complete defense when re-pleading, but only as a mitigating factor.

606 ICTY, Prosecutor v. Erdemović, Joint Separate Opinion of Judge McDonald and Judge Vohrah, Appeals Chamber, 7 October 1997, par. 79-81 and 83.

607 ICTY, Prosecutor v. Erdemović, Separate and Dissenting Opinion of Judge Li, Appeals Chamber, 7 October 1997, par. 11.

608 ICTY, Prosecutor v. Erdemović, Joint Separate Opinion of Judge McDonald and Judge Vohrah, Appeals Chamber, 7 October 1997, 7 October 1997, par. 83-85. 
SCOPE

Judges McDonald and Vohrah define duress as "imminent threats to the life of an accused if he refuses to commit a crime". ${ }^{609}$ They, however, do not explicitly say that the defense is available in case the relevant crime is not committed by a soldier charged with crimes against humanity or war crimes involving the killing of innocents, nor do they provide criteria for duress in such a case (i.e. in cases where duress is not a priori excluded). ${ }^{610}$ Judge Li, however, does mention criteria applicable to other cases of duress:

a. The fact was done to avoid an immediate danger both serious and irreparable;

b. There was no adequate means of escape; and

c. The remedy was not disproportionate to the evil. ${ }^{611}$

These are the same criteria as the ones mentioned by Trial Chamber I and are objective criteria as well. Considering the contemplations by Judges McDonald and Vohrah on the increased responsibility of a soldier, criterion (b) should probably be tested more strictly when a soldier commits a crime other than killing, for a soldier should try harder to find an alternative means of escape.

\section{NeCESSITy/Duress}

Judges Vohrah, McDonald and Li use the word "duress" consistently. They define this concept as described above, under Scope. On the relationship between superior orders and duress they hold:

Superior orders and duress are conceptually distinct and separate issues and often the same factual circumstances engage both notions, particularly in armed conflict situations. [...] As superior orders may be considered merely as factual element in determining whether duress is made out on the facts, the absence of a superior order does not mean that duress as a defense must fail. ${ }^{612}$

609 ICTY, Prosecutor v. Erdemović, Joint Separate Opinion of Judge McDonald and Judge Vohrah, Appeals Chamber, 7 October 1997, 7 October 1997, par. 66.

610 They, however, do cite the general requirements for duress provided by the UNWCC: ICTY, Prosecutor v. Erdemović, Joint Separate Opinion of Judge McDonald and Judge Vohrah, Appeals Chamber, 7 October 1997, par. 42.

611 ICTY, Prosecutor v. Erdemović, Separate and Dissenting Opinion of Judge Li, Appeals Chamber, 7 October 1997, par. 5.

612 ICTY, Prosecutor v. Erdemović, Joint Separate Opinion of Judge McDonald and Judge Vohrah, Appeals Chamber, 7 October 1997, 7 October 1997, par. 34-36. 
Chapter IX

\subsubsection{Separate and dissenting opinion of Judge Cassese}

\section{APPLICABILITY}

Judge Cassese recognizes the defense of duress in principle. Consequently, when it concerns duress in case of killing innocents, he disagrees with the conclusions of the majority. Firstly, because the majority, after concluding that there is no specific international rule on duress in case of killing, should have fallen back on the general rule of international law ${ }^{613}$ (or, if an international rule is lacking, to the law applicable in the former Yugoslavia). ${ }^{614}$ Consequently, a policy-oriented approach based on notions of common-law countries runs contrary to the principle of nullum crimen sine lege. ${ }^{615}$

When duress cannot be admitted as a defense, Cassese holds it can be taken in mitigation. ${ }^{616}$ Cassese agrees with the majority that the case should be remitted to the Trial Chamber. However, he holds that the Trial Chamber should enter a notguilty plea in order to satisfy itself, during a full trial, whether Erdemović acted under duress and whether he should therefore be excused. ${ }^{617}$ He holds that, during re-trial, the Trial Chamber should take into account all the factors mentioned in his dissenting opinion (see below, under Scope), but specifically, whether:

[...] the situation leading to duress was voluntarily brought about by the Appellant. In particular, the Trial Chamber must satisfy itself whether the military unit to which he belonged and in which he had voluntarily enlisted (the $10^{\text {th }}$ Sabotage Unit) was purposefully intent upon actions contrary to international humanitarian law and the Appellant either knew or should have known of this when he joined the Unit or, if he only later became aware of it, that he then failed to leave the Unit or otherwise disengage himself from such actions. ${ }^{618}$

\section{SCOPE}

Cassese defines duress as "acting under a threat from a third person of severe and irreparable harm to life or limb". In respect of the difference between necessity and duress he writes:

613 ICTY, Prosecutor v. Erdemović, Separate and Dissenting Opinion of Judge Cassese, Appeals Chamber, 7 October 1997, par. 11 and 49.

614 ICTY, Prosecutor v. Erdemović, Separate and Dissenting Opinion of Judge Cassese, Appeals Chamber, 7 October 1997, par. 49.

615 ICTY, Prosecutor v. Erdemović, Separate and Dissenting Opinion of Judge Cassese, Appeals Chamber, 7 October 1997, par. 11 and 49.

616 ICTY, Prosecutor v. Erdemović, Separate and Dissenting Opinion of Judge Cassese, Appeals Chamber, 7 October 1997, par. 12.

617 ICTY, Prosecutor v. Erdemović, Separate and Dissenting Opinion of Judge Cassese, Appeals Chamber, 7 October 1997, par. 12.

618 ICTY, Prosecutor v. Erdemović, Separate and Dissenting Opinion of Judge Cassese, Appeals Chamber, 7 October 1997, par. 50. 
Duress is often termed "necessity", both in national legislation and in cases relating to war crimes or crimes against humanity. I too have occasion to use these two terms as equivalent. However, as rightly pointed out in the British Manual of Military Law, from a technical viewpoint, necessity proper also covers situations other than those where one is faced with threats or compulsion of a third party, for instance the condition where a person "in extremity of hunger kills [another person] to eat him". In other words, necessity is a broader heading than duress, encompassing threats to life and limb generally and not only when they emanate from another person. ${ }^{619}$

In relation to the difference between superior orders and necessity/duress Cassese writes:

[...] there is no necessary connection between the two. Superior orders may be issued without any threats to life and limb. In these circumstances, if the superior order is manifestly illegal under international law, the subordinate is under a duty to refuse to obey the order. If, following such a refusal, the order is reiterated under a threat to life or limb, then the defence of duress may be raised, and superior orders lose any legal relevance. Equally, duress may be raised entirely independently of superior orders, for example where the treat issues from a fellow serviceman. Thus, where duress is raised in conjunction with manifestly unlawful superior orders, the accused may only have a defence if he first refused to obey the unlawful order and then only carried it out after a threat to life or limb. ${ }^{620}$

According to Cassese the general conditions for duress - on which case law is unanimous $-{ }^{621}$ are:

a. The act charged was done under an immediate threat of severe and irreparable harm to life or limb;

b. There was no adequate means of averting such evil;

c. The crime committed was not disproportionate to the evil threatened (i.e., the lesser of two evils);

d. The situation leading to duress must not have been voluntarily brought about by the person coerced. ${ }^{62}$

In relation to requirement (d), Cassese asserts that "duress or necessity cannot excuse from criminal responsibility the person who intends to avail himself of such defense if he freely and knowingly chose to become a member of a unit,

619 ICTY, Prosecutor v. Erdemović, Separate and Dissenting Opinion of Judge Cassese, Appeals Chamber, 7 October 1997, par. 14.

620 ICTY, Prosecutor v. Erdemović, Separate and Dissenting Opinion of Judge Cassese, Appeals Chamber, 7 October 1997, par. 15.

621 ICTY, Prosecutor v. Erdemović, Separate and Dissenting Opinion of Judge Cassese, Appeals Chamber, 7 October 1997, par. 16.

622 ICTY, Prosecutor v. Erdemović, Separate and Dissenting Opinion of Judge Cassese, Appeals Chamber, 7 October 1997, par. 16. 
organization or group institutionally intent upon actions contrary to international humanitarian law". ${ }^{623} \mathrm{He}$ adds to this list of requirements ((a)-(d)), that "the existence in law of any special duty on the part of the accused towards the victim may preclude the possibility of raising duress as a defense". 624

In cases of duress and killing, according to Cassese, the proportionality principle (c) would be the most difficult to meet. He even holds it possible that the proportionality requirement will never be satisfied in situations where the accused saves his own life at the expense of his victim "since there are enormous, perhaps insurmountable, philosophical, moral and legal difficulties in putting one life in the balance against that of others in this way: How can a judge satisfy himself that the death of one person is a lesser evil than the death of another?". ${ }^{625}$ However, he can imagine a scenario where killing under coercion is excusable: a Masetti situation. In such a situation, the victim will die anyway. Consequently, there is no choice between the life of the perpetrator and the life of the victim, but between either the life of the victim, or the lives of both the victim and the perpetrator. Choosing to save one's own life could in these cases be proportionate, ${ }^{626}$ because:

Law is based on what society can reasonably expect of its members. It should not set intractable standards of behavior which require mankind to perform acts of martyrdom, and brand as criminal any behavior falling below those standards. ${ }^{627}$

This interpretation of the proportionality principle is endorsed by case law. ${ }^{628}$ Cassese, however, adds that even in a Masetti situation, the court has to decide whether the proportionality requirement has been met, based on the available evidence. He continues:

The court may decide, in a given case, that the accused did not do all he could to save the victims before yielding to duress, or that it is too speculative to assert that they would have died in any event. The important point, however - and this is the fundamental source of my disagreement with the majority - is that this question should be for the Trial Chamber to decide with all the facts before it. The defence should not be cut off absolutely and a priori from invoking the excuse of duress by a

623 ICTY, Prosecutor v. Erdemović, Separate and Dissenting Opinion of Judge Cassese, Appeals Chamber, 7 October 1997, par. 17. Cassese enumerates more or less the same criteria in a different wording in par. 41.

624 ICTY, Prosecutor v. Erdemović, Separate and Dissenting Opinion of Judge Cassese, Appeals Chamber, 7 October 1997, par. 16.

625 ICTY, Prosecutor v. Erdemović, Separate and Dissenting Opinion of Judge Cassese, Appeals Chamber, 7 October 1997, par. 42.

626 ICTY, Prosecutor v. Erdemović, Separate and Dissenting Opinion of Judge Cassese, Appeals Chamber, 7 October 1997, par. 12.

627 ICTY, Prosecutor v. Erdemović, Separate and Dissenting Opinion of Judge Cassese, Appeals Chamber, 7 October 1997, par. 47.

628 ICTY, Prosecutor v. Erdemović, Separate and Dissenting Opinion of Judge Cassese, Appeals Chamber, 7 October 1997, par. 43. 
ruling of this International Tribunal whereby, in law, the fact of acting under duress can never be a defence to killing innocents. ${ }^{629}$

Judge Cassese adds that mitigation of punishment as the only option is not an adequate solution in Masetti situations, because:

Any such contention would neglect a critical, inescapable point, namely that the purpose of criminal law, including international criminal law, is to punish behavior which is criminal, i.e., morally reprehensible or injurious to society, not to condemn behavior which is "the product of coercion that is truly irresistible" or the choice of the lesser of two evils. No matter how much mitigation a court allows an accused, the fundamental fact remains that if it convicts him, it regards his behavior as criminal, and considers that he should have behaved differently. ${ }^{630}$

At the end of his contemplation, Cassese adds two other factors, relevant to the determination of duress: (a) the rank of the defendant (the lower the rank, the less likely that the defendant had a "real moral choice") ${ }^{631}$ and (b) the degree to which the defendant wanted to commit the offense. In the latter case, the absence of a confession at the earliest possible opportunity is an indication that the defendant wanted to perform the act under duress. ${ }^{632}$ All in all, Cassese holds that "the general requirements for duress be applied particularly strictly in case of killing of innocent persons". ${ }^{633}$ Cassese's requirements for duress are objective criteria.

\subsubsection{Separate and Dissenting Opinion of Judge Stephen}

\section{ApPLICABILITY}

Judge Stephen, in his Separate and Dissenting Opinion, agrees with Judge Cassese that duress could be a complete defense under international criminal law when the proportionality requirement is met in a Masetti-like situation. ${ }^{634}$ However, he does not say that duress should be a complete defense in general. ${ }^{635}$ In line with Cassese

629 ICTY, Prosecutor v. Erdemović, Separate and Dissenting Opinion of Judge Cassese, Appeals Chamber, 7 October 1997, par. 42.

630 ICTY, Prosecutor v. Erdemović, Separate and Dissenting Opinion of Judge Cassese, Appeals Chamber, 7 October 1997, par. 48.

631 ICTY, Prosecutor v. Erdemović, Separate and Dissenting Opinion of Judge Cassese, Appeals Chamber, 7 October 1997, par. 45.

632 ICTY, Prosecutor v. Erdemović, Separate and Dissenting Opinion of Judge Cassese, Appeals Chamber, 7 October 1997, par. 46.

633 ICTY, Prosecutor v. Erdemović, Separate and Dissenting Opinion of Judge Cassese, Appeals Chamber, 7 October 1997, par. 44.

634 ICTY, Prosecutor v. Erdemović, Separate and Dissenting Opinion of Judge Stephen, Appeals Chamber, 7 October 1997, par. 67.

635 ICTY, Prosecutor v. Erdemović, Separate and Dissenting Opinion of Judge Stephen, Appeals Chamber, 7 October 1997, par. 64. 
and the majority, Stephen holds that there is no customary rule in international criminal law, prohibiting duress as a complete defense in case of killing. ${ }^{636}$ As to the "general principles of law recognized in civilized nations", Stephen acknowledges there is a common law exception to the availability of duress in case of killing, but that this exception is (a) "much criticized" 637 - mainly because it lacks foundation on any legal principle -638 and is (b) based on life against life situations and not on situations of either one life or both lives. ${ }^{639}$ Consequently, there is no principle prohibiting duress as a complete defense in the present case. ${ }^{640}$ He rejects the majority's policy argument by stating:

I am at the same time alive to the concerns expressed by other members of this Appeals Chamber of the need to protect innocent life in conflicts such as that in the former Yugoslavia which involve so great a threat to innocent life. However, to my mind, that aim is not achieved by the denial of a just defence to one who is in no position to effect by his own will the protection of innocent life. ${ }^{641}$

Judge Stephen holds that Erdemović was in a Masetti-like situation:

If [...] the choice open to him was not that of the victims' deaths or his own but, rather, that of their deaths or their deaths together with his own, the whole question of proportionality would necessarily be seen to be meaningless; there would be no question of weighing one life against another or others, the choice, if it can be described as a choice, would be between many lives or many lives plus one, his own. The Appellant was but one member of a firing squad and, according to his statements, no other member supported him when he made his protest. Nor is it more than speculation that if, as ethnically a Croat, as he was, in a unit of the Bosnian Serb army, he had followed up his protest by handing over his weapon and joining the first group of Muslim civilians to be executed, the other members of the firing squad would have refused the order to execute them all. Even if any of them had refused, as, according to the Appellant, some did later when, after four hours of killing, the squad was next ordered to kill another five hundred civilians imprisoned in a nearby hall, there were other willing executioners at hand ready to kill and who did kill those five hundred. Indeed, during the initial four-hour-long killing of civilians the Appellant's firing squad was joined by members of another unit who not only joined in the task of execution but beat and brutalized the victims before

636 ICTY, Prosecutor v. Erdemović, Separate and Dissenting Opinion of Judge Stephen, Appeals Chamber, 7 October 1997, par. 24.

637 Judge Cassese also notes this in par. 29 of his dissenting opinion.

638 ICTY, Prosecutor v. Erdemović, Separate and Dissenting Opinion of Judge Stephen, Appeals Chamber, 7 October 1997, par. 49.

639 ICTY, Prosecutor v. Erdemović, Separate and Dissenting Opinion of Judge Stephen, Appeals Chamber, 7 October 1997, par. 25.

640 ICTY, Prosecutor v. Erdemović, Separate and Dissenting Opinion of Judge Stephen, Appeals Chamber, 7 October 1997, par. 64.

641 ICTY, Prosecutor v. Erdemović, Separate and Dissenting Opinion of Judge Stephen, Appeals Chamber, 7 October 1997, par. 65. 
executing them. It is surely difficult to suppose that an heroic act of self-sacrifice by the Croatian Appellant would have deflected the Bosnian Serb army from the task of extermination of Muslim civilians on which it was embarked. ${ }^{642}$

Like Judge Cassese, Judge Stephen holds that the case should be remitted to the Trial Chamber so that Erdemović has an opportunity to re-plead. ${ }^{643}$ Stephen does not discuss whether duress can also be taken in mitigation.

SCOPE

Stephen seems to have the same definition of necessity/duress as Cassese (necessity is a broader concept than duress, including threats not emanating from others). ${ }^{644} \mathrm{He}$ also adheres to the same objective criteria for duress as his co-dissenter. ${ }^{645}$

\subsubsection{Trial Chamber II}

\section{ApPLICABILITY}

The Appeals Chamber sends the case back to a new Trial Chamber - because the plea of the defendant was "uninformed" - ${ }^{646}$ so that the defendant can re-plead. ${ }^{647} \mathrm{At}$ the second Trial Chamber, Erdemović changes this plea. He pleads guilty to violations of laws or customs of war (instead of crimes against humanity). The Trial Chamber "accepts that the accused committed the offense in question under a threat of death". 648 However, since the majority of the Appeals Chamber rejected the defense of duress in case of killing, Trial Chamber II could only take duress in mitigation, which it did. The contemplation of the second Trial Chamber shows on the one hand that it finds Erdemović's attitude as the "helpless victim" not wholly credible because he was occasionally able to take "positive action". The Trial Chamber therefore holds that "[t]he risks that he took appear to have been

642 ICTY, Prosecutor v. Erdemović, Separate and Dissenting Opinion of Judge Stephen, Appeals Chamber, 7 October 1997, par. 19. See also par. 52.

643 ICTY, Prosecutor v. Erdemović, Separate and Dissenting Opinion of Judge Stephen, Appeals Chamber, 7 October 1997, par. 69.

644 See: ICTY, Prosecutor v. Erdemović, Separate and Dissenting Opinion of Judge Stephen, Appeals Chamber, 7 October 1997, par. 34, where Stephen cites $R$ v. Dudley and Stephens and calls this a case "of necessity rather than duress" and par. 58 where he makes the distinction between duress emanating from "a natural source or from another human being".

645 ICTY, Prosecutor v. Erdemović, Separate and Dissenting Opinion of Judge Stephen, Appeals Chamber, 7 October 1997, par. 68.

646 Erdemović was not fully aware of the difference between war crimes and crimes against humanity. He did not know that pleading the first type of crime could have resulted in a lighter sentence. See: ICTY, Prosecutor v. Erdemović, Joint Separate Opinion of Judge McDonald and Judge Vohrah, Appeals Chamber, 7 October 1997, par. 11.

648 ICTY, Prosecutor v. Erdemović, Trial Chamber II, 5 March 1998, par. 14. 
calculated". However, on the other hand the Trial Chamber believes that the risk at the moment of the crime was "real" and that Erdemovic "had no choice in the matter: he had to kill or be killed". ${ }^{649}$ What is significant about about this reasoning is that the Trial Chamber seems to think that at the moment of the crime Erdemovic had no choice and that there was an obvious duress-situation. However, the Trial Chamber reveals doubt as to Erdemović's lack of choice in earlier decisions, suggesting some sort of culpa in causa reasoning, without being very explicit. This lack of clarity may be explained by the fact that the occurrence of duress was part of the plea agreement between the Prosecutor and Erdemović. With an agreement on the table the Trial Chamber probably found it no longer necessary to delve into the exact circumstances under which the duress took place. ${ }^{650}$ The second Trial Chamber reduced the initial sentence from ten to five years, ${ }^{651}$ however probably more factors contributed to this than only duress in mitigation (for example the change of plea from crimes against humanity to war crimes). ${ }^{652}$

\section{SCOPE}

The second Trial Chamber Judgment does not contain any information on the scope of duress as a complete defense, for duress is applied in mitigation. However, in accepting duress in mitigation, lack of choice - both at the moment of the crime and in situations leading up to the crime (as in culpa in causa) - appears to be an important factor.

\section{NeCESSITY/Duress}

The second Trial Chamber speaks consistently about "duress" without defining the concept.

\subsubsection{Conclusion on Prosecutor v. Erdemović}

\section{APPLICABILITY}

Duress in principle

In Prosecutor v. Erdemovic the first Trial Chamber a priori rejects the complete defense of duress in case of crimes against humanity. The Appeals Chamber's majority (3-2) a priori rejects the complete defense of duress in case of a soldier killing innocents. The second Trial Chamber follows the Appeals Chamber. Duress

\footnotetext{
649 ICTY, Prosecutor v. Erdemović, Trial Chamber II, 5 March 1998, par. 17.

650 Linton, S., 1999, p. 266.

651 ICTY, Prosecutor v. Erdemović, Trial Chamber II, 5 March 1998, par. 23.

652 ICTY, Prosecutor v. Erdemović, Trial Chamber II, 5 March 1998, par. 8.
} 
is thus a priori excluded as a complete defense in case of war crimes or crimes against humanity involving a soldier killing innocents. In other cases the defense could still be available.

The first Trial Chamber a priori rejects duress, because the nature of crimes against humanity makes it practically impossible to meet the proportionality requirement. The Appeals Chamber's rejection of duress is based on practical policy reasons. In brief, the policy argument of the majority contains that denying duress in case of killing innocents has a normative effect, i.e. it influences the behavior of soldiers in the field. This normative effect contributes to the objective of international humanitarian law (protection of the weak), which must be enforced by the Tribunal. Note that the a priori rejection of the Trial Chamber is based on the merits (in case $\mathrm{x}$ requirement y is never met) while the Appeals Chamber's rejection is not (in case $\mathrm{z}$ the defense is not available).

The Appeals Chamber's majority opinion explicitly rejects two other approaches to duress in case of killing innocents. The first being the approach where duress in case of killing may be admissible if the perpetrator would have sacrificed his life in vain (Masetti approach), the second being the reasonable person test. The Masetti approach is rejected because (a) the majority prefers their own policy approach, (b) meeting the proportionality requirement in a Masetti situation does not erase moral blameworthiness of the defendant, (c) the proportionality requirement is not a helpful tool in case of killings, for it is impossible to "weigh" human lives, (d) the proportionality requirement leads to unequal results as to people who could save a life, but had no choice either and (e) saying the proportionality requirement is met in a Masetti situation leads to absurd results (justifying everybody in a criminal group participating in a joint massacre).

The reasonable person test is also rejected by the majority, because (a) they prefer their own policy approach, (b) trained fighters should not have access to duress and (c) denying this test does not demand heroism, for in case of duress mitigation is possible (up to no punishment at all).

Dissenter Cassese rejects the policy argument of the majority. He holds that this approach runs contrary to nullum crimen sine lege. When the majority concluded there is no rule in case of duress and killing, he writes, they should not have fallen back on common law doctrine, but instead should have relied on the general rule on duress. Dissenter Stephen rejects the majority's policy argument for efficiency reasons: he doubts whether denying the defense of duress protects innocent lives. ${ }^{653}$ Apart from that, he points out that the common law approach, adhered to by the majority, is both highly criticized and not applicable to the case at hand.

Both Stephen and Cassese favor the Masetti approach that is rejected by the majority. Cassese holds that this is probably the only situation in which the proportionality requirement could be met, because (a) the law can simply not demand from people to be heroes and throw away their lives away in vain and (b)

653 This argument is also mentioned by the majority in par. $75-77$, where it holds it is "not persuaded" by this reasoning. 
mitigation of punishment, as suggested by the majority, is not an adequate solution. When the requirements for duress have been met, the behavior of the defendant is not criminal and should therefore not be punished. Only when duress cannot be established as a complete defense it can be taken in mitigation. Finally, Cassese and Stephen point out that (c) the Masetti approach is endorsed by case law.

\section{Duress in casu}

Trial Chamber I rejects duress, both as a complete defense (in the context of assessing the validity of the guilty plea) and in mitigation, due to lack of evidence. The majority of the Appeals Chamber only discusses duress in general terms. However, according to their definition, Erdemović could not have successfully pleaded duress, being a soldier charged with murder. Although the dissenters in the Appeals Chamber do not explicitly state whether duress should be admissible in the case at hand, they do suggest a remission to the Trial Chamber in order to investigate whether Erdemović had been acting under duress. Both Cassese and Stephen hand this future Trial Chamber some tools in deciding on the matter.

Cassese suggests that the proportionality requirement has been met (Erdemović was in a Masetti- situation) and that two other important factors are present as well: (a) the low rank of the defendant and (b) the fact that Erdemovic did not want to commit the offense (demonstrated by his prompt confession). The issue that is not entirely clear to Cassese is, however, whether Erdemović voluntarily exposed himself to duress. He therefore wants the Trial Chamber to investigate whether the $10^{\text {th }}$ Sabotage Unit was "purposefully intent upon actions contrary to international humanitarian law" and whether Erdemović should therefore have refrained from joining this Unit or should have left the Unit at an earlier stage.

Stephen holds that in Erdemović's case both the necessity (i.e. no other option was available) and the proportionality requirement have been met. He points out that nobody supported Erdemovićs protest, that he had a powerless position as a Croat in the Bosnian Serb Army and that even if he had sacrificed his own life, other soldiers would have killed the Muslims.

Since the majority of the Appeals Chamber rejected the defense of duress in case of killing, Trial Chamber II could only take duress in mitigation, which it did. The second Trial Chamber reduced the initial sentence from ten to five years, ${ }^{654}$ however, in all probability, other mitigating factors apart from duress contributed to this (for example the change of plea from crimes against humanity to war crimes).

\section{SCOPE}

Several sources mention general criteria for the defense of necessity/duress. Trial Chamber I, Judge Cassese, Judge Stephen (who is in line with Cassese), Judge 
McDonald, Judge Vohrah and Judge Li all refer to criteria that have been derived from case law:

a. The act charged was done to avoid an immediate danger both serious and irreparable (Cassese and Stephen refer to "harm to life or limb". Trial Chamber I also refers to this interpretation);

b. There was no adequate means of escape;

c. The remedy was not disproportionate to the evil (Cassese and Stephen are more strict: the remedy must be the lesser of two evils).

In addition, both the dissenters and Trial Chamber I refer to a fourth requirement: (d) the situation leading to duress must not have been voluntarily brought about by the accused. What is more: several sources mention the rank of the accused as an important factor. Trial Chamber I holds that the rank of the soldier giving orders and the rank of the soldier receiving it are indications for the amount of duress exercised. Cassese also points out that the rank of the defendant is an important issue. The lower the rank he holds, the less moral choice. Judges Vohrah and McDonald mention that being a soldier contributes to the a priori exclusion of duress (for due to their training, soldiers are supposed to resist a certain amount of pressure). Cassese also mentions the degree to which the defendant wanted to commit the offense as an important aspect. If the defendant does not confess immediately after the fact, this is an indication that he willingly committed the offense. In addition, Cassese holds that a special legal duty of the accused towards the victim may preclude the availability of duress. The requirements mentioned are all objective.

\section{NECESSITY/DURESS}

The first Trial Chamber uses the terms 'duress' and 'necessity' as synonyms. What is more, this Trial Chamber also holds that a superior order is a prerequisite for the necessity/duress defense. Judges Vohrah and McDonald as well as Judge Li, consequently use the word 'duress'. McDonald and Vohrah define duress as "imminent threats to the life of an accused if he refuses to commit a crime". They also hold that "absence of a superior order does not mean that duress as a defense must fail". McDonald and Vohrah refer to Judge Stephen who (referring to Dinstein) also notes that a superior order is merely a factor that can contribute to the establishment of duress. ${ }^{65}$ Judge Cassese points out that 'necessity' is a broader concept than duress for it encompasses threats to life and limb generally, while duress only refers to threats that emanate from another person. Necessity, on the other hand also refers to threats resulting from extreme situations such as "hunger".

655 ICTY, Prosecutor v. Erdemović, Separate and Dissenting Opinion of Judge Stephen, Appeals Chamber, 7 October 1997, par. 59. 
Stephen agrees. As to the relationship between necessity/duress and superior orders, Cassese seems to be in line with the Appeals Chamber when holding that there is no necessary connection between the two. The second Trial Chamber only speaks of duress.

Now, what can be concluded from statements on necessity and duress? The utterances of the first Trial Chamber - mixing up necessity, duress and superior orders - seem to be corrected by the subsequent authorities. The other Judges consistently speak of duress, which seems to refer at least to "threats" against the accused. As to the sources of these threats, dissenters Cassese and Stephen hold that duress emanates from persons. However, the other authorities do not limit duress to threats by persons. All authorities after the first Trial Chamber Judgment hold that duress and superior orders are different defenses. The criteria mentioned under Scope further define the concept of duress. Since according to these criteria an appeal to duress can only be successful if the defendant picked the lesser of two evils, the definition of duress in this case must be classified as a justification. This is confirmed by Judge Li who calls duress a "justification". 656 Judges Vohrah and McDonald are less clear; they speak of duress in terms of "justified or excused". 657 Judge Cassese consistently refers to duress as an "excuse". Stephen does not refer to duress in these terms. The defense raised in this case resembles an excuse: Erdemović did not claim he did the right thing, but that it was impossible for him to resist the pressure.

\subsection{Prosecutor v. Aleksovski}

\subsubsection{Relevant passages}

In 1993 Zlatko Aleksovski is a commander of a prison facility in Bosnia and Herzegovina. In May 1999 the ICTY Trial Chamber convicts him for maltreatment of detainees in this facility (a war crime under article 3 of the ICTY Statute). ${ }^{658}$ On Appeal the defense argues that:

[...] the criminal law concept of extreme necessity had to be applied to the facts. This concept excludes the perpetrator's unlawful actions since such actions are motivated by the intent to avoid a worse violation. ${ }^{659}$

656 ICTY, Prosecutor v. Erdemović, Separate and Dissenting Opinion of Judge Li, Appeals Chamber, 7 October 1997, par. 8 and 11.

657 ICTY, Prosecutor v. Erdemović, Joint Separate Opinion of Judge McDonald and Judge Vohrah, Appeals Chamber, 7 October 1997, par. 71 and 80.

658 ICTY, Prosecutor v. Aleksovski, Trial Chamber, 25 June 1999, par. 89.

659 ICTY, Prosecutor v. Aleksovski, Appeals Chamber, 24 March 2000, par. 40. 
As a reaction to the response of the prosecution that asserts that the defense should have brought up the necessity/duress argument during the (pre-)trial stage, the defense adds that:

[...] the concept of extreme necessity (exceptio casu necessitatis) is familiar to civil law. In civil law procedure, the court is authorized to apply the concept on its own in accordance with the principle iura novit curia. The parties only have to prove the facts and their legal claims or opinions do not bind the court. In this regard, the applicable facts proved by the defence are that: (a) an armed conflict existed outside Kaonik prison in the Busovača municipality; (b) there was a large number of civilian casualties in that armed conflict; (c) not one of the prisoners in Kaonik was wounded or killed apart from the prison guards; and (d) the Appellant did not participate in the decision-making regarding the imprisonment of Bosnian Muslims, as he was forced into a situation with no proper options. These factual findings could be interpreted under the legal principle exceptio casu necessitatis. The Appellant further submits that extreme necessity is not the same as duress, since the former has a broader meaning and could be used to exclude the guilt, illegality or punishment of the perpetrator. A provision similar to extreme necessity is found in article 31(d) of the ICC Statute. This concept, although absent from the Statute of the Tribunal, should be applied as a general principle of law from a national system, as provided for in article 21(c) of the ICC Statute. ${ }^{660}$

The Appeals Chamber rejects the necessity/duress defense because it:

[...] considers that, in general, accused before this Tribunal have to raise all possible defences, where necessary in the alternative, during the trial, and where so required under the Rules of Procedure and Evidence of the International Tribunal ("Rules"), before trial. It follows that accused, generally, cannot raise a defence for the first time on appeal. ${ }^{661}$

However, the Appeals Chamber concludes its deliberation by stating that:

In this Appeal, the Appeals Chamber will nevertheless consider the defence of necessity, as pleaded. ${ }^{662}$

Considering the merits of the necessity-defense the Appeals Chamber holds:

Assuming for the moment that necessity constitutes a valid defence and that the Appellant is entitled to raise it, the Appeals Chamber is of the view that this ground of appeal is entirely misplaced. The reasons for this conclusion are as follows.

$[\ldots]$

660 ICTY, Prosecutor v. Aleksovski, Appeals Chamber, 24 March 2000, par. 43 and 44.

661 ICTY, Prosecutor v. Aleksovski, Appeals Chamber, 24 March 2000, par. 51.

662 ICTY, Prosecutor v. Aleksovski, Appeals Chamber, 24 March 2000, par. 51. 
Chapter IX

What the Appellant is in effect submitting is that the mistreatment the detainees suffered - not the fact of detention, with which he was not charged - should have been interpreted by the Trial Chamber as somehow having been justified by the assertion that they would have suffered even more had they not been treated the way they were while in detention. The Appellant does not and cannot argue, in the present case, that he was faced with only two options, namely, mistreating the detainees or freeing them. The Appellant, faced with the actual choice of mistreating the detainees or not, was convicted for choosing the former.

[...]

In light of the misplaced basis of this aspect of the Appellant's appeal, the Appeals Chamber considers it unnecessary to dwell on whether necessity constitutes a defence under international law, whether it is the same as the defence of duress or whether the principle iura novit curia should be applied in this case. ${ }^{663}$

\subsubsection{Applicability}

The Appeals Chamber in Aleksovski is ambiguous in its recognition of (extreme) necessity as a complete defense. On the one hand it holds that it will not "dwell on whether necessity constitutes a defense under international law", thereby neither accepting, nor rejecting the defense in general terms. On the other hand it discusses the defense on its merits "assuming [...] that necessity constitutes a valid defense", thereby implicitly recognizing it. Either way, the defense is rejected in casu. Aleksovski argues that he had a choice between a lesser evil (mistreating detainees) and a greater evil (freeing detainees, in which case they would be endangered by the armed conflict situation outside the prison facility). He also asserts "he was forced into a situation with no proper options". The Appeals Chamber holds that the choice he had to make was between two different options: mistreating detainees or not mistreating the detainees. Aleksovski should have chosen the latter. The Appeals Chamber does not discuss the assertion that he was forced into the situation.

What is noteworthy about this Judgment is that the Appeals Chamber holds that the necessity/duress defense should have been rejected in the first place because "in general" complete defenses cannot be brought up for the first time on appeal.

\subsubsection{Scope}

Apart from the rejection for procedural reasons, the rejection of the defense of necessity is based on the fact that Aleksovski had other options. It was not absolutely necessary to commit a crime. The rejection is based on an objective test. 


\subsubsection{Necessity/duress}

An interesting aspect about this Judgment is that the Appeals Chamber finds it unnecessary to dwell on whether necessity "is the same as the defense of duress", thereby indicating that the difference between these two defenses is not clear-cut. The defense, however, raises "extreme necessity" and indicates the difference between necessity and duress: necessity "has a broader meaning and could be used to exclude guilt, illegality or punishment". In terms of justification and excuse, this is exactly what the defense does. On the one hand it argues that the defendant picked the lesser of two evils, implying absence of "illegality" and thus a justification. On the other hand it claims the defendant was "forced into a situation with no proper options" implying absence of "guilt" and thus an excuse.

\subsection{Kvočka et al.}

\subsubsection{Relevant passages}

During of the Bosnian War, Bosnian Serbs held about 6,000 Bosniaks and Croats under appalling conditions in Omarska camp throughout the spring and summer of 1992. In Kvočka et al. several individuals charged with crimes committed in Omarska stand trial. Dragoljub Prcać, former administrative aid at Omarska, is one of them. He is charged with violations of the laws and customs of war and crimes against humanity. On trial, he brings up the defense of necessity/duress:

Prcać contends that he did not want to go to the camp but that Drljača threatened him. During trial he insisted that he went to the camp "under duress". Some Defence witnesses testified to this effect. Prcać's son, Ljubisa Prcać, testified that his father told him that Simo Drljača threatened him "with the life of his children and the burning of his house". Obrad Popović, one of the porters at Omarska camp, testified that he saw Simo Drljača conversing with Prcać, who later told him that Drljača had threatened him. ${ }^{664}$

The Trial Chamber, however, rejects Prcać's necessity/duress argument:

The Trial Chamber notes, however, that Prcać never mentioned any threats when he was interviewed by the Prosecution. The Trial Chamber is not convinced that these threats took place and does not accept his assertion that he worked at the camp under duress. ${ }^{665}$

664 ICTY, Prosecutor v. Kvočka et al., Trial Chamber, 2 November 2001, par. 427.

665 ICTY, Prosecutor v. Kvočka et al., Trial Chamber, 2 November 2001, par. 427. 
On appeal, Prcać challenges the conclusion reached by the Trial Chamber and argues that:

[...] his arrival at the Omarska camp under duress evidences his lack of will to participate in any joint criminal enterprise. According to Prcać, the Trial Chamber's conclusion is based on its finding that he "never mentioned any threats when he was interviewed by the Prosecution". He claims that this finding is erroneous. Prcać submits that he did state in his interview with the Prosecution that he went to the camp under threat, that he raised this again in his Pre-Trial Brief and opening statement, and that two witnesses corroborated his assertion. ${ }^{666}$

The Appeals Chamber, however, denies that the Trial Chamber made an erroneous finding on duress:

The Appeals Chamber considers that, even if Prcać's statement in his interview with the Prosecution provided evidence that he may have gone to the camp under duress, in the absence of any further evidence that Prcać continued to work at the camp as a result of such duress, the Trial Chamber's finding is entirely reasonable. This is especially so in light of its finding with respect to Radić, namely that "guards could come and go from their assignments in the camp without suffering repercussions." The Appeals Chamber also notes that the evidence presented at trial does not support such a conclusion. Moreover, the Trial Chamber based its finding on the evidence as a whole, including, in particular, the testimony of defence witnesses Ljubisa Prcać and Obrad Popović, in addition to the arguments contained in Prcać's Pre-Trial Brief and his opening statement. The assertion that Prcać never mentioned any threats in his interview with the Prosecution was only one of the factors relevant to the finding. In light of the totality of material available to the Trial Chamber, the Appeals Chamber is of the view that Prcać has not established that no reasonable trier of fact could have found that he did not work at the camp under duress. This sub-ground of appeal is, therefore, dismissed. ${ }^{667}$

\subsubsection{Applicability}

In these passages both Trial Chamber and Appeals Chamber seem to accept the defense of duress in principle, for they suggest it could have been a defense if the relevant threats were convincingly established. However, another passage in the Kvočka et al. Trial Chamber Judgment confuses this issue. When addressing the criminal responsibility of defendant Miroslav Kvočka, who did not bring up duress, the Trial Chamber produces the following dictum:

Even if a knowing participant in a criminal enterprise was unwilling to resign because it would prejudice his career, or he feared he would be sent to the front lines,

666 ICTY, Prosecutor v. Kvočka et al., Appeals Chamber, 28 February 2005, par. 643.

667 ICTY, Prosecutor v. Kvočka et al., Appeals Chamber, 28 February 2005, par. 645. 
imprisoned, or punished, the Trial Chamber emphasizes that this is not an excuse or a defense to liability for participating in war crimes or crimes against humanity. It is well established in the jurisprudence of this Tribunal that duress is not a defense to committing war crimes or crimes against humanity. ${ }^{668}$

Consequently, in the same Judgment the Trial Chamber both recognizes the defense of duress, and rejects it a priori. The Trial Chamber thus, inconsistently, allows the defense of duress - in principle - for one accused, but rules it out for the other (be it in a dictum). What is more, the a priori exclusion of duress in Kvocka et al., broadens the a priori exclusion of duress beyond the majority rule in Erdemovic. ${ }^{669}$ While Erdemovic rules out duress in the specific case of a war crime or crime against humanity involving the killing by a soldier of innocent human beings, Kvočka et al., rejects duress in case of all war crimes and crimes against humanity. Since this extension of the Erdemović-rule on duress is not substantiated and because the relevant passage refers to the Erdemovic Judgment, the duress-rule ex Kvočka et al. must be conceived as a misstatement. The Trial Chamber's recognition of duress in principle, is not inconsistent with Erdemović. Prcać was not a soldier and even if he was, he was not only charged with murder (but also with torture, cruel treatment, etc.). The Erdemovic-exclusion is thus not applicable to the facts of his case.

Although recognized in principle, the defense of duress is rejected in casu because the Trial Chamber is not convinced that the threats took place, due to lack of evidence. In addition, Prcać did not mention the threats when he was interviewed by the prosecution. In relation to the latter argument, Prcać holds, on Appeal, that this finding is erroneous. The Appeals Chamber, however, denies the importance of this interview, for even if the defendant went to the camp under duress, there is lack of other evidence supporting that he continued to work under duress. Another defendant (Radić) even asserted "guards could come and go from their assignments in the camp without suffering repercussions". What is more, the interview by the prosecution was only one aspect relevant to the finding that the defendant had not been under duress.

\subsubsection{Scope}

Kvočka et al., does not reveal much information on the requirements for necessity/ duress. The defense is mainly dismissed due to lack of evidence. However, the Appeals Chamber - by referring to the statement "guards could come and go from their assignments in the camp without suffering repercussions" - seems to validate the necessity-requirement: since Prcać had other options open to him, he was not forced to commit the crimes charged. Kvočka et al., also emphasizes that being

668 ICTY, Prosecutor v. Kvočka et al., Trial Chamber, 2 November 2001, par. 403.

669 Zahar, A. and Sluiter, G., 2008, p. 427/428. 
forced into a situation does not absolve a defendant from the obligation to continue to make an effort to get out.

\subsubsection{Necessity/duress}

In Kvocka et al., the relevant legal figure is referred to as duress. However, the concept is not defined. The defense brought up in this case must be qualified as an excuse, for Prcać did not claim that he chose the lesser of two evils, but that he did not have a choice due to severe threats.

\subsection{Other ICTY references to necessity/duress}

Apart from the appeals to complete defenses discussed above, there are other references to the legal figure of necessity/duress at the ICTY. In his Report on the establishment of the ICTY the Secretary-General writes that "coercion or lack of moral choice" may determine whether superior orders can be brought in mitigation. $\mathrm{He}$, however, does not address necessity/duress as a separate mitigating factor or defense. ${ }^{670}$

In his Separate and Partly Dissenting Opinion to Prosecutor v. Simić, Judge Per-Johan Lindholm argues that - in relation to a charge of persecutions through deportation - defendant Miroslav Tadić acted under duress and should therefore be found not guilty on the relevant counts. ${ }^{671}$ When arguing his point Lindholm relies on the general requirements for duress cited from a Report of the UNWCC by Judges McDonald and Vohrah in Erdemović:

a. the act charged was done to avoid an immediate danger both serious and irreparable;

b. there was no other adequate means of escape;

c. the remedy was not disproportionate to the evil. ${ }^{672}$

In relation to requirement (a) Lindholm argues that non-Serb civilians in the detention center for which Tadić worked were severely mistreated. This mistreatment constituted a danger both serious and irreparable. Lindholm is convinced that Tadić participated in the deportation of these non-Serb civilians in order to avoid such danger. ${ }^{673}$ According to Lindholm, requirement (b) has been met because deportations where the

670 Report of the Secretary-General pursuant to paragraph 2 of the Security Council Resolution 808 (1993), par. 57.

671 ICTY, Prosecutor v. Simić, Separate and Partly Dissenting Opinion by Judge Per-Johan Lindholm, Trial Chamber, 17 October 2003, par. 27/28.

672 ICTY, Prosecutor v. Simić, Separate and Partly Dissenting Opinion by Judge Per-Johan Lindholm, Trial Chamber, 17 October 2003, par. 18.

673 ICTY, Prosecutor v. Simić, Separate and Partly Dissenting Opinion by Judge Per-Johan Lindholm, Trial Chamber, 17 October 2003, par. 21. 
only means of escaping the horrors of the detention facilities, since Tadić did not have the authority to employ other means. ${ }^{674}$ Finally requirement (c) has been met because, the remedy of deportation (accompanied with the loss of property), Lindholm argues, is proportionate to the evil avoided, i.e. the appalling conditions in the detention facilities. In addition, Lindholm stresses that Tadic was not responsible for the inhumane conditions in the detention facilities (no prior fault) ${ }^{675}$ and that he sincerely believed he was doing the right thing. ${ }^{676}$ Lindholm employs an objective duress test, but also mentions a subjective argument (sincere belief). Duress in this case amounts to a justification, as Tadic claims that he chose the lesser of two evils.

In Prosecutor v. Hadžihasanović and Kubura the Trial Chamber discusses the state of necessity as a defense to plunder "in the context of an actual or looming famine". It holds that:

[...] in the context of an actual or looming famine, a state of necessity may be an exception to the prohibition on the appropriation of public or private property. Property that can be appropriated in a state of necessity includes mostly food, which may be eaten in situ, but also livestock. To plead a defence of necessity and for it to succeed, the following conditions must be met: (i) there must be a real and imminent threat of severe and irreparable harm to life existence; (ii) the acts of plunder must have been the only means to avoid the aforesaid harm; (iii) the acts of plunder were not disproportionate and, (iv) the situation was not voluntarily brought about by the perpetrator himself. ${ }^{677}$

In this case the necessity/duress defense is thus recognized in principle, however not as a complete defense but as a specific defense to plunder in case of famine. The defense is specifically referred to as "necessity". The legal figure bears a necessity requirement (condition (ii)). Apart from that, the famine must pose a serious threat (condition (i)), the plunder must be proportionate to the threat (condition (iii)) and the perpetrator may not have caused the famine himself (condition (iv)). Prosecutor v. Hadžihasanović and Kubura demonstrates a justificatory defense with an objective necessity-test.

In Prosecutor v. Orić, the Trial Chamber implicitly recognizes the possibility of a duress/necessity-defense (or possibly self-defense) when discussing the command responsibility of the defendant:

It is the Trial Chamber's considered opinion that, as a general rule, the treatment of prisoners in armed conflict, including their physical and mental integrity, cannot be

674 ICTY, Prosecutor v. Simić, Separate and Partly Dissenting Opinion by Judge Per-Johan Lindholm, Trial Chamber, 17 October 2003, par. 22.

675 ICTY, Prosecutor v. Simić, Separate and Partly Dissenting Opinion by Judge Per-Johan Lindholm, Trial Chamber, 17 October 2003, par. 23.

676 ICTY, Prosecutor v. Simić, Separate and Partly Dissenting Opinion by Judge Per-Johan Lindholm, Trial Chamber, 17 October 2003, par. 27.

677 ICTY, Prosecutor v. Hadžihasanović and Kubura, Trial Chamber, 15 March 2006, par. 53. 
Chapter IX

relegated to a position of importance inferior to other considerations, military or otherwise, however important they may be. This general rule is, of course, predicated on the assumption that at all times, the person entrusted with this responsibility, is in a position to fulfill this obligation. It does not, and cannot, apply when, for instance, there is the impossibility to act, or when it would be utterly unreasonable to expect one to act, as in the case of a life-threatening situation. ${ }^{678}$

In this fragment the Trial Chamber suggests that the obligations of a commander towards POWs can recede in situations in which it is impossible or unreasonable to fulfill them.

In Prosecutor v. Tolimir Judge Antoine Kesia-Mbe Mindua holds in his Separate and Concurring Opinion - in relation to genocide charges - that there was no joint criminal enterprise (JCE) to forcibly remove the Bosnian Muslim population, for there was no common purpose for such an enterprise: evacuations were based on war-time necessity. ${ }^{679}$

\section{NECESSITY AND DURESS AT THE ICTR}

\subsection{Prosecutor v. Kajelijeli}

\subsubsection{Relevant passages}

During the Rwandan Genocide of 1994 Juvénal Kajelijeli is Bourgmestre of the Mukingo commune, an area where large-scale killings of Tutsi took place. At the ICTR he stands trial for genocide (article 2 of the ICTR Statute), crimes against humanity (article 3 of the ICTR Statute) and Violations of Article 3 common to the Geneva Conventions and Additional Protocol II (article 4 of the ICTR Statute). In reaction to a genocide charge under article 6(3) of the ICTR Statute (superior responsibility), the accused explains that he could not punish the perpetrators of genocide because:

[...] when he became a bourgmestre for the second time, his safety was not guaranteed. The soldiers that had deserted were threatening him. Part of Mukingo commune had been deserted. Many people had been massacred by the RPF. People were fleeing the massacres. It was even being said that the RPF had infiltrated the area. No civil servant could do their job, as they wanted. During the night, the Accused could not stay in Mukingo. He was only there in the daytime and was moving about accompanied by the commune police. There were RPF sympathizers who were

678 ICTY, Prosecutor v. Orić, Trial Chamber, 30 June 2006, p. 559.

679 ICTY, Prosecutor v. Tolimir, Separate and concurring opinion Judge Antoine Kesia-Mbe Mindua, 12 December 2012, par. 85. 
working in the commune. People from the RPF knew the Accused, and he could not hide from them. It was then that his family ran away, a week before he himself left. ${ }^{60}$

The Trial Chamber gives him the benefit of the doubt:

The Chamber considered the Accused's testimony that he attempted to punish those involved in these crimes, but does not find it credible. Therefore, the Chamber does not find it established that the Accused did in fact take measures to punish the attackers. The Chamber also finds, however, that the Prosecution did not prove that the situation prevailing at the end of June 1994 was such that the Accused, as the new bourgmestre, would have had the material ability to punish the perpetrators for the killings. Accordingly, the Chamber does not find that the Accused failed to punish the perpetrators. ${ }^{681}$

\subsubsection{Applicability}

Kajelijeli brings up a necessity/duress defense to demonstrate that it was impossible for him to punish the perpetrators of massacres. The defense in principle appears to have been accepted, for the Trial Chamber suggests that, were the defendant's story credible, it would have influenced his criminal responsibility. In casu the defense is rejected because the Trial Chamber does not find Kajelijeli's story credible. However, because the prosecution did not prove its case, the Trial Chamber concludes that the defendant did not have the ability to punish perpetrators ex article 6(3) of the ICTR Statute. Nevertheless, this finding is not of much consequence since Kajelijeli is convicted for failure to take the necessary measures to prevent acts of genocide under the same article. ${ }^{62}$

\subsubsection{Scope}

Since the defense is rejected because the Trial Chamber does not believe the defendant, this case bears no information as to the scope of either necessity or duress.

\subsubsection{Necessity/duress}

The defense brought up in this case is not labeled. The argument, however, comes down to an excuse. The defendant does not argue that he did the right thing, but that he could not help doing what he did.

\footnotetext{
680 ICTR, Prosecutor v. Kajelijeli, Trial Chamber, 1 December 2003, par. 738.

681 ICTR, Prosecutor v. Kajelijeli, Trial Chamber, 1 December 2003, par. 741.

682 ICTR, Prosecutor v. Kajelijeli, Trial Chamber, 1 December 2003, par. 840/841.
} 
Chapter IX

\subsection{Prosecutor v. Kamuhanda}

\subsubsection{Relevant passages}

During the 1994 Rwandan genocide Jean de Dieu Kamuhanda was an influential figure in several government functions. From May 1994 he was the Minister of Higher Education and Scientific Research in the Interim Government ${ }^{683}$ that planned and executed the genocide. ${ }^{684} \mathrm{He}$ is charged with genocide, crimes against humanity and violations of Article 3 common to the Geneva Conventions and Additional Protocol II. ${ }^{65}$ As to his individual criminal responsibility for the acts of the Interim Government he asserts that he:

[...] became a member of the Interim Government because his life and that of his family were threatened and at stake, and, as such, (he) had no choice but to accept the position in the Interim Government. In these circumstances (he) became a member of the Interim Government under duress. Therefore (he) maintained that (he) should not be held liable in any way for the acts of the Interim Government as the Prosecution sought to do. ${ }^{686}$

The Trial Chamber rejects this argument, by holding that it:

[...] has noted the submission of the Defence in respect of the appointment of the Accused to the Interim Government. The Chamber further notes that this appointment occurred in May after the events that are charged in the Indictment with regard to Gikomero commune. The Chamber therefore finds the evidence tendered relating to the appointment of the Accused to the Interim Government irrelevant to the acts and conduct of the Accused as regards events in the Gikomero commune. Moreover, on the basis of the evidence heard at trial, the Chamber finds no merit in the contention that the Accused was reluctant to be appointed Minister. ${ }^{687}$

However, dissenting Judge Maqutu, who wants to reduce the imposed life sentence to twenty-five years, makes a rather ambivalent statement, holding that:

The Accused told the Chamber that he became a Minister because he was afraid to decline the honor. There is evidence from Nkiko Nsengimana (which is not challenged) that Sindikubwabo, whose Tutsi wife had been killed, was fetched from Butare and made Acting President when he believed he was about to be killed. Not long thereafter Acting President Sindikubwabo was addressing meetings saying that

683 ICTR, Prosecutor v. Kajelijeli, Trial Chamber, 1 December 2003, par. 6 and 13.

684 Leave None to Tell the Story: Genocide in Rwanda, Report by Human Rights Watch, 1 April 2004.

685 ICTR, Prosecutor v. Kamuhanda, Trial Chamber, 22 January 2004, par. 12.

686 ICTR, Prosecutor v. Kamuhanda, Trial Chamber, 22 January 2004, par. 78.

687 ICTR, Prosecutor v. Kamuhanda, Trial Chamber, 22 January 2004, par. 79-80. 
the Hutu should "work" and kill Tutsis. It is difficult to believe that the Accused could have been afraid of a regime that was clearly on the verge of falling. We are not being told the whole story. ${ }^{688}$

\subsubsection{Applicability}

In Kamuhanda the necessity/duress defense is implicitly recognized, for the defense is explicitly mentioned by the Defense and the Trial Chamber does not deny its existence. The defense is, however, rejected in casu, because some of the crimes charged were committed before the appointment of the accused to the interim government. As to the other crimes, the Trial Chamber holds that it does not find the presence of coercion credible, based on "evidence heard at trial". This is a rather general reference, since the Trial Chamber does not indicate which evidence negates the presence of duress. Judge Maqutu's dissenting opinion does not bring us any further in this respect. His statement on duress is rather ambivalent. On the one hand he argues, that the duress defense can be credible for the Interim Government has exercised duress in another case. On the other hand, Maqutu does not seem to believe that the accused could be afraid of this regime "on the verge of falling". It seems as if Maqutu looks at the necessity/duress defense from both sides (defense and prosecution), but refrains from drawing conclusions. Significantly, the Trial Chamber does not discuss whether the defendant had an opportunity to leave the relevant organization, as was argued by the Appeals Chamber in Kvočka.

\subsubsection{Scope}

Because the Trial Chamber finds the defendant's argument irrelevant and because the reference to "evidence heard at trial" is rather general and brief, the rejection of necessity/duress in this case does not contain any information on the criteria for this type of defense. Dissenter Maqutu suggests that a necessity/duress defense gains credibility when other persons have been threatened in a similar manner. However, due to the fact that this issue is only mentioned in a contradictory statement as part of a dissenting opinion, not much value can be adhered to this remark.

\subsubsection{Necessity/duress}

The defense refers to the defense at issue as "duress". However, since the Judgment barely contains data on the contents of this defense, this classification does not contain much information either. The duress brought up must be categorized as an excuse, for the defendant does not claim his actions were morally right, but that he did not have a choice in what he did.

688 ICTR, Prosecutor v. Kamuhanda, Judge Maqutu's Dissent on the Sentence, Trial Chamber, 22 January 2004, par. 9. 
Chapter IX

\subsection{Other ICTR references to necessity/duress}

The final report of the Commission of Experts on the establishment of the ICTR mentions that duress is "a possible defence[s] to individual allegations of serious human rights violations". 689

\section{NeCESSITY AND DURESS AT THE ICC}

\subsection{Applicability}

Necessity/duress is recognized by the ICC in article 31 paragraph (1)(d) and heading (Grounds for excluding criminal responsibility) of the ICC Statute:

1. In addition to other grounds for excluding criminal responsibility provided for in this Statute, a person shall not be criminally responsible if, at the time of that person's conduct:

[...]

(d) The conduct which is alleged to constitute a crime within the jurisdiction of the Court has been caused by duress resulting from a threat of imminent death or of continuing or imminent serious bodily harm against that person or another person, and the person acts necessarily and reasonably to avoid this threat, provided that the person does not intend to cause a greater harm than the one sought to be avoided. Such a threat may either be:

(i) Made by other persons; or

(ii) Constituted by other circumstances beyond that person's control.

An unsuccessful appeal to necessity/duress can be considered in mitigation under Rule 145(2)(a)(i), which provides that "circumstances falling short of constituting grounds of exclusion of criminal responsibility, such as substantially diminished mental capacity" may be taken in mitigation.

\subsection{Scope}

Paragraph 1(d) of article 31 bears several conditions for a successful appeal to necessity/duress:

a. There must be a threat;

b. This threat consists of either:

- imminent death or 
- continuing or imminent serious bodily harm;

c. The threat must be issued against:

- the defendant or

- another person;

d. The crime has been caused by duress resulting from the threat;

e. The defendant must have acted necessarily to avoid the threat;

f. The defendant must have acted reasonably to avoid the threat;

g. The defendant must not have intended to cause a greater harm than the one sought to be avoided;

h. The threat may result from:

- persons or

- circumstances beyond that person's control.

The following Section provides an analysis - per condition - of the necessity/duress provision in the ICC Statute.

(a) There must be a threat

The requirement of a threat means that the provision is not applicable in case a defendant falsely believes he is threatened. ${ }^{690}$

(b) This threat consists of either imminent death or continuing or imminent serious bodily harm

Only specific threats fall within the scope of article 31(1)(d): threats of death and of serious bodily harm. Both species of threats have to be "imminent". An elevated possibility that a dangerous situation might occur is thus insufficient. According to Eser, serious bodily harm refers to injuries more serious than easily healed superficial wounds. ${ }^{691}$ Note that the scope of the threat is narrower than in case of self-defense (article 31(1)(d)), where the use of force is not specified. This lack of specification is however compensated by an objective proportionality requirement in case of self-defense, so that a severe crime can only be justified in case of a severe threat.

(c) The threat must be issued against the defendant or another person

Unlike some national laws, the Statute does not require a special relationship between the defendant and the other. As long as the threat is issued against a person, article 31(1)(d) is applicable. However, when a special relationship does exist, it can make the duress more compelling ${ }^{692}$ and consequently influence the requirement of

\footnotetext{
690 Cryer, R. et al., 2010, p. 412.

691 Eser, A., 2008, p. 885.

692 Eser, A., 2008, p. 885.
} 
reasonability or causation (see (d) and (f), below). Although a threat against property used to be included in the proposal, it was later removed. ${ }^{693}$ The fact that property is not included as a protected interest is another difference between the definitions of duress and self-defense in the ICC Statute.

\section{(d) The crime has been caused by duress resulting from the threat}

This is a causation requirement: the threat must have caused the defendant to commit the crime. ${ }^{694}$ If the defendant would have committed the crime anyway, an appeal to this provision is of no avail. However, as Cryer notes, there is nothing in article $31(1)(d)$ that says that these threats have to be the only cause. ${ }^{695}$ Eser holds that this requirement should be interpreted objectively: it is only met when a reasonable person could not have endured the threat. ${ }^{696}$ Ambos suggests that this requirement should be subjectivised (e.g. a trained soldier should display more resistance to threats than a defendant with a "weak" personality). 697

\section{(e) The defendant must have acted necessarily to avoid the threat}

The act of the defendant must have been "necessary" in the sense that no other means were available: the means employed were absolutely necessary to avert the situation. ${ }^{698}$

\section{(f) The defendant must have acted reasonably to avoid the threat}

The reasonability-criterion has been interpreted in different ways. The majority of authors adhere to the interpretation offered by Ambos. According to him "reasonably" is an "umbrella term" both encompassing necessity and proportionality. ${ }^{699}$ Eser rejects this approach for a) paragraph (1)(c) (self-defense) mentions both proportionality and reasonability separately (i.e. if proportionality was meant to be a requirement in case of duress it would have been mentioned separately as well) and (b) paragraph (1)(d) explicitly requires subjective proportionality (see below, requirement (e)). ${ }^{700}$ According to Eser, "reasonably" should be interpreted as "reaching the desired effect" 701 He gives an example of torturing a terrorist to prevent an attack. Although this may be necessary (no other means are available) torture is always an inadequate tool to reach the desired effect, because of the high risk of unreliable information. It is therefore always

693 Scaliotti, M., 2001, p. 152.

694 Werle, G., 2005, p. 145.

695 Cryer, R. et al., 2010, p. 413.

696 Eser, A., 2008, p. 886.

697 Ambos, K., 2002, p. 1040.

698 Ambos, K., 2002, p. 1040 and Eser, A., 2008, p. 886.

699 Ambos, K., 2002, p. 1040. See also: Scaliotti, M., 2001, p. 156; Knoops, G.J., 2001, p. 69 and Werle, G., 2005, p. 146.

700 Eser, A., 2008, p. 887. Another argument against the interpretation of Ambos is that the necessity requirement is already mentioned separately in article 31(1)(d) of the ICC Statute.

701 Eser, A., 2008, p. 886. 
unreasonable. ${ }^{702}$ Other writers have a more defendant-oriented interpretation of the word "reasonably": the defendant must have acted as a reasonable person. ${ }^{703}$ According to Gilbert this reasonability consists of three aspects: (a) the defendant must have reasonably believed the existence of the threat, (b) he would have had some reason to believe the threat would materialize and (c) the accused must have been reasonably brave. According to Eser the reasonable person requirement is embedded in the causation-criterion ((c), above). Note that ICC definition of reasonability in case of self-defense is entirely different (more a necessity/efficiency requirement). Ambos rightly notes that it is unfortunate that the terms "necessity", "reasonability" and "proportionality" used in paragraph (1)(c) and (1)(d) were not harmonized. ${ }^{704}$

(g) The defendant must not have intended to cause a greater harm than the one sought to be avoided

That the defendant must not have intended to cause a greater harm than the one sought to be avoided is a subjective proportionality requirement: even if the defendant did not objectively avoid the greater harm, the requirement can still be met as long as the defendant intended to do so. ${ }^{705}$ The function of this requirement is to insert a mental element: if the defendant, who is exposed to a risk not otherwise avoidable, wished to commit the crime anyway (i.e. apart from the extreme situation), his criminal responsibility is not excluded under paragraph (1) (d). ${ }^{706}$ So far, the requirement overlaps with the causation requirement (d), which is not met in case the defendant (or an objective reasonable person) would have committed the crime without the pressure. A further characteristic of this present requirement is, however, that the defendant not only must have committed the crime because of the threat, but also must have intended to take objectively the best course of action.

(h) The threat may result from persons or circumstances beyond that person's control.

This source-requirement has also been interpreted in various ways. According to Bantekas, the criterion simply means that the defendant can only be exculpated when the threat is not brought about by actions of the accused, but by other persons or circumstances beyond his control. ${ }^{707}$ Eser notes that the clause "circumstances beyond that persons control" insinuates that self-induced risks (prior faults) are excluded from exemption under paragraph (1)(d). ${ }^{708}$ Others are more specific and

\footnotetext{
702 Eser, A., 2008, p. 886 (footnote 153).

703 Gilbert, J., 2006, p. 154 and Cryer, R. et al., 2010, p. 413.

704 Ambos, K., 2002, p. 1040.

705 Dixon R. and Khan, K.(eds.), 2009, p. 1288.

706 Eser, A., 2008, p. 888.

707 Bantekas, I., 2004, p. 274.

708 Eser, A., 2008. p. 885.
} 
hold that this clause means article $31(1)(d)$ does not apply in case of a prior fault. ${ }^{709}$ Nevertheless, the drafting history of the article demonstrates that the distinction between "persons" and "circumstances beyond that persons control" was inserted to differentiate between the various sources of threats and that an exact definition of prior fault was consciously avoided. It was left to decide by the court under paragraph (2) of article $31 .^{710}$ Whether article $31(1)(\mathrm{d})$ bears a prior fault criterion, is thus not entirely clear.

\section{Objective/subjective}

The provision is an interesting mixture of objective and subjective requirements. Requirements (a)-(c) and (h) are objective (the presence, severity, object, and source of the threat). The causation requirement (d) can be interpreted either objectively or subjectively. Requirements (e) and (f) (necessity and reasonability) are objective as well. The intent requirement $(\mathrm{g})$ is subjective.

\subsection{Necessity/duress}

The ICC provision consistently speaks of duress and defines this concept as described in Section 6.2 (Scope). This "duress"-defense, however, can neither be qualified as a justification, nor as an excuse. The defense is not a justification because, due to the subjective proportionality requirement, it does not demand the defendant to make objectively the best choice. However, due to the very same subjective proportionality requirement, the defense is not an excuse either. Namely, because of this requirement, a defendant, who succumbs to pressure which would be unbearable to any reasonable person, but, at the same time, did not intend to act proportionally (for he simply intended to save himself and his loved ones from harm) cannot successfully plea the ICC-version of duress. Consequently article 31(1)(d) leaves the possibility that a defendant, who did not act blameworthy in the sense of Chapter II of this thesis, cannot resort to duress under the definition of the ICC, because he did not intend to act proportionately. ${ }^{711}$ Interesting detail on the ICC duress provision is that earlier proposals contained two provisions: necessity and duress. However during negotiations the two were mixed into one provision. ${ }^{712}$

\footnotetext{
709 Ambos, K., 2002, p. 1039; Gilbert, J., 2006, p. 156 and Werle, G., 2005, p. 148.

710 Scaliotti, M., 2001, pp. 153 and 155.

711 Similar observations made by: Eser, A., 2008, p. 884 and Bantekas, I, 2004, 274.

712 Bantekas, I. and Nash, S., 2007, p. 62.
} 


\section{ANALYSIS OF NECESSITY/DURESS}

\subsection{Applicability}

\subsubsection{In principle}

The post World War II tribunals discuss several necessity/duress defenses, however, the defense is never explicitly recognized. At the ICTY the defense ("duress") is rejected a priori in case a soldier kills innocent human beings in the context of a war crime or a crime against humanity (Erdemović). However, in the later Aleksovski-case the Appeals Chamber seems to implicitly acknowledge the necessity/duress defense in the form of "extreme necessity", but at the same time refuses to investigate whether "necessity constitutes a defense under international law". This ambivalence towards the necessity/duress defense continues in Kvočka et al., where the ICTY both acknowledges and excludes this defense in the same Judgment. On the other hand, in ICTY cases where necessity/duress was discussed (but not brought up as a complete defense) the defense seems to be recognized. The ICTR does recognize the necessity/duress defense (both in case law and in the Report of the Commission of Experts), as does the ICC in article 31(1)(d) of its Statute.

From the above can be concluded that the necessity/duress-argument is generally recognized in principle. Exception is the ICTY, where controversial utterances and an a priori exclusion make it difficult to establish in which cases a necessity/duress defense could be applicable.

\subsubsection{In casu}

The necessity/duress defense has never been accepted as a complete defense. Reasons for rejection can be brought back to several (recurring) arguments. In order of frequency:

a. The defendant had other options (Itagaki, Matsui, Dohihara, Aleksovski, Kvočka);

b. The court does not believe the defendant (Kvočka, Kajelijeli, Kamuhanda);

c. The defendant did not intend to choose the lesser of two evils (general part of the Nuremberg Judgment, Togo);

d. Prior fault (Dönitz);

e. Procedural reasons (Aleksovski).

\subsubsection{Mitigation}

The Appeals Chamber in Erdemovic holds that duress is not a complete defense when a soldier kills innocents by committing war crimes or crimes against 
humanity. However it suggests that in these cases, duress can theoretically still be taken in mitigation of punishment. Eventually, in Erdemović, duress was a mitigating factor in sentencing. After Erdemović, most pleas of duress in mitigation at the international courts, subject of this study, have been rejected. ${ }^{713}$ The exception is Prosecutor $v$. Ndahimana where duress was taken in mitigation. ${ }^{714}$ According to the ICC Rule 145(2)(a)(i), a failed appeal to necessity/duress can be taken in mitigation.

\subsubsection{Other legal consequences}

There are no remarkable legal consequences to the rejection of necessity/duress in the cases subject to this research. Usually the rejection contributes to a conviction for the crime charged or to the rejection of a ground for appeal. Only in Kajelijeli the rejection of necessity/duress was of no consequence: because the prosecution failed to prove its case, Kajelijeli was not convicted for this specific charge. At the ICC a successful appeal to article 31(1)(d) leads to acquittal.

\subsection{Scope}

The requirements for necessity/duress that can be extracted from case law are:

(a) Presence and severity of threat

According to the ICC Statute there must be "a threat of imminent death or of continuing or imminent serious bodily harm". The Erdemović-majority mentions a similar - but less specific - condition ("the act charged was done to avoid an immediate danger both serious and irreparable”) as a general requirement for duress.

(b) The threat must be issued against the defendant or another person

This requirement related to the object of the threat is only mentioned in the ICC Statute.

713 ICTY, Prosecutor v. Kvočka et al., Trial Chamber, 2 November 2001, par. 403 and 427; ICTY, Prosecutor v. Kvočka et al., Appeals Chamber, 28 February, 2005, par. 643; ICTY, Prosecutor v. Mrđa, Trial Chamber, 31 March 2004, par. 66; ICTY, Prosecutor v. Bralo, Trial Chamber, 7 December 2005, par. 55; ICTY, Prosecutor v. Bralo, Appeals Chamber, 2 April 2007, par. 25; ICTY, Prosecutor v. Češić, Trial Chamber, 11 March 2004, par. 95-97; ICTY, Prosecutor v. Simić, Appeals Chamber, 28 November 2006, par. 255; ICTY, Prosecutor v. Blaškić, Appeals Chamber, 29 July 2004, par. 696 and ICTR, Prosecutor v. Nzabirinda, Trial Chamber, 23 February 2007, par. 94; ICTR, Prosecutor v. Bizimungu et al., Trial Chamber II, 30 september 2011, par. 2018.

714 ICTR, Prosecutor v. Ndahimana, Trial Chamber, 30 December 2011, par. 30. However, in her dissenting opinion, Judge Florence Rita Arrey disagrees. According to her, duress should not have been taken in mitigation due to unpersuasive evidence. See: ICTR, Prosecutor $v$. Ndahimana, Dissenting opinion of Judge Florence Rita Arrey, Trial Chamber, 30 December 2011, par. 193-196. 
(c) The crime has been caused by duress resulting from the threat

The causation requirement is mentioned in the ICC Statute and by the Erdemovic majority ("the act charged was done to avoid an immediate danger both serious and irreparable").

(d) The defendant must have acted necessarily to avoid the threat

The act of the defendant must have been "necessary" in the sense that no other means were available: the means employed were absolutely necessary to avert the situation. The necessity criterion is the most frequently mentioned requirement in the cases studied. It features in Itagaki, Dohihara, Matsui, Aleksovski and Kvočka. Necessity is also mentioned by the Erdemović-majority as a general requirement for duress. What is more, article 31(1)(d) of the ICC Statute also bears a necessity requirement.

(e) The defendant must have acted reasonably to avoid the threat

This requirement is only mentioned in the ICC Statute. It has been interpreted in various ways: as encompassing both necessity and proportionality, as "reaching the desired effect," and as a reasonable person test.

(f) The defendant must not (have intended to) cause a greater harm than the one sought to be avoided

The proportionality requirement appears as an objective condition in Erdemovic and as a subjective condition in the general part of the Nuremberg Judgment, Togo (both in the context of a justification) and the ICC Statute.

(g) The threat may result from persons or circumstances beyond that person's control.

Several ICC commentators have interpreted this condition as a prior fault requirement. There is, however, no unanimity on this issue. The only necessity/ duress case that displays a prior fault reasoning is the Nuremberg verdict on Dönitz.

\section{Objective/subjective}

Most requirements demand an objective test. However, condition (c) and (f) can be interpreted both objectively and subjectively.

\subsection{Necessity/duress}

The introduction to this Chapter mentions additional research questions in relation to the distinction necessity/duress:

a. Can the defenses brought up be classified as either a justification or an excuse? 
b. Is this distinction similar to the linguistic distinction between necessity and duress?

c. Can necessity and duress be distinguished by any other feature(s)?

To start with (a), most of the arguments brought up can be categorized as either a justification or an excuse. Exception is the ICC definition: this defense is not a justification because it does not require the defendant to make objectively the best choice. However, it is probably not an excuse either for it has a subjective proportionality requirement. In relation to (b): most necessity/duress defenses brought up were not labeled, neither as necessity, nor as duress. In several cases where "duress" is raised, the defendant meant to plead an excuse. However, to conclude that "duress" always refers to an excuse is too far-fetched. Not only because the ICC provision refers to "duress". Also, the Erdemović-case - where the excuse raised was defined in terms of a justification (requiring the defendant to pick the lesser evil) - forms an obstacle to defining duress as an excuse. Only on one occasion was "necessity" raised ("extreme necessity", to be precise). This wording referred to both a justification and an excuse. However, in this case the relevant Chamber is ambiguous as to the existence of a necessity/duress defense to begin with. There are barely any other distinguishing features between "necessity" and "duress" (c). The only regularity that can be detected seems to be that the word "duress" is always used in case the defense brought up involves $a$ threat by other human beings. ${ }^{715}$ Conclusively, it can be held that most necessity/ duress defenses can be defined in terms of a justification or an excuse, but that this categorization does not equal the linguistic distinction between "necessity" and "duress" and that the word "duress" generally refers to threats by other human beings.

\subsection{Categorization}

Chapter II demonstrates that international criminal theory distinguishes between three different types of defenses. The question answered in this subsection is whether the necessity/duress defense matches any of these three types. Since the necessity/duress defense can both be brought up as a justification and as an excuse (see previous Section), the defense could theoretically appear in any of the three types described in Chapter II:

715 Literature on necessity and duress displays similar mix-ups of terminology. Some writers differentiate between necessity and duress by compulsive source (human or circumstances), other by effect (justification or excuse). In American and British textbooks necessity is defined as 'duress of circumstances'. However, other writers refer to necessity as either choice of evils, or as covering both justifying and excusing circumstances (compare Eser, A., 2008, p. 884). 


\begin{tabular}{|l|l|l|l|}
\hline Defense & Effect & $\begin{array}{l}\text { Justification or } \\
\text { excuse? }\end{array}$ & Affirmative or not? \\
\hline$X$ & $\begin{array}{l}\text { General requirements } \\
\text { for criminal liability are } \\
\text { not negated }\end{array}$ & Justification & Affirmative \\
\hline $\begin{array}{l}\text { No definitional } \\
\text { subjective element }\end{array}$ & $\begin{array}{l}\text { Defense negates } \\
\text { definitional subjective } \\
\text { element }\end{array}$ & Justification or excuse & Not affirmative \\
\hline No blameworthiness & $\begin{array}{l}\text { Defense negates } \\
\text { blameworthiness }\end{array}$ & Excuse & Affirmative \\
\hline
\end{tabular}

The fact that necessity/duress matches the second type of defense (defense $=$ no definitional subjective element) is expressed by the first Trial Chamber in Erdemović, who holds that necessity/duress:

[...] may also be regarded as a defence for the criminal conduct, which might go so far as to eliminate the mens rea of the offense and therefore the offense itself. ${ }^{716}$

A statement, suggesting that the necessity/duress defense does not affect the definitional subjective element, but instead refrains from negating the elements of the offense (defense $=x$ or defense $=$ no blameworthiness), is made by Judge McDonald and Judge Vohrah:

Given that duress has been held at common law not to negate mens rea, the availability of the defence turns on the question whether, in spite of the elements of the offense being strictly made out, the conduct of the Defendant should be justified or excused.717

Judges McDonald and Vohrah also explicitly acknowledge that the presence of duress affects the blameworthiness of the defendant:

[...] it is, in our view, a general principle of law recognized by civilized nations that an accused person is less blameworthy and less deserving of the full punishment when he performs a certain prohibited act under duress. ${ }^{718}$

Exception is the ICC definition, which probably neither qualifies as a justification, nor as an excuse. In conclusion, it can be held that the necessity/duress defense can be categorized any possible way: as a justification, an excuse, or as neither.

716 ICTY, Prosecutor v. Erdemović, Trial Chamber I, 27 November 1996, par. 14.

717 ICTY, Prosecutor v. Erdemović, Joint Separate Opinion of Judge McDonald and Judge Vohrah, Appeals Chamber, 7 October 1997, par. 71.

718 ICTY, Prosecutor v. Erdemović, Joint Separate Opinion of Judge McDonald and Judge Vohrah, Appeals Chamber, 7 October 1997, par. 66. 
Chapter IX

\subsection{Conclusion on necessity/duress}

The status of necessity/duress in international law is far from clear. Not only as to its general applicability, but also in terms of scope and categorization. Therefore the following questions are paramount to the further development of necessity/duress in international criminal law:

1. Should there be a distinction between a justificatory and an excusing defense and, if so, how should these defenses be defined?

2. Should the Erdemović-exclusion be applicable in case of a justificatory defense and/or an excusing defense?

3. When should necessity/duress be taken in mitigation?

4. Does the ICC-definition suffice and how should it be interpreted (for the necessity requirement seems to be the only non-controversial condition)?

\subsection{Preview Part III}

Part III of this thesis argues that a distinction should be made between a justificatory and an excusing version of necessity/duress. It also demonstrates why the Erdemović-exclusion should not be applicable and that necessity/duress can only be taken in mitigation of punishment when a complete defense is not established. Finally, an amendment to the ICC provision is proposed. 


\section{Chapter X \\ BELLIGERENT REPRISALS}

\section{INTRODUCTION}

In general a belligerent reprisal (hereinafter 'reprisal') can be defined as an otherwise unlawful act by a belligerent as a response to a violation of the law by the adversary, taken for the purpose of seeking compliance with the law by this adversary. For example, adversary $\mathrm{X}$ attacks civilians. In order to stop these attacks belligerent party $\mathrm{Y}$ uses prohibited weapons. The action by party $\mathrm{Y}$ could qualify as a lawful belligerent reprisal, since Y's only reason for violating the law is to stop $\mathrm{X}$ from attacking civilians.

Reprisals are traditionally an international law defense. The defense was only discussed at the ICTY. Also, the ICC Statute leaves room for this defense under article 31(3). The Chapter below discusses the relevant law and concludes that the defense of reprisals is generally available, as long as the reprisal is not in violation of the applicable humanitarian law.

\section{REPRISALS AT THE ICTY}

\subsection{Prosecutor v. Kupreškić}

\subsubsection{Facts of the case}

In 1993 Croat forces attacked the Muslim population of the village of Ahmići, killing 116 people, destroying buildings and driving the remaining Muslim population out. Several perpetrators were charged with violations of the laws and customs of war and crimes against humanity in Kupreškić et al. ${ }^{719}$ One argument put forward by the defense is that the civilian deaths in Ahmići were the result of a militarily-justified action between warring factions. ${ }^{720}$ Due to the length of the relevant passages on complete defenses in Kupreškić et al., these passages are paraphrased in the analysis below.

\subsubsection{Applicability}

The Trial Chamber in Kupreškić a priori rejects the defense of belligerent reprisals in case of attacks on the civilian population. ${ }^{721}$ Consequently, the defense is also

719 ICTY, Prosecutor v. Kupreškić et al., Trial Chamber, 14 January 2001, par. 31-37.

720 ICTY, Prosecutor v. Kupreškić et al., Trial Chamber, 14 January 2001, par. 512.

721 ICTY, Prosecutor v. Kupreškić et al., Trial Chamber, 14 January 2001, par. 510. 
rejected in casu. However, by mentioning the general criteria for reprisals at the end of their contemplation, the Trial Chamber acknowledges that reprisals can be a complete defense against other charges. ${ }^{722}$

The Trial Chamber mainly rejects reprisals against civilians because they are convinced that this is customary law. In this general rejection, the Trial Chamber distinguishes between civilians in the hands of the adversary and civilians in combat zones. The latter category of civilians is at issue in the present case. The prohibition of reprisals against civilians in the hands of the adversary is customary law. Reprisals against civilians in combat zones are prohibited by the First Additional Protocol of 1977. The Trial Chamber argues that this latter set of rules has also transformed into custom. Although there is not much State practice on this issue, an opinio iuris may have emerged "under the pressure of the demands of humanity or the dictates of the public conscience".723 The Trial Chamber holds that opinio iuris exists by referring to several national military manuals, a $1970 \mathrm{UN}$ resolution declaring that reprisals should not be taken against civilians, the high number of States that has ratified the First Protocol (which prohibits reprisals against civilians), a 1983 memorandum of the International Committee of the Red Cross (ICRC) and by referring to the Martić Trial Chamber (in an article 61 procedure). ${ }^{724}$ In addition, the Trial Chamber refers to the fact that States have refrained from claiming the right to visit reprisals upon enemy civilians. It concludes that "the aforementioned elements seem to support the contention that the demands of humanity and the dictates of public conscience, as manifested in opinio necessitas, have by now brought about the formation of a customary rule" excluding reprisals against civilians. It holds that this is confirmed by a Commentary of the ILC, which communicates that common article 3 (applicable in non-international armed conflicts) must be read as prohibiting reprisals against civilians. The Trial Chamber holds that the principles put down in this article are also applicable to armed conflicts because "it would be absurd to hold that while reprisals against civilians [...] are prohibited in civil wars, they are allowed in international armed conflicts as long as the civilians are in the combat zone".

Apart from arguing that the ban on reprisals against civilians is customary law, the Trial Chamber displays several other objections against reprisals involving civilians:

1. These reprisals are not directed at the authors of the initial violation, but at a vulnerable group that has no influence over the situation.

722 ICTY, Prosecutor v. Kupreškić et al., Trial Chamber, 14 January 2001, par. 535.

723 ICTY, Prosecutor v. Kupreškić et al., Trial Chamber, 14 January 2001, par. 527.

724 An article 61 procedure is held in absence of the defendant. In such a case, the Trial Chamber determines, based on evidence brought up by the prosecution, whether there are reasonable grounds to believe that the defendant has committed the indicted offenses. The article 61 proceedings in Martić must not be confused with the Martić Judgment, discussed below. 
2. Killing innocents without a trial is a "blatant infringement of the most fundamental principles of human rights". Consequently, denying reprisals against civilians is in accord with the trend of humanization of armed conflict.

3. Reprisals are outdated. In the past they probably were the only effective means to compel the enemy to abandon unlawful acts. Nowadays we have other means to attain similar results, such as the prosecution of war criminals. $^{725}$

The Trial Chamber concludes its contemplation by demonstrating that in the case at hand, the customary status of the ban on reprisals against civilians is irrelevant, for the treaty provisions prohibiting them (article 51(6) and 52(1) of the First Additional Protocol of 1977) were applicable anyway to the case in issue. $^{726}$

\subsubsection{Scope}

While the Trial Chamber a priori excludes the defense of reprisals in case of attacks on civilian populations, it suggests that in other situations reprisals can be a complete defense if the following requirements have been met:

a. The reprisal must have been the last resort;

b. The reprisal may only be exercised after a prior warning;

c. Reprisals may only be taken after a decision to this effect has been made at the highest political or military level (thus not by local commanders);

d. The measures taken must be proportionate to the initial violation of the law of armed conflict by the opposite party (according to this condition, the reprisal must cease as soon as the breach, which provoked the reprisal, ends);

e. The reprisal must respect considerations of humanity. ${ }^{727}$

As to the interpretation of these criteria, the Judgment provides little information, for the defense is a priori rejected. However, the last criterion (e) refers to the Martens Clause. ${ }^{728}$ The Trial Chamber seems to have interpreted this criterion as not met in case of attacks on civilians. All criteria require an objective test.

\footnotetext{
725 ICTY, Prosecutor v. Kupreškić et al., Trial Chamber, 14 January 2001, par. 528-530.

726 ICTY, Prosecutor v. Kupreškić et al., Trial Chamber, 14 January 2001, par. 536.

727 ICTY, Prosecutor v. Kupreškić et al., Trial Chamber, 14 January 2001, par. 535.

728 The Martens Clause prevents the assumption that anything, which is not explicitly prohibited by the relevant conventions on humanitarian law, is permitted. See ICRC commentaries on article 1 (which includes the Martens Clause) of the Additional Protocol I to the Geneva Conventions of 12 August 1949.
} 
Chapter X

\subsection{Prosecutor v. Milan Martić}

\subsubsection{Facts of the case}

Following a Croatian Government offensive in May 1995 (Operation Flash) recapturing the Krajina region from Serb forces - Zagreb was shelled by Serbian units, resulting in injury and death among civilians. Milan Martić, who had held several top positions in the Serb dominated Krajina region, ordered this shelling of Zagreb. He was charged by the ICTY for violations of laws and customs of war and crimes against humanity. ${ }^{729}$ On trial the defense argued that "the shelling of Zagreb may be considered a lawful reprisal". ${ }^{730}$ This argument is rejected, both in the first instance and on appeal. Due to the length of the relevant passages on complete defenses in Martic these passages are paraphrased in the analysis below.

\subsubsection{Applicability}

Although the Trial Chamber accepts the defense of reprisals in principle, it is rejected in casu because -at least - two of the requirements for this defense have not been met. First, the shelling of Zagreb was "not carried out as a last resort, after having exhausted all other means" (see requirement (d) below). In support, the Trial Chamber points out that peace negotiations were ongoing at the moment of the alleged reprisal. Second, no formal warning was given prior to the act of shelling (see requirement (e) below). ${ }^{731}$

On appeal, Martić argues that (i) the Trial Chamber failed to consider the unlawfulness of the operation launched by Croat forces. In relation to the first ground of rejection (no last resort) he argues that (ii) this argument is supported by a message to Kofi Annan and by the fact that (iii) the Trial Chamber's finding that peace negotiations were ongoing at the time of the alleged reprisal is erroneous, because the Croats had rejected a Serb proposal for the cessation of hostilities. Martić also holds that (iv) the Trial Chamber's finding that he was in favor of nonpeaceful solutions is mistaken. In relation to the second ground of rejection (no formal warning) Martic argues that, (v) although there was no formal warning "the repeated warning that Zagreb would be shelled in the case of "aggression" against the RSK, the context of peace negotiations, and the practice of announcing military targets to save civilians meant that no reasonable trier of fact could have concluded that no warning had been given "during negotiations or subsequently"', 732

Considering the first ground of rejection, the Appeals Chamber holds - in relation to argument (ii) - that the relevant message merely supports the

ICTY, Prosecutor v. Martić, Appeals Chamber, 8 October 2008, par. 216.

ICTY, Prosecutor v. Martić, Trial Chamber, 12 June 2007, par. 464.

ICTY, Prosecutor v. Martić, Trial Chamber, 12 June 2007, par. 468.

ICTY, Prosecutor v. Martić, Appeals Chamber, 8 October 2008, par. 237-238. 
conclusion that the alleged reprisal was a "response" to the Croatian attack, and not a last resort. In addition, the Appeals Chamber notes that the Croats rejected a Serb proposal for cessation of hostilities on one particular day, but that negotiations continued (iii). Martić's challenge to the Trial Chamber's finding that he was in favor of non-peaceful solutions (iv) is rejected because he failed to substantiate this allegation. The Appeals Chamber rejects Martićs argument related to the second ground of rejection (v) because it is based on the same evidence as the Trial Chamber's decision. Argument (i) is not discussed by the Appeals Chamber, because Martić failed to show that the Trial Chamber erred when finding that the two conditions for reprisals (discussed above) had not been met. ${ }^{733}$

\subsubsection{Scope}

The Trial Chamber defines reprisals as "acts resorted to by one belligerent which would (a) otherwise be unlawful, but which are rendered lawful by the fact that they are taken (b) in response to a violation of that law committed by the other belligerent" with (c) "the sole purpose of seeking compliance with the law of armed conflict by the opposite party". In addition, the Trial Chamber mentions the following conditions:

d. The reprisal must have been the last resort (in Martic this requirement was not met, because peace-negotiations were ongoing);

e. Reprisals may be exercised only after a prior and formal warning;

f. Reprisals may only be taken after a decision to this effect has been made at the highest political or military level;

g. The measures taken must be proportionate to the initial violation of the law of armed conflict by the opposite party (according to this condition, the reprisal must cease as soon as the breach, which provoked the reprisal, ends);

h. The reprisal must respect the "laws of humanity and dictates of public conscience" (the Trial Chamber interprets this condition to mean that reprisals must be exercised, to the extent possible, in keeping with the principle of the protection of the civilian population in armed conflict and the general prohibition of targeting civilians). ${ }^{734}$

When defining the defense of reprisals the ICTY Trial Chamber refers to the ICRC commentary on the Additional Protocols, the Kupreškić-case and to several national military field manuals. The criteria mentioned for the defense of reprisals are objective.

733 ICTY, Prosecutor v. Martić, Appeals Chamber, 8 October 2008, par. 264-267.

734 ICTY, Prosecutor v. Martić, Trial Chamber, 12 June 2007, par. 465-467. 
Chapter X

\section{Reprisals at THE ICC}

Although the complete defense of reprisals cannot be found in the ICC Statute it could technically be a defense under article 31(3) and article 21 of this Statute. The contents of these provisions are discussed in Chapter XII (Other possible complete defenses in international criminal law).

\section{Analysis OF REPrisals}

\subsection{Applicability}

International criminal courts have produced few cases featuring reprisals. The two relevant judgments in this area have been issued by the ICTY. Both in Kupreškić and in Martic the defense of reprisals seems to be generally available. However, in Kupreškić the defense is rejected a priori in case of attacks on civilians. This rejection is substantiated by both customary law and the applicable provisions of international humanitarian law. The Martić Trial Chamber does not confirm the $a$ priori rejection based on customary law, although it holds that reprisals must be "in keeping with the principle of the protection of the civilian population in armed conflict and the general prohibition of targeting civilians". The Trial Chamber in Martić probably noted the criticism ${ }^{735}$ on the a priori exclusion in Kupreškić and decided not to deliberate on a customary prohibition of reprisals against civilians, but to judge the case on its merits. Although the complete defense of reprisals cannot be found in the ICC Statute, it could technically be a defense under article 31(3) and article 21 of this Statute. Despite the lack of legal sources, it can thus be concluded that the defense of reprisals is generally available, as long as the reprisal is not in violation of applicable humanitarian law. However, it cannot be derived from the case law studied in exactly which cases a reprisal is in violation of this law.

735 Greenwood, C., 'Belligerent Reprisals in the Jurisprudence of the ICTY', In: May, C. (ed.), Essays on War in International Law, Cameron May, London, 2006, pp. 331-351. The customary law status of the prohibition of reprisals against civilians in combat zones, as argued by the Trial Chamber, has been severely criticized by Greenwood for referring to passages in military manuals that do not support their view. Moreover, Greenwood holds that the fact that states are prepared to accept a treaty obligation, does not mean that they regard this obligation as binding under customary law, that when states refrain from engaging in reprisals this does not mean that they do so because they consider themselves legally obliged, that the ICRC does not create customary law (States do) and that the reference to the ILC commentary does not hold water. Greenwood also points out that the Trial Chamber substitutes the lack of State practice by the principles of the Martens Clause and that this is not an acceptable way to avoid this requirement. Greenwood, however, agrees with the Trial Chamber that, in the case at hand, the customary status of the ban on reprisals against civilians is irrelevant, for the treaty provisions prohibiting them were applicable in the case at issue. 
The defense of reprisals has never been accepted. In Kupreškić it was rejected because the reprisal in casu was directed against civilians, and the Trial Chamber held that this was both in violation of customary law and in violation of the applicable provisions of humanitarian law. In Martić the defense was rejected on its merits: the reprisal was not a last resort (peace negotiations were ongoing) and no formal warning had been given. Reprisals have never been discussed as a mitigating factor. However, if they were to be accepted as a complete defense under the ICC Statute, they could technically be brought in mitigation under its Rules (145(2)(a)(i)).

\subsection{Scope}

From the ICTY-cases discussed above, the following requirements for reprisals can be derived:

a. The reprisal is an otherwise unlawful response by a belligerent to a violation of law committed by the other belligerent;

b. The sole purpose of the reprisal is seeking compliance with the law of armed conflict by the opposite party;

c. The reprisal must have been the last resort. In Martić this requirement was not met, because peace-negotiations were ongoing;

d. Reprisals may be exercised only after a prior and formal warning;

e. Reprisals may only be taken after a decision to this effect has been made at the highest political or military level and thus not by local commanders;

f. The measures taken must be proportionate to the initial violation of the law of armed conflict by the opposite party. According to this condition, the reprisal must cease as soon as the breach, which provoked the reprisal, ends;

g. The reprisal must respect the "laws of humanity and dictates of public conscience". The Trial Chamber in Kupreškić interprets this condition as an $a$ priori exclusion of reprisals in case of attacks on civilians. The Trial Chamber in Martić interprets this condition to mean that reprisals must be exercised, to the extent possible, in keeping with the principle of the protection of the civilian population in armed conflict and the general prohibition of targeting civilians. The latter Trial Chamber thus plays down the a priori exclusion by the first, mainly by the words "to the extent possible". All criteria require an objective test.

\subsection{Categorization}

Chapter II has demonstrated that international criminal theory distinguishes between three different types of complete defenses. The question answered in this subsection is whether the defense of reprisals matches any of these three types. 
More precisely: what is the effect of the fulfillment of requirements (a)- $(\mathrm{g})$ on the offense charged?

The two ICTY Trial Chambers consistently refer to reprisals as a justification, and they are probably right. ${ }^{736}$ The party taking the reprisal had a choice between two evils: letting the adversary continue violating the law or attempting to stop these violations by violating the law itself. When the criteria for reprisals have been met, the defendant has chosen the best course of action, which negates the wrongfulness of his act. Reprisals can thus be categorized as either defense $=x$ or as defense $=$ no definitional subjective element, the latter only in case the definitional subjective element equals negligence.

\subsection{Conclusion on reprisals}

The following questions are relevant to the further development of reprisals in international criminal law:

1. Should reprisals be a ground for excluding criminal responsibility under article 31(3) of the ICC Statute?

2. If yes, on what conditions?

3. When are reprisals a priori excluded (e.g. by international humanitarian law)?

\subsection{Preview Part III}

Part III of this study suggests that a detailed codification of reprisals is a better option than to range the defense under the open provision of the ICC Statute. However, codification is only appropriate after more research is performed on the limits imposed by international humanitarian law on the scope of reprisals. 


\section{Chapter XI TU QUOQUE}

\section{INTRODUCTION}

Tu quoque (literally: "you too") is the defense whereby the defendant argues that the crime charged has equally been perpetrated by his adversary. For example, belligerent A is charged with the killing of civilians. On trial, however, he argues that his adversary, B, has killed civilians as well, and that A should therefore not be convicted for this war crime.

Tu quoque is traditionally an international law defense. It has been discussed at the IMT, IMTFE, ICTY and ICTR. The ICC has no tu quoque provision. The conclusion to this Chapter demonstrates that although accepted at the IMT, $t u$ quoque has consistently been rejected ever since.

\section{Tu quoque at Nuremberg}

\subsection{The verdict on Karl Dönitz}

\subsubsection{Relevant passages}

The part of the Nuremberg Judgment that discusses the individual criminal responsibility of each defendant addresses an appeal to tu quoque by Karl Dönitz, who was, at the time, commander of the submarine fleet. Dönitz is, among other things, charged with "unrestricted submarine warfare" in violation of the London Naval Agreement of 1930 and its Protocol of 1936. As to this charge the Tribunal briefly holds that:

1. Dönitz is "not guilty" for the attacks on British merchant ships in violation of the protocol, for these merchant ships were used as warships;

2. The attacks on other neutral merchant vessels are "a violation of the Protocol";

3. Dönitz is "guilty" for not rescuing shipwrecked survivors in violation of the Protocol.

However, at the end of its contemplation the Tribunal concludes that:

In view of all the facts proved and in particular of an order of the British Admiralty announced on 8 May 1940, according to which all vessels should be sunk at night in the Skagerrak, and the answers to interrogatories by Admiral Nimitz stating that unrestricted submarine warfare was carried on in the Pacific Ocean by the United 
States from the first day that Nation entered the war, the sentence of Dönitz is not assessed on the ground of his breaches of the international submarine warfare. ${ }^{737}$

\subsubsection{Applicability}

From the text of the Judgment it cannot be derived whether Dönitz himself appealed to tu quoque or whether the IMT decided proprio motu that this defense was applicable. Fact is however, that the IMT held that the defense was valid. Nevertheless, it does not explicitly refer to tu quoque. The IMT merely states that although Dönitz has violated the Protocol of the London Naval Agreement (by attacks on neutral merchant vessels and by not saving shipwrecked survivors of an attack), his sentence will not be assessed on these breaches because of (a) "all the facts proved" and in particular because of (b) a British order to sink all vessels at night at the Skagerrak and because of (c) Admiral Nimitz stating that unrestricted submarine warfare was carried on in the Pacific Ocean by the United States from the first day it entered the war. Although it is not exactly clear what is meant by (a), it can be derived from (b) and (c) that the IMT holds that because the British and the Americans equally violated rules of submarine warfare, the breaches committed by Dönitz are not taken into account when determining his sentence.

What is significant about the legal consequence of the applicability of tu quoque is that, at least in relation to the shipwrecked survivors, the IMT holds the defendant is "guilty", but that this guilt is not relevant to the sentence to be imposed. This feature sets $t u$ quoque apart from justifications and excuses, which respectively negates guilt through the absence of wrongfulness (and consequently blameworthiness) or through the absence of blameworthiness alone. Not imposing a sentence, while guilt is established, does not fit this picture. On the other hand, it is possible that the IMT uses the word "guilty" in the sense of "he did it" and not in the sense of "blameworthiness". In this case tu quoque could theoretically still be categorized as a justification or excuse. However, this is highly unlikely (see below Section 7.2).

Another legal consequence of the applicability of tu quoque is that, although the breaches by Dönitz of submarine warfare rules were not taken into account when determining his sentence, he was still held liable for other war crimes and crimes against peace. The acceptance of tu quoque thus did not result in an acquittal.

\subsubsection{Scope}

As to the requirements of tu quoque the Judgment does not bear much information. However, the essence seems to be that tu quoque is applicable when the adversary has violated the same set of rules (in this case: the rules of submarine warfare). It can be deduced from the Judgment that these violations must be grossly similar.

737 International Military Tribunal (Nuremberg), Judgment and Sentences, 1 October 1946, p. 305. 
Violations are not with precision inventoried and balanced against each other. The defense requires an objective test.

\subsection{The verdict on Erich Raeder}

Top executive in the Third Reich navy Erich Raeder was charged with more or less the same violations ("unrestricted submarine warfare") of the London Protocol as Dönitz. The Tribunal holds that it "makes the same finding on Raeder on this charge as it did to Dönitz". 738 Raeder's violations of the London Protocol were thus also not relevant to his sentence because the British and the Americans equally violated these rules. As with Dönitz, the applicability of $t u$ quoque was of no consequence: Raeder was still liable for other war crimes and crimes against peace. ${ }^{739}$

\subsection{Other sources on tu quoque at Nuremberg}

According to secondary sources, the defense of $t u$ quoque must have been more commonly raised than suggested by the above verdicts, for breaches of the crimes featured in the IMT Statute by allied forces occurred frequently during the course of World War II. ${ }^{740}$ On the other hand it is worth noting that the defense of $t u$ quoque was somewhat allowed for in the charges brought on by the IMT prosecutors. For example, only on one occasion does the indictment refer to the unlawful bombardments of civilians (in the context of civilian deaths in Leningrad), ${ }^{741}$ a crime frequently perpetrated by both parties.

\section{TU QUOQUE AT THE IMTFE}

The Tokyo verdict does not explicitly discuss the defense of tu quoque. However, in an interview (by Antonio Cassese), former IMTFE Judge Bert Röling explains that in Tokyo the defense counsel was forbidden to elaborate on war crimes committed by the countries sitting in the Judgment. Under section 13(b) of the IMTFE Charter, the Tribunal could require to be informed on the nature of any kind of evidence before it was offered. If this evidence amounted to a $t u$ quoque argument, it was rejected. ${ }^{742}$ At the IMTFE tu quoque was thus a priori excluded before it could be brought up. Consequently, allied misbehavior probably had more influence in Nuremberg than in Tokyo. ${ }^{743}$

\footnotetext{
738 International Military Tribunal (Nuremberg), Judgment and Sentences, 1 October 1946, p. 308.

739 International Military Tribunal (Nuremberg), Judgment and Sentences, 1 October 1946, p. 309.

740 Davidson, E., 1997, pp. 33 and 36 and Taylor, T., The Anatomy of the Nuremberg Trials, a Personal Memoir, Bloomsbury Publishing, London, 1993, p. 639.

741 Http://avalon.law.yale.edu/imt/count3.asp (01/01/2012).

742 Cassese, A., 1993, p. 59/60.

743 Cassese, A., 1993, p. 54/55.
} 
Chapter XI

\section{TU QUOQUE AT THE ICTY}

\subsection{Prosecutor vs. Kupreškić}

\subsubsection{Facts of the case}

In 1993, Croat forces attacked the Muslim population of the village of Ahmići, killing 116 people, destroying buildings and driving the remaining Muslim population out. Several perpetrators were charged with violations of the laws and customs of war and crimes against humanity in Kupreškić et al. During trial, tu quoque was raised to justify attacks against the Muslim population in Lašva Valley. According to the defense these attacks were justifiable because similar attacks were being perpetrated by Muslims against Croats. In relation to this argument the Trial Chamber holds that "the tu quoque defense has no place in contemporary international humanitarian law". ${ }^{74}$ Due to the length of the passages on tu quoque the arguments of the Trial Chamber are paraphrased in the 'Applicability' and 'Scope' Sections below.

\subsubsection{Applicability}

In Kupreškić et al., the defense of tu quoque is a priori rejected because the defense "has no place in contemporary international humanitarian law". This point of view is substantiated by the following arguments:

1) The defense of tu quoque has been universally rejected in war crimes trials after the Second World War and there is no support for this defense, neither in State Practice nor in the opinions of publicists. ${ }^{745}$ Although this may be generally true, this statement is not precise, since the defense of tu quoque was accepted twice at Nuremberg (Dönitz and Raeder).

2) The tu quoque argument is flawed in principle because international humanitarian law has an absolute character. This means that it is not based on reciprocity. Consequently, its obligations must be fulfilled regardless whether the adversary fulfills its obligations. The absolute character of humanitarian law is put down in Common Article 1 of the 1949 Geneva Conventions and several other Common Provisions. Although these provisions are directed at States, this does not mean that the absolute character diminishes in case of individual criminal responsibility for violations of humanitarian law. The rationale behind the absolute character of international humanitarian law is that these rules were not designed to protect State interests, but to protect human beings as members 
of the international community as a whole. The international community is not protected by rules, the observance of which is dependent on reciprocity. ${ }^{746}$

3) Most norms of international humanitarian law, in particular those prohibiting war crimes, crimes against humanity and genocide, are also ius cogens. In case of ius cogens the principle of reciprocity is not applicable either. ${ }^{747}$

\subsubsection{Scope}

The Trial Chamber does provide a definition of tu quoque: "the argument whereby the fact that the adversary has also committed similar crimes offers a valid defence to the individuals accused". ${ }^{748}$ Next, the Trial Chamber outlines two different species of $t u$ quoque: "[t]his argument may amount to saying that breaches of international humanitarian law, being committed by the enemy, justify similar breaches by a belligerent. Or it may amount to saying that such breaches, having been perpetrated by the adversary, legitimize similar breaches by a belligerent in response to, or in retaliation for, such violations by the enemy". The difference between these two types of $t u$ quoque is that the second type is always a reaction to the adversary, while the first is not. The Trial Chamber therefore holds that the second type of $t u$ quoque "coincides with the doctrine of reprisals" and that the a priori rejection of $t u$ quoque in this case only considers the first type.

\subsection{Prosecutor v. Kordić and Čerkez}

\subsubsection{Relevant passages}

In Prosecutor v. Kordić and Čerkez two Bosnian Croat leaders are charged with the persecution of Muslims (crimes against humanity, article 5(h) of the ICTY Statute). defendant Mario Čerkez brings up the argument that it were "not the Muslims who were unprotected and unarmed, exposed to self-will, provocation, maltreatment and attacks of Croats, but both sides took roughly equal part in incidents".749 The Trial Chamber rejects this argument by stating that "[ $\mathrm{t}]$ he fact that there may have been persecution of Croats by Muslims in other municipalities does not detract from this finding [of crimes against humanity] and in no way justifies the HVO persecution". 750

\footnotetext{
746 ICTY, Prosecutor v. Kupreškić et al., Trial Chamber, 14 January 2000, par. 515-520.

747 ICTY, Prosecutor v. Kupreškić et al., Trial Chamber, 14 January 2000, par. 517-520.

748 ICTY, Prosecutor v. Kupreškić et al., Trial Chamber, 14 January 2000, par. 515.

749 ICTY, Prosecutor v. Kordić and Čerkez, Defendant Mario Čerkez's Final Trial Brief, 13 December 2000 , p. 18.

750 ICTY, Prosecutor v. Kordić and Čerkez, Trial Chamber, 26 February 2001, par. 520.
} 


\subsubsection{Applicability}

Although this Judgment does not literally refer to the defense of tu quoque, a tu quoque argument is rejected as a complete defense ("in no way justifies"). It is not clear whether the defense is rejected a priori or rejected in casu, but accepted in principle. The Trial Chamber simply holds that crimes by the adversary do not justify the crimes charged and does not indicate whether this is the case because generally crimes committed by the adversary do not justify the crimes charged or because the specific crimes committed by the adversary in this case do not justify the crimes charged.

\subsubsection{Scope}

The defense brought up is defined as the argument that similar crimes have been committed by the adversary.

\subsection{Prosecutor v. Milan Martić}

\subsubsection{Relevant passages}

On 2 and 3 May 1995 Zagreb was shelled by Serbian units, resulting in injury and death among civilians. Milan Martić, who held several top positions in the Serb dominated Krajina region, ordered this operation. He was charged and convicted for this by the ICTY under the heading of violations of laws and customs of war and crimes against humanity. ${ }^{751}$ One of the sub-grounds of his appeal contains that the Trial Chamber failed to reach findings on the background and political objectives of the Serb leadership. ${ }^{752}$ In relation to this ground of appeal the Appeals Chamber holds, among other things, that:

To the extent that Martić's argument is an attempt to plead a defence of tu quoque, i.e., to plead that the acts for which he was found responsible should not be considered criminal because they were in response to crimes committed against him and his people, it must be rejected. It is well established in the jurisprudence of the Tribunal that arguments based on reciprocity, including the tu quoque argument, are no defence to serious violations of international humanitarian law. ${ }^{753}$

\subsubsection{Applicability}

Referring to Kupreškić et al., the Appeals Chamber a priori rejects the tu quoque defense. What is more, the Appeals Chamber in Martić takes its rejection a little

751 ICTY, Prosecutor v. Martić, Appeals Chamber, 8 October 2008, par. 216.

752 ICTY, Prosecutor v. Martić, Appeals Chamber, 8 October 2008, par. 108.

753 ICTY, Prosecutor v. Martić, Appeals Chamber, 8 October 2008, par. 111. 
further than Kupreškić et al. for it does not only specifically reject tu quoque, but all "arguments based on reciprocity" as a "defense" in case of serious violations of international humanitarian law.

\subsubsection{Scope}

In Martic the tu quoque defense is defined as a plea "that the acts for which the defendant was found responsible should not be considered criminal because they were in response to crimes committed against him and his people". Martic thus refers to the second type of tu quoque distinguished in Kupreškić et al.

\subsection{Other sources on tu quoque at the ICTY}

In Prosecutor v. Kunarac et al., the defense argued that the conditions of life in Serb detention centers were no worse than the conditions in the centers run by the Muslim side. ${ }^{754}$ However, the Judgment does not discuss this issue. In a more recent proceeding before the ICTY, both parties seem to acknowledge that $t u$ quoque is not a complete defense under international criminal law. In Prosecutor $v$. Hadžihasanović and Kubura the defense indicates that it does not intend to plead the tu quoque argument. However, although the Trial Chamber holds that "the caselaw of the Tribunal does not accept the defense of $t u$ quoque", it notes that "case-law has accepted - on non-repetitious and very circumscribed points - evidence relating to crimes allegedly committed by other parties to the conflict when they sought, inter alia, to refute the prosecution's factual allegations". ${ }^{755}$ It seems that although tu quoque is not a complete defense, the argument can still provide evidence. For example, to disprove that a certain ethnic group has been subject to persecution. ${ }^{756}$

\section{TU QUOQUE AT THE ICTR}

\subsection{Prosecutor vs. Bagosora et al.}

\subsubsection{Relevant passages}

In Bagosora et al., several high government and army officials stand trial for their role in the 1994 Rwandan Genocide. They are charged with conspiracy to commit

\footnotetext{
754 ICTY, Prosecutor v. Kunarac et al., Final Trial Brief Submissions by the Defence, 10 November 2000.

755 ICTY, Prosecutor v. Hadžihasanović and Kubura, Decision on Defence Motion for Clarification of the Oral Decision of December 172003 regarding the scope of cross-examination pursuant to Rule 90(H) of the Rules, Trial Chamber, 28 January 2004.

756 As has been suggested in: ICTY, Prosecutor v. Kupreškić, Decision on Evidence of the Good Character of the Accused and the Defence of Tu Quoque, Trial Chamber, 17 February 1999.
} 
genocide, crimes against humanity and war crimes (respectively article 2, 3, and 4 of the ICTR Statute). In defense to these charges the Defense argues that the Rwandan Patriotic Front (RPF) has committed crimes as well (tu quoque). In relation to the alleged RPF attack on President Habyarimana's plane, the Trial Chamber holds:

Even assuming that the RPF were responsible, it would not have any bearing on the Accused's criminal responsibility. The attacks for which they have been held responsible were organized military operations directed at civilians. There can be no justification for this even if the opposing military force commenced the hostilities. ${ }^{757}$

A few paragraphs down, the Trial Chamber is more explicit:

Regarding the allegation that the RPF may have committed crimes in Rwanda other than those charged in the Indictments during the same period, the Appeals Chamber has held that "it is well established in the jurisprudence of the Tribunal that arguments based on reciprocity, including the tu quoque argument, are no defence to serious violations of international humanitarian law".758

\subsubsection{Applicability}

Like the IMTFE and the ICTY, the ICTR a priori rejects the defense of tu quoque. The ICTR does not substantiate this contention but refers to ICTY case law (Kupreškić and Martić). As in Martić, the ICTR Trial Chamber takes its rejection a little further and holds that "all arguments based on reciprocity" are "no defense". The ICTR also rejects the second type of tu quoque (tu quoque as a reaction to the adversary) by referring to the alleged RPF attack on the President's plane.

\section{Tu QUOQUE AT THE ICC}

The ICC Statute contains no tu quoque provision. Technically $t u$ quoque could be newly adopted defense under article 31(3) of the ICC Statute. However, since these defenses have to be in accordance with the sources of international criminal law ex article 21 of the ICC Statute, and tu quoque was consistently rejected after Nuremberg, it is highly unlikely that the ICC will adopt this defense. 


\section{Analysis of tu Quogue}

\subsection{Applicability and scope}

In international criminal law tu quoque refers to the defense that the adversary has committed similar crimes as the accused. Different types of tu quoque can be distinguished in international criminal law: tu quoque raised in the situation where the defendant and the adversary both did not comply with the rules (referred to above as the 'first type') and tu quoque as a reaction of the defendant to the adversary (referred to above as the 'second type'). Consequently, to qualify as a $t u$ quoque, it does not seem to matter whether the crime committed by the adversary took place before, after or during the crime committed by the party claiming $t u$ quoque. Another distinction between the different species of tu quoque can be found in the relationship between the adversary and the judges sitting in the bench. In Nuremberg and Tokyo the adversary equaled the judges sitting in the bench (i.e. the Allied forces). However, at the later ad hoc tribunals this was not the case. Consequently, the defendants at the IMT and IMFTE literally argued tu quoque (you too), while the defendants at the ICTY and ICTR technically argued illi quoque (they too).

In Nuremberg the first type of $t u$ quoque has been accepted in the cases of Dönitz and Raeder because the British and the Americans had grossly violated the same set of rules (London Protocol). However, tu quoque in this case did not seem to negate the guilt of the defendants, but was merely not taken into account when determining sentences. As if the Nuremberg judges meant to say: "Your behavior is both wrongful and blameworthy, but it would be rather hypocritical to take these violations of the London protocol into account, because we violated this protocol as well". What is more, the successful appeal to this defense did not result in an acquittal because the defendants were found guilty of other charges. As to the scope of the $t u$ quoque that was accepted in Nuremberg: it required grossly similar violations of the same set of rules and was established by an objective test. In Nuremberg the tu quoque argument was probably raised on more occasions than Dönitz and Raeder, but these appeals were not addressed by the Tribunal.

At the subsequent international tribunals all types of tu quoque (or, in case of the ICTY and ICTR illi quoque) were consistently - a priori - rejected. At the IMTFE tu quoque was rejected before it could be raised. At the ICTY the first type of tu quoque was rejected in Kupreškić et al., because:

1. There is no support for $t u$ quoque in case law, State practice and opinions of publicists;

2. International humanitarian law has an absolute character, consequently the compliance with its rules is not based on reciprocity (while tu quoque is);

3. A similar reasoning is applicable to ius cogens, which covers most international crimes. 
In Martić the second type of tu quoque is a priori rejected by referring to Kupreškić. Other ICTY decisions confirm the a priori rejection of tu quoque, but hold that the argument can still provide evidence to inter alia refute the prosecution's allegations. The ICTR seems to confirm the ICTY case law.

Considering the development of the tu quoque defense in international criminal law, it is very unlikely that the ICC will adopt this defense under article 31(3) of the ICC Statute. However, the tu quoque argument could still provide evidence. In addition, the second type of tu quoque could also be accepted as a reprisals defense, when the requirements for this legal concept are made out (see previous Chapter). Tu quoque has never been taken in mitigation.

\subsection{Categorization}

Chapter II has demonstrated that international criminal theory distinguishes between three different types of complete defenses, which, in turn, can be qualified as either a justification or an excuse or both. The question answered in this subsection is whether the defense of $t u$ quoque matches any of these three types.

In order to qualify a defense as either a justification or an excuse, the defendant must have respectively chosen the lesser of two evils, he must have had no ability to choose, any reasonable person would have acted the way he did, or he was not in a position to determine his will freely. Tu quoque cannot be qualified as a justification, for the wrongfulness of the act is not eliminated by the fact that the adversary has committed similar crimes. This wrongfulness is only eliminated if the defendant has chosen the lesser of two evils. However, when a defendant has a choice between committing a crime and not committing a crime, and there is no interest served by committing a crime (contrary to what is the case with self-defense, necessity or reprisals) he has not chosen the lesser of the two evils.

Tu quoque can not be qualified as an excuse, for it cannot be said that a defendant in a tu quoque situation has no ability to choose differently or has no ability to determine his will freely. Nor is the simple fact that the adversary violated the law, enough to claim that in this case any reasonable person would have violated the law. In a tu quoque situation the defendant has the choice between violating the law or not, but there is no urgent reason or motive to violate the law (as in case of duress, mistake or insanity). The bare fact that the adversary has violated the law as well is simply not enough to negate blameworthiness of the perpetrator, for this piece of evidence does not automatically affect the perpetrator's range of possibilities.

In sum, the defense of tu quoque does not claim to be objectively the best course of action or the only reasonably possible course of action. Therefore, tu quoque has no effect on the wrongfulness of the act or the blameworthiness of the actor and can thus not be categorized as any of the complete defenses ex Chapter II of this thesis. The fact that tu quoque cannot be categorized as a complete defense seems to be confirmed by Dönitz and Raeder, where the tu quoque argument apparently did not affect the blameworthiness of the defendants. 


\subsection{Conclusion on tu quoque}

The analysis above shows that $t u$ quoque is no longer considered a complete defense in international criminal law. However, its rejection in case law is mainly based on the allegation that $t u$ quoque is incompatible with bodies of law with an absolute character (international humanitarian law and ius cogens). This raises several questions:

1. Are there situations in which tu quoque could still provide a complete defense (for example when the crime charged does not amount to a violation of international humanitarian law or ius cogens)?

2. Since violations of international criminal law are violations of legal bodies with an absolute character, are not all complete defenses incompatible with international criminal law? In other words, is the reasoning employed in Kupreškić et al., not applicable to all complete defenses?

3. If $t u$ quoque is not a complete defense, what should its role in international criminal law be?

\subsection{Preview Part III}

The first Chapter of Part III argues that complete defenses, in general, are not a priori excluded by international humanitarian law or ius cogens. As for tu quoque, Part III reiterates that this legal concept can never be a complete defense: tu quoque has neither a justifying nor an excusing effect. The legal concept can, however, still provide evidence, as it has previously done at the ICTY. 



\section{Chapter XII \\ OTHER POSSIBLE COMPLETE DEFENSES IN \\ INTERNATIONAL CRIMINAL LAW}

\section{INTRODUCTION}

The final Chapter of this Part discusses the discretionary power of the active international criminal courts subject to this research - ICTY, ICTR and ICC - to construct new defenses (or, in case of the ICC, also to adapt existing defenses). Below follows a description of the relevant rules and practices of each court. Part III discusses which complete defenses could be adopted within the frames of the active international criminal courts.

\section{OTHER POSSIBLE COMPLETE DEFENSES AT THE ICTY AND ICTR}

The ICTY body of law does not contain a catalogue of complete defenses. It was probably therefore that the UN Secretary-General provided the Tribunal with an open mandate. In its report on the establishment of the ICTY the Secretary-General wrote:

The International Tribunal itself will have to decide on various personal defenses which may relieve a person from individual criminal responsibility, such as minimum age or mental incapacity, drawing upon general principles of law recognized by all nations. ${ }^{759}$

The ICTY can thus formulate complete defenses as it goes along, be it that these defenses reflect general principles of law recognized by all nations.

Like at the ICTY, the ICTR body of law does not contain a catalogue of complete defenses. However, a passage containing an open mandate, similar to the one quoted above, cannot be found in the Secretary-General Report on the ICTR. 760

Still, in international criminal law literature and practice it is generally accepted that international tribunals (thus both ICTY and ICTR) can, apart from their own body of law, draw from the general sources of international law ex article 38 of the ICJ Statute, ${ }^{761}$ and thus not only from the "general principles" referred to in the UN

759 Report of the Secretary-General Pursuant to Paragraph 2 of Security Council Resolution 808 (1993), U.N. Doc S/257004, par. 58.

760 See: S/1994/1125 4 October 1994 (Report of the Secretary-General on Rwanda).

761 Akande, D., 2009, p. 43; Cryer, R. et al., 2010, p. 9; Herik, L. van, 2005, p. 274; ICTY, Prosecutor v. Erdemović, Appeals Chamber, Joint Separate Opinion of Judge McDonald and Judge Vohrah, Appeals Chamber, 7 October 1997, par. 40; ICTY, Prosecutor v. Kupreškić et al., Trial Chamber, 14 January 2000, par. 540 and ICTY, Prosecutor v. Mucić et al., Appeals Chamber, 20 February 2001, par. 583. 
Secretary-General's report mentioned above. The sources of law, listed in this article are elaborately discussed in the Introduction to this thesis. They are treaties and custom, general principles of law and as a subsidiary means, judicial decisions and writings of publicists. In practice, this means that if the operative ad hoc tribunals want to apply a complete defense, they have to refer to at least one of these sources.

\section{OTHER POSSIBLE COMPLETE DEFENSES AT THE ICC}

Contrary to the earlier ad hoc tribunals, the ICC Statute contains a catalogue of complete defenses. However, this catalogue is not a limited inventory, but an open system. Paragraph 2 of article 31 allows the Court to alter existing defenses, while paragraph 3 empowers the Court to create new ones, be it both within the scope of article 21 . Article 21 is concerned with the law to be applied by the ICC and is elaborately discussed in the Introduction to this thesis. According to this article, the legal sources applicable to the ICC are in the first place the ICC Statute, the Elements of Crimes, and the Rules of Procedure and Evidence. In the second place, applicable treaties and the principles and rules of international law, and, failing that, the general principles of law derived by the Court from national laws.

Now, let's take a closer look at paragraph 2 and 3 of article 31. Paragraph 2 of article 31 reads:

The Court shall determine the applicability of the grounds for excluding criminal responsibility provided for in this Statute to the case before it.

To "determine the applicability" of exclusionary grounds probably means more than merely applying the law, since this function does not need an explicit statement. Consequently, this paragraph must empower the Court to adjust available grounds for excluding criminal responsibility in such a way that they are applicable to the individual case. The Court can, for example, adjust the definition for selfdefense when the proportionality requirement is not met, and the circumstances of the case are excusing. According to Cryer, the power to adjust includes the possibility to narrow the scope of a defense and thus refrain from applying a ground for excluding criminal responsibility. ${ }^{762}$

The power to adjust is limited to the case before the Court, i.e. the court cannot pronounce new general definitions of complete defenses based upon paragraph 2, but is restricted to the specific case in issue. However, since according to article 21(2), the Court has the discretionary power to refer to precedents, the specific adjustment of a complete defense can very well set the standard for a new rule, if confirmed by subsequent judgments.

762 Cryer, R., 2005, p. 307. 
Since paragraph 2 covers, all "grounds for excluding criminal responsibility provided for in this Statute", paragraph 31(2) is also applicable to the other defenses in the ICC Statute (article 32 and 33). Finally, although not explicitly mentioned, when adapting a ground for excluding criminal responsibility, the Court is bound by article 21 of the ICC Statute. ${ }^{763}$

Paragraph 2 of article 31 is not the only possibility to alter the ICC catalogue of defenses. Paragraph 3 contains a related competence:

At trial, the Court may consider a ground for excluding criminal responsibility other than those referred to in paragraph 1 where such a ground is derived from applicable law as set forth in article 21. The procedures relating to the consideration of such a ground shall be provided for in the Rules of Procedure and Evidence.

The competence given to the Court in this paragraph reaches further than the power to adjust ex paragraph 2 , in that the Court is authorized to adopt new defenses. ${ }^{764}$ Although the provision literally refers to "other grounds than those referred to in paragraph 1", it is also meant to refer to the supplementary grounds for excluding criminal responsibility mentioned in the Statute (article 32 and 33). Paragraph (3) thus refers to other defenses than the ones mentioned in the Statute. ${ }^{765}$ Like the defenses in paragraph (2), the defenses in paragraph (3) must be "derived from the applicable law as set forth in article 21 ". The "procedures relating to the consideration of such a ground" can be found in Rule 80, which only contains a few rules on how the Defense should raise a paragraph (3) defense.

\section{Conclusion}

The discretionary powers of the ICTY and ICTR are similar. There is no catalogue of complete defenses and at both tribunals the court can ad hoc decide on the applicability of complete defenses based on the sources of law mentioned in article 38 of the ICJ Charter. At the ICC there is a catalogue of complete defenses. The Court can, however, still adapt existing defenses (article 31(2)) or adopt new ones (article 31(3)), within the limits of article 21 ICC Statute. Other differences between the ICTY and ICTR on the one hand, and the ICC on the other, that must be taken into account when looking at the ability to create new complete defenses are, that:

\footnotetext{
763 Eser, A., 2008, p. 889.

764 Eser, A., 2008, p. 892. Eser holds that the clause "other than those referred to in paragraph 1" includes article 32 and 33, that are referred to in the heading of article 31 . 
- Contrary to the ad hoc tribunals, the ICC Statute and its Elements of Crimes contain very detailed descriptions of both offenses and defenses. In this respect the ICC may have less room to create new complete defenses than the operative ad hoc tribunals.

- The ICC is not restrained by the doctrine of stare decisis - as opposed to the operative ad hoc tribunals - when creating new defenses. In this respect the ICC may have more room to create new defenses than the operative ad hoc tribunals.

Relevant questions in relation to the discretionary power of international courts considering complete defenses are:

1. Which defenses could be applicable under these existing frameworks?

2. Are these frameworks compatible with the principle of nullum crimen sine lege?

\section{Preview Part III}

Part III of this thesis demonstrates that many defenses fit within both the proposed and the existing framework as long as they contain either the requirements of a justification or the requirements of an excuse. Several recommendations are made to keep new defenses within the limits of nullum crimen sine lege. 


\section{Analysis Part II \\ ANALYSIS OF COMPLETE DEFENSES IN INTERNATIONAL \\ CRIMINAL LAW IN GENERAL}

\section{INTRODUCTION}

The previous Chapters have drawn sub-conclusions on specific complete defenses in international criminal law as to their applicability, scope and categorization. These sub-conclusions were represented in the final Section of each Chapter. This analysis discusses the general features of complete defenses in international criminal law, by answering the questions mentioned in the Introduction to this Part, reiterated below:

1. Considering the applicability of complete defenses:

- Is the legal concept of complete defenses generally recognized? (Section 2)

- How are defenses raised? (Section 3)

- Which defenses are recognized? (Section 4)

- Which defenses are rejected a priori? (Section 4)

- Why are defenses a priori rejected? (Section 5)

- Why are defenses recognized in principle? (Section 6)

- Which defenses are only rejected in case law? (Section 4)

- Which defenses are accepted in case law? (Section 4)

- What can be said, in general, about the grounds for acceptation or rejection? (Sections 6 and 7)

- What is the relationship between complete defenses and mitigating circumstances? (Section 8)

- What are the possible legal consequences of complete defenses? (Section 9)

2. Considering the scope of complete defenses:

- Do the requirements for complete defenses demonstrate common denominators (e.g. proportionality, necessity, reasonable person test, Garantenstellung, prior fault, mental element)? (Section 10)

- Are these common denominators always tested in the same manner (i.e. objectively or subjectively)? (Section 10)

- Do defenses overlap? (Section 10)

3. Considering the categorization of complete defenses:

- Which types of the three types of defenses from Chapter II can be found in international criminal law? (Section 11)

- What do the findings on the categorization of complete defenses contribute to theory on the relationship between complete defenses and general requirements for criminal liability? (Section 11) 
Analysis Part II

This analysis finishes with several concluding remarks on complete defenses in general.

\section{GeNERAL RECOGNITION OF COMPLETE DEFENSES}

The previous Chapters demonstrate that complete defenses have gradually gained position in international criminal law, at least in theory. In the statutes of the earlier ad hoc tribunals (IMT and IMTFE) complete defenses were not mentioned in the charters, except for an a priori exclusion of superior orders and prescription of law. The judgments of these tribunals contain barely any mention of complete defenses, except for explicit references to self-defense and a more implicit reference to consent and insanity. Other defenses that have been discussed are recognizable by their structure of argumentation, but not labeled as such (mistake of both law and fact, necessity/duress and $t u$ quoque). At the earlier ad hoc tribunals, thus, the notion of complete defenses, seemed to be recognized without being formalized.

In respect of complete defenses, the statutes of the ICTY and ICTR are similar to the earlier ad hoc tribunals: no mention of complete defenses except for an $a$ priori exclusion of superior orders. However, in its report on the establishment of the ICTY, the UN Secretary-General opens the door to complete defenses:

The International Tribunal itself will have to decide on various personal defences which may relieve a person from individual criminal responsibility, such as minimum age or mental incapacity, drawing upon general principles of law recognized by all nations. ${ }^{766}$

This recognition of complete defenses in general is confirmed in ICTY case law. The Trial Chamber in Prosecutor v. Kordić and Čerkez held that:

[...] the Statute of the International Tribunal does not provide for self-defence as a ground for excluding criminal responsibility. "Defences" however form part of the general principles of criminal law, which the International Tribunal must take into account in deciding the cases before it. ${ }^{767}$

Also the ICTR seems to recognize the legal concept of complete defenses. In Prosecutor v. Kamuhanda the Trial Chamber held:

In general, a defence comprises grounds excluding criminal responsibility although the accused has fulfilled the legal elements of a criminal offense. [...] In

766 Report of the Secretary-General Pursuant to Paragraph 2 of Security Council Resolution 808 (1993), U.N. Doc S/25704, par. 58.

767 ICTY, Prosecutor v. Kordić and Čerkez, Trial Chamber, 26 February 2001, par. 449. Confirmed on Appeal (17 December 2004, par 837). 
the case of a defence, the criminal conduct has already been established and is not necessarily disputed by the accused who argues that due to specific circumstances he or she is not criminally responsible, e.g. due to a situation of duress or intoxication. ${ }^{768}$

Apart from a more explicit recognition of complete defenses at the later ad hoc tribunals, complete defenses are also more elaborately discussed, especially at the ICTY. The latter also addresses the largest variety of defenses, revealing its thoughts on reprisals, in addition to the defenses discussed at the earlier ad hoc tribunals.

Contrary to the ad hoc tribunals, the ICC Statute contains a catalogue of complete defenses. The Statute both explicitly mentions complete defenses and grants the Court the power to adjust existing defenses (article 31 paragraph 2) and to adopt new defenses (article 31 paragraph 3). The catalogue of complete defenses consists of article 31 (insanity, intoxication, self-defense and necessity/ duress), 32 (mistake of fact and mistake of law) and 33 (superior orders and prescription of law). In conclusion it can be held that complete defenses in international criminal law have gradually moved from implicit to explicit recognition, at least in theory.

Significantly this development runs parallel to the development from victor's justice initiated by the Allied Powers of World War II to a permanent international criminal court adhered to by a major part of the international community. The Nuremberg and Tokyo Tribunals were established by the victors of World War II. Logically, their primary purpose was not to justify or excuse the deeds by their former opponents. What is more, the compatriots of those who created the IMT and IMTFE could not be tried by these courts. Hence, there was no self-interest that could motivate the creation of a catalogue of complete defenses. The situation at the ICTY and ICTR is more or less the same, be it that governments of the creators of these tribunals were generally not parties to the conflict. This may be a reason for a little more leniency towards complete defenses. Contrary to the ad hoc tribunals, the creators of the ICC (or their fellow countrymen) could very well be tried by the court they established. It is therefore not surprising that this is the first court with a catalogue of complete defenses. ${ }^{769}$

\section{HoW ARE DEFENSES RAISED?}

In the judgments studied, most defenses are brought up by the Defense. There are several exceptions. In two consent cases (Prosecutor v. Kunarac and Prosecutor $v$.

\footnotetext{
768 ICTR, Prosecutor v. Kamuhanda, Appeals Chamber, 19 September 2005, par. 167.

769 For more effects of this development see: Cryer, R., 2005, pp. 291-302 (on safe and unsafe international criminal courts).
} 
Gacumbitsi), the prosecution initiates the discussion on the defense, to shift the burden of proof (they want the Defense to establish consent of the victim, instead of proving absence of consent themselves). The judges in Prosecutor v. Gotovina et al., partially discussed self-defense proprio motu: self-defense had been accepted in a local court judging the direct perpetrator. Consequently, the judges probably felt obliged to discuss the issue. In several cases it cannot be derived from the text of the judgment why a certain defense is discussed (the IMT verdicts on Rudolf Hess, Dönitz and Raeder, the general part of the IMT Judgment on plunder, and the general part of the IMTFE Judgment, Prosecutor v. Stakić and Prosecutor v. Kamuhanda).

\section{ThE APPLICABILITY OF COMPLETE DEFENSES}

The previous Sections showed that complete defenses is a generally recognized legal concept, usually brought up by the defense. The current Section investigates the responses to specific complete defenses at the courts studied. The different reactions that have surfaced are:

- The court recognizes the defense in principle, but does not discuss the defense in casu (in short: accepted in principle)

- The court accepts the defense in casu (and thus also recognizes the defense in principle) (in short: accepted)

- The court rejects the defense in casu, but (probably) recognizes the defense in principle (in short: rejected)

- The court rejects the defense a priori (in short: a priori rejected)

- The court produces contradictory or otherwise indistinct reasoning (in short: unclear)

- The court holds that the defense is technically not a complete defense (in short: not a defense)

- The defense was not brought up (as a complete defense) at the relevant court (in short: not discussed)

The table below organizes these different reactions for each defense by court. 
Analysis of complete defenses in international criminal law in general
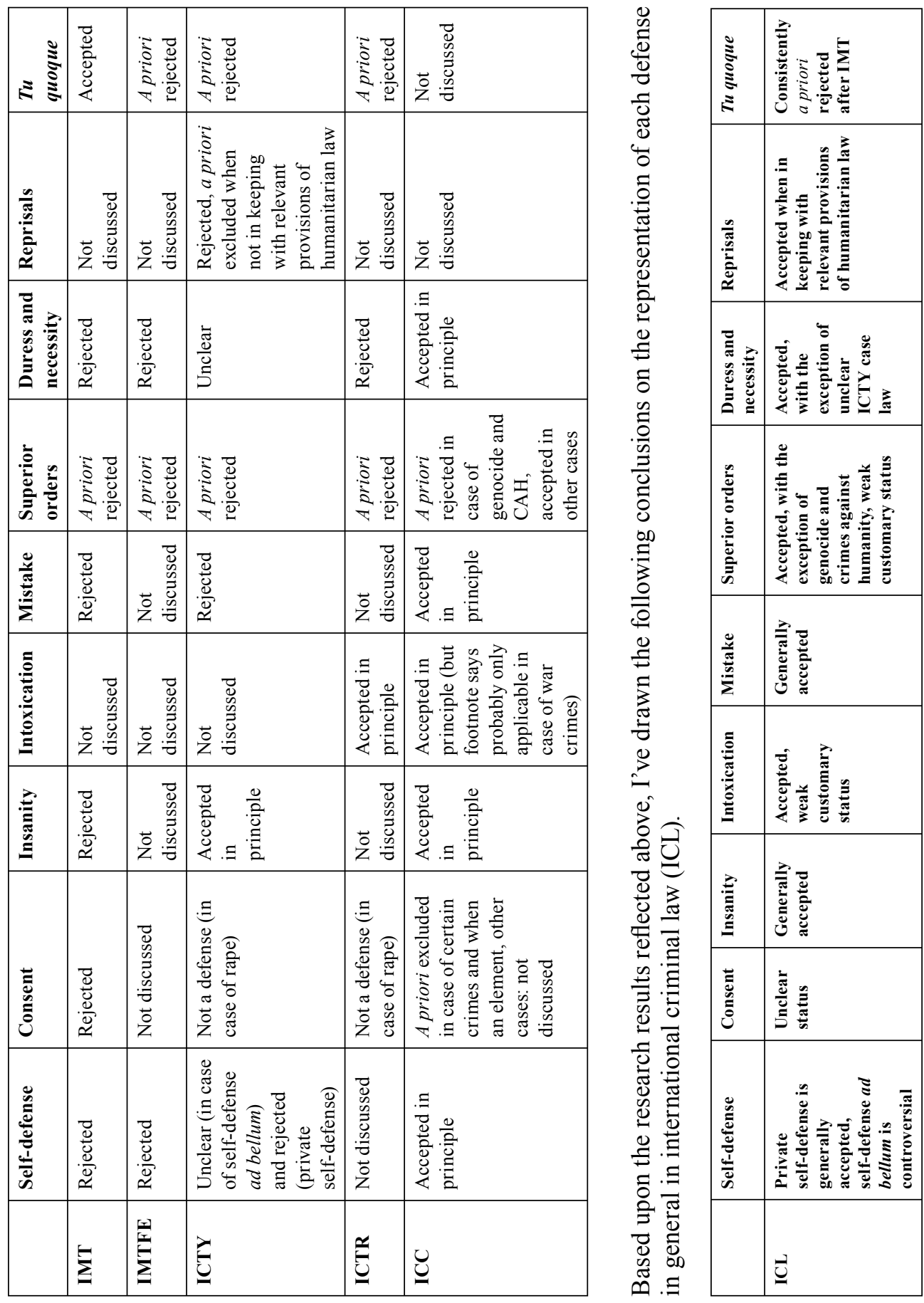
The most remarkable conclusion that can be drawn from these tables is that in practice, complete defenses are as good as consistently rejected in international criminal law. Although several defenses are generally accepted in principle (insanity, mistake, private self-defense and maybe intoxication), only on two occasions has an international court acknowledged the applicability of a complete defense: tu quoque was accepted in the verdicts on Dönitz and Raeder (IMT). Two marginal notes should be made on this acceptance. First, tu quoque at the IMT is not employed as a complete defense in a technical sense - negating wrongfulness or blameworthiness - but more as a tool to determine sentences. The reason for this may be that tu quoque in general is probably not a complete defense in a technical sense. Second, tu quoque, the only accepted complete defense ever in international criminal law, has been consistently a priori rejected ever since. From the above can be concluded that although tu quoque was the only complete defense ever accepted in international criminal law, the acceptance of this defense has lost its significance today.

The fairly consistent rejection of complete defenses in international criminal law questions their raison d'etre: are these defenses at all compatible with international crimes? Or do horrific and large-scale offenses call for a different approach? These questions are addressed in Part III of this thesis.

Between the defenses that have been generally accepted in principle at one extreme (insanity, intoxication, mistake, private self-defense) and tu quoque, which has been consistently a priori rejected after Nuremberg on the other, there is a grey area. This grey area consists of (a) defenses that have been accepted but are $a$ priori excluded in case of specific crimes and (b) defenses with an unclear status.

Category (a) consists of superior orders (which is a priori excluded in case of genocide and crimes against humanity), reprisals (which is a priori excluded in case of humanitarian law provisions prohibiting reprisals), and duress/necessity (which is in principle applicable but could be a priori rejected in case of specific crimes, though in which cases specifically and how is not clear due to contradictory (case) law). Category (b) consists of: self-defense ad bellum (on which (case) law is controversial) and consent (which has an indistinct status as a complete defense due to a priori exclusion in a number of situations. However, it is not clear whether this means it could be a complete defense in other circumstances). Schematically the applicability of complete defenses in international criminal law, provide the following picture:

\begin{tabular}{|l|l|l|l|}
\hline Generally accepted & Partially accepted & A priori rejected & Unclear \\
\hline Insanity & Superior orders & Tu quoque & Self-defense ad bellum \\
Intoxication & Reprisals & & \\
Mistake & Necessity/duress & & \\
Private self-defense & & & \\
\hline
\end{tabular}


It is worth noting that the defenses marked as "not discussed" at the ICC, can technically be a defense under article 31(2) and/or (3) of the ICC, be it that the availability of tu quoque is very unlikely, due to the requirements of article 21(c), demanding a basis in law (custom, principles etc.).

\section{A PRIORI REJECTION: REASONS}

Below an overview is provided of all reasons forwarded by courts for a priori rejection for each defense.

\subsection{Self-defense ad bellum}

On several occasions the ICTY a priori rejected self-defense ad bellum. Reasons: self-defense ad bellum is no justification for serious violations of international humanitarian law or the crime charged involves (disproportionate) attacks on civilians and this is absolutely prohibited. It must be mentioned, however, that this type of self-defense was not consistently a priori rejected at the ICTY, but also occasionally on its merits, suggesting the availability of the defense in principle. Finally, in a few cases the defense brought up was considered irrelevant because it was aimed at the legitimacy of the attack itself (ad bellum) and not at the legitimacy of the crimes committed during the attack (in bello).

\subsection{Consent}

Consent has occasionally been a priori excluded for two reasons (a) because absence of consent is part of the definition of the offense (rape, enforced prostitution, sexual violence, enforced sterilization and pillaging) and (b) because the defense has been a priori excluded in case of mutilation and medical and scientific experiments. The first type of exclusion seems to be motivated by legal tradition (in most legal systems absence of consent is an element of sexual crimes), the second type by the fact that the subjective consent of the victim is not enough to legalize certain invasions of the human physique. Apparently, these invasions must be measured against an objective medical standard.

\subsection{Superior Orders}

Superior orders is a priori excluded by statute. Consequently, there are no lengthy motivations of this rejection. However (case) law leaves some suggestions. In its Judgment, the IMT holds that a priori rejection of superior orders is "in conformity with the law of all nations" when it comes to "such acts of brutality", thereby suggesting that a priori rejection has a basis in legal principles and custom when it 
concerns serious crimes. The ICTY holds that superior orders is not a complete defense an sich, but merely a factor in determining the presence of duress or mistake of fact. The ICC excludes superior orders in case of genocide and crimes against humanity, because in these cases a subordinate should always have known that the relevant order is manifestly unlawful. Note that this latter a priori rejection is based on the merits (in case $\mathrm{x}$ and $\mathrm{y}$, requirement $\mathrm{c}$ is never met).

\subsection{Necessity/duress}

In Prosecutor v. Erdemović, the first Trial Chamber a priori rejects duress in case of crimes against humanity, because the nature of these crimes makes it practically impossible to meet the proportionality requirement. The Appeals Chamber's rejection of duress (in case of a soldier killing innocents) is based on practical policy reasons. In brief, the policy argument of the majority contains that denying duress in case of killing innocents has a normative effect, i.e. it influences the behavior of soldiers in the field. This normative effect contributes to the objective of international humanitarian law (protection of the weak), which must be enforced by the Tribunal. Note that the a priori rejection of the Trial Chamber and the Appeals Chamber differ in that the rejection of the Trial Chamber is based on the merits (in case $\mathrm{x}$ requirement $\mathrm{b}$ is never met) while the Appeals Chamber's rejection is not (in case $\mathrm{z}$ the defense is not available). In Prosecutor v. Kvočka et al., duress is a priori rejected as a defense to war crimes and crimes against humanity (however, in the same Judgment the defense is tested on its merits and thus implicitly recognized).

\subsection{Reprisals}

Reprisals are a priori excluded as a complete defense when not in keeping with the relevant provisions of humanitarian law. Certain provisions, e.g. in the Geneva Conventions, prohibit the use of reprisals, usually to protect the civilian population. In these cases, reprisals are not available as a complete defense.

\subsection{Tи quоque}

At the IMTFE tu quoque was a priori rejected without grounds (before it was brought up). At the ICTY (later confirmed by the ICTR) tu quoque was rejected because:

1. There is no support for $t u$ quoque in case law, state practice and opinions of publicists;

2. International humanitarian law has an absolute character; consequently the compliance with its rules is not based on reciprocity (while tu quoque is);

3. A similar reasoning is applicable to ius cogens, which covers most international crimes. 


\subsection{Conclusion on reasons for a priori rejection}

In the vast majority of cases, defenses are (partially) a priori rejected due to the nature of the crimes charged. These crimes are categorized as (serious) violations of international humanitarian law, "attacks on civilians", "acts of brutality", crimes against humanity and/or genocide. Grounds for a priori exclusion of complete defenses in case of serious crimes may vary. In several cases the absolute character of international humanitarian law and/or ius cogens are underlined as being incompatible with defenses. Sometimes no specific reason is mentioned. The courts (or statutes) also refer to the manifest unlawfulness of the crime, the severity of the crime, and the impossibility to meet a specific requirement of the defense in case of a particularly serious crime.

On several occasions the horrendous nature of the crimes charged is not the only ground for rejection. The courts also refer to legal sources (custom, principles of law, case law, opinions of publicists) in order to substantiate their a priori rejection. Defenses have as well been excluded when the defense does not justify or excuse the crime charged (consent, superior orders), when the defense is part of the definition of a crime (consent) and when denying the defense is supposed to have a normative effect (duress). In a few cases the defense brought up was considered irrelevant because it was aimed at the legitimacy of the attack itself (ad bellum) and not at the legitimacy of the crimes committed during the attack (in bello).

\section{RECOGNITION IN PRINCIPLE (EXPLICIT RECOGNITION)}

The majority of recognitions in principle of complete defenses occurs within the catalogue of complete defenses of the ICC Statute. The inclusion of these defenses is not explicitly clarified. ${ }^{770}$ The acceptance in principle of insanity in ICTY case law is also not substantiated. As is the ICTR acceptance of intoxication. The recognition of tu quoque is based on violations of the same set of rules by the adversary.

\section{GROUNDS FOR REJECTION ON MERITS (IMPLICIT RECOGNITION)}

\subsection{Self-defense}

In most self-defense cases where the defense was rejected on its merits the intent to act in self-defense was lacking. The relevant court substantiated this lack of intent by finding alternative motives for the alleged action in self-defense, e.g. in the sphere of aggression or ethnic cleansing. In some cases other missing requirements

770 See: UN Diplomatic Conference of Plenipotentiaries on the Establishment of an International Criminal Court, Rome, 15 June - 17 July 1998, Official Records Vol. I, II and III. 
are discussed as well, i.e.: the necessity requirement (Verdict on Hideiki Tojo, Prosecutor v. Stakić), the unlawful attack requirement (Tojo and possibly Prosecutor v. Delić, Prosecutor v. Gotovina et al.), the immediacy requirement (Verdict on Erich Raeder, general part of the Tokyo Judgment and in Prosecutor $v$. Stakić, Prosecutor v. Gotovina et al.) and the proportionality requirement (Prosecutor v. Stakić, possibly also in Prosecutor v. Delić, Prosecutor v. Gotovina et al.). Prosecutor v. Hadžihasanović and Kubura is the only case in which selfdefense was brought up, but not discussed. In Prosecutor v. Delić the defense was discussed and rejected; however, grounds were not explicitly mentioned (only implicitly by describing the situation).

\subsection{Consent}

Consent was only rejected on its merits on one occasion at the IMT (General Part of the IMT Judgment). Rejection was based on the fact that consent of the victim was obtained by duress and therefore not genuine. Apart from that there was no consent from the international community either, which the Tribunal held was necessary.

\subsection{Insanity}

In Mucić et al., the Trial Chamber rejects an appeal to diminished responsibility as a complete defense because the relationship between the personality disorder of the defendant and the inability to control his physical acts was not established. Although the IMT's finding that Hess was sane when the acts charged against him were committed is not a rejection on merits, it is still an implicit recognition of the insanity defense.

\subsection{Mistake}

Mistake is either rejected because the court holds the defendant was aware of the relevant law or fact (Göring and Raeder), because he should have been aware (General part of the IMT Judgment, Mucić et al. and Dragomir Milošević) or because of a combination of both (In Lubanga the ICC rejects an appeal to mistake of law because the defendant both knew and should have known about the law). 


\subsection{Necessity/duress}

Reasons for the rejection of necessity/duress can be brought back to several (recurring) arguments. In order of frequency:

- The defendant had other options (Itagaki, Matsui, Dohihara, Aleksovski, Kvočka)

- The tribunal does not believe the defendant was in a necessity/duress situation (Kvočka, Kajelijeli, Kamuhanda)

- The defendant did not intend to choose the lesser of two evils (general part of the Nuremberg Judgment, Togo)

- Prior fault (Dönitz)

- Procedural reasons (Aleksovski)

\subsection{Reprisals}

In Martic the ICTY rejected reprisals because the reprisal was not a last resort and no formal warning had been given.

\subsection{Conclusion}

In the vast majority of cases defenses are rejected, because the intent to act in accordance with the lesser evil is lacking. However, this ground is only mentioned in case of self-defense and necessity/duress. The runner up is the necessityrequirement, not only mentioned in case of these two defenses but also in the context of reprisals in the form of the last resort requirement (i.e. a reprisal is not necessary if the defendant had other options to end the violation of law by the adversary). Other grounds for rejection mentioned are the requirements of unlawful attack, immediacy and proportionality (in case of self-defense), the genuine consent of the victim and the international community (consent), the causal relation between personality disorder and the inability to control physical acts (insanity), the unawareness (was or should have been) of the relevant law or facts (mistake) and the credibility of the existence of a necessity/duress situation, absence of a prior fault and procedural reasons (necessity/duress).

\section{Complete defenses AND Mitigating CiRCUMSTANCES}

At the ICC, circumstances falling short of constituting grounds for exclusion of criminal responsibility can be taken in mitigation in accordance with Rule 145(2)(a) (1). At the ad hoc tribunals only a few defenses have been explicitly recognized as a mitigating factor in principle. Superior orders was explicitly mentioned as a mitigating factor by the statutes of all four tribunals. Both the ICTY and the ICTR 
have acknowledged that duress can be a mitigating factor. The ICTY has also recognized diminished responsibility as a mitigating factor (although probably under a different definition than the ICC) and intoxication when forced, coerced or otherwise involuntary. The only cases in which a defense was accepted in mitigation are Erdemovic at the ICTY and Ndahimana at the ICTR (both duress). In other cases failed defenses (or defenses brought up as a mitigating factor) were consistently rejected at the courts subject to this research.

\section{LEgAL CONSEQUENCES OF COMPLETE DEFENSES}

As demonstrated above only on two occasions an international court has acknowledged the applicability of a complete defense: $t u$ quoque was accepted by the IMT in the verdicts on Dönitz and Raeder. However, the legal consequences thereof were not drastic. The acceptance of tu quoque did not result in an acquittal, since both defendants were held liable for other charges. The only other information on the legal consequences of a successful complete defense can be derived from the ICC Statute. According to this statute a successful appeal to a complete defense leads to exclusion or relief from criminal responsibility (see article 31(1), article 32(1) and (2) and article 33(1) of the ICC Statute). Consequently the defendant must be acquitted (article 81 of the ICC Statute).

In most cases the rejection of a complete defense contributes to the conviction of the defendant. However, in several cases the rejection of a defense had no consequences:

1. In Prosecutor v. Delic the rejection of self-defense did not influence the criminal responsibility of the accused because his command responsibility in relation to relevant crime could not be established.

2. In Prosecutor v. Gotovina et al., the rejection of self-defense had no consequences for one of the accused, for he was acquitted for other reasons.

3. In Kajelijeli the prosecution failed to prove its case. Consequently, Kajelijeli was not convicted for this specific charge.

Remarkable is that the legal consequences in case of a successful insanity plea are non-existent. Not any of the institutions subject to this research has a clear legal framework, applicable to the defendant whose acquittal is based upon a successful insanity plea. Consequently, the acquitted but insane perpetrator appears to go free, whereas in most domestic systems he is committed to some sort of mental institution or psychiatric program. 


\section{THE SCOPE OF COMPLETE DEFENSES}

The subsections below present an overview of the conditions of the complete defenses, as identified in Part II of this thesis. These conditions are an accumulation of all requirements mentioned by the sources studied. Consequently, this junction may result in the narrowest possible interpretation of a specific defense (and not necessarily in the most desirable scope, which is discussed in Part III). Requirements are tested objectively unless indicated otherwise.

\subsection{Requirements}

\section{Self-defense}

- The attack must be immediate;

- The attack must be unlawful;

- The defense must be necessary;

- The defense must be proportionate;

- The defense must be related to a defensible interest;

- The defendant must have had the intent to act in self-defense.

\section{Consent}

- The victim must have consented;

- Third parties must have consented;

- Consent must not have been obtained under duress.

\section{Insanity}

- The defendant must have had an abnormal mental condition;

- This condition must have been present when the crime was committed;

- The abnormal condition causes the defendant to either:

- Not know what he is doing;

- Not know that he is doing something wrong/unlawful;

- Have no capacity to control his conduct.

Insanity requires a subjective test.

\section{Intoxication}

- The defendant is in a state of intoxication;

- This intoxication destroys: 
Analysis Part II

- The defendant's capacity to appreciate the unlawfulness or nature of his or her conduct; or

- The defendant's capacity to control his or her conduct to conform to the requirements of law;

- The defendant did not become voluntarily intoxicated under such circumstances that he knew, or disregarded the risk, that, as a result of the intoxication, he was likely to engage in conduct constituting a crime within the jurisdiction of the court.

Intoxication requires a subjective test, with an objective element ("disregarded the risk").

\section{Mistake}

Did the defendant know and/or should he have known about a certain law/fact (relevant to form the required definitional subjective element)?

The way mistake is tested is far from clear. Mistake either requires a subjective test, an objective test or an objectivised subjective test.

\section{Superior orders}

- The order must involve a crime within the jurisdiction of the court;

- The crime was committed pursuant to an order;

- The order came from the government or of a superior;

- The government or superior is either military or civilian;

- The defendant was under a legal obligation to obey the order (condition (a));

- The defendant did not know that the order was unlawful (condition (b)) (subjective requirement);

- The order was not manifestly unlawful (condition (c));

- The order did not amount to the commission of genocide or crimes against humanity.

\section{Necessity/Duress}

- Presence and severity of a threat;

- The threat must be issued against the defendant or another person;

- The crime has been caused by duress resulting from the threat (requirement can be interpreted as a subjective test);

- The defendant must have acted necessarily to avoid the threat;

- The defendant must have acted reasonably to avoid the threat; 
- The defendant must not (have intended to) cause a greater harm than the one sought to be avoided (requirement can be interpreted as a subjective test);

- The threat may result from persons or circumstances beyond that person's control.

\section{Reprisals}

- The reprisal is an otherwise unlawful response by a belligerent to a violation of law committed by the other belligerent;

- The sole purpose of the reprisal is seeking compliance with the law of armed conflict by the opposite party;

- The reprisal must have been the last resort;

- Reprisals may be exercised only after a prior and formal warning;

- Reprisals may only be taken after a decision to this effect has been made at the highest political or military level;

- The measures taken must be proportionate to the initial violation of the law of armed conflict by the opposite party;

- The reprisal must respect the "laws of humanity and dictates of public conscience".

Tu quoque

The adversary has committed roughly similar violations of the law.

\subsection{Analysis of the scope of complete defenses}

As can be gathered from the above requirements, complete defenses, based upon similarities, can be grouped into three categories:

1. Self-defense/reprisals/necessity \& duress.

2. Insanity/intoxication/mistake/superiororders/necessity \& duress.

3. Consent/tu quoque.

Each category is discussed below.

\section{(1) Self-defense/Reprisals/Necessity\&Duress}

The common denominators of these defenses are:

1. A defensible interest (e.g. a person, compliance with international law);

2. An urgent threat to this interest;

3. The act of the defendant was necessary to avoid the threat; 
4. The defendant acted proportionately (or intended to do so);

5. The defendant must have had a justificatory purpose (mental element requirement).

The presence of a proportionality requirement indicates that all three defenses are justifications or a justificatory version of a defense (necessity/duress): the defendant is only absolved from criminal responsibility if the legal community would have approved of his act. He had no other option but to commit a crime (necessity) and acted in accordance with the lesser of two evils (proportionality). The differences are that in case of self-defense and reprisals the act of the defendant is a reaction to a violation of the law, while in case of necessity/duress this does not have to be the case. A necessity/duress situation can, for example, also come into being following a natural disaster (e.g. earthquake). Apart from that, necessity/duress requires a causal relation between threat and crime and is probably not available in case of a prior fault. ${ }^{771}$ Reprisals are different in that the decision to engage in a reprisal must be made at the highest political or military level and must respect "the laws of humanity and dictates of public conscience". This extension could be explained by the fact that reprisals are a typical international law defense, while self-defense and necessity/duress are respectively a mixed (international and national version) and a domestic defense.

\section{(2) Insanity/Intoxication/Mistake/Superior-Orders/Necessity\&Duress}

In case of all these defenses:

- The defendant has an deviating mental condition (e.g. due to a disease, intoxication, the lack of essential knowledge, an extremely stressful situation);

- The defendant has no control over the situation (because he lacks certain knowledge or because he cannot control his behavior).

All these defenses are excuses or have an excusing component (necessity/duress). Consequently most of these defenses require some sort of a reasonable person test: the defendant is only absolved from criminal responsibility if he cannot be blamed for not having control. Blame is absent if a reasonable person in a similar situation would not have had control either. This reasonable person test is covered by the conscious risk-taking element in case of voluntary intoxication, the should have known criterion in case of mistake and the required absence of manifest unlawfulness in case of superior orders. Because the criteria for the necessity/ duress defense are rather undefined, mixing up a justification and an excuse, it is hard to identify a reasonable person test among its requirements. It could however be read into the reasonability-requirement of the necessity/duress defense. Only in 
the case of insanity is there no reasonable person test. In case of this defense only the subjective state of mind of the defendant matters, not how he should have behaved. It is noteworthy that in the case of many of these reasonable person tests, a so-called Garantenstellung (the weight of the societal position of the defendant when determining how he should have behaved) is a factor of importance. This factor has been mentioned in case of mistake and superior orders (both in the context of the ICC) and in case of necessity/duress (both at the ICTY and the ICC). Some of these defenses demand a causal relation between mental condition and crime (insanity, intoxication and necessity/duress). Several reasonable person tests can also be read as to extend to some sort of prior fault criterion. This would be the case with intoxication and possibly necessity/duress. Superior orders is the only defense whose requirements limit its availability to certain crimes (a priori exclusion in case of crimes against humanity and genocide).

\section{(3) Consent/Tu quoque}

Consent and tu quoque form a third category because they have nothing in common with the other defenses, or with each other except for that:

- They are neither justifications nor excuses;

- Their status as a complete defense in international criminal law is unclear and/ or controversial.

It thus seems that the unclear/controversial status of these defenses can be explained by the fact that they are not compatible with the system.

In short, the above categories can be labeled as: (1) justifications, (2) excuses and (3) neither. The division in justifications and excuses is remarkable, since the statutes and judgments of international criminal courts generally don't make this distinction explicitly. Implicitly, however, this distinction seems to be recognized: the conditions required for a specific defense reveal whether the defense is a justification or an excuse. Justifications require a largely objective test, but demand an occasional mental element of the defendant, either tested objectively or subjectively. Excuses require a largely subjective test, which is usually objectivised by the introduction of a reasonable person test. It is probably due to their objective nature that justifications require a mental element (the defendant must have had a noble purpose), while excuses do not. 
Analysis Part II

\section{Categorization of COMPlete defenses}

Chapter II demonstrates that international criminal theory distinguishes between three different types of defenses:

\begin{tabular}{|l|l|l|l|}
\hline Defense & Effect & $\begin{array}{l}\text { Justification or } \\
\text { excuse? }\end{array}$ & Affirmative or not? \\
\hline$X$ & $\begin{array}{l}\text { General requirements } \\
\text { for criminal liability are } \\
\text { not negated }\end{array}$ & Justification & Affirmative \\
\hline $\begin{array}{l}\text { No definitional } \\
\text { subjective element }\end{array}$ & $\begin{array}{l}\text { Defense negates } \\
\text { definitional subjective } \\
\text { element }\end{array}$ & Justification or excuse & Not affirmative \\
\hline No blameworthiness & $\begin{array}{l}\text { Defense negates } \\
\text { blameworthiness }\end{array}$ & Excuse & Affirmative \\
\hline
\end{tabular}

This Section provides an overview of the types of complete defenses that have featured in international criminal law. It discusses the conclusions that can be drawn from these findings and, specifically, how these conclusions contribute to the existing theory in international criminal law on the relationship between complete defenses and the general requirements for criminal responsibility.

All three types of complete defenses are represented in international criminal law in the following manner:

\begin{tabular}{|l|c|c|c|c|c|c|c|c|c|}
\hline & $\begin{array}{l}\text { Self- } \\
\text { Defense }\end{array}$ & Consent & Insanity & Intoxication & Mistake & $\begin{array}{l}\text { Superior } \\
\text { Orders }\end{array}$ & $\begin{array}{l}\text { Necessity/ } \\
\text { Duress }\end{array}$ & Reprisals & $\begin{array}{l}\text { Tu } \\
\text { Quoque }\end{array}$ \\
\hline Defense = $\mathbf{x}$ & $\mathrm{X}$ & & & & & & $\mathrm{X}$ & $\mathrm{X}$ & \\
\hline $\begin{array}{l}\text { Defense = no } \\
\text { definitional } \\
\text { subjective element }\end{array}$ & $\mathrm{X}$ & & $\mathrm{X}$ & $\mathrm{X}$ & $\mathrm{X}$ & $\mathrm{X}$ & $\mathrm{X}$ & $\mathrm{X}$ & \\
\hline $\begin{array}{l}\text { Defense = no } \\
\text { blameworthiness }\end{array}$ & & & $\mathrm{X}$ & $\mathrm{X}$ & $\mathrm{X}$ & $\mathrm{X}$ & $\mathrm{X}$ & & \\
\hline $\begin{array}{l}\text { Justification or } \\
\text { excuse? }\end{array}$ & Justification & Neither & Excuse & Excuse & Excuse & Excuse & $\begin{array}{l}\text { Can be either } \\
\text { justificatory, } \\
\text { excusing or } \\
\text { neither }\end{array}$ & Justification & Neither \\
\hline Affirmative? & Yes and no & $\begin{array}{l}\text { Yes and } \\
\text { no }\end{array}$ & $\begin{array}{l}\text { Yes and } \\
\text { no }\end{array}$ & Yes and no & $\begin{array}{l}\text { Yes and } \\
\text { no }\end{array}$ & $\begin{array}{l}\text { Yes and } \\
\text { no }\end{array}$ & Yes and no & Yes and no & Yes \\
\hline
\end{tabular}

Now what is the contribution of these findings to the existing theory in international criminal law on the relationship between complete defenses and the general requirements for individual criminal responsibility? First of all, the above conclusions demonstrate that justifications behave in a similar way. Either they negate the wrongfulness of the act, which is not part of the definition of the crime, or they negate the definitional subjective element in case of negligence. Secondly, excuses behave in a similar manner as well: they either negate the blameworthiness 
of the act, which is not part of the definition of the crime, or they negate the definitional subjective element. However, as opposed to justifications, the definitional subjective element can be negated in various ways when it comes to excuses. Not only in case of negligence, but also because the required intent cannot be established either based on a psychological (the defendant cannot form the required intent, as in case of insanity, intoxication and mistake) or a normative test (intent is established by a should have known test, as in case of mistake). Excuses can thus negate the definitional subjective element in three different manners. Thirdly, the defenses that are unclear/controversial (consent and tu quoque) cannot be categorized in terms of defenses negating the general requirements for criminal responsibility. Note that the categorization of defenses in (a) justifications, (b) excuses and (c) neither is the same as the categorization based on the conditions for each specific defense in Section 10.

The research displayed in Part II demonstrates a different perspective on the relationship between complete defenses and the general requirements for criminal responsibility than the theories discussed in Part I of this thesis. Part I explains that some theorists describe the relationship between general requirements for criminal responsibility and complete defenses as one of confession and avoidance, while others adhere to the theory of negation of subjective element. The present analysis demonstrates that both theories are inadequate. According to the first theory (confession and avoidance), in case of a complete defense the objective element and definitional subjective element have been established, but are "avoided" by reasons afforded as to why the defendant should not be punished. The present analysis, however, demonstrates that each defense, depending on the context, can negate the definitional subjective element. This element is thus not consistently avoided. Note that the finding that complete defenses can negate part of the definitional subjective element of an offense makes the earlier-quoted passage from Kamuhanda, defining complete defenses, inaccurate:

In general, a defence comprises grounds excluding criminal responsibility although the accused has fulfilled the legal elements of a criminal offense. [...] $]^{772}$

Not only the theory of confession and avoidance is inadequate to describe the relationship between complete defenses and general requirements for criminal responsibility, also the theory of negation of subjective element does not suffice. According to this theory a complete defense always negates the definitional subjective element. However, the present analysis demonstrates that each defense can also negate either the wrongfulness of the offense or the blameworthiness of the perpetrator and that these elements are not (always) included in the definitional subjective element. Consequently, complete defenses do not consistently negate the definitional subjective element.

772 ICTR, Prosecutor v. Kamuhanda, Appeals Chamber, 19 September 2005, par. 167. 
The deduction in the present analysis also settles the issue of affirmative and non-affirmative defenses. Part I established that international criminal law acknowledges two types of defenses, affirmative and non-affirmative (of the prosecution's case), but that their definitions are flustered. The above categorization of defenses demonstrates that the very same defense can be both affirmative and non-affirmative. Being affirmative or not is thus not dependent on the definition of the defense but both on the crime charged and the reasoning of the Defense. More specifically, in case of a justification, being affirmative depends on whether the crime charged requires intent (in which case the defense is affirmative) or negligence (non-affirmative). In case of an excuse, the qualification not only depends on whether the crime charged requires negligence or intent but also on the arguments of the defense. If the crime charged requires negligence the defense is not affirmative. In case the crime charged requires intent, being affirmative depends on whether the defense argues that the defendant is not blameworthy (affirmative), the intent requirement is not met because there is no psychological intent (not affirmative) or the intent requirement is not met because there is no normative intent (not affirmative). Conclusively, it can be held that the qualification affirmative (or not) is not a tool to label specific defenses as either one or the other, but merely a description of two possible effects of the same defense depending on the context. Only one defense has been qualified as always affirmative: tu quoque. However, the status of this defense is (very) controversial.

Schematically, the effect of complete defenses (justifications and excuses) on the general requirements for criminal responsibility provides the following picture:

\begin{tabular}{|l|l|l|l|}
\hline Effect & Defense & $\begin{array}{l}\text { Justification of } \\
\text { excuse? }\end{array}$ & $\begin{array}{l}\text { Affirmative or } \\
\text { not? }\end{array}$ \\
\hline $\begin{array}{l}\text { Wrongfulness is negated but crime } \\
\text { charged is not }\end{array}$ & $\begin{array}{l}\text { Act is not } \\
\text { wrongful }\end{array}$ & Justification & Affirmative \\
\hline $\begin{array}{l}\text { Blameworthiness is negated but crime } \\
\text { charged is not }\end{array}$ & $\begin{array}{l}\text { Act is not } \\
\text { blameworthy }\end{array}$ & Excuse & Affirmative \\
\hline $\begin{array}{l}\text { Definitional subjective element of } \\
\text { negligence is negated by absence of } \\
\text { wrongfulness }\end{array}$ & $\begin{array}{l}\text { Act is not } \\
\text { wrongful }\end{array}$ & Justification & Not affirmative \\
\hline $\begin{array}{l}\text { Definitional subjective element } \text { of } \\
\text { negligence is negated by absence of } \\
\text { blameworthiness }\end{array}$ & $\begin{array}{l}\text { Act is not } \\
\text { blameworthy }\end{array}$ & Excuse & Not affirmative \\
\hline $\begin{array}{l}\text { Definitional subjective element is negated } \\
\text { by absence of psychological intent }\end{array}$ & No intent & Excuse & Not affirmative \\
\hline $\begin{array}{l}\text { Definitional subjective element is negated } \\
\text { by absence of normative intent }\end{array}$ & $\begin{array}{l}\text { Act is not } \\
\text { blameworthy }\end{array}$ & Excuse & Not affirmative \\
\hline
\end{tabular}

It can be concluded from the above that the relationship between complete defenses and the general requirements for criminal liability is not only determined by the nature of the complete defense (a justification or an excuse?), but also by the crime 
charged (is the definitional subjective element intent or negligence?) and the facts underlying the situation (is the definitional subjective element negated by absence of normative or psychological intent?). In reference to the latter type of intent it is, however, doubtful whether the defense brought up truly acts as a complete defense, for the mental element is negated without necessarily negating the wrongfulness of the act or the blameworthiness of the actor. This issue is further elaborated in Part III.

When we compare the above picture to the scheme reflecting international criminal literature in Part I of this study (represented at the beginning of this Section) we see that both in theory and in practice a complete defense can negate either the wrongfulness of the act or the blameworthiness of the actor without negating the general requirements for criminal responsibility (first two categories in the above diagram) or that a complete defense negates the definitional subjective element (subsequent categories). In reference to the first two categories, the study reflected in the current Part thus confirms international criminal theory. However, in reference to the third category (defense negates definitional subjective element) the research represented in this Part demonstrates that this category is more diverse than international criminal literature suggests, for this category consists of four sub-categories: definitional subjective element is negated by (1) absence of wrongfulness in case of negligence (2) absence of blameworthiness in case of negligence (3) absence of psychological intent, or (4) absence of normative intent. The existence of subcategories explains why international criminal literature is not clear whether the category defense negates subjective element refers to a justification or an excuse (see scheme at the beginning of this Section). In conclusion, it can be held that the highlights of the relationship between complete defenses and general requirements for criminal liability are correctly described in international criminal literature, but that this description does not touch upon the complexity of this relationship.

\section{Concluding Remarks}

The conclusion to this Part demonstrates that complete defenses have gradually moved from implicit to explicit recognition, at least in theory. In practice they have been as good as consistently rejected. Exception to this is the tu quoque defense: the only complete defense ever acknowledged in international criminal law, but at the same time the only complete defense which has been consistently a priori rejected ever since. What is more, this research demonstrates that tu quoque is not really a complete defense in a technical sense, for it does not justify or excuse the acts of the defendant. Other complete defenses have been rejected a priori as well, but not in their entirety. In the vast majority of cases this a priori rejection is linked to the nature of the crimes charged: genocide, crimes against humanity or serious violations of international humanitarian law. Also remarkable is that these $a$ priori rejections are rarely consistent: not only per court, but even within the same 
judgment a Trial Chamber may deny the availability of a defense to one defendant while admitting it in face of another accused. When a defense is rejected on its merits, rejection is usually based on a lacking mental element or on non-compliance with the necessity requirement. Conclusively, it can thus be held that complete defenses are consistently rejected, either a priori or because certain requirements for the defense have not been met.

As is the case with complete defenses, failed defenses in mitigation or defenses brought up as a mitigating factor, are rarely accepted by international courts. The legal consequence of a successful appeal to a complete defense seems to be acquittal, although there is not much legal practice to support this assertion. Defenses can be categorized as justifications and excuses. Consent and tu quoque fall in neither category. In case of a justification, there has been an urgent threat to a defensible interest and the defendant has acted intentionally, necessarily and proportionately to avoid the threat. Justifications can either negate the wrongfulness of the act, which is not part of the definition of the crime, or negate the definitional subjective element in case of negligence. Excuses work in a similar manner except for the difference that an excuse negates the blameworthiness of the crime and can negate the definitional subjective element in three different manners. In case of an excuse the defendant has a deviating mental condition and no control over the situation. Whether a defense is affirmative or not does not depend on, as literature suggests, the definition of the complete defense at issue but on the definition of the crime charged and the reasoning of the defense. In conclusion, it can be held that complete defenses either leave the elements of the crime charged untouched (for a number of different reasons) or they negate the definitional subjective element of the crime charged (also for a number of different reasons). 


\section{Part III}

\section{RECOMMENDATIONS}





\section{Introduction Part III}

Part II has demonstrated that complete defenses in international criminal law gradually moved from implicit to explicit recognition in theory. However, in practice they have been (as good as) consistently rejected. Complete defenses are both rejected a priori and in casu. In most cases a priori rejection is based on the incompatibility of complete defenses with certain crimes. Complete defenses are rejected in casu, because certain requirements for the defense have not been made out.

Gradual recognition in theory and rejection in practice make the status of complete defenses in international law rather ambiguous. On the one hand most defenses seem to be available, on the other hand they are not. This double-faced standing raises the question whether complete defenses should apply at all in case of international crimes. Are international crimes compatible with a system of complete defenses? Or do these horrific and large scale offenses call for a different approach? Chapter XIII demonstrates that international crimes and complete defenses are not mutually exclusive by arguing that although complete defenses will hardly ever apply in the practice of international criminal law, the principle of individual criminal responsibility bars an a priori exclusion of these defenses. Chapter XIV concludes that the current system of complete defenses - or lack thereof - is not satisfactory and displays several general suggestions on what a system of complete defenses should look like. It supports the idea that complete defenses should be subdivided into justifications and excuses. A justification should be applicable when the defendant objectively chooses the best course of action, while an excuse is appropriate in cases where the defendant had no reasonable alternative. The Chapter also argues that prior fault is a relevant factor when determining the legal guilt of a defendant. Chapter XV discusses the availability of the specific complete defenses discussed in Part II of this thesis and proposes suggestions for improvement of the ICC Statute. These suggestions are related to the questions posed at the end of each of the chapters on particular complete defenses in Part II. As it turns out, most complete defenses discussed in Part II of this thesis should be available under the suggested ICC regime, except for consent and tu quoque. Chapter XVI presents a summary of and a conclusion to the thesis as a whole. 



\section{Chapter XIII \\ SHOULD COMPLETE DEFENSES APPLY TO \\ INTERNATIONAL CRIMES?}

\section{InTRODUCTION}

This Chapter demonstrates that international crimes and complete defenses are not mutually exclusive. First, arguments in favor of a system of complete defenses in international criminal law are discussed in Section 2. Next, arguments against such a system are evaluated in Section 3. The conclusion of this Chapter demonstrates that although complete defenses will hardly ever apply in the practice of international criminal law, the principle of individual criminal responsibility bars an a priori exclusion of these defenses.

\section{Arguments Pro the aVAILABILITY OF COMPLETE DEFENSES IN INTERNATIONAL CRIMINAL LAW}

\subsection{Introduction}

The most important argument supporting the availability of complete defenses in international criminal law is that an a priori exclusion of this legal concept is in violation of the principle of individual criminal responsibility (Section 2.2). Although a violation of this principle is enough reason to substantiate the availability of complete defenses in international criminal law, there are several other arguments supporting their accessibility. First of all, the fact that complete defenses have customary status in international criminal law cannot be ignored (2.3). Second, complete defenses support (most) objectives of international criminal law (2.4). Third, complete defenses are available to a defendant charged with international crimes under national law (2.5). The last argument supporting the availability of complete defenses is that it enhances the credibility of international criminal tribunals (2.6).

\subsection{Individual criminal responsibility}

Excluding the availability of complete defenses in international criminal law amounts to a violation of the principle of individual criminal responsibility. According to this principle, nobody can be convicted unless guilt is legally established. The principle of individual criminal responsibility can be found in the statutes of the later ad hoc tribunals (article 21(3) of the ICTY Statute and article 20(3) of the ICTR Statute) and in article 66(1) of the ICC Statute. The principle is also reflected in fair trial provisions of general human rights treaties 
such as article 6(2) of the European Convention on Human Rights (ECHR) and article 14(2) of the International Covenant on Civil and Political Rights (ICCPR). Research has demonstrated that the culpability principle is widely recognized in international criminal law. ${ }^{773}$ Even among scholars who study alternatives to the classic notion of individual criminal responsibility as a response to system criminality. ${ }^{774}$ Some authors even argue that the principle of individual criminal responsibility amounts to ius cogens. ${ }^{775}$

As has been set out in Part I, legal guilt is established by the presence of an objective and a subjective element, the latter consisting both of the definitional subjective element and the blameworthiness of the defendant. Blameworthiness is absent when the defendant lacked the ability to choose, did what any reasonable person would have done, or did not possess the freedom of will, mental capacity, or knowledge of law to act otherwise.

By excluding the arguments contained in complete defenses (either directly negating the blameworthiness of the defendant or negating the blameworthiness through negating the wrongfulness of the act), an overall assessment of the defendant's blameworthiness is avoided. Consequently a defendant can be convicted without his legal guilt being established. ${ }^{776}$

To illustrate the consequences of the (non-) availability of complete defenses, I refer back to an example mentioned in Part I of this thesis:

A commander forces a soldier at gunpoint to kill a civilian. This commander has just shot a fellow combatant, who refused to kill the very same civilian. What is more, the superior threatens that if the soldier does not obey he will not only kill him, but also his best friend. If the soldier kills the civilian, his act qualifies as "willful killing” under the 1949 Geneva Conventions. He killed a person (objective element), and he willfully did so (definitional subjective element), because he wanted to save himself and his friend.

Assuming that the soldier did what any reasonable person in the same situation would have done, the outcome of his case depends on the availability of complete defenses. If they are available, the soldier can successfully claim that he did what any person in the same situation would have done and will be acquitted. However,

773 Francisco Francisco, M.I., 2003, p. 39; Sliedregt, E. van, 2003, p. 362 and Werle, G., 2009, p. 55.

774 Drumbl, M.A., Atrocity, Punishment and International Law, Cambridge University Press, 2007, p. 208; Nollkaemper, A. and Wilt, H.G. van der, 'Conclusions and Outlook', In: Nollkaemper, A. and Wilt, H.G. van der (eds.), In: System Criminality in International Law, Cambridge University Press, 2009, pp. 338-353, p. 352 and Smeulers, A. and Holá, B., 'ICTY and the Culpability of Different Types of Perpetrators of International Crimes', In: Smeulers, A. (ed.), Collective Violence and International Criminal Justice: An Interdisciplinary Approach, Intersentia, Antwerp, 2010, pp. 175-205.

775 Francisco Francisco, M.I., 2003, p. 48 and Knoops, G.J., 2001, pp. 9 and 263.

776 Ambos, K., 2002, p. 1045; Eser, A., 2008, p. 876; Fletcher, G.P., 2000, p. 511 and Knoops, G.J., 2001, p. 63. 
if complete defenses are not available, the soldier will be convicted, despite the fact that he acted as a reasonable person and was thus not legally guilty. In conclusion, it can be held that denying defendants a resort to complete defenses amounts to denying them a basic human right and can result in the conviction of those who are legally innocent.

\subsection{Customary status}

Part II of this study demonstrates that complete defenses have been gradually recognized in international criminal law. They have evolved from implicit recognition at the earlier ad hoc tribunals to an explicit catalogue in the ICC Statute. This development establishes the customary status of complete defenses and cannot be ignored. Opinio iuris can be derived from the fact that all three operative international courts have acknowledged the availability of complete defenses in principle. Consequently many complete defenses were discussed in practice (or further developed in the ICC Statute), confirming this general recognition.

One may argue that this customary status is doubtful since complete defenses are only recognized in principle, while in practice they have been consistently rejected, both a priori and in casu. This argument must, however, be rejected. Firstly, as to a priori rejections, because the previous paragraph has demonstrated that an a priori rejection is in violation of the principle of individual criminal responsibility. Consequently, a priori rejections, as they occur in practice, cannot affect the customary status of complete defenses in international criminal law. Secondly, rejection in casu only confirms the customary status or complete defenses, for it constitutes an implicit recognition of such a defense: the court communicates that a defense would have been available if the relevant criteria had been met.

\subsection{Objectives of criminal law}

The availability of complete defenses at international courts supports the objectives of criminal law. To a great extent the objectives of operative international criminal courts are similar to those of domestic criminal law: deterrence both of the perpetrator and of society as a whole, retribution and isolation of the perpetrator. ${ }^{777}$ These objectives can be gathered from statutes of international courts, case law and other official documents. ${ }^{778}$ Only the objective of rehabilitation (reformation of the

\footnotetext{
777 Ashworth, A., 2009, pp. 16-18 and Fletcher, G.P., 2000, pp. 414-415.

778 See UN Security Council Resolution 827 (1993), UN Security Council Resolution 955 (1994), UN Doc. S/1994/1125 4 October 1994, par. 133-142 and 150-152 and the Preamble of the ICC Statute. Also judges of international courts stress certain objectives of their institution in case law. See for example: ICTR, Trial Chamber, Prosecutor v. Kambanda, 4 September 1998, par. 28 and ICTY, Sentencing Judgment, Prosecutor v. Momir Nicolić, 2 December 2003, Klip/ Sluiter ALC-XV-731, par. 59/60.
} 
offender), common under domestic law, has not gained much ground in international criminal law. ${ }^{779}$

Most of the above objectives are supported by the availability of complete defenses. Consider deterrence: deterring a defendant who is free from wrongful behavior is useless. Such a perpetrator has deliberately chosen the lesser of two evils. This is behavior that a legislator wants to encourage, not deter. Likewise, deterring a defendant who is free of blame is ineffective as well. Blame is only absent if the defendant has no other reasonable option but to commit a crime. When a defendant has no other option, he cannot be deterred by punishment. If he found himself in the same situation again, he would probably make the same choice, and so would anybody else in a similar situation. ${ }^{780}$ Complete defenses thus, filter out a group of defendants who should not or cannot be deterred, and whose punishment should not or cannot have a deterrent effect on others.

As for retribution and rehabilitation: it makes no sense to punish or rehabilitate a defendant who is not blameworthy, because there is nothing to punish and there is no need for the perpetrator to change his behavior (cases of insanity are an exception to the latter). ${ }^{781} \mathrm{~A}$ similar reasoning is applicable to the objective of isolation: a person who made a reasonable decision, and is therefore not blameworthy, does not need to be isolated. He made a decision that anybody in the same situation could have made. Consequently, he is not more of a danger to society than the rest of the legal community (cases of insanity, again, being an exception).

In conclusion: if complete defenses were not available, this would run against most of the general objectives of criminal law because when a defendant can successfully claim a complete defense, neither he nor society needs or can be deterred, nor is there a need to punish, rehabilitate or isolate the defendant.

Apart from the above-mentioned objectives that are common to both domestic and international criminal law, there are several objectives that are more specific for the latter system. Throughout the history of international criminal courts, objectives may have slightly varied, ${ }^{782}$ but especially the later ad hoc tribunals and the ICC have several goals in common. The overarching objective of these common goals seems to be to end threats to peace and security. ${ }^{783}$ Other aims are means to attain this main objective. These aims, or sub-objectives, are:

779 Cryer, R. et al., 2010, p. 28.

780 Ambos, K, 2002, p. 1045. Note that this point of view, advocated by Bentham, has been criticized by Hart. He argues that the absence of complete defenses may have a general deterrent effect. See: Hart, H.L.A., Punishment and Responsibility: Essays in the Philosophy of Law (1967), Oxford University Press, 2008.

781 This is why cases of insanity call for a special regulation. See Chapter XV, Section 4.

782 See for example writings on the reasons for the establishment of the IMTFE (revenge for Pearl Harbor and distraction from domestic politics): Cassese, A. and Röling, B., 1993, pp. 78-80 and Poelgeest, L. van, 1989, pp. 14 and 39.

783 See UN Security Council Resolution 827 (1993), UN Security Council Resolution 955 (1994) and the Preamble of the ICC Statute. 
1. The promotion of more effective use of national justice systems; 784

2. The promotion of the rule of law in international relations; ${ }^{785}$

3. To end a culture of impunity; 786

4. Distinguishing individual responsibility from group responsibility; 787

5. The establishment of the truth in a historical record; 788

6. Education; 789

7. Closure for victims; ${ }^{790}$

8. Reconciliation of the war torn society. ${ }^{791}$

Whether the availability of complete defenses supports the main objective of these courts (to end threats to peace and security) is a complex question to answer. One can reason both ways. On the one hand it can be argued that the non-availability of complete defenses hinders the establishment of peace and security: an international court convicting a defendant free of blame will frustrate the societal group (e.g. Hutu, Serbians) to which this defendant belongs and consequently hold back the peace process. On the other hand it can be argued that the availability of complete defenses hinders the establishment of peace and security: a party to a conflict may be less prone to decrease hostilities when one of their (former) enemies is acquitted on account of a complete defense. It is, therefore, not obvious whether the admissibility of complete defenses contributes to the establishment of peace and security in post-conflict societies. The subject matter is way too complex to find an answer on the spot. However, in general, it is very possible that doing justice in the particular case, and ending threats to peace and security, not necessarily support each other. They may even represent conflicting goals of criminal trials. ${ }^{792}$

Nevertheless, many sub-objectives of international courts - i.e. the means to attain the goal of ending threats to peace and security - are indeed supported by the

784 Herik, L., van, 2005, p. 45.

785 Knoops, G.J., 2001, p. 263; Minear, R.H., Victors' Justice: The Tokyo War Crimes Trial, Princeton University Press, 1971, p. 9 and Overy, R., 'The Nuremberg Trials: International Law in the Making', In: Sands, P. (ed.), From Nuremberg to The Hague: The Future of International Criminal Justice, Cambridge University Press, 2003, pp. 1-29, p. 5.

786 Www.unictr.org/AboutICTR/GeneralInformation/tabid/101/Default.aspx (February 2012) and Preamble ICC Statute.

787 Cassese, A. and Röling, B., 1993, p. 89; Sliedregt, E. van, 2003, p. 362 and ICTY, Sentencing Judgment, Prosecutor v. Momir Nicolić, 2 December 2003, Klip/Sluiter ALC-XV-731, par. $59 / 60$.

788 Minear, R., 1971, p. 9; Taylor, T., 1993, p. 54 and ICTY, Sentencing Judgment, Prosecutor v. Momir Nicolić, 2 December 2003, Klip/Sluiter ALC-XV-731, par. 59/60.

789 Knoops, G.J., 2001, p. 3 and Overy, R., 2003, p. 26.

790 Cryer, R. et al., 2010, pp. 30/31.

791 Cryer R. et al., 2010, p. 33.

792 Cryer, R. et al., 2010, pp. 30/31 and 34/35. See also news items, reporting that ICC investigations hinder the peace process. For example: Chin-A-Fo, H., 'Internationale Strafhof houdt voet bij stuk', In: NRC Handelsblad, 5 March 2008 and Chin-A-Fo, H. and Haenen, M., 'Rechters zonder beklaagde', In: NRC Handelsblad, 18/19 October 2008. 
availability of complete defenses. Since complete defenses are part of international customary law their availability promotes the rule of law (2). The availability of complete defenses does not promote impunity (3). Impunity refers to the situation where blameworthy perpetrators remain unpunished, whereas the availability of complete defenses merely prevents people who are not blameworthy from being punished. In addition, the availability of complete defenses can communicate subtle differences in individual criminal responsibility of members of a group (e.g. why one defendant is punished, while the other is excused) (4). Consequently, the historical record of events will be more nuanced, more truthful (5) and therefore also a more valuable tool for education (6). Hopefully all this has the desired effect on national jurisdictions (1). However, whether the availability of complete defenses brings closure to victims (7) and reconciliation (8) is doubtful for the same reasons as mentioned above when discussing the all-embracing objective of establishing peace and security. For do victims care about the distinction between a physical, justified and an excused perpetrator? Does this distinction help them cope? And is it an incentive to reconciliation?

The general outcome of the analysis above is that the over-arching objective of international tribunals may not be supported by the availability of complete defenses, but that many of its sub-objectives, and the general objectives of criminal law, are. This observation can be explained by the fact that although the availability of complete defenses enhances the legal quality of international criminal trials, there is no indication that their availability promotes or hampers closure for victims, reconciliation and the establishment of peace and security as an overarching goal of international criminal courts. This matter is part of a bigger issue: are international criminal courts in general an adequate means to end threats to peace and security, bring closure to victims and promote reconciliation in a post-conflict society? Whether or not an adequate means, it is submitted here that if international criminal courts are established for the purpose of ending threats to peace and security by among other tools - reconciliation, this should not be a ground for changing the content of criminal law. If the principles on which criminal law is based, such as that of individual criminal responsibility, could be altered depending upon the goal that the institution employing criminal law wishes to attain, criminal law would become an arbitrary and therefore dangerous tool in the hands of those with power.

\subsection{Availability under national law}

Complete defenses are available to defendants charged with international crimes under several national legislations. ${ }^{793}$ If complete defenses were only available at a

793 See for example: Memorie van Toelichting bij de Wet Internationale Misdrijven (WIM), Tweede Kamer, 28 337, Vergaderjaar 2001-2002, p. 29, §2 of the Völkerstrafgesetzbuch and Code Pénal Book I, Title II, Chapter II (Des causes d'irresponsabilité ou d'atténuation de la responsabilité) in conjunction with Book II, Title I (Des crimes contre l'humanité et contre l'espèce humaine). 
domestic level and not at an international level, this would result in the peculiar situation where it is dependent on the forum whether a defendant can appeal to a complete defense. For example, if complete defenses were not available on an international level and a military official is charged with crimes against humanity by the Dutch authorities, this official could plead a complete defense. However, were he arrested by an international tribunal, no such plea would be available. The position of the defendant is more in accordance with the principles of legal certainty and procedural equality when complete defenses are also available under international criminal law.

An additional argument supporting this point of view is that, due to the rules of deferral, ${ }^{794}$ referral ${ }^{795}$ and complementarity, ${ }^{796}$ the line between domestic and international jurisdiction is rather thin. Consequently, the forum prosecuting the defendant can even change during investigations.

\subsection{Credibility of international criminal courts}

Recognizing complete defenses enhances the quality of international criminal courts and consequently their overall credibility. ${ }^{797}$ Throughout the years, international criminal courts have been susceptible to criticism considering their credibility. The main point of disapproval has been that international courts perform "show trials", for the purpose of convicting a specific group of defendants. The IMT was after the Germans, the IMTFE after the Japanese. War crimes committed by the allied forces were ignored. The fact that the statutes of these early ad hoc tribunals refer to "criminals" instead of defendants, suggests it was not the guilt of

794 The UN tribunals and national courts have concurrent jurisdiction (art. 8(1) of the ICTR Statute and art. 9(1) of the ICTY Statute). This means that both tribunals and national courts are able to adjudicate international crimes committed within their competence. Still, the tribunals have primacy over national courts: at any stage of the procedure the prosecutor may request national courts to defer to the competence of the tribunals (art. 8(2) of the ICTR Statute and art. 9(2) of the ICTY Statute). The prosecutor can request deferral (Rule 9 at both tribunals) when proceedings under national law either:

1. are, or should be, subject to an investigation by the prosecutor; or

2. are subject of an indictment of the tribunals; or

3. are in violation of certain fair trial principles (only at the ICTY).

795 The tribunals cannot only ask for deferrals: the principle also works the other way around. Pursuant to Rule 11bis the tribunals can refer cases to national courts. The execution of the completion strategies of the UN tribunals demonstrates that smaller perpetrators are referred to national jurisdictions.

796 The ICC complementarity rule is contained by article 17 of the ICC Statute. According to this rule The ICC can investigate and prosecute only if a country is unwilling or unable to genuinely do this. This means that, under the regime of the ICC, national courts can in principle adjudicate low-ranking soldiers, main leaders and everything in between. However, the practice of ICC indictments demonstrates that also the ICC is prosecuting main leaders.

797 Fichtelberg, A., 2008, p. 17 and Taylor, T., 1993, pp. 601 and 606. See also Knoops, G.J., 2001, p. 8: "Equal application of the law should supersede Realpolitik" and p. 283. 
the defendants that had to be determined by trial. Although, with the establishment of the UN ad hoc tribunals, the era of victor's justice was obviously over and the procedural rights of the accused were better established, ${ }^{798}$ also these tribunals have been criticized for their one-sided prosecution policy and lack of due process. ${ }^{799}$ In this context the establishment of a catalogue of complete defenses in the ICC Statute is an important step in breaking down the stigma of prejudice attached to international courts: the position of the defendant is reinforced and thereby the credibility of international criminal courts in general. ${ }^{800}$

\section{Arguments CONTRA COMPLETE DEFENSES IN INTERNATIONAL CRIMINAL LAW}

\subsection{Introduction}

In both literature and case law, several arguments can be found against complete defenses in international criminal law. Below the most prominent arguments are discussed: ethical arguments (Section 3.2), technical arguments (Section 3.3) and practical arguments (Section 3.4). Ethical arguments refer to the gross human rights violations that are inherent to international crimes; technical arguments discuss the relation between complete defenses and the definition of international crimes; and practical arguments get into the specific characteristics of international criminal law (prosecution of main leaders, system criminality), which makes complete defenses often irrelevant.

\subsection{Ethical reasons}

\subsubsection{Introduction}

Generally, two different types of ethical arguments can be distinguished. Complete defenses are incompatible with international crimes because of:

a. The abhorrent nature of international crimes (Section 3.2.2); or

b. The absolute character of international crimes (Section 3.2.3).

798 E.g., at the IMT and IMTFE the right to appeal was void, the principle of legality was infringed by introducing new crimes, vague definitions of crimes and a large discretionary power of the judges. What is more, the tribunals were not impartial for numerous reasons (See: Cassese, A., 2008, p. 322; Poelgeest, van L., 1989, p. 107 and Taylor, T., 1993, pp. 601, 606 and 627/628). For reference to victor's justice see: Cassese, A., 2008, p. 444.

For criticism on the ICTY and ICTR see: Sluiter, G. and Zahar, A., 2008, p. 322, Banning, C. and Koning, P. de, Balkan aan de Noordzee: Over het Joegoslavië-tribunaal, over recht en onrecht, Prometheus, Amsterdam, 2005, p. 45 and Herik, van L., 2005, p. 30.

A similar argument is made by Nill-Theobald, C., 1998, p. 395. 
Both types of arguments are explained and commented on below. Despite the fact that the arguments are refutable, the abhorrence and absolute nature of international crimes makes it difficult in these cases to meet the requirements for a specific complete defense (Section 3.2.4).

\subsubsection{The abhorrent nature of international crimes}

International crimes are abhorrent by nature. They generally take place in a context of organized violence. Consequently, international crimes tend to be committed on a large scale. For example, in the context of a concentration camp policy or a policy of ethnic cleansing. Several cases at international courts refer to the abhorrent nature of international crimes when rejecting complete defenses. The IMT underlines that superior orders is not a defense to "such acts of brutality". The majority in Erdemović refers to the a priori rejection of duress in case of murder under British law, and argues:

If national law denies recognition of duress as a defence in respect of killing of innocent persons, international law can do no less than match that policy, since it deals with murders often of far greater magnitude. If national law denies duress as a defence even in a case in which a single innocent life is extinguished, due to action under duress, international law, in our view, cannot admit duress in cases which involve the slaughter of innocent human beings on a large scale. ${ }^{801}$

Also, in literature reference is made to the incompatibility of complete defenses and international crimes due to the abhorrent nature of the latter. ${ }^{802}$

There is no denying that international crimes are generally abhorrent by nature. However, this is not the topic under discussion here. The relevant issue is whether the abhorrence of a crime is a legitimate reason to a priori exclude a complete defense. I don't think it is, and for the following reason: the gravity of a crime is not conclusive when determining the guilt of the defendant. Let me illustrate this with an example:

In principle stealing (e.g. cash from a wallet) is a less severe crime than assault upon a person, causing injuries and risking death. If $X$ steals cash, he should receive less punishment than $B$, who assaults a person. However if $X$ steals cash because he wants to treat himself to a five star dinner and $B$ assaults a person who tries to kill him, A deserves punishment and B - acting in self-defense - does not.

801 ICTY, Prosecutor v. Erdemović, Separate Opinion of Judge McDonald and Judge Vohrah, Appeals Chamber, 7 October 1997, par. 75 (italics added, mk).

802 Chiesa, L.E, 'Duress, Demanding Heroism, and Proportionality', In: Vanderbilt Journal of Transnational Law, Vol. 41, 2008, pp. 741-773, pp. 756/757; Fletcher, G.P., 2000, p. 833; NillTheobald, C., 1998, p. 58; Ohlin, J.D., 2009, p. 385 and Wilt, H.G. van der, 2011, p. 276. 
The example above demonstrates that the severity of the crime is not conclusive when determining the guilt of the perpetrator, whereas the circumstances under which the crime was committed, are. If because of these circumstances the act is not wrongful, or the perpetrator himself is not blameworthy, he should be absolved from punishment. Consequently, the severity of international crimes is not a conclusive reason to ban defenses from the arena of international criminal law.

Apart from this not every international crime is shockingly abhorrent and/or committed on a large scale. The Rome Statute enumerates several crimes that are not necessarily more severe than domestic crimes (killing, assault, rape). What is more, not every international crime involves a direct assault on human life (e.g. destruction of property does not). ${ }^{803}$

\subsubsection{Absolute character of international crimes}

A related argument against the applicability of complete defenses in case of international crimes is yielded by the legal translation of their abhorrence: the fact that international crimes generally consist of the violation of norms with an absolute character, i.e. ius cogens and international humanitarian law.

Article 53 of the 1969 Vienna Convention on the Law of Treaties defines ius cogens as "a norm accepted and recognized by the international community of States as a whole as a norm from which no derogation is permitted". Different opinions exist on which crimes are covered by ius cogens; however there seems to be unanimity on the peremptory character of the prohibition of aggression and genocide. ${ }^{804}$

The absolute character of international humanitarian law can be derived from the fact that these norms are non-reciprocal: if one of the belligerent parties violates these norms it does not provide the adversary the right to violate norms in return (1949 Geneva Conventions Common article 1). This means, for example, that if one belligerent is unlawfully attacked, this does not automatically give him the right to commit an international crime under the pretext of self-defense.

Some authors have argued that the absolute character of international crimes makes them incompatible with complete defenses, especially justifications. ${ }^{805}$ Case law of international tribunals occasionally refers to the absolute character of the norms violated. For example, in a number of cases (Prosecutor v. Kupreškić et al.,

803 See article 8 of the Rome Statute.

804 Brownlie, I, 1998, p. 517; Bassiouni, M.C., 'International Crimes: 'Jus Cogens' and 'Obligatio Erga Omnes", In: Law and Contemporary Problems, Vol. 59, Issue 4, 1996, pp. 63-74, p. 68; Kooijmans P.H., Internationaal Publiekrecht in Vogelvlucht, Ninth Edition, Kluwer, Deventer, 2002 , p. 18.

805 David, E., Éléments de Droit Pénal International et Européen, Bruylant, Bruxelles, 2009, pp. 734-737 and Knoops, G.J., 2001, p. 29, who mentions self-defense as the exception to the ban on justifications. 
Prosecutor v. Martić, Prosecutor v. Boškoski and Tarčulovski) the ICTY has expressed that the prohibition against targeting civilians is absolute.

All these references to the absolute character of international crimes raise the question: how absolute is absolute? Or, more concretely, does the absolute character of international crimes bar a defendant from raising a complete defense? I don't think it does. In the first place, because ius cogens and international humanitarian law are (conceptual) bodies of law essentially directed to states. They require states to refrain from committing international crimes and, in specific situations, they demand the state to prosecute perpetrators of international crimes. ${ }^{806}$ However, when an individual is charged with the violation of an absolute norm, his procedural rights (including the right to prove one's innocence by demonstrating that wrongfulness of the act or blameworthiness of the perpetrator is absent) cannot be violated based upon the obligation of the state to prosecute him. The obligation to prosecute - alleged - perpetrators does not extend to the obligation to convict defendants free of blame or wrong. On top of that, as Section 2.2 postulates, the conviction of legally innocents could equally amount to a violation of ius cogens.

In the second place, the non-reciprocal character of international humanitarian law probably does not extend to complete defense situations. The case law analyzed in Part II demonstrates that, in principle, complete defenses are available to a defendant charged with a violation of international humanitarian law. Indeed, it seems logical that the non-reciprocal character of international humanitarian law and complete defenses are not mutually exclusive. To come back to the example of self-defense: if one belligerent is unlawfully attacked, this does not give him the right to commit an international crime under the pretext of self-defense, unless this action is absolutely necessary, proportionate etc. In other words: if his action is not wrongful or blameworthy. Finally it has to be mentioned that probably not every international crime amounts to a violation of either ius cogens or international humanitarian law, such as small-scale, less severe classes of crimes against humanity. An example of this could be a single assault.

\subsubsection{Meeting the requirements of complete defenses in case of international crimes}

The insight that the abhorrence or the absolute status of international crimes is not a conclusive reason to bar defenses from the international arena does not mean that these characteristics of international crimes are irrelevant when assessing a complete defense. Due to the character of most international crimes (violation of human rights on a large scale and of humanity as a whole), it will obviously be

806 See for example Common Article 49, 50, 129 and 146 to the 1949 Geneva Conventions. These articles compel all High Contracting Parties to enact criminal legislation applicable to individuals suspected of committing "grave breaches" under the Conventions and to search and adjudicate them. The 1948 Genocide convention requires the Contracting Parties to prevent and punish genocide (article 1). 
difficult to meet all the requirements for a complete defense in these cases. ${ }^{807}$ To give a fictitious example:

Tribe $X$ is threatened by tribe $Y$. Therefore several powerful $X$-men plan and execute a genocide to exterminate all Ys. However, although the Xs where threatened by the $Y$, they will not be able to claim self-defense, because genocide is not a proportionate and necessary means to end the threat. It is not proportionate, for example, because not every $Y$ is wrongfully attacking the Xs. Genocide is also not necessary: there are less invasive means to end this situation. Asking for international assistance, for example, or fighting a war in accordance with the rules of international humanitarian law (i.e. without implicating the civilian population).

The above example illustrates the difficulty of meeting the requirements of a complete defense in the case of an international crime. However, the fact that the complete defense raised will rarely be established, is not a reason to a priori exclude complete defenses in these cases. We cannot foresee all possible scenarios, and there might be situations in which an international crime is committed, but wrongfulness or blameworthiness is absent. As observed above, the corpus of international crimes embodies several crimes of lesser gravity and/or crimes that resemble domestic crimes, which may very well be compatible with complete defenses.

\subsection{Technical arguments}

Meeting the requirements of a complete defense is not only problematic due to the absolute and abhorrent character of international crimes. According to some authors there is also a technical problem when linking complete defenses and international crimes: the double mental element requirement of several international crimes hinders their compatibility with complete defenses. ${ }^{808}$ The introduction to this thesis explains that the structure of domestic crimes differs from international crimes. The violent context of the latter category is reflected in their double-layered

807 Schabas, W., 2009, pp. 388, 392 and 395-397 and Wilt, H.G. van der, 2011, p. 276. This idea is also discussed in ICTY, Prosecutor v. Erdemović, Separate and Dissenting Opinion of Judge Cassese, Appeals Chamber, 7 October 1997, par. 42 and Trial Chamber I, 27 November 1996, par. 16-19.

808 Denis, C. and Romero, M., 'Synthèse des débats de l'atelier du 12 juillet 2000 (Dossier: L'article 31(1)(c) du Statut de la cour pénale internationale. Travaux de l'atelier organisé par la commission consultative de droit international humanitaire de la Croix-Rouge de Belgique Communauté Francophone)', In: Revue belge de droit international, vol. 33, issue 2, 2000, pp. 355-483, p. 478 (S. Szurek) and Abi-Saab, G. and Condorelli, L., 'Réponses à la question 1, b) (Dossier: L'article 31(1)(c) du Statut de la cour pénale internationale. Travaux de l'atelier organisé par la commission consultative de Droit international humanitaire de la Croix-Rouge de Belgique Communauté Francophone)', In: Revue belge de droit international, vol. 33, issue 2, 2000, pp. 355-483, p. 406. 
structure: apart from the intent to commit the actual crime (murder, rape), the violent context is an element of the crime (e.g. the intent to destroy a group as a whole, knowledge of widespread attacks on the civilian population or the presence of an armed conflict). In case of crimes against humanity and genocide this doublelayered structure has consequences for the mental element of the crime: apart from the intent of the underlying offense, the mental element extends to the contextual element. Authors, arguing that the double intent requirement of international crimes hinders the compatibility with complete defenses, hold it impossible to prove all elements of an international crime (for example genocide) and at the same time act under a complete defense (for example self-defense). This argument can be illustrated by the following example:

The D people are launching genocidal attacks on the $X$ people. During this genocide, an X attacks a D. The D strikes back in self-defense. Because D's assault is motivated by self-defense - and not by the intent to destroy a specific group as a whole - the genocidal intent cannot be established. Consequently, genocide and self-defense cannot coincide.

There is however another way to approach this issue. If $\mathrm{D}$ is charged with genocide, the intent for the underlying crime (assault) can be established, but the genocidal intent can not be proved if the defendant's action was motivated by self-defense only. Consequently, the sole point the above example illustrates is that, in case of a crime with a double intent requirement, the defense raised can have the effect of a failure of proof defense, rather than an affirmative defense. Legitimate claims to a complete defense in the context of genocide can have the effect of a failure of proof defense, because the defendant has a different state of mind than a génocidaire (e.g. he has the intent to save his life when under pressure, the intent to do whatever his psychosis tells him to do, etcetera). The fact that a complete defense can only be raised as a failure of proof defense, however, does not change the contents of the argument and should therefore not be a reason for exclusion.

In addition, even if $\mathrm{D}$ actually had the intent to participate in the genocide and averted the attack within the limits of self-defense, such a plea could still be successful, if not barred by a prior fault. In this case a plea of self-defense has the effect of an affirmative defense: the intent to kill and to kill a group are established but the act of the defendant was not wrongful because he acted within the limits of self-defense and had the intent to do so. ${ }^{809}$ An affirmative defense is also imaginable in case of other complete defenses, for example insanity or intoxication: the defendant is delusional. He kills because as a result of this delusion he intends to exterminate a specific group of people. Consequently, the double intent requirement

809 Compare Sliedregt, E. van, 2012, p. 236. According to Van Sliedregt "there is no fundamental reason why one could not have the special genocide intent and on top of that the will to defend oneself or another person". However, according to Van Sliedregt, this is only possible if there is a "continuous threat". 
can be established. However, due to his mental condition the defendant may not be blameworthy.

In case of crimes against humanity the double-layered structure of international crimes seems even less of a problem. In this category of crimes the extra mental element is restricted to knowledge. One can easily imagine a defendant knowing about a widespread attack on the civilian population, but not necessarily agreeing with it, and still finding himself in a situation where he needs to defend himself, acts under necessity/duress, makes a mistake or commits a crime under the influence of a physical or mental defect. Finally, in case of war crimes, the doublelayered structure (presence of an armed conflict) is not part of the mental element, which makes this category of crimes most similar to domestic offenses in their relation to complete defenses.

\subsection{Practical arguments}

Several practical arguments underline the irrelevance of complete defenses in case of international crimes: the tendency to prosecute main leaders (Section 3.4.1), the fact that international crimes occur in a violent context (Section 3.4.2), the fact that acquittal is not a popular option in international criminal law (Section 3.4.3), the increasing amount of guilty pleas in international criminal trials (Section 3.4.4), and inapplicability of complete defenses in practice (Section 3.4.5).

\subsubsection{Big fish}

Most international courts have been after the big fish: in Nuremberg 24 Nazi heavyweights were charged and the IMTFE indicted 28 representatives of the wargovernment (Tojo government). ${ }^{810}$ The prosecution policy of the ICTY was obscure and frequently changed during the early years, but in 1999 the president of the ICTY designed a completion strategy, according to which the ICTY was only to prosecute political and military leaders. ${ }^{811}$ The prosecution policy of the ICTR shows a similar pattern: after an obscure start, the Tribunal switched to main leaders. ${ }^{812}$ Finally, also the ICC prosecution policy has a focus on main leaders. The Court was established to ensure prosecution of persons with the "greatest responsibility" for "the most serious crimes of concern to the international community". 813

The problem with big fish in relation to complete defenses is that they are at the top of the hierarchy of a criminal structure. Therefore certain defenses are by

\footnotetext{
810 Poelgeest, L. van, 1989, p. 109.

811 Banning, C. and Koning, P. de, 2005, pp. 16/17, 91 and 185/186.

812 ICTR, Annual Report: A/51/399-S/1996/778, par. 42.

813 See www.icc-cpi.int.
} 
definition excluded ${ }^{814}$ Superior orders, for example, because the defendant himself had a superior position, and thus nobody to receive orders from. Necessity/duress is also hard to establish because there is no superior to spread fear and exercise pressure. Mistake may be problematic, because a superior ought to be aware of the law and the relevant circumstances. Although a large number of people in power positions would probably qualify as insane or intoxicated (or both), ${ }^{815}$ the likelihood of a successful appeal to these defenses seems almost contradictory to the nature of their position: as power can be defined by control and knowledge, these defenses are defined by complete lack thereof. ${ }^{816}$ What is left are self-defense and reprisals. It is not surprising that these defenses are justifications and thus defined by deliberate decisions and not a lack of control. It seems that, when it comes to big fish, there are not many complete defenses they can fall back on. As a logical consequence, defense pleas at international courts usually revolve around other arguments than complete defenses. In most cases the defendant claims he lacks command responsibility and is thus not liable for the crimes committed by his subordinates. ${ }^{817}$

\subsubsection{System criminality}

In the introduction to this thesis, international crimes have been defined among other things as system criminality, referring to the large scale and violent context of these crimes. This feature has several consequences when it comes to the applicability of complete defenses.

\section{NO “HEAT OF THE MOMENT"}

International crimes are usually planned on a large scale and are of a systematic nature. Therefore, many complete defenses that are related to the heat of the moment are of no avail. A defendant under national law may convince a judge that he committed a murder under the influence of involuntary intoxication or a psychotic episode. However, establishing that a whole genocide was planned and executed in such a state is, as touched upon above, virtually inconsistent with a plea of insanity or intoxication, because of the knowledge and control involved in such an operation and the duration of the crime. ${ }^{818}$ Similar problems are encountered by necessity/duress. Acting under this defense in the heat of a specific moment can be credible. A more permanent form of duress is definitely harder to establish: the longer the duress-situation lasts, the more opportunities for the defendant to find a moment to escape. As for self-defense and reprisals: in a context of organized

814 This argument has been brought up by, Scaliotti, M., 2002, p. 26.

815 See: Owen, D., In Sickness and In Power, Praeger, Westport, 2008.

816 Scaliotti, M., 2002, p. 46.

817 Khan, K.A.A. and Dixon, R. (eds.), 2009, pp. 1271/1272.

818 Ohlin, J.D., 2009, p. 385. 
violence, aggression of the adversary is more foreseeable and therefore easier to avoid. Mistake seems to be less affected by the systematic nature of international crimes: in the chaos of armed conflict or internal disturbances people are prone to make mistakes. All in all it seems as if the applicability of complete defenses is rarely possible when crimes lack a unique and/or spontaneous character.

\section{MuLTiPLE CHARGES}

On a national level it is common to charge a defendant with a single crime: one theft or one assault. Practice in international criminal law is different. Due to the large scale and systematic nature of international crimes, suspects of these crimes are rarely charged for one single transgression. Usually the indictment consists of a series of crimes committed during a specific period, covering for example, various war crimes and/or crimes against humanity. Consequently, when a complete defense negates one of the charges, the acquittal for this specific charge does not result in a general acquittal: the defendant can still be convicted for the remaining charges. At most, the acceptance of a complete defense can mitigate his sentence. The practice of multiple charges is thus another reason why complete defenses are not so relevant in international criminal law. The effect of a (complete) defense in the context of multiple charges is illustrated by the cases of Dönitz and Raeder (IMT), where the acquittal on one specific charge did not have radical consequences, since the defendants were convicted for the remaining charges.

\subsubsection{Acquittal is not a popular option}

As the history of prosecution policies at international courts demonstrates, international courts have generally pursued the main political and military leaders responsible for massive crimes. These big fish are usually not an easy catch. International courts do not have their own police force so that apprehending alleged perpetrators can take years of diplomatic effort. Usually defendants are well-known by the general public and have already been convicted by them and the media. Surviving victims are numerous and hoping for justice to be done. It is unlikely that a prosecutor of an international court will go through the effort of building a timeconsuming, expensive, and for survivors emotionally stressful case against an alleged perpetrator of massive crimes when there is the slightest chance that he will successfully plead a complete defense and be acquitted under the eye of the international media. Therefore, when there is the possibility of a successful appeal to a complete defense, the prosecutor will probably stop his investigations. And if prosecution has already started, there are moments in the pre-trial stage where a court tests the solidity of the case. If a successful appeal to a complete defense is 
very likely, a court will probably decide that there is insufficient evidence for the case to continue. ${ }^{819}$

\subsubsection{Guilty pleas}

The increasing amount of guilty pleas at international courts ${ }^{820}$ makes the availability of complete defenses irrelevant, because guilty pleas and complete defenses are not compatible. This was decided in the ICTY Erdemović case, where the Trial Chamber held that a guilty plea makes an appeal to a complete defense equivocal. ${ }^{821} \mathrm{~A}$ logical conclusion, for one cannot claim guilt (guilty plea) and deny it (complete defense) at the same time. Consequently, an appeal to a complete defense can only be raised in combination with the plea of 'not guilty'. As the amount of guilty pleas at international courts increases, the relevance of complete defenses decreases.

\subsubsection{Practice}

The irrelevance of complete defenses in international criminal law is also illustrated by the analysis of complete defense in Part II of this thesis. This analysis confirms that complete defenses are rarely applicable in international criminal law: they have not been accepted since the Nuremberg Tribunal. What is more, in the light of contemporary doctrine it is doubtful whether the complete defense of tu quoque, accepted at the IMT, is a complete defense in a technical sense.

\subsubsection{Discussion}

The arguments above demonstrate that complete defenses are usually not relevant in cases of international crimes. However, as true as this may be, this should never be a reason to exclude complete defenses a priori. Although most cases revolve around government and military leaders, responsible for highly organized and large-scale crimes, there may always be cases in which an appeal to a complete defense would very well be possible. This includes for instance cases involving smaller fish (soldiers, low ranking civil servants), spontaneous crimes or 'not guilty' pleas. Especially in case of smaller fish many practical arguments blocking complete defenses (see above, 3.4.1) are not applicable. Small fish are not on top of

819 See for example: Rule 47 (Submission of indictment by the Prosecutor) RPE of the ICTY and Article 58 (Issuance by the Pre-trial Chamber of a warrant of arrest or a summons to appear) and 61 (Confirmation of the charges before trial) of the ICC Statute.

820 Mainly at the ICTY: Banning, C. and Koning, P. de, 2005, pp. 30 and 221 and www.icty.org/ sections/TheCases/GuiltyPleas (June 2012). More elaborate information on guilty pleas at international courts can be found in: Combs, N., Guilty Pleas in International Criminal Law: Constructing a Restorative Justice Approach, Stanford University Press, 2007. 
the hierarchy. Accordingly, they have less knowledge and power. Small fish work on an executing, not on a planning level, which makes them more prone to commit spontaneous crimes. As a consequence of their position, small fish are more susceptible to superior orders and duress. Due to a lower level of responsibility, mistakes will sooner be excused. Contrary to main leaders, insanity and intoxication are not incompatible to the nature of their position.

We cannot foresee all future scenarios. The fact that a complete defense does rarely apply is not a reason to set aside the principle of individual criminal responsibility and risk the conviction of people that are free of wrong and/or blame. Besides, as Section 2.5 points out, although complete defenses may be of little relevance in international criminal law, they may affect the adjudication of smaller fish at a national level.

\section{Conclusion}

This Chapter has discussed several arguments both in favor of and against the availability of complete defenses in international criminal law. The most decisive argument in favor of complete defenses is that a priori exclusion of these defenses amounts to a violation of the principle of individual criminal responsibility. If there were no complete defenses, defendants devoid of wrong and/or blame could be convicted.

Other arguments (including those that defuse counterarguments) in favor of the availability of complete defenses are:

- The availability of complete defenses has customary status in international criminal law;

- Complete defenses support most objectives of (international) criminal law. The fact that complete defenses may also fail to support certain objectives of international criminal law is not a valid reason to ban complete defenses from the international arena;

- Complete defenses are available in case of international crimes under domestic criminal law: it should not depend on the forum whether a defendant can appeal to a complete defense;

- Over the years, international criminal courts have had a serious amount of criticism on their alleged partiality and lack of procedural rights for defendants. The availability of complete defenses enhances the legal quality of international criminal courts and therefore their credibility;

- The abhorrent nature of international crimes is not a reason to exclude the availability of complete defenses, for the severity of a crime is not conclusive when determining the guilt of the perpetrator;

- The absolute character of international crimes is not a reason to exclude complete defenses, because this absoluteness refers to the obligation of a state to 
prosecute alleged perpetrators of international crimes and not to an obligation to convict defendants devoid of wrong and/or blame;

- It is true that complete defenses have rarely been applied in case of international crimes. This can be explained by, for example, the disproportionality between crime and defense, the superior position of the defendant, the systematic nature of the crimes charged, the increasing amount of guilty pleas at international courts and the simple reason that acquittal is not a popular option. The fact, however, that complete defenses are and will be rarely applied in international criminal law is not a reason to set aside the principle of individual criminal responsibility and ban complete defenses from the international arena.

In the end, the desire to render effective criminal accountability for the most severe crimes in the world must never overshadow a legal analysis of the actual guilt of the defendant. Conflicting as these objectives may seem, these ostensible opposites (accountability for international crimes and rights of the defendant) are not so different after all. Both have the same interest at heart: the protection of fundamental human rights. 



\section{Chapter XIV \\ HOW SHOULD COMPLETE DEFENSES BE APPLIED \\ UNDER INTERNATIONAL CRIMINAL LAW \\ (IN GENERAL)?}

\section{INTRODUCTION}

The previous Chapter argued complete defenses should be available in international criminal law. The present Chapter discusses in which way complete defenses must be available. Part II of this thesis has demonstrated that there are few rules dealing with complete defenses and that judges have great discretionary power. Although, recently, complete defenses have been codified in the ICC Statute, this catalogue lacks internal logic, as some defenses require absence of blameworthiness or wrongfulness, while others require absence of intent (mistake) ${ }^{822}$ or lack of something in between wrongfulness and blameworthiness (necessity/duress). An understandable consequence of negotiations between diplomats - and not necessarily lawyers - of different cultural backgrounds. ${ }^{823}$ As a result, the current status of complete defenses in international criminal law raises the question whether a more systematic approach is desirable. And if it is, what should a system of complete defenses look like?

The present Chapter first discusses the desirability of a system of complete defenses (Section 2). Section 3 sets out some ideas for such a system. It promotes a subdivision in justifications and excuses and extracts the definitions of these concepts from international criminal case law. Next, this Section argues how the concepts of justification and excuse should be defined. These definitions of justification and excuse are represented in a flowchart of questions underlying complete defenses in general. Section 4 discusses the effects of complete defenses on the crime charged. These effects necessitate an alteration in the flowchart represented in Section 3. The issue whether complete defenses should have a mitigating effect is discussed in Section 5. Finally, Section 6 contains a summary of the previous Sections and several concluding remarks.

\section{A SYSTEM OF COMPLETE DEFENSES?}

There are several arguments in favor of a more structured system of complete defenses. First of all, there is a pattern visible in international criminal case law implying an underlying system. As demonstrated in Part II of this thesis, complete defenses can generally be subdivided into justifications and excuses. These sub-

822 Compare: Eser, A., 2008, p. 904.

823 Fletcher, G.P. and Ohlin, J.D., Defending Humanity: When force is Justified and Why, Oxford University Press, 2008, p. 76 and Scaliotti, M., 2002, pp. 45/46. 
categories have their own recurring requirements. That complete defenses have common traits has also been confirmed by literature. ${ }^{824}$

Second, the principle of nullum crimen sine lege demands that people can know whether their planned course of action is acceptable or not. ${ }^{825}$ Consequently not only the definitions of crimes must be foreseeable and accessible, but also the general part of criminal law, including complete defenses. ${ }^{826}$ The foreseeability and accessibility of complete defenses increases when they are subjected to a system with its own internal logic.

One may argue that complete defenses are not protected by nullum crimen sine lege, because they are technically not part of the definition of the crime. Defenses are not crimen. However, this argument is, to an extent, fallacious. First, because Part II of this study demonstrates that complete defenses can be part of the definition of a crime. ${ }^{827}$ Every complete defense, depending on the context, can operate as a failure of proof defense. A failure of proof defense negates part of the definition of the crime. This part of the definition can thus be defined by the absence of complete defenses. Consequently, understanding this element implies knowledge of complete defenses. For example, in case the mental element of a crime is defined as negligence, this negligence is also defined by the absence of complete defenses. In order to know what the word "negligence" means, a defendant must also know the absence of which complete defenses, define negligence.

The argument that complete defenses are not protected by nullum crimen sine lege is also fallacious for a second reason. Independent of their formal appearance (crimen or not), complete defenses always have the same effect: they are elements that help determine the criminal liability of the defendant. ${ }^{828}$ Therefore it should not be left to the whim of the legislator (who decides on the definition of the crime and thus also on the negative inclusion of complete defenses in this definition) whether a complete defense is covered by nullum crimen sine lege or not.

In sum, it can be held that every complete defense should to some extent be protected by nullum crimen sine lege, because (a) complete defenses can be part of the definition of a crime and because (b) they co-determine the criminal liability of

See for example: Blomsma, J., 2012, p. 530-531.

Cryer, R. et al., 2010, p. 17.

Knoops, G.J., 2001, p. 168.

Confirmed by G.P. Fletcher in his analysis of defeasible and comprehensive rules. Defeasible rules of liability contain an incomplete definition of a crime and are not negated by a complete defense, whereas comprehensive rules are complete and are consequently negated by a complete defense. When a prohibition is phrased as a comprehensive rule, it includes the absence of complete defenses. See: Fletcher, G.P., 1998, p. 96/97.

Fletcher, G.P., 1998, p. 108; The judges in the Mucic et al. Appeals Chamber seem to take the same stand when they argue that judges under article 15 are not allowed to create new defenses, because they are not allowed to create new offenses, since both determine the criminal liability of the defendant. See: ICTY, Prosecutor v. Mucić et al., Appeals Chamber, 20 February 2001, par. 583. 
the defendant. However, should complete defenses be subjected to the same degree of foreseeability and accessibility as the definitions of crimes?

Although the border between offense and defense is not always clear, ${ }^{829}$ offenses and defenses are different classes of rules. Roughly they can be characterized as rule (offense) and exception (defense). Offenses are directed at civilians for the purpose of steering their conduct, yet, complete defenses are not necessarily directed at civilians. They are instead decision rules: tools for judges to determine the outcome of a case and to communicate this outcome to the general public. ${ }^{830}$ One can demand from an average person to have knowledge of offenses, but one cannot demand the same person to understand the exact scope of complete defenses. An average person knows he is not allowed to steal, but he does not exactly know under which circumstances he is allowed to steal.

While the guilt of the defendant is equally determined by the definition of offenses and defenses, a defendant may be more inclined to base his behavior on the definition of offenses. Therefore both offenses and defenses must be foreseeable and accessible, ${ }^{831}$ however the latter do not need to be defined with the same degree of exactitude as offenses. All the more so, it is even desirable that complete defenses are formulated in an open manner, ${ }^{832}$ so that a court has the flexibility to apply a defense to very specific situations as long as the basic requirements ${ }^{833}$ of the defense have been met. Consequently a foreseeable and accessible but open system of complete defenses has my preference. ${ }^{834}$

My perspective on international law defenses (self-defense ad bellum and reprisals) slightly deviates from my general outlook on complete defenses. Although complete defenses in general are said to be decision rules and need to be - though foreseeable and accessible - broad and flexible, I think international law defenses have a more conduct steering function. They are generally defenses against planned decisions, not against spontaneous actions. When planning e.g. a reprisal, the planner must know when he is allowed to do so. In this case, a rule stating, 'reprisals may only be ordered when necessary and proportionate' is too vague. Therefore it is desirable that these provisions specify when a complete defense may be necessary, proportionate, etcetera. For example, a reprisal is only necessary in case it is the last resort and after a formal warning.

829 See for examples: Fletcher, G.P., 1998, p. 94.

830 Fletcher, G.P., 1998, pp. 96/97 and Sliedregt, E. van, 2012, p. 260.

831 ICTY, Prosecutor v. Vasiljević, Trial Chamber, 29 November 2002, par. 193-204.

832 Eser, A., 2008, p. 890.

833 'Basic requirements' are equal to essential conditions (as opposed to clarifying conditions). The difference between the two is explained below in Section 3.2.1.

834 Sangero comes to a similar conclusion. See: Sangero, B., Self-Defence in Criminal Law, Hart Publishing, Oxford, 2006, p. 355. 
Chapter XIV

\section{A SYSTEM OF COMPLETE DEFENSES: THE BASICS}

The previous Section has determined that a system of complete defenses is desirable and that this system must be foreseeable, accessible and open. First step in determining a system of complete defenses is to see what there already is. The previous parts of this study have demonstrated that although the distinction between justifications and excuses is very common in international criminal law literature, statutes and judgments of international criminal courts generally don't make this distinction explicitly. Implicitly however this distinction seems to be recognized because the conditions required for a specific defense reveal whether the defense is a justification or an excuse. The first question I will therefore address is whether the distinction between justifications and excuses is desirable when designing a foreseeable, accessible and open system of complete defenses in international criminal law.

\subsection{A distinction between justifications and excuses}

In Part I of this study justifications are defined as referring to the situation where the defendant has fulfilled the definitional elements of a crime, but his conduct is not considered wrongful, as his act has the approval of the legal community. The legal community could approve of the defendant's act when it is established that he has chosen the lesser of two evils.

Excuses are defined as referring to the situation where the defendant has fulfilled the objective element of a crime, this conduct is wrongful, but the defendant has a claim to remain unpunished because he is not blameworthy. According to international criminal law literature, absence of blameworthiness is based on lack of ability to choose, the fact that any reasonable person would have acted in the same manner, or on the fact that the defendant was not in a position to determine his will freely.

Part II of this study demonstrates that the distinction between justification and excuse has been implicitly recognized in practice. The next logical question is therefore 'are there arguments to maintain this distinction in international criminal law?'

The most convincing argument supporting the distinction between justification and excuse is that it differentiates between justified acts and wrongful, but excusable acts. This differentiation has important consequences for the judicial fairness of decisions. ${ }^{835}$ A justification communicates to the general public that what the defendant did was ok. Everybody in his position should behave in the same manner. An excuse, on the other hand, stresses that what the defendant did was not ok. Nobody in his position should do that. However, the circumstances being as

Ambos, K., 2013, p. 307. 
How should complete defenses be applied under international criminal law (in general)?

they where, the defendant had no other option. ${ }^{836}$ By distinguishing between justifications and excuses, the court can strike a balance between on the one hand fairness towards the individual defendant (applying an excuse when a defendant is not blameworthy) and, on the other hand, the wider context of the objectives of (international) criminal law (only recognizing justifications when the behavior was truly desirable). ${ }^{837}$ As a consequence, the distinction may prevent courts from conviction in cases where an excuse would be more fitting. If a court only has the choice between guilt and innocence, it may be inclined to convict in case of wrongful, but excusable behavior in order to avoid both harm to the authority of the legislator, ${ }^{838}$ and sending the message to the public that the behavior is warranted. ${ }^{839}$ This inclination towards conviction may even enhance as the wrongfulness of the crime increases, e.g. in case of international crimes.

The struggle resulting from the lack of distinction between justification and excuse is reflected by the debates in the Erdemovic case. The absence of the relevant distinction has two major consequences: (a) the majority rejects duress a priori because it wants to send the message that killing under pressure is not desirable. However, had the majority distinguished between justification and excuse it might have found that, while killing under pressure never absolves the act from its wrongful character, an individual perpetrator having no choice may be excused. ${ }^{840}$

A second consequence of the mix-up of justification and excuse, also displayed in Erdemović, is that (b) much time is spent on discussing the proportionality requirement, while - duress being brought up as an excuse - this discussion is not crucial to the outcome of the case (See also Section 8, next Chapter).

Apart from a more nuanced communication between court and general public, and increased judicial fairness, a distinction between justifications and excuses also enhances the internal logic of complete defenses, by introducing flexible preconditions. ${ }^{841}$ Consequently, the distinction contributes to a foreseeable, accessible but open system of complete defenses in international criminal law.

The distinction between justifications and excuses is also supported by international criminal law literature (see Part I) and practice (see Part II). The only complete defenses that, according to their requirements, cannot be categorized as either a justification or an excuse, are defenses with a highly questionable status in

\footnotetext{
836 Or as Fletcher eloquently puts it: "[D]ecisions on justifying circumstances modify the applicable legal norm. Decisions on excuses, in contrast, leave the norm intact, but irreversibly modify the factual background of succeeding claims of excuse." See: Fletcher, G.P., 2000, p. 812.

837 Ambos, K., 2002, pp. 1046/1047; Fletcher, G.P., 1998, pp. 90/91; Sliedregt, E. van, 2012, p. 267 and Wilt, H.G. van der, 'Commentary on Prosecutor v. Erdemović', In: Klip, A. and Sluiter, G. (eds.), Annotated Leading Cases of International Criminal Tribunals: The International Criminal Tribunal for Former Yugoslavia 1993-1998, Intersentia, Antwerp, Volume 1, 1999, pp. 503-677, p. 676.

Because the court would label a person, who violated the law as innocent.

839 Sangero, B., 2006, p. 16.

840 Ohlin, J.D., 2009, p. 432.

841 Blomsma, J., 2012, p. 332.
} 
international criminal law ( $t u$ quoque and consent) or defenses that display a mixture between a justification and an excuse (necessity/duress). Finally, the distinction between justifications and excuses is also upheld by domestic criminal law systems. ${ }^{842}$

The main criticism of the theory of justification and excuses is that the boundaries of these two concepts are not exactly clear. ${ }^{843}$ Numerous examples have been provided to illustrate the boundary problem. For instance, in case of great disparity between the interests sacrificed and saved (ignoring a traffic sign on a dead-end road in north Alaska under death threat), shouldn't the defendant rather be justified than excused? Or how is the requirement of justificatory purpose related to the universal application of justifications? ${ }^{844}$ Boundary-issues, however, have never been an argument not to employ the distinction. ${ }^{845}$ In order to be useful, the distinction between justifications and excuses does not need to be one of mathematical certainty. A few problematic - rather academic - cases do not make the distinction meaningless. ${ }^{846}$

Another point of criticism on the distinction between justifications and excuses is that the utility of their distinction is not apparent. ${ }^{847}$ The latter argument is refuted by the above reasoning (outlining the advantages of this distinction).

\subsection{The definition of justification and excuse}

Now that I have determined that a distinction between justifications and excuses is desirable, it is time to further define these two concepts. First I will address the definition of justifications (3.2.1), next the definition of excuses (3.2.2).

\subsubsection{Justifications: The definition from case law}

Part II of this study has demonstrated that justifications and excuses have recurring requirements. In case of a justification these requirements are:

- A defensible interest (e.g. a person, compliance with international law);

- An urgent threat to this interest;

- The act of the defendant was necessary to avoid the threat;

- The defendant acted proportionately (or intended to do so);

- The defendant must have had a justificatory purpose (mental element requirement).

842 Ambos, K., 2013, p. 304; Blomsma, J., 2012, p. 321, Dolman, M., Overmacht, Wolf Legal Publishers, Nijmegen, 2006, p. 323 and Fletcher, G.P., 2000, p. 774.

843 Greenawalt, K., 'The Perplexing Borders of Justification and Excuse', In: Columbia Law Review, Vol. 84, Issue 8, 1984, pp. 1897-1927.

844 Blomsma, J., 2012, pp. 324 and 331.

845 Greenawalt, K., 1984, pp. 1898.

846 Ambos, K., 2013, p. 305.

847 Schabas, W.A., 2009, p. 368. 
Next step in defining the concept of justifications is to take a close look at these requirements and to differentiate between essential conditions and clarifying conditions. By essential conditions, I mean requirements that define a complete defense. With the term clarifying conditions I refer to requirements that are already covered by the essential conditions, but may clarify the scope of such a condition. For example, in case of a justification, the act of the defendant must have been necessary. A defense is, however, only necessary if the interest is defensible and the threat to this interest is urgent. The necessity requirement is thus an essential condition, covering the clarifying conditions of defensible interest and urgent threat.

Analyzing a defense in terms of essential and clarifying conditions provides us with information on the number and nature of requirements a specific defense needs in an open but foreseeable system of complete defenses. A definition of a defense that bears less requirements than its essential conditions is no longer foreseeable. Necessity for example is an essential condition of a justification. If the legislator leaves out this requirement in its definition of self-defense, it is no longer clear when this defense may apply. Increasing the number of conditions by adding clarifying conditions to the defense definition enhances its foreseeability, because these clarifying conditions explain the essential conditions. For example, if in case of self-defense an urgency requirement is added, we have more information on the definition of the necessity requirement in this provision. The urgency requirement further defines the condition of necessity. At the same time, including clarifying conditions in the defense definition reduces its flexibility or openness. For example, if the condition of a necessary act in case of self-defense is only applicable when the clarifying condition of a death threat situation is met, the defense is not applicable in case of theft. Identifying the essential and clarifying conditions of a complete defense can be helpful in finding a balance between foreseeability and openness in a complete defenses provision.

Continuing on the definition of a justification: apart from a necessary act (that covers the clarifying conditions of defensible interest and urgent threat), the act must have been proportionate. Now is proportionality an essential condition or is it also covered by the necessity requirement? In international criminal case law, reflected in Part II of this thesis, the necessity requirement had been met when the defendant had no other option to resolve the situation but to commit a crime. The proportionality requirement has been met if the defendant chose the lesser of two evils. Necessity thus refers to the means available, while proportionality refers to the balance between harm avoided and harm done.

However, despite their different definitions, the concepts of necessity and proportionality are interrelated. This is demonstrated by the research results displayed in Part II of this thesis, where 'necessity' and 'reasonability' are often employed as umbrella terms encompassing both necessity and proportionality and by the fact that this alternating terminology is also common to national 
jurisdictions. ${ }^{848}$ I have found necessity and proportionality to be interrelated in the following manner.

Necessity can be determined by proportionality. For example, shooting a person who wants to hit you, when you could have hit him back instead of shooting, is not necessary, because there are more proportionate means to solve the situation. ${ }^{849}$ When shooting in this situation was necessary (because, for example, the aggressor looks like Mike Tyson, while you look like Shirley Temple), it was necessary because the means employed are proportionate (injuries inflicted by a Mike Tyson are more severe than the injuries resulting from a shot in a non -fatal area).

However, although necessity can be determined by proportionality, it does not have to be. For example: killing a thief may be necessary to stop him from stealing, when there is no alternative course of action. However, this would never qualify as proportionate.

On the other hand, proportionality does not seem to be determined by necessity. Proportionality refers to the objective balance between harm avoided and harm done. When harm avoided and harm done are in proportion it is irrelevant whether other, less invasive means were available. For example: when hit by an aggressor, hitting back may be proportionate, but it is not necessary, when the defendant had the opportunity to walk away.

In sum, necessity can be determined by proportionality, but does not have to be. Proportionality is generally not determined by necessity. Despite their interrelation, both requirements thus have an independent function. Consequently, both the proportionality and the necessity requirement must be met when determining the justificatory nature of an act. As a result, each requirement must be qualified as an essential condition.

Final requirement derived from case law is that the defendant must have had a justificatory purpose (mental element). In other words: the defendant must at least have known that he acted in self-defense, by means of a lawful reprisal, etcetera. Since - although unlikely - it is very well possible to act necessarily and proportionately by accident ( $\mathrm{X}$ hits $\mathrm{Y}$, not knowing that $\mathrm{Y}$ is on the verge of hitting him), the mental element must also be an essential condition (The theoretical discussion on this mental element is touched upon in Section 3.3.1 below). Essential conditions for a justification are thus:

- A necessary act;

- A proportionate act;

- A mental element.

848 Sliedregt, E. van, 2012, p. 236.

849 This definition of proportionality was employed in: ICTY, Prosecutor v. Gotovina et al., Trial Chamber, 15 April 2011, par. 1730. 
How should complete defenses be applied under international criminal law (in general)?

\subsubsection{Excuses: The definition from case law}

In case of an excuse the requirements mentioned in Part II are:

- The defendant has a deviating mental condition (e.g. due to a disease, intoxication, the lack of essential knowledge, an extremely stressful situation);

- The defendant has no control over the situation (because he lacks certain knowledge or because he cannot control his behavior).

Essential conditions for an excuse are thus:

- A deviating mental condition;

- No control;

- A causal relation between mental condition and lack of control.

\subsection{The definition of justifications and excuses}

The previous Section has demonstrated that - based upon the research results displayed in Part I and II - justifications can be defined in terms of a necessary and proportionate act accompanied by a mental element, whereas an excuse refers to the situation where the defendant has no control due to a mental condition. This Section further develops the concepts of justification and excuse. Section 3.3.1. discusses the requirements for justifications: necessity, proportionality and the mental element. Section 3.3.2 elaborates on the lack of control in case of excuses.

\subsubsection{Justifications}

\section{NeCESSITY}

Part II of this study demonstrates that the necessity requirement is generally defined as the situation where the defendant had no other option but to commit a crime. This criterion requires an objective test: the court looks at the situation from an eagle eye perspective and determines the best possible course of action in the often difficult - situation. The necessity requirement is a broadly accepted criterion, not only in international criminal law but also in national jurisdictions. ${ }^{850}$ The requirement has been criticized, because one never knows what would have happened if the defendant had not taken a specific course of action. ${ }^{851}$ For example:

$D$ is charged with breaking and entering his neighbor's house. However, D committed this act because he saw a fire in his neighbor's house and wanted to

850 See Blomsma, J., 2012, p. 550/551.

851 Dinstein, Y., 2000, p. 376. 
extinguish it. Consequently D claims a justification. However was breaking and entering really necessary?

Point is, that you never know what would have happened if $\mathrm{D}$ did not extinguish the fire. It might have extinguished by itself, because it ran out of fuel or the owner of the property, receiving a text message from his smoke detector, might have returned in a few minutes and extinguish the fire himself. Because you never know what would have happened had the defendant made a different choice, you never know whether an allegedly justificatory act was truly necessary.

Although this argument is very true, it is not a reason to put aside the necessity requirement. The requirement may not be $100 \%$ accurate, yet it is still an adequate tool to determine whether the defendant has acted, as the legal community would have wished him to act. More than the proportionality requirement, the necessity criterion requires the defendant to think about alternatives: how can I solve this situation without committing a crime? As a consequence, the necessity requirement filters out the situations where the act of the defendant was proportionate, but could have been avoided. Section 3.2.1 of the present Chapter provides an example of such a situation (where hitting the aggressor - who hit the defendant first - was proportionate, but not necessary, because the defendant had the opportunity to walk away).

\section{ProportionALity}

Part II of this thesis has defined a proportionate act as an act in accordance with the lesser of two evils. This means that when there are two evils - committing a crime or not intervening in a difficult situation - the commission of a crime must be the lesser of the two evils. However, the analyzed case law demonstrates that in practice courts generally do not explicitly demand the lesser of the two evils. They simply demand the act to be not disproportionate, i.e. the two evils must be balanced out. See for example Prosecutor v. Stakić and Prosecutor v. Gotovina.

Whether the proportionality criterion requires the lesser evil, a more lenient test demanding a 'not disproportionate' reaction or even a 'tolerable reaction' is a discussion familiar to criminal law literature. ${ }^{852}$ As to the difference between these definitions of a proportionate reaction, I think a reaction is proportionate when there is no alternative that would be more proportionate. Depending on the context, thus, a proportionate reaction can either be the lesser of two evils or the reaction that balances out the other evil. As to the 'tolerable reaction', this is never the best possible course of action. Proponents of this definition argue that the law cannot expect from a person in an extremely difficult situation to accurately balance all

852 Dijk, A.A. van, Strafrechtelijke aansprakelijkheid heroverwogen, Maklu, Apeldoorn, 2008, p. 15. See also: Sangero, B., 2006, p. 19, who describes a discussion between Dressler and Fletcher on whether a justified act should be 'right' or 'permissible' and Blomsma, J., 2012, pp. 327-329, who discusses several approaches to this issue in domestic criminal law. 
How should complete defenses be applied under international criminal law (in general)?

options and pick the morally best course of action. Although this is very true, this does not make a tolerable reaction, the response desired by society. Therefore it is submitted here that the tolerable reaction therefore never qualifies as a justification, although it could meet the requirements of an excuse.

Now that has been demonstrated that a proportionate reaction must be defined as a choice for the lesser of two evils, or the reaction that balances out the other evil, one may wonder how this lesser or equal evil is determined. As was signaled above, the proportionality requirement weighs the choice between committing a crime and not committing a crime. Committing a crime can be in the interests of the perpetrator or another person and must always be in the interests of society as a whole. Not committing a crime is generally in the interest of the victim(s) of the crime. ${ }^{853}$ In case of a justification the balance between crime and no crime thus look like this (very abstract representation):

\begin{tabular}{|l|l|}
\hline Crime & No crime \\
\hline a. Interests of the defendant & - Interests of the victim(s) \\
b. Interests of other person(s) & \\
c. Interests of society as a whole & \\
\hline
\end{tabular}

When the crime committed is - at least - in the interest of category (a) and (c) or (b) and (c) mentioned in the left box, and this interest is objectively the lesser (or equal) evil, the reaction of the defendant can held to be proportionate.

\section{Mental element}

The last requirement for a justification is a mental element: the defendant must at least have known that he acted on justificatory grounds. Opponents have convincing arguments against a mental element requirement. Their main argument is that it does not make a difference whether the defendant has a mental element or not. In both cases, the lesser evil has prevailed. The defendant, possibly a third party and society as a whole benefit from a justificatory act, whether the defendant had a mental element or not. ${ }^{854}$

In my mind, however, whether a mental element should be required in case of a justification, does not only depend on whether society benefits but on what society desires. Does society want to absolve from punishment those who with hindsight committed a crime on justificatory grounds? Or does it only want to justify a defendant making a deliberate choice to act for noble reasons?

I have to agree with Fletcher that the latter option is the most appealing. Assuming that society wants the defendant not only to act for utilitarian reasons,

853 Sangero, B., 2006, pp. 93-106.

854 See: Fletcher, G.P., 1998, p. 137, referring to Robinson and Williams. In addition, a defendant acting in self-defense without knowing it can still legitimately be assisted by third parties. 
but also in a morally right way, ${ }^{855}$ and thus make a deliberate choice for the best course of action, it will not justify a defendant who, for example, attacked someone because he felt like fighting and this person turns out to be on the verge of attacking him. This desire of society that its subjects act in a morally right way is reflected in the essence of a justificatory act: a successful claim to a justification demonstrates that the defendant committed the crime with a completely different mindset than is suggested by the definition of the crime. He committed a crime for justificatory reasons. To establish this mindset, a mental element is paramount.

An additional argument supporting the mental element requirement is that the criterion is broadly acknowledged, both in international ${ }^{856}$ and in domestic case law and in literature. ${ }^{857}$ In the research displayed in Part II of this book, absence of a mental element was often a crucial argument to reject a complete defense.

A mental element is thus a requirement for a successful claim to a justification. However, how must this mental element be defined? Does awareness of the justificatory situation suffice or is a justificatory purpose required? The cases displayed in Part II of this book illustrate that lack of a mental element is demonstrated by establishing (a) alternative motives of the defendant negating justificatory purpose or (b) lack of necessity/proportionality negating justificatory purpose. Also the ICC provisions demanding a mental element seem to require that the defendant is - at least partially - motivated by justificatory purpose. It is submitted here that this standard - of an at least partial justificatory purpose should be retained.

\subsubsection{Excuses}

Part I of this study has demonstrated that excuses are applicable in case a defendant is not blameworthy. A defendant is not blameworthy when he had no ability to choose, did what any reasonable person would have done or had no freedom of will, mental capacity or knowledge of law. Part II of this study has defined blameworthiness as the lack of control due to a deviating mental condition. Whether this lack of control is blameworthy, is usually determined by some sort of reasonable person test. Two issues are addressed in the present Section:

a. The relationship between the different definitions of blameworthiness.

b. The most appropriate definition of blameworthiness.

Both issues are discussed simultaneously below in the context of different elements of the definition of blameworthiness.

855

856

857

Fletcher, G.P., 1998, p. 137.

See Analysis at the end of Part II, Section 10.

Blomsma, J., 2012, p. 293; Fletcher, G.P., 1998, p. 137. However, the issue hardly comes up in practice, because it is uncommon for all the other conditions of a defense to be fulfilled while the defendant acted with a different purpose (see Blomsma at cited page). 
How should complete defenses be applied under international criminal law (in general)?

\section{Choice versus CONTROL}

International criminal literature refers to blameworthiness in terms of choice, while I have used the description 'lack of control' to portray a common denominator in the practice of excuses. The concepts of choice and control are related in that a person who has a choice between two or more alternatives has some control over a situation. Alternatively, somebody with control over a situation has at least a choice between two alternatives. Choice thus implies - at least - some control and control is defined by the ability to choose. In order to determine criminal liability of a defendant, the question whether he could have chosen an alternative course of action is crucial. Since the word 'control' has a connotation of being on top of things, I prefer - when investigating the criminal responsibility of the defendant the questions 'did the defendant have the ability to choose?' or 'did the defendant have some control?' as opposed to the question 'did the defendant have control'?

\section{Did THE DEFENDANT HAVE THE ABILITY TO CHOOSE?}

Having the ability to choose covers both internal and an external circumstances. A defendant can lose his ability to choose when he suffers from a deviating mental condition (internal), such as no freedom of will, no mental capacity or no knowledge of certain facts (or law). However, he can also lose this ability when there is no reasonable alternative available (external). In these cases the mental capacities of the defendant are not relevant when assessing his possibilities, because the quantity of his options is not narrowed down by his mind but by the situation. For example, in a situation where the defendant has to choose between killing and being killed, he only has one reasonable option. ${ }^{858}$ This option is independent of whether the situation influences his mental capacities or not.

Since the ability to choose can be determined by both internal and external factors, excuses cannot always be defined as a mental deviation causing lack of ability to choose. Consequently, excuses are more suitably defined by 'the absence of an ability to choose'.

\section{REASONABLE PERSON TEST}

Now, how is this ability to choose determined? Part I and II of this thesis have demonstrated that the blameworthiness of the defendant can be measured by a so-called reasonable person test. This is an objective, normative test. A reasonable

858 The adjective 'reasonable' indicates that the alternative must be an act that the law can require its subjects to perform. The option to sacrifice one's own life may be qualified as an alternative, but not as a reasonable alternative, for the law cannot require its subjects to sacrifice their own life. See: ICTY, Prosecutor v. Erdemović, Separate and Dissenting Opinion of Judge Cassese, Appeals Chamber, 7 October 1997, par. 47; Dolman, M., 2006, pp. 317/318 and Fichtelberg, A., 2008, p. 14. 
person test, logically, checks whether the defendant has behaved like a reasonable person, would this reasonable person have found himself in a similar situation. In case there is no reasonable alternative, a reasonable person, and thus also the defendant, could be excused. However, if there is a reasonable alternative, but the defendant lacks the mental capacity to choose this alternative, it must be investigated whether a reasonable person in the same situation would have lacked this capacity as well. For example, in case of mistake it must be investigated whether a reasonable person would equally not be aware of certain facts or law. In case of necessity/duress it must be investigated whether a reasonable person would equally succumb to the same amount of pressure. Consequently, the reasonable person test consists of two stages:

1. Was there objectively a reasonable alternative for the defendant? (If there was not, the defendant could be excused);

2. If there was such an alternative, would a reasonable person still have made the same choice as the defendant did? (If he would, the defendant could be excused)

However, the reasonable person test is no panacea. I have several points of criticism on this test. First, as the conclusion to Part II demonstrates, the test is not workable in case of insanity. An insane person will never behave like a reasonable person, since we use the word 'insane' to label people that deviate from the average or reasonable standard. To test an insane person against a reasonable person would be useless; to test an insane person against a reasonable insane person would be a contradictio in terminis.

Secondly, a similar argument, though toned down, can be brought up in other cases where the disability to choose is a result of the mental condition of the sane defendant. In these cases the test may be workable, but will not always lead to a just result. For example, in case of mistake it must be investigated whether a reasonable person would equally not be aware of certain facts or law. But what if the defendant doesn't know as much as a reasonable person, would it be just to punish a defendant for being uninformed, without any extra criterion? The test looks into the objective circumstances of the case and how an objective reasonable person would have behaved in such circumstances. It does not look into the subjective mental capacities of the specific defendant, and whether he had the ability to make a different choice. Consequently, not only a defendant can be convicted for being not so smart, also a person with mental capacities that are more developed than those of an average reasonable person, could be acquitted because he behaved 'reasonably', while he had the capacity to make a different choice.

A way to prevent this problem is to subjectivise the reasonable person test. ${ }^{859}$ For example, if the mental capacities of the defendant are more developed than those of an average reasonable person, the choice of the defendant must be tested 
against that of a 'very developed reasonable person'. However, allowing for subjectivising runs into another problem: where do we draw the line? Can we test against a reasonable person with a stress management problem? A dyslectic reasonable person? Or a reasonable person with a short fuse? Too much subjectivising turns the objective reasonable person test in an ordinary subjective test, in which case it would be misleading to call this test a reasonable person test. $^{860}$

Following from the above, it can be concluded that the reasonable person test can be a useful tool when determining the blameworthiness of the defendant, however, the tool provides insufficient footing.

\section{Alternative MOdeL}

In my opinion a more nuanced investigation is needed, when determining the blameworthiness of the defendant. For this purpose I support a model based upon the above-mentioned existing theories, to investigate whether the defendant lacked the ability to choose. Basic assumption of this model is that not only the moment of the crime is crucial when determining the defendant's ability to choose, but also the question whether he can be blamed for not having a choice at this moment. Compared to a reasonable person test, this is a rather subjective test. However, the test has objective elements when measuring against an objective standard is necessary to make a more accurate decision. I will first describe the model. At the end of the Section the model is represented in a flowchart.

\section{COULD THE DEFENDANT HAVE CHOSEN A REASONABLE ALTERNATIVE?}

The first question a court should ask when determining the blameworthiness of the defendant is, could the defendant have chosen a reasonable alternative? The answer to this question is negative in two different kinds of situations:

a. There is no reasonable alternative.

b. There is a reasonable alternative, but the mental capacities of the defendant did not allow him to choose this alternative.

\section{(a) There is no reasonable alternative}

The adjective 'reasonable' indicates that the alternative must be an act that the law can require its subjects to perform. If there is no reasonable alternative, the defendant only had one reasonable option open to him. Consequently, the law cannot demand from him to opt for another course of action.

860 Fletcher, G.P., 2000, p. 513 summarizes this problem by referring to the French maxim: Tout comprendre, c'est tout pardonner. 
An excuse due to no reasonable alternative clearly differs from a justificatory situation. In case of a justification, the defendant had different options open to him, but has deliberately chosen the option of committing a crime because it was objectively the best course of action to end a difficult situation. Acting under an excuse, due to no reasonable alternative, means that the defendant made an understandable choice. The fact that the defendant, in case of a justification, took the best course of action is reflected in the proportionality requirement that demands a balance between the crime of the defendant and the danger avoided. In case of an excuse, this balance is not a conditio sine qua non. An excuse can be understandable, despite the disproportionality of the act. Proportionality, however, can be a factor in determining whether the defendant's act was understandable.

(b) There is a reasonable alternative, but the mental capacities of the defendant did not allow him to choose this alternative.

When there is a reasonable alternative, a court should investigate whether the defendant could have chosen this course of action. This requires an examination of the - subjective - mental capacities of the defendant at the moment of the crime. If the defendant had the mental capacities to choose the reasonable alternative, but simply did not do so, he should be convicted. However, if the defendant was, for example, insane, intoxicated, lacked important knowledge or could not think straight due to a stressful situation, it is very possible that the defendant could not see or act on the reasonable alternative. In case of an excuse affecting the defendant's mental capacity, this excuse either affects the cognitive (mistake, superior orders, some cases of insanity or intoxication) or the volitional (some cases of insanity and intoxication, necessity/duress) abilities of the defendant.

In order to investigate the mental capacities of the defendant, the causality requirement must be taken into account: did the mental condition of the defendant cause him to see no alternatives? The case law analyzed in Part II demonstrates that in practice a causality condition is required in case of insanity, intoxication and necessity/duress. However, I see no reason why in case of a mistake or superior orders the crime of the defendant must not be caused by his lack of knowledge. The causality requirement is, in a way, the equivalent of the mental element requirement in case of a justification. Whereas a defendant, in case of the latter, must deliberately take the best course of action, the defendant acting under this type of excuse must have no other option to act in a certain way caused by his exceptional mental condition.

If there is an alternative course of action but no mental condition (or no causal relation between mental condition and crime) the defendant could have chosen a reasonable alternative. Consequently, he is fully responsible for his act.

Although the mental capacities of the defendant are tested subjectively, objective tools may be employed to investigate the mind of the defendant. ${ }^{861}$ We cannot look 
inside a defendant's head. So if, for example, a court wants to determine whether the defendant pleading necessity/duress could have resisted the pressure and act in accordance with the reasonable alternative, its judgment does not only depend on the defendant's statement. The court should also investigate whether a person with the same characteristics of the accused (e.g. personality, age, background, societal position) would have made the same choice. Crucial in this investigation is whether this person, and thus the defendant, can be expected to control his subjective personality traits. ${ }^{862}$ For example, a judge cannot expect a defendant to control a severe form of insanity, however, he can expect him to control his temper. In objectivising this subjective test, a Garantenstellung can also be decisive.

\section{Intermezzo: Garantenstellung}

A so-called Garantenstellung - the weight of the societal position of the defendant when determining how he should have behaved - is a factor of importance when determining the amount of choice a defendant had in a specific situation. One can imagine, for example, that a soldier, who has been trained to fight, should not succumb to the stress of a combat situation as soon as a regular civilian would have. In the case law studied, the Garantenstellung factor has been mentioned in the context of mistake and superior orders (both in the context of the ICC) and in case of necessity/duress (both at the ICTY and the ICC). I do not see why a Garantenstellung should not be a factor of importance in case of other excuses. For example, a mistake of law should sooner be an excuse to an illiterate person than to a lawyer. ${ }^{863}$ What is more: a Garantenstellung may also influence the demands of necessity and proportionality in case of a justification. For example, a person with a high rank and an outstanding military training may have to think more about another course of action in case of an emergency situation, than a low rank soldier.

\section{PRIOR FAUlt?}

If there was no reasonable alternative or the defendant did not have the ability to choose the reasonable alternative, the next question is whether he can be blamed for not having a choice at the moment of the crime. In several domestic legal systems, a defendant can be blamed for not having a choice when he could have foreseen and avoided the situation in which he had to commit a crime. ${ }^{864} \mathrm{~A}$ defendant getting deliberately intoxicated to commit a crime could have foreseen and thus avoided this crime. Also, a defendant who joins an extremely violent gang can possibly foresee and thus avoid harming others. If the defendant could not have foreseen and

862 Fletcher, G.P., 2000, pp. 513/514.

863 Sliedregt, E. van, 2012, p. 275 and Werle, G., 2005, p. 148.

864 Krabbe, M.J.M., 2004, p. 54. However, in domestic criminal law complete defenses are not always rejected in case of prior fault. For example, in cases where the conduct that gave rise to the defense situation was lawful, a prior fault will not always bring about the rejection of a defense. See: Blomsma, J., 2012, p. 360. 
avoided the situation, he is excused. However, if a prior fault can be established, he must be convicted. Like the previous question on the reasonable alternative, the prior fault question must also be tested subjectively, employing objective tools when necessary. This, despite of the fact that, as demonstrated by Part II of this study, prior fault is tested objectively in practice. Reasons for this different approach are the same as the grounds for rejecting the objective reasonable person test discussed above (i.e. an objective test is hard to apply in case of a deviating mental condition, especially insanity).

\section{Intermezzo: Prior fault and individual criminal responsibility}

The question of foreseeability and avoidability refers to the doctrine of prior fault/ culpa in causa. Essence of this doctrine is that the previous behavior of the defendant prevents him from resort to a defense. Although this requirement has featured in several cases of international courts (mainly in case of necessity/duress and intoxication), prior fault doctrine is not undisputed. Main objection against this theory is that a defendant can be convicted without a subjective element being established. 865

As explained in Chapter II of this thesis, criminal liability can only be established if both an objective and a subjective element are present. If a defendant is convicted while at least one of these basic requirements is missing, this amounts to a violation of the principle of individual criminal responsibility. The weak spot of prior fault reasoning is that a defendant can be convicted without a subjective element being established at the moment of the crime. This lack of a subjective element can both consist of the absence of a definitional subjective element or of the absence of blameworthiness.

A prior fault reasoning in case of a lacking definitional subjective element is illustrated by the following example:

Mary is hunting and aims at what she holds for a deer. However, after she pulled the trigger she discovers she shot her neighbor.

Without a prior fault reasoning Mary cannot be convicted: she had no intent to shoot a human being. However, in case of a prior fault test, Mary will only be acquitted if she could not have foreseen and consequently have avoided shooting her neighbor. If, for example, Mary was short sighted and - I apologize for yet another terrible armchair example - stupid enough to go hunting without her glasses, she should have foreseen and therefore avoided shooting something that she could not identify. By wearing her glasses, Mary could have foreseen and avoided shooting her neighbor. Consequently, under prior fault theory, Mary could be convicted without possessing the required intent at the moment of the crime. 
How should complete defenses be applied under international criminal law (in general)?

An example of a prior fault reasoning when blameworthiness is lacking at the moment of the crime can be found in the Erdemovic case, discussed in Part II of this thesis. Erdemovic had to choose between killing and being killed. He had probably no other reasonable alternative at the moment he committed the crime charged. However, under the prior fault doctrine, if he could have foreseen and avoided this situation, he could still be convicted, despite the fact that he was not blameworthy at the moment of the crime.

The above examples demonstrate that the drawback of prior fault reasoning is that a defendant may be convicted without the relevant blameworthiness or definitional subjective element being established. However, prior fault reasoning also has a major advantage: it is a practical tool to correct injustices. For example:

$X$ voluntarily joins a gang while he knows that this gang deals drugs and kills. After a while $X$ is forced at gunpoint to kill a member of a competing gang.

$Y$ is out on the street walking his dog. All of a sudden he is grabbed by a group of men and forced at gunpoint to kill somebody.

Without the availability of prior fault both $\mathrm{X}$ and $\mathrm{Y}$ can successfully plead duress. They had no reasonable choice at the moment the crime was committed. However, under prior fault theory, duress is only available to Y. X could have foreseen and avoided the murder by not joining the gang.

On the one hand, thus, prior fault reasoning seems to lead to more nuanced and thus more just results. On the other hand it stretches the scope of criminal liability exceeding the traditional limits of individual criminal responsibility. As a consequence both legal theory and practice have found constructions that avoid prior fault reasoning (and thereby avoid a violation of the principle of individual criminal responsibility). However, they do not always bring satisfactory solutions.

The prior fault can, for example, be charged as a separate crime (in case of the above "gang"-example this crime could be "membership of a criminal organization"). ${ }^{866}$ A possible disadvantage of this solution is that the perpetrator, who saw the crime coming and could have avoided it $(\mathrm{X})$, gets away with a lesser offense. Another argument against this option is that there are situations possible, where the prior fault cannot be defined as a crime, but the crime charged was still foreseeable and avoidable to the perpetrator. For example, in cases where the defendant has provoked the victim to assault him.

An alternative solution employed in national jurisdictions to circumvent prior fault problems, is to convict the defendant for a crime requiring negligence instead of intent. ${ }^{867}$ For example, in the case of near-sighted Mary who shot her neighbor, intent to kill cannot be established. However, culpable homicide may be proved due

\footnotetext{
866 Robinson, P.H. 'Causing the Conditions of One's Own Defence: A Study in the Limits of Theory in Criminal Law Doctrine', Virginia Law Review, Volume 71, Issue 1, 1985, pp. 1-63, pp. 14/15. 
to her prior fault. Then again, this solution is not workable in international criminal law, since most international crimes require some form of intent. ${ }^{868}$

Another legal solution to avoid a prior fault requirement is to demand more of an effort from the perpetrator in case of an earlier fault. ${ }^{869}$ Since he contributed to the situation in which the commission of a crime was necessary, he should have tried harder to find an alternative solution. This way, absence of prior fault is not a conditio sine qua non but merely a factor that determines the presence of the other requirements for the defense. This may be an effective means in some situations. For instance, in case of provocation, because the perpetrator created the state of affairs, he can never be completely surprised by the reaction of the victim and therefore had more time to think of alternative solutions than a perpetrator who was overwhelmed by an attack. In other more extreme situations this solution is less adequate. Take the example of Erdemović. Since he only had one reasonable option open to him, he could not find a better option at the moment of the crime, even if he had foreseen the situation.

From the above can be concluded that alternative solutions to a prior fault reasoning are not completely satisfactory. It therefore seems that the only obstacle to prior fault reasoning is the alleged violation of the principle of individual criminal responsibility. However, does prior fault reasoning truly violate this principle?

Chapter II has demonstrated that the objective and subjective element must be present in order to come to a conviction. Nevertheless, there is no general rule in international criminal law doctrine that the objective and subjective element must coincide (i.e. both be present at the moment of the crime). Still, the lack of this rule can be attributed to the fact that international criminal law is relatively young and undeveloped. In national legal systems, generally, the objective and subjective element must - to a certain extent - coincide. ${ }^{870}$ This rule is founded on the same considerations as the principle of individual criminal responsibility in general: most of the purposes of criminal law (deterrence both of the perpetrator and of society as a whole, retribution, and rehabilitation) can best be effectuated in case a defendant can exercise control over his behavior, because he has the choice to act otherwise. The idea behind the coincidence rule is that when the objective and subjective element are not present at the same time, the defendant did not control the situation and should therefore not be held responsible. For example:

868 This problem was also noticed by the Appeals Chamber in Mucić et al., where the Chamber reasoned that partial defenses (e.g. turning murder into manslaughter) are not an option in international criminal law because "there is no appropriate lesser offense available". See: ICTY, Prosecutor v. Mucić et al., Appeals Chamber, 20 February 2001, par. 590.

870 Blomsma, J., 2012, p. 250. 
How should complete defenses be applied under international criminal law (in general)?

Janey intends to poison her husband. She kills him a few weeks later in a traffic accident that she could have avoided (culpable homicide).

Although Janey did not have the amount of control over the accident that goes with criminal intent, she would be guilty of murder if objective and subjective element were not required to coincide, for she had the intent to kill her husband and she was blameworthy in killing him. However, now that she only had a lesser degree of control at the moment of the accident, she can only be held liable for culpable homicide.

It is submitted here that prior fault reasoning is not contrary to the purpose of the coincidence rule and therefore also not to the purposes of criminal law, for it allows only for conviction in case the defendant could have controlled the outcome of the case. In case of a prior fault reasoning a complete defense can only be denied if the crime charged was foreseeable and avoidable. This is what distinguishes prior fault from the example of Janey: her husband's accident was not foreseeable and therefore not avoidable at the time she formed the criminal intent. This earlier intent can therefore not be considered when determining her criminal liability.

What is more, when balancing the rights of the defendant, the victim and society as a whole, it is not in the interest of the victim and society to provide the defendant with a limitless possibility to appeal to a complete defense when he had the ability to control a different outcome.

In addition, the case law analyzed in Part II of this thesis demonstrates that the prior fault requirement has been recognized in case of intoxication, necessity/duress and possibly self-defense. I see no reason why this requirement should be limited to these specific defenses. One can also imagine prior fault in case of mistake, insanity or reprisals.

Finally, it is almost rigid to let the blameworthiness of the defendant only depend on the exact moment of the crime. Not to look at the bigger picture seems artificial. If the defendant had it coming, for example, by voluntarily participating for a long time in a very violent and criminal military unit, he should not get off the hook. Especially in case of international crimes, the larger context of a crime may be of importance. These crimes generally do not happen in the heat of the moment but are carefully planned. Especially military chiefs planning large operations where human lives are on the line, should be motivated to make decisions that are well thought through, and not continue an action, despite being unsure about, for example, its legal implications (mistake) or their own mental fitness (insanity).

I would like to stress, however, that the prior fault criterion should be applied with due care. Wrong decisions are always easier to judge with hindsight. On the ground, at that moment, people tend to think that the situation won't get that bad. 
The model discussed above can be represented in the following flowchart:

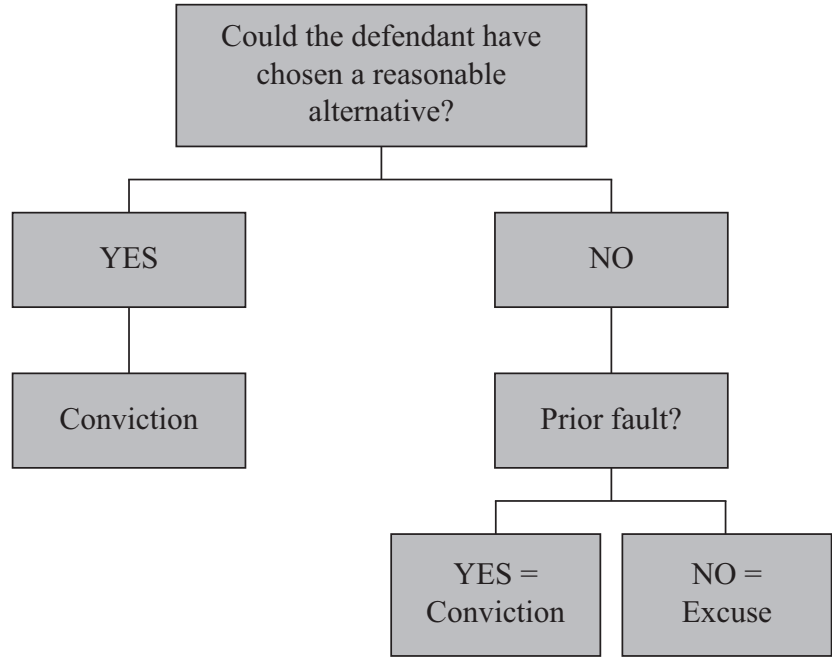

\subsubsection{A model of justifications and excuses}

The question as to a justification can also be included in this flowchart:

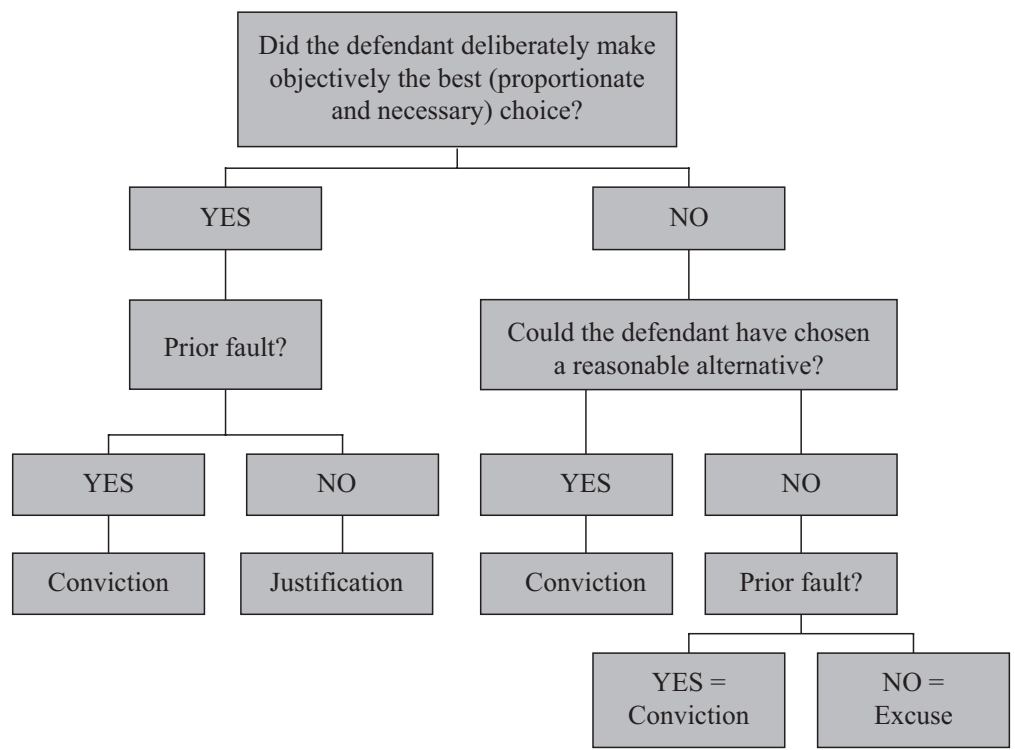


How should complete defenses be applied under international criminal law (in general)?

\section{PRIOR FAULT AND JUSTIFICATIONS}

As one can see I have included prior fault in the justifications test, despite the fact that this test is not represented in the case law on justifications reflected in Part II of this thesis. However, just like excuses, justifications can be subject to a prior fault test. For example:

Aggressor Margret hits Ben. Ben wants to hit Margret back, lifts his arm, but is stopped by another blow from Margret. As to her second blow, Margret claims self-defence.

Without a prior fault reasoning, Margret can claim self-defense. At the very moment she hits Ben for the second time, her act is necessary to avert the danger, it is proportionate to the danger, and she has the intent to avert the attack. However, were prior fault applied to the situation, Margret should have foreseen and avoided Ben hitting her: if you hit someone you can expect this person to hit you back. Commentators on the ICC Statute have confirmed that a prior fault reasoning could be applicable in case of justifications. ${ }^{871}$

According to Fletcher prior fault reasoning mainly applies to excuses. ${ }^{872}$ Although I see some contradiction in the fact that in case of a prior fault the act could have been avoided, while a justification is an act that should not be avoided, the above example demonstrates that a prior fault can negate the justificatory character of an act, despite the fact that the act meets the criteria of a justification at the moment of the crime.

\section{THE EFFECT OF JUSTIFICATIONS AND EXCUSES ON THE CRIME CHARGED}

Now that the general features of justifications and excuses and their underlying questions are defined, the effect of these justifications and excuses on the crime charged deserves some attention. Part II of this thesis has demonstrated that complete defenses affect the crime charged in six different ways:

\begin{tabular}{|l|l|l|l|}
\hline Effect & Defense & $\begin{array}{l}\text { Justification of } \\
\text { excuse? }\end{array}$ & $\begin{array}{l}\text { Affirmative or } \\
\text { not? }\end{array}$ \\
\hline Wrongfulness is negated but crime charged is not & $\begin{array}{l}\text { Act is not } \\
\text { wrongful }\end{array}$ & Justification & Affirmative \\
\hline $\begin{array}{l}\text { Blameworthiness is negated but } \text { crime charged is } \\
\text { not }\end{array}$ & $\begin{array}{l}\text { Act is not } \\
\text { blameworthy }\end{array}$ & Excuse & Affirmative \\
\hline $\begin{array}{l}\text { Definitional subjective element } \text { of negligence is } \\
\text { negated by absence of wrongfulness }\end{array}$ & $\begin{array}{l}\text { Act is not } \\
\text { wrongful }\end{array}$ & Justification & Not affirmative \\
\hline
\end{tabular}

871 See for example: Sliedregt, E. van, 2012, p. 238, who holds that a prior fault reasoning could be applied at the ICC in case of self-defense. See also Section 8.6.2 of Chapter IX.

872 Fletcher, G.P., 2000, pp. 797/798. 


\begin{tabular}{|l|l|l|l|}
\hline Effect & Defense & $\begin{array}{l}\text { Justification of } \\
\text { excuse? }\end{array}$ & $\begin{array}{l}\text { Affirmative or } \\
\text { not? }\end{array}$ \\
\hline $\begin{array}{l}\text { Definitional subjective element } \text { of negligence is } \\
\text { negated by absence of blameworthiness }\end{array}$ & $\begin{array}{l}\text { Act is not } \\
\text { blameworthy }\end{array}$ & Excuse & Not affirmative \\
\hline $\begin{array}{l}\text { Definitional subjective element is negated by } \\
\text { absence of psychological intent }\end{array}$ & No intent & Excuse & Not affirmative \\
\hline $\begin{array}{l}\text { Definitional subjective element is negated by } \\
\text { absence of normative intent }\end{array}$ & $\begin{array}{l}\text { Act is not } \\
\text { blameworthy }\end{array}$ & Excuse & Not affirmative \\
\hline
\end{tabular}

To be complete, I also have to add that there is a seventh way in which a complete defense can interact with the crime charged. Namely, when a justification negates the objective element of the crime. For example, the crime of deportation has been defined by the ICTY as deportation performed "without grounds permitted under international law". ${ }^{873}$ In case of a justification, the deportation would be permitted under international law and the justification would thus negate part of the objective element. However, as has been explained in Part I of this thesis, these so-called definitional defenses are excluded from the scope of this research. Despite this exclusion, for the purpose of being complete, I would like to demonstrate that this seventh way of interaction between complete defense and crime charged looks like this:

\begin{tabular}{|l|l|l|l|}
\hline Effect & Defense & $\begin{array}{l}\text { Justification of } \\
\text { excuse? }\end{array}$ & $\begin{array}{l}\text { Affirmative or } \\
\text { not? }\end{array}$ \\
\hline $\begin{array}{l}\text { Wrongfulness is negated as part of the objective } \\
\text { element of the crime charged }\end{array}$ & $\begin{array}{l}\text { Act is not } \\
\text { wrongful }\end{array}$ & Justification & Not affirmative \\
\hline
\end{tabular}

Next question is whether the above overview of the different interactions between crime charged and general requirements for criminal responsibility leaves room for the model displayed in Section 3.3.3 of this Chapter. Since this model is only applicable in case of a justification or an excuse, the option of an excuse negating psychological intent drops out. For, although an excuse can negate the required intent, the absence of psychological intent is not enough to establish an excuse. The previous Section, namely, has demonstrated that the defendant should be submitted to subsequent tests (some objectivising of the reasonable alternative test and a prior fault test) in addition to an investigation of his subjective state of mind at the moment of the crime. For example, in case of the nearsighted Mary, who shot her neighbor, psychological intent cannot be established. However, this does not automatically mean she is excused. 
How should complete defenses be applied under international criminal law (in general)?

This leaves the following possibilities:

\begin{tabular}{|l|l|l|l|}
\hline Effect & Defense & $\begin{array}{l}\text { Justification of } \\
\text { excuse? }\end{array}$ & $\begin{array}{l}\text { Affirmative or } \\
\text { not? }\end{array}$ \\
\hline $\begin{array}{l}\text { Wrongfulness is negated but crime charged is } \\
\text { not }\end{array}$ & $\begin{array}{l}\text { Act is not } \\
\text { wrongful }\end{array}$ & Justification & Affirmative \\
\hline $\begin{array}{l}\text { Blameworthiness is negated but crime charged is } \\
\text { not }\end{array}$ & $\begin{array}{l}\text { Act is not } \\
\text { blameworthy }\end{array}$ & Excuse & Affirmative \\
\hline $\begin{array}{l}\text { Definitional subjective element } \text { of negligence is } \\
\text { negated by absence of wrongfulness }\end{array}$ & $\begin{array}{l}\text { Act is not } \\
\text { wrongful }\end{array}$ & Justification & Not affirmative \\
\hline $\begin{array}{l}\text { Definitional subjective element } \text { of negligence is } \\
\text { negated by absence of blameworthiness }\end{array}$ & $\begin{array}{l}\text { Act is not } \\
\text { blameworthy }\end{array}$ & Excuse & Not affirmative \\
\hline $\begin{array}{l}\text { Wrongfulness is negated as part of the objective } \\
\text { element } \text { of the crime charged }\end{array}$ & $\begin{array}{l}\text { Act is not } \\
\text { wrongful }\end{array}$ & Justification & Not affirmative \\
\hline $\begin{array}{l}\text { Definitional subjective element } \text { is negated by } \\
\text { absence of normative intent }\end{array}$ & $\begin{array}{l}\text { Act is not } \\
\text { blameworthy }\end{array}$ & Excuse & Not affirmative \\
\hline
\end{tabular}

The next pertinent question is: how do we deal with the category that does not fit the system? More precisely, how do we categorize situations in which the psychological intent cannot be established? This issue is mainly relevant to cases of mistake, where the defendant was not aware of the relevant law or facts or in cases of insanity/intoxication where the defendant had no idea what he was doing, or cannot control his acts. Should in these cases, the defendant be acquitted, or can he still be submitted to additional tests?

On the one hand, Section 3.3 has demonstrated that employing an objectivised subjective test and a prior fault test in cases where the subjective element is lacking at the moment of the crime, can be legitimate. On the other hand, it is contrary to the principle of individual criminal responsibility to convict a defendant without intent being established. In essence, the situation in which the defendant did not possess the required intent, but is still blameworthy - because he should have behaved differently or should have foreseen the crime - represents a clash between the formal requirements of criminal law (no conviction without intent) and its substantive requirements (conviction in case the defendant had a reasonable choice to act otherwise). Unifying these opposing requirements leads to the following result: prior fault reasoning is only legitimate in case the definition of the crime has been established. 874

For example, in a case of necessity/duress $\mathrm{X}$ shot $\mathrm{Y}$, because he was forced to do so. Consequently, $\mathrm{X}$ intended to shoot $\mathrm{Y}$ and he did it. As a result the objective element and definitional subjective element can be established. However, X's blameworthiness is negated by the duress. Still, this can be turned around in case of a prior fault, where $\mathrm{X}$ could have foreseen and thus avoided the situation in which

874 Compare: Verseveld, A. van, 2012, p. 5: "If a mistake negates the required intent, any mistake, reasonable or unreasonable, will exculpate. If the mistake concerns an element extrinsic to the required intent, a reasonableness standard may be applied". 
he had to commit a crime. However, when $\mathrm{X}$ shot $\mathrm{Y}$, because due to a psychosis, he thought $Y$ was a grizzly bear, X's intent to kill a human being cannot be established. Even if $\mathrm{X}$ would have made a prior fault, for example, not taking his medication, he cannot be convicted because prior fault cannot turn around the absence of intent.

Although the application of a prior fault reasoning in case intent cannot be established is illegitimate, a court should be allowed - for the reasons discussed in Section 3 - to slightly stretch the concept of intent, making the concept more normative (last option in the above chart). In this case, intent is absent if the defendant did not know and could not have known what he was doing. This is what the Court did in, for example, the Lubanga case.

In sum, in cases where psychological intent cannot be established, the intent requirement can be slightly objectivised. However, when the intent of the defendant cannot be established under this test, lack of intent cannot be turned around by a prior fault. While a prior fault can negate the availability of a defense, in case the definition (including intent) of the crime has been established, a prior fault cannot establish intent, when an objectivised subjective test cannot.

Considering the relationship between complete defenses and crimes charged, the flowchart suggested in Section 3.3.3 should be slightly altered:

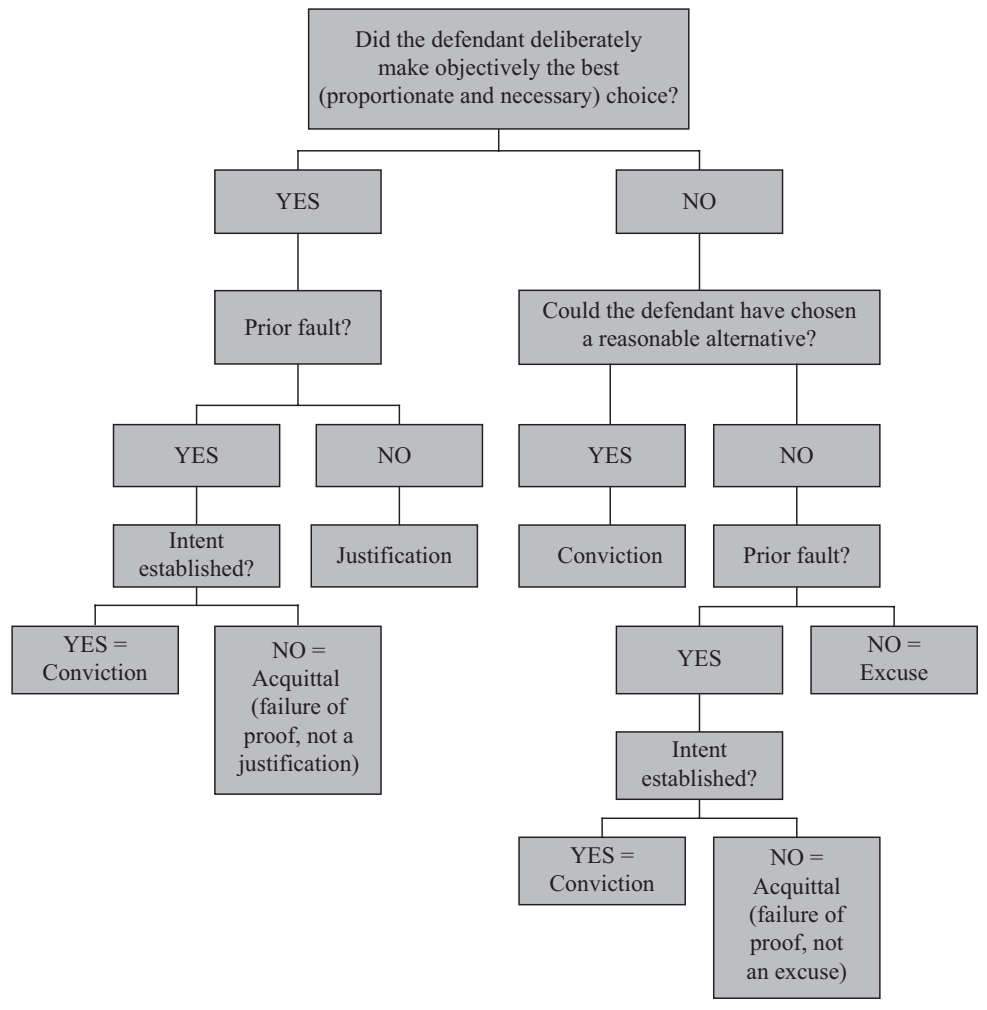


How should complete defenses be applied under international criminal law (in general)?

\section{FAILED COMPLETE DEFENSES IN Mitigation}

Part II of this study has demonstrated that international courts have acknowledged the possibility of several failed complete defenses being taken in mitigation. This practice has been formalized including all complete defenses in ICC Rule 145(2)(a) (1). This seems fair. If a court holds that the defendant should have made a different choice, it can still take into account that he had to make a difficult decision when determining his sentence. International courts should however be vigilant that they do not employ complete defenses as mitigating factors. A complete defense must always be open to a defendant free from wrong or blame. As Cassese puts it in Erdemović:

No matter how much mitigation a court allows an accused, the fundamental fact remains that if it convicts him, it regards his behavior as criminal, and considers that he should have behaved differently. ${ }^{875}$

\section{Conclusion}

The present Chapter has established that a foreseeable, accessible and open system of complete defenses is desirable. This system should be based on the division between justification and excuse and the questions underlying this distinction. Crucial questions when determining the availability of a complete defense are:

1. Did the defendant make objectively the best choice?

2. Could the defendant have chosen a reasonable alternative?

3. Should the defendant have foreseen and avoided the situation in which he had to commit a crime?

4. Can the required intent be established?

While the present Chapter has made an attempt to uncover the general questions underlying the specific complete defenses available to a defendant at an international court, the next Chapter discusses the conditions for each specific complete defense. By discussing these specific conditions I hope to provide an answer to the questions put at the end of each of the Chapters of Part II of this thesis.

875 ICTY, Prosecutor v. Erdemović, Separate and Dissenting Opinion of Judge Cassese, Appeals Chamber, 7 October 1997, par. 48. 



\section{Chapter XV \\ HOW SHOULD COMPLETE DEFENSES BE APPLIED \\ UNDER INTERNATIONAL CRIMINAL LAW \\ (FOR EACH DEFENSE)?}

\section{INTRODUCTION}

This Chapter discusses recommendations for each specific type of complete defense. In Part II, each Chapter on a defense ends with several questions, relevant to the further development of this defense in international criminal law. This Chapter hopes to answer these questions. Most questions come down to the following two issues:

1. Should the specific defense be a complete defense under international criminal law? And/or:

2. What should be its requirements under the ICC Statute?

Consequently, the following Sections (2-12) have a similar structure, in which the questions, posed at the end of each Section in Part II are answered. As to the first question, the general line is that defenses should be considered a complete defense under international criminal law when their effect is either excusing or justificatory. In relation to the second question, the general answer is that every justification and excuse should contain the basic requirements discussed in the previous Chapter. In addition, for each specific defense is argued whether additional conditions are required. The balance between an open and flexible provision on the one hand and a foreseeable and accessible provision on the other, is always crucial in this matter. Although answers to the above questions (1) and (2) can be understood in general terms, the recommendations contained in this last Chapter are presented as suggestions for the alteration of the ICC Statute. Section 12 concludes with a proposal for amendments to the ICC Statute. This proposal contains most defenses addressed in Part II of this thesis except for consent and tu quoque.

\section{Self-defense}

(1) What is the availability of the different types of self-defense in international criminal law?

Part II of this study has demonstrated that self-defense is a justification and that international criminal case law is familiar with different types of self-defense: private self-defense, self-defense in bello and self-defense ad bellum. Private selfdefense is uncontroversial, but self-defense in bello and ad bellum are not. Selfdefense ad bellum has been both rejected a priori and (tested on its merits and thus) 
implicitly recognized. Considering the incoherent case law on self-defense ad bellum, it is doubtful whether this should be a complete defense under international criminal law.

Despite the inarticulate case law on self-defense ad bellum, I think this type of self-defense can be a justification. However, to contain the distinction between ius ad bellum and ius in bello, ${ }^{876}$ self-defense ad bellum can only be a defense against charges of aggression. It is therefore submitted here that the scope of the current ICC provision must be stretched to include self-defense ad bellum. 877

Part II of this thesis demonstrates that ICC commentators also hold that selfdefense in bello could be covered by the ICC Statute. However, as is already suggested in several ICTY cases, serious violations of international humanitarian law will probably never meet these requirements. Nevertheless, this is not a reason to make the defense a priori unavailable. ${ }^{878}$ If the action of the defendant was an intentional act of self-defense, necessary and proportionate, he should be justified under international criminal law.

Even though all three types of self-defense can in principle function as a justification, the requirements of proportionality, necessity and mental element are not the only criteria determining whether a specific defendant can appeal to selfdefense under international criminal law. Humanitarian law, namely, has its own rules applicable to self-defense situations. The applicability of these rules depends on the circumstances at hand. For example, the status of the defendant and the victim(s) (e.g. combatant/non-combatant acting in public or private capacity) ${ }^{879}$ and the rules applicable to the combat situation (depending on, for example, the nature of the conflict, where it takes place and the dictates of the rules of engagement (ROE), ${ }^{880}$ if there are any). Many defensive acts are legitimate under humanitarian law, and in these cases, a criminal law justification is superfluous. ${ }^{881}$ In the context

876 The rationale of which has been explained in the introduction to Chapter III of this thesis.

877 Although Part II of this thesis demonstrates that preparatory work on the ICC Statute displays that article $31(1)(\mathrm{c})$ is not applicable to interstate relations, preparatory work on the crime of aggression does neither expressly confirm, nor deny the applicability of article 31(1)(c) of the ICC Statute in case of aggression. These documents, however, do mention on several occasions that self-defense is a defense to the crime of aggression: www.icc-cpi.int/Menus/ASP/ ReviewConference/Crime +of + Aggression.htm (November 2011).

Keijzer provides an example of a situation in which self-defense in bello could be available. See: Keijzer, N., 'Self-Defence in the Statute of Rome', In: Duyx et al., War Crimes Law and the Statute of Rome: Some Afterthoughts? Report on the Seminar of Rijswijk, Revue de Droit Militaire et de Droit de la Guerre, Vol. 39, 2000, pp. 69-78, p. 77-88. According to this example the taking of civilian hostages could be permitted to protect lawful weapons.

Sliedregt, E. van, 2012, p. 263. Van Sliedregt here refers to an example of a situation in which a defendant has a defense in his public capacity, but not in his private, and vice versa.

Knoops, G.J., 2001, pp. 183-192. Knoops here analyses the relationship between domestic selfdefense and ROE.

881 Ipsen, K., 'Combatants and non-combatants', In: Fleck, D. (ed.), The Handbook of Humanitarian Law in Armed conflicts, Oxford University Press, New York, 1998, pp. 65-104, p. 90. See also: Sliedregt, E. van, 2012, p. 238 and Wilt, H.G. van der, 2011, p. 280. 
of self-defense, the exact ratio between humanitarian and criminal law is not always evident. ${ }^{882}$ Neither are the definitions of ius ad bellum and ius in bello. ${ }^{883}$ Therefore, it is submitted here that additional research - to map out this complex relationship - would be advisable. Especially, since (a) the present research demonstrates that self-defense is the most frequently brought up defense in international criminal law and (b) the ad bellum species may be brought up against charges of aggression in future cases.

(2) What is the scope of these different types of self-defense in international criminal law (are they subjected to the same criteria?)?

Generally all three types of self-defense should be subjected to the same basic criteria for justifications: necessity, proportionality and a mental element. However, the interpretation of these requirements can occasionally depend on the relevant type of self-defense. For example, in case of self-defense at an interstate level, there is no higher authority to call upon. Consequently, self-defense may sooner be necessary than in case of private self-defense. ${ }^{884}$ Also, in case of defense of the other, according to the ICJ, the attacked state must formally ask for assistance. Private self-defense, on the other hand, does not require the victim to ask for help: the defendant is allowed to help the victim without his consent. ${ }^{885}$ Finally, while criminal law self-defense demands an unlawful attack, article 51 of the UN Charter demands that this unlawful attack is an armed attack. ${ }^{886}$ It can thus be held that all types of self-defense have the same basis requirements. However, these conditions may require different interpretations depending on the type of self-defense in issue. $^{887}$

(3) How do these types of self-defense translate to the ICC Statute? (Which types of self-defense are covered by the criteria mentioned in the first sentence of article 31(1)(c) and which are not?)

Part II of this thesis has demonstrated that although the commentators on the ICC Statute hold that both private self-defense and self-defense in bello are covered by this Statute, they disagree on whether these types of self-defense are covered by article 31(1)(c). However, since I have concluded under the previous question (2) that

882 Wilt, H.G. van der, 2009, pp. 533/534.

883 Weiler, J.H.H. and Deshman, A., 'Far be it from Thee to Slay the Righteous with the Wicked: An Historical and Historiographical Sketch of the Bellicose Debate Concerning the Distinction between Ius ad Bellum and Ius in Bello', In: European Journal of International Law, Vol. 24, issue 1, 2013, pp. 25-61.

884 Fletcher, G.P. and Ohlin, J.D., 2008, p. 78.

885 Fletcher, G.P. and Ohlin, J.D., 2008, p. 70.

886 Dinstein, Y., 'The Hazards of Interdisciplinary Pollination. Some Critical Comments on Defending Humanity', In: Journal of International Criminal Justice, Vol. 7, 2009, pp. 517-520, p. 519.

887 Self-defense ad bellum may require more detailed criteria. See Chapter XIV, Section 2 on the conduct-steering function of international law defenses. 
all three types of self-defense must abide by the same basic requirements, they can also be covered by the same article. In this case it is advisable to rephrase article $31(1)(c)$ in the following manner:

1. A defendant shall not be criminally responsible if at the time of his conduct:

The defendant acts necessarily to avoid an imminent or present and unlawful use of force while not causing greater harm than the one sought to be avoided.

\section{Comments}

- In the heading of article 31, the phrase "In addition to other grounds for excluding criminal responsibility provided for in this Statute" has been deleted, because all complete defenses should be united in one provision. 'Defendant' has substituted the word 'person' for editing purposes.

- The word 'reasonably' is replaced by 'necessarily'. According to the commentators on the Rome Statute, 'reasonably' in this paragraph refers to both necessity and efficiency. However, I do not see why efficiency should be a separate criterion apart from necessity and proportionality: averting an attack by a means that is not efficient is either not necessary (hitting back when you could have done nothing), not proportionate (throwing an explosive when you could have hit back) or not illegal (averting an attack by performing a peace dance). The commentators on the Rome Statute have also suggested that the reasonability criterion could cover situations of prior fault. However since a separate prior fault clause is suggested below, this is no longer a reason to retain the reasonability criterion.

- The defensible interests should be removed. The property clause of this condition, especially, has proved to be rather controversial, largely due to its unhappy phrasing ${ }^{888}$ and for not being reflective of customary law. ${ }^{889}$ One option would be to delete this property clause, and leave the defense only open to "himself or herself or another person". However, this would a priori block self-defense in case of property, while (a) literature has come up with examples in which defense of property could be legitimate, ${ }^{890}$ and (b) we cannot foresee all future scenarios. Therefore it may be best to leave all defensible interests out. After all, whether an interest is defensible is in the end determined by the requirements of necessity and proportionality. The legislator should therefore not establish defensible interests beforehand.

Cassese, A., 1999, pp. 154-155 and Knoops, G.J., 2001, p. 90.

Bantekas, I., 2004, p. 279; Cassese, A., 2008, p. 262 and Eser, A., 2008, p. 881. The customary status of article 31(1)(c) is stressed in Prosecutor v. Kordić and Čerkez but was never confirmed in subsequent case law.

Bantekas, I., 2004, p. 279; Keijzer, N., 2000, p. 77-78 and Knoops, G.J., 2001, pp. 89/90. 
- When the defensible interests are removed from the provision, the words "to defend" no longer make sense and should be replaced by 'to avoid' in order to retain a mental element.

- The requirement of imminence is more of a clarifying condition than an essential condition of self-defense, because imminence is covered by the necessity requirement (if the threat is not imminent, self-defense is not necessary, because there are alternative courses of action). Whether it should be retained in the provision depends on the tipping point between an open provision on the one hand (so that judges preserve a certain amount of flexibility in different situations) and a foreseeable and accessible provision (so that a defendant has some idea of the types of behavior that incur liability) on the other. In the end, this is not an issue of major importance. Importantly, a judge realizes that the factor of imminence partly defines the necessity requirement and that this factor has played a crucial role on several occasions in the case law discussed in Part II. For reasons of foreseeability and accessibility I have preserved the imminence requirement. Besides, an imminence requirement provokes a cautious approach towards pre-emptive and preventive attacks. ${ }^{891}$

- The alternative of a present attack has been added, to underline that not only imminent but also ongoing attacks fall within the scope of self-defense.

- The unlawful force requirement must be retained, because it distinguishes the legal figure of self-defense from necessity/duress, where the victim is not an aggressor.

- The last sentence of this provision ('The fact that the person was involved in a defensive operation conducted by forces shall not in itself constitute a ground for excluding criminal responsibility under this subparagraph') should be deleted. All it says is that a person participating in a defensive operation can only successfully appeal to self-defense when he acts in accordance with the requirements of article $31(1)(\mathrm{c})$. However, since everybody who wants to successfully appeal to self-defense must act in accordance with this provision, including persons involved in a defensive operation, this phrase is superfluous. ${ }^{892}$

- In general it would be better to refer to the self-defense provision in the ICC statute as 'legitimate defense', ${ }^{893}$ because the notion is much broader than the defense of the 'self'.

- In addition to the paragraph on self-defense, a separate general paragraph should be added to article 31, establishing the prior fault doctrine:

891 Fletcher, G.P. and Ohlin, J.D., 2008, Chapter 7.

892 According to Van Sliedregt the last phrase of article 31(1)(c) is superfluous as well, but for another reason: A defensive operation does not qualify as a reaction to an 'unlawful use of force'. Sliedregt, E. van, 2012, p. 239.

893 This terminology is also used by Ohlin and Fletcher in their previously cited work Defending Humanity (2008). 
The availability of a complete defense can be excluded to a defendant who could have foreseen and avoided the situation in which he had to commit a crime. A defendant cannot be convicted when he could have foreseen and avoided the situation in which he had to commit a crime, but the elements of the crime charged cannot be established.

\section{Consent}

\section{(1) Should consent be a defense under international criminal law?}

The most convincing reason why consent should not be a complete defense under international criminal law is that the defense - as defined in Part II of this thesis is not a complete defense in a technical sense (negating either the wrongfulness of the act or the blameworthiness of the actor).

\section{Consent is not a justification}

In case of a justification the defendant has chosen the lesser of two evils. This lesser evil is objectively determined by the legal community. The presence of genuine consent of the victim (and third parties) does not automatically establish that the defendant objectively chose the lesser evil: the legal community may have other values than the victim and third parties. Consent is therefore not a justification per se.

Whether consent is a justification thus depends on how a legal community defines the lesser evil. This is a normative issue, which strongly depends on a legal community's perspective on society in general: should society protect its subjects from their own - destructive - desires and if it must, to what extent? If the legal community has a preference for laissez-faire, the lesser evil could be defined as 'the option to which the victim consented'. In this case, consent of the victim could amount to a justification. However, if the legal community has a more interventionist view, it will probably hold that this lesser evil must be (co-)determined by some sort of objective standard.

There are several arguments against an exclusive role of consent of the victim, when determining the lesser of two evils. First, the fact that a victim and possibly third parties genuinely consent to a crime, does not always erase the wrongfulness of the act. For example:

A mad scientist pays students (always low on cash) large amounts of money to subject their bodies to tests with highly experimental and possibly toxic medication.

Several of the colleagues of the mad scientist approve of these experiments.

Would this level of consent erase the wrongfulness of the experiments? Or must these acts be measured against some sort of objective standard? I would opt for the latter: a court should not only take into account the desire of the victim and 
several third parties, but also the interests of society as a whole, when balancing interests.

Secondly, the importance of an objective standard seems even more crucial in international criminal law. International crimes do not only violate the rights of the victim, but generally target interests beyond those of the individual (e.g. 'humanity as a whole'). Consequently the consent of the victim (and maybe third parties) to an international crime, would not be enough to erase the wrongfulness of the act. ${ }^{894}$

Finally, the need for an objective standard is confirmed by the Nuremberg case law and the ICC provisions (considering mutilation and medical and scientific experiments) analyzed in Part II of this thesis. They demonstrate that the isolated consent of the victim is not a defense. Consequently, invasions (of the human physique) must be measured against an objective (medical) standard.

\section{Consent is not an excuse}

Classification of consent as an excuse runs into similar problems as its justificatory equivalent. An excuse is applicable if there was no reasonable alternative available to the defendant. Since consent of the victim does not have to be crucial in determining whether there is a reasonable alternative available to the defendant, consent cannot be qualified as an obvious excuse either. Referring back to the above mad scientist example, consent of the victim does not mean that the mad scientist had to commit the crime, that there was no reasonable alternative, or that he could not see a reasonable alternative due to the consent of the victim.

\section{Arguments in favor of consent as a complete defense}

Fletcher has argued in favor of consent as a complete defense. However, his argumentation is written from a different angle. He argues that consent should be a defense instead of an element of the definition of the crime, for technical legal reasons. ${ }^{895} \mathrm{He}$ has not written about consent within the context of other complete defenses and its intrinsic legitimacy as a justification, i.e. whether consent really eliminates the wrongfulness of the act or the blameworthiness of the actor. Fletcher's main argument for consent as a justification is that if non-consent of the victim were an element, the defendant would get off the hook in case of an honest but unreasonable mistake 896 (defendant: "yes, I had sex with the victim, but I did not know that she did not consent, so this element cannot be proved"). Although this may be a legitimate argument to exclude 'without consent' from the definition of the crime, it is not a reason to label consent as a justification.

\footnotetext{
894 Cassese, A., 2008, p. 258 and Werle, G., 2005, pp. 164/165.

895 Fletcher, G.P., 2000, p. 707.

896 Fletcher, G.P, 2000, p. 705.
} 
Other arguments in favor of consent as a complete defense are, first, the $a$ priori exclusions in the ICC Statute and in Prosecutor v. Lubanga. Reasoning a contrario one could argue that the exclusion of the consent defense in specific cases means that the defense could be available in other cases. However, although the a priori exclusion may a contrario imply that the consent argument may be available in other cases, it does not necessarily imply that it must be available as a complete defense. A final argument in favor of consent as a complete defense is that it has some backup in (international) criminal (case) law. ${ }^{897}$

In sum, although it can be argued that consent should be a justification, because (a) it should not be an element of a crime, (b) it could be a complete defense under the ICC Statute through an a contrario reasoning and (c) the defense has some backup in (international) criminal case law, the fact that consent under its current definition is not a complete defense in a technical sense, is for now, a decisive argument against consent as a complete defense in international criminal law.

\section{(2) If consent were a complete defense: What should be its conditions?}

Next relevant question is whether the definition of the defense of consent could be altered in such a way that it could fall within the scope of a justification or an excuse. The answer to this question must be positive: if the general requirements for either justifications or excuses are added to the criteria of consent, this legal concept could function as a complete defense. In this case, the defense would have been met when the victim genuinely consented to the commission of the crime and this crime was objectively the best course of action, or when the defendant had no reasonable alternative. However, although consent could be molded into a complete defense, it is questionable whether this is desirable. Existing defenses may already cover these situations. What is more, it is doubtful whether in these situations consent really is a crucial factor. If the defendant for instance objectively chose the lesser evil, is it still relevant whether the victim consented? Finally, the opinion expressed by the ICTY and ICTR that international crimes are "almost universally coercive" does not leave much room for consent as a complete defense under international criminal law. Additional research is probably required to determine whether consent could be an independent complete defense under the ICC Statute.

Complete defense or not, consent of the victim can always be a factor of importance when determining the presence of a justification or an excuse. In case the victim consents to a crime, this may tip the scale to the lesser evil or, in case of excuses, make the option chosen by the defendant more reasonable.

See Part II and Blomsma, J., 2012, p. 417, who demonstrates that consent is controversial but has been, and could be recognized as a complete defense in domestic criminal law. Note that other authors (Schabas, Eser, Nill-Theobald and Van Sliedregt) mention consent as a possible defense in international criminal law. See for reference to these authors: Sliedregt, E. van, 2012, p. 223. 
How should complete defenses be applied under international criminal law

(for each defense)?

\section{INSANITY}

(1) What is the difference between insanity and diminished responsibility? (Particularly with respect to the volitional (control) element and the destruction or impairment of mental capacities.)

The analysis in Part II of this thesis demonstrates two points of obscurity when it comes to the distinction between insanity and diminished responsibility. The first revolves around the volitional prong of the insanity defense. ICTY case law defines the insanity defense in terms of cognition (the defendant does not know what he is doing or what he is doing wrong) while the ICC insanity provision defines insanity in terms of both cognition and volition (as to the latter the defendant cannot control his behavior). In ICTY case law, this volitional part is covered by diminished responsibility. 898 This raises the question whether insanity should be defined in terms of a cognitive disorder only, or in terms of both a cognitive and a volitional disorder.

The second area of vagueness pertains to the scope of insanity. The interpretation of the ICC Statute, discussed in Part II, demonstrates that commentators disagree on whether the defendant's capacities must be completely destroyed or merely impaired.

Below I first address why the definition of insanity should include both cognition and volition. Next I argue why the insanity definition should be restricted to destruction of mental capacities.

\section{Cognitive and volitional elements}

Although, in domestic legal systems, the volitional prong is more controversial than the cognitive prong, ${ }^{899}$ this is not a crucial reason to exclude this volitional prong from an insanity test. First, because an insanity definition in terms of volition and/ or cognition can also be brought back to several national legal systems. ${ }^{900}$ Second, because it is very possible that there are psychiatric conditions that prevent a person from resisting his impulses, ${ }^{901}$ and thus negate his criminal responsibility through the volitional prong. Third, because specialists in the field of forensic psychology

898 This is the definition from Mucić et al. discussed in Part II, Chapter V. Later case law on diminished responsibility, however, displays a broader definition, including a cognitive prong. See for example: ICTY, Prosecutor v. Banović, Trial Chamber, 28 October 2003, par. 80 and ICTY, Prosecutor v.Vasiljević, Trial Chamber, 29 November 2002, par. 283. That the ICTY has come to define diminished responsibility both in terms of cognition and volition is a fifth reason - next to the arguments mentioned below - to include both a cognitive and a volitional prong in an ICC insanity definition (as it currently does).

Scaliotti, M., 2002, p. 27. The reason for this may be that the volitional prong is probably harder to establish with a great degree of certainty.

900 Fletcher, G.P., 2000, pp. 841/842; Janssen, S., 2004, p. 84 and Sliedregt, E. van, 2012, p. 224.

901 Damasio, A. et al., 'Insensitivity to Future Consequences Following Damage to Human Prefrontal Cortex', In: Cognition, Vol. 50, pp. 7-15. The article demonstrates that patients with 
and psychiatry hold that it is fairly impossibly to determine the psychological condition of the defendant at the moment of the crime with an airtight degree of certainty, since you always have to go back in time. Consequently, second best is to make a reconstruction of facts with all options open (i.e. no a priori restrictions as to the volitional prong). ${ }^{902}$ Finally, the origin of the defendant's lack of options (cognitive or volitional) does not seem to be crucial in determining his criminal responsibility. Crucial is whether the defendant had a reasonable alternative. In my mind this reasonable alternative can, theoretically, be absent both in case of a cognitive and a volitional disorder. For all the above reasons, I recommend an insanity provision that covers both the cognitive and the volitional prong. Consequently, I do not recommend the ICC insanity provision to be altered on this point.

\section{Destruction or impairment}

The majority of commentators on the Rome Statute opt for destruction of mental capacities as opposed to impairment. I have to agree with them. Although, in earlier drafts of the ICC Statute, diminished responsibility was grouped with the insanity defense (in a separate paragraph), it was later deleted. ${ }^{903}$ This indicates that article 31(1)(a) means to cover a complete defense only. Impairment of mental capacities is now enclosed by Rule 145(2)(a)(i), which provides that "circumstances falling short of constituting grounds of exclusion of criminal responsibility, such as substantially diminished mental capacity" may be taken in mitigation.

The difference between insanity and diminished responsibility is thus that while they probably both cover the cognitive and the volitional prong of the insanity defense, insanity is a complete defense only applicable in case of destruction of mental capacities, while diminished responsibility is a mitigating factor applicable in case of impaired mental capacities. The classification of insanity as a complete defense versus diminished responsibility as a mitigating factor is common to many national jurisdictions. ${ }^{904}$

\section{(2) Should temporal mental incapacities also fall within the scope of insanity?}

Part II has demonstrated that many commentators on the ICC Statute have argued that temporal mental incapacities are not covered by article 31(1)(a). According to them the word "suffers" refers to a more permanent condition. They argue that temporal defects could still be covered by other complete defenses, such as duress

specific brain damage (to the prefrontal cortex) are oblivious to the future consequences of their actions and are guided by immediate prospects only. 
(article 31(1)(d) of the ICC Statute) and disproportionate self-defense (article 31(1) (d) in conjunction with article 31(2) of the ICC Statute).

I disagree with this interpretation. The previous Chapter has established that the absence of the ability to choose a reasonable alternative negates the blameworthiness of the defendant. Consequently, the relevant question in determining the responsibility of the defendant is to what extent does the insanity block the possibilities of the defendant? In answering this question it is not crucial whether the insanity is temporary or permanent. All the more so, because it is theoretically very well possible that the mental capacities of the defendant are only briefly disturbed by a cause beyond his control ${ }^{905}$ and that during this brief disturbance he did not see any option but to commit a crime. In addition, as the answer under question (1) demonstrates, specialists in the field of forensic psychology and psychiatry also hold that all options should be left open, when reconstructing the mental condition of the defendant at the moment of the crime.

What is more, though it is true that temporal defects can be covered by duress and disproportionate self-defense, these legal concepts do not cover temporary mental disturbances that are caused by a sudden internal imbalance (e.g. an epileptic episode). The argument that other complete defenses cover temporal mental disturbances can thus not eliminate the necessity of a temporary insanity defense.

Additionally, the ban on temporary insanity is a typical ICC fad. It cannot be traced back to the (case) law of the ad hoc tribunals.

Finally, contrary to the opinion of ICC commentators, the word 'suffers' is not a linguistic bar to including temporary insanity. One can suffer from a fit of coughing which only lasts two minutes.

\section{(3) What is the policy in relation to the acquitted insane?}

Part II of this study has demonstrated that nowhere in international criminal law is there a policy in relation to the acquitted insane. The acquitted insane is free to go wherever he wants. There is no special program or mental hospital. This is an urgent problem that should be fixed with due dispatch. As long as there is no clear policy as to the acquitted insane, international courts will never accept an insanity plea: sending off an excused but completely insane person is simply not an option. ${ }^{906}$ I therefore recommend that the ICC prioritizes the development of a clear and reasonable policy to cope with not only the acquitted insane, but also perpetrators suffering from diminished responsibility. This policy could be based on comparative (legal) research.

905 Cartwright, R., 'Sleepwalking Violence: A Sleep Disorder, a Legal Dilemma, and a Psychological Challenge', In: The American Journal of Psychiatry, Vol. 161, Issue 7, pp. 11491158.

906 Cryer, R. et al., 2010, p. 406 and Janssen, S., 2004, p. 85. 


\section{INTOXICATION}

(1) The distinction between voluntary and involuntary intoxication: Is it an adequate tool to determine the criminal responsibility of the defendant?

The previous Chapter has established that a defendant is not blameworthy when there is no reasonable alternative available to him. In determining whether the distinction voluntary/involuntary intoxication is an adequate tool to establish the criminal responsibility of the defendant, it is crucial that this distinction tells us something about the options available to the defendant. In my opinion this distinction does not provide a necessary contribution to the determination of the options of the defendant for the following reasons.

First, the distinction between voluntary and involuntary intoxication is not well defined. Part II of this thesis demonstrates that it is not clear whether the distinction voluntary/involuntary refers to the division intentional/not intentional or to voluntary/coerced. What is more, it is obscure whether this voluntariness refers to the taking of the substance or the intoxication itself. In addition, it is ambiguous how the ICTY case law on intoxication must be understood in the light of the ICC provision. Also international criminal law literature struggles with the definitions of voluntary and involuntary intoxication. ${ }^{907}$ This lack of a clear definition, in turn, has - among other reasons - resulted in a controversy on which types of intoxication should be available as an excuse. ${ }^{908}$

Second, even if we would agree on a definition of both types of intoxication (for example, in case of voluntary intoxication the defendant has a mental element as to the state of intoxication, in case of involuntary intoxication he has not) we would still have the problem that this categorization provides a somewhat roundabout way of determining the blameworthiness of the defendant. For - according to the ICC provision - when a defendant had no mental element at the moment of the crime, the Court first has to determine whether this defendant got negligently intoxicated (i.e. voluntarily). When the intoxication was indeed negligent (i.e. voluntary), the Court has to determine whether the defendant was negligent as to the intoxication causing the commission of the crime. The necessity of such a three-stage process is debatable. The problem of the intoxicated defendant can probably also be addressed through a two-stage approach: a provision applicable in case the defendant a) had no other reasonable option at the moment of the crime b) did not make a prior fault. ${ }^{909}$ Under the latter condition the court can take all relevant prior faults into account simultaneously. Since this two-stage option circumvents the definitional problems of voluntary/involuntary intoxication, is at least equally able to determine the blameworthiness of the defendant, and better suits the system proposed in this Chapter, I prefer this model. 


\section{(2) How should voluntary and involuntary intoxication be defined?}

Since the distinction between voluntary and involuntary intoxication is not necessary to determine the blameworthiness of the defendant, the above question is irrelevant to the proposal submitted in this thesis.

\section{(3) Can voluntary intoxication be a complete defense?}

Since the distinction between voluntary and involuntary intoxication is not necessary to determine the blameworthiness of the defendant, the above question is irrelevant to the proposal submitted in this thesis.

\section{(4) What should the defense of intoxication look like?}

For the reasons argued under question (1), the ICC intoxication provision should be replaced by a provision applicable in case the defendant a) had no other reasonable option at the moment of the crime b) did not make a prior fault. In this case a defendant can only be acquitted when his mental capacities are absolutely destroyed at the moment of the crime and he could not foresee and avoid committing a crime. As a result, the conditions for intoxication are no longer different from those of insanity. Consequently, intoxication should merge with the insanity provision in the following manner:

1. A defendant shall not be criminally responsible if at the time of his conduct:

The person suffers from a disease or defect that destroys that person's capacity to appreciate the unlawfulness or nature of his or her conduct, or capacity to control his or her conduct to conform to the requirements of law;

The general prior fault provision (Section 2) should also be applicable to this defense.

\section{Comments}

- An additional argument for merging insanity and intoxication lies in the fact that the difference between these two conditions is not always clear-cut. For example, if intoxication is a chronic condition, should it be qualified as insanity (alcoholism is a mental disease) or intoxication? And what if insanity is caused by intoxication? In many cases it will be hard to draw the line. ${ }^{910}$

- An explicit reference to intoxication is not necessary, since intoxication can be defined as a defect.

- The word "mental" is deleted to include situations of automatism (see Section 11).

910 Cryer, R. et al., 2010, p. 407; Knoops, G.J., 2001, p. 123 and Sliedregt, E. van, 2012, p. 232. For the interrelationship between mental condition (diminished responsibility) and alcoholism see: ICTY, Prosecutor v. Vasiljević, Trial Chamber, 29 November 2002. 


\section{Mistake}

\section{(1) Should mistake require an objective or subjective test (or both)?}

The previous Chapters have demonstrated that mistake is an excuse (Part II). A defendant is excused when he could not have chosen a reasonable alternative. The availability of this reasonable alternative is tested subjectively (Could this defendant have chosen a reasonable alternative?). However, objectivising is almost always necessary, since we cannot look inside the defendant's head (Chapter XIV).

The current mistake provision of the ICC displays a - different - subjective test (derived from Anglo-American legal culture), ${ }^{911}$ demanding a lacking definitional subjective element. This makes the provision superfluous: conviction without a definitional subjective element is impossible anyway, as is also expressed by article 30 of the ICC Statute.

What is more, the provision allows for conviction in violation of the principle of individual criminal responsibility, for it leaves no room for a defendant acting intentionally, but reasonably (because he had no reasonable alterative). ${ }^{912}$ For example:

A defendant intentionally directs attacks against buildings dedicated to religion (article 8(2)(b)(ix) of the ICC Statute), but makes a reasonable mistake as to its status as a military objective.

In this case, the ICC defense of mistake is not available because the intent of the perpetrator can be established. However, because the defendant's mistake is reasonable, he is not blameworthy. Still, he can be convicted.

Part II of this study has demonstrated that both the commentators on the ICC Statute and case law have favored normative and/or objective tools investigating reasonable alternatives to determine whether the defendant could have avoided his mistake. They have introduced a 'should have known' test (hereinafter 'knowledge test'). According to this knowledge test, a defendant who should have known about a reasonable alternative, i.e. about specific circumstances that would have made him behave differently, is criminally responsible. In case of a knowledge test, not only the defendant lacking a definitional subjective element is acquitted, but also the defendant possessing a definitional subjective element, but with no reasonable alternative available to him due to an excusable lack of knowledge (as in the above example). Under a knowledge test a defendant who is not blameworthy, cannot be convicted, as opposed to the defendant submitted to the definitional subjective element test in the current ICC provision. The knowledge approach, displays a civil law angle. ${ }^{913}$

\footnotetext{
911 Sliedregt, E. van, 2012, p. 286.

912 Verseveld, A. van, 2012, pp. 59 and 76-78. See also Chapter XIII of the present thesis.

913 Cryer, R. et al., 2010, p. 414.
} 
An additional advantage of the knowledge test is that mistakes in relation to defenses can also be excused when the defendant is not blameworthy. ${ }^{914}$ Take for example a mistake in relation to the availability of self-defense:

\section{A soldier believes he can commit a crime against humanity to defend the property of his military unit, while art. 31(1)(c) only allows for war crimes under these circumstances. ${ }^{915}$}

Under the current ICC provision, the required intent of the soldier can be established and he can be convicted for a crime against humanity. However, if mistake is also defined in terms of a knowledge test, the soldier can be acquitted, if he was not and could not have been aware of the exact distinction between war crime and crime against humanity.

In addition, a mistake provision including a knowledge test renders a separate superior orders provision superfluous (superior orders is an exception to article 32: the provision absolves the defendant who does possess the required definitional subjective element but passes a knowledge test). ${ }^{916}$

Based on the foregoing, I suggest a rephrasing of the mistake provision of the ICC Statute including both an objective test (testing what the defendant should have known) and a subjective test (testing the actual knowledge of the defendant). The latter can negate the definitional subjective element but does not necessarily have to: ${ }^{917}$

1. A defendant shall not be criminally responsible if at the time of his conduct:

The defendant had no reasonable alternative because he was mistaken and his mistake was unavoidable. ${ }^{918}$

The general prior fault provision (Section 2) should also be applicable to mistake. ${ }^{919}$

914 In the context of the Goetz case Fletcher discusses three different approaches to putative defenses and concludes, referring to Aristotle's Nicomachean Ethics, that a mistake in relation to the availability of a defense can negate the blameworthiness of the actor. See: Fletcher, G.P., 1998, pp. 88-91.

Ambos, K., Der Allgemeine Teil des Völkerstrafrechts. Ansätze einer Dogmatisierung, Duncker \& Humblot, Berlin, 2004, p. 819. Van Verseveld refers to an interview with a military professional and points out, that this example is "purely theoretical" because it "unjustly presumes that a soldier knows what constitutes a crime against humanity" (See: Verseveld, A. van, 2012, p. 152). However, I have decided to use the example for its illustrative value.

916 Verseveld, A. van, 2012, p. 96.

917 For example, in case of mistakes relating to the availability of the defense, the absence of knowledge does generally not negate the definitional subjective element.

918 Verseveld, A. van, 2012, p. 97 has designed a provision with a similar content, but different phrasing.

919 Despite the fact that the knowledge test and the prior fault test may overlap. 
(2) Do mistake of fact and mistake of law require different tests (i.e. is the distinction between these legal figures relevant)?

The above rephrasing of the ICC mistake provision refers to mistake in general terms, without distinguishing between mistake of law and mistake of fact. Deleting this distinction is motivated by several considerations. Firstly, the distinction is not always clear. In Part II a mistake of fact has been defined as a non-recognition of a material element of the crime, while in case of a mistake of law the defendant is aware of the material elements of the crime, but erroneously evaluates the law, because of the unawareness or misinterpretation of an existing norm. However, this distinction is not always obvious in practice. Literature has demonstrated there are borderline cases, residing between mistake of law and mistake of fact. ${ }^{920}$ For example, whether a certain group is legally protected with regard to genocide is a matter that straddles both law and fact. ${ }^{921}$

Secondly, the distinction is not conclusive in determining the legal guilt of the defendant. True, Part II has demonstrated that a mistake of fact generally negates intent, while a mistake of law does not (knowledge of a legal norm is usually not an element of a crime). It has also established that, for policy reasons, ${ }^{922}$ a mistake of law is less accessible (ignorantia legis non excusat) than a mistake of fact. However, that does not mean that a mistake of law can never negate intent or exculpate. The distinction does not touch upon the blameworthiness of the defendant, which is prescribed by the reasonable options available, not the nature of his mistake. Consequently, the distinction between mistake of fact and mistake of law is not conclusive in determining the legal guilt of the perpetrator. Similar reasoning can be applied in case of insanity, intoxication (above) and necessity/duress (below), where the exact definition of the cause of the excusing circumstances is not as important as the reasonable alternatives available to the defendant.

\section{(3) How, if at all, should putative defenses be included in the mistake defense?}

The answer under (1) has demonstrated that putative defenses should be included in the mistake defense and how this should be done (by extending mistake provision to blameworthiness).

\section{(4) How, if at all, should the mistake defense be extended to ignorance?}

Part II has referred to the argument that mistake must be interpreted to cover ignorance, because both mistaking and not perceiving a fact negates the definitional subjective element. However, now that an extension of the mistake requirement has been suggested (question (1)) in the form of a knowledge test, is this argument still valid? I reckon it is. Both mistaking and not perceiving a fact can negate the

920 Fletcher, G.P., 2000, p. 686; Ohlin, J.D., 2009, p. 423; Sliedregt, E. van, 2012, pp. 271 and 227 and Verseveld, A. van, 2012, p. 5.

921 Eser, A., 2008, pp. 935/936.

922 Schabas, W.A., 2009, p. 395. 
blameworthiness of the defendant, as long as he did not know and could not have been aware of the relevant circumstances. ${ }^{923}$

\section{SUPERIOR ORDERS}

\section{(1) Should superior orders in general be a complete defense in international} criminal law?

In the history of international criminal tribunals, superior orders has been one of the most controversial complete defenses. Over the last few decades, international courts have moved from an absolute liability approach at the ad hoc tribunals to a partial absolute, partial conditional liability approach at the ICC. However, is this development desirable? Should superior orders be available as a complete defense under international criminal law, especially since its availability at an international criminal court is a novelty introduced by the ICC Statute?

Chapter XIV has demonstrated that a defendant deprived of a reasonable alternative should in general be excused. Consequently, somebody acting under a superior order with no reasonable alternative - because he did not know the order was unlawful and could not have been aware of it -924 should be able to raise this argument successfully. Superior orders should thus be available as a complete defense under international criminal law. A priori excluding this defense, as was done at Nuremberg and the subsequent ad hoc tribunals, is contrary to the principle of individual criminal responsibility, as was argued in Chapter XIII.925

(2) If superior orders must be a complete defense, are the ICC criteria adequate? In the ICC Statute, the superior orders provision (article 33) is an extension of the mistake provision (article 32) absolving a subordinate making a mistake of law, who is not blameworthy. However, since one of the recommendations on mistake (previous Section) is that this provision should be extended to include blameworthiness - and thus the situations covered by the original superior orders provision - a separate superior orders provision is no longer necessary.

If superior orders is covered by the suggested mistake provision, certain requirements of the current provision are dropped, mainly the whole requirement of an order by a superior that the defendant is legally obliged to follow and the a priori exclusion of superior orders in case of genocide and crimes against humanity. As to the first issue: although these requirements, when met, illustrate the position of the defendant, they do not say anything conclusive about his blameworthiness. When a

923 An extension of the definition of mistake puts the case law studied in Part II in a different light. Especially in Nuremberg, defendants argued occasionally that they did not perceive a certain fact (Wir haben es nicht gewusst): International Military Tribunal (Nuremberg), Judgment and Sentences, 1 October 1946. In: American Journal of International Law, vol. 41, 1947, p. 285 (Kaltenbrunner), p. 290 (Frank), p. 320 (Seyss-Inquart) and p. 325 (Von Neurath).

925 For a specific argument in relation to superior orders see: Knoops, G.A., 2001, p. 45. 
defendant did not know he was acting against the law and could not have been aware of this, he is not blameworthy. When he was not under a legal obligation to act the way he did, this cannot turn his innocence to guilt. ${ }^{926}$ That the defendant acted under an order by a superior, which the defendant had a legal obligation to follow, are mere factors that can be taken into account when determining whether the defendant should have know his act was illegal. The superior order may, for example, be a sign of the subordinate position of the defendant and thus indicate a minimum amount of knowledge. Or it may underline that the defendant could not have been aware of the relevant legal situation, since he reasonably relied on the information provided by his superior, etcetera. If the superior has exercised such a degree of pressure on the defendant that he thought he had no other option but to obey, the defendant should raise a different defense, namely necessity/duress (discussed below). ${ }^{927}$

Considering the a priori restriction as to genocide and crimes against humanity, Chapter XIII has demonstrated that a priori restrictions as to a specific defense or a specific crime are in violation of the principle of individual criminal responsibility and contrary to the objectives of international criminal law. However, this restriction has also been criticized for several other reasons. These reasons are related to the somewhat problematic idea that genocide and crimes against humanity are manifestly unlawful, while war crimes are not.

First, article 33(2) assumes that every example of a war crime will necessarily be less repulsive than every example of a crime against humanity and, perhaps more legitimately, every example of genocide. ${ }^{928}$ This is, however, not always the case. A single assault can for example be qualified as a crime against humanity, while mass killings can be qualified as a war crime.

Second, article 33(2) causes problems in case a double qualification of the crime charged is possible. In these cases the qualification may be crucial to the outcome of a case: a war crime may lead to a successful appeal to superior orders followed by an acquittal while a crime against humanity may lead to a conviction. The availability of a complete defense should not depend on the qualification of a crime.

Third, it is doubtful whether the distinction between war crimes on the one hand and the manifestly unlawful crimes on the other is always clear to the average soldier, since these crimes often cover the same set of facts. ${ }^{929}$

Fourth, article 33(2) is contrary to customary law. The distinction between the two categories of crimes has no foundation in international custom and is merely the result of negotiations..$^{930}$

\footnotetext{
926 Dinstein makes the same argument, however, only related to the mental element: Dinstein, Y., 2000 , p. 381.

927 Dinstein, Y., 2000, p. 388.

928 Cryer, R. et al., 2010, p. 419.

929 Zahar, A., 2009, p. 527.

930 Cassese, A., 2008, p. 279.
} 
Finally, article 33(2) is practically superfluous anyway, because genocide and crimes against humanity can in most cases be found manifestly unlawful based upon the should have known criterion contained by paragraph (1)(c).931

Although it is highly unlikely that a reasonable mistake in relation to genocide or crimes against humanity may occur, the a priori exclusion in case of these crimes should be dropped from the Statute of Rome for the reasons mentioned above.

As to the interpretation of the should have known criterion in the context of superior orders (absence of manifest illegality in article 33), a narrow interpretation is probably advisable. Traditionally the concept of manifest illegality excludes cases where situational judgment is necessary. ${ }^{932}$ Consequently, only the obvious cases of gross human rights violations fall within the concept of manifest unlawfulness. On the other hand, there are sensible arguments to widen the scope of manifest unlawfulness and thereby enhance the personal responsibility of the individual soldier to find and evaluate information on the legality of a situation. ${ }^{933}$ Still, this responsibility must never outgrow the possibility of the individual soldier to obtain reliable information, independent of their government. ${ }^{934}$

\section{NeCESSITY/DURESS}

\section{(1) Should there be a distinction between a justificatory and an excusing} defense and, if so, how should these defenses be defined?

Part II of this thesis has demonstrated that the legal practice of international criminal tribunals has developed both a justificatory and an excusing version of necessity/duress. However, these versions do not equal the linguistic distinction between 'necessity' and 'duress'. In the justificatory equivalent of necessity/duress, the defendant claims he objectively made the best choice. In the excusing equivalent, the defendant argues he had no reasonable alternative. I think this distinction between justification and excuse in case of necessity/duress should be formalized in international criminal law for the following reasons:

- The distinction already exists in international criminal case law;

- Several international criminal law scholars prefer this distinction; ${ }^{935}$

- The distinction exists in several national jurisdictions; ${ }^{936}$

\footnotetext{
931 Sliedregt, E. van, 2012, p. 296.

932 Osiel, M., 1999, pp. 73/74.

933 Osiel, M., 1999, pp. 83-86.

934 Osiel, M., 1999, pp. 86.

935 Ambos, K, 2008, p. 1036; Chiesa, L.E., 2008, p. 773 and Sliedregt, E. van, 2012, p. 267. However, a number of scholars do not make this distinction. They distinguish the concepts of necessity and duress on other grounds. See: Cassese, A., 2008, p. 281; Dinstein, Y., 2000, p. 373; Gilbert, J., 2006, p. 150; Ohlin, J.D., 2009, p. 431; Bantekas, I and Nash, S, 2007, p. 64 and Knoops, G.J., 2001, p. 13.

936 Dolman, M., 2006, p. 323; Fletcher, G.P. and Krabbe, M.J.M., 2004, p. 52.
} 
- A distinction between justifications and excuses in general leads to a more nuanced communication between court and general public and increases judicial fairness; it contributes to a foreseeable, accessible but open system of complete defenses in international criminal law and the distinction exists in international criminal law literature, practice and national jurisdictions (see Section 3.1 of Chapter XIV).

- Literature does not offer any convincing reasons why this distinction should not be maintained (see also Section 3.1 of Chapter XIV).

The justificatory version of necessity/duress should at least contain the basic requirements for a justification:

- A necessary act;

- A proportionate act;

- A mental element.

The excusing prong of necessity/duress should only be applicable in case the defendant had no reasonable alternative. A suggestion for rephrasing the necessity/ duress provision of the ICC Statute is provided for under question (4).

\section{(2) Should the Erdemović-exclusion be applicable in case of a justificatory defense and/or an excusing defense?}

In the ICTY Erdemovic case it was established that duress is not a complete defense in case a soldier kills innocents. The reasoning of the majority is based on a conduct-shaping argument: a priori rejection influences the behavior of soldiers in the field. This, in turn, contributes to the objective of international humanitarian law (protection of the weak), which must be enforced by the Tribunal. According to the majority, duress can, however, be a mitigating factor. Chapter XIII has demonstrated that an a priori exclusion of a complete defense is contrary to the principle of individual criminal responsibility and to the objectives of criminal law. The exclusion should thus never be applicable without testing the situation on its merits first; neither in case of a justification, nor in case of an excuse. ${ }^{937}$

However, when a justification would be pleaded in an Erdemović-like situation - or in any situation where innocent victims are killed - the proportionality requirement will probably be never met, for weighing lives against each other is both practically impossible and ethically doubtful. ${ }^{938}$ So although complete defenses should not be excluded a priori, a soldier killing innocents probably only has a chance of successfully pleading an excuse, not a justification. 


\section{ADDITIONAL GROUNDS FOR REJECTING THE MAJORITY REASONING}

Apart from being a violation of the principle of individual criminal responsibility, the reasoning in the Erdemović case is fallacious for several other reasons. Additional grounds for rejecting the majority reasoning are listed below.

\section{Foreseeability and accessibility}

First and foremost, the majority approach has no foundation in international criminal law. Although complete defenses may not be fully protected by nullum crimen sine lege, they must be foreseeable and accessible to some extent (see Chapter XIV). Consequently, when concluding that there is no customary rule or legal principle in the specific case of duress and killing, the judges should not have created a new rule in international criminal law by falling back on common law doctrine (not foreseeable), but instead rely on the general rule on duress (i.e. the requirements derived from custom and general principles). ${ }^{939}$ The fact that the common law doctrine on duress itself has been subject to severe criticism for lack of foundation on any legal principle ${ }^{940}$ only adds to the questionable status of the rule chosen by the majority.

\section{Conduct-shaping effect?}

Not only this formal aspect (i.e. the source of the applicable rule) of the majority's reasoning is susceptible to criticism, also the way they substantiate their decision does not hold water. The majority presumes that a priori rejection of duress influences the behavior of soldiers in the field and would therefore save innocent lives. It is, however, doubtful whether denying the defense of duress would protect lives. ${ }^{941}$ This assertion is not supported by empirical evidence. What is more, even as a common sense reasoning, the argument of the majority is fallacious. It may be true that if a person under pressure has to choose between instant death and acquittal for acting under duress, he will presumably opt for the latter. However, if this very same person had to choose between instant death and possible future prosecution, he would prefer the latter option as well (being less severe and not in the near future), nullifying the deterrent effect of the denial of duress. ${ }^{942}$ On top of

939 As noted by Judge Cassese in: ICTY, Prosecutor v. Erdemović, Separate and Dissenting Opinion of Judge Cassese, Appeals Chamber, 7 October 1997, par. 11 and 49.

940 See: ICTY, Prosecutor v. Erdemović, Separate and Dissenting Opinion of Judge Stephen, Appeals Chamber, 7 October 1997, par. 49.

941 Eser, A., 1996, p. 265. Point also made by Judge Stephen: ICTY, Prosecutor v. Erdemović, Separate and Dissenting Opinion of Judge Stephen, Appeals Chamber, 7 October 1997, par. 65.

942 Brooks, R., 'Law in the Heart of Darkness: Atrocity and Duress', In: Virginia Journal of International Law, Vol. 43, Issue 3, 2003, pp. 861-888, p. 867 and Paphiti, A.S., 1999, pp. 249288, p. 279. 
that, one could easily argue the other way round, i.e. that not admitting the defense of duress magnifies the number of innocent victims (e.g. if $\mathrm{X}$ kills $\mathrm{Y}$ under duress, and can't resort to this defense, $\mathrm{X}$ might find it necessary to kill witnesses $\mathrm{Z}$ and $\mathrm{Q}$ as well to prevent them from telling on him). Finally, the essence of an excuse is that it is only applicable to the defendant who had no reasonable alternative as he chose this particular option because there was no other. Finding himself again in exactly the same situation, the defendant would make precisely the same choice. Consequently, the conduct of a defendant acting under an excuse cannot be deterred. ${ }^{943}$

Apart from all these arguments that revolve around the conduct-shaping effect of duress, it is also questionable whether complete defenses in general - and duress specifically - are supposed to have a conduct-shaping effect, since they are 'decision rules' directed at judges, employed to assess a situation after the facts have taken place and not a tool with which individual conduct is shaped. ${ }^{944}$

\section{Too high a standard}

Finally, the majority rule is also inadequate as to its contents. First criticism on the contents of the majority rule is that it sets too high a standard. The rule basically demands from a person (in this case a person being a soldier), who has to choose between his life and that of another, to forfeit his own. Since law should be based on what society can reasonably expect of its members, and we can hardly reasonably expect people to sacrifice their own lives, the rule is inadequate. ${ }^{945}$ Even in case of a soldier, whose job, in the words of Judges McDonald and Vohrah, "entails the occupational hazard of dying" 946 the standard is harsh. For although a soldier may have considered the possibility of dying on the battlefield, his decision to join the army despite this risk, does not automatically oblige him to sacrifice his own life when forced to commit an international crime at gunpoint. ${ }^{947}$

The majority denies that their rule effectively puts up a high standard. On the contrary, the threat under which the defendant acted can mitigate his punishment. In some cases it can even mitigate his punishment to no punishment at all. ${ }^{948}$

Cassese rightly rejects this approach. He holds that conviction plus mitigation communicates that the behavior of the accused was criminal and that he should have behaved differently. This is not the correct approach in cases where, based

\footnotetext{
943 Ambos, K., 2002, p. 1045.

944 See Chapter XIV, Section 2.

945 Ambos, K, 2002, p. 1043; Nill-Theobald, C., 1998, p. 279. Also noted by Judge Cassese: ICTY, Prosecutor v. Erdemović, Separate and Dissenting Opinion of Judge Cassese, Appeals Chamber, 7 October 1997, par. 47.

ICTY, Prosecutor v. Erdemović, Joint Separate Opinion of Judge McDonald and Judge Vohrah, Appeals Chamber, 7 October 1997, par. 84.

947 Compare: Wilt, H.G. van der, 2011, p. 293.

948 ICTY, Prosecutor v. Erdemović, Joint Separate Opinion of Judge McDonald and Judge Vohrah, Appeals Chamber, 7 October 1997, par. 85.
} 
upon the merits, the defendant could not have behaved differently and is thus not guilty. ${ }^{949}$

Intuitively, the majority reasoning does not seem unreasonable. A perpetrator who did something awful (Erdemović killed about 70 people and thereby deprived hundreds of people of their loved ones) on the one hand received punishment, while on the other hand the extremity of the situation (no reasonable choice at the moment of the crime) is taken into account through mitigation. Since both acquittal and conviction seem inappropriate, the majority rule brings a middle-of-the-road solution. However the previous paragraphs have demonstrated that the majority rule demands an unreasonable amount of courage from people and that it violates the principle of individual criminal responsibility. Apart from that, the majority rule is at odds with nullum crimen sine lege and its purpose is substantiated by untenable arguments.

\section{(3) When should necessity/duress be taken in mitigation?}

Necessity/duress should only be taken in mitigation when (a) the defense cannot be made out and (b) there are reasons for mitigation. Mitigation should not be employed to compensate for the unavailability of a complete defense, as the Erdemović majority suggests. This for the reasons mentioned by Cassese, paraphrased under question (2).

\section{(4) Does the ICC definition suffice and how should it be interpreted?}

Part II has demonstrated that the ICC necessity/duress provision is a mixture of a justification and an excuse and therefore, neither. The defense is not a justification because, due to the subjective proportionality requirement, it does not demand the defendant to make objectively the best choice. However, due to the very same subjective proportionality requirement a defendant who has no reasonable alternative (and is thus technically not blameworthy) cannot resort to duress in the sense of the ICC, if he did not intend to act proportionately. It is submitted here that article 31(d) of the ICC Statute should be re-phrased, containing a separate justification and excuse, for the reasons mentioned under question (1), in the following manner:

A defendant shall not be criminally responsible if at the time of his conduct:

The defendant reacted to an imminent or present danger and:

(a) deliberately performed a necessary act that did not cause greater harm than the one sought to be avoided; or

(b) there was no reasonable alternative available to the defendant.

949 ICTY, Prosecutor v. Erdemović, Separate and Dissenting Opinion of Judge Cassese, Appeals Chamber, 7 October 1997, par. 48. 


\section{Comments}

General

- The justificatory prong of the defense includes a mental element and the requirements of necessity and proportionality.

- The excusing prong of the defense includes the requirement of absence of a reasonable alternative.

- The specific description of the required amount of necessity/duress and the object of necessity/duress ("a threat of imminent death or of continuing or imminent serious bodily harm against that person or another person") is deleted, to keep the provision broad. This is necessary in order to prevent from conviction a person, who was (a) under a lesser threat or defending property and (b) who has either objectively taken the best course of action or had no reasonable alternative. The word 'imminent' should be retained as a clarifying condition and to bring the necessity/duress provision in accordance with the provision on self-defense.

- The alternative of a present danger has been added, to underline that not only imminent but also ongoing dangers fall within the scope of necessity/ duress.

- The causal connection between crime and threat is expressed by the words "reacted to" (in the original provision the word "resulting" was inserted for this purpose).

- The requirements of necessity, reasonably and proportionality are rephrased and brought in accordance with the self-defense provision, since Part II of this study has established that there is much confusion about the use of these elements in article 31(1).

- The prior fault requirement is deleted but has reappeared in a general prior fault provision applicable to all complete defenses.

- Note that cases of excusing necessity/duress that affect the mental condition of the defendant also fall within the scope of the suggested insanity/intoxication provision.

PROPORTIONALITY IS NOT A REQUIREMENT OF THE EXCUSING PRONG

In the above suggestion for a necessity/duress provision, proportionality is not a requirement for the excusing prong. Since the proportionality requirement is a frequently appearing requirement of necessity/duress this choice must be further explained. The reason that proportionality is not included in the excusing prong is that it is not a requirement in case of excuses (See Chapter XIV). An excuse refers to the situation where the conduct of the defendant is wrongful, but the defendant himself is not blameworthy, because he had no reasonable alternative. This means that when a proportionate choice would have been a reasonable alternative, the defendant should have made such a choice as well. However, if a proportionate 
choice was not a reasonable alternative, the defendant's choice can be disproportionate, while the defendant is free of blame. One can think of situations in which a reasonable alternative is not a proportionate choice. For example, due to the amount of pressure, lack of information or lack of time to make a balanced decision. Consequently, proportionality is not a conditio sine qua non when it comes to excuses: it is a factor in determining blameworthiness, not the determinant factor.

This is confirmed by requirements for other excuses, where the proportionality criterion is also absent. The reaction of an insane or intoxicated person is not required to be proportionate, nor the reaction of a person committing a crime by mistake. Both the lack of distinction between justification and excuse and consequently the unwarranted demand of a proportionality requirement by the minority, take up a lot of discussion space in the Erdemović Judgment, while not touching upon the essence of the underlying dilemma.

\section{LAWFUL BELLIGERENT REPRISALS}

(1) Should reprisals be a ground for excluding criminal responsibility under article 31(3) of the ICC Statute?

Part II has established that reprisals are a generally available justification, as long as the reprisal is not in violation of the applicable humanitarian law. Consequently, a reprisal under this condition could also be available as a complete defense under article $31(3)$ of the ICC Statute ${ }^{950}$ or as a codified defense.

\section{(2) If yes, on what conditions?}

The conditions for a lawful reprisal derived from the case law analyzed in Part II are the following:

a. The reprisal is an otherwise unlawful response by a belligerent to a violation of law committed by the other belligerent;

b. The sole purpose of the reprisal is seeking compliance with the law of armed conflict by the opposite party;

c. The reprisal must have been the last resort;

d. Reprisals may be exercised only after a prior and formal warning;

e. Reprisals may only be taken after a decision to this effect has been made at the highest political or military level;

f. The measures taken must be proportionate to the initial violation of the law of armed conflict by the opposite party;

g. The reprisal must cease as soon as the breach, which provoked the reprisal, ends;

950 Sliedregt, E. van, 2012, pp. 261/262. See also: Schabas, W.A., 2009, p. 396. 
h. The reprisal must respect the "laws of humanity and dictates of public conscience".

The above criteria derived from case law include the general criteria for a justification mentioned in Chapter XIV: necessity, proportionality and a mental element. Case law has developed these criteria in several more specific (clarifying) conditions (e.g.: there can only be a last resort when there has been a formal warning), which are also supported by literature. ${ }^{951}$ There is no need to delete these clarifying conditions for the purpose of creating a broader provision. Chapter $\mathrm{XIV}$ has explained that international law defenses (such as reprisals and selfdefense ad bellum) have more of a conduct-steering purpose than other defenses. Consequently, the requirements of an international law defense can be more detailed.

\section{(3) When are reprisals a priori excluded (e.g. by international humanitarian law)?}

The last condition (h) refers to the fact that reprisals must respect the "laws of humanity and dictates of public conscience". When these laws and dictates are not respected, the reprisal is thus not lawful. However, when is the defense of reprisals a priori excluded by these laws and dictates? The answer to this question is not clear-cut: there are a lot of grey areas and defining them demands a study beyond the scope of this thesis. However, there are some general handles.

In international conflicts, the Geneva Conventions and Additional Protocol I prohibit reprisals against most targets other than enemy combatants engaged in hostilities. ${ }^{952}$ However, this does not mean that these reprisals are always a priori excluded. The Protocol does not have the same uncontested customary law status as the Conventions (this was an issue in Kupreškić et al.) and the relevant provisions only protect specific categories of persons. ${ }^{953}$ Also, Additional Protocol II and common article 3 (applicable to internal armed conflict) are completely silent on the issue of reprisals. ${ }^{954}$ Despite these openings, there is a general tendency to move away from reprisals as an accepted legal concept. ${ }^{955}$ The most convincing argument against reprisals is that they are not necessarily effective in seeking compliance with the law from the adversary. They may even produce a contrary effect, setting up a process of escalation. ${ }^{956}$ Considering the foregoing there is probably not much room for reprisals in international criminal law. However, this may be an extra

\footnotetext{
951 Greenwood, C., 2006, p. 333 and Sliedregt, E. van, 2012, p. 262.

952 Greenwood, C., 2006, p. 331.

953 Sliedregt, E. van, 2012, p. 261.

954 Doctrine has argued in favor of analogous application of the prohibition on reprisals in Protocol II. See: Kalshoven, F. en Zegveld, L., 2001, p. 144.

955 Sliedregt, E. van, 2012, p. 261.

956 Oeter, S., 'Methods and Means of Combat', In: Fleck, D. (ed.), The Handbook of Humanitarian Law in Armed Conflicts, Oxford University Press, New York, 1998, pp. 105-207, p. 205.
} 
incentive for future codification, since it can prevent abuse. ${ }^{957}$ Especially since the defense of reprisals may become more relevant after 2017, when the ICC gains jurisdiction over aggression.

\section{Tu QUOQUE}

(1) Are there situations in which tu quoque could still provide a complete defense (for example when the crime charged does not amount to a violation of international humanitarian law or ius cogens)?

Part II has demonstrated that tu quoque has been - almost - consistently rejected, by and large for its anti-humanitarian character ( $t u$ quoque is based on reciprocity whereas international humanitarian law and ius cogens are non-reciprocal). This raises the question whether the defense could still be available in case of crimes not consisting of a violation of international humanitarian law or ius cogens. However, ultimately the anti-humanitarian character of tu quoque is not crucial to its availability as a complete defense. This anti-humanitarian character is merely a symptom of a more fundamental problem: the fact that tu quoque is not a complete defense in a technical sense. As Part II demonstrates, tu quoque is neither a justification nor an excuse, because the argument neither negates the wrongfulness of the crime nor the blameworthiness of the actor. Therefore tu quoque can never be a complete defense: not in case of severe international crimes, but also not in case of small domestic offenses.

The fact that tu quoque is not a complete defense in a technical sense is enough reason to exclude the defense from the ICC Statute. However, to be exhaustive there are several additional arguments against tu quoque as a complete defense:

a. Tu quoque has been consistently rejected after Nuremberg;

b. When the defense was accepted in Nuremberg it did not seem to negate the wrongfulness of the act or the blameworthiness of the defendant, i.e. the argument did not operate as a complete defense;

c. The argument discussed in Nuremberg was truly a tu quoque, directed at the bench, not an illi quoque that was brought up at subsequent courts. Therefore the acceptance of tu quoque in Nuremberg must be seen as an acknowledgement of hypocrisy by the allied forces sitting in the bench, rather than the acknowledgement of a complete defense;

d. In general, the tu quoque argument paves the way for an ever-increasing escalation of competing crimes. ${ }^{958}$

957 Nill-Theobald, C., 1998, p. 393.

958 Eser, A., 1996, p. 269. 
(2) Since violations of international criminal law are violations of legal bodies with an absolute character, are not all complete defenses incompatible with international criminal law? In other words, is the reasoning employed in Kupreškić et al. not applicable to all complete defenses?

In Kupreškić et al., tu quoque was rejected because the argument is based on reciprocity, and international humanitarian law and ius cogens are non-reciprocal: obligations arising from international humanitarian law or ius cogens must be fulfilled regardless whether the adversary fulfills his obligations. Continuing this line of reasoning, one could argue that for example self-defense is not a valid defense against violations of international humanitarian law and ius cogens, either: whatever the adversary does to you, you are not allowed to commit a crime under the pretext of self-defense, for you must fulfill your obligations regardless whether the adversary fulfills his. However, there is a difference between $t u$ quoque and other complete defenses (i.e. the defenses discussed in Section 2-9, with the exception of consent). While tu quoque really violates the principle of nonreciprocity, because a crime is countered by a crime, other complete defenses do not violate this principle. In case of a real complete defense in a technical sense, there is no crime: the defendant is justified or excused. Because tu quoque - as was demonstrated in Part II - cannot justify or excuse the act of the defendant, it cannot negate the criminal character of his act. Consequently, the tu quoque argument is contrary to the absolute character of ius cogens and international humanitarian law, while other complete defenses are not.

\section{(3) If $t u$ quoque is not a complete defense, what should its role in international criminal law be?}

The fact that $t u$ quoque is not a complete defense is not a reason to exclude the argument completely. A priori excluding the argument, as was done at the Tokyo Tribunal, will enhance the sense of victor's justice, which has haunted international courts ever since the establishment of the Nuremberg Tribunal. ICTY case law has demonstrated that the $t u$ quoque argument can be evidence refuting factual allegations. I see no reason why this line should not be continued. Whether $t u$ quoque should be a mitigating factor is debatable. The arguments mentioned under (1) argue against it.

\section{OTHER POSSIBLE DEFENSES IN INTERNATIONAL CRIMINAL LAW}

\section{(1) Which defenses could be applicable under these existing frameworks?}

Part II has demonstrated that all active international courts have open systems. Judges have the power to create new complete defenses and, in case of the ICC, to adjust existing defenses. Considering the open systems of active international criminal courts the question arises, as to which defenses could be applicable under these systems? 
Not every complete defense discussed in Part II of this thesis could be a complete defense within these open structures. The present Chapter has demonstrated that neither consent under its current definition nor tu quoque should be a complete defense under international criminal law. On the other hand, reprisals could be a complete defense under these open structures, although Section 9 of the present Chapter has indicated that codification of this complete defense is preferable. Self-defense, insanity, intoxication, mistake, superior orders and necessity/duress (both the justifying and the excusing prongs) currently are and should continue to be part of catalogue of complete defenses in the ICC Statute. These defenses should equally be accessible within the open systems of the ICTY and ICTR.

In addition, there are several complete defenses that have not been addressed by international criminal courts, but could be a complete defense in future cases under the open provisions of international courts. These are self-defense excess, automatism and what I refer to as indoctrination. All these possible defenses are briefly discussed below.

\section{Self-defense excess}

Self-defense excess is the excusing prong of self-defense. The defense refers to the situation where the defendant was attacked and resisted, but, due to the stress of the attack, exceeded the limits of proportionate self-defense. ${ }^{959}$ For example, X wants to hit Y. Consequently Y shoots X in self-defense. Although this is objectively a disproportionate means to avert the attack, Y was so stressed by the attack that he could not have seen another reasonable alternative. Consequently $\mathrm{Y}$ is excused. In Anglo-American literature a similar defense is referred to as 'provocation' or 'loss of control'. ${ }^{960}$ In a way it is not surprising that this defense has not come up in international criminal law. International conflict situations are inherently stressful and therefore bear the risk of defendants continuously being excused for exceeding the limits of self-defense. It is probably for this reason that the defense was not explicitly included in article 31 of the ICC Statute.

On the other hand, one can imagine situations where the attack on the defendant causes stress that affects the mind of the defendant in such a manner that he did not have a reasonable alternative to act excepting the way he did. In such cases a complete defense must be available to the defendant. It is, however, doubtful whether these situations require a separate provision under the ICC Statute. They will probably fit within the heading of the suggested provisions for either insanity or excusing necessity/duress. ${ }^{961}$

\footnotetext{
$959 \quad$ Sliedregt, E. van, 2012, p. 239.

960 Blomsma, J., 2012, p. 432 and Fletcher, G.P., 2000, p. 526.

961 Commentators on the ICC Statute have argued that this defense could be brought under the existing provisions. See Chapter 3, Section 5.2.
} 


\section{Automatism}

Automatism is at least once mentioned in ICTY case law. In the context of a contemplation on evidential issues in Prosecutor v. Hadžihasanović and Kubura the Trial Chamber refers to defenses "such as self-defense, duress, alibi, automatism (involuntary uncontrollable reflexes) and provocation". 962 The legal figure of automatism originates from Anglo-Saxon legal tradition and describes such states where the defendant's mind is prevented from directing his movements. ${ }^{963}$ For example, in case of an epileptic episode or sleepwalking. Technically, automatism is not a complete defense but a denial of the objective element negating the presence of a voluntary act. ${ }^{964}$ Part I of this thesis has however demonstrated that the issue whether the objective element should be a voluntary act is controversial but of little relevance, since one who committed an involuntary act will always be absolved of punishment (unless prior fault can be established). The fact that automatism may not be considered a complete defense in a technical sense is, however, not a reason to exclude the argument from the international arena. It is nonetheless doubtful whether automatism situations require a separate provision in the ICC Statute since cases of automatism where the defendant had no reasonable alternative, would fall within the scope of either insanity or intoxication.

\section{Indoctrination}

What I refer to as indoctrination, is a legal concept, which has been touched upon as a possible complete defense in international criminal literature. ${ }^{965}$ It refers to the situation where people have been consistently indoctrinated by their surroundings to such an extent that they had no reasonable alternative when committing a crime. For example, in case a young Hutu - who has been brought up with the idea that Tutsi do not deserve to live - participates in a genocide, chances are that he did not have a reasonable alternative. Likewise, when people grow up in a totalitarian regime with no access to information from the outside world (e.g. North Korea), they may perform acts which would be a crime to us, but perfectly legal within their frame of reference. Allowing for the defense of indoctrination is tricky for it can theoretically provide entire societies with an excuse. ${ }^{966}$ On the other hand, if a person really lacked a reasonable alternative, the

ICTY, Prosecutor v. Hadžihasanović and Kubura, Trial Chamber, 15 March 2006, par. 230.

McAuley, F. and McCutcheon, P., Criminal Liability, Round Hall Sweet \& Maxwell, Dublin, 2000 , p. 142.

965 Nill-Theobald, C., 1998, p. 386 and Smeulers, A., 'What Transforms Ordinary People into Gross Human Rights Violators?', In: Carey, S.C and Poe, S.C. (eds.), Understanding Human Rights Violations: New Systematic Studies, 2004, Ashgate Publishing Limited, Aldershot, pp. 239-251, p. 250.

966 Nill-Theobald, C., 1998, p. 386.
} 
previous Chapters have demonstrated that it is both immoral and ineffective to punish him. Consequently, prosecutors of international courts better aim their arrows at indoctrinators than at the indoctrinated. However, when faced with an allegedly indoctrinated defendant a court should always carefully assess whether the defendant did not have a reasonable alternative, and did not make a prior fault. If a defendant really did not have a choice in what he did, he should not be punished. Nevertheless, in this day and age of modern technology and - in most societies - unlimited access to information this will not be the case for much longer. A separate provision for indoctrination is not necessary, for these situations probably fall within the scope of insanity/mistake (in case of brainwashing) or duress (in case of a government of terror).

\section{Conclusion}

In conclusion, all theoretically possible complete defenses discussed under this heading (self-defense excess, automatism and indoctrination) could be available to a defendant charged with an international crime, be it that the basic requirements for an excuse are met (no reasonable alternative, no prior fault). Separate provisions for these legal concepts are probably not necessary since they fall within the scope of existing defenses (and the suggested provision). All defenses discussed in Part II of this thesis should - if not codified - be available under the open structures of international courts, except for consent under its current definition and tu quoque.

\section{(2) Are these frameworks compatible with the principle of nullum crimen sine lege?}

The principle of nullum crimen sine lege demands that people can know whether their planned course of action is acceptable or not. The previous Chapter has established that although the behavior of a defendant is probably not based on the definitions of complete defenses and therefore not fully protected by nullum crimen sine lege, this is no reason why complete defenses should not be foreseeable and accessible to some extent. After all, the guilt of the defendant is based both on offense and (lack of) defense. The operative international courts allow judges to make up new complete defenses. This raises the question whether this competence is in accordance with nullum crimen sine lege.

I reckon three factors are crucial in determining the limits of nullum crimen sine lege when it comes to creating new complete defenses:

a. The sources of international criminal law;

b. The basic questions underlying complete defenses;

c. Limits to changing the contents of a defense. 


\section{(a) The sources of international criminal law}

Foreseeability and accessibility is partially guaranteed by the fact that judges must base their self-created complete defenses on existing sources of international criminal law (as laid down in article 38 of the ICJ Statute at the recent ad hoc tribunals and article 21 of the ICC Statute) ${ }^{967}$ Note that these sources do not have to be written, as is common in continental European legal systems (nullum crimen sine lege scripta). ${ }^{968}$

\section{(b) The basic questions underlying complete defenses}

Foreseeability and accessibility is also partially guaranteed if judges of international courts base additional complete defenses on the basic questions underlying all complete defenses set out in the previous Chapter. In general, an underlying system increases internal logic and consequently foreseeability and accessibility of the rules based on this system.

\section{(c) Limits to changing the contents of a defense}

This factor is of particular relevance to the competence laid down in article 31(2) of the ICC Statute: the power to adapt existing defenses. This power should be limited in the following manner: the ICC should not adapt existing defenses in a manner detrimental to the defendant by narrowing down the scope of the complete defenses explicitly defined in its Statute. ${ }^{969}$ Once a defense is defined in a general manner (i.e. not in case law, but in a statute) a defendant must be able to rely on it. This outlook is an extended interpretation of the in dubio pro reo principle laid down in article 22(2) of the ICC Statute which provides that in case of ambiguity of a definition of a crime "the definition shall be interpreted in favor of the person being investigated, prosecuted or convicted".

If the above factors are complied with, a violation of - the extended - principle of nullum crimen sine lege is minimized. However, the question remains whether a system with the same degree of openness as is currently available to the operative international criminal courts, is truly necessary.

Although both existing complete defenses and the possible future complete defenses mentioned under question (1) all fit within the (suggested model of) complete defenses in the ICC Statute, some sort of open provision may still be desirable. One cannot foresee all future cases. When the Court finds that the basic conditions for a complete defense have been met (the defendant did objectively the best thing or he had no reasonable alternative), it should be able to acquit. Therefore article 31(3) should be retained by the ICC Statute, although an amendment requiring a justifying or excusing effect of the new complete defense may be

\footnotetext{
967 McAuliffe de Guzman, M., 2008, p. 702.

968 Akande, D., 2009, p. 51 and Weigend, T., 2004, p. 322.

969 Eser, A., 2008, p. 890.
} 
desirable. The necessity however of adapting existing defenses (article 31(2)), I do not see. The provision that was obviously inserted for reasons of compromise, undermines legal certainty and bears the risk of interpretation detrimental to the defendant. What is more, my suggestions for amendments to the ICC Statute have the purpose of opening up existing provisions to make them more general and flexible. This decreases the need to alter existing provisions. In sum, the combination of broadly defined complete defenses and one general open provision renders the precarious article 31(2), superfluous.

\section{Conclusion}

The above evaluation of complete defenses in international criminal law has established that most defenses discussed in Part II of this thesis should be available to a defendant at an international criminal court. Exceptions are consent under its current definition and $t u$ quoque. Main reason for this exclusion is that these legal figures are not technically a complete defense. Therefore my suggested amendment to the ICC Statute only covers the defenses of self-defense, intoxication, insanity, mistake, superior orders and both an excusing and a justifying prong of necessity/ duress. Defenses such as self-defense excess, automatism and indoctrination could also fall within the scope of the suggested provision. The proposal contains a general prior fault provision and an open provision to provide a court with the opportunity to acquit in case a defendant objectively took the best course of action or had no reasonable alternative available to him. The defense of reprisals could be applicable under this open provision. Codification of this defense is nevertheless preferable. This, however, requires additional research as to the scope of reprisals. Other points of departure for further research are: the relationship between criminal law self-defense and self-defense in international humanitarian law, the possibility of consent as a complete defense, the nature of the policy for the acquitted insane/ diminished responsible at international courts, the necessity of a distinction between voluntary and involuntary intoxication, and the procedural rules in relation to complete defenses. Based upon the foregoing Sections, the ICC provisions with regard to complete defenses should be amended in the following manner:

\section{Complete defenses}

1. A defendant shall not be criminally responsible if at the time of his conduct:

(a) The defendant acts necessarily to avoid an imminent or present and unlawful use of force while not causing greater harm than the one sought to be avoided.

(b) The defendant reacted to an imminent or present danger and:

(i) deliberately performed a necessary act that did not cause greater harm than the one sought to be avoided; or 
(ii) there was no reasonable alternative available to the defendant.

(c) The defendant suffers from a disease or defect that destroys that person's capacity to appreciate the unlawfulness or nature of his or her conduct, or capacity to control his or her conduct to conform to the requirements of law;

(d) The defendant had no reasonable alternative because he was mistaken and his mistake was unavoidable.

2. The availability of a complete defense can be excluded to a defendant who could have foreseen and avoided the situation in which he had to commit a crime. A defendant cannot be convicted when he could have foreseen and avoided the situation in which he had to commit a crime, but the elements of the crime charged cannot be established.

3. At trial, the Court may consider a ground for excluding criminal responsibility other than those referred to in paragraph 1 where such a ground is derived from applicable law as set forth in article 21 and this ground either negates the wrongfulness of the act or the blameworthiness of the defendant. The procedures relating to the consideration of such a ground shall be provided for in the Rules of Procedure and Evidence. 


\section{Chapter XVI SUMMARY AND CONCLUSION}

The legal dilemmas that surfaced in Prosecutor v. Erdemovic were the starting point of this thesis. The case inspired me to phrase the following research question: How, if at all, should complete defenses be available in case of international crimes? On the previous pages this question was answered in three stages. A summary of these three Parts is provided below.

\section{Part I Theory}

The central question of Part I of this thesis is What is a complete defense, both in a substantive and in a procedural sense? In a substantive sense, saying "I did it, but I don't think I should be punished", means, according to the different theories in international criminal law literature, that the defendant acknowledges he committed the objective element of the crime (i.e. the physical criminal conduct), but argues either that although the subjective element (i.e. the relevant standard for personal guilt) can also be established, there are still reasons why the presence of these confessed elements will not lead to criminal liability (theory of confession and avoidance), or that the subjective element cannot be established (theory of negation of the subjective element). The fact that there is no univocal theory on the relationship between the general requirements for criminal responsibility and complete defenses in international criminal law can be explained by the fact that there is no uniform theory on the general requirements for criminal liability, either. The definition of the objective element does not show dramatic differences between authors, but the definition of the subjective element is susceptible to variation. Two visions on the subjective element predominate. The psychological theory holds that the subjective element is determined by only the definitional subjective element (e.g. intent). The normative theory holds that the subjective element is determined by both the definitional subjective element and the element of blameworthiness. The element of blameworthiness refers to the defendant's ability to have behaved differently.

Legal theory tends to divide complete defenses into justifications and excuses. Justifications refer to the situation where the defendant has fulfilled the definitional elements of a crime, but his conduct is not considered wrongful because the legal community positively approves of his act. Excuses are related to the concept of blameworthiness. They refer to the situation where the defendant has fulfilled the objective element, this conduct is wrongful, but the defendant remains unpunished because he is not blameworthy. Recognition of the theory of justification and excuse implies that blameworthiness is a general requirement for criminal responsibility. 
In a procedural sense a complete defense is not a legal concept that requires international courts to mention grounds. Still, courts seem to have the habit of discussing complete defenses. The evidential burden (the obligation to establish the facts of a particular case) of complete defenses is on the defendant. The defenses of insanity and intoxication should be established on the balance of probabilities. The standard required for other defenses depends on whether the defense at issue is a "defense in a true sense". Which defenses can be qualified as such is not entirely clear. However, the idea that there are at least two types of complete defenses affirmative defenses or "defenses in a true sense", that should be proved on the balance of probabilities and defenses that negate an element of the prosecution's case that must be proved by a lesser standard - seems to be emerging in the case law of international criminal courts.

When combining the theories of confession and avoidance and negation of subjective element, three theoretically possible types of defenses can be identified. These types can be categorized as either affirmative or not affirmative, while two of them can also be categorized as justification or excuse. The following Parts discuss whether these theoretical types are (Part II) and should be (Part III) represented in international criminal law.

\section{Part II Practice}

Part II of the thesis provides an overview of the complete defenses that have come up in the practice of international criminal law. In separate Chapters the following complete defenses are analyzed per international court: self-defense, consent, insanity, intoxication, mistake, superior orders, necessity/duress, lawful belligerent reprisals and $t u$ quoque. All analyses in this Part are based upon the questionnaire set out in the introduction to Part II. This survey contains questions such as Is the defense recognized in principle, or a priori rejected? and How is the defense defined?. The discretionary power of operative international criminal courts to construct new defenses is also discussed. Each Chapter on a specific complete defense ends with several questions reflecting the blind spots of the defense (e.g. issues that are controversial or simply not clear).

The conclusion to Part II demonstrates that complete defenses have gradually moved from implicit to explicit recognition in international criminal law, at least in theory. In practice they have been as good as consistently rejected. Exception to this is the tu quoque defense. It is the only complete defense ever acknowledged in international criminal law, but at the same time the only complete defense, which has been consistently a priori rejected ever since. What is more, this study demonstrates that $t u$ quoque is not really a complete defense in a technical sense, for it does not justify or excuse the act of the defendant. Other complete defenses have been rejected a priori as well, but none in its entirety. In the vast majority of cases this a priori rejection is linked to the nature of the crimes charged: genocide, crimes against humanity or serious violations of international humanitarian law. 
Also remarkable is that these a priori rejections are rarely consistent. Not only between courts, but even within the same judgment, a Trial Chamber may deny the availability of a defense to one defendant, while admitting it in face of another. When a defense is rejected on its merits, rejection is usually based on a lacking mental element or on non-compliance with the necessity requirement. Conclusively, it can thus be held that complete defenses are fairly consistently rejected, either $a$ priori or because certain requirements for the defense have not been met.

Similar to complete defenses, failed defenses in mitigation, or defenses brought up as a mitigating factor, are rarely accepted by international courts. The legal consequence of a successful appeal to a complete defense seems to be acquittal, although there is not much legal practice to support this assertion. Most complete defenses in international criminal law can be categorized as either justifications or excuses. Consent and tu quoque fall in neither category. In case of a justification there has been an urgent threat to a defensible interest and the defendant has acted intentionally, necessarily and proportionately to avoid the threat. Justifications can either negate the wrongfulness of the act, which is not part of the definition of the crime, or they negate the definitional subjective element in case of negligence. Excuses work in a similar manner, with the difference that an excuse negates the blameworthiness of the crime and can negate the definitional subjective element in three different ways. In case of an excuse, the defendant has a deviating mental condition and no control over the situation. Whether a defense is affirmative or not does not depend on the definition of the complete defense at issue (as literature suggests), but on the definition of the crime charged and the reasoning of the defense.

In conclusion it can be held that complete defenses either leave the elements of the crime charged, untouched (for a number of different reasons), or negate the definitional subjective element of the crime charged (also for a number of different reasons). What Part II of this study demonstrates is that, in practice, complete defenses and general requirements for criminal responsibility interact in a more complex way than literature on complete defenses in international criminal law, suggests. The literature analyzed in Part I describes three different types of relationships between complete defenses and general requirements for criminal responsibility. However, in practice at least six different relationships can be distinguished.

\section{Part III Recommendations}

Since complete defenses have almost consistently been rejected when it comes to international crimes, the conclusions to this study provoke the question whether complete defenses and international crimes are at all compatible. Chapter XIII of Part III discusses several arguments both in favor and against the availability of complete defenses in international criminal law. The most decisive argument in favor of complete defenses is that a priori exclusion of these defenses amounts to a 
violation of the principle of individual criminal responsibility: without complete defenses defendants devoid of wrong and/or blame, could be convicted.

Other arguments (including those that defuse counterarguments) in favor of the availability of complete defenses are:

- The availability of complete defenses has customary status in international criminal law;

- Complete defenses support most objectives of (international) criminal law. The fact that complete defenses may also fail to support certain objectives of international criminal law is not a valid reason to ban complete defenses from the international arena;

- Complete defenses are available in case of international crimes under domestic criminal law: it should not depend on the forum whether a defendant can appeal to a complete defense;

- Over the years, international criminal courts have had a serious amount of criticism on their alleged partiality and lack of procedural rights for defendants. The availability of complete defenses enhances the legal quality of international criminal courts and therefore their credibility;

- The abhorrent nature of international crimes is not a reason to exclude the availability of complete defenses, for the severity of a crime is not conclusive when determining the guilt of the perpetrator.

- The absolute character of international crimes is not a reason to exclude complete defenses, because this absoluteness refers to the obligation of a state to prosecute alleged perpetrators of international crimes and not to an obligation to convict defendants devoid of wrong and/or blame;

- It is true that complete defenses have rarely been applied in case of international crimes. This can be explained by, for example, the disproportionality between crime and defense, the superior position of the defendant, the systematic nature of the crimes charged, the increasing amount of guilty pleas at international courts and the simple reason that acquittal is not a popular option. The fact, however, that complete defenses are and will be rarely applied in international criminal law is, again, not a reason to set aside the principle of individual criminal responsibility and ban complete defenses from the international arena.

My conclusion is that complete defenses ought indeed to have a place in international criminal law. Leading from this conclusion, the next question is What should a system of complete defenses look like? In Chapter XIV, I argue that the current system - or lack thereof - is not satisfactory. A foreseeable, accessible but open system of complete defenses is desirable. This system should be based on the distinction between justifications and excuses and the questions underlying this distinction. Crucial questions - when determining the availability of a complete defense to a defendant - are: 
1) Did the defendant make objectively the best choice? (Justification)

2) Could the defendant have chosen a reasonable alternative? (Excuse)

3) Should the defendant have foreseen and avoided the situation in which he had to commit a crime? (Prior fault)

4) Can the required intent be established? (No conviction without intent)

Chapter XV discusses the availability and conditions for each specific complete defense. By evaluating the availability and conditions, answers are provided to the questions put at the end of each of the Chapters of Part II. The upshot of these answers is that most defenses discussed in Part II should be available to a defendant at an international criminal court. Exceptions are consent under its current definition and tu quoque. The main reason for this exclusion is that these legal figures are not technically a complete defense.

Based upon the recommendations for specific complete defenses, an amendment to the ICC Statute is suggested below. This amendment covers the defenses of intoxication, insanity, self-defense, mistake, superior orders and necessity/duress. However, intoxication and insanity, just as mistake and superior orders, have been merged into one defense, while the defense of necessity/duress has been split up into two prongs: a justifying and an excusing prong. Defenses such as self-defense excess, automatism and indoctrination could also fall within the scope of the suggested provision. The proposal contains a general prior fault provision and an open provision, to provide a judge with the opportunity to acquit in case a defendant objectively took the best course of action (justification), or had no reasonable alternative available to him (excuse). The defense of reprisals could be applicable under this open provision, though codification may be preferable. Codification of reprisals, however, requires additional research as to its scope. Other points of departure for further research are: the relationship between criminal law selfdefense and self-defense in international humanitarian law, the possibility of consent as a complete defense, the nature of the policy for the acquitted insane/ diminished responsible at international courts, the necessity of a distinction between voluntary and involuntary intoxication, and the procedural rules in relation to complete defenses.

The ICC provisions with regard to complete defenses should be amended in the following manner:

\section{Complete defenses}

1. A defendant shall not be criminally responsible if at the time of his conduct:

(a) The defendant acts necessarily to avoid an imminent or present and unlawful use of force while not causing greater harm than the one sought to be avoided.

(b) The defendant reacted to an imminent or present danger and: 
Chapter XVI

(i) deliberately preformed a necessary act that did not cause greater harm than the one sought to be avoided; or

(ii) there was no reasonable alternative available to the defendant.

(c) The defendant suffers from a disease or defect that destroys that person's capacity to appreciate the unlawfulness or nature of his or her conduct, or capacity to control his or her conduct to conform to the requirements of law;

(d) The defendant had no reasonable alternative because he was mistaken and his mistake was unavoidable.

2. The availability of a complete defense can be excluded to a defendant who could have foreseen and avoided the situation in which he had to commit a crime. A defendant cannot be convicted when he could have foreseen and avoided the situation in which he had to commit a crime, but the elements of the crime charged cannot be established.

3. At trial, the Court may consider a ground for excluding criminal responsibility other than those referred to in paragraph 1 , where such a ground is derived from applicable law as set forth in article 21 and this ground either negates the wrongfulness of the act or the blameworthiness of the defendant. The procedures relating to the consideration of such a ground shall be provided for in the Rules of Procedure and Evidence.

\section{FinAL WORDS}

The key research question of this thesis consists of two questions Should complete defenses be available in case of international crimes? and How should complete defenses be available in case of international crimes? The first question is answered in the positive. The desire to assure effective criminal accountability for the most severe crimes in the world must never overshadow a legal analysis of the actual guilt of the defendant. Conflicting as these objectives may seem, these ostensible opposites (accountability for international crimes and rights of the defendant) are not so different after all. Both have the same interest at heart: the protection of fundamental human rights.

As to the how part, this thesis has established that only defendants, who made objectively the best choice (justification), or who had no reasonable alternative (excuse), must be absolved from punishment. However, considering the nature of international crimes, elaborated on in Chapter XIII of this thesis, complete defense will rarely be applicable in case of international crimes.

With the conclusion of this thesis in mind, one single question remains unanswered: do the results of this thesis draw a different perspective on the case of Prosecutor v. Erdemović, the starting point of this study?

As pointed out above, the majority approach in Erdemovic fails, the most ponderous objection being that the a priori exclusion of duress amounts to a violation of the principle of individual criminal responsibility. Consequently, the case should have been decided on its merits. Thus the next question is: which 
merits? Looking at section 1(b)(ii) and 2 of the proposed complete defenses provision, the case of Erdemović should have been assessed on the following two criteria:

a. Was there a reasonable alternative?

b. Was there a prior fault?

As to requirement (a) it is remarkable that in the last instance of Erdemović, the relevant facts are not an issue: the prosecution does not contest that Erdemović could only choose between killing and being killed. ${ }^{970}$ Consequently, whether requirement (a) has been met, does not depend on the question whether other options were available but on whether he choose the right option, and thus whether being killed is a reasonable alternative. Chapters XIV and XV have argued that this is not the case. Requirement (a) has thus been met. Consequently, the outcome of the case should have depended on whether Erdemovic had made a prior fault (requirement (b)). ${ }^{971}$ Unfortunately, this matter was not thoroughly investigated. This is largely due to the plea agreement on the fact that there had been duress, cutting short the discussion on a possible prior fault. ${ }^{972}$ Within the small amount of facts available, I see two pivotal points: (i) when the atmosphere in the VRS unit changed due to the presence of nationalists and (ii) when Erdemović was first ordered to perform a mission in violation of international humanitarian law. The crucial question is whether Erdemović should have foreseen the events in Pilica at these moments and thus avoided them. However, due to lack of facts, these questions are hard to answer. Relevant could be for instance whether these nationalists had genocidal tendencies, and whether Erdemovic knew of other war crimes being committed. What is more, in order to answer the prior fault question, additional information about Erdemović's life between October 1994 and June 1995 is necessary, for there could have been other pivotal points. Finally, it must be

970 ICTY, Prosecutor v. Erdemović, Trial Chamber II, 5 March 1998, par. 14 and 18. Apart from the plea agreement the case displays several factors that indicate that Erdemović only had two options open to him. Indicators that Erdemović would have been killed on refusal are:

The death threat from his superior;

- The - alleged - fact that a fellow-soldier of Erdemović was killed after refusing to participate in the massacre;

- That Erdemović was shot after successfully refusing to participate in the next round of killings;

- Erdemović's powerless position as a Croat in the BSA.

- Erdemović's rank: the lower the rank, the less options available. Erdemović was a simple soldier. In his own words, his rank was so low that he was not in a position to refuse orders.

971 This is probably the main reason why Cassese opts for the holding of a full trial. In his dissenting opinion he suggests it is questionable whether the voluntary exposure requirement has been met. See: ICTY, Prosecutor v. Erdemović, Separate and Dissenting Opinion of Judge Cassese, Appeals Chamber, 7 October 1997, par. 50. Fichtelberg comes to the same conclusion, see: Fichtelberg, A., 2008, pp. 15/16.

Linton, S., 1999, p. 266. 
investigated whether Erdemović had the opportunity to leave the relevant VRS unit. For he must not only have foreseen the events at Pilica, he also must have had the opportunity to avoid them. In conclusion, due to lack of information it cannot be determined whether requirement (b) has been met. However, had this information been available, Erdemović could have been acquitted when a prior fault was absent ${ }^{973}$ On the other hand, the presence of a prior fault might still have left the defense of duress available as a mitigating factor. This way, mitigation could have been applied when the requirements for the defense had not been made out, and not, like the majority suggest, have served as a safety net when a complete defense is $a$ priori excluded.

In the end, it has to be stressed that Erdemovic is not an average case at an international tribunal. For one thing, it was the first case to be completed by the ICTY. This may have been an additional reason for conviction: after the failing of the international community to prevent international crimes in the former Yugoslavia, acquittal would simply not have looked good. ${ }^{974}$ Further, Erdemović was a low-ranking soldier, while international tribunals generally tend to prosecute big fish. Also remarkable about this case is that Erdemović's conviction is based on his own testimony. There was no corroborating evidence. If Erdemović had kept quiet about the event, he would probably never have been prosecuted. ${ }^{975}$

Looking at the relationship between the above peculiarities, the question surfaces what this remorseful small fish was doing at The Hague as the first ICTY defendant ever? It seems that another issue precedes the matter of Erdemović's guilt, namely, whether the ICTY should have prosecuted Erdemović in the first place. Looking at the later prosecution policy of the ICTY (and other international courts) the answer must be in the negative. After Erdemović, also the ICTY quickly shifted to big fish, making Erdemović not only the odd man out, but also a prosecutorial slip-up.

It is exactly in this pre-trial stage though, where the ICTY in Erdemovic made an awkward prosecutorial decision, that I hope the information contained in this thesis will be of relevance. Cases, where a complete defense obviously applies, should never be prioritized when it comes to prosecution. The purpose of international criminal law, is not to go after people who found themselves in a difficult situation and had to make an impossible decision. On the contrary, its primary goal is to prosecute the deliberate instigators, planners and organizers of the most appalling crimes in the world.

973 See for a different outcome: Chiesa, L.E., 2008, p. 772, whose reasoning is founded on the Masetti-approach, proclaimed by dissenters Cassese and Stephen.

975 Brooks, R, 2003, p. 863. 


\section{SAmenvatting}

"Ik heb het wel gedaan, maar verdien toch geen straf." Een verdachte die dit argument gebruikt, beroept zich op een strafuitsluitingsgrond. Verdachte erkent bijvoorbeeld dat hij zijn buurman heeft geslagen (hij heeft het gedaan), maar zegt dit te hebben gedaan uit zelfverdediging (hij is dus niet strafbaar). In dit geval beroept verdachte zich op noodweer. Andere voorbeelden van strafuitsluitingsgronden zijn ontoerekeningsvatbaarheid (verdachte lijdt aan een psychische stoornis) en overmacht (verdachte is gedwongen een misdrijf te plegen). Binnen nationale rechtssystemen zijn strafuitsluitingsgronden vrij algemeen geaccepteerd. Een Nederlandse rechter kan bijvoorbeeld een verdachte vrijspreken ${ }^{976}$ van moord, wanneer deze zelf onder schot werd gehouden (overmacht). Echter, hoe zit dat met een bedreigde verdachte die niet één moord, maar honderd moorden heeft gepleegd? Kan een rechter hem eveneens vrijspreken?

Deze problematiek komt naar voren wanneer strafuitsluitingsgronden uit het nationaal recht opduiken in het internationaal strafrecht, waar ernstige, grootschalige misdrijven het beeld bepalen. Men kan zich afvragen of internationale misdrijven, zoals oorlogsmisdrijven en genocide, überhaupt wel ruimte laten voor strafuitsluitingsgronden. Deze misdrijven zijn zo omvangrijk en schokkend dat een beroep op een strafuitsluitingsgrond weinig kans van slagen heeft. Een rechter zal nu eenmaal niet snel zeggen: "Meneer Mladić u bent volledig ontoerekeningsvatbaar. Die genocide bij Srebrenica kunnen we dus niet aan u toeschrijven." Zo op het eerste gezicht lijken strafuitsluitingsgronden en internationale misdrijven onverenigbaar. Echter, een verdachte van een internationaal misdrijf moet zich wel tegen een aanklacht kunnen verweren. Is dat wel mogelijk, wanneer een geslaagd beroep op een strafuitsluitingsgrond nagenoeg ondenkbaar is?

Dit proefschrift gaat over de verhouding tussen strafuitsluitingsgronden en internationale misdrijven. De centrale onderzoeksvragen zijn:

Moeten strafuitsluitingsgronden beschikbaar zijn voor verdachten van internationale misdrijven? En zo ja, in welke vorm?

Om deze vragen te beantwoorden moet eerst duidelijk zijn wat het begrip strafuitsluitingsgronden inhoudt. Deel I gaat in op de verschillende definities van dit begrip. Vervolgens verschuift de focus naar de praktijk. De analyse van rechtspraak in Deel II richt zich op de beschikbaarheid van strafuitsluitingsgronden voor verdachten die zijn aangeklaagd door een internationale rechtbank. Deel III bevat aanbevelingen met betrekking tot de rol van strafuitsluitingsgronden in het internationaal strafrecht.

976 Of ontslaan van alle rechtsvervolging. Zie art. $352 \mathrm{~Sv}$. 


\section{DeEl I Theorie}

De centrale vraag in Deel I van dit boek luidt Wat is een strafuitsluitingsgrond, zowel in materieel-als in formeelrechtelijke zin? Het antwoord op deze vraag wordt gezocht zowel in wetteksten en uitspraken van internationale rechtbanken (wat betreft het formele recht), als in handboeken internationaal strafrecht (wat betreft het materiële recht). In materieelrechtelijke zin zijn de woorden "ik heb het wel gedaan, maar verdien toch geen straf" op twee verschillende manieren uit te leggen:

1. Verdachte bekent zowel de objectieve bestanddelen (d.w.z. het fysieke strafbare handelen) als het subjectieve bestanddeel (opzet of schuld) van het delict, maar vindt desondanks dat hij niet strafbaar is (confession and avoidance theorie);

2. Verdachte bekent de objectieve bestanddelen van het delict, maar is van mening dat het subjectieve bestanddeel van het delict niet vastgesteld kan worden (negation of subjective element theorie).

In het internationaal strafrecht bestaat geen eenduidige theorie over de verhouding tussen de algemene voorwaarden voor strafbaarheid en strafuitsluitingsgronden. Dit is niet verwonderlijk. Immers, binnen dit relatief jonge rechtsgebied bestaat eveneens geen uniforme theorie over de algemene voorwaarden voor strafbaarheid. De objectieve zijde van het delict wordt door de meeste auteurs wel op dezelfde manier gedefinieerd. De subjectieve zijde echter niet. Met betrekking tot deze subjectieve zijde bestaan twee dominante theorieën: de psychologische theorie (de subjectieve zijde verwijst alleen naar het subjectieve bestanddeel) en de normatieve theorie (de subjectieve zijde verwijst zowel naar het subjectieve bestanddeel als naar de verwijtbaarheid van verdachte).

Binnen de internationale strafrechtstheorie worden strafuitsluitingsgronden onderverdeeld in rechtvaardigings- en schulduitsluitingsgronden. Is er sprake van een rechtvaardigingsgrond, dan heeft verdachte alle bestanddelen uit de delictsomschrijving vervuld. Zijn gedrag is echter niet wederrechtelijk. Hij kan daarom niet gestraft worden. Schulduitsluitingsgronden zijn gerelateerd aan het begrip verwijtbaarheid. Is er sprake van een schulduitsluitingsgrond, dan heeft verdachte de objectieve bestanddelen van het delict vervuld. Zijn gedrag is daarnaast ook wederrechtelijk. Echter, van verwijtbaarheid is geen sprake. Hij kan daarom eveneens niet gestraft worden. Het erkennen van de theorie van rechtvaardigings- en schulduitsluitingsgronden, impliceert aanvaarding van verwijtbaarheid als algemene voorwaarde voor strafbaarheid.

Met betrekking tot de formeelrechtelijke kant van strafuitsluitingsgronden valt op dat rechters van internationale tribunalen regelmatig het verwerpen van strafuitsluitingsgronden motiveren, terwijl er geen specifieke motiveringseisen voor deze rechtsfiguur bestaan. De bewijslast van strafuitsluitingsgronden ligt bij de verdachte. 
Bij ontoerekeningsvatbaarheid ${ }^{977}$ en intoxication ${ }^{978}$ moet de aanwezigheid van een strafuitsluitingsgrond aannemelijk gemaakt worden on the balance of probabilities. De bewijsstandaard voor andere strafuitsluitingsgronden is afhankelijk van de aard van de relevante strafuitsluitingsgrond. Gaat het om een echte strafuitsluitingsgrond (defense in a true sense), dan is een andere standaard van toepassing dan wanneer dit niet het geval is. Het is daarentegen niet duidelijk welke strafuitsluitingsgronden als 'echt' te kwalificeren zijn. Mogelijk worden hiermee strafuitsluitingsgronden bedoeld die de delictsomschrijving niet ontkrachten (affirmative defenses). Hoe dan ook, bij internationale rechtbanken lijkt het idee te ontstaan dat er ten minste twee verschillende soorten strafuitsluitingsgronden zijn: strafuitsluitingsgronden die de delictsomschrijving ontkrachten en strafuitsluitingsgronden die dit niet doen.

Drie verschillende typen strafuitsluitingsgronden zijn te identificeren wanneer we de theorieën van confession and avoidance en negation of subjective element combineren. Deze drie typen zijn eveneens in te delen in strafuitsluitingsgronden die affirmative en not affirmative zijn. Twee van de drie typen vertonen de kenmerken van een rechtvaardigings- of schulduitsluitingsgrond. Deel II van dit boek gaat onder andere in op de vraag of deze drie typen strafuitsluitingsgronden terug te vinden zijn in de rechtspraak van internationale rechtbanken. De wenselijkheid van de indelingen uit de eerste twee delen komt aan de orde in Deel III.

\section{Deel II PraktiJK}

Deel II van dit boek gaat over de strafuitsluitingsgronden, die besproken zijn bij internationale rechtbanken. Binnen het kader van dit onderzoek is de rechtspraak van de volgende internationale rechtbanken onderzocht: het Internationale Militaire Tribunaal van Neurenberg (IMT), het Internationale Militaire Tribunaal van Tokio (IMFTE), het Joegoslavië-tribunaal (ICTY), het Rwanda-tribunaal (ICTR) en het Internationaal Strafhof (ICC). In aparte hoofdstukken komen de volgende strafuitsluitingsgronden aan de orde: noodweer, consent $^{979}$, ontoerekeningsvatbaarheid, intoxication, afwezigheid van alle schuld wegens verontschuldigbare dwaling, onbevoegd ambtelijk bevel, overmacht, represailles en tu quoque. Het onderzoek in dit deel is uitgevoerd met behulp van een vragenlijst. Iedere bespreking van een strafuitsluitingsgrond door een internationale rechtbank is aan alle vragen uit deze lijst onderworpen. Voorbeelden van vragen zijn: "Wordt de strafuitsluitingsgrond in

977 In deze samenvatting wordt steeds de Nederlandse benaming van een strafuitsluitingsgrond gebruikt, wanneer deze qua inhoud vergelijkbaar is met het Angelsaksische equivalent.

978 Men spreekt van intoxication wanneer de verwijtbaarheid bij verdachte ontbreekt, omdat deze onder de invloed was van alcohol, medicijnen of drugs. Intoxication kent geen specifieke Nederlandse variant. Binnen het Nederlandse stelsel van strafuitsluitingsgronden valt deze rechtsfiguur onder 'afwezigheid van alle schuld wegens verontschuldigbare onmacht'.

979 Consent kent geen officiële Nederlandse equivalent. Er is sprake van consent wanneer slachtoffer heeft ingestemd met het plegen van het misdrijf. 
beginsel erkend of bij voorbaat verworpen?" 980 en "Hoe definieert de rechtbank de strafuitsluitingsgrond?" De volledige vragenlijst is opgenomen in de inleiding op Deel II. De discretionaire bevoegdheid van de actieve internationale rechtbanken om nieuwe strafuitsluitingsgronden te ontwikkelen komt eveneens in dit deel aan de orde. Ieder hoofdstuk over een specifieke strafuitsluitingsgrond eindigt met een aantal vragen over de controversiële aspecten van deze strafuitsluitingsgrond. In Deel III tracht ik deze vragen te beantwoorden.

De conclusie van Deel II laat zien dat strafuitsluitingsgronden in theorie expliciet erkend worden binnen het internationaal strafrecht. De praktijk laat echter een min of meer stelselmatige verwerping van strafuitsluitingsgronden zien. Uitzondering is tu quoque. Dit is de enige strafuitsluitingsgrond die ooit door een internationaal tribunaal (IMT) is aanvaard. Echter, tu quoque is ook de enige strafuitsluitingsgrond die vervolgens consequent bij voorbaat is verworpen.

Andere strafuitsluitingsgronden dan $t u$ quoque zijn eveneens bij voorbaat verworpen. Reden voor verwerping is meestal gelegen in de ernst van het tenlastegelegde misdrijf. Vaak gaat het om genocide, misdaden tegen de menselijkheid of grove schendingen van humanitair recht. Opvallend is dat deze verwerpingen bij voorbaat zelden consistent zijn. Niet alleen zijn er verschillen per rechtbank, ook binnen één uitspraak kan het voorkomen dat een gerechtelijke instantie een strafuitsluitingsgrond in principe zowel erkent als verwerpt.

Wanneer een strafuitsluitingsgrond om inhoudelijke redenen wordt verworpen, gebeurt dit meestal of omdat verdachte niet de vereiste subjectieve gemoedstoestand bezit (d.w.z. de wil om uit zelfverdediging, overmacht etc. te handelen) of omdat niet voldaan is aan het subsidiariteitsvereiste (verdachte had alternatieven). Kort samengevat worden alle strafuitsluitingsgronden - op tu quoque na - consequent verworpen, of bij voorbaat of om inhoudelijke redenen.

Een mislukt beroep op een strafuitsluitingsgrond geldt zelden als strafverminderende omstandigheid. Ook een beroep op een van een strafuitsluitingsgrond afgeleide strafverminderende omstandigheid heeft weinig kans van slagen. Het rechtsgevolg van een succesvol beroep op een strafuitsluitingsgrond is waarschijnlijk vrijspraak. $^{981}$

De meeste strafuitsluitingsgronden in het internationaal strafrecht zijn te kwalificeren als rechtvaardigings- of schulduitsluitingsgronden. Consent en tu quoque zijn niet als zodanig te kwalificeren. Uit de onderzochte rechtspraak blijkt dat er sprake is van een rechtvaardigingsgrond bij een acute dreiging ten aanzien van een verdedigbaar belang, waarbij verdachte opzettelijk heeft gehandeld in overeenstemming met de eisen van proportionaliteit en subsidiariteit om de dreiging af te wenden. Rechtvaardigingsgronden kunnen de wederrechtelijkheid van de daad wegnemen, wanneer deze geen deel uitmaakt van de delictsomschrijving. Daarnaast kunnen ze

980 'Verwerping bij voorbaat' wil zeggen: zonder inhoudelijk op de voorwaarden van een specifieke strafuitsluitingsrond in te gaan.

981 Het onderscheid tussen ontslag van alle rechtsvervolging en vrijspraak bestaat niet in het internationaal strafrecht. 
het subjectieve bestanddeel teniet doen gaan wanneer dit bestanddeel gelijk is aan negligence. Schulduitsluitingsgronden nemen de verwijtbaarheid van de dader weg. Zij kunnen op drie verschillende manier het subjectieve bestanddeel teniet doen gaan. In geval van een schulduitsluitingsgrond heeft verdachte een afwijkende gemoedstoestand en geen controle over de situatie.

Of een strafuitsluitingsgrond affirmative is, hangt af van de definitie van het tenlastegelegde misdrijf en de argumentatie van de verdediging. Kort samengevat kan gezegd worden dat strafuitsluitingsgronden of (a) alle bestanddelen van het tenlastegelegde misdrijf intact laten (om verschillende redenen) of (b) dat zij het subjectieve bestanddeel teniet doen gaan (ook om verschillende redenen). Deel II van dit boek laat zien dat de interactie tussen algemene voorwaarden voor strafbaarheid en strafuitsluitingsgronden complexer is dan de handboeken op dit gebied - besproken in Deel I - suggereren. Deze handboeken suggereren immers dat er drie verschillende typen strafuitsluitingsronden bestaan. Deel II toont aan dat dit er minstens zes zijn.

\section{Deel III Aanbevelingen}

Deel II van deze studie laat zien dat strafuitsluitingsgronden nagenoeg nooit worden aanvaard bij internationale misdrijven. Hier zijn meerdere verklaringen voor. De disproportionaliteit tussen misdrijf en strafuitsluitingsgrond, bijvoorbeeld. Ook een rol spelen de hiërarchische positie van verdachte, de systematische aard van de misdrijven, het toenemende aantal schuldbekentenissen bij internationale rechtbanken en de eenvoudige reden dat vrijspraak geen populaire optie is.

$\mathrm{Nu}$ blijkt dat strafuitsluitingsgronden consequent verworpen worden, kan men de vraag stellen of deze rechtsfiguren überhaupt wel samengaan met internationale misdrijven. Hoofdstuk XIII gaat in op een aantal argumenten voor en tegen de beschikbaarheid van strafuitsluitingsgronden bij internationale rechtbanken. Het meest overtuigende argument voor de beschikbaarheid van strafuitsluitingsgronden is dat uitsluiting bij voorbaat een schending van het schuldbeginsel kan opleveren. Zonder strafuitsluitingsgronden kunnen verdachten die niet verwijtbaar hebben gehandeld immers veroordeeld worden.

Andere argumenten voor de beschikbaarheid van strafuitsluitingsgronden zijn:

- strafuitsluitingsgronden hebben een gewoonterechtelijke status in het internationaal strafrecht;

- strafuitsluitingsgronden ondersteunen de meeste doelen van het internationaal strafrecht. Het feit dat strafuitsluitingsgronden niet alle doelen ondersteunen, is geen geldige reden om strafuitsluitingsronden bij voorbaat uit te sluiten;

- verdachten van internationale misdrijven die berecht worden onder nationaal recht, kunnen een geslaagd beroep doen op een strafuitsluitingsgrond. De beschikbaarheid van strafuitsluitingsgronden mag niet afhankelijk zijn van de aard van de aanklagende partij (staat of internationale gemeenschap); 
- internationale rechtbanken hebben in de loop der jaren veel kritiek gekregen vanwege vermeende partijdigheid en het gebrek aan procedurele rechten voor verdachten. De beschikbaarheid van strafuitsluitingsgronden vergroot de kwaliteit van internationale rechtbanken en daarmee hun geloofwaardigheid;

- de gruwelijke aard van internationale misdrijven is geen reden om strafuitsluitingsgronden bij voorbaat uit te sluiten. Immers, de ernst van een misdrijf is niet doorslaggevend bij het bepalen van de schuld van de dader;

- het absolute karakter van internationale misdrijven is geen reden om strafuitsluitingsgronden uit te sluiten. Dit absolute karakter verplicht staten om verdachten van internationale misdrijven te vervolgen, niet om hen te veroordelen zonder dat zij verwijtbaar hebben gehandeld.

Conclusie is dus dat strafuitsluitingsgronden een plek moeten hebben in het internationaal strafrecht. Maar hoe moet deze plek eruit zien? Aan welke kenmerken moet een systeem van strafuitsluitingsgronden in het internationaal strafrecht voldoen? Hoofdstuk XIV laat zien dat het huidige (gebrek aan) systeem niet bevredigend is. Wenselijk is een voorzienbaar, toegankelijk maar open stelsel. Het onderscheid tussen rechtvaardigings- en schulduitsluitingsgronden zou in dit stelsel centraal moeten staan. Cruciale vragen die de beschikbaarheid van een strafuitsluitingsgrond bepalen, zijn:

1. Heeft verdachte objectief de beste keuze gemaakt? (rechtvaardigingsgrond)

2. Was voor verdachte een redelijk alternatief beschikbaar? (schulduitsluitingsgrond)

3. Had verdachte de situatie waarin hij een misdrijf heeft begaan moeten voorzien en vermijden? (culpa in causa)

4. Kan het vereiste opzet worden vastgesteld? (geen veroordeling zonder opzet)

Hoofdstuk XV bespreekt de beschikbaarheid en voorwaarden van alle strafuitsluitingsgronden afzonderlijk. Door deze beschikbaarheid en voorwaarden onder de loep te nemen, wordt getracht antwoord te geven op de vragen, die gesteld zijn aan het eind van ieder hoofdstuk in Deel II. De grote lijn in de antwoorden op deze vragen is dat de meeste van de in Deel II besproken strafuitsluitingsgronden beschikbaar zouden moeten zijn voor verdachten bij internationale rechtbanken. Uitzonderingen zijn consent en tu quoque. Reden voor deze uitzonderingen is dat deze rechtsfiguren geen strafuitsluitingsgronden in technische zin zijn.

De aanbevelingen uit hoofdstuk XV komen samen in een voorstel tot aanpassing van het Statuut van Rome. Dit voorstel omvat de volgende strafuitsluitingsgronden: intoxication, ontoerekeningsvatbaarheid, noodweer, afwezigheid van alle schuld wegens verontschuldigbare dwaling, onbevoegd ambtelijk bevel en overmacht. Echter, intoxication en ontoerekeningsvatbaarheid, evenals afwezigheid van alle schuld wegens verontschuldigbare dwaling en onbevoegd ambtelijk bevel, zijn samengevoegd onder één afzonderlijke strafuitsluitingsgrond. Overmacht daarentegen, is opgesplitst in een rechtvaardigende en een schulduitsluitende component. Strafuit- 
sluitingsgronden als noodweerexces, automatism ${ }^{982}$ en indoctrinatie zouden eveneens onder het onderhavige voorstel kunnen vallen. Naast een culpa in causa clausule bevat het voorstel ook een open clausule. Op grond van deze open clausule kan een rechtbank vrijspreken indien verdachte objectief de beste keuze heeft gemaakt (rechtvaardigingsgrond) of geen redelijk alternatief had (schulduitsluitingsgrond). Ook de strafuitsluitingsgrond represailles zou onder het voorstel kunnen vallen. Codificatie heeft echter de voorkeur. Dit vereist wel onderzoek naar de reikwijdte van represailles. Overige aanknopingspunten voor verder onderzoek zijn: de relatie tussen het strafrechtelijke noodweer en het internationaalrechtelijke self-defense, de mogelijkheden van consent als strafuitsluitingsgrond, het beleid bij internationale rechtbanken met betrekking tot de ontoerekeningsvatbare en de verminderd toerekeningsvatbare verdachte, de noodzaak van het onderscheid tussen vrijwillige en onvrijwillige intoxication en, ten slotte, de procedurele regels met betrekking tot strafuitsluitingsgronden.

De ICC bepalingen met betrekking tot strafuitsluitingsgronden zouden op de volgende manier kunnen worden aangepast:

\section{Strafuitsluitingsgronden}

1. Verdachte is niet strafrechtelijk verantwoordelijk wanneer hij op het moment van zijn gedrag:

(a) handelt om een naderend of aanwezig en wederrechtelijk gebruik van geweld te verhinderen, terwijl hij niet meer kwaad aanricht dan het kwaad dat hij probeert te vermijden en zijn handeling voldoet aan de eisen van subsidiariteit.

(b) reageert op een naderend of aanwezig gevaar en:

(i) hij niet meer kwaad aanricht dan het kwaad dat hij probeert te vermijden en zijn handeling voldoet aan de eisen van subsidiariteit.

(ii) er voor verdachte geen redelijk alternatief beschikbaar was.

(c) lijdt aan een ziekte of gebrek welke zijn vermogen vernietigt om de wederrechtelijkheid of de aard van zijn gedragingen in te zien of om zijn gedragingen te beheersen teneinde de wettelijke vereisten na te leven.

(d) geen redelijk alternatief had, omdat hij dwaalde en niet op de hoogte had moeten zijn van zijn dwaling.

2. De beschikbaarheid van een strafuitsluitingsgrond kan worden uitgesloten ten aanzien van een verdachte die de situatie waarin hij een misdrijf moest plegen had kunnen voorzien en vermijden. Een verdachte kan niet veroordeeld worden wanneer de bestanddelen van het tenlastegelegde misdrijf niet bewezen kunnen wor-

982 Automatism kent geen Nederlandse variant. Binnen het Nederlandse stelsel van strafuitsluitingsgronden zou deze rechtsfiguur kunnen vallen onder 'afwezigheid van alle schuld wegens verontschuldigbare onmacht'. In Angelsaksische rechtssystemen is automatism geen strafuitsluitingsgrond, maar valt onder het leerstuk van de bewuste handeling (voluntary act requirement). 
den, ook al had hij de situatie waarin hij een misdrijf moest plegen kunnen voorzien en vermijden.

3. Tijdens het proces kan het Hof een andere strafuitsluitingsgrond overwegen dan de onder lid 1 vermelde gronden, wanneer deze grond is ontleend aan het in artikel 21 beschreven toepasselijk recht. De procedure houdende het onderzoek van een dergelijke grond wordt geregeld in het Reglement voor de proces- en bewijsvoering. ${ }^{983}$

983 Voor de Nederlandse vertaling van dit wijzigingsvoorstel is aansluiting gezocht bij de strafuitsluitingsgronden in de artikelen 39-43 van het Wetboek van Strafrecht en bij de officiële Nederlandse vertaling van het Statuut van Rome in het Tractatenblad (Tractatenblad van het Koninkrijk der Nederlanden, jaargang 2000 no. 120, pp. 187-189). 


\section{BiBLIOGRAPHY}

Abi-Saab, G. and Condorelli, L., 'Réponses à la question 1, b) (Dossier: L'article 31(1)(c) du Statut de la cour pénale internatonale. Travaux de l'atelier organisé par la commission consultative de droit international humanitaire de la Croix-Rouge de Belgique Communauté Francophone)', In: Revue belge de droit international, Vol. 33, Issue 2, 2000 , pp. 355-483.

Akande, D., 'Sources of International Criminal Law', In: Cassese, A. (ed.), The Oxford Companion to International Criminal Justice, Oxford University Press, 2009.

Ambos, K., 'Other Grounds for Excluding Criminal Responsibility', In: Cassese, A. et al. (eds.), The Rome Statute of the ICC: A Commentary, Oxford University Press, Vol. 1, 2002, pp. 1003-1048.

Ambos, K., Der Allgemeine Teil des Völkerstrafrechts. Ansätze einer Dogmatisierung, Duncker \& Humblot, Berlin, 2004.

Ambos, K., Treatise on International Criminal Law. Volume I: Foundations and General Part, Oxford University Press, 2013.

Ashworth, A., Principles of Criminal Law, Sixth Edition, Oxford University Press, 2009.

Badar, M.E., 'Rethinking Mens Rea in the Jurisprudence of the International Criminal Tribunals for the Former Yugoslavia and Rwanda'. In: Olusanya, O. (ed.), Rethinking International Criminal Law: The Substantive Part, Europa Law Publishing, Groningen, 2007, pp. 13-33.

Banning, C. and Koning, P. de, Balkan aan de Noordzee. Over het Joegoslavië-tribunaal, over recht en onrecht, Prometheus, Amsterdam, 2005.

Bantekas, I., 'Defences in International Criminal Law', In: McColdrick, D. (ed.), The Permanent International Criminal Court, Hart Publishing, Oxford, 2004, pp. 263284.

Bantekas, I. and Nash, S., International Criminal Law, Third Edition, Routledge-Cavendish, London, 2007.

Bassiouni, M.C., 'International Crimes: 'Jus Cogens' and 'Obligatio Erga Omnes', In: Law and Contemporary Problems, Vol. 59, Issue 4, 1996, pp. 63-74.

Bassiouni, M.C., Introduction to International Criminal Law, Transnational Publishers Inc., Ardsley, 2003.

Bentham, J., An Introduction to the Principles of Morals and Legislation (1789), Hafner Publishing, New York, 1948.

Bitti, G., 'Article 21 of the ICC and The Treatment of Sources of Law in the Jurisprudence of the ICC', In: The Emerging Practice of the International Criminal Court, Stahn, C. and Sluiter, G. (Eds.), Martinus Nijhoff Publishers, Leiden, 2009, pp. 285-304.

Blomsma, J., Mens rea and defences in European Criminal Law, Intersentia, Antwerp, 2012.

Boersma, M., Corruption: A Violation of Human Rights and A Crime Under International Law?, Intersentia, Antwerp, 2012. 
Bogert, P.C., Voor rechtvaardiging en schulduitsluiting, Kluwer, Deventer, 2005.

Brooks, R., 'Law in the Heart of Darkness: Atrocity and Duress', In: Virginia Journal of International Law, Vol. 43, Issue 3, 2003, pp. 861-888.

Brownlie, I., Principles of Public International Law, Fifth Edition, Oxford University Press, 1998.

Cartwright, R., 'Sleepwalking Violence: A Sleep Disorder, a Legal Dilemma, and a Psychological Challenge', In: The American Journal of Psychiatry, Vol. 161, Issue 7, pp. 1149-1158.

Cassese, A. and Röling, B.V.A., The Tokyo Trial and Beyond, Polity Press, Cambridge, 1993.

Cassese, A., 'The Statute of the International Criminal Court: Some Preliminary Reflections', European Journal of International Law, Vol. 10, Issue 1, 1999, pp. 144171.

Cassese, A., 'Justifications and Excuses in International Criminal Law', In: Cassese, A. et al. (eds.), The Rome Statute of the ICC: A Commentary, Oxford University Press, Vol. 1, 2002, pp. 951-956.

Cassese, A., International Criminal Law, Second Edition, Oxford University Press, 2008.

Chiesa, L.E., 'Duress, Demanding Heroism, and Proportionality', In: Vanderbilt Journal of Transnational Law, Vol. 41, 2008, pp. 741-773.

Chin-A-Fo, H., 'Internationale Strafhof houdt voet bij stuk', In: NRC Handelsblad, 5 March 2008.

Chin-A-Fo, H. and Haenen, M., 'Rechters zonder beklaagde', In: NRC Handelsblad, 18/19 October 2008.

Combs, N., Guilty Pleas in International Criminal Law: Constructing a Restorative Justice Approach, Stanford University Press, 2007.

Cryer, R., Prosecuting International Crimes: Selectivity in the International Criminal Law Regime, Cambridge University Press, 2005.

Cryer, R., et al., An Introduction to International Criminal Law and Procedure, Cambridge University Press, 2007.

Cryer, R. et al., An Introduction to International Criminal Law and Procedure, Cambridge University Press, Second Edition, 2010.

Damasio, A., et al., 'Insensitivity to Future Consequences Following Damage to Human Prefrontal Cortex', In: Cognition, Vol. 50, pp. 7-15.

Daqun, L., 'Actus Reus', In: Cassese, A. (ed.), The Oxford Companion to International Criminal Justice, Oxford University Press, 2009, pp. 229/230.

David, E., Éléments de Droit Pénal International et Européen, Bruylant, Bruxelles, 2009.

Davidson, E., Trial of the Germans: An Account of the Twenty-Two Defendants before the International Military Tribunal at Nuremberg, University of Missouri Press, Columbia, 1997.

Denis, C. and Romero, M., 'Synthèse des débats de l'atelier du 12 juillet 2000 (Dossier: L'article 31(1)(c) du Statut de la cour pénale internatonale. Travaux de l'atelier organisé par la commission consultative de droit international humanitaire de la Croix-Rouge 
de Belgique Communauté Francophone)', In: Revue belge de droit international, Vol. 33, Issue 2, 2000, pp. 355-483.

Dennis, I.H., The Law of Evidence, Third Edition, Sweet \& Maxwell, London, 2007.

Dijk, A.A. van, Strafrechtelijke aansprakelijkheid heroverwogen, Maklu, Apeldoorn, 2008.

Dinstein, Y., The Defence of 'Obedience to Superior Orders', Martinus Nijhoff Publishers, Dordrecht, 1965.

Dinstein, Y., 'Defences', In: Kirk McDonald, G. (ed.), Substantive and Procedural Aspects of International Criminal Law, Kluwer International, The Hague, 2000, pp. 371-388.

Dinstein, Y., 'The Hazards of Interdisciplinary Pollination. Some Critical Comments on Defending Humanity'. In: Journal of International Criminal Justice, Vol. 7, 2009, pp. 517-520.

Dolman, M., Overmacht, Wolf Legal Publishers, Nijmegen, 2006.

Drumbl, M.A., Atrocity, Punishment and International Law, Cambridge University Press, 2007.

Eser, A., 'Justification and Excuse', In: American Journal of Comparative Law, Vol. 24, 1976, pp. 621-637.

Eser, A., “"Defences” in War Crime Trials', In: Dinstein, Y. and Tabory, M. (ed.), War Crimes in International Law, Martinus Nijhoff Publishers, The Hague, 1996, pp. 251273.

Eser, A., 'Mental Elements - Mistake of Fact and Mistake of Law', In: Cassese, A. et al. (eds.), The Rome Statute of the ICC: A Commentary, Oxford University Press, Vol. 1, 2002, pp. 889-948.

Eser, A., 2008, 'Article 31: Grounds for Excluding Criminal Responsibility', In: Triffterer, O. (ed.), Commentary on the Rome Statute of the International Criminal Court: Observers' Notes, Article by Article, Hart Publishing, Oxford, 2008, pp. 863-893.

Fichtelberg, A., 'Liberal Values in International Criminal Law: A Critique of Erdemović', In: Journal of International Criminal Justice, Volume 6, Issue 1, pp. 3-19.

Fletcher, G.P., Rethinking Criminal Law, Little, Brown and Co., Boston, 1978.

Fletcher, G.P., Basic Concepts of Criminal Law, Oxford University Press, 1998.

Fletcher, G.P., Rethinking Criminal Law, Oxford University Press, Second Edition, 2000.

Fletcher, G.P., The Grammar of Criminal Law: American, Comparative and International. Volume One: Foundations, Oxford University Press, 2007.

Fletcher, G.P and Ohlin, J.D., Defending Humanity: When force is Justified and Why, Oxford University Press, 2008.

Francisco Francisco, M.I., Aspects of Implementing the Culpability Principle both under National and International Criminal Law, Wolf Legal Publishers, Nijmegen, 2003.

Garner, B.A. (ed.), Black's Law Dictionary, Eighth Edition, Westgroup, 2004.

Gilbert, J., 'Justice not Revenge: The International Criminal Court and the 'Grounds to Exclude Criminal Responsibility' - Defences or Negation of Criminality?', In: The International Journal of Human Rights, Vol. 10, Issue 2, 2006, pp. 143-160.

Greenawalt, K., 'The Perplexing Borders of Justification and Excuse', In: Columbia Law Review, Vol. 84, Issue 8, 1984, pp. 1897-1927. 
Bibliography

Greenwood, C., 'Belligerent Reprisals in the Jurisprudence of the ICTY', In: May, C. (ed.), Essays on War in International Law, Cameron May, London, 2006, pp. 331-351.

Hart, H.L.A., Punishment and Responsibility: Essays in the Philosophy of Law (1967), Oxford University Press, 2008.

Heller, K.J., 'Mistake of Legal Element, the Common Law, and Article 32 of the Rome Statute', In: Journal of International Criminal Justice, Volume 6, 2008, pp. 419-445.

Herik, L. van, The Contribution of the Rwanda Tribunal to the Development of International Law, Koninklijke Brill, Leiden, 2005.

Hullu, J. de, Materieel Strafrecht. Over algemene leerstukken van strafrechtelijke aansprakelijkheid naar Nederlands recht, Fifth Edition, Kluwer, Deventer, 2012.

Human Rights Watch Report, Leave None to Tell the Story: Genocide in Rwanda, 1 April 2004.

Ipsen, K., 'Combatants and non-combatants', In: Fleck, D. (ed.), The Handbook of Humanitarian Law in Armed conflicts, Oxford University Press, New York, 1998, pp. 65-104.

Janssen, S., 'Mental Condition Defences in Supranational Criminal Law', In: International Criminal Law Review, Vol. 4, 2004, pp. 83-98.

Kalshoven, F. and Zegveld, L., Constraints on the Waging of War: An introduction to International Humanitarian Law, Third Edition, International Committee of the Red Cross, Geneva, 2001.

Kant, I., Grundlegung zur Metaphysik der Sitten (1785), Heimann, Berlin, 1870.

Keijzer, N., 'Self-Defence in the Statute of Rome', In: Duyx et al., War Crimes Law and the Statute of Rome: Some Afterthoughts? Report on the Seminar of Rijswijk, Revue de Droit Militaire et de Droit de la Guerre, Vol. 39, 2000, pp. 69-78.

Kemp, G., Individual Criminal Liability for the International Crime of Aggression, Intersentia, Antwerp, 2010.

Khan, K. and Dixon, R. (eds.), Archbold International Criminal Courts: Practice, Procedure and Evidence, Sweet and Maxwell, Second Edition, London, 2005.

Khan, K. and Dixon, R. (eds.), Archbold International Criminal Courts: Practice, Procedure and Evidence, Sweet and Maxwell, Third Edition, London, 2009.

Knoops, G.A., Defences in Contemporary International Criminal Law, Transnational Publishers Inc., Ardsley, 2001.

Kok, R., Statutory Limitations in International Criminal Law, T.M.C. Asser Press, The Hague, 2007.

Kooijmans P.H., Internationaal Publiekrecht in Vogelvlucht, Ninth Edition, Kluwer, Deventer, 2002.

Krabbe, M.J.M., Tot doden gedwongen: een rechtsvergelijkend onderzoek naar overmacht in moordzaken in Nederland, Engeland en Frankrijk, 2004 (master's thesis).

Linton, S., 'Reviewing the Case of Dražen Erdemović: Unchartered Waters at the International Criminal Tribunal for the Former Yugoslavia', In: Leiden Journal of International Law, Vol. 12, 1999, pp. 251-270.

Malanczuk, P., Akehurst's Modern Introduction to International Law, Seventh Edition, Routledge, London, 1997. 
Maogoto, J.N., 'The Defence of Superior Orders', In: Olusanya, O. (ed.), Rethinking International Criminal Law: The Substantive Part, Europa Law Publishing, Groningen, 2007, pp. 91-128.

McAuliffe de Guzman, M., 'Applicable Law', In: Triffterer, O. (ed.), Commentary on the Rome Statute of the International Criminal Court: Observers' Notes, Article by Article, Hart Publishing, Oxford, 2008, pp. 701-712.

McAuley, F. and McCutcheon, P., Criminal Liability, Round Hall Sweet \& Maxwell, Dublin, 2000.

Minear, R.H., Victors' Justice: The Tokyo War Crimes Trial, Princeton University Press, 1971.

Morris, V. and Scharf, M.P., An Insider's Guide to the International Criminal Tribunal for the Former Yugoslavia, Transnational Publishers Inc., Irvington-on Hudson, 1995.

Morris, V. and Scharf, M., The International Criminal Tribunal for Rwanda, Transnational Publishers Inc., Irvington-on-Hudson, 1998.

Nerlich, V., 'The Status of the ICTY and ICTR Precedent in Proceedings Before the ICC', In: Stahn, C. and Sluiter, G. (Eds.), The Emerging Practice of the International Criminal Court, Martinus Nijhoff Publishers, Leiden, 2009, pp. 305-325.

Nill-Theobald, C., "Defences" bei Kriegsverbrechen am Beispiel Deutschlands und der USA, Iuscrim, Freiburg im Breisgau, 1998.

Nollkaemper, A. and Wilt, H.G. van der, 'Conclusions and Outlook', In: Nollkaemper, A. and Wilt, H.G. van der (eds.), In: System Criminality in International Law, Cambridge University Press, 2009, pp. 338-353.

Oeter, S., 'Methods and Means of Combat', In: Fleck, D. (ed.), The Handbook of Humanitarian Law in Armed Conflicts, Oxford University Press, New York, 1998, pp. 105-207.

Ohlin, J.D., 'Intoxication', In: Cassese, A. (ed.), The Oxford Companion to International Criminal Justice, Oxford University Press, 2009, pp. 385/386.

Ohlin, J.D., 'Mental Disease', In: Cassese, A. (ed.), The Oxford Companion to International Criminal Justice, Oxford University Press, 2009, pp. 415/416.

Ohlin, J.D., 'Mistake of Law', In: Cassese, A. (ed.), The Oxford Companion to International Criminal Justice, Oxford University Press, 2009, pp. 422/423.

Ohlin, J.D., 'Necessity and Duress', In: Cassese, A. (ed.), The Oxford Companion to International Criminal Justice, Oxford University Press, 2009, pp. 431-433.

Osiel, M.J., Obeying Orders: Atrocity, Military Discipline and the Law of War, Transaction Publishers, New Brunswick/London, 1999.

Overy, R., 'The Nuremberg Trials: International Law in the Making', In: P. Sands (ed.), From Nuremberg to The Hague: The Future of International Criminal Justice, Cambridge University Press, 2003, pp. 1-29.

Owen, D., In Sickness and In Power, Praeger, Westport, 2008.

Paphiti, A.S., 'Duress as a Defence to War Crimes Charges', In: Revue de Droit Militaire et de Droit de la Guerre, Vol. 38, 1999, pp. 249-288.

Poelgeest, L. van, Nederland en het Tokyo Tribunaal, Gouda Quint, Arnhem, 1989.

Raimondo, F.O., General Principles of Law in the Decisions of International Criminal Courts and Tribunals, Martinus Nijhoff Publishers, Leiden, 2008. 
Bibliography

Robinson, P.H. 'Causing the Conditions of One's Own Defence: A Study in the Limits of Theory in Criminal Law Doctrine', Virginia Law Review, Volume 71, Issue 1, 1985, pp. 1-63.

Sangero, B., Self-Defence in Criminal Law, Hart Publishing, Oxford, 2006.

Scaliotti, M., 'Defences before the International Criminal Court: Substantive Grounds for Excluding Criminal Responsibility - Part I', In: International Criminal Law Review, Vol. 1, 2001, pp. 111-172.

Scaliotti, M., 'Defences before the International Criminal Court: Substantive Grounds for Excluding Criminal Responsibility - Part 2', In: International Criminal Law Review, Vol. 2, 2002, pp. 1-46.

Schabas, W.A., Genocide in International Law, Cambridge University Press, 2000.

Schabas, W.A., Genocide in International Law, Second Edition, Cambridge University Press, 2009.

Sliedregt, E. van, The Criminal Responsibility of Individuals for Violations of International Humanitarian Law, T.M.C. Asser Press, The Hague, 2003.

Sliedregt, E. van, Individual Criminal Responsibility in International Law, Oxford University Press, 2012.

Smeulers, A., 'What Transforms Ordinary People into Gross Human Rights Violators?', In: Carey, S.C. and Poe, S.C. (eds.), Understanding Human Rights Violations: New Systematic Studies, Ashgate Publishing Limited, Aldershot, 2004, pp. 239-251.

Smeulers, A. and Holá, B., 'ICTY and the Culpability of Different Types of Perpetrators of International Crimes', In: Smeulers, A. (ed.), Collective Violence and International Criminal Justice: An Interdisciplinary Approach, Intersentia, Antwerp, 2010, pp. 175205.

Taylor, T., The Anatomy of the Nuremberg Trials: A Personal Memoir, Bloomsbury Publishing, London, 1993.

Than, C. de and Shorts, E., International Criminal Law and Human Rights, Sweet \& Maxwell, London, 2003.

Triffterer, O., 'Article 32: Mistake of Fact or Mistake of Law', Triffterer, O. (ed.), Commentary on the Rome Statute of the International Criminal Court: Observers' Notes, Article by Article, Hart Publishing, Oxford, 2008, pp. 895-929.

Vallini, A., 'Mens Rea', In: Cassese, A. (ed.), The Oxford Companion to International Criminal Justice, Oxford University Press, 2009, pp. 412-415.

Verseveld, A. van, Mistake of Law: Excusing Perpetrators of International Crimes, T.M.C. Asser Press, The Hague, 2012.

Weigend, T., 'The Harmonization of General Principles of Criminal Law: The Statutes and Jurisprudence of the ICTY, ICTR and the ICC', In: Nouvelles Études Pénales, Vol. 19, 2004, pp. 319-335.

Weigend, T., 'Intent, Mistake of Law and Co-perpetration in the Lubanga Decision on Confirmation of Charges', In: Journal of International Criminal Justice, Vol. 6, 2008, pp. 471-487.

Weiler, J.H.H. and Deshman, A., 'Far be it from Thee to Slay the Righteous with the Wicked: An Historical and Historiographical Sketch of the Bellicose Debate 
Concerning the Distinction between Ius ad Bellum and Ius in Bello, In: European Journal of International Law, Vol. 24, Issue 1, 2013, pp. 25-61.

Werle, G., Principles of International Criminal Law, T.M.C. Asser Press, The Hague, 2005.

Werle, G., 'General Principles of International Criminal Law', In: Cassese, A. (ed.), The Oxford Companion to International Criminal Justice, Oxford University Press, 2009, pp. 54-62.

Wilt, H.G. van der, 'Commentary on Prosecutor v. Erdemović', In: Klip, A. and Sluiter, G. (eds.), Annotated Leading Cases of International Criminal Tribunals: The International Criminal Tribunal for Former Yugoslavia 1993-1998, Intersentia, Antwerp, Volume 1, 1999, pp. 503-677.

Wilt, H.G. van der, 'Justifications and Excuses in International Criminal Law: An Assessment of the Case-law of the ICTY', In: Swart, B., Zahar, A. and Sluiter, G. (eds.), The Legacy of the International Criminal Tribunal for the Former Yugoslavia, Oxford University Press, 2011, pp. 275-295.

Zahar, A. and Sluiter, G., International Criminal Law, Oxford University Press, 2008.

Zahar, A., 'Superior Orders', In: Cassese, A. (ed.), The Oxford Companion to International Criminal Justice, Oxford University Press, 2009, pp. 525-527.

Zimmermann, A., 'Superior Orders', In: Cassese, A. et al. (eds.), The Rome Statute of the ICC: A Commentary, Oxford University Press, Vol. 1, 2002, pp. 957-974.

\section{Case law of international courts and tribunals}

IMT

IMT, Judgment and sentences, 1 October 1946, In: American Journal of International Law, 41, 1947.

\section{IMTFE}

Röling, B.V.A. and Rüter, C.F. (eds.), The Tokyo Judgment: The international military tribunal of the far east (I.M.T.F.E.), 29 April 1946 - 12 November 1948, APAUniversity Press Amsterdam BV, Amsterdam, 1977 (Vol. I and II).

\section{ICTY}

ICTY, Prosecutor v. Tadić, Decision on the Defence Motion for Interlocutory Appeal on Jurisdiction, Appeals Chamber, 2 October 1995.

ICTY, Prosecutor v. Erdemović, Trial Chamber I, 27 November 1996.

ICTY, Prosecutor v. Erdemović, Appeals Chamber, 7 October 1997.

ICTY, Prosecutor v. Erdemović, Separate Opinion of Judge McDonald and Judge Vohrah, Appeals Chamber, 7 October 1997.

ICTY, Prosecutor v. Erdemović, Separate and Dissenting Opinion of Judge Li, Appeals Chamber, 7 October 1997. 
Bibliography

ICTY, Prosecutor v. Erdemović, Separate and Dissenting Opinion of Judge Cassese, Appeals Chamber, 7 October 1997.

ICTY, Prosecutor v. Erdemović, Separate and Dissenting Opinion of Judge Stephen, Appeals Chamber, 7 October 1997.

ICTY, Prosecutor v. Erdemović, Trial Chamber II, 5 March 1998.

ICTY, Prosecutor v. Mucić et al., Trial Chamber, 16 November 1998.

ICTY, Prosecutor v. Kupreškić, Decision on Evidence of the Good Character of the Accused and the Defence of Tu Quoque, Trial Chamber, 17 February 1999.

ICTY, Prosecutor v. Aleksovski, Trial Chamber, 25 June 1999.

ICTY, Prosecutor v. Kupreškić et al., Trial Chamber, 14 January 2000.

ICTY, Prosecutor v. Aleksovski, Appeals Chamber, 24 March 2000.

ICTY, Prosecutor v. Kunarac et al., Final Trial Brief Submissions by the Defence, 10 November 2000.

ICTY, Prosecutor v. Kordić and Čerkez, Defendant Mario Čerkez's Final Trial Brief, 13 December 2000.

ICTY, Prosecutor v. Kupreškić et al., Trial Chamber, 14 January 2001.

ICTY, Prosecutor v. Mucić et al., Appeals Chamber, 20 February 2001 (also cited as Prosecutor v. Delalić et al.).

ICTY, Prosecutor v. Kunarac et al., Trial Chamber, 22 February 2001.

ICTY, Prosecutor v. Kordić and Čerkez, Trial Chamber, 26 February 2001.

ICTY, Prosecutor v. Todorović, Trial Chamber, 31 July 2001.

ICTY, Prosecutor v. Krstić, Trial Chamber, 2 August 2001.

ICTY, Prosecutor v. Kvočka et al., Trial Chamber, 2 November 2001.

ICTY, Prosecutor v. Krnojelac, Trial Chamber, 15 March 2002.

ICTY, Prosecutor v. Kunarac et al., Appeals Chamber, 12 June 2002.

ICTY, Prosecutor v. Simić, Trial Chamber, 17 October 2002.

ICTY, Prosecutor v. Vasiljević, Trial Chamber, 29 November 2002.

ICTY, Prosecutor v. Stakić, Trial Chamber, 31 July 2003.

ICTY, Prosecutor v. Krnojelac, Appeals Chamber, 17 September 2003.

ICTY, Prosecutor v. Simić, Separate and Partly Dissenting Opinion by Judge Per-Johan Lindholm, Trial Chamber, 17 October 2003.

ICTY, Prosecutor v. Banović, Trial Chamber, 28 October 2003.

ICTY, Prosecutor v. Nicolić, Trial Chamber, 2 December 2003.

ICTY, Prosecutor v. Galić, Trial Chamber, 5 December 2003.

ICTY, Prosecutor v. Hadžihasanović and Kubura, Decision on Defence Motion for Clarification of the Oral Decision of December 172003 regarding the scope of crossexamination pursuant to Rule 90(H) of the Rules, Trial Chamber, 28 January 2004.

ICTY, Prosecutor v. Vasiljević, Appeals Chamber, 25 February 2004.

ICTY, Prosecutor v. Češić, Trial Chamber, 11 March 2004.

ICTY, Prosecutor v. Mrđa, Trial Chamber, 31 March 2004.

ICTY, Prosecutor v. Blaškić, Appeals Chamber, 29 July 2004.

ICTY, Prosecutor v. Kordić and Čerkez, Appeals Chamber, 17 December 2004.

ICTY, Prosecutor v. Strugar, Trial Chamber, 31 January 2005. 
ICTY, Prosecutor v. Kvočka et al., Appeals Chamber, 28 February 2005.

ICTY, Prosecutor v. Bralo, Trial Chamber, 7 December 2005.

ICTY, Prosecutor v. Hadžihasanović and Kubura, Trial Chamber, 15 March 2006.

ICTY, Prosecutor v. Orić, Trial Chamber, 30 June 2006.

ICTY, Prosecutor v. Simić, Appeals Chamber, 28 November 2006.

ICTY, Prosecutor v. Bralo, Appeals Chamber, 2 April 2007.

ICTY, Prosecutor v. Martić, Trial Chamber, 12 June 2007.

ICTY, Prosecutor v. Milošević, Trial Chamber, 12 December 2007.

ICTY, Prosecutor v. Delić, Trial Chamber, 15 September 2008.

ICTY, Prosecutor v. Martić, Appeals Chamber, 8 October 2008.

ICTY, Prosecutor v. Milošević, Appeals Chamber, 12 November 2009.

ICTY, Prosecutor v. Boškoski and Tarčulovski, Appeals Chamber, 19 May 2010.

ICTY, Prosecutor v. Đordević, Trial Chamber, 23 February 2011.

ICTY, Prosecutor v. Gotovina et al., Trial Chamber, 15 April 2011.

ICTY, Prosecutor v. Gotovina and Markač, Appeals Chamber, 16 November 2012.

ICTY, Prosecutor v. Tolimir, Separate and concurring opinion Judge Antoine Kesia-Mbe Mindua, 12 December 2012.

\section{ICTR}

ICTR, Prosecutor v. Kambanda, Trial Chamber, 4 September 1998.

ICTR, Prosecutor v. Kayishema and Ruzindana, Trial Chamber, 21 May 1999.

ICTR, Prosecutor v. Kanyabashi, Dissenting Opinion of Judge Shahabuddeen, Appeals Chamber, 3 June 1999.

ICTR, Prosecutor v. Kajelijeli, Trial Chamber, 1 December 2003.

ICTR, Prosecutor v. Kamuhanda, Trial Chamber, 22 January 2004.

ICTR, Prosecutor v. Kamuhanda, Judge Maqutu's Dissent on the Sentence, Trial Chamber, 22 January 2004.

ICTR, Prosecutor v. Muhimana, Trial Chamber, 28 April 2005.

ICTR, Prosecutor v. Kamuhanda, Appeals Chamber, 19 September 2005.

ICTR, Prosecutor v. Gacumbitsi, Appeals Chamber, 7 July 2006.

ICTR, Prosecutor v. Nzabirinda, Trial Chamber, 23 February 2007.

ICTR, Prosecutor v. Bagosora et al., Trial Chamber, 18 December 2008.

ICTR, Prosecutor v. Nyiramasuhuko, Trial Chamber, 24 June 2011.

ICTR, Prosecutor v. Bizimungu et al., Trial Chamber, 30 September 2011.

ICTR, Prosecutor v. Ndahimana, Trial Chamber, 30 December 2011.

ICTR, Prosecutor v. Ndahimana, Dissenting opinion of Judge Florence Rita Arrey, Trial Chamber, 30 December 2011.

\section{ICC}

ICC, Prosecutor v. Lubanga Dyilo, Decision on the confirmation of charges, Pre-Trial Chamber, 29 January 2007. 
Bibliography

ICC, Prosecutor v. Lubanga Dyilo, Judgment pursuant to Article 74 of the Statute, Trial Chamber I, 14 March 2012.

\section{Other case law}

\section{ICJ}

ICJ, Columbia v. Peru (Asylum Case), Judgment, 20 November 1950.

ICJ, Fed. Rep. Of Germany v. Denmark and v. The Netherlands (North Sea Continental Shelf), Judgment, 20 February 1969.

ICJ, Nicaragua v. U.S. (Military and Paramilitary activities in and against Nicaragua), Judgment, 27 June 1986.

\section{Selected official documents}

Convention on the Prevention and Punishment of the Crime of Genocide (1948).

ICTR, Annual Report: A/51/399-S/1996/778.

S/25704 (1993).

SC/Res. 827 (1993).

$\mathrm{S} / 1125$ (1994).

$\mathrm{S} / 1405$ (1994).

SC/Res. 955 (1994).

SC/Res. 977 (1995).

UN Diplomatic Conference of Plenipotentiaries on the Establishment of an International Criminal Court, Rome, 15 June - 17 July 1998, Official Records Vol. I, II and III.

Memorie van Toelichting bij de Wet Internationale Misdrijven (WIM), Tweede Kamer, 28 337, Vergaderjaar 2001-2002.

RC/Res. 6 of 11 June 2010. 


\section{Curriculum Vitae Maartje Krabbe}

Maartje Krabbe (Amsterdam, 1977) spent her high school years in Amsterdam and Groningen. After obtaining her gymnasium diploma, she studied a year at Lawrence University (USA) with a Fulbright Center scholarship. Upon her return to the Netherlands, she enrolled in Maastricht University Law School, spending one semester at Université Paris V (France) and another one at the University of Limerick (Ireland). She graduated in 2004, majoring in law and languages. From 2004 to 2012 Maartje Krabbe worked as a lecturer and researcher at Maastricht University, where she taught tort law, substantive criminal law, criminal procedure, comparative criminal law and international criminal law. She also carried out several research projects during this appointment, one of which resulted in the present thesis. Currently Maartje Krabbe is a lecturer and researcher at the criminal law department of Radboud University (Nijmegen, the Netherlands). 



\section{School of Human Rights RESEARCh SERIES}

The School of Human Rights Research is a joint effort by human rights researchers in the Netherlands. Its central research theme is the nature and meaning of international standards in the field of human rights, their application and promotion in the national legal order, their interplay with national standards, and the international supervision of such application. The School of Human Rights Research Series only includes English titles that contribute to a better understanding of the different aspects of human rights.

Editorial Board of the Series:

Prof. dr. J.E. Goldschmidt (Utrecht University), Prof. dr. D.A. Hellema (Utrecht University), Prof. dr. W.J.M. van Genugten (Tilburg University), Prof. dr. M.T. Kamminga (Maastricht University), Prof. dr. P.A.M. Mevis (Erasmus University Rotterdam), Dr. J.-P. Loof (Leiden University) and Dr. O.M. Ribbelink (Asser Institute).

For previous volumes in the series, please visit http://shr.intersentia.com.

Published titles within the Series:

54. Jeroen Blomsma, Mens rea and defences in European Criminal Law ISBN 978-1-78068-104-7

55. Masha Fedorova, The Principle of Equality of Arms in International Criminal Proceedings

ISBN 978-1-78068-111-5

56. Martine Boersma, Corruption: A Violation of Human Rights and a Crime Under International Law?

ISBN 978-1-78068-105-4

57. Hendrik J. Lubbe, Successive and Additional Measures to the TRC Amnesty Scheme in South Africa

ISBN 978-1-78068-116-0

58. Hana van Ooijen, Religious Symbols in Public Functions: Unveiling State Neutrality. A Comparative Analysis of Dutch, English and French Justifications for Limiting the Freedom of Public Officials to Display Religious Symbols ISBN 978-1-78068-119-1

59. Sarah Haverkort-Speekenbrink, European Non-Discrimination Law. A Comparison of EU Law and the ECHR in the Field of Non-Discrimination and Freedom of Religion in Public Employment with an Emphasis on the Islamic Headscarf Issue ISBN 978-1-78068-126-9

60. Johannes Keiler, Actus Reus and Participation in European Criminal Law ISBN 978-1-78068-135-1

61. Simone F. van den Driest, Remedial Secession. A Right to External Self-Determination as a Remedy to Serious Injustices?

ISBN 978-1-78068-153-5

62. Ramona Biholar, Transforming Discriminatory Sex Roles and Gender Stereotyping: The implementation of Article 5(a) CEDAW for the realisation of women's right to be free from gender-based violence in Jamaica

ISBN 978-1-78068-167-2 
